\title{
La administración de justicia en la provincia de Buenos Aires, 1853-1881
}

\author{
Licenciada María Angélica Corva
}

Tesis para optar por el grado de Doctor en Historia

Director Doctor Osvaldo Barreneche, UNLP

La Plata, 8 de mayo de 2013 


\section{Agradecimientos}

Lo que me permitió iniciar, transitar y terminar esta tesis fue antes que nada la confianza que familia, amigos y colegas tuvieron en mí. Confianza que me permitió creer en que yo era capaz de hacerlo. Por esto antes que nada gracias a todos por confiar. Y gracias...

A Alberto David Leiva por darme un espacio de pertenencia.

A Osvaldo Barreneche por arriesgarse a dirigir a una mujer madura para el circuito académico, por su enorme paciencia y por toda la dedicación que puso en este proyecto.

Al director del doctorado Fernando Barba, a la secretaria Betina Riva y a todos mis profesores de los seminarios en los que aprendí tanto y en los que junto a mis compañeros pasé tan buenos momentos: Viviana Kluger, Marta Valencia, Jorge Troisi, Abelardo Levaggi, Rodolfo Gaeta, Nélida Gentile, Susana Lucero, Osvaldo Barreneche, María Teresita Minellono, María Cecilia Corda y Mónica Pené.

A Nélida Liparoti, a José María Díaz Couselo, a Víctor Tau Anzóategui y a los miembros del Instituto de Historia del Derecho de todo el país, por sus consejos y sobre todo por ser tan buenos compañeros.

A Dardo Pérez Ghilou, por haberme enseñado con rigidez y acompañado con cariño.

A Darío Barriera por haber confiado siempre en mí, dándome un espacio académico para pensar y sobre todo su amistad junto con su esposa Miriam Moriconi.

A todos los colegas con los que compartimos jornadas y encuentros, por sus críticas y por su estímulo. Un agradecimiento especial a Eduardo Zimmermann, Leandro Di Gresia, Carolina Piazzi, Claudia Freidenraij, Eugenia Molina y en recuerdo de Orieta Zeberio.

A Federico Reggiani, jefe de la Biblioteca Central de la Suprema Corte de Justicia, mi jefe, que me dio la posibilidad de volver a empezar y de brindarle al Poder Judicial todo lo que aprendí. A mis compañeros, por aceptarme y hacer cada día tan agradable.

A todos mis amigos, especialmente a María de los Ángeles, Mercedes, Marcelo, Beatriz, Ángel, Laura y César, por comprenderme, quererme y ayudarme siempre a saber quién soy y qué soy capaz de hacer.

A mi mamá y a mi papá por darme la vida, pero además a mamá por transmitirme la pasión por la justicia, y a papá por enseñarme el gusto por la investigación.

A mis tíos del alma, Beatriz y Rodolfo, por todo su amor y su protección.

A mis suegros, Teté y Vicente, por haberme dado siempre su aceptación, su alegría y su contención. A Isabel, nuestra compañera cotidiana, por ayudarme a llevar la casa adelante y regalarnos toda su sabiduría y su cariño.

A Francisco Javier, por ser siempre nuestra luz. 
A mis amores, fruto de mi verdadera vocación, María Pilar, Lucía y Juan Pedro, mis hijos y brillantes asistentes de investigación. Por acompañarme, por escucharme, por comprenderme.

A Horacio, mi esposo y compañero de ruta, con quien llevamos veintiséis años juntos y con quien compartimos este amor inexplicable por la historia. Por su paciencia, por su confianza, por darme fuerza y sobre todo por quererme. 


\section{Resumen y palabras clave}

administración de justicia- división de poderes- provincia de Buenos Aires

El estudio de la estructura, la organización y el funcionamiento del sistema judicial tiene un valor en sí mismo, determinado por la necesidad de descubrir quiénes administraban justicia, de qué manera lo hacían y con qué resultados. Entonces, es indispensable establecer la relación entre la solución jurídica y los factores extrajurídicos de una época, poniendo como punto de partida el tratamiento hermenéutico de los textos. Determinar las intenciones del autor de las normas puede llevarnos a encontrar el camino de las fuerzas ideales y sociales, para lo que también es esencial averiguar sobre la vida y la formación de los legisladores y magistrados.

Esta tesis doctoral, que se ubica en la provincia de Buenos Aires entre 1853 y 1881, tiene por objetivo estudiar el proceso de constitución y consolidación del poder judicial, responsable de la administración de justicia, como integrante del Estado provincial, legitimador de su accionar político y mediador con la sociedad civil. Por ello la investigación, centrada en la Justicia, gira sobre estos tres ejes teniendo siempre presente la relación del poder judicial con el Estado y la Sociedad. El estudio de la administración de justicia se inscribe en el marco más amplio de la justicia como valor, ligado a los de libertad e igualdad. Sobre la concepción que de ellos se tenía, fue construido el ordenamiento jurídico del Estado, su legitimidad y la relación que se estableció con la sociedad. De todas las teorías del Estado que buscaron controlar el poder estatal y poner límite a su ejercicio, la más significativa fue la doctrina de la separación de poderes, un sistema de conceptos confuso y ambiguo. Esta doctrina nunca fue aplicada por si sola como base de un sistema político efectivo y estable, sino que se ha combinado con otras ideas políticas como la del estado mixto, la idea de equilibrio o el concepto de frenos y contrapesos.

La judicatura apareció gradualmente como una rama independiente del Estado y la noción de un poder judicial autónomo siguió evolucionando. Si bien no puede atribuírsele a Montesquieu la originalidad de la doctrina de la separación de poderes, cierto es que enriqueció la doctrina haciendo mayor hincapié en la función judicial, encargada de sancionar a los criminales o dirimir las disputas entre los ciudadanos. Este nuevo "poder de juzgar", lo colocó al mismo nivel analítico de las otras dos funciones estatales, estableciendo la trinidad que caracterizaría el pensamiento moderno. La judicatura sería independiente de los conflictos de intereses que surgieran en el Estado, instancia fundamental para el posterior desarrollo de la doctrina.

La elección del tema de tesis ha estado guiada por dos cuestiones, una teórica y otra práctica. En el primer caso, está orientada a contribuir a conocer la relación entre ley y política, rasgo central del proceso de construcción del Estado en el siglo XIX en América Latina. Comprender la formación y el funcionamiento del sistema judicial puede ayudar a desenmarañar esa relación. En 
cuanto a la práctica, he atendido durante años numerosas consultas de investigadores dedicados a diferentes temas por los recurrieron a la fuente judicial. El primer paso siempre ha sido explicarles de donde y en qué forma ha surgido esa fuente, pues aunque su tema no sea necesariamente la justicia, no se puede realizar un trabajo heurístico sin comprender el origen del documento con el que estamos trabajando.

La investigación se ubica en la provincia de Buenos Aires, entre 1853 y 1881. Buenos Aires no juró la Constitución Nacional hasta 1860, pero sancionó su propia Constitución en 1854, en la que declaraba que el poder judicial sería independiente de todo otro en el ejercicio de sus funciones. Es decir que en esta provincia la consagración de la teoría de los poderes del Estado e imposición de la ley como definidora de lo que era justo, requería de la organización del poder judicial. Si bien esto sucedía también en el resto de las provincias, la atención se centra en Buenos Aires por la particularidad de su proceso y porque en estos años la ciudad de Buenos Aires era la capital de la provincia y al mismo tiempo residencia de las autoridades nacionales, provocando esto confusión entre la justicia federal y la provincial a la hora de estudiarlas.

En cuanto a los años establecidos como marco cronológico, debemos advertir que estamos hablando de procesos en los que no pueden establecerse cortes definidos; pero como es necesario limitar nuestra tarea, hemos puesto como fechas límite 1853 y 1881. El año 1853 fue significativo para la organización judicial, pues, aún antes de sancionarse la Constitución provincial, se instalaron juzgados de primera instancia en la campaña, a partir de un proyecto de Valentín Alsina, que como presidente de la Cámara de Justicia observó la imperiosa necesidad de llevar jueces letrados al interior de la provincia. A lo largo de estos años la preocupación sobre la administración de justicia giró en torno a la organización del más alto tribunal, la descentralización judicial, la formación técnica de los magistrados, la fundamentación legal de las sentencias y la codificación. La Constitución provincial de 1873 introdujo cambios como la creación de la Suprema Corte, la segunda instancia, el juicio por jurados y la elección popular de los jueces de paz. Las dos últimas reformas no se concretaron y la estructura definitiva del poder judicial provincial quedó formalizada en su primera ley orgánica en 1881, para una provincia que ya no contaba con la ciudad de Buenos Aires como capital. 


\section{Índice}

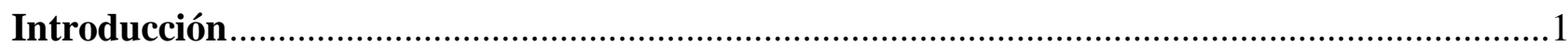

I. La relación entre administrar justicia y gobernar: cómo crear un Estado...................................

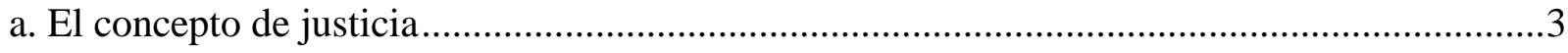

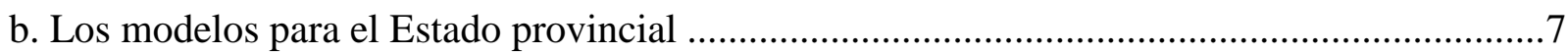

II. Creación, estructura y funcionamiento de un sistema judicial provincial: fundamentación y

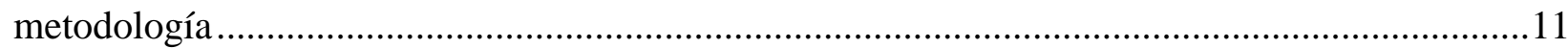

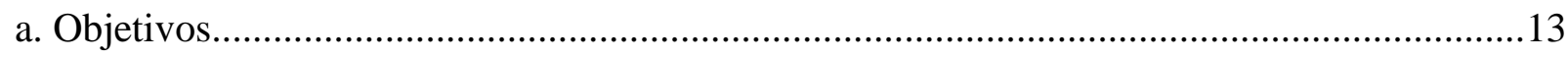

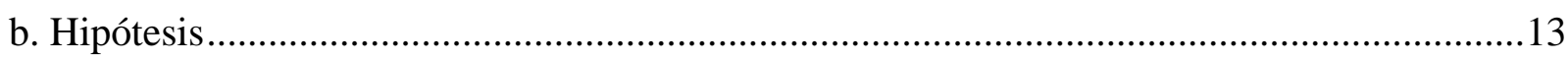

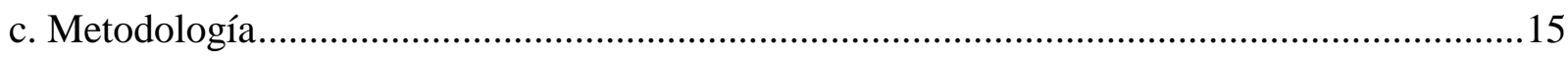

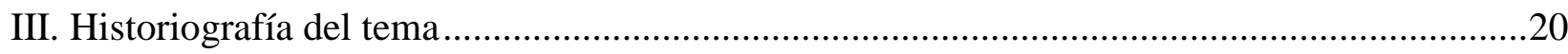

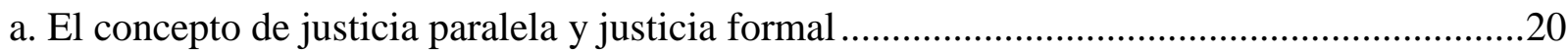

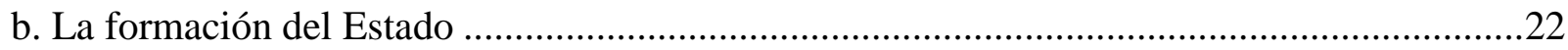





\section{Capítulo I}



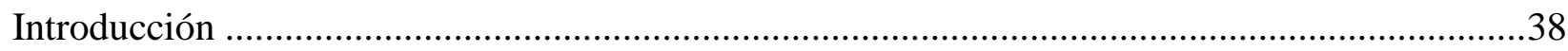

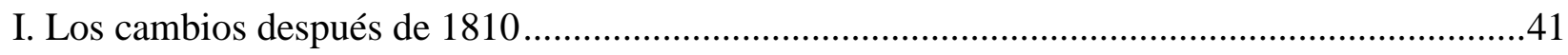

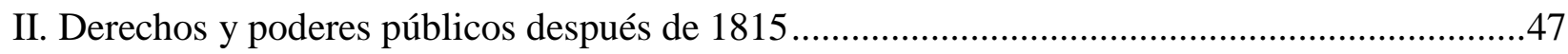

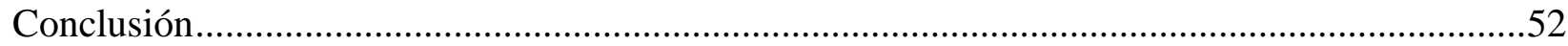

\section{Capítulo II}

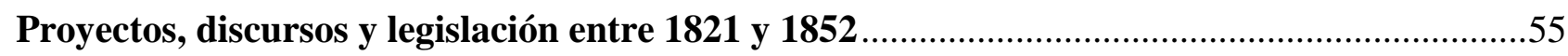

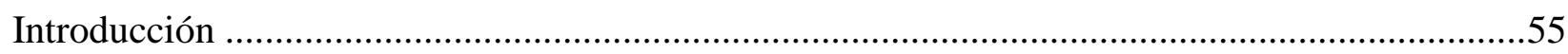

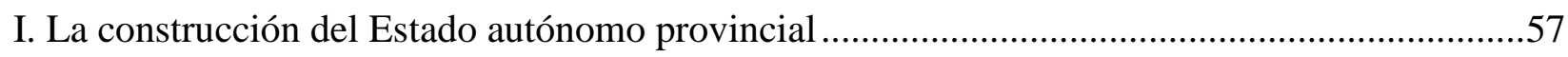

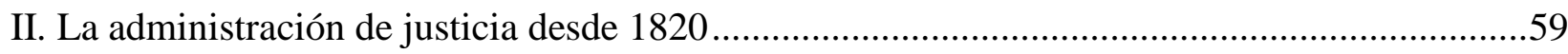

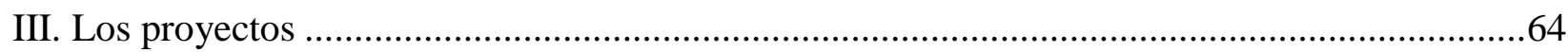

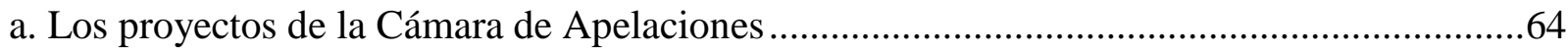

b. Plan general de la organización judicial para Buenos Aires de Guret Bellemare................66

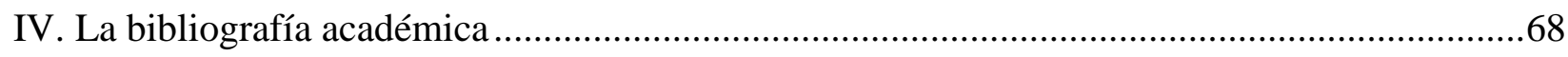

a. Instituciones elementales sobre el Derecho Natural y de Gentes de Antonio Sáenz ............69

b. Principios de derecho civil de Pedro Somellera .................................................................. 70 
d. Tratado elemental de los procedimientos civiles en el foro de Buenos Aires de Miguel

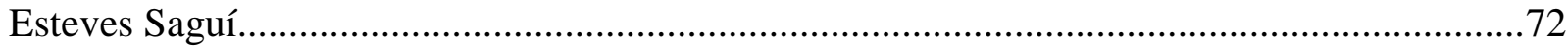

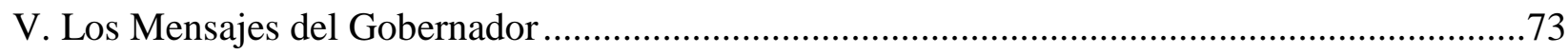

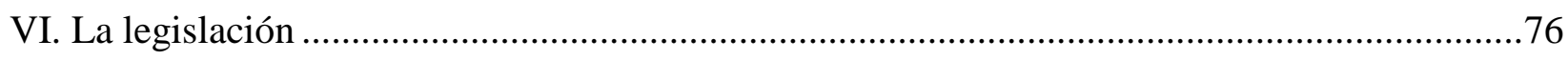

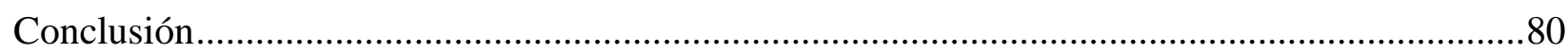

\section{Capítulo III}

Ideas políticas y administración de justicia (1852-1881) ................................................ 84

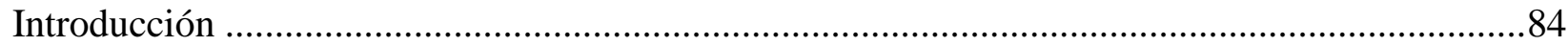

I. La dimensión política provincial en el contexto nacional .....................................................86

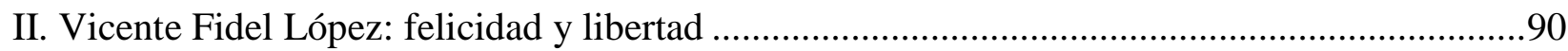

III. Antonio Ezequiel Malaver: necesidad y competencia …..................................................99

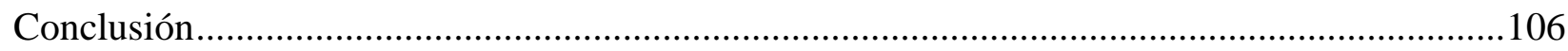

\section{Capítulo IV}

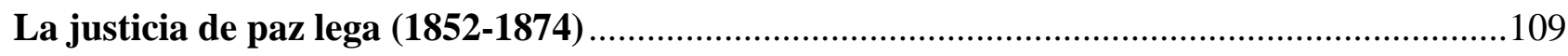

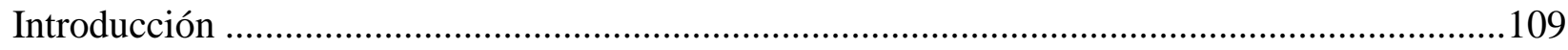

I. La concentración de funciones y la ampliación de competencia de los jueces de paz .............114

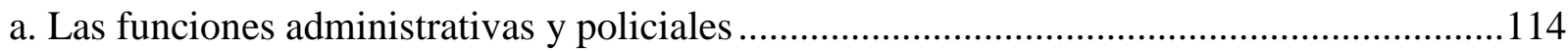

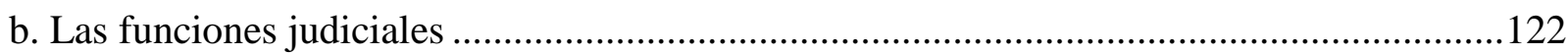



III. La preocupación por la descentralización ..........................................................................135

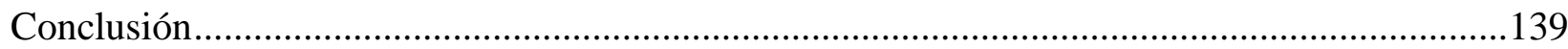

\section{Capítulo V}

La primera instancia letrada civil, penal, correccional y comercial $(\mathbf{1 8 5 3 - 1 8 7 4}) \ldots \ldots \ldots \ldots \ldots \ldots . . .142$

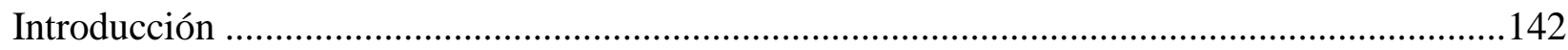



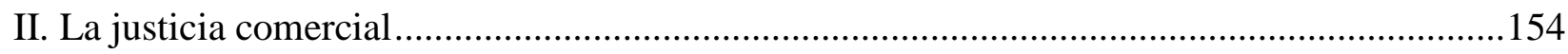

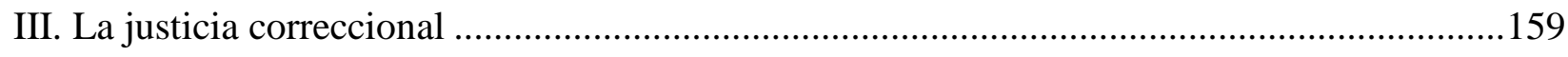

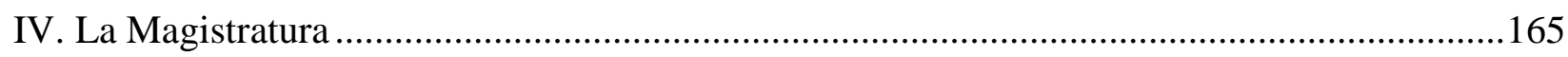

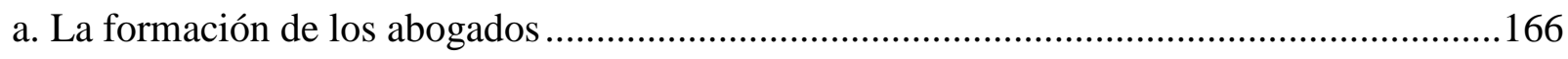

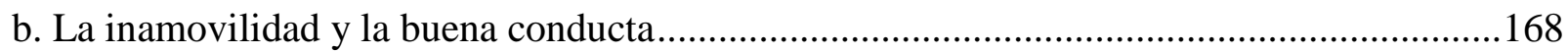




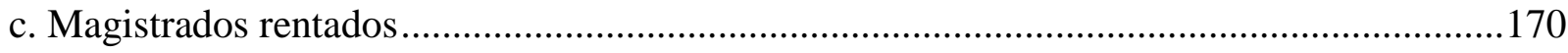

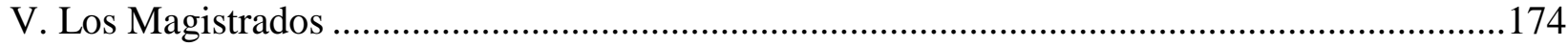

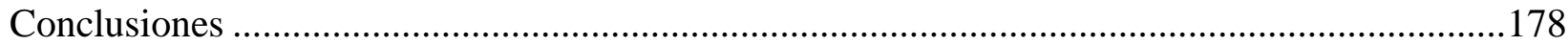

\section{Capítulo VI}

El Superior Tribunal de Justicia de la provincia de Buenos Aires (1857-1874)....................184

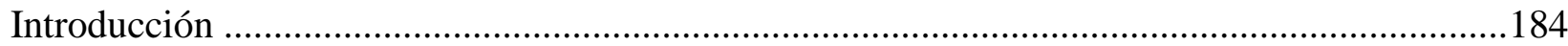

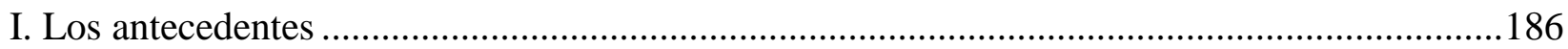

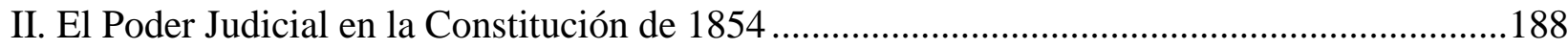

III. La organización del Superior Tribunal de Justicia ...............................................................191

IV. Los conflictos entre los particulares y el Estado ...............................................................196

V. La Superintendencia sobre la administración de justicia .....................................................199

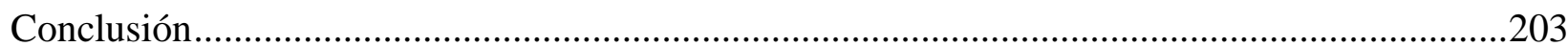

\section{Capítulo VII}

El Poder Judicial de la provincia de Buenos Aires en la Constitución de 1873_....................205

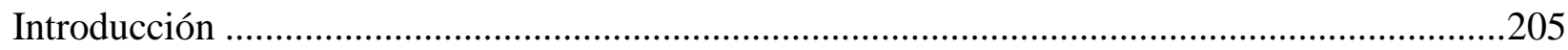

I. La definición del Poder Judicial en la Constitución provincial de 1873 ...............................208

II. La conformación del Poder Judicial: garantía y responsabilidad del magistrado ...................210

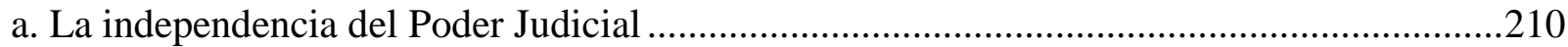

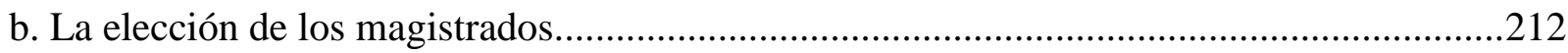

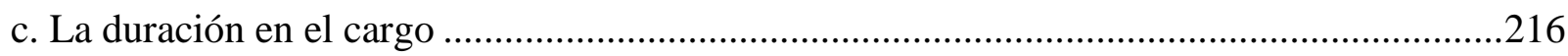

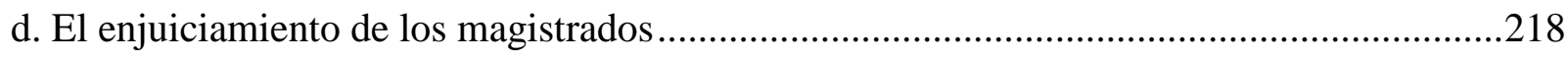

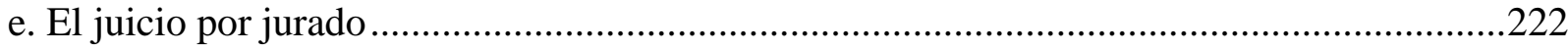



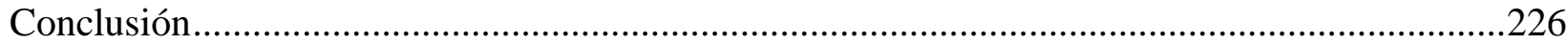

\section{Capítulo VIII}

El Poder Judicial después de la Constitución de 1873 de la provincia de Buenos Aires (1875-

1881)

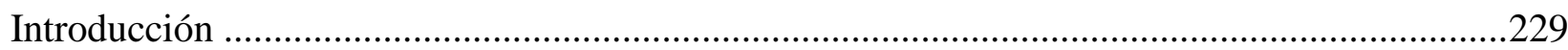

I. La importancia de las reformas previas a la organización judicial .......................................230

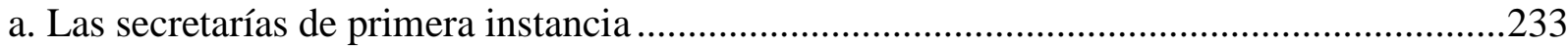

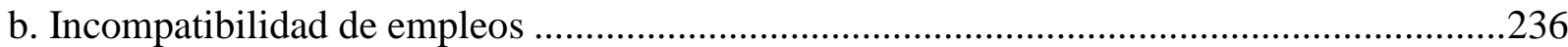


II. La participación de los Poderes en la conformación del Poder Judicial ................................238

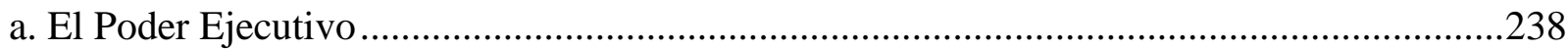

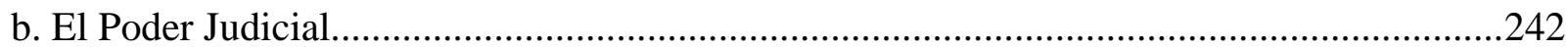

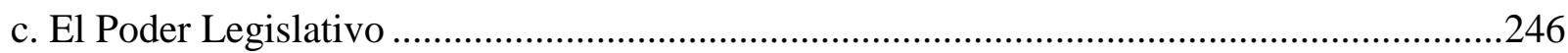

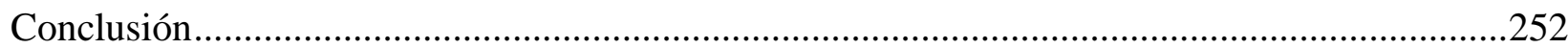

\section{Capítulo IX}

El "nuevo" Poder Judicial en funcionamiento (1875-1881) .................................................255

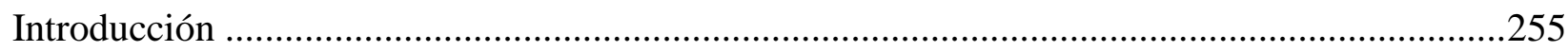



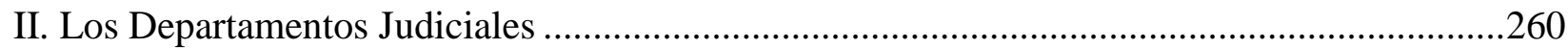

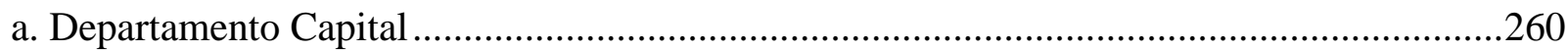

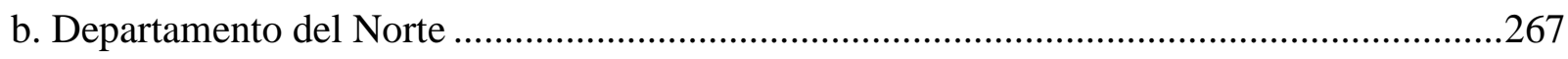

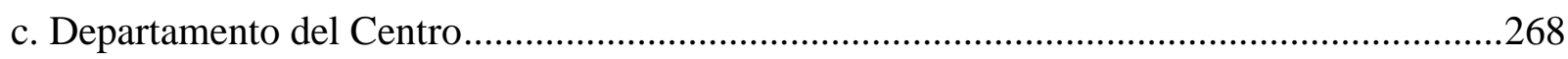

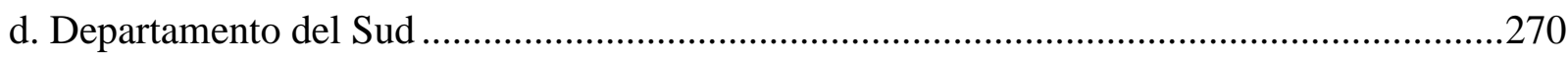

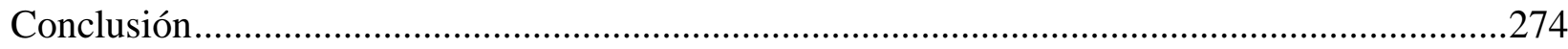

\section{Capítulo X}

La vida: pena de muerte, indulto y división de poderes. El caso de Clorinda Sarracán .........276

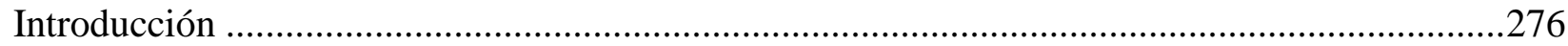

I. De la averiguación del delito y del delincuente (sumario) ...............................................278

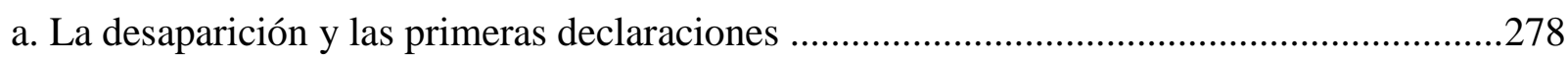

b. La confesión de Crispín y la detención de Clorinda ..........................................................281

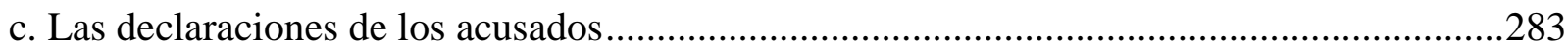



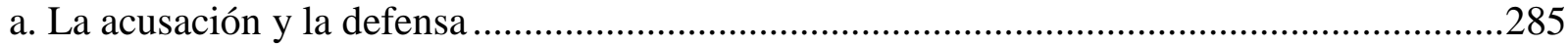

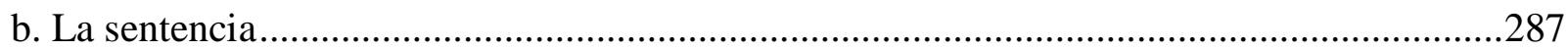

III. La sociedad movilizada y la respuesta de los Poderes ....................................................289

IV. La liberación de Clorinda...........................................................................................294

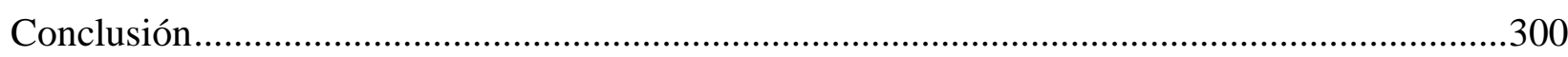




\section{Capítulo XI}

La propiedad: vías administrativas y judiciales para la resolución de conflictos de tierras en la provincia de Buenos Aires, 1860-1880. Luis Goya contra los chacareros..............................303

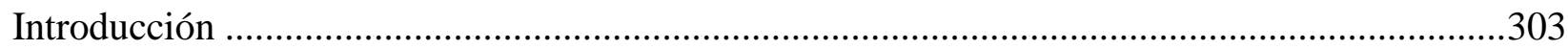

I. Del fortín Esperanza al partido de General Alvear..............................................................305

II. Los recursos de Luis Goya para recuperar sus tierras .........................................................309

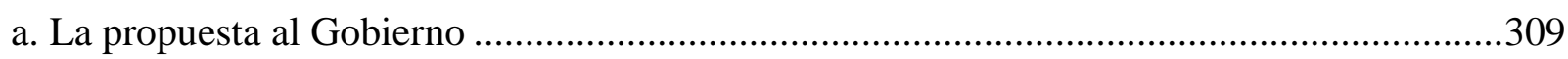

b. Cobro de arrendamientos y desalojo: el juicio en primera instancia...................................311

III. Los recursos de los chacareros para recuperar sus tierras ...................................................319

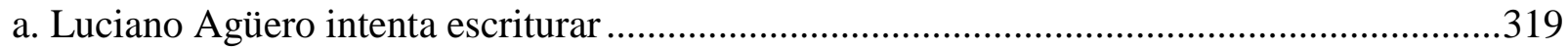

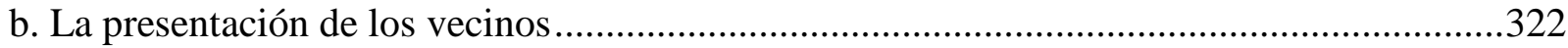

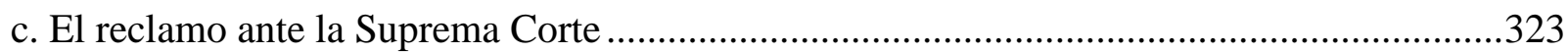

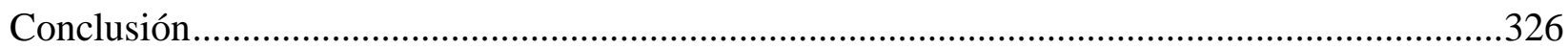

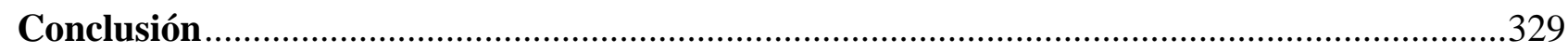

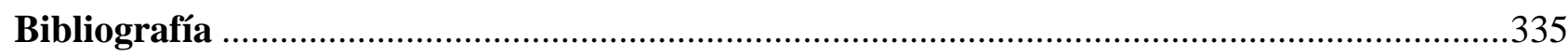

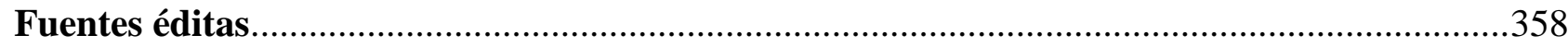

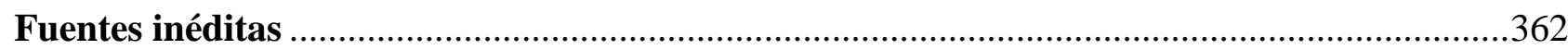




\section{Introducción}

La historia del pensamiento político occidental muestra el desarrollo y la evolución de los valores como la justicia, la libertad, la igualdad y la inviolabilidad de la propiedad. Pero la misma importancia reviste la historia de los debates sobre las estructuras y procedimientos institucionales necesarios para poner en práctica y compatibilizar esos valores, que no aseguran su propia aplicación, siendo potencialmente contradictorios. Por esto es cada vez mayor la preocupación por la articulación de las instituciones del sistema político y por la medida en que promovieron esos valores considerados fundamentales para la organización política del Estado. Las categorías que forman la base de gran parte del pensamiento actual sobre la estructura y funcionamiento del Estado han sido resultado del desarrollo gradual de ideas que reflejan diversos problemas sobre la naturaleza del Estado, parte de los cuales comenzaron a percibirse en la Inglaterra del siglo XVII y que siguen siendo objeto de debate hoy en día. Las "funciones del Estado" responden a problemas específicos de las sociedades occidentales y reflejan la demanda de que las estructuras y procedimientos institucionales se basen en unos valores determinados. ${ }^{1}$

Las perspectivas historiográficas sobre la vida política del siglo XIX latinoamericano se han agrupado alrededor de tres cuestiones fundamentales: la ciudadanía política y la formación de la nación; la violencia y las guerras; y la institucionalización del Estado. La revisión del proceso histórico de consolidación estatal, demostró que el Estado moderno no resultó de la marginalización progresiva y de la expropiación de los poderes políticos locales por la monarquía, sino de fenómenos de articulación y de interdependencia entre ambas esferas. En cuanto a la institucionalización del Estado, se tiende a analizar el conjunto de procesos sociales, las transformaciones de las instituciones, las normativas y comportamientos colectivos que permiten determinar la fisonomía y el funcionamiento de un sistema político, en la medida que establecieron los atributos que definieron el Estado moderno. Desde esta perspectiva, un tema poco abordado y que requiere ser estudiado es el del poder judicial, que según las diferentes maneras de concebir la división de poderes, dio por resultado un determinado régimen jurídico integrado por varias fuentes del derecho (las leyes positivas, la costumbre, el derecho indiano, el principio de equidad). ${ }^{2}$

Entonces la organización del poder judicial formaba parte de la consagración de la teoría de los poderes del Estado y la ley (en sentido amplio) como definidora de lo que era justo, y a través de la historia de las instituciones judiciales puede observarse la interacción entre el mundo legal y el amplio proceso político, económico, social y cultural a través del cual tuvo lugar la transición del

\footnotetext{
1 Vile, M.J.C., [1967] Constitucionalismo y separación de poderes, Madrid, Centro de Estudios políticos y constitucionales, 2007, pp. 1-23. En Argentina esto puede observarse en Plotkin, Mariano Ben y Zimmermann, Eduardo, (compiladores) Los saberes del Estado, Buenos Aires, Edhasa, 2012; Las prácticas del Estado. Política, sociedad y elites estatales en la Argentina del siglo XX, Buenos Aires, Edhasa, 2012

${ }^{2}$ Morelli, Federica, "Entre el antiguo y el nuevo régimen. La historia política hispanoamericana del siglo XIX", en Historia Crítica, núm. 33, Bogotá, enero-julio 2007, pp. 122-155.
} 
status colonial a la nación independiente durante el siglo XIX en América Latina. ${ }^{3}$ Pero en la conformación de ese poder se generaron tensiones entre los discursos jurídicos (deber ser) y las prácticas (lo que efectivamente pasó o está pasando) a las que se debe acceder. Para ello es primordial conocer la organización de las distintas instancias judiciales y sus competencias, junto con las normas que regularon la resolución de los conflictos, universo sometido a una triple tensión de la primacía de la costumbre, la legislación aún vigente del Antiguo Régimen y la codificación que estaba surgiendo a partir del pacto constitutivo que intentaba imponer una nueva lógica de legitimidad, de la cual sus gestores se consideraban garantes. ${ }^{4}$

El estudio de la estructura, la organización y el funcionamiento del sistema judicial tiene un valor en sí mismo, determinado por la necesidad de descubrir quiénes administraban justicia, de qué manera lo hacían y con qué resultados. Entonces, es indispensable establecer la relación entre la solución jurídica y los factores extrajurídicos de una época, poniendo como punto de partida el tratamiento hermenéutico de los textos. Determinar las intenciones del autor de las normas puede llevarnos a encontrar el camino de las fuerzas ideales y sociales, para lo que también es esencial averiguar sobre la vida y la formación de los legisladores y magistrados. ${ }^{5}$

Esta tesis doctoral, que se ubica en la provincia de Buenos Aires entre 1853 y 1881, tiene por objetivo estudiar el proceso de constitución y consolidación del poder judicial, responsable de la administración de justicia, como integrante del Estado provincial, legitimador de su accionar político y mediador con la sociedad civil. Por ello la investigación, centrada en la Justicia, gira sobre estos tres ejes teniendo siempre presente la relación del poder judicial con el Estado y la Sociedad.

A lo largo de los años que trabajé en esta tesis leía cotidianamente en diarios y revistas políticas y escuchaba en distintos medios de comunicación social, reclamos referidos a la Justicia. La violencia, la falta de seguridad y la violación a los derechos individuales hacen que la sociedad espere de las instituciones judiciales una respuesta que no obtiene de otros sectores del poder estatal. En el momento en que estoy cerrando este largo camino de la tesis doctoral se debaten en el Congreso nacional los proyectos de ley elevados por la Presidenta para lograr la "democratización de la justicia". Se habla permanentemente del tema, pero como dijo en su momento Eugenio Zaffaroni, integrante de la Corte Suprema de la Nación, los problemas del poder judicial se han

\footnotetext{
3 Zimmermann, Eduardo, (editor) Judicial Institutions in Nineteenth-Century Latin America, Institute of Latin American Studies, University of London, 1999, Introduction, pp.1-7.

${ }^{4}$ Bonaudo, Marta, "Hecho jurídico...hecho político. La conflictividad entre poder y justicia en la construcción de la República Posible. Santa Fe 1856-1890”, en Carzolio, María Inés y Barriera, Darío G (compiladores) Política, Cultura, Religión. Del Antiguo Régimen a la formación de los Estados Nacionales, Rosario, Prohistoria, 2005, p. 215.

${ }^{5}$ Coing, Helmut, Las tareas del Historiador del derecho (reflexiones metodológicas), Publicaciones de la Universidad de Sevilla, Sevilla, 1977.
} 
"naturalizado", es decir que se considera su estructura tan natural como la de una flor y "toda naturalización es un encubrimiento legitimante de una estructura cuya discusión se omite". 6

A través de esta tesis espero lograr un mayor conocimiento y comprensión del funcionamiento actual de la administración de justicia, a partir del estudio de su historia a nivel provincial. Es posible pensar que la historia pueda contribuir a esclarecer el rol, funcionamiento, alcances y limitaciones de la justicia, previniendo de este modo la continuidad de la citada "naturalización" de la misma. Por ello, esta investigación no sólo busca ampliar los conocimientos históricos sobre el poder judicial, sino también poder aportar a los debates actuales y a los proyectos de reforma. No menos importante, desde mi punto de vista, esta tesis reúne un conjunto de informaciones hasta ahora fragmentadas y dispersas, que pueden servir de asistencia a los investigadores que necesiten de cualquier forma conocer la organicidad y funcionalidad de la administración de justicia de la provincia de Buenos Aires a través de su historia.

\section{$\underline{\text { I. La relación entre administrar justicia y gobernar: cómo crear un Estado }}$}

\section{a. El concepto de justicia}

El estudio de la administración de justicia se inscribe en el marco más amplio de la justicia como valor, ligado a los de libertad e igualdad. Sobre la concepción que de ellos se tenía, fue construido el ordenamiento jurídico del Estado, su legitimidad y la relación que se estableció con la sociedad. Por ese motivo es necesario, antes que nada, realizar una revisión de los conceptos de justicia que permitan comprender cuál fue el que guió su administración en la provincia de Buenos Aires en el período a investigar.

A pesar de ser innumerables sus definiciones y diversos los discursos en función de los cuales se la quiera definir, Carlos Nino determinó puntos comunes a los que se ha arribado en la formación del concepto. ${ }^{7}$ El primero de ellos es el que Aristóteles sostenía sobre la justicia como "la única virtud de una persona que es considerada como el bien de alguna otra, ya que ella asegura una ventaja para otra persona, sea un funcionario o un socio". ${ }^{8}$ El segundo es la coincidencia en relacionarla con la idea de asignar derechos y obligaciones entre los integrantes de un grupo social. El tercero, y partiendo también de Aristóteles, es creer que el valor justicia puede frustrarse o satisfacerse independientemente de la intención del actor y que "un acto es injusto sólo cuando es voluntario y un agente sólo puede ser reprochado como injusto si actúa con conocimiento y voluntad". 9

\footnotetext{
${ }^{6}$ Zaffaroni, Eugenio Raúl, "Reconstrucción institucional de la justicia", "Estudio preliminar" en Guarnieri, Carlo, Judicialismo, Buenos Aires, Hammurabi, Serie Negra, 2003, p.38.

${ }^{7}$ Nino, Carlos Santiago, "Justicia", en Doxa, Cuadernos de Filosofía del Derecho, 14, 1993, pp. 61-74. este artículo lo hemos utilizado de guía, profundizando en las definiciones más importantes en relación a la temática de la tesis.

${ }^{8}$ Aristóteles, Ética Nicomaquea, Libro Cuarto- De la Justicia, ii, en Nino, 1993, op.cit. p.62.

${ }^{9}$ Aristóteles, Ética Nicomaquea, Libro Cuarto- De la Justicia, vi y viii, en Nino, 1993, op.cit. p.62.
} 
Para Aristóteles ser "justo" tendía a producir la felicidad de una "asociación política”, era la cualidad de obrar conforme a las leyes cuando éstas buscaban la ventaja común. ${ }^{10}$ En este plano, la justicia fue relacionada íntimamente con el bienestar por Platón, por lo que las acciones injustas del hombre derivaban de su discordia interna, que le impedían actuar en común con otros hombres y finalmente lo hacían incapaz de ser feliz. ${ }^{11}$ Llevando la justicia a una perspectiva metafísica, Santo Tomás de Aquino definió la sindéresis como la facultad que le permitía al hombre detectar los principios más generales de justicia en el derecho natural, parte de la ley eterna de Dios que le era permitido conocer a la razón humana. El bien debía hacerse y el mal evitarse, de allí que una ley era injusta cuando imponía cargas innecesarias al bien común. ${ }^{12}$

Desde una mirada materialista, a pesar de ser la vida cruel, brutal y corta, los hombres podían afrontarla por acuerdos mutuos, según creía Thomas Hobbes, controlados por un poder (el del Estado o Leviatán) que los obligara a cumplirlos. Buscar la paz y el respeto de la libertad, eran parte de los artículos del pacto que establecían los principios fundamentales de la justicia. En este sentido "cuando se ha hecho un pacto, romperlo es injusto. La definición de injusticia no es otra sino ésta: el incumplimiento de un pacto. En consecuencia, lo que no es injusto es justo". ${ }^{13}$

Por su parte, el utilitarismo, que se basaba en el interés general, consideraba como justos los actos e instituciones si contribuían a expandir el bien, la felicidad general. Entre los utilitaristas, fueron leídos en el ámbito rioplatense Jeremy Bentham, que asociaba la felicidad con el placer, y Stuart Mill que definió distintos tipos de placer según su calidad. El comunitarismo, de carácter anti-individualista con antecedentes en el siglo XIX, ponía la clave en las personas insertas en comunidades, consideradas como sujetos históricos con derechos y deberes. En ellas primaba la concepción del bien de la persona, sin existir principios de justicia universales y abstractos, pues surgían de las prácticas y convenciones de una sociedad y variaban con cada una de ellas.

Desde una postura relativista, la definición de justicia de Hans Kelsen requería de una moral de la tolerancia y de la democracia, pues

si hay algo que la historia del conocimiento humano puede enseñarnos, es la inutilidad de los intentos de encontrar por medios racionales una norma de conducta justa que tenga validez absoluta, es decir, una norma que excluya la posibilidad de considerar como justa la conducta opuesta. Si hay algo que podemos aprender de la experiencia espiritual del pasado es que la razón humana sólo puede concebir valores relativos, esto es que el juicio con el que juzgamos algo como justo no puede pretender jamás excluir la posibilidad de un valor opuesto. La justicia absoluta es un ideal irracional. ${ }^{14}$

\footnotetext{
${ }^{10}$ Ética Nicomaquea, Libro Quinto, en Nino, 1993, op.cit. p.66.

${ }^{11}$ La República, Libro Primero, 352-354, en Nino, 1993, op.cit. p.65-66.

12 Suma Teológica, I-II, en Nino, 1993, op.cit. p.66.

${ }^{13}$ Hobbes, Thomas, [1651] Leviatan. O la materia, forma y poder de una república eclesiástica y civil, Buenos Aires, Fondo de Cultura Económica, 2009, pp.118-119.

${ }^{14}$ Kelsen, Hans, [1953] ¿Qué es la justicia?, no 32, traducción de Garzón Valdés, Buenos Aires, 2006.
} 
Frente a estas concepciones teleológicas, la definición deontológica de Emanuel Kant sostenía los principios básicos de la moral como autónomos, categóricos y universales, tratando a la humanidad como un fin en sí misma y no como un medio. De allí, según la relación entre justicia y bondad moral, trataba a otros como fines en sí mismos cuando respetaba sus fines subjetivos. ${ }^{15}$

John Rawls revitalizó la teoría deontológica de la justicia, recurriendo al contractualismo de las concepciones de Rousseau y Kant para oponerse al utilitarismo. Rawls definió dos principios de justicia: cada persona debe tener un derecho igual al sistema más extenso de libertades básicas (de conciencia, de palabra, contra detenciones arbitrarias, de voto, etc.), que sea compatible con un sistema igual de libertades para todos; las desigualdades sociales y económicas deben ser dispuestas de modo que sean de mayor beneficio para los menos aventajados (principio de diferencia), y deben ser abiertas a una equitativa igualdad de oportunidades. ${ }^{16}$

Kant y Rawls reemplazaron la relación entre justicia y felicidad o justicia y bien, por la relación entre justicia y libertad para elegir el bien personal. Sin embargo lo que más interesa rescatar de la teoría de Rawls para esta tesis, es su definición de las instituciones y la justicia formal. La institución es "un sistema público de reglas que definen cargos y posiciones con sus derechos y deberes, poderes e inmunidades, etc. Estas reglas especifican ciertas sanciones y garantías para cuando ocurren violaciones a las reglas". ${ }^{17} \mathrm{Al}$ ser un sistema público de normas, las personas que forman parte de una sociedad conocen las normas que existen en ella y lo que estas le exigen a él y a los demás. A su vez sabe que los demás saben esto y que él lo sabe y así sucesivamente. $^{18}$

Las instituciones definen una regla correcta, regularmente observada y adecuadamente interpretada por las autoridades. "A esta administración imparcial y congruente de las leyes e instituciones, cualesquiera que sean sus principios sustantivos, podemos llamarla justicia formal". ${ }^{19}$ La justicia formal es para las instituciones jurídicas, un aspecto del imperio del derecho que apoya y asegura las expectativas legítimas. El juez es injusto cuando no se ajusta a las reglas apropiadas o a sus interpretaciones al resolver una demanda. La fuerza de las demandas de justicia formal y de obediencia al sistema, depende claramente de la justicia sustantiva de las instituciones y de sus posibilidades de reforma.

En una concepción marxista de la justicia, Jon Elster y los defensores de su postura han sostenido que Marx avanzó sobre el principio de justicia con su sentencia “de cada uno según su

\footnotetext{
${ }^{15}$ Kant, Emanuel, Critica de la razón práctica; Fundamentación de la metafísica de las costumbres, en Nino, 1993, op.cit. p.68.

${ }^{16}$ Rawls, John, Teoría de la justicia, México, Fondo de Cultura Económica, 1995, pp. 67-72.

${ }^{17}$ Rawls, 1995, op. cit., p. 62.

${ }^{18}$ Rawls, 1995, op. cit., p.63.

${ }^{19}$ Rawls, 1995, op. cit., p.65.
} 
capacidad; a cada uno según sus necesidades". ${ }^{20}$ El liberalismo criticó esta postura por ignorar la relación interna entre la justicia y el valor de la libertad o autonomía personal, a lo que podía sumarse la igualdad, y acordarse en la necesidad de ambos valores como complementarios. El conflicto se suscitó en torno a quiénes debían ser beneficiarios de esa libertad y qué personas morales debían ser iguales. Pero se plantearon otros valores externos a la justicia, como el orden y la legitimidad política, pues quienes estaban legitimados para tomar decisiones políticas podían estarlo injustamente.

Según Jüger Habermas "la justicia debe depender de la legitimidad política, sosteniendo que el proceso de discusión y decisión democrática es la única forma de constituir principios morales intersubjetivos como los de la justicia”. ${ }^{21}$ En el derecho moderno, para que la norma jurídica fuera válida, el Estado debía garantizar las condiciones institucionales para que esta norma se produjera en términos de legitimidad y que la norma fuera obedecida, recurriendo de ser necesario a sanciones. En la modernidad la esfera pública constituyó el espacio fundamental en la mediación entre sociedad civil y Estado, siendo la opinión pública decisiva en la legitimidad política. ${ }^{22}$ Habermas partió en su análisis de la crisis de legitimidad del Estado que trajo la posmodernidad y destacó "la tensión interna entre hechos y normas". En función de esta teoría existe hoy un conflicto entre legitimidad y legalidad del Estado. ${ }^{23}$

Una definición de justicia que se apartó de lo enunciado hasta aquí, fue la expresada por Michel Foucault que, declarándose nietzscheano, expresaba que la idea de justicia en sí era una idea inventada y puesta a funcionar en diferentes tipos de sociedades como instrumento de cierto poder político y económico, o como un arma contra ese poder. El concepto de justicia funcionaba dentro de la sociedad de clases como una demanda de la clase oprimida y como su justificación. ${ }^{24}$

Con el fin de intentar una reflexión histórica "acerca del modo en que se vivenció y se pensó la justicia" en el mundo occidental, Paolo Prodi partió de una "tradición" como parte de un patrimonio cultural que llega a su ocaso. Esto no puede evitarse a pesar de toda "brillante invención teórica", haciendo referencia el autor a la obra de John Rawls. ${ }^{25}$

En cuanto a su organización, el ideal occidental de justicia -ahora en vías de desapariciónfue resultado de un itinerario mucho más prolongado que el efectuado a partir del iluminismo y de las codificaciones, y se basa sobre la copresencia de un doble plano de normas: el derecho positivo, la norma escrita, y el plano de las normas que escandieron la vida de

\footnotetext{
${ }^{20}$ Elster, Jon, Making sense of Marx, Cambridge, 1986, en Nino, op.cit. p. 71.

${ }^{21}$ Habermas, Jüger The Theory of Communicative Action, Boston, 1981, en Nino, 1993, op.cit. p. 73.

${ }^{22}$ Habermas, Jüger, Historia y crítica de la opinión pública, México, Ed. Gili, México, 1981.

${ }^{23}$ Cárdenas Rivera, Miguel Eduardo, "Acerca del vínculo entre derecho, el estado y la democracia. A propósito de Habermas y su aporte a la metodología de la interpretación y aplicación del derecho", en Utopía y Praxis Latinoamericana, enero-marzo, 2003, vol. 8, número 020, Universidad de Zulia, Maracaibo, Venezuela, pp.81-104.

${ }^{24}$ Debate con Noam Chomsky emitido por la televisión holandesa en noviembre de 1971, y publicado en el libro $L a$ Naturaleza Humana: Justicia vs. Poder, Katz Editores, 2006.

${ }^{25}$ Prodi, Paolo, Una historia de la justicia. De la pluralidad de fueros al dualismo moderno entre conciencia y derecho. Madrid, Katz Editores, 2008, p. 11.
} 
quienes nos precedieron en los últimos milenios y regularon la vida cotidiana de nuestra sociedad en su hálito más interior: ethos, mos, lo consuetudinario, ética, moral, como quiera designárselo. El vínculo entre este doble plano de normas constituyó el hálito -desde dentro de la vida a la necesaria objetivación de las instituciones- de toda la cultura jurídica occidental, hálito que mengua cuando la sociedad está normativizada en una sola dimensión. ${ }^{26}$

De esta definición sobre el origen de la organización de la justicia, surge que el fuero es el lugar físico, ideal o simbólico, donde se ejerce la justicia como juicio del comportamiento humano. Allí las controversias entre los hombres -las causas- se definen concretamente en relación con la ley y el poder, que se enfrentan con la realidad cotidiana de los hombres; allí se manifiesta el triángulo hombre-ley-poder, en todas sus formas y en todas sus expresiones, siendo el nodo central el vínculo que se establece entre delito y pecado. En la historia de la civilización cristiana occidental, el nodo medular para comprender el nacimiento del Estado de derecho y del ideal liberal es la progresiva distinción entre el concepto de pecado, como desobediencia a la ley moral, y el concepto de delito, como desobediencia a la ley positiva. ${ }^{27}$ Es necesario entrar a la vida concreta del fuero, ante el cual se convoca al hombre a responder por sus acciones. En el siglo XIX, "se tiende a extender en el pensamiento y en la práctica, el concepto de delito hasta abarcar lo máximo posible de las acciones que son consideradas peligrosas para el orden establecido, para la seguridad del Estado, o que son juzgadas en cierto modo un desvío de la moral convencional de la sociedad" ${ }^{28}$

Estos conceptos de justicia forman parte del proceso definido por Prodi como la distancia entre delito y pecado, no sólo contra la vida, sino también contra la propiedad o el honor. Para acceder a este proceso, se requiere conocer la vida del fuero y para hacerlo encaramos esta investigación en que permanentemente están presentes los hombres en relación con la ley y el poder dentro de un Estado en formación en base a la división poderes. Pero ese Estado no tuvo una única alternativa de resolución, sino que podía decidir entre distintos modelos foráneos, adaptados a su vez a cada situación local.

\section{b. Los modelos para el Estado provincial}

Para abordar aquí la doctrina de la separación de poderes en función de la formación del Estado de la provincia de Buenos Aires, hemos recurrido a la obra de Vile sobre constitucionalismo y división de poderes, con el fin de establecer las corrientes de pensamiento constitucional vigentes al momento de definir el modelo estatal. ${ }^{29}$ Sobre esta base, accedimos al libro utilizado en la

\footnotetext{
${ }^{26}$ Prodi, 2008, op. cit., p. 14.

${ }^{27}$ Prodi, 2008, op. cit., p. 19.

${ }^{28}$ Prodi, 2008, op. cit., pp. 411-415.

${ }^{29}$ Vile, 2007, op. cit.
} 
formación de los abogados, las Lecciones de derecho constitucional, del profesor de la materia en la Universidad de Buenos Aires entre 1868 y 1875, Florentino González. ${ }^{30}$

De todas las teorías del Estado que buscaron controlar el poder estatal y poner límite a su ejercicio, la más significativa fue la doctrina de la separación de poderes, un sistema de conceptos confuso y ambiguo. Esta doctrina nunca fue aplicada por si sola como base de un sistema político efectivo y estable, sino que se ha combinado con otras ideas políticas como la del estado mixto, la idea de equilibrio o el concepto de frenos y contrapesos. Según la "doctrina pura" de la separación de poderes era esencial para el establecimiento y conservación de la libertad política que el estado se dividiera en tres ramas o departamentos, llamados legislativo, ejecutivo y judicial. A cada rama le correspondía una función, y debía limitarse a cumplir la que le era propia, sin interferir en la función de las otras dos ramas. Las personas que componían cada una de las tres agencias debían ser diferentes, sin formar más de una simultáneamente.

La idea del equilibrio surgió del poder estatal dividido entre el rey y las Cámaras de los Lores y los Comunes, estando dos de las tres instancias habilitadas para evitar los excesos de la tercera en sus atribuciones. Pero la división de instituciones y de funciones no era suficiente, porque cada agencia no contaba con acciones concretas para controlar al resto y hacerlo podía ser una “interferencia” en sus funciones. De allí surgió la teoría del estado mixto, y en su versión posterior la teoría de frenos y contrapesos, que introducían en la doctrina de separación de poderes la noción de controles positivos sobre el ejercicio del poder. Cada rama recibía la potestad de ejercer un cierto grado de poder directo sobre las otras dos, autorizándolas a desempeñar un papel limitado en el ejercicio de las funciones de las demás. ${ }^{31}$

En esta división de funciones el poder legislativo cobró su identidad a partir del desarrollo de la ley como mandato -expresión de órdenes o prohibiciones más que de costumbres inmutables- y de la aparición de la moderna noción de soberanía, depositaria del poder para emitir mandatos inapelables. La doctrina de la soberanía popular estimuló la clarificación progresiva de la idea de función legislativa. La función ejecutiva diferenciada fue relativamente moderna y no se desarrolló completamente hasta finales del siglo XVIII y la primera división de funciones del Estado lo separaba en dos ramas: la legislativa y la ejecutiva, entendida bien como la función de impartir

\footnotetext{
${ }^{30}$ González, Florentino, Lecciones de derecho constitucional, Buenos Aires, Imprenta, Litografía y Fundición de tipos de J. A. Bernheim, 1869. Florentino González fue jurista nacido en 1806 en la Cincelada, Colombia, murió en Buenos Aires en 1875. Graduado antes de los veinte años ocupó diversos cargos en su país, fue diplomático, periodista, diputado, senador, ministro y académico. Por razones políticas emigró a Chile entre 1860 y 1868 . Después pasó a Buenos Aires donde ocupó el cargo en la cátedra de derecho constitucional. Tradujo obras de Stuart Mill, Grisake y de Lieber, además de constituciones de algunos Estados americanos. Tuvo una profusa producción bibliográfica entre la que se encuentra esta obra reeditada en París en 1871, 1874 y 1889.

${ }^{31}$ Vile, 2007, op. cit., pp. 13-21.
} 
justicia de acuerdo con las leyes, bien como los mecanismos por medio de los cuales se ponían en práctica las leyes. ${ }^{32}$

La judicatura apareció gradualmente como una rama independiente del Estado y la noción de un poder judicial autónomo siguió evolucionando. Si bien no puede atribuírsele a Montesquieu la originalidad de la doctrina de la separación de poderes, cierto es que enriqueció la doctrina haciendo mayor hincapié en la función judicial, encargada de sancionar a los criminales o dirimir las disputas entre los ciudadanos. Este nuevo "poder de juzgar”, lo colocó al mismo nivel analítico de las otras dos funciones estatales, estableciendo la trinidad que caracterizaría el pensamiento moderno. La judicatura sería independiente de los conflictos de intereses que surgieran en el Estado, instancia fundamental para el posterior desarrollo de la doctrina. Blackstone, discípulo de Montesquieu, "domesticó" su teoría, reuniendo y entretejiendo "las hebras sueltas del discurso" creando un alegato en pro de la existencia de un poder judicial independiente, siguiendo las líneas del que ya existía en Inglaterra, a cargo de jueces profesionales, versados en derecho. La libertad pública residía en un cierto grado de separación de la administración de justicia tanto del poder ejecutivo como del legislativo y esta fue la base sobre la que se cimentó el poder judicial de la Constitución estadounidense. $^{33}$

La división de las funciones del poder fue enseñada en Buenos Aires por Florentino González, que como profesor de Derecho Constitucional, redactó sus Lecciones, en las que definía al sistema político como la organización del gobierno y al sistema social como la organización de la sociedad, que tenían necesaria conexión y que debían armonizar. ${ }^{34}$ Las Naciones cristianas "más adelantadas en civilización y que se ocupaban mejor de sus instituciones políticas", se encontraban entre dos sistemas de gobierno. Uno era la monarquía constitucional, a la que llamó sistema europeo, y definió como una transacción entre la monarquía y la democracia, "con la cual se ha conformado el pueblo" para destruir de a poco las clase privilegiadas y establecer la igualdad. La otra, la república democrática representativa, denominada sistema americano, fue establecida en América, por los anglo-sajones que dependían de Inglaterra y se habían declarado independientes, formando una de las naciones "más poderosas y felices del mundo". Podían allí fomentar el progreso moral, intelectual y material de sus miembros bajo los auspicios de la libertad.

\footnotetext{
${ }^{32}$ Vile, 2007, op. cit., pp. 23-31.

${ }^{33}$ Vile, 2007, op. cit., pp. 97-108; 116.

34 Tengamos presente aquí que la función judicial colonial integraba la compleja actividad gubernativa y era considerada como un deber de conciencia y un altísimo honor, como una de las cuatro ramas junto con gobierno, hacienda y guerra. La tradición indiana se reflejó en el "Reglamento Provisional de las Secretarías de Estado del Supremo Gobierno de las Provincias Unidas del Río de la Plata" cuando dispuso que cada una de ellas se encargaría de las causas de gobierno, hacienda y guerra, tres de las que se indicaban en la Ordenanza de Intendentes dejando a la de justicia en ejercicio de otros órganos determinados por Reglamento de Administración de Justicia de 1812. Díaz Couselo, José María, "La tradición indiana y la formación del derecho argentino", en Temas de historia argentina y americana 7, Buenos Aires, Pontificia Universidad Católica Argentina, Facultad de Filosofía y Letras, Centro de Historia Argentina y Americana, julio-diciembre de 2005.
} 
La mayor diferencia entre ambos estaba en el sistema social, pues en el sistema europeo había transformado el "orden natural de la sociedad, que no admite que seres racionales, que se hallan reunidos con el objeto de buscar su común felicidad, se distribuyan en clases que sean unas más favorecidas que otras". El sistema americano buscaba la distribución del bien entre todos, y por tanto, según el profesor, fue la mejor para fundar los principios de la Constitución de 1853, que "calcada sobre el modelo americano, vino a formar la nacionalidad argentina, y hacerla empezar la marcha ordenada y próspera que desde entonces ha seguido con pocas interrupciones." 35

En cuanto a la soberanía popular, González aseguraba que estaba confirmada por la escritura santa, quedando establecido que el pueblo, en uso de esa soberanía, era quien podía constituir el gobierno representativo que debía regir la comunidad política. Pero esa soberanía era limitada, ya fuera ejercida en forma directa o a través de personas delegadas, pues no podía extenderse a otras cosas que aquellas conforme con los preceptos de la justicia. ${ }^{36}$

Para poder atender a todos los intereses, lo más ventajoso era distribuir el poder entre un gobierno central y gobiernos locales, pudiendo así los que lo ejercieran recibir las inspiraciones y límites de la opinión. Pero a esto debía sumarse la distribución de funciones en distintas manos que hiciesen, ejecutasen y aplicasen la ley. El problema se resolvía con la división del ejercicio de las funciones del poder en varios departamentos, cuyos miembros servían recíprocamente de "contrapeso" para contener sus excesos.

Hacer esta división, arreglar las relaciones entre los funcionarios de los departamentos que ella comprenda, asegurar a estos la independencia de acción dentro de la esfera de sus respectivas facultades, al mismo tiempo que los medios de hacerlos responsables por los abusos de autoridad que cometen, es lo que propiamente puede llamarse constituir un gobierno; pues las declaraciones de libertades y derechos que se hagan en una constitución no implica otra cosa que una limitación puesta al ejercicio del poder, y la distribución de este en distintas jurisdicciones una facilidad para atender mejor a los intereses comunes y ser controlado por los ciudadanos. ${ }^{37}$

Pero lo interesante de la enseñanza de González era el agregado de una cuarta función, fundada en el proyecto de Constitución de Bolivar, que daba al cuerpo electoral el carácter de un departamento. La función de elegir era un acto del poder soberano distinto de las funciones legislativas, ejecutivas y judiciales, generador del personal que las ejercían. Entonces la división en cuatro departamentos - electoral, legislativo, ejecutivo y judiciario- era la más apropiada, porque se fundaba en las distintas manifestaciones que el pueblo podía hacer de su soberanía, que eran elegir, legislar, ejecutar y juzgar.

En este contexto, la justicia era útil y necesaria para el gobierno y la sociedad, pues sin seguridad personal y sin propiedad no habría gente civilizada; la libertad de cada pueblo iba en

\footnotetext{
${ }^{35}$ González, 1869, op. cit., 1869, pp. 3-9.

${ }^{36}$ González, 1869, pp. 16-21.

${ }^{37}$ González, 1869, op. cit., 1869, pp. 172-173.
} 
relación a la "justicia social”. La riqueza del sistema judicial de Estados Unidos residía en que había descubierto que la justicia era un poder político, mientras que aquí se había reducido "a desempeñar el papel de ramificación de la administración, de dependencia del ejecutivo, de función del gobierno y función subalterna." El departamento judicial debía decidir sobre los derechos, tanto públicos como privados, castigar los crímenes, administrar justicia y proteger al inocente de ofensas y usurpaciones. ${ }^{38}$

\section{Creación, estructura y funcionamiento de un sistema judicial provincial: fundamentación y metodología}

La elección del tema de tesis ha estado guiada por dos cuestiones, una teórica y otra práctica. En el primer caso, coincido con Eduardo Zimmermann, en que "el eslabón, difícil de explicar, entre ley y política fue el rasgo central del proceso de construcción del Estado en el siglo XIX en América Latina" ${ }^{39}$. Comprender la formación y el funcionamiento del sistema judicial puede ayudar a desenmarañar esta relación. En cuanto a la práctica, he atendido durante años numerosas consultas de investigadores dedicados a diferentes temas por los recurrieron a la fuente judicial. El primer paso siempre ha sido explicarles de donde y en que forma ha surgido esa fuente, pues aunque su tema no sea necesariamente la justicia, no se puede realizar un trabajo heurístico sin comprender el origen del documento con el que estamos trabajando ${ }^{40}$.

La investigación se ubica en la provincia de Buenos Aires, entre 1853 y 1881. Buenos Aires no juró la Constitución Nacional hasta 1860, pero sancionó su propia Constitución en 1854, en la que declaraba que el poder judicial sería independiente de todo otro en el ejercicio de sus funciones. ${ }^{41}$ Es decir que en esta provincia la consagración de la teoría de los poderes del Estado e imposición de la ley como definidora de lo que era justo, requería de la organización del poder judicial. Si bien esto sucedía también en el resto de las provincias, la atención se centra en Buenos Aires por la particularidad de su proceso y porque en estos años la ciudad de Buenos Aires era la capital de la provincia y al mismo tiempo residencia de las autoridades nacionales, provocando esto confusión entre la justicia federal y la provincial a la hora de estudiarlas. Hilda Sábato definió a la ciudad como espacio experimental y de referencia del proyecto político argentino ${ }^{42}$, y si bien la dirigencia política que hegemonizó el poder en la provincia después de Caseros buscaba liderar la

\footnotetext{
${ }^{38}$ González, 1869, op. cit., 1869, pp.418-421.

${ }^{39}$ Zimmerman, Eduardo (editor), Judicial Institutions in Nineteenth-Century Latin America, Institute of Latin American Studies, University of London, 1999, Introduction, p.7.

${ }^{40}$ Durante veintidós años trabajé en el Departamento Histórico-Judicial de la Suprema Corte de la provincia de Buenos Aires, encargado de la preservación de los documentos producidos por el Poder Judicial de la provincia de Buenos Aires. Actualmente formo parte de la Biblioteca central de la Suprema Corte.

${ }^{41}$ Artículo 118 de la Constitución de la provincia de Buenos Aires de1854.

${ }^{42}$ Sábato, Hilda, La política en las calles. Entre el voto y la movilización. Buenos Aires, 1862-1880, Buenos Aires, Editorial Sudamericana, 1998, p.11.
} 
construcción de un Estado y un orden político nacionales, esa ciudad era la capital de una provincia, que tenía su vida política, económica y social, con un sistema judicial en formación, parte de su Estado provincial, que es necesario diferenciar.

En cuanto a los años establecidos como marco cronológico, debemos advertir que estamos hablando de procesos en los que no pueden establecerse cortes definidos; pero como es necesario limitar nuestra tarea, hemos puesto como fechas límite 1853 y 1881. El año 1853 fue significativo para la organización judicial, pues, aún antes de sancionarse la Constitución provincial, se instalaron juzgados de primera instancia en la campaña, a partir de un proyecto de Valentín Alsina, que como presidente de la Cámara de Justicia observó la imperiosa necesidad de llevar jueces letrados al interior de la provincia. A lo largo de estos años la preocupación sobre la administración de justicia giró en torno a la organización del más alto tribunal, la descentralización judicial, la formación técnica de los magistrados, la fundamentación legal de las sentencias y la codificación. La Constitución provincial de 1873 introdujo cambios como la creación de la Suprema Corte, la segunda instancia, el juicio por jurados y la elección popular de los jueces de paz. Las dos últimas reformas no se concretaron y la estructura definitiva del poder judicial provincial quedó formalizada en su primera ley orgánica en 1881, para una provincia que ya no contaba con la ciudad de Buenos Aires como capital.

En sus lecciones, Florentino González explicaba que para cumplir con sus fines, el poder judicial requería de una organización, no sólo para que lo pusiera "a cubierto de influencias que pudieran pervertirla, sino que facilite los medios de hacer eficiente su acción benéfica sobre la sociedad". ${ }^{43}$ Es decir que la organización institucional tenía dos claros objetivos: evitar la corrupción y asegurar la eficiencia en beneficio de la sociedad. Puesta en vigencia la Constitución de 1873 , legisladores y magistrados hablaban de una "nueva organización que requería de las leyes orgánicas de esos Tribunales y las reglamentarias de los juicios". ${ }^{4}$ Se confunden aquí dos significados para la expresión "procedimientos judiciales", uno como organización y otro como procedimiento propiamente dicho. A los fines de nuestra investigación, el término organización judicial abarcará, respecto a los tribunales y juzgados, la creación (ley que les dio origen, antecedentes y debates legislativos), la estructura (miembros que los componían y función que desempeñaban) y el funcionamiento (interno; en relación con otros juzgados y oficinas de Gobierno o Legislatura).

\footnotetext{
${ }^{43}$ González, 1869, op. cit., p. 425.

${ }^{44}$ Malaver, Antonio, Curso de procedimientos judiciales en materia civil y mercantil, Buenos Aires, Imprenta especial para obras, de Pablo E. Coni, 1875.
} 


\section{a. Objetivos}

Objetivo general: estudiar el proceso de formación y consolidación del poder judicial como parte constitutiva del Estado provincial, legitimador de su accionar político y mediador con la sociedad civil.

Objetivos específicos:

1. Aprehender los conceptos de justicia y cultura jurídica imperantes en el período, teniendo en cuenta la relación entre el iusnaturalismo y la doctrina liberal. ${ }^{45}$

2. Relacionar las modificaciones espaciales del territorio provincial con la división jurisdiccional, la concentración de funciones y la competencia de los magistrados.

3. Establecer quiénes eran, de dónde provenían, cuál era la formación y ubicación en el contexto político de los integrantes del poder judicial y establecer la forma de elección, duración en el cargo, formas de control de su desempeño en el sistema judicial (práctica institucional-judicial). Esto irá acompañado de los organigramas que se puedan reconstruir, en función de la legislación de forma y de fondo que fue modificando el funcionamiento del fuero.

\section{b. Hipótesis}

- El sistema judicial de la provincia de Buenos Aires comenzó su formación como poder del Estado a partir de la reforma rivadaviana. El proceso alcanzó su madurez entre 1853 y 1881, como parte fundamental del proyecto liberal, asentado sobre la autoridad de la ley. El poder judicial garantizaba la legitimidad del sistema político republicano de matriz liberal, buscando superar la falta de confianza, herencia del sistema jurídico colonial, y la justicia urbana y subordinada del período pos independiente. Sin embargo, la dependencia se mantuvo en parte, representada en el presupuesto, los nombramientos y el jury de enjuiciamiento.

\footnotetext{
45 Leandro Di Gresia realizó un pormenorizado recorrido por las definiciones de cultura jurídica para proponer diferenciar "cultura jurídica", "cultura legal” y cultura judicial”, como conceptos autónomos pero intercomunicados. La cultura jurídica es el concepto más amplio que comprende el universo de lo jurídico a escala nacional e inclusive continental, pero que a la vez y paradójicamente, es el más limitado socialmente, en tanto está vinculado con la producción de derecho en íntima relación con las élites dirigentes y los profesionales de la ley. La cultura legal incluye saberes y concepciones más abstractas respecto a la ley, los derechos, el transgresor, el delincuente, lo justo y lo injusto, la autoridad que decide y opera, que son compartidas por los miembros de una determinada sociedad. La "cultura judicial" es el conjunto de las apreciaciones y concepciones que los miembros de una sociedad tiene acerca de "la justicia" -en tanto valor social- y las instituciones judiciales -en tanto ordenadores de la vida cotidiana puestos al alcance de la población para dirimir sus conflictos. En este núcleo simbólico-conceptual ocupan un lugar destacado la percepción de la legitimidad/ilegitimidad de los funcionarios judiciales y la imagen de ecuanimidad/ inecuanimidad del procedimiento judicial. Junto a esto, existe un núcleo práctico de esta cultura, un saber hacer en situación judicial, especie de "recetas" aprendidas en la experiencia, formas de litigar y estrategias puestas en juego por víctimas e imputados. En este núcleo práctico se diferencia una cultura judicial lega de una letrada, en las formas de litigar, las estrategias puestas en juego en un proceso o el uso dado a la justicia. Di Gresia, Leandro, "Una aproximación al estudio de la cultura judicial de la población rural bonaerense. Tres Arroyos, segunda mitad del siglo XIX”, en Barriera, Darío, (coordinador) La justicia y las formas de autoridad. Organización política y justicias locales en territorios de frontera. El Río de la Plata, Córdoba, Cuyo y Tucumán, siglos XVIII y XIX, ISHIR CONICET-Red Columnaria, Rosario, 2010, pp. $163-164$
} 
- La organización judicial en formación incluyó al ámbito rural con una fisonomía institucional que tendía a consolidar la relación entre Estado y sociedad civil. Esta manifestaba sus necesidades a través de la opinión pública y el poder las interpretaba con el fin de legitimar su acción política. En este proceso de legitimación, el poder judicial era funcional al Estado, lo que luego se consolidó. La Constitución de 1873, a pesar de ser ideal en algunas de sus propuestas, dio protagonismo y efectividad a las instituciones judiciales que se formaron y pusieron en funcionamiento con una nueva concepción de justicia, que sin dejar de lado el derecho natural se consolidó en una función más positiva, atenta a los derechos individuales y de propiedad.

La consagración de la división de poderes en el texto constitucional de 1853 fue el resultado de un largo proceso histórico que requirió de una profunda transformación de la sociedad civil y de la comunidad política. La división de poderes, directamente relacionada con la extensión de libertades individuales y los cambios en el derecho de propiedad, requirió de años de ensayos y debates. ${ }^{46}$ El tiempo transcurrido entre 1820 y 1853 fue el "período genético" de las instituciones políticas ${ }^{47}$ que, sin romper totalmente los moldes de la estructura colonial, se inspiraron en el modelo liberal buscando legitimar el poder fortaleciendo la figura del ciudadano y dando contenido a la idea de progreso. La conformación de cada uno de los poderes fue conflictiva. En lo relativo al poder judicial, el debate estuvo centrado en torno a su definición como ramo de gobierno o poder del Estado. Esta definición estaba ligada al concepto de justicia que a lo largo del siglo XIX fue cambiando de "arraigada virtud" y "guía de los gobernantes"48 a una concepción externa, legal, que tenía como finalidad la defensa de la seguridad individual antes que el bien común.

Para comprender el rol que jugó el sistema de justicia en la formación del Estado es necesario desenmarañar la compleja trama de relaciones entre poder político y magistrados, y a su vez entre ellos y la sociedad. Pero esto no se puede realizar sin conocer y comprender qué entendían por justicia y cómo organizaron su administración. Gran parte de la crisis institucional por la que pasa hoy el poder judicial se encuentra ligada a su conformación orgánica y a su eficacia funcional, que formaron su base en el periodo que estudiamos. La organización institucional y el mapa judicial siguen creciendo sobre la estructura sellada entre 1853 y 1881 en una provincia que ha extendido su territorio, multiplicado sus habitantes y ampliado sus problemas.

\footnotetext{
${ }^{46}$ Cansanello, Carlos Oreste, De súbditos a ciudadanos, ensayo sobre las libertades en los orígenes republicanos 1810 1852, Buenos Aires, Imago Mundi, 2003, Capítulo V.

${ }^{47}$ Tau Anzoátegui, Víctor, "La administración de justicia en las provincias argentinas (1820-1853)", en Revista de Historia del Derecho, Buenos Aires, Instituto de Investigaciones de Historia del Derecho, no 1, 1973, p.205.

${ }^{48}$ En el Derecho indiano la Justicia era fin supremo del Estado, para lograr la paz y el desarrollo de las demás virtudes. Función gubernativa que no estaba limitada a ciertos órganos o poderes del Estado, sino que concernía a la generalidad de estos. El Rey orientaba a la comunidad hacia el bien común mediante el ordenamiento legal inspirado en la justicia. Zorraquín Becú, Ricardo, La organización judicial argentina en el período hispano, Buenos Aires, Librería del Plata, 1952, Capítulo I: La función de justicia en el derecho indiano, pp.7-28.
} 


\section{c. Metodología}

Desde la historia política renovada, la construcción del Estado y de la Nación, temas tradicionales, han recibido una nueva mirada, concebidos como problemas y no como presupuestos, centrándose en las relaciones entre sociedad civil y sociedad política. El eje central es la construcción, reproducción y legitimación del poder político que involucran a la dirigencia y a la comunidad política. En el Río de la Plata, la opción por la república representativa genera interrogantes sobre las formas de soberanía, representación y participación, de los lenguajes políticos y de las identidades colectivas, de la esfera pública y de las instituciones, donde el poder judicial adquiere centralidad. ${ }^{49}$

Para abordar este tema, Helmut Coing aconseja que desde la historia del derecho, como para toda investigación histórica, debe partirse de la búsqueda de fuentes, definiendo la idea de Derecho de la época y así establecer las fuentes del Derecho. El paso siguiente es exponer el pensamiento jurídico para, con ambas cosas, comprender las normas y las instituciones. ${ }^{50}$ Esta tarea requiere de gran cuidado para no caer en conceptos jurídicos anacrónicos, logrando observar que fueron respuesta a problemas de la época, en los que debemos a su vez distinguir los relacionados con la organización política, económica y social, de los problemas técnicos de las ciencias jurídicas, teniendo en cuenta que las ideas fundamentales sobre los institutos e instituciones especiales están vivas en el espíritu del pueblo y las cuestiones técnicas corresponden a los juristas.

La solución a los problemas sociales suele basarse o estar ligada a soluciones anteriores, por ello deben tenerse en cuenta la tradición y la reforma a la hora de construir el ordenamiento jurídico que se investiga. Para Coing es indispensable establecer la relación entre la solución jurídica y los factores extrajurídicos de una época, poniendo como punto de partida el tratamiento hermenéutico de los textos. Determinar las intenciones del autor de las normas puede llevarnos a encontrar el camino de las fuerzas ideales y sociales, para lo que también es esencial averiguar sobre la vida y la formación de los legisladores y magistrados.

La última etapa es la que se refiere a la realización o cumplimiento del derecho. La primera cuestión es la fuerza o poder que lleva consigo todo ordenamiento jurídico. La siguiente es el estudio de la organización institucional a la que es encomendada la realización del derecho. ${ }^{51}$ Esto incluye las normas que le dieron origen, el funcionamiento de las instituciones (duración de los

\footnotetext{
${ }^{49}$ Sábato, Hilda, "La política Argentina en el siglo XIX: notas sobre una historia renovada"; en Ensayos sobre la Nueva Historia Política en América Latina, siglo XIX, México, El Colegio de México y Comité Internacional de Ciencias históricas, 2007.

${ }^{50}$ Coing, Helmut, Las tareas del Historiador del derecho (reflexiones metodológicas), Publicaciones de la Universidad de Sevilla, Sevilla, 1977.

51 Eduardo Martiré, destacando textos de Alfonso García Gallo, insiste sobre la necesidad del estudio de las instituciones vinculándolas a lo social pero teniendo la precaución de no vaciarlas de lo jurídico. "La Historia del Derecho, disciplina histórica", en Revista de Instituto de Historia del Derecho Ricardo Levene, núm.20, Buenos Aires, 1969, p.93.
} 
procesos, acceso, nivel de corrupción), su competencia y composición (origen social, situación económica), el uso que los sujetos de derecho han hecho de las instituciones. En la realización de esta investigación atenderé a las soluciones que el ordenamiento jurídico debía brindar a una determinada sociedad ${ }^{52}$ en las instituciones que lo formaron ${ }^{53}$ y las ideas de quienes lo gestaron. ${ }^{54}$

El uso de la fuente judicial será fundamental para poder unir teoría y praxis, comprobar si la letra de la ley fue cumplida en la administración de justicia y de qué manera. Pero cabe aquí advertir que con este término no nos limitamos al expediente, sino que incluimos los Acuerdos y sentencias de los tribunales superiores, las notas de los juzgados de primera instancia y de paz, y todos los documentos emanados del funcionamiento del poder judicial. Sobre la metodología de su uso ha sido fundador Carlos Mayo, junto a Silvia Mallo y Osvaldo Barreneche, que no sólo enunciaron los beneficios de dicha fuente para la definición de los marcos normativos que sostienen la trama social, el conocimiento de la vida cotidiana y el rescate de las prácticas no escritas de la sociedad, sino que advierten y responden sobre los problemas teórico-metodológicos. Estos son una posible visión sesgada de la sociedad, dominada por el conflicto, que se resuelve completando la investigación con otra fuente; la representatividad del caso, a lo que responden que cada caso es real y se representa a sí mismo; la dificultad de generalización, pero que permite sacar un patrón de comportamiento; la duda sobre la verdad de lo que expone la fuente, sosteniendo que lo importante es la verosimilitud. ${ }^{55}$

Arlette Farge, a través de su experiencia en el archivo judicial de París, hace una bella descripción de la fuente judicial y las potencialidades de su uso. La presenta como una vía de acceso a los conflictos sociales, las formas de expresión popular, de representación y sociabilidad. ${ }^{56}$ Pero como hemos dicho, la fuente judicial confirmará o no la aplicación de las leyes dictadas por el poder legislativo y los decretos emanados del ejecutivo. Por ellos será necesario reconstruir los organigramas del poder judicial a partir del estudio de los Registros Oficiales y los debates legislativos de la provincia. Los debates legislativos permiten ver los complejos vínculos e identificaciones de los viejos integrantes de esos espacios jurídicos y los nuevos actores con sus

\footnotetext{
${ }^{52}$ Coing, 1977, op. cit., pp. 36, 52.

${ }^{53}$ Martiré, 1969, op. cit, p.94.

${ }^{54}$ Zorraquín Becú, Ricardo, “Apuntes para una teoría Apuntes para una teoría de la Historia del Derecho”, en Revista de Instituto de Historia del Derecho Ricardo Levene, núm.24, Buenos Aires, 1968, p. 323-342; Egües, Carlos A., "Objeto y método en la historia de las ideas políticas", en Investigaciones y Ensayos, Academia Nacional de la Historia, núm.49, Buenos Aires, 1999.

${ }_{55}$ Mayo, Carlos, Mallo, Silvia y Barreneche, Osvaldo, "Plebe urbana y justicia colonial. Las fuentes judiciales. Notas para su manejo metodológico", Estudios-Investigaciones, №1, Facultad de Humanidades y Ciencias de la Educación de la Universidad Nacional de la Plata, 1989, pp.47-80. Estos autores junto a Raúl Fradkin cerraron las Jornadas sobre La Fuente Judicial en la construcción de la memoria, organizadas por la Suprema Corte de la Provincia de Buenos Aires y la Universidad Nacional de Mar del Plata en 1999, en cuya publicación fueron reproducidas sus ponencias. En ellas enriquecen lo dicho y Raúl Fradkin sostiene que no siempre los grandes cambios anunciados en la organización de la justicia o en la normativa vigente se hacen evidentes en la práctica judicial. Los expedientes se impregnan del discurso político y de los hechos de la vida política.

${ }^{56}$ Farge, Arlette, La atracción del archivo, Valencia, Edicions Alfons el Magnànim-IVEI, 1991.
} 
resistencias a legitimar lo propuesto como normalidad y su esfuerzo por ubicarse en una comunidad política asentada en la soberanía del pueblo. La observación de las fuentes a utilizar nos permite agregar que nuestra tarea incluirá la elaboración de mapas de la provincia, escasos para estos años, en los que podamos observar el avance de la frontera y la expansión del sistema judicial.

A los fines metodológicos es de utilidad rescatar las definiciones de Carlos Garriga en relación al universo judicial.

Si la justicia se define como la constante y perpetua voluntad de dar a cada uno lo suyo, actos judiciales son aquellos que declaran en cada caso el derecho (de cada uno). Por ser actos de jurisdicción, los magistrados son los únicos oficiales facultados para dictarlos y se definen por el procedimiento seguido en su adopción: son los actos dictados con conocimiento de causa, esto es, para resolver un conflicto mediante proceso, que entonces como ahora tenían por nombre propio el de sentencia. ${ }^{57}$

La tesis está dividida en once capítulos, los tres primeros están dedicados a los antecedentes inmediatos del período en estudio y a las ideas de quienes proyectaron la administración de justicia. Los capítulos IV al VI están dedicados a las distintas instancias del poder judicial previo a la constitución de 1873 y los capítulos VII al IX al posterior. Los capítulos X y XI realizan dos estudios de caso, para observar en funcionamiento al sistema judicial y a sus protagonistas a lo largo de estos treinta años. El estudio de caso es una estrategia de investigación, definida por la elección del objeto de estudio, "el caso", que concentra la atención investigadora orientada a un análisis intenso de sus significados con la intensión de comprenderlo. En nuestra tesis, a partir del interés por estudiar un fenómeno general, seleccionamos dos casos de observación para proveer una base empírica a nuestro estudio. Con Robert Stake podemos decir que nuestro estudio de caso es instrumental, pues cumple el rol de mediación para comprender un fenómeno que lo trasciende -la administración de justicia- en una investigación que va más allá y utilizándolo como instrumento para observar la estructura y el funcionamiento del poder judicial con sus protagonistas. ${ }^{58}$

En el capítulo I se presentan y analizan las principales disposiciones que afectaron a la administración de la justicia desde 1810, buscando rastrear las ideas que acompañaron el proceso que llevó a la ley de 1821 -punto de llegada y de partida- y los cambios (novedosos o no) de la organización judicial que proponía. Es importante estar atentos a la jurisdicción que abarcaban los cambios que se intentaban imponer, pues entre 1810 y 1820 fueron de alcance "nacional", pero luego Buenos Aires como provincia autónoma creará su propio poder judicial.

Partiendo del contenido de la ley que en 1821 modificó la organización judicial, en el capítulo II nos proponemos indagar en los proyectos de organización judicial, la bibliografía académica, los

\footnotetext{
${ }^{57}$ Garriga, Carlos, "Gobierno y Justicia: el Gobierno de la Justicia”, en Lorente Sariñena (directora), La jurisdicción contenciosa-administrativa en España. Una Historia de los orígenes, Cuadernos de Derecho Judicial VII, Madrid, Consejo del Poder Judicial, Centro de Documentación Judicial, 2009.

${ }^{58}$ Marradi, Alberto, Archenti, Nélida y Piovani, Juan Ignacio, Metodología de las ciencias sociales, Buenos Aires, Cengage Learning, 2010, capítulo II "Estudios de caso", pp. 213-222.
} 
mensajes de los gobernadores, leyes y decretos relacionados buscando determinar las ideas y conceptos liberales innovadores en el discurso político y jurídico sobre los que se pretendía estructurar y hacer funcionar el sistema judicial. Si bien en muchos casos no superaron la teoría y no llegaron a llevarse a la práctica, conformaron un legado sobre el que se organizó el poder judicial bonaerense entre la instalación definitiva de la primera instancia letrada a la campaña en 1853 y la ley orgánica judicial de 1881, sancionada para una provincia que había perdido su capital.

A los fines de crear un observatorio de los códigos culturales compartidos por los hombres que proyectaron la administración de justicia, seleccionamos dos autores, a partir de cuyas miradas podremos conformar un repertorio con matices sobre el cual se iba a configurar la organización del poder judicial, en el capítulo III realizaremos una cuidadosa lectura del pensamiento de dos políticos y juristas, Vicente Fidel López y Antonio E. Malaver, que expresaron sus ideas sobre la formación y el funcionamiento de los organismos judiciales de la provincia. Su estudio nos permitirá analizar en las ideas de estos intelectuales, los códigos culturales de la época que se abrió a partir del final del régimen político encarnado por Juan Manuel de Rosas.

El objetivo del capítulo IV es conocer y analizar la justicia de paz como organismo administrativo y judicial y su relación con el Gobierno y los otros órganos judiciales. Para ello hemos dividido el capítulo en tres partes. En la primera determinaremos la concentración de funciones administrativas, policiales y judiciales en el juez de paz, que se prolongó más allá de la sanción de la Constitución provincial, y la ampliación de competencia de los jueces de paz en los distintos aspectos de la organización local. En la segunda nos introduciremos en un juzgado a través de sus notas, como estudio de caso para determinar su movimiento y sus relaciones administrativas y judiciales. Finalmente, describiremos la preocupación por la descentralización que manifestaban los hombres de Estado y que apuntaba, fundamentalmente, a lograr que el juez de paz se convirtiera en la base del sistema judicial provincial, terminando con su poder omnímodo.

Para la provincia, el proceso de constitución y consolidación del poder judicial como parte constitutiva del Estado, legitimador de su accionar político y mediador con la sociedad civil, ha sido poco estudiado después de 1852, menos aún la conformación de su primera instancia. Este capítulo V está dedicado a estudiar en primer lugar cómo se conformó la primera instancia en todos sus fueros y para toda la provincia. Luego nos dedicaremos a las características de la magistratura, para finalmente determinar quiénes la ocuparon en esa primera instancia. Entre 1853 y 1874 se sentaron las bases para la formación de la carrera judicial, con abogados dedicados a la magistratura (hombres "íntegros y competentes") que comenzaban a dejar la vida política para dedicarse a una formación específica que se expresaría en la especialización del derecho positivo de los años siguientes. De aquí la tarea realizada en este capítulo con los debates parlamentarios y la legislación para comprender cómo surgieron y cuáles fueron las raíces de la justicia de primera instancia civil, 
criminal y correccional, teniendo en cuenta todo el territorio provincia y las diferencias que se establecieron entre capital y campaña.

Sigue ahora investigar la reforma de la Cámara de Justicia que dio como resultado la constitución del Superior Tribunal, que encabezaría la administración de justicia provincial desde 1857, con el objetivo de saber si se trató de una nueva institución, conocer las ideas que guiaron su organización y establecer el grado de dependencia con los demás poderes. En este capítulo VI será de especial interés definir las atribuciones del Tribunal, centrándonos en lo referido a la corrección disciplinaria y de enjuiciamiento, y a la competencia en los conflictos entre el poder ejecutivo y los particulares. Basados en los debates de los legisladores provinciales, definiremos qué papel jugaba el poder judicial como parte fundamental del proyecto liberal, asentado sobre la autoridad de la ley y la división de poderes del Estado provincial. Por esto nos dedicaremos especialmente en este capítulo a los debates de las leyes que sostuvieron el proceso de conformación del Superior Tribunal, sus atribuciones e integración.

Surgen entonces nuevas preguntas en el capítulo VII, específicamente relacionadas con el concepto de garantía; garantías para el magistrado como administrador de justicia y para el pueblo como receptor de esa justicia. Las respuestas a esas preguntas, que indagaremos en los debates constitucionales que se desarrollaron entre 1870 y 1873, deberán tener presente la relación entre lo político y lo jurídico, permanentemente puesto de manifiesto en los discursos de las sesiones de la Convención. Para poder comprender mejor los debates, hemos seguido a pie de página la evolución de los tres proyectos previos y el de la Constitución desde el primero, presentado por la Comisión dedicada al Poder Judicial. Luego de acceder a la conformación del poder judicial en sus distintos niveles, analizaremos los debates de la Constitución provincial, concluida en 1873, como un "momento bisagra", en que se articularon un punto de llegada y otro de partida.

En el caso concreto de la estructura judicial de la provincia de Buenos Aires, se han realizado investigaciones relacionadas especialmente con el fuero criminal, pero nos proponemos en el capítulo VIII determinar cómo se organizó el poder judicial en general, después de la Constitución provincial de 1873, y establecer la participación de los tres poderes en la organización del nuevo poder. El objetivo es, desde una perspectiva institucional, determinar el significado de la división de poderes en el Estado provincial y el papel que el poder judicial jugó en ella.

Conociendo la estructura que el sistema judicial, el objetivo del capítulo IX es determinar entre 1875 y 1881 quiénes lo conformaron, reflejando todos los movimientos de personal (nombramientos, renuncias, fallecimientos, reemplazos, etc.). Es por esto que volcamos la investigación en cuadros comenzando por los primeros nombramientos realizados el 27 de agosto de 1874 por decreto del poder ejecutivo en cumplimiento de lo dispuesto en el artículo 217 de la Constitución provincial de 1873 y en la ley del 30 de junio de 1874, con acuerdo del Senado del 26 
de agosto de 1874. En este contexto, consideramos que esta “instantánea” tomada al poder judicial bonaerense en la segunda mitad de la década de 1870, resulta un (imprescindible) primer paso que puede devenir en la base para una indagación ulterior.

El brutal asesinato en 1856 de un pintor de la sociedad porteña y la condena a muerte de su esposa -que lo planeó- y de sus ejecutores, constituye el núcleo del capítulo $\mathrm{X}$, ya que este caso instaló en la agenda política de la provincia el debate sobre el indulto de la pena capital y sobre la división de poderes del Estado que se estaba organizando. A lo largo de los doce años que se extendió la causa puede observarse en acción a todos los agentes judiciales de la justicia criminal (incluidos algunos de la justicia civil relacionados con los bienes y los hijos del difunto), desde el alcalde hasta los magistrados del Superior Tribunal. El expediente se convierte así en un observatorio de la organización y el funcionamiento de la justicia criminal vistos desde distintas perspectivas. El capítulo se desarrolla siguiendo la evolución de la causa por dos razones; en primer lugar porque permite conocer el funcionamiento del "universo judicial" en el que magistrados, funcionarios, agentes judiciales, víctimas y victimarios se mueven. En segundo lugar por ser necesario para comprender la trayectoria de los enunciados normativos de garantías que se sancionaron en estos años.

Finalmente, el capítulo XI se propone conocer la relación entre administración de justicia y propiedad. Siguiendo el litigio entre Luis Goya, dueño de tierras del Fortín Esperanza, y los chacareros, a quienes fueron prometidas, seguiremos el proceso legal para la resolución de los conflictos que hemos planteado. Analizamos de este modo la actitud del Gobierno, que debía dar respuesta a la gestión de administraciones anteriores, como así también las relaciones entre el poder ejecutivo y el poder judicial, que a nivel local estaban representadas en la figura del juez de paz. Damos cuenta, entonces, de las modificaciones que se fueron operando durante este período en el que se fue definiendo la división de poderes y se organizó la administración de justicia bonaerense.

\section{Historiografía del tema}

\section{a. El concepto de justicia paralela y justicia formal}

Desde la perspectiva foucaultiana de la justicia, aplicada a las instituciones de vigilancia y control, Lila Caimari ha estudiado la historia del castigo administrado por el Estado moderno al criminal, entre fines del siglo XIX y las primeras décadas del XX. Esa mirada le permitió a la autora integrar interrogantes sobre el proceso de formación estatal, los modos de relación de los grupos subordinados con la ley y las instituciones, y su relación con la sociedad. ${ }^{59}$. De sus investigaciones concluye una definición de justicia paralela, según la cual,

\footnotetext{
${ }^{59}$ Caimari, Lila, Apenas un delincuente, crimen, cultura y castigo en la Argentina, 1880-1955, Colección Historia y Cultura, Buenos Aires, Siglo XXI, 2004, Introducción.
} 
este universo legal paralelo, parte real y parte fantasía, no estaba hecho solamente de denuncia: también había en él todo un código de premios y castigos que canalizaba las potentes tensiones simbólicas en movimiento en las acusaciones cotidianas. Los derechos de expresión de los perseguidos y condenados encontraban su realización en este espacio alternativo, en el que se volvía a repartir las cartas de las culpas y las disculpas. Al corregir simbólicamente las injusticias de la ley, el universo penal de crítica se completaba a sí mismo. $\mathrm{Su}$ éxtasis denunciativo se colma fuera de las instituciones, en el mundo ficticio de la justicia paralela, donde jueces, carceleros y policías son castigados con el ridículo y donde el ingenio del perseguido es celebrado. ${ }^{60}$

Al estudiar el delito, la justicia y el castigo en Chile y América Latina, el historiador chileno Mauricio Rojas Gómez reunió varias de las definiciones de justicia, pero partiendo del concepto de legitimación de E.P. Thompson. ${ }^{61}$ Concluyó así, que en la sociedad convivían dos justicias, una legal formal y otra popular legítima; al Estado le competía la legalidad y a la sociedad civil la legitimación, nacida de conductas consideradas parte de su subsistencia. La comunidad fue desarrollando estrategias y mecanismos para acomodarse a la legalidad y le confirió legitimidad a ciertas acciones, aunque no estuvieran de acuerdo con la ley. Los llamó "códigos normativos de los sectores subalternos" que respondieron a patrones culturales de lo que se estimaba como justo. ${ }^{62}$

Ampliando su marco de análisis a la cultura popular, en relación con la cultura política en el espacio urbano, José Carlos Barreiro definió para Brasil espacios de relaciones humanas informales que se contraponían a organizaciones de hombres en los llamados espacios institucionales de poder, en los que se incluían el Estado y sus canales institucionales como también las formas organizativas operarias. ${ }^{63}$

El interés de esta investigación está centrado en la justicia definida como formal, encarnada en la ley y puesta a consideración de hombres que formaban una institución, un poder del Estado, el poder judicial. Los modelos europeos que inspiraron los primeros intentos de organización institucional marcaban un claro predominio del poder ejecutivo o del poder legislativo, por ello se dio una estrecha relación entre política y judicatura hasta la organización nacional y podríamos decir, difícil de superar hoy. ${ }^{64}$

\footnotetext{
${ }^{60}$ Caimari, 2004, op. cit., pp.217-218.

${ }^{61}$ Thompson, E. P., Tradición, revuelta y conciencia de clase. Estudios sobre la crisis de la sociedad preindustrial, Barcelona, Editorial Crítica, 1989, p.65.

${ }^{62}$ Rojas Gómez, Mauricio F., "Estrategias y legitimidad en las rupturas matrimoniales y bigamia de la provincia de Concepción, 1820-1875", en Revista de Historia del Derecho, Nº19, 2003-2004, Centro de Investigaciones de Historia del Derecho del Departamento de Ciencia del derecho, Facultad de Derecho de la Universidad de Chile, pp.199-221; Charla ofrecida el 30 de noviembre de 2006 en el Instituto de Investigaciones de Historia del Derecho, Buenos Aires, sobre "Criminalización y legitimidad en torno al delito de abigeato en la Provincia de Concepción (Chile). 1820 $1850 ”$.

${ }^{63}$ Barreiro, José Carlos, “A rua e a taberna. Algunas consideraçoes teóricas sobre la cultura popular e cultura polític. Brasil, 1820-1880. I Congreso de Latinoamericanistas, Salamanca, 1996. História, Sao Pablo, 16:173-184, 1997.

${ }^{64}$ Pugliese,María Rosa, "La administración de justicia”, en Nueva Historia de la Nación Argentina, tomo 5, Academia Nacional de la Historia, Buenos Aires, Planeta, 2000, pp.405-438.
} 
La dialéctica entre teoría y praxis, presente en la creación de todo derecho, fue formadora no sólo de la organización judicial formal sino de la cultura jurídica dentro de un contexto histórico. ${ }^{65}$.Conocerla, requiere desprenderse del presente para partir del pasado y una vez allí buscar que los juristas nos permitan aprehender el ordenamiento jurídico, con sus continuidades y discontinuidades. Esta tarea implica, como afirma Carlos Garriga, asumir que el Derecho es toda una cultura, que presupone una concepción de la persona y del mundo y que para acceder al orden jurídico de determinada época se requiere acceder a las reglas, a su formulación y a su mecanismo de cumplimiento dentro de la cultura que les da sentido. ${ }^{66}$

Ricardo Zorraquín Becú, en sus Apuntes para una teoría de la Historia del Derecho estableció como Derecho todo lo que ha existido como tal, en las normas, en la práctica y en las ideas. Además de conocer el derecho escrito debe conocerse como funcionó, de qué manera fue interpretado y aplicado, en qué medida tuvo vigencia y si surgieron costumbres contrarias o supletorias. El autor destacó la necesidad del análisis integral de cada institución estudiando sus antecedentes y su contenido, sus características y transformaciones. ${ }^{67}$ En este proceso tiene sentido estudiar hasta qué punto continuó el predominio del derecho natural y de gentes, que Juan Carlos Chiaramonte definió como fundamento de las ideas políticas de la primera mitad del siglo XIX. ${ }^{68}$

\section{b. La formación del Estado}

Sobre la formación del Estado en América Latina, Fernando López Alves concluyó que la diferencia más importante en la construcción de las instituciones fue política. En Chile, Argentina y México, las instituciones estatales crecieron fuertes y fueron capaces de monopolizar la coerción, en cambio en Uruguay, Colombia y Venezuela permanecieron débiles y no pudieron afirmarse en la campaña. Respecto a la creación del Estado, en Colombia, Chile, Uruguay, Argentina y Perú, estuvo liderada por la elite política, coalición tradicional de intereses terratenientes y mercantiles, mientras que en Venezuela y Paraguay, la encabezaron el ejército y las asociaciones de milicias. Para explicar estas diferencias el autor intentó develar dos enigmas: la complejidad de la formación del Estado, ligada a la centralización del poder y el diseño de las instituciones de gobierno; el tipo de coalición y su impacto en la formación del régimen, entendiendo éste como el método utilizado

\footnotetext{
${ }^{65}$ Díaz Couselo, José María, "Pensamiento jurídico y renovación legislativa", en Nueva Historia de la Nación Argentina, tomo 5, Academia Nacional de la Historia, Buenos Aires, Planeta, 2000, pp.363-403.

${ }^{66}$ Garriga, Carlos, "Historia y derecho, historia del derecho" y "Orden jurídico y poder en el Antiguo Régimen" en Istor, Revista de Historia Internacional, año IV, núm.16, México, primavera del 2004, pp.3-8, 13-44. En ambos trabajos el autor toma los conceptos metodológicos del enfoque histórico-jurídico crítico destacando a António Manuel Hespanha y a Bartolomé Clavero.

${ }^{67}$ Zorraquín Becú, 1968, op. cit., p.323-342. Sus ideas fueron retomadas por José María Díaz Couselo en "Las Ideas de Ricardo Zorraquín Becú sobre la Historia del Derecho", Revista de Historia del Derecho, núm. 28, Homenaje a Ricardo Zorraquín Becú, Buenos Aires, Instituto de Investigaciones de Historia del Derecho, 2000, pp. 39-75.

${ }^{68}$ Chiaramonte, Juan Carlos, Nación y Estado en Iberoamérica. El lenguaje político en tiempos de las independencias, Buenos Aires, Editorial Sudamericana, 2004.
} 
para elegir a los gobernantes, los mecanismos de representación y los modelos de represión $\operatorname{adoptados}^{69}$.

En esta tesis es fundamental comprender cómo se formó el Estado provincial y qué relación estableció con el Estado nacional. Juan Carlos Chiaramonte analizó la cuestión de qué fue primero, si la nación o las provincias, el derecho de cada parte a separarse del conjunto y "si las provincias que concurrieron al nacimiento del actual Estado nacional argentino en 1853 eran Estados independientes y soberanos que pactaban su fusión en un Estado federal o sólo eran partes remanentes de una nación previa que se había disgregado luego de 1810 o 1819 y que desde entonces habían intentado reunirse sin éxito". ${ }^{70}$ Concluyó que después de 1810, las primeras entidades soberanas fueron las ciudades con Ayuntamiento, que luego se convirtieron en cabeceras de provincias, que trataron de organizarse como Estados soberanos e independientes actuando como tales, más allá de los intentos de organización nacional. ${ }^{71}$

En lo que respecta a lo que sería la nación argentina, Marcela Ternavasio reflexionó en torno a la definición de la división de poderes en la coyuntura revolucionaria, momento en que cambiaron las normas que regulaban la relación entre gobernantes y gobernados y la distribución del poder. Este régimen político fue el resultado de un largo proceso histórico en el que se fueron definiendo reglas y valores que construirían una determinada cultura política. ${ }^{72}$ El desafío era evitar el despotismo y para ello fue indispensable la aplicación de un régimen representativo con autoridades electivas que garantizaran la legitimidad del poder. ${ }^{73}$ El otro principio moderno de la división de poderes, tardaría más en incorporarse, ya que la distribución del poder y la pregunta de donde residía la soberanía estaba atada a la cuestión territorial y al debate en torno a la adopción de formas centralizadas o confederales.

Sobre la justicia, la autora explica la fuerte restricción de la potestad judicial, cifrada en la desconfianza hacia el juez y en una sobrevaloración del poder legislativo. Temor compartido con Francia, procedente de las viejas instituciones encargadas en ambos países de ejercer justicia, y manifestado en los reglamentos de 1811 y 1817 en el Río de la Plata y las Constituciones de 1819 y 1826, con la noción de ley como fuente del sistema jurídico y la prohibición de los jueces a interpretarla. El recuerdo de toda autoridad colonial como magistrado de justicia, evocaba la imagen

\footnotetext{
${ }^{69}$ López Alves, Fernando, State formation in Latin America, 1810-1900, Duke University Press, Durham \& London, 2000.

${ }^{70}$ Chiaramonte , Juan Carlos, "La cuestión de la soberanía en la génesis y constitución del Estado argentino", ponencia presentada en el Simposio “Argentina-Brasil, La Visión del Otro, Una aproximación interdisciplinaria a la cuestión de la soberanía”, organizado por la Fundaçao Centro de Estudios Brasileiros, la Fundaçao Alexandre Gusmão, y la Biblioteca Nacional argentina, Buenos Aires, 5 y 6 de diciembre de 2000, p.4

${ }^{71}$ Chiaramonte, Juan Carlos, Ciudades, provincias y estados. Orígenes de la nación argentina, Biblioteca del Pensamiento argentina I, Buenos Aires, Ariel Historia, 1997.

${ }^{72}$ Ternavasio, Marcela, "La división de poderes en los orígenes de la política argentina", en Ciencia Hoy, volumen 14 $\mathrm{N}^{\mathrm{o}} 80$ (abril-mayo, 2004).

${ }^{73}$ Chiaramonte, Juan Carlos y Ternavasio, Marcela, "Procesos electorales y cultura política: Buenos Aires 1810-1850", en Ciencia Hoy, volumen 5 N³0 (1995).
} 
del despotismo y la lógica jurídica del "se acata pero no se cumple", que no se querían transferir a la nueva estructura política. Por ello las ramas centrales en la disputa serían la legislativa y la ejecutiva quedando neutralizada la judicial. Los reclamos de juristas y publicistas apuntaban a la eficacia de funcionamiento y no a romper con los límites del racionalismo normativo. ${ }^{74}$

Después de 1819 los cabildos comenzaron a ser suprimidos y las provincias se erigieron en entidades autónomas emergiendo la división de poderes con distintos matices y solidez jurídica. Se crearon legislaturas unicamerales, encargadas de nombrar al poder ejecutivo, y se organizaron estructuras judiciales formadas por jueces legos y tribunales superiores integrados por abogados. Al no concretarse la codificación, el orden jurídico funcionó con leyes coloniales y costumbres que no se opusieran a la nueva normativa que surgía en respuesta a las necesidades. A partir de aquí nadie pudo aspirar a legitimar el poder sin respetar, de alguna forma, la división de poderes. ${ }^{75}$

Los intentos de establecer una Constitución iban de la mano de la forma en que se organizaría la sociedad, las diversas opciones fueron estudiadas por Roberto Gargarella, entre 1810 y 1860 para parte de Latinoamérica. En su análisis estableció tres cosmovisiones, una liberal, otra radical y la tercera conservadora, las que a su vez definieron el lugar que el poder judicial ocuparía. ${ }^{76}$ Carlos Egües, siguió estas tres corrientes en las ideas políticas en torno al constitucionalismo del siglo XIX, con sus respectivas definiciones del poder judicial: liberalismo (independiente del poder político), radicalismo democrático (independiente con participación popular) y conservadurismo (independiente con profesionalidad y permanencia). Pero en los debates los actores no se ubicaban indefectiblemente en un grupo, sino que podían cambiar el problema que se estaba tratando. ${ }^{77}$

Para explorar todos estos elementos de la vida política en Argentina a lo largo del siglo XIX, Hilda Sábato y Alberto Lettieri, realizaron una recopilación de investigaciones, partiendo de la instauración de formas representativas de gobierno y de la formación de nuevas repúblicas luego del derrumbe del poder español en América. El hilo que une los trabajos es el problema de la construcción del poder en el siglo XIX, con la temprana adopción de formas republicanas y representativas de gobierno, basadas en la soberanía del pueblo. El análisis de la relación entre

\footnotetext{
${ }^{74}$ Ternavasio, Marcela, Gobernar la Revolución. Poderes en disputa en el Río de La Plata, 1810-1816, Buenos Aires, Siglo XXI, 2007.

${ }^{75}$ Ternavasio, Marcela, "De la ciudad colonial al municipio moderno: la supresión de los Cabildos en el Estado de Buenos Aires", Jornadas Inter. Escuelas- Departamentos de Historia, Neuquén, 1999; "La supresión del Cabildo de Buenos Aires: ¿crónica de una muerte anunciada?, en Boletín del Instituto de Historia Argentina "Dr. Emilio Ravignani” Tercera serie, núm. 21, 1º semestre de 2000.

${ }^{76}$ Gargarella, Roberto, "El período fundacional del constitucionalismo sudamericano (1810-1860)", en Desarrollo Económico, vol.43, № 170, julio-setiembre 2004, pp.305-328.

${ }^{77}$ Egües, Carlos, "Las ideas políticas en el constitucionalismo argentino del siglo XIX. Un aporte metodológico", en Revista de Historia del Derecho, núm. 24, Buenos Aires, Instituto de Investigaciones de Historia del Derecho, 1996, pp. 45-62. Sobre las constituciones bonaerenses de 1854 y 1873 véase Pérez Ghilhou, Dardo, 1854 Dos proyectos políticos constitucionales, Buenos Aires y Mendoza, Instituto Argentino de Estudios Constitucionales y Políticos, Mendoza, 2005; Sanucci, Lía E.M, “Crónica de la primera Convención Constituyente Bonaerense, 1870-1873”, en Trabajos y Comunicaciones, núm.12, Facultad de Humanidades y Ciencias de la Educación de la Universidad Nacional de la Plata, 1964.
} 
sociedad civil y sociedad política apuntó a determinar el lugar que ocuparon los gobernados en la construcción del sistema político y la legitimación de la autoridad. ${ }^{78}$ Para esto fue fundamental la institución de la ciudadanía y la definición de ciudadano, estudiada por Carlos Cansanello en "una historia de los habitantes durante la formación de la sociedad provincial y de la relación que entablaron con las formas estatales en construcción". ${ }^{79}$

Sobre la historia política, dos obras son fundamentales, la de Tulio Halperin Donghi y la de Natalio Botana. El primero como llave de entrada para comprender la construcción y puesta en marcha de un sistema institucional y político que incluía los cambios en la justicia. Si bien su mirada está dirigida a la nación, se detuvo en el surgimiento de un nuevo sistema de poder en la provincia, del que participaron propietarios, intelectuales y población urbana. Sin embargo, en lo referido al sistema judicial, quedó especialmente concentrado en la justicia de paz, sin detenerse en el funcionamiento de la administración de justicia y en ver que en los debates que la construían, las divisiones entre autonomistas y nacionalistas no eran tan claras. ${ }^{80}$

Botana trabajó sobre las ideas políticas como "horizonte que se despliega ante nosotros y también un depósito que guarda las maneras en que los actores de una época discurrieron acerca del poder y la obediencia". ${ }^{81}$ Son de utilidad sus análisis de Rousseau, Montesquieu y Hobbes, sobre todo cuando estos aparecen como inspiradores de la legislación que conformó el poder judicial provincial. La definición de la distancia entre legitimidad e ilegitimidad aporta una guía para buscarlas en el nuevo proyecto, como la "división entre los gobiernos moderados, regulados por la ley, las instituciones sociales o la costumbre, y los gobiernos arbitrarios sujetos al capricho de la voluntad". ${ }^{82}$ Sus interlocutores fueron Alberdi y Sarmiento en búsqueda del principio de legitimidad de la República. Su visión en torno a lo público no se estancó en la relación directa entre hecho e ideas, sino que unió la realidad, los publicistas que le dieron vida intelectual y el genio que los puso en funcionamiento.

Para abordar las complejas formas que rigieron los vínculos entre poderes locales y poder central en la edificación del orden político y para acceder a la dos dinámicas convergentes, la provincial y la nacionales, del que resultó tributario el proceso de centralización del poder contamos con la compilación realizada por Beatriz Bragoni y Eduardo Míguez, de colaboraciones sobre diversas cuestiones provinciales debatidas en las jornadas de trabajo realizadas en el Instituto de

\footnotetext{
${ }^{78}$ Sábato, Hilda y Lettieri, Alberto, La vida política en Argentina del siglo XIX. Armas, votos y voces, Buenos Aires, Fondo de Cultura Económica, 2003.

${ }^{79}$ Cansanello, 2003, op. cit.

80 Halperín Donghi, Tulio Proyecto y construcción de una nación (1846-1880), Buenos Aires, Biblioteca del Pensamiento Argentino II, Ariel Historia, 1995.

${ }^{81}$ Botana, Natalio, La tradición republicana: Alberdi, Sarmiento y las ideas políticas de su tiempo, Buenos Aires, Sudamericana, 1997, p. 9.

${ }^{82}$ Botana, 1997, op. cit., p.31.
} 
Estudios Históricos y Sociales en Tandil y en la Facultad de Derecho de la Universidad Nacional de Cuyo. $^{83}$

La tesis doctoral de Fernando E. Barba, siguiendo el hilo conductor del autonomismo, investigó en profundidad la formación y actuación de un sector dentro de la elite política, compuesta por burguesía urbana y pequeños propietarios rurales, en especial agricultores. Este grupo, aspiraba a la modernización de la provincia, apuntando a instalar en la legislatura el debate sobre reforma agraria, reorganización administrativa (en lo que estaba incluido el sistema judicial) y educación pública. Barba siguió la diferenciación que se fue operando dentro del autonomismo, estudiando la formación de los clubes que le dieron origen y sus proyectos.

Los cambios propuestos en la organización político administrativa fueron vistos junto a la problemática social de la campaña, logrando amalgamar en torno al concepto de descentralización, piedra fundamental del discurso de estos jóvenes autonomistas, el régimen municipal, la organización de la justicia de paz y la ley de policía, como respuesta a la injusta situación sufrida por el paisano en la campaña y denunciada años atrás por José Hernández en su Martín Fierro. El autor destacó el efímero, pero no despreciable triunfo del nuevo movimiento, que con un visible ideal de progreso, alcanzó reformas que debieron enfrentarse al triunfo de Carlos Tejedor en la gobernación de la provincia. El trabajo cierra con un rico apéndice documental que acompaña las conclusiones obtenidas. ${ }^{84}$

Sobre la relación entre los pocos que gobiernan y los muchos que son gobernados, se preguntó Hilda Sábato estudiando los conflictos y vínculos políticos que se originaban, en la ciudad de Buenos Aires, entre 1862 y 1880. Siguió los problemas y dificultades relacionados con la construcción y ejercicio del poder, no sólo de los gobernantes sino de los gobernados que participaron del experimento político iniciado en Argentina en 1862, basándose en las prácticas electorales y las formas de movilización pública. Resulta útil el desarrollo de la constitución del Estado y la sociedad civil como instancias diferenciadas, para comprender la formación de la ciudadanía y la sociabilidad política. ${ }^{85}$

Otro tema fundamental para la formación de la provincia fue la expansión de su frontera y ligado a esto, el usufructo y apropiación de sus tierras. A esta cuestión dedicó María Elena Infesta su investigación, realizando un pormenorizado estudio de la legislación sancionada en la provincia, confrontándola con el análisis de solicitudes de tierras al Estado, duplicados de Mensuras y Protocolos de los Escribanos, lo que le permitió seguir el proceso de ocupación del espacio en la

\footnotetext{
${ }^{83}$ Bragoni, Beatriz y Míguez, Eduardo, Un nuevo orden político. Provincias y Estado Nacional 1852-1880, Buenos Aires, Biblos, 2010.

${ }^{84}$ Barba, Fernando E., Los autonomistas del 70. Auge y frustración de un movimiento provinciano con vocación nacional, Buenos Aires entre 1868 y 1878, Buenos Aires, Centro Editor de América Latina, 1982, primera edición de 1967.

${ }^{85}$ Sábato, 1998, op. cit.
} 
provincia de Buenos Aires durante la primera mitad del siglo XIX. A partir de su libro, es posible establecer lo que significó el traspaso de tierras públicas a manos privadas para la provincia, que a pesar de generar una importante concentración de la propiedad rural, no fue de la magnitud que había manifestado la historiografía clásica. ${ }^{86}$

También a la ocupación del territorio, la población, la transmisión de tierras públicas a manos privadas y la conformación de un mercado de tierras, dedicó su pesquisa Guillermo Banzato. El autor trabajó sobre una región atractiva para la colonización, los partidos de Ranchos, Montes y Chascomús, desde el corrimiento de frontera de 1779 hasta 1880, atendiendo a los conflictos por la posesión y propiedad de la tierra. Durante el período independiente, la legislación colonial dio sustento a la antigua posesión, hasta que nuevas disposiciones modificaron el acceso a la tierra pública. $^{87}$

Marta Valencia estudió las políticas sobre tierras implementadas para dotar de un nuevo marco legal al proceso de transferencia de las tierras públicas a manos privadas. Superada la revisión de la política rosista, aplicada al reparto de tierras públicas, la enfiteusis fue reemplazada en 1857 por el arriendo y la venta de tierras. A partir de la década del 60, se logró un sistema definitivo, la propiedad plena, que otorgó la seguridad necesaria para las inversiones de capital. La autora recurrió, además de muchas otras fuentes, a los fondos documentales de los juzgados de paz y a las sucesiones, para conjugar marco legal, aplicación de la ley y expansión de la frontera. ${ }^{88}$

El rol que jugó el Estado en el proceso de privatizaciones de tierras públicas en un espacio de frontera (Tandil, 1823-1895) fue investigado por Valeria Mosse, quien desarrolló el concepto de propiedad y concluyó que en Buenos Aires, el Estado se encargó de legislar y hacer cumplir la ley, la sanción del Código civil cerró una larga etapa de construcción de la legalidad en la ocupación de la tierra. ${ }^{89}$

La solución del conflictivo tema de la propiedad de la tierra y su ocupación, estaba relacionado con la definición del espacio y los límites, indispensable para establecer y comprender la división judicial provincial. La provincia de Buenos Aires tuvo mapas muy difusos hasta 1865 y en verdad el más claro y accesible corresponde al censo de 1881. Perla Zusman y Sandra Minvielle realizaron un estudio sobre la delimitación del territorio en la construcción del Estado-Nación, relacionado con la ocupación de tierras y la delimitación de fronteras, mientras que Germán Torres

\footnotetext{
${ }^{86}$ Infesta, María Elena, La Pampa criolla. Usufructo y apropiación privada de tierras públicas en Buenos Aires, 1820 1850, La Plata, Archivo Histórico de la Provincia de Buenos Aires, 2003.

${ }^{87}$ Banzato, Guillermo, La expansión de la frontera bonaerense. Posesión y propiedad de la tierra en Chascomús, Ranchos y Montes, Bernal, Universidad de Quilmes, 2005.

${ }^{88}$ Valencia, Marta, Tierras públicas, tierras privadas, Buenos Aires 1852-1876, La Plata, Edulp, 2005.

${ }^{89}$ Mosse, Valeria, "La construcción estatal en la frontera sur. Un análisis a partir de los derechos de propiedad", Jornada de Debate Estado, justicia y conflictividad en la campaña rioplatense, siglos XVIII-XIX, Red de Estudios Rurales, Instituto de Historia Argentina y Americana "Dr. Emilio Ravignani", Universidad de Buenos Aires, 2006.
} 
analizó la influencia del espacio y el papel del Estado en su ocupación. Pero a pesar de su valor no aportan cartografía de la provincia. ${ }^{90}$

\section{c. El orden institucional}

Planteadas las bases para la formación del nuevo Estado provincial, la división de poderes requería de la construcción de un orden institucional. De esto trató la investigación de María E. Barral y Raúl Fradkin, siguiendo la imperiosa necesidad del Estado de adquirir capacidad de control y coacción efectiva. El proceso de la construcción de las estructuras de poder institucional se expresó en la creciente ramificación territorial, la centralización de los mecanismos de ejercicio de poder y el desarrollo de nuevos medios de coacción y control institucional. Para los autores, si bien el proceso no se completó, se sentaron las bases, y para comprenderlo se deben adoptar dos dimensiones de análisis: la de las autoridades que ejercieron el poder y la de los grupos sociales que buscaban posiciones dentro de la nueva estructura institucional.

Ese proceso de construcción de las estructuras de poder institucional fue concebido, a los fines de esta investigación, como el despliegue de ramas diferenciadas, dominada cada una por su propia lógica de funcionamiento, con jerarquías, intensidades y modalidades de inserción en el medio social rural. De allí que existieron tres tipos de estructura de poder institucional: la militarmiliciana, la eclesiástica y la judicial-policial. Esta última estructura, con funciones distintas, fracasó en el intento de organizar instituciones diferenciadas en el ámbito rural. Los pueblos rurales son definidos, siguiendo a Anthony Giddens, como sedes, región física que interviene como escenario de la acción social, con fronteras que contribuyen a concentrarla y permite fijar las instituciones, ${ }^{91}$ y algunos de ellos alcanzaron una mayor jerarquía institucional como cabecera de los Departamentos Judiciales de Campaña o cabecera de partido. El crecimiento económico y demográfico de algunos pueblos rurales los transformó en espacios de construcción del poder institucional pero no alcanzó para sostener una estructura institucional intermedia. Claro ejemplo de ello fue el fracaso de la primera instancia letrada en la campaña bonaerense. ${ }^{92}$

Siguiendo esta línea, el "Estado" es un personaje central en los estudio sobre la historia iberoamericana durante la primera mitad del siglo XIX, asegura Juan Carlos Garavaglia. Sin embargo ni este ni sus aparatos ideológico, jurídico, burocrático y militar han sido objeto de una “discusión seria". El autor se dedicó a estudiar el papel coercitivo del Estado trabajando sobre

\footnotetext{
${ }^{90}$ Torres, Germán, "Dimensiones en el proceso de transformación del espacio pampeano" (1850-1890), [en línea] http://www.monografias.com/trabajos12/monogh/monogh.shtml. Consultado el 14 de junio de 2006.

${ }^{91}$ Giddens, Athony, La constitución de la sociedad. Bases para la teoría de la estructuración, Buenos Aires, Amorrortu Editores, 1995, pp.149-151.

${ }^{92}$ Barral, María E. y Fradkin, Raúl O., "Los pueblos y la construcción de las estructuras de poder institucional en la campaña bonaerense (1785-1836)", en Boletín del Instituto de Historia Argentina y Americana "Dr. Emilio Ravignani”, tercera serie, núm. 27, primer semestre de 2005, pp. 7-48
} 
definiciones de Estado, el proceso de construcción y su consolidación, y la financiación del mismo. $\mathrm{Su}$ estudio sobre el cuerpo profesional de servidores del Estado, es útil a la hora de definir qué es el Estado o a que tipo de Estado nos referimos. El análisis de los presupuestos demuestra las formas de dominación del período en un encuadre militar y represivo (fuerza militar y policial), mientras el personal judicial quedaba reservado a la función de control, definiéndose así el papel del Estado en la tarea de reprimir y controlar. Sin embargo, el orden en la campaña estaba asentado sobre los jueces de paz, que constituían un entramado de relaciones sociales de dominación, ejerciendo en una misma persona funciones policiales y judiciales, lo que aseguraba parte de la eficacia en el mantenimiento del orden. ${ }^{93}$

El mismo autor continuó su investigación analizando las principales líneas de desarrollo del entramado estatal en la provincia, presentando al Estado provincial (y a su continuador en el período autónomo de 1852-1861) como la matriz fundacional del Estado argentino a partir de Pavón. Para esto es necesario conocer los cambios en la construcción de los "instrumentos" del Estado, etapa indispensable de conocimiento de la burocracia, la policía, el sistema judicial, el ejército, etc., preliminar al estudio de las formas más profundas de dominación estatal. De aquí me interesa fundamentalmente la estructura del poder judicial en esos años y cómo participó del despliegue estatal. ${ }^{94}$

Por su parte, Carlos Rafart y Ernesto Bohoslavsky insistieron sobre la necesidad de redefinir las características centrales de las instituciones estatales de los siglos XIX y también el XX, mostrando los mecanismos de funcionamiento de la justicia, la policía y la cárcel. Esto responde a su convicción de la necesidad de conocer los sectores poderosos y el Estado, para abordar su connotación ideológica. Esta tarea la realizaron desde el estudio social del delito y el uso de la fuente judicial, resaltando el enfoque de los trabajos de Richard Slatta, Ricardo Salvatore y Juan Carlos Garavaglia, por permitir alejarse de la clave criminológica o legalista para poder realizar una lectura social. Destacaron el crecimiento de las investigaciones en torno al desarrollo histórico de los sistemas legales y el aparato judicial, pero en el repaso sobre esta producción historiográfica no se mencionó nada sobre la segunda mitad del siglo XIX. ${ }^{95}$

Sobre el Estado y la formación de las instituciones, ha trabajado Alberto Lettieri, ${ }^{96}$ su último libro lo dedicó al análisis de Buenos Aires frente al interior en la década de 1850. En él, privilegió

\footnotetext{
${ }^{93}$ Garavaglia, Juan Carlos, "La apoteosis del Leviathán: El estado en Buenos Aires durante la primera mitad del siglo XIX” en Latin American Research Review, volume 38, number 1, 20003, pp.135-168.

${ }^{94}$ Garavaglia, Juan Carlos, "El despliegue del Estado en Buenos Aires: de Rosas a Mitre”, en Desarrollo Económico, vol.44, No 175 (octubre-diciembre 2004), pp.415-445.

${ }^{95}$ Rafart, Carlos Gabriel y Bohoslaslavsky, Ernesto, "La frontera y la historia social del delito. Un primer balance", en Historia y cultura, 27, julio, 2001. Sociedad Boliviana de Historia, La Paz, Bolivia, pp.127-147.

${ }^{96}$ Lettieri, Alberto R., Vicente Fidel López: la construcción histórico-política de un liberalismo conservador, Buenos Aires, Editorial Biblos, Fundación Simón Rodríguez, 1995; "De la "República de la Opinión" a la "República de las instituciones", Nueva Historia Argentina Liberalismo, estado y orden Burgués (1852-1880), Tomo IV, Buenos Aires,
} 
el estudio del proceso de construcción de la autoridad y de la obligación política, haciendo hincapié en dos cuestiones fundamentales, la producción de una nueva legitimidad política y de un nuevo consenso socio-político. A pesar de realizar un pormenorizado estudio sobre las instituciones políticas en Buenos Aires en el siglo XIX, la atención dedicada a la administración de justicia, definida como "espacio clave de la vida institucional", fue muy escueta y no entró en detalles sobre el funcionamiento del sistema judicial. ${ }^{97}$

En este período se consolidó un grupo social dominante conformado por comerciantes, hacendados y financistas, acompañado por la elaboración de un modelo de desarrollo basado en la producción de bienes primarios para la exportación y la idea de progreso. Esto generó los conflictos comerciales que abordó Jeremy Adelman, estudiando la transición de la Ley Natural colonial al nuevo marco legal Republicano en Buenos Aires, donde predominaban conceptos instrumentales de la propiedad. En su análisis, puede comprenderse, a través de la justicia comercial, cómo lo político influyó en la ley privada, mientras que la definición del concepto de propiedad afectó las luchas políticas. ${ }^{98}$ Sin embargo, en lo referido a la organización judicial comercial del período que interesa, en el que se crearon y pusieron en funcionamiento los tribunales de comercio, el autor realizó una referencia vaga basada en bibliografía muy valiosa pero del período anterior. ${ }^{99}$

\section{d. La administración de justicia}

Estudiando la administración de justicia criminal en la ciudad de Buenos Aires entre el período tardo colonial y mediados del siglo XIX, Osvaldo Barreneche siguió las continuidades en la ley criminal, los cambios en el discurso penal, la adaptación de los procedimientos judiciales y los movimientos en las relaciones de poder entre la judicatura y los agentes de aplicación de la ley, concluyendo que la justicia criminal no fue parte activa del mecanismo de formación de la nación argentina. Políticos, legisladores y juristas coincidían en cuanto al rol ideal de la judicatura y la ley criminal en la formación del nuevo Estado, pero era imposible su implementación dada la inestabilidad política; el sistema penal sería un resultado pero no un instrumento en dicho proceso. $^{100}$

Editorial Sudamenricana, 1999; "Opinión pública y régimen político en Buenos Aires después de Caseros", en Investigaciones y Ensayos, Academia Nacional de la Historia, núm. 49, Buenos Aires, 1999.

${ }^{97}$ Lettieri, Alberto R., La construcción de la República de la opinión, Buenos Aires frente al interior en la década de 1850, Bue,nos Aires, Prometeo Libros, 2006.

${ }_{98}$ Adelman, Jeremy, Republic of Capital, Buenos Aires and Legal Transformation of the Atlantic World, Stanford University Press, Stanford, California, 1999.

${ }^{99}$ Adelman, op. cit., p.244 y cita 57.

${ }^{100}$ Barreneche, Osvaldo "Criminal Justice and State Formation in Early Nineteenth. Century Buenos Aires" en Zimmermann, Eduardo Judicial Institutions..., cit., pp. 86-103. 
En cuanto a los estudios específicos del sistema judicial, son escasos los relacionados con la justicia civil, como el de Nidia Robles, ${ }^{101}$ que describió y estudió el modelo de organización y administración de justicia en la provincia de Buenos Aires entre 1825 y 1834. A través del trabajo cuantitativo con expedientes del fuero civil evalúo la magnitud de la conflictividad social en la campaña, y en definitiva, la justicia civil letrada tuvo escasa incidencia en el medio rural y la justicia de paz se presentaba como única vía de acceso a la justicia.

Sobre el sistema judicial, descontando el trabajo de Ibáñez Frocham que reconstruyó su conformación hasta $1853,{ }^{102}$ prevalecen los estudios relacionados con la justicia penal, dada la proliferación de investigaciones sobre el delito y el castigo. Pero en verdad, los estudios dedicados directamente a la justicia criminal son pocos. Tal es el caso de Osvaldo Barreneche, quien sin dejar de atender la relación de la justicia con la formación del Estado post-independiente, realizó un pormenorizado análisis de los rasgos básicos del sistema de justicia penal en la Argentina moderna que surgieron durante el período que el definió como de transición. Esos rasgos fueron "la subordinación y debilidad institucional del poder judicial; la interferencia policial en las relaciones entre la sociedad civil y la justicia; la manipulación de las fases iniciales del proceso judicial (a través del sumario u otros procedimientos legales y administrativos) por policía de alto rango; y la institucionalización de procedimientos penales maleables como sistema punitivo, sin perjuicio del resultado de los casos delictivos judicialmente evaluados". 103

Otro trabajo relacionado con el funcionamiento de la justicia en el contexto latinoamericano es el de Pilar Domingo, en el que consideró que a pesar de haberse incrementado las investigaciones sobre política institucional, la mayor parte de trabajos sobre el sistema de justicia ha sido realizado por juristas. Su tarea fue dedicada al estudio de los cambios de la Suprema Corte de México y su relación con el poder ejecutivo, resaltando la importancia de ver la naturaleza del sistema político y las peculiaridades de la forma del desarrollo constitucional. La construcción de las biografías de los integrantes del alto tribunal permitió observar las estrategias e incidencias en el sistema presidencial. Su investigación consideró los factores sociales y políticos en el análisis de la administración de justicia, concluyendo que el papel de la Suprema Corte en el desenvolvimiento del sistema político mexicano sirvió a la consolidación del estado de legalidad y el poder judicial estuvo políticamente subordinado a la lógica de dominación. ${ }^{104}$

\footnotetext{
${ }^{101}$ Robles, Nélida N., "La justicia civil en la campaña bonaerense: una aproximación cuantitativa (1825-1834)", en Prohistoria, año V, número 5, Rosario, primavera del 2001, pp.203-221.

${ }^{102}$ Ibáñez Frocham, Manuel La organización judicial argentina, Buenos Aires, La Facultad, 1938.

${ }^{103}$ Barreneche, Osvaldo, Dentro de la ley, TODO. La justicia criminal de Buenos Aires en la etapa formativa del sistema penal moderno de la Argentina, La Plata, Ediciones Al Margen, 2001, pp.16-17.

104 Domingo, Pilar, "Judicial Independence: The Politics of the Supreme Court in Mexico", en Journal of Latin American Studie, Vol. 32, Parte 3, Cambridge University Press, Cambridge, 2000, pp. 705-735.
} 
También para México, Linda Arnold, sostuvo que no fue creado rápidamente un orden jurídico republicano porque no existía una visión de consenso de una ideología crítica mexicana en relación con los valores políticos republicanos y con una sociedad política republicana. El consenso nació con la guerra civil y se consagró en la constitución de 1857, cuando la gente que buscaba justicia descubrió la necesidad de un orden jurídico innovador. ${ }^{105}$ En México, como en Argentina, los jueces ocupaban cargos en el sistema político. Lo mismo pudo comprobar Víctor Uribe para Colombia al estudiar la historia de los abogados y concluir que fueron quienes controlaron el Estado y sus recursos, siendo éste el principal recurso de trabajo, honor, poder, prestigio y patronazgo. ${ }^{106}$

La justicia de paz ha sido mucho más estudiada. En este sentido, fue fundador el libro de Benito Díaz ${ }^{107}$ que investigó sobre los juzgados de paz de campaña entre 1821 y $1854 .{ }^{108}$ Esta primera instancia de práctica legal, legitimada en el espacio de la comunidad de vecinos, debe ser estudiada, según Sergio Cercós, porque las bases de los fundamentos jurídicos de una sociedad sólo adquirían valor si estaban garantizados por la autoridad del Estado. La construcción del derecho fue parte de la construcción del Estado y los tenientes alcaldes, alcaldes y jueces de paz eran personal del Estado provincial. ${ }^{109}$

Los juzgados de paz de campaña entre 1830 y 1852, su estructura, personal y accionar, observando la función de disciplinamiento social, pero también las tensiones entre las necesidades de ese aparato judicial y las exigencias de Rosas, han sido estudiados por Juan Carlos Garavaglia. ${ }^{110}$ El mismo autor, junto con Jean-Frédéric Schaub, dirigió la obra sobre ley, justicia y costumbre, que permitió conocer espacios geográficos y mentales desde nuevas perspectivas, las autoridades y funcionarios del Estado, la formación de los jueces, prácticas, normas y procedimientos y la construcción de la legitimidad. ${ }^{111}$ Raúl Fradkin presentó allí una investigación sobre ley y costumbre, tema profundamente por él analizado. ${ }^{112}$

\footnotetext{
${ }^{105}$ Arnold, Linda, "Política y justicia. La Suprema Corte de Justicia mexicana (1824-1855)", en Estudios históricos, Instituto de investigaciones jurídicas, serie C, núm.62, UNAM, 1996.

${ }^{106}$ Uribe-Uran, Víctor Manuel, "Elites, construcción del Estado y negocios. El cambio de significado del Honor, Status y Clase: los letrados y burócratas de Nueva Granada en el período tardo colonial y temprano post-colonial", UribeUran, Víctor Manuel, (editor) State and Society in Spanish America during the Age of Revolucion, Scholarly Resources Inc., Wilmington, 2001, pp.59-88.

${ }^{107}$ Díaz, Benito, Juzgados de Paz de Campaña de la provincia de Buenos Aires (1821-1854), Facultad de Humanidades y Ciencias de la Educación de la Universidad Nacional de la Plata, La Plata, 1959.

${ }_{108}$ Otro estudio de un país latinoamericano: Flory, Thomas, El juez de paz y el jurado en el Brasil imperial, 1808-1871. Control social y estabilidad política en el nuevo Estado, México, Fondo de Cultura Económica, 1986.

${ }^{109}$ Cercós, Sergio, "La práctica jurídica en la campaña bonaerense en el período federal", en La fuente judicial en la construcción de la memoria, Suprema Corte de Justicia de la provincia de Buenos Aires, La Plata, 1999.

${ }_{110}$ Garavaglia, Juan Carlos, "Paz, orden y trabajo en la campaña: la Justicia rural y los Juzgados de Paz en Buenos Aires, 1830-1852", en Desarrollo Económico, vol.37, núm.146, Buenos Aires, julio-setiembre 1997. Este es uno de los trabajo del autor más relacionado con el funcionamiento del sistema judicial, pero a lo largo de la tesis presentaremos otros específicos.

${ }^{111}$ Garavaglia, Juan Carlos, y Jean-Frédéric Schaub, Lois, justice, coutume. Amérique et Europe latines (16è-19è siècle), Editions de I'EHESS, Collection Recherches d’histoire et de sciences sociales, 99, París, 2005.

${ }_{112}$ Fradkin. Raúl O., "Entre la ley y la práctica: la costumbre en la campaña bonaerense de la primera mitad del siglo XIX”, en Anuario IEHS, n.12, 1990.
} 
La administración de justicia puede ser vista desde la historia social, como lo demostró Laura Solares Robles, indagando en fuentes judiciales sobre el bandolerismo y la manera de castigar el delito por la justicia. ${ }^{113}$ Similar es la tarea de Raúl Fradkin que desde una perspectiva interactiva busca identificar y evaluar las formas de resistencia y de intervención de los grupos subalternos rurales en sus condiciones de existencia y en las experiencias históricas vividas, dedicando parte de su libro a la descripción del sistema de justicia precodificado, sus procedimientos y las dificultades de construir un poder institucional firme y sólido en la campaña. ${ }^{114}$

En el mismo campo de la historia social, la investigación de Ricardo Salvatore sobre la experiencia de los paisanos durante el rosismo en la provincia de Buenos Aires, reconstruyó la relación entre los subalternos y el Estado, recurriendo a archivos judiciales y militares. Específicamente, en el capítulo 5, "El poder de la ley”, el autor demuestra que Rosas poco agregó al cuerpo de leyes en vigencia y a las instituciones judiciales en funcionamiento. Lo que distinguió al período fue la pedagogía de la ley, el esfuerzo por restaurar la autoridad de la ley como reguladora de las interacciones sociales, diseminando en la campaña, las prohibiciones y las penas contenidas en la ley a través de los jueces de paz (los maestros). Las prácticas del sistema judicial produjeron familiaridad con los procedimientos legales, ello generó conciencia y contrato. La ley se convirtió en la llave simbólica que permitió a los subalternos entender el significado del Estado y su orden, constituyéndose también en fuente de resistencia subalterna. La distancia que separaba al subalterno del sistema de justicia fue acortada. ${ }^{115}$

Uniendo Estado y sociedad, el enfoque sociocultural de la política que realizó Pilar González Bernaldo, dirigido al estudio de las "prácticas relacionales de la población de la ciudad de Buenos Aires", aportó al debate sobre la constitución de la nación argentina. En el primer período, 18201850, reconstruyó las formas relacionales, específicamente los espacios de sociabilidad pública, la nueva sociabilidad asociativa, la sociabilidad étnica y la vida política. Si bien esta investigación no abarcó el tema judicial, es de utilidad la segunda etapa, década del 50, que estudió la "explosión asociativa”, articulando las nuevas formas de sociabilidad con la redefinición de la esfera pública y las prácticas representativas, lo que permite conocer la dinámica de los vínculos sociales y sus puntos de encuentro con la esfera institucional. ${ }^{116}$

\footnotetext{
${ }^{113}$ Solares Robles, Laura, Bandidos somos y en el camino andamos, Bandidaje, caminos y administración de justicia en el siglo XII. El caso de Michoacán, Morelia Michoacán, Instituto Michoacano de Cultura, Instituto de Investigación Dr. José María Luis Mora, dic.1999.

${ }^{114}$ Fradkin. Raúl O., La historia de una montonera: bandolerismo y caudillismo en Buenos Aires, 1826, Buenos Aires, Siglo XXI Ediciones Argentina, 2006.

115 Salvatore, Ricardo D., Wandering Paysanos, Statae order and subaltern experience in Buenos Aires during Rosas era, Duke University Press, Durham and London, 2003.

${ }^{116}$ González Bernaldo de Quirós, Pilar, Civilidad y política en los orígenes de la Nación Argentina. Las sociabilidades en Buenos Aires, 1829-1862, Buenos Aires, FCE, 2000.
} 
La producción historiográfica que avanzan sobre Caseros no es tan abundante en lo referido al Estado y la justicia. La búsqueda estuvo orientada a la división de poderes del Estado y al papel que el poder judicial tomó en ella; a la nueva concepción de justicia (ideas jurídicas), su administración y la cultura jurídica nacida de ambas. En cuanto a la visión de la sociedad, es importante para esta tesis los sectores que conformaron la administración de justicia, sancionando las leyes e integrando las instituciones, sin dejar de atender a la sociedad civil. ${ }^{117}$

Para ahondar en las ideas jurídicas y el proceso codificador, fue Víctor Tau Anzoátegui quien los estudió poniendo la mirada en el mundo jurídico de tradición romano-canónica, buscando allí los grandes influjos ideológicos. A través de sus estudios, afirmó la originalidad del pensamiento argentino y la existencia de una tradición jurídica propia. ${ }^{118}$ Esto a su vez va de la mano de la vida y práctica de los publicistas, a quienes podemos acceder por los trabajos de Alberto Leiva, sobre el foro de Buenos Aires, ${ }^{119}$ y el de Eduardo Zimmermann sobre la educación de los abogados en la Argentina de la Organización Nacional. ${ }^{120}$

Con respecto a las pesquisas relacionadas con el funcionamiento del sistema judicial, Blanca Zeberio se dedicó al fuero civil desde su investigación de la sociedad centrada en el individuo como sujeto, creadora de reglas que aseguraran la consolidación de los mercados y la propiedad privada. Estudió la familia, las mujeres, los derechos de propiedad y herencia en Argentina durante el siglo XIX, partiendo de los cambios introducidos por el Código Civil.

El fuero penal ha sido el más estudiado, por estar ligado a la investigación social del delito y el castigo. Melina Yangilevich realizó su tesis doctoral sobre el sistema judicial penal en la provincia de Buenos Aires entre 1850 y 1880, relacionando ley, control social, delito y conflicto al sur del río Salado durante la segunda mitad del siglo XIX. ${ }^{121}$

Para México, Elisa Speckman Guerra avanzando en los años de nuestro estudio, pero en la misma línea de la investigación del crimen y el castigo, ha dedicado un capítulo de su libro a

\footnotetext{
${ }^{117}$ Las investigaciones citadas a continuación tratan en ocasiones más de un tema de los rastreados, por ello para presentarlas di prioridad al central.

${ }^{118}$ Tau Anzoátegui, Víctor, Las ideas jurídicas en la Argentina (siglos XIX y XX), Buenos Aires, Editorial Perrot, 1977. Para un estudio más profundo sobre el proceso codificador véase Tau Anzoátegui, Víctor, La Codificación en la Argentina, 1810-1870. Mentalidad social e ideas jurídicas, Buenos Aires, Librería-Editorial Histórica Emilio J. Perrot, 2008.

${ }^{219}$ Leiva, Alberto David, "La colegiación de abogados en el foro de Buenos Aires", en Revista de Historia del Derecho, núm. 12, Instituto de Investigaciones de Historia del Derecho, Buenos Aires, 1984; Aprendizaje jurídico y entrenamiento profesional (siglos XVIII al XX), Buenos Aires, Ediciones Dunken, 1996; "Del periodismo forense a las revistas jurídicas. Un aspecto en la evolución de la literatura jurídica argentina (1850-1950)", en La revista jurídica en la cultura contemporánea, edición al cuidado de Víctor Tau Anzoátegui, Buenos Aires, Ediciones Ciudad Argentina, 1997; "La enseñanza penal de Carlos Tejedor, en Revista de Historia del Derecho, núm. 26, Instituto de Investigaciones de Historia del Derecho, Buenos Aires, 1998; Historia del foro de Buenos Aires. La tarea de pedir justicia durante los siglos XVIII a XX, Ad-Hoc, Buenos Aires, 2005.

${ }^{120}$ Zimmermann, Eduardo, (editor) "The Education of Lawyers and Judges in Argentina’s Organización Nacional (1860-1880)", en Judicial Institutions in Nineteenth-Century, Institute of Latin American Studies, University of London, 1999, pp. 104-123.

${ }^{121}$ Yangilevich, Melina, Estado y criminalidad en la frontera sur de Buenos Aires (1850-1880), Rosario, Prohistoria Ediciones, 2012.
} 
estudiar la administración de justicia. La autora se planteó si la concepción del derecho y los principios éticos que se reflejaban en la legislación, coincidían con los que tenían otros sectores de la sociedad. Para responder recurrió a analizar la normatividad de la conducta, la criminalidad, la práctica judicial y el castigo en escritos sobre derecho penal, policía, literatos, revistas, artículos periodísticos e impresos sueltos dirigidos a grupos populares. Surge nuevamente la mirada paralela, pero en este caso no de la justicia sino de la ley. Una ley que define al delito y por otro lado ideas y códigos éticos que pertenecen a otros sectores de la sociedad, presentándose el juez como mediador entre la ley y esas otras concepciones. ${ }^{122}$

Una cuestión delicada es la de lograr abocarse al sistema judicial de la provincia de Buenos Aires, sin "nacionalizar la cuestión”. Para esto son fundamentales los estudios sobre el poder judicial desde una perspectiva institucional, que se están realizando para otras provincias, aunque sería interesante plantear un proyecto que abarcara la mayor cantidad posible de ellas y que permitiera determinar y analizar similitudes y diferencias en un mismo proceso. Abelardo Levaggi realizó una minuciosa investigación sobre los orígenes de la codificación argentina, desde los reglamentos de administración de justicia anteriores a 1850, para demostrar que Buenos Aires no era entonces la única preocupada en los códigos y reglamentos de justicia, mientras las demás provincias esperaban a que se los proveyera. Por el contrario, tuvieron una prolífica sanción de reglamentos de justicia. ${ }^{123}$ Marta Bonaudo analizó la relación entre el poder y la justicia entre 1856 y 1890 en Santa Fe. ${ }^{124}$ Por su parte Ariel De la Fuente, estudiando el caudillismo y la política popular en La Rioja durante el proceso de formación del Estado, se dedicó a la administración de justicia en la provincia. ${ }^{125}$ Ramírez Braschi trabajó sobre el poder judicial de Corrientes en el siglo XIX, partiendo de la idea de que la conformación de los poderes del Estado y su funcionamiento determinaron la maduración política de la provincia. ${ }^{126}$ Carolina Piazzi realiza un importante aporte a la historia de la justicia para la provincia de Santa Fe, desde la administración de justicia criminal. $^{127}$

\footnotetext{
${ }^{122}$ Speckman Guerra, Elisa, Crimen y castigo: legislación penal, interpretaciones de la criminalidad y administración de justicia (ciudad de México, 1872-1910), México, Instituto de Investigaciones Históricas. UNAM, 2002

${ }^{123}$ Levaggi, Abelardo, Orígenes de la codificación argentina: los reglamentos de administración de justicia, Universidad del Museo Social Argentino, Buenos Aires, 1995. Para citar algunos ejemplos sobre las pesquisas provinciales para la segunda mitad del siglo XIX

${ }^{124}$ Bonaudo, Marta, "Hecho jurídico... hecho político. La conflictiva relación entre poder y justicia en la construcción de la República Posible. Santa Fe 1856-1890”, María Inés Carzolio, Darío G. Barriera, (compiladores) Política, cultura, religión. Del Antiguo Régimen a la formación de los Estados nacionales, Rosario, Prohistoria, 2005, pp. 215-240.

${ }^{125}$ de la Fuente, Ariel, Children of Facundo, caudillo and gaucho insurgency during the argentine state-formation process (La Rioja, 1853-1870), Duke University Press, Durham and London, 2000.

${ }^{126}$ Ramírez Braschi, Dardo, Judicatura, poder y política. La Justicia en la provincia de Corrientes durante el siglo XIX, Corrientes, Moglia Ediciones, 2008.

${ }^{127}$ Piazzi, Carolina, A., "Notas sobre la instalación del Juzgado de Alzadas en la provincia de Santa Fe (1855-1863)" en Barriera, Darío, (coord). La justicia y las formas de autoridad. Organización política y justicias locales en territorios de frontera. El Río de la Plata, Córdoba, Cuyo y Tucumán, siglos XVIII y XIX, ISHIR CONICET-Red Columnaria, Rosario, 2010, pp.233-261; Justicia criminal y cárceles en Rosario (segunda mitad del siglo XIX) Prohistoria, Rosario, 2011.
} 
Un tema en algunos aspectos pendiente fue el de la policía, tratado aquí en cuanto auxiliar de la justicia, sobre el cual Francisco Romay ha escrito la obra de referencia. ${ }^{128}$ Sandra Gayol se ha dedicado a la policía de Buenos Aires en la segunda mitad del siglo XIX, destacando que en algunas oportunidades llegó a administrar justicia además de sus muchas atribuciones, superando las de fijar el orden y la seguridad pública. ${ }^{129}$ En línea comparativa es valiosa la perspectiva brasilera de Marcos Luis Bretas, que desde su preocupación por los contactos entre pueblo y Estado, consideró a la policía el principal punto de encuentro entre ellos, estudiándola no sólo como instrumento de poder, sino como un espacio de lucha por el poder. Según el autor, prevaleció una cultura policial fuerte, resistente a los cambios, ante una supuesta realidad intransformable que debían controlar. En este contexto, compatibilizar la tarea de la magistratura con la de la policía era una tarea difícil, girando en torno a la capacidad de efectuar arrestos y conservar a los presos. ${ }^{130}$

El sistema judicial, su formación y funcionamiento, en los años que siguieron a la federalización de Buenos Aires, no han sido mucho más estudiados. Juan Manuel Palacio indagó en el origen de las culturas locales, partiendo del funcionamiento de la ley y la administración de justicia en un distrito rural de la zona triguera de la provincia de Buenos Aires y con fuentes de la justicia de paz del partido de Coronel Dorrego, logró perfilar la identidad e historia propia del mismo. ${ }^{131}$ Beatriz Ruibal estudió la justicia, pero apuntando al control social en Buenos Aires entre 1880 y $1920 .^{132}$ Lila Caimari tomó al sistema judicial como parte de sus investigaciones dedicadas al delito y al castigo en Argentina entre 1880 y $1955 .{ }^{133}$ Gisela Sedeillan realizó su tesis doctoral sobre la administración de la justicia penal en la provincia de Buenos Aires entre 1877-1906. ${ }^{134}$

Para terminar, son de destacar los balances historiográficos sobre la producción de la historia social de la justicia, como la compilación de investigaciones sobre la ley y la justicia en América Latina realizada por Juan Manuel Palacio y Magadalena Candioti, generando un diálogo interdisciplinario relacionado con el nuevo protagonismo de actores y prácticas, con el descubrimiento de los archivos judiciales como espacios privilegiados de observación. ${ }^{135}$

\footnotetext{
${ }^{128}$ Romay, Francisco L., "Historia de la Policía Federal Argentina”, Biblioteca Policial, Buenos Aires, 1966; "Reseña histórica de la policía bonaerense", en Primer Congreso de Historia de los Pueblos.

${ }^{129}$ Gayol, Sandra, "Entre lo deseable y lo posible. Perfil de la Policía de Buenos Aires en la segunda mitad del siglo XIX”, en Estudios Sociales, Revista Universitaria Semestral, Año VI, No10, Santa Fe, $1^{\circ}$ semestre de 1996, pp.123-138.

${ }^{130}$ Luiz Bretas, Marcos, A guerra das ruas: povo e policía na ciudade do Río de Janeiro, Arquivo Nacional, Río de Janeiro, 1997.

${ }^{131}$ Palacio, Juan Manuel, La paz del trigo. Cultura legal y sociedad local en el desarrollo agropecuario pampeano, 1890-1945, Buenos Aires, Edhasa, 2004.

${ }^{132}$ Ruibal, Beatriz, Ideología y control social: Buenos Aires, 1880-1920, Buenos Aires, Centro Editor de América Latina, 1993.

${ }^{133}$ Caimari, Lila, "Whose Criminals are These? Church, State Patronatos and the Rehabilitation of Female Convicts (Buenos Aires, 1890-1940)", The Americas, vol.54, N², 1997; 2004, op. cit.

${ }^{134}$ Sedeillan, Gisela, La administración de la justicia penal en la provincia de Buenos Aires. Instituciones, prácticas y codificación del derecho (1877-1906), Buenos Aires, Biblos, 2012.

${ }_{135}$ Palacio, Juan Manuel y Candioti, Magdalena, (compiladores) Justicia, política y derechos en América Latina, Prometeo Libros, Buenos Aires, 2007; Barriera, Darío G., “Justicias, jueces y culturas jurídicas en el siglo XIX
} 
En los últimos años diversos grupos académicos han realizado un aporte fundamental al estudio de la justicia. Un ejemplo de ello son las publicaciones surgidas de los encuentros promovidos desde el nodo rioplatense de la Red Columnaria a cargo de Darío Barriera, que centrados en la administración de justicia entraron en diálogo con otras cuestiones relacionadas con el territorio, la construcción de la autoridad, la institucionalidad y el diseño del poder político. Los diferentes vínculos trazables entre justicia y sociedad quedan representados por preocupaciones "que ensayan intersecciones -metafóricamente bocacalles- de naturaleza diversa", desde distintas perspectivas sobre la relación entre la Justicia, la sociedad y la construcción del Estado en la Argentina. ${ }^{136}$ Del mismo tenor es la publicación resultado del encuentro realizado por el Leyes, justicias e instituciones de seguridad en Argentina y América Latina, dirigido por Osvaldo Barreneche y Angela Oyhandi, del CISH, de la Universidad Nacional de La Plata. ${ }^{137}$

En suma, esta tesis se inscribe en un prolífico contexto historiográfico, en el cual la disciplina histórica contribuye a esclarecer muchas cuestiones relacionadas con la justicia como idea, como institución y como praxis política. Es nuestro anhelo que el resultado de nuestra pesquisa también pueda ser un aporte para tal fin.

rioplatense", en Nuevo Mundo Mundos Nuevo [En línea], Debates, 2010. Puesto en línea el 23 de marzo de 2010, URL: http://nuevomundo.revues.org/59352. Consultado el 25 de marzo de 2010.

${ }^{136}$ Barriera, Darío G., (compiladores), Justicias y fronteras. Estudios sobre historia de la justicia en el Río de la Plata. Siglos XVI-XIX, Ed. Universidad de Murcia, 2009; La justicia y las formas de autoridad. Organización política y justicias locales en territorios de frontera. El Río de la Plata, Córdoba, Cuyo y Tucumán, siglos XVIII y XIX, ISHIR CONICET-Red Columnaria, Rosario, 2010; Piazzi, Carolina, (coordinadora) Modos de hacer justicia. Agentes, normas y prácticas (Buenos Aires, Tucumán y Santa Fe en el siglo XIX), Rosario, Prohistoria Ediciones, 2011; Polimene, María Paula, (coordinadora) Autoridades y prácticas judiciales en el Antiguo Régimen. Problemas jurisdiccionales en el Río de la Plata, Córdoba, Tucumán, Cuyo y Chile, Rosario, Prohistotria Ediciones, 2011.

137 Barreneche, Osvaldo y Oyhandi, Angela, (editores) Leyes, justicias e instituciones de seguridad en la provincia de Buenos Aires. Estudios sobre su pasado y presente, La Plata, Edulp, 2012 (en prensa). 


\section{Capítulo I}

\section{Los ensayos de la primera década revolucionaria}

\section{Introducción}

A comienzos del siglo XIX se produjeron en España y sus colonias americanas, grandes transformaciones en el escenario político, derrumbándose el edificio de la monarquía y redefiniéndose las soberanías, siendo su base normativa el ideario liberal, en sus diferentes versiones. Los gobiernos independientes se fundaron sobre el principio de soberanía del pueblo y la república representativa en la mayoría de las antiguas colonias, y aunque el caso de Brasil fue diferente, su gobierno fue de tipo constitucional conforme a los principios liberales. ${ }^{1}$

En el Río de la Plata la Revolución de Mayo de 1810 inició una década que expandió corrientes derivadas de la Ilustración racionalista y sus hombres públicos vieron en ella no sólo un cambio de gobierno sino la oportunidad de realizar el pensamiento filosófico en versión republicana. Pero hasta 1820 el sistema de representación política estuvo regido por la ciudad y los "vecinos" de la tradición hispánica, por lo que adoptar una forma de gobierno requirió de prácticas representativas y proyectos provisorios. Entraron entonces en conflicto, durante esos años en Buenos Aires, dos ámbitos políticos de distinta naturaleza y función: el gobierno central y el capitular, que no podía ser suprimido por representar la soberanía de la ciudad capital. En 1820, cuando se instaló el gobierno provincial, se produjo una superposición de jurisdicciones con el Cabildo que no podían coexistir. ${ }^{2}$

En los años que siguieron a esta experiencia, las instituciones judiciales sufrieron una lenta evolución con una "continuidad substancial" entre lo indiano y las expresiones jurídicas patrias, donde el elemento jurídico hispano sirvió de cauce a las novedades brindadas por el ideario liberal, con permanentes contradicciones entre las expresiones doctrinarias y la práctica. ${ }^{3}$ En un principio, la Revolución no produjo cambios radicales ni de organización ni de procedimiento, y las garantías individuales enunciadas se contradecían con comisiones especiales y juicios sumarios, así como la división de poderes con el ejercicio de la función judicial por órganos ajenos. El lenguaje normativo liberal no bastaba para imponer un cambio profundo en la práctica, pero sin embargo se trataba de

\footnotetext{
${ }^{1}$ Sábato, Hilda "Introducción”, en Sábato, Hilda, (coordinadora), Ciudadanía política y formación de las naciones. Perspectivas histórica de América Latina, México, Fondo de Cultura Económica, 1999. pp. 11-12.

${ }^{2}$ Goldman, Noemí, "Crisis imperial, Revolución y guerra (1806-1820)", en Nueva Historia Argentina, tomo III, Revolución, República, Confederación (1806-1852), dirigida por Noemí Goldman, Buenos Aires, Editorial Sudamericana, 2005, pp. 41-45; 66-67.

${ }^{3}$ Díaz Couselo, José María, "Pervivencia indiana y cambio en la organización de la justicia ordinaria en Buenos Aires (1810-1854)", en Actas del XV Congreso del Instituto internacional de Historia del Derecho indiano, Diputación de Córdoba, Universidad de Córdoba, 2005, pp.769-794.
} 
un nuevo lenguaje. ${ }^{4}$ A pesar de esto, y si bien la ley de 1821 fue el paso que inició la reorganización judicial, los movimientos más importantes en la vida forense habían comenzado en la década que terminaba y los cambios que vendrían serían en buena medida sus consecuencias. ${ }^{5}$

El derecho indiano se basaba en un orden político que distinguía las funciones del poder dándoles el nombre de causas. Las lecturas que llegaron al Río de la Plata, especialmente el Espíritu de la leyes de Montesquieu, motivaron esfuerzos dirigidos a la separación de poderes que requería de un órgano judicial y su limitación como intérprete de la ley. ${ }^{6}$ Esto, sumado a la imagen colectiva de la administración de justicia, influyó en la definición de la división de poderes de la coyuntura revolucionaria, momento en que cambiaron las normas que regulaban la relación entre gobernantes y gobernados y la distribución del poder.

Era necesario vencer la fuerte restricción de la potestad judicial, cifrada en la desconfianza hacia el juez y en la sobrevaloración del poder legislativo. Temor compartido con Francia, procedente de las viejas instituciones encargadas en ambos países de ejercer justicia, y manifestado en los reglamentos de 1811 y 1817 y las Constituciones de 1819 y 1826 en el Río de la Plata, con la noción de ley como fuente del sistema jurídico y la prohibición de los jueces de interpretarla. En la práctica las funciones de ejecutar y aplicar la ley seguían relacionadas, quedando el poder judicial como rama del ejecutivo. $^{7}$

Entre tanto, la coyuntura guerrera confirió poder a las autoridades locales -militares, policiales y judiciales- que debían canalizar los recursos humanos y económicos de las zonas rurales; pero las familias que integraban las sociedades locales y se incorporaron al proceso revolucionario reclamaban parte de la soberanía que antes estaba depositada en el monarca. Los gobiernos centrales y las asambleas constituyentes promovieron proyectos políticos estatales de mayor unidad que no se concretaron y los pueblos les acordaron un carácter provisional. Al coexistir la tendencia a la identidad política nacional con la hispanoamericana y la local, por la desaparición del poder central en 1820, los esfuerzos de reorganización estatal se concentraron en lo que se mantuvo como el ámbito más real de unidad sociopolítica: la ciudad y su jurisdicción, convertida en provincia soberana. ${ }^{8}$

Dentro del Cabildo, que definía legalmente la existencia de una ciudad, el fuero común estuvo confiado a los alcaldes de primero y segundo voto, que atendían por turno y en primera

\footnotetext{
${ }^{4}$ Seghesso de López Aragón, M. Cristina, “Génesis histórica del Poder Judicial Argentino" (1810-1853), en Pérez Guilhou, Dardo, El Poder Judicial, Instituto argentino de estudios constitucionales y políticos, Buenos Aires, Ediciones Depalma, 1989, pp 11; 59; 62-63.

${ }^{5}$ Leiva, 2005, op. cit., p. 100.

${ }^{6}$ Seghesso, 1989, op. cit., pp. 2-5.

7 Ternavasio, op. cit., 2004; Gobernar la Revolución. Poderes en disputa en el Río de La Plata, 1810-1816, Buenos Aires, Siglo XXI, 2007.

${ }^{8}$ Chiaramonte, Juan Carlos, Nación y Estado en Iberoamérica. El lenguaje político en tiempos de las independencias, Buenos Aires, Editorial Sudamericana, 2004.
} 
instancia todas las causas civiles y criminales de la jurisdicción urbana, de no corresponder a los fueros especiales. Eran elegidos anualmente en número de dos entre los vecinos más representativos y si bien la Recopilación de las leyes de Indias de 1680 definió y reguló el papel de la magistratura, los magistrados adaptaban las normas generales a las necesidades y objetivos institucionales locales de Buenos Aires. En el ámbito rural, los alcaldes de hermandad tuvieron atribuciones judiciales delegadas de menor cuantía y en causas correccionales, que ejercían en el distrito de su jurisdicción, es decir los pueblos asiento de los antiguos partidos. ${ }^{9}$

Después de 1819 los Cabildos comenzaron a ser suprimidos y las provincias se erigieron en entidades autónomas, que para legitimar su poder debían establecer la división de poderes, lo que fue realizado con distintos matices y solidez jurídica. ${ }^{10}$ El objetivo era monopolizar el poder público, participando de una idea imperativa del derecho que reservaba la producción de las leyes a legislaturas unicamerales, encargadas de nombrar al poder ejecutivo, que tenía capacidad normativa. Se organizaron estructuras judiciales formadas por jueces legos y tribunales superiores que, al menos en Buenos Aires, tendieron a ser integrados por abogados, intentando reducir al máximo la capacidad de crear derecho de los magistrados, cuya tarea debía consistir en aplicar la ley. ${ }^{11}$

En el derecho indiano la Justicia era fin supremo del Estado para lograr la paz y el desarrollo de las demás virtudes, era una función gubernativa que no estaba limitada a ciertos órganos o poderes del Estado, sino que concernía a la generalidad de estos. El Rey orientaba a la comunidad hacia el bien común mediante el ordenamiento legal inspirado en la Justicia. ${ }^{12}$ A partir de 1820 nadie pudo aspirar a legitimar el poder sin respetar, al menos en la letra de la ley, la división de poderes, aspirando a la paz social que incluyera a la sociedad civil y a la comunidad política. ${ }^{13}$

Esto marca la necesidad de estudiar las normas que afectaron a la administración de la justicia desde 1810, buscando rastrear las ideas que acompañaron el proceso que llevó a la ley de 1821 punto de llegada y de partida- y los cambios (novedosos o no) de la organización que proponía. Para esto, en este capítulo analizaremos las principales disposiciones desde 1810, para recuperar las ideas que inspiraron la primera organización de la justicia provincial. Consideramos que en esta década se inició un proceso en que se buscaba superar las funciones establecidas por la Real Ordenanza de Intendentes y llegar así a la división de poderes, para lo cual era indispensable

\footnotetext{
${ }^{9}$ Ibáñez Frocham, 1938, op. cit., pp. 6-7; Zorraquín Becú, 1952, op. cit. Para abordar la práctica de los alcalde de hermandad en su medio véase Barriera, Darío G., "El execrable libro de sus hechos: Cultura jurídica, retórica y deslegitimación de la autoridad en un proceso contra el alcalde del Rosario (1810-1811)", en Anuario del Instituto de Historia Argentina, núm. 10, 2010, pp. 57-84. [en línea] http://www.memoria.fahce.unlp.edu.ar/art_revistas/pr.4699/pr.4699.pdf. Consultado el 3 de noviembre de 2012.

${ }^{10}$ Tau Anzoátegui, op. cit., p. 205.

${ }^{11}$ Cansanello, 2003, op. cit., pp. 153-154.

${ }^{12}$ Zorraquín Becú, 1952, op. cit. pp.7-28.

${ }^{13}$ Ternavasio, 2000, op. cit.
} 
quitarle al Cabildo la función de Justicia, conformar la primera instancia letrada y la justicia de paz lega, sin necesidad de crear una Alta Corte como la que se había creado en la Constitución de 1819, esperando a incorporarse en algún momento a un Estado Nación.

La exigencia teórica de garantizar los derechos individuales y la separación de poderes fue respetada por casi todos los ensayos del período, según la orientación ideológica de los redactores y su percepción de la realidad en que esos textos serían aplicados. Esto nos obliga a tener en cuenta dos cuestiones fundamentales: en primer lugar vamos a estudiar la teoría, no su aplicación, es decir el esfuerzo pendular por resolver desde la legislación problemas coyunturales y formar un poder del Estado. En segundo lugar, es importante estar atentos a la jurisdicción que abarcaban los cambios que se intentaban imponer, pues entre 1810 y 1820 fueron de alcance "nacional", pero luego Buenos Aires como provincia autónoma creará su propio poder judicial, que es lo que aquí nos interesa estudiar. ${ }^{14}$

\section{$\underline{\text { I. Los cambios después de } 1810}$}

Por el acuerdo del 25 de mayo de 1810 fueron tomados los sueldos de la Real Audiencia Pretorial (junto con el del virrey, el Tribunal de Cuentas y la renta de Tabacos) para enviar quinientos hombres a auxiliar a las provincias del interior. En el mismo se indicaba a los miembros de la Junta observar "puntualmente las leyes del Reino" y en el artículo séptimo quedaban “excluidos de ejercer el poder judiciario, el cual se refundirá en la Real Audiencia, a quien se pasarán todas las causas contenciosas, que no sean de Gobierno". ${ }^{15}$ Esta definición era importante a futuro, pues indicaba la legislación vigente y dejaba establecida la independencia judicial, mientras reservaba las causas de gobierno, entre las que se encontraban las que conformarían el fuero contencioso-administrativo. ${ }^{16}$

La Real Audiencia seguía en funciones pero con nuevos jueces, nombrados el 22 de junio de 1810, a quienes se les pedía en su juramento desinterés, imparcialidad, justicia y la vida por la defensa de Fernando VII. Podrían tener un máximo de dos mil quinientos pesos de sueldo,

\footnotetext{
${ }^{14}$ Para comparar con lo pasaba en el resto de las provincias, véase Tau Anzoátegui, 1973, op. cit.; Levaggi, Abelardo Orígenes de la codificación argentina: los reglamentos de administración de justicia, Universidad del Museo Social Argentino, Buenos Aires, 1995.

${ }^{15}$ Erección de la Junta provisional y atribuciones fijadas por el Cabildo de Buenos Aires a la misma, a raíz de una petición de vecinos, comandantes y oficiales de los cuerpos voluntarios el 25 de mayo de 1810. Acuerdo del 25 de mayo de 1810 en RavignanI, Emilio, Asambleas constituyentes argentinas seguidas en los textos constitucionales, legislativos y pactos interprovinciales que organizaron políticamente la Nación, tomo VI, segunda parte, 1810-1898, Buenos Aires, Talleres S.A. Jacobo Peuser, Ltda., 1939, pp. 626-627. (en adelante Ravignani VI)

16 "La pervivencia del derecho indiano es declarada incluso por quienes con más decisión se proclamaban reformistas e inducidos por la corriente racionalista lo criticaban". Díaz Couselo, José María, "La tradición indiana y la formación del derecho argentino", en Temas de historia argentina y americana, Pontificia Universidad Católica Argentina, Facultad de Filosofía y Letras, Centro de Historia Argentina y Americana, Julio-diciembre de 2005, p. 52.
} 
tratamiento y traje de abogados, guardando en el orden de asientos la antigüedad de su recepción y haciendo de su concepto público un nuevo vínculo con la confianza del pueblo. ${ }^{17}$

Al año siguiente, al instituirse las Juntas subalternas de las provincias interiores, la Junta introdujo los conceptos de felicidad y de bien "en hacer gustar a los pueblos las ventajas de un Gobierno popular" que ofrecería "magistrados poderosos, pero esclavos de las leyes, ciudadanos libres, pero que saben que no hay libertad para el que no ama las leyes, virtudes civiles, virtudes políticas, amor a la gloria, amor a la patria, disciplina austera, y en fin hombres destinados a sacrificarse por el bien del estado". ${ }^{18}$

En relación a la justicia esto se traducía en mandar a las Juntas abstenerse "de todo acto de jurisdicción contenciosa, o administración que no sea de los asuntos comprendidos en estas declaraciones; dejando obrar libremente, y aún auxiliando a las justicias, cabildos y funcionarios públicos en lo que corresponda a su conocimiento y autoridad respectiva". Indicaba claramente que si alguno de los alcaldes ordinarios (recordemos sus funciones judiciales) era elegido asesor de provincia, debía elegir una de las dos funciones y que los vocales de las Juntas de provincia no podían ser simultáneamente oidores de Audiencia. ${ }^{19}$

Unos meses después, el intento de reglamentar la división de poderes generó enfrentamientos entre la Junta Conservadora (en la que devino la Junta Grande y que operaba como órgano legislativo) y el Gobierno Ejecutivo, que ponían de manifiesto que la organización republicana no tenía un único significado ni una sola posibilidad de resolución y que la forma por la que se optara establecería quién tendría el poder. Para la Junta Conservadora, la felicidad pública dependía de la capacidad de los gobernantes de afianzar la confianza que el pueblo debía tenerles, siendo capaces de corregir sus errores. El Gobierno, Triunvirato flamantemente formado por Feliciano Chiclana, Manuel de Sarratea y Juan José Paso, con Rivadavia como secretario, los instó el 30 de septiembre para que acordaran una norma que debía "nivelar su conducta", y "reglar el despacho de los asuntos judiciales". 20

El 22 de octubre de 1811, la Junta Conservadora sancionó el Reglamento Orgánico, que sostenía la división de poderes legislativo, ejecutivo y judiciario. El poder ejecutivo no podía “conocer de negocio alguno judicial" ni "alterar el sistema de administración de justicia", pero sí atender las causas de contrabando y de deudas por derechos de aduanas. Las demás causas le serían

\footnotetext{
${ }^{17}$ Registro Nacional 1810-1821, pp.45-46. La Primera Junta de 1810 retuvo el derecho de revisión judicial o instancia extraordinaria que antes tenía el Consejo de Indias en España.

${ }^{18}$ Orden del Día [de la Junta superior de gobierno de Buenos Aires por la cual se instituyen juntas subalternas en las provincias interiores], 10 de febrero de 1811, Ravignani VI, pp.3-4. En cada capital de provincia, incluida Charcas, se formaría una Junta con el presidente o gobernador intendente y cuatro vocales elegidos por el pueblo.

${ }^{19}$ Sobre el funcionamiento de las audiencias véase Martiré, Eduardo, Las Audiencias y la Administración de Justicia en las Indias, Buenos Aires, Librería Histórica Perrot, 2009.

${ }^{20}$ Reglamento de la división de poderes sancionado por la Junta conservadora, precedido de documentos oficiales que lo explican, 30 de septiembre a 29 de octubre de 1811, en Ravignani VI, pp. 599-603.
} 
remitidas a la Real Audiencia, pero las sentencias contra el fisco debían serle consultadas al ejecutivo, que velaría por la "urgencia y utilidad hacia el bien común”. El Gobierno no podía tener arrestado a ningún individuo por ningún caso más de cuarenta y ocho horas, dentro de cuyo término debía remitirlo al juez competente, no hacerlo era un atentado contra la libertad de los ciudadanos, y "cualquiera en este caso podrá elevar queja a la Junta Conservadora". ${ }^{21}$

En cuanto al poder judicial, se reafirmaba su independencia, haciendo responsable a sus miembros de la libertad y seguridad de los ciudadanos y se reservaba dirigir y deslindar el poder que establecía el Reglamento, presentado al Gobierno el 25 de octubre. Pero para sorpresa de la Junta, el texto fue elevado en consulta al Cabildo, lo que consideraban un procedimiento ilegal, pues los pueblos los habían elegido y conferido sus poderes, encargándolos de "su felicidad y bienestar". ${ }^{22}$ De todas formas el Gobierno, guiado por la "justicia, la utilidad y la libertad”, decretó un Estatuto provisional que realizaba un diagnóstico de la situación y enunciaba los valores a establecer. Dejaba sin efecto el Reglamento de la Junta, que -a su entender- bajo el velo de la "pública felicidad", se erigió en soberana. ${ }^{23}$

Este Estatuto provisional del 22 de noviembre de 1811 - redactado, según Piccirilli, por Rivadavia como testimonio de la lealtad hacia el Cabildo y por extensión hacia el pueblo de Buenos Aires- ${ }^{24}$ rechazaba el Reglamento de la Junta Conservadora, basándose en el dictamen del respetable Cabildo y el juicio de los ciudadanos ilustrados; declarando ante "la faz del mundo entero que su resistencia no conoce otro principio que el bien general, la libertad y la felicidad de los pueblos americanos." La felicidad pública sería en adelante representada por la libertad de imprenta y la seguridad individual, por ello los decretos que fueron establecidos formaron parte del Estatuto.

El conocimiento de los asuntos de justicia correspondía privativamente a las autoridades judiciarias con arreglo a las disposiciones legales y para resolver en los asuntos de segunda suplicación, se asociaría el gobierno de dos ciudadanos de probidad y luces. Es destacable la definición de "seguridad individual" como el derecho sagrado de todo ciudadano a la protección de su vida, de su honor, de su libertad y de sus propiedades; ningún ciudadano podía ser penado, ni expatriado sin que precediera forma de proceso y sentencia legal.

En cuanto a la organización judicial específicamente, el 23 de enero de 1812 fue firmado por los miembros del Triunvirato y su secretario, el Reglamento de institución y administración de justicia, cuya introducción rescataba los valores ya enunciados. Los hombres consagraban todos sus

\footnotetext{
${ }^{21}$ Reglamento de la división de poderes sancionado por la Junta conservadora, cit.

${ }^{22}$ Reglamento de la división de poderes sancionado por la Junta conservadora, cit.

${ }^{23}$ Estatuto provisional del Gobierno Superior de las Provincias Unidas del Río de la Plata a nombre del Sr. D. Fernando VII, [seguido de los decretos de seguridad individual y libertad de imprenta], 26 de octubre a 23 de noviembre de 1811, Ravignani, VI, pp.603-607.

${ }^{24}$ Piccirilli, Ricardo Rivadavia y su tiempo, Buenos Aires, Peuser, 1943, tomo I, p. 147.
} 
afanes a la defensa de la libertad, pero como una prerrogativa necesaria para llegar a la felicidad, fin de sus desvelos. Para ser libres bastaba rechazar con valor la tiranía, pero para ser felices era indispensable mejorar las instituciones políticas. No había felicidad pública sin una buena y sencilla administración de justicia, para lo que se requería de "magistrados sabios que merezcan la confianza de sus conciudadanos". ${ }^{25}$

El tribunal de la Real Audiencia quedaba "disuelto y extinguido", llamándose en adelante Cámara de Apelaciones. ${ }^{26}$ Pero más allá de los cambios en el alto tribunal, el objetivo del Reglamento era superar los enfrentamientos, mejorando las relaciones en tres etapas. Primero fomentar el arreglo personal; de no lograrse, buscar el arbitramiento de un tribunal de concordia compuesto de hombres buenos; y finalmente restablecer la deprimida autoridad de los jueces ordinarios. Todo tendía a "prevenir la ruina de tantas familias honradas restableciendo el sosiego interior, que es uno de los mejores bienes de la sociedad”. El rápido crecimiento de la población rural y la intensa movilización política generada por la crisis revolucionaria requería la construcción de un orden institucional en la campaña, la valorización de los bienes agrarios y la definición del derecho de propiedad. Esto generó nuevas relaciones entre la ciudad y la campaña que debía ser incluida en el diseño institucional. ${ }^{27}$

En la ciudad se mantenía la misma jurisdicción de los jueces ordinarios, con arreglo a las leyes vigentes; en la campaña, atendiendo a las distancias, a la poca fortuna y las labores de sus pobladores, los alcaldes de hermandad conocerían hasta librar sentencia definitiva en cuestiones civiles de no más de cincuenta pesos, en juicio verbal y por hombre de buena razón y conducta, con apelación ante el alcalde ordinario, que atenderían en primera instancia toda causa que superara esa suma. Los juicios resueltos por los alcaldes ordinarios podían ser revocados y apelados ante la alzada de provincia, constituida por el jefe del Gobierno y dos individuos del vecindario de buen juicio y conducta. Los juicios verbales debían ser registrados en libros de actas, con audiencia, prueba y sentencia, siendo el objetivo de todo juicio la averiguación de la verdad, de lo que debían ocuparse todas las autoridades, celando especialmente el Gobierno Superior de no dejar impune cualquier infracción.

La Cámara de Apelaciones se integraba de cinco miembros, tres letrados y dos vecinos de buen juicio, costumbres y opinión, un agente de Cámara (con las funciones de los fiscales) y un

\footnotetext{
${ }^{25}$ Reglamento de institución y administración de justicia del Gobierno Superior Provisional de las provincias del Río de la Plata. Supresión de la Audiencia y creación de la Cámara de Apelaciones, (en adelante Reglamento de 1812). Acuerdos y sentencias dictadas por la Suprema Corte de Justicia de la Provincia de Buenos Aires, Autos acordados desde 1810, acuerdos extraordinarios, resoluciones y noticias referentes a la administración de justicia. Segunda edición autorizada, realizada por el secretario de la Suprema Corte, Dr. Aurelio Prado y Rojas, tomo I, Buenos Aires, Jacobo Peuser, 1892, pp. 144-148. (en adelante Acuerdos y Sentencias, tomo I).

${ }^{26}$ Se reemplazaron los jueces quedando los escribanos, procuradores y porteros que servían a la Real Audiencia.

${ }^{27}$ Fradkin, Raúl, "Bandolerismo y politización de la población rural de Buenos Aires tras la crisis de la independencia (1815-1830)", en Nuevo mundo. Mundos nuevos, 2005. [En línea], Debates, 2005. Puesto en línea el 22 de febrero de 2005, URL: http://nuevomundo.revues.org/59352. Consultado el 16 de mayo de 2010.
} 
letrado redactor (que tenía la función de relatar breve y sustancialmente las causas para acelerar el despacho), todos nombrados cada bienio por el Gobierno Superior. A ellos se sumaban dos escribanos, cuatro procuradores, dos porteros y alguacil de vara. Los camaristas y el agente estaban sujetos al juicio de residencia, el resto respondía a la Cámara, que tenía a su cargo el comportamiento y cumplimiento de las obligaciones, con conocimiento y facultad plena, es decir la superintendencia. $^{28}$

La Cámara tenía como funciones la apelación, segunda suplicación, recursos ordinarios y extraordinarios por injusticia o nulidad notoria -que antes se llevaban al Consejo de Indias-, fuerzas eclesiásticas y demás que por las leyes y ordenanzas conocían las Audiencias y Chancillerías de América. En la sesión del 3 de febrero de 1814 la Asamblea dictó un Reglamento para la Comisión permanente compuesta por cinco de sus miembros, encargada de sentenciar en los recursos de segunda suplicación y extraordinarios de nulidad e injusticia notoria contra las sentencias de la Cámara de Apelaciones. ${ }^{29}$ Después de estos intentos de asignar los recursos extraordinarios a un Tribunal Superior, estos peregrinaron entre el poder ejecutivo y el poder judicial hasta la Constitución de $1819 .^{30}$

En las causas criminales (que requerían de un despacho preferente por justicia y humanidad, pero a su vez cuidadoso) a más de la apelación y suplicación, podía votar o conocer en consulta. El Reglamento restituyó el derecho de todo hombre que "por naturaleza ha debido siempre poseer" de defenderse libremente en juicio, por lo que no se exigiría firma de letrado, podría hacer por sí informes verbales en las causas y patrocinarse de letrado si así lo quería. En los análisis que Uribe realizó de los reglamentos de justicia hispanoamericanos, destacaba el derecho de representación dado a cualquier persona, a su entender para reducir el monopolio de los abogados, y la intención de los revolucionarios de ampliar la participación de los ciudadanos legos en la administración de justicia con los Tribunales de Concordia, iniciada por los alcaldes ordinarios del Cabildo. ${ }^{31}$

El presidente de la Cámara, rotaba cada cuatro meses entre los cinco miembros según el orden de nombramiento. Debía llevar la voz, ocuparse de la policía interior y cuidar la pureza y exactitud de las funciones de los subalternos. La presidencia de la Alzada de Comercio rotaba entre los tres jueces letrados de la Cámara, pero por el Reglamento de 1813 pasó a turnarse entre todos

\footnotetext{
${ }^{28}$ El asiento del Tribunal era el mismo que el de la Audiencia. Los magistrados llevaban un vestido austero, acorde a los pueblos libres, y su primera obligación debía ser su integridad y la segunda una laboriosa contracción a los objetos de su cargo. Debían mantener el equilibrio en los derechos de todo ciudadano por una administración de justicia breve y simple, pero con el menor margen de arbitrio, observando las reglas y providencias.

${ }^{29}$ Reglamento que debe observarse por la comisión permanente en el despacho de los recursos de $2^{\circ}$ suplicación y extraordinarios de nulidad e injusticia notoria, en RAVIGNANI, Emilio, Asambleas constituyentes argentinas seguidas en los textos constitucionales, legislativos y pactos interprovinciales que organizaron políticamente la Nación, tomo I, 1813-1833, Buenos Aires, Talleres S.A: Jacobo Peuser, Ltda., 1939, pp. 85-86. (en adelante Ravignani I)

${ }^{30}$ Seghesso de López Aragón, 1989, op. cit., p. 27.

${ }^{31}$ Uribe-Uran, Víctor Manuel, “La América Latina colonial y postcolonial: ¿tierra de abogados y leguleyos?”, en UribeUran, Víctor y Ortiz Mesa, Luis Javier, (editores) Naciones, gentes y territorio. Ensayos de historia e historiografía comparada de América Latina y el Caribe, Medellín, Editorial Universidad de Antioquía, 2000, pp. 141-174.
} 
los camarista, ocho meses cada uno en orden inverso al nombramiento y por los juicios de arbitrio determinaba si había mérito a una cuestión judicial sobre hecho o derecho.

El Reglamento para la administración de justicia de las provincias Unidas del Río de la Plata, sancionado el 1 de septiembre de 1813 estableció que los camaristas debían ser abogados, que durarían en su cargo mientras durara su buena conducta (letrados e inamovibles) y que la presidencia se turnaría cada cuatro meses empezando por el orden de nombramiento. Apuntando a la deseada división de poderes, el Reglamento no permitía conocer en primera instancia a Gobernadores y Tenientes Gobernadores de las causas en que debían ser jueces de apelación, y también exigía que todos los escritos fueran firmados por abogados, a diferencia de lo establecido en el Reglamento anterior.

Una mención aparte merecen las Comisiones especiales, que Ibáñez Frocham definió como deformaciones formadas de jueces nombrados ad hoc sin responsabilidad. La primera de ellas apareció el 18 de abril de 1812, conformada de un juez de la Cámara de Apelaciones, un ciudadano letrado (ex juez) y el jefe de policía, para atender en primera y única instancia los delitos de robo y homicidio, juzgando en breve plazo y sujetándose a un reglamento sancionado el 20 de abril y derogado expresamente por el Reglamento de $1815 .{ }^{32}$

En el orden local, el Cabildo -mediador entre la ciudad y la autoridad central- conservó sus funciones de justicia y se convirtió en el núcleo constitutivo de las nuevas entidades políticas, siendo importante para la campaña como instancia de apelación de las causas atendidas por los alcaldes de hermandad. Para Carlos Heras, la Real Ordenanza de Intendentes fue el comienzo de la decadencia de los Cabildos, su golpe de muerte y un avasallamiento a las ciudades. ${ }^{33}$

Pero mientras mantuvo su vigencia, el 13 de octubre de 1814 el Director Posadas mandó redactar las Ordenanzas de Justicia y Regimiento de la Ciudad para reglamentar su funcionamiento interno y establecer que su naturaleza y facultades serían las determinadas por la Real Ordenanza de Intendentes y las demás leyes publicadas con posterioridad. Dos de sus quince regidores tenían atribuciones judiciales, el alcalde de primer voto era el juez de la ciudad y para su mejor desempeño proponía un asesor letrado nombrado por el Ayuntamiento y que debía asistir a las demandas verbales. Pero el objetivo era siempre resolver "de un modo suave y amigable" los litigios; debiendo además el asesor dejar al alcalde entrante una razón de las causas pendientes. Contaba el regente con dos ordenanzas para los emplazamientos y diligencias. ${ }^{34}$

\footnotetext{
${ }^{32}$ Ibáñez Frocham, 1938, op. cit., pp. 59-60; 263-265.

${ }^{33}$ Heras, Carlos, "La supresión del Cabildo de Buenos Aires", en Humanidades, núm.20, UNLP, La Plata, 1925, pp. 445-485; Díaz Couselo, José María, “La Real Ordenanza de Intendentes y la revolución”, en Mariluz Urquijo, José M., director, Estudios sobre la Real Ordenanza de Intendentes del Río de la Plata, Buenos Aires, Instituto de Investigaciones de Historia del derecho, 1995, pp.262-263.

${ }^{34}$ Ordenanzas provisionales del Cabildo, Justicia y Regimiento de la Ciudad de Buenos Aires, 13 de octubre de 1814 , en Ravignani VI, pp. 948-959.
} 
El alcalde de segundo voto reemplazaba al de primer voto por ausencia, enfermedad o muerte; contaba con la jurisdicción ordinaria además de tener como principal tarea la apertura de los testamentos cerrados, la reducción de memorias simples a escritura pública y todos los asuntos en primera instancia donde mediaran intereses o persona de menor, siendo así juez de menores, interviniendo en estas causas el regidor defensor de menores. Para la administración a su cargo contaba también con un asesor letrado, en iguales condiciones que el otro alcalde. Es decir que la ciudad tenía dos jueces de primera instancia, electivos por un año, sin sueldo y legos, pero que debían ajustarse a derecho con la colaboración de asesores letrados, aunque no estaban obligados a seguir su dictamen.

Esta organización judicial se completaba con el regidor defensor de pobres, el regidor defensor de menores y el síndico personero del común. Todos ellos debían ser preferentemente letrados, y de no serlo contaban con un asesor letrado. El defensor de pobres atendía el despacho de las causas criminales de los pobres detenidos en cárceles y hospitales; en lo civil protegía a los esclavos destinados a panaderías, en primera y segunda instancias. Era también alcalde de cárcel, visitándolas personalmente, al igual que el presidio, los hospitales y hospicios, panaderías y casas de corrección, informándose de los padecimientos de pobres no sólo por las demoras en sus causas sino también por la falta de cumplimiento de las ordenanzas del Gobierno.

El defensor general de menores estaba encargado del cuidado de huérfanos y pupilos, de la defensa de sus derechos y de sus intereses; debían intervenir en toda causa, en todas las instancias en que participaran menores y tomar parte siempre que, por negligencia o codicia, los albaceas, tutores o curadores pusieran en peligro sus bienes. Además cuidaban de que los niños huérfanos accedieran a la educación, "supliendo así la patria por su ministerio la falta de los padres naturales", igualmente si los padres fueran incapaces, condenados u ociosos. El síndico, encargado de vigilar el cumplimiento de las ordenanzas municipales, hacía la personería de la ciudad en todos los pleitos entre particulares, corporación o comunidad y el Ayuntamiento.

\section{Derechos y poderes públicos después de 1815}

El 18 de abril de 1815 cayó el Director Supremo Carlos María de Alvear y el Cabildo formó un gobierno provisorio a cargo de Ignacio Álvarez Thomas, como Director, y la Junta de Observación integrada por cinco abogados: Esteban Agustín Gazcón, Pedro Medrano, Antonio Sáenz, José Mariano Serrano y Tomás Manuel de Anchorena. Ésta redactó el 5 de mayo de 1815 el Estatuto Provisional para la dirección y administración del Estado, destinado a organizar sus funciones y regir los derechos de los individuos. ${ }^{35}$ El objetivo del mismo era "proporcionar la

\footnotetext{
${ }^{35}$ Estatuto provisional para dirección y administración del Estado, 5 de mayo de 1815, en Registro Nacional 18101821 , pp. 311-323.
} 
felicidad", superando el escandaloso desorden a que habían llevado los reglamentos anteriores, para custodiar la libertad, la igualdad, la propiedad y la seguridad, que ellos consideraban los más interesantes derechos del hombre.

Con el Estatuto de 1815 surgió la definición moderna de ciudadano, al enunciar por primera vez reunidos los elementos de representatividad, ajustándose al principio de la soberanía popular, el voto y la igualdad ante la ley, incorporando también la representación de la campaña. ${ }^{36}$ La visión clásica de ciudadanía suponía la participación del ciudadano en la comunidad política en búsqueda del bien común y el énfasis de la ciudadanía liberal estaba puesto en el ejercicio de los derechos individuales en función del interés propio. Pero esa ciudadanía política liberal, que como define Pierre Rosanvallon supone "una ruptura completa con las visiones tradicionales del cuerpo político", está recorrida por la tensión de llevar implícita una dimensión comunitaria durante el siglo XIX, una comunidad política de iguales que forma un cuerpo político, pero de una comunidad abstracta. ${ }^{37}$ En función de esta tensión, cobra sentido conocer el significado de los derechos y los deberes que enunció el texto al cumplirse un lustro de la Revolución.

Los derechos de los habitantes del Estado eran la vida, la honra (que debía labrarse cada uno en la opinión de los demás por la rectitud e integridad de sus procedimientos), la libertad (facultad de obrar cada uno a su arbitrio sin violar las leyes ni dañar los derechos de otro), la igualdad (por el cual la ley era igual para todos y favorecía a todos por igual para conservar sus derechos, del poderoso al miserable), la propiedad (derecho a gozar de sus rentas, bienes y productos) y la seguridad (garantía que concedía el Estado de que no se violasen los derechos de cada uno, sin que se verificaran las condiciones señaladas por la ley para perderla). Esta definición de la seguridad como derecho dado por el Estado, coincidía con el monopolio legítimo que éste tenía de la coacción física. $^{38}$

Los deberes estaban establecidos para cada hombre y para el Cuerpo Social. Para el hombre implicaban sumisión completa a la ley, "haciendo el bien que ella prescribe y huyendo el mal que ella prohíbe"; obediencia, respeto y honor a magistrados y funcionarios públicos como ministros de la Ley y primeros ciudadanos; sobrellevar gustoso los sacrificios que demandaba la patria, sin exceptuar la vida; contribuir al sostén de los derechos de los ciudadanos y a la felicidad pública del Estado; merecer el título de hombre de bien, lo que significaba ser buen padre, buen hijo, buen hermano y buen amigo. El Cuerpo Social debía garantir el goce de los derechos del hombre,

\footnotetext{
${ }^{36}$ Cansanello, 2003, op. cit., pp. 114-115; Goldman, 2005, op. cit., pp. 24; 65.

37 Sábato, 1999, op. cit., p. 12; 16. El concepto de comunidad abstracta lo tomó de Guerra, Francois Xavier, Modernidad e independencias, Madrid, MAPFRE, 1992.

38 "Por estado debe entenderse un instituto político de actividad continuada, cuando y en la medida en que su cuadro administrativo mantenga con éxito la pretensión al monopolio legítimo de la coacción física para el mantenimiento del orden vigente", Weber, Max, Economía y sociedad, México, Fondo de Cultura Económica, 1983, pp. 43-44. Sobre las definiciones de Weber trabajó Juan Carlos Garavaglia el papel coercitivo del Estado de la primera mitad del siglo XIX en América Ibérica. Garavaglia, 2003, op. cit.
} 
aliviando la miseria y desgracias de los ciudadanos, proporcionándoles los medios de prosperar e instruirse.

El Estatuto garantía la libertad de imprenta, poniendo en vigencia nuevamente el de 1811, uniendo esto a la publicidad de los actos oficiales y la seguridad individual que establecía claros límites al accionar de los jueces, de quienes quedaban exentas las acciones privadas de los hombres, que no podían penar ni confinar sin proceso y sentencia legal. Los mandamientos se realizaban por escrito, debían recibir informe de semiplena prueba del preso y podían allanar "el sagrado hogar del individuo" ante resistencia y con debida moderación. Podían corregir toda acción de la cárcel -lugar de seguridad y no de castigo- que mortificara al reo.

Según el texto, el poder ejecutivo podía suspender las ejecuciones capitales, conceder perdón o conmutación el día de Aniversario de la Libertad del Estado u otro acontecimiento que le añadiera nuevas glorias, pero no en el caso de traición a la patria. Quedaba a su cargo el nombramiento de todo funcionario con calidad de letrado a propuesta de la Cámara de Apelación, pero no podía alterar de ninguna forma la administración de justicia que seguía rigiéndose por los mismos principios con algunas reformas.

Quedaba abolido el Reglamento de 1812, fijando las garantías de la defensa en juicio, al restablecer el padrino en las causas criminales, sin perjuicio del abogado y procurador establecidos por ley y práctica de los tribunales. ${ }^{39}$ Cuando se presentaban recursos de segunda suplicación, nulidad e injusticia notoria, las Cámaras debían dar cuenta al Director del Estado, quien nombraría una Comisión de cinco letrados, la que terminado el acto quedaría disuelta. Los recursos de nulidad e injusticia notoria de las sentencias del Tribunal de Alzadas de Comercio se decidían en las Cámaras de Apelaciones. El Tribunal de Concordia fue disuelto, debiendo los jueces de primera instancia invitar a las partes a la conciliación antes de iniciar el juicio.

Para interpretar este Estatuto de 1815 es necesario tener presente para estos años un concepto de ley que incluía mandamientos, ordenes, decretos o acuerdos y, como sugiere la historia crítica del derecho, distinguir norma (como significado) y formulación de norma (como significante). Así podrán observarse estas formulaciones novedosas que seguían siendo leídas en función de la cultura tradicional. ${ }^{40}$ El desafío es establecer cuando comienza a cambiar esta cultura jurídica y la letra de la norma puede ser leída con otro sentido, que genere la modificación en la administración de justicia.

\footnotetext{
${ }^{39}$ El artículo 35 del Reglamento de 1812 restituia " $a$ todo hombre el derecho que por naturaleza ha debido siempre poseer de hacer por sí sus defensas."

${ }^{40}$ Agüero, Alejandro, "Formas de continuidad del orden jurídico. Algunas reflexiones a partir de la justicia criminal de Córdoba (Argentina), primera mitad del siglo XIX", en Nuevo Mundo Mundos Nuevo [En línea], Debates, 2010. Puesto en línea el 23 de marzo de 2010, URL: http://nuevomundo.revues.org/59352. [Consultado 25 de marzo de 2010 ].
} 
Entre tanto, el Congreso que en julio de 1816 había declarado la independencia, se trasladó a Buenos Aires en febrero de 1817, estableciendo el 3 de diciembre un Reglamento Provisorio ${ }^{41}$, cuya sección IV estaba dedicada al poder judicial que residía "originariamente en la nación." Su ejercicio residía, hasta que se sancionara la Constitución del Estado, en el Tribunal de recursos de segunda suplicación, nulidad e injusticia notoria, en las Cámaras de Apelaciones y en los demás juzgados. Para los casos que no tuvieran tribunal señalado por la ley, decidiría el Congreso.

No tendría dependencia alguna del Poder Ejecutivo Supremo y en sus principios, formas y extensión de sus funciones se regiría por las leyes de su instituto. Pero el Director Supremo estaba facultado para suspender a los magistrados, dando causa justa al Congreso. Si las causas de suspensión eran políticas las resolvería por sí y si eran de justicia nombraría una comisión de fuera que determinar el mérito de la remoción. El ejecutivo conservaba la facultad de suspender sentencias y de participar en los juicios que comprometían fondos del Estado.

Se mantenía lo relativo a los juicios criminales del antiguo reglamento y quedaba prohibida toda licencia para ejecutar sentencias de presidio, azotes o destierro sin consultar a las Cámaras, con pena de multa o inhabilitación perpetua, exceptuando el caso que por conmoción popular o peligro de salud pública no pudiera diferirse la ejecución. Toda sentencia para ser tenida como válida debía ser "pronunciada por el texto expreso de la ley", cuya infracción sería crimen del magistrado, pero no quedaban derogadas las leyes que permitían el arbitrio prudente de los jueces, según naturaleza y circunstancia del delito. Para ser arrestado era necesaria semi plena prueba o indicios del crimen, que debían constar en el sumario, no pudiendo mantener al acusado preso más de tres días sin saber causa de su prisión.

El resto de los artículos se referían a cuestiones ya enunciadas, sobre el objetivo de las cárceles, al procedimiento de los embargos, y a los intentos conciliadores de los jueces de primera instancia. Para Díaz Couselo, este Estatuto que reiteraba los derechos de seguridad individual y libertad de imprenta, fue el instrumento preconstitucional que fijó provisoriamente las bases para la organización del nuevo Estado y que tuvo considerable trascendencia en todo el territorio. ${ }^{42}$ UribeUran considera que inició la tendencia hacia la profesionalización de la administración de justicia, al menos en la instancia de apelación, que se enfrentaba con la falta de abogados, al igual que en México, Colombia y Perú. ${ }^{43}$

\footnotetext{
${ }^{41}$ Reglamento provisorio sancionado por el Soberano Congreso de las Provincias-Unidas de Sud-América para la dirección y administración del Estado mandado observar entre tanto se publica la Constitución, Raviganai, VI, pp. 684-696. Cabe aquí aclarar que el 22 de noviembre de 1816 el Congreso había sancionado otro Reglamento provisional, que era la aprobación con modificaciones del de 1815, rechazado por el Director Supremo, cuyo texto referido a la justicia es muy similar al que estamos analizando. Ver Ravignani, VI, pp. 667-680.

${ }^{42}$ Díaz Couselo, 2005, op. cit., p. 61.

${ }^{43}$ Uribe-Uran, 2000, op. cit.
} 
El texto constitucional sancionado por el Congreso el 22 de abril de 1819, que como el proyecto embrionario de $1815^{44}$ rescataba el objetivo de fomentar las medidas "necesarias y convenientes a la felicidad del Estado" y organizaba tres poderes, con una "Alta Corte de Justicia" compuesta de siete jueces y dos fiscales, que “ejercería el Supremo Poder Judicial del Estado.” Sus miembros debían ser letrados, con ocho años de ejercicio y cuarenta de edad, nombrados por el Director del Estado, con noticia y consentimiento del Senado. Durarían en su cargo por el tiempo de su buen comportamiento; no podrían ser empleados del poder ejecutivo sin consentimiento y sus sueldos eran intangibles mientras permanecieran en su oficio. El presidente era electo cada cinco años por sus miembros y fiscales y la Corte elegiría sus oficiales.

Es de destacar que los procedimientos de todos los tribunales serían públicos, al igual que los votos de cada juez para las resoluciones y sentencias. A su vez la Alta Corte informaría al cuerpo legislativo de las mejoras convenientes para la administración de justicia y recibiría de las Cámaras de Justicia informes sobre el estado de las causas para lograr una justicia más pronta. Quedaban así enunciadas todas las cuestiones que durante años se discutirían en pro de formar un poder judicial independiente y que en algunos aspectos continúan siendo temas de debate.

La Constitución rescataba los derechos a la vida, reputación, libertad, seguridad y propiedad (permitiendo la expropiación), igualdad ante la ley, inviolabilidad del domicilio y correspondencia. Uno de los artículos de los derechos particulares declaraba el derecho de ser juzgado por jueces "los más libres, independientes e imparciales que sea dado a la condición de las cosas humanas.” El cuerpo legislativo debía encargarse de poner en funcionamiento el juicio por jurados, en cuanto lo permitieran las circunstancias. Ciertamente, quedaban declarados en la letra derechos que llevaría años alcanzar en la práctica.

En ese camino fueron fundamentales las nuevas formas de sociabilidad que surgieron en Iberoamérica y que extraían "su legitimidad no de la costumbre o de la ley, sino de la asociación misma, de la voluntad de los asociados”. Se formaron instituciones (asociaciones profesionales o étnicas, sociedades de ayuda mutua, salones, logias masónicas, clubes sociales y culturales, periódicos), expresión de una sociedad civil vigorosa, base de lo que Habermas llamó una "esfera pública política", instancia creada por la sociedad civil por "personas privadas que reunidas formaron un público", para entablar el diálogo y el debate con el Estado. ${ }^{45}$ Especialmente el objetivo de la prensa de esos años era la discusión, aunque también informara, y su irrupción en América Latina se dio junto con los conflictos políticos e ideológicos generados por la

\footnotetext{
${ }^{44}$ Sólo el proyecto embrionario de 1815 y la Constitución de 1819 estuvieron asociadas a la idea monárquica, en un lustro que se pensó en mantener el sistema existente hasta 1810, pero no de una monarquía absoluta, sino en términos semejantes a la inglesa. Levaggi, Abelardo, "Constitucionalismo argentino 1810-1850", en IUSHISTORIA, Revista electrónica, núm. 2, octubre de 2005, Buenos Aires, Universidad del Salvador, p. 11, [en línea] hppt//salvador.edi.ar/juri/reih/2da/I04.pdf [Consultado: 8 de abril de 2010]

${ }^{45}$ Sábato, 1999, op. cit. 25-26. Habermas, Jüger Historia y crítica de la opinión pública, México, Ed.Gili, 1981.
} 
Independencia, siendo a lo largo del siglo XIX ámbito de debate público y forma de hacer política, que estimulaba la formación de una "moderna opinión pública". ${ }^{4}$

\section{Conclusión}

La inspiración ideológica de la Revolución deviene de tradiciones, lenguajes ilustrados y formas de vocabulario que surgieron pertenecientes o ajenas a las prácticas políticas inauguradas por la Independencia y a la conformación de una cultura rioplatense que relacionó cultura eclesiástica y cultura ilustrada. La Revolución de Mayo expandió corrientes derivadas de la Ilustración racionalista y sus hombres públicos vieron en ella no sólo un cambio de gobierno sino la oportunidad de realizar el pensamiento filosófico en versión republicana ${ }^{47}$. Dentro de este proceso se desarrolló el racionalismo jurídico y fue elaborado un Derecho de alta jerarquía intelectual, que creyendo ciegamente en la razón y despreciando la tradición, produjo un cambio abrupto en el que hicieron eclosión las ideas incubadas. ${ }^{48}$

Para acceder a esas ideas debe tenerse en cuenta que las mediaciones y reelaboraciones de que eran víctimas los textos creaba distancia con los originales, por lo que puede resultar más fructífero acercarse al discurso político y su lenguaje marcado entre 1810 y 1820 por el tránsito al lenguaje de la utilidad, recurriendo a la tradición cultural hispana y a las lecturas de apropiación erudita y vulgar de producciones teóricas ajenas. ${ }^{49}$ En este capítulo analizamos los textos que buscaban dar forma a la administración de justicia y pudimos observar ese tránsito.

En los textos estudiados en la primera décadas revolucionaria, los conceptos de felicidad, bien común y libertad van surgiendo ligados al principio de utilidad, tradición de teoría ética que establecía la validez del conjunto de acciones o decisiones según el grado de bienestar que generaba. ${ }^{50}$ El principio de utilidad implicaba más beneficio que daño por parte de la ley, que debía tener un fundamento racional, científico y sin arbitrariedad, ofreciendo beneficios pero imponiendo obligaciones. Estas ideas fueron enseñadas por Pedro Somellera desde su cátedra en la Universidad

\footnotetext{
${ }^{46}$ Alonso, Paula (compiladora), Construcciones impresas. Panfletos, diarios y revistas en la formación de los Estados Nacionales en América Latina, 1820-1920, Buenos Aires, FCE, 2004, Introducción; Molina, Eugenia, El poder de la opinión pública. Trayectos y avatares de una nueva cultura política en el Río de la Plata, 1800-1852, Santa Fe, Universidad Nacional del Litoral, 2009, p.253.

${ }^{47}$ Goldman, 2005, op cit, p.45.

${ }^{48}$ Tau Anzoátegui, Víctor, Las ideas jurídicas en la Argentina (siglos XIX-XX), Buenos Aires, Editorial Perrot, 1977.

49 Dávilo, Beatriz, "De los derechos a la utilidad: el discurso político en el Río de la Plata durante la década revolucionaria”, en Prismas, $N^{\circ}$ 7, Universidad Nacional de Quilmes, 2003, p. 74-75.

${ }^{50}$ Gallo, Klaus, "A la altura de las luces del siglo: el surgimiento de un clima intelectual en la Buenos Aires posrevolucinaria”, en Altamirano, Carlos, Historia de los intelectuales en América Latina I, Buenos Aires, Katz Editores, 2008, p. 193.
} 
de Buenos Aires, inspirado por Jeremy Bentham ${ }^{51}$, pero todos estos conceptos estaban presentes en los reglamentos y textos constitucionales sancionados entre 1810 y 1819.

En la institución de las Juntas subalternas, en 1811, se mencionaban la felicidad y el bien, y el mismo año, la Junta Conservadora explicaba que la felicidad pública dependía de la capacidad de los gobernantes para ganar la confianza y corregir los errores del pueblo, que los había elegido, les había conferido sus poderes, y les había encargado que miraran por su felicidad y bienestar, depositando en ellos su confianza. El Triunvirato los cuestionó acusándolos de utilizar la felicidad pública como velo y afirmando que la justicia y la utilidad dictaron a los pueblos de las provincias el reconocimiento del Gobierno Provisorio y que su resistencia se basaba en el principio que el bien genera - la libertad y la felicidad de los pueblos americanos - sostenidas en la libertad de imprenta y la seguridad individual.

El Reglamento de justicia de 1812 ponía a la felicidad como objeto de sus desvelos, deseos y sentimientos, siendo indispensable para lograrla una buena y sencilla administración de justicia. Pero el Estatuto de 1815 fue más contundente y respondió a todos los requisitos del utilitarismo. En primer lugar se impuso como objetivo proporcionar felicidad común, pero requería sumisión completa a la ley, "haciendo el bien que ella prescribe y huyendo el mal que ella prohíbe" y determinaba los deberes y derechos del cuerpo social y de todo hombre de bien, lo que significaba ser buen padre, buen hijo, buen hermano y buen amigo.

La Constitución de 1819 anunciaba las medidas para alcanzar la felicidad del Estado y tanto el Reglamento de 1811 como el Estatuto de 1815 dieron potestades judiciales al poder ejecutivo en función de la urgencia y utilidad hacia el bien común. En cuanto al elemento que nos falta, que es el fin de la arbitrariedad del magistrado, hemos podido observar que si bien no se logró eliminar totalmente dada la vigencia de la legislación castellana, en varios puntos se hizo referencia a ésta, buscando atenuarla, mandando el Reglamento de 1817 a redactar las sentencias según el texto expreso de la ley, permitiendo el arbitrio prudente de los jueces, según naturaleza y circunstancia del delito.

Determinadas las ideas con las que trabajaban los redactores de estos Reglamentos y Estatutos, hemos concluido que fue tejiéndose un proyecto con determinadas características locales, con el objetivo de lograr la división de poderes en el texto de una Constitución nacional. Pero uno de los problemas era lograr la formación de un poder judicial independiente, objetivo imposible de alcanzar mientras estuviera la primera instancia dentro del Cabildo, con jueces legos, sin sueldo y elegibles. Después de 1820 y llevado al plano provincial, este es uno de los motivos por los que la

\footnotetext{
${ }^{51}$ Candioti, Magdalena, "Revolución y derecho. La formación jurisprudencial en los primeros años de la Universidad de Buenos Aires (1821-1829), en Barriera, Darío, "Justicias y Fronteras. Estudios sobre Historia de la Justicia en el Río de la Plata, Siglos XVI-XIX", EDITUM, 2009, pp.119-142.
} 
ley de 1821 eliminó el Cabildo y creó jueces de primera instancia letrados, rentados e inamovibles, trípode que se fue gestando en la Cámara de Apelaciones durante la primera década revolucionaria. 


\section{Capítulo II}

\section{Proyectos, discursos y legislación entre 1821 y 1852}

\section{Introducción}

La caída del poder central en 1820 disparó el esfuerzo de las provincias por afirmarse como Estados autónomos, que no surgían de la disgregación de una Nación preexistente - en el sentido de Estado nacional contemporáneo- sino que eran punto de partida desde la ciudad-provincia, única unidad socio-política existente. ${ }^{1}$ La autonomía de hecho se tradujo en autonomía de derecho, de provincias que ya no se correspondían con las amplias jurisdicciones determinadas por la Ordenanza de Intendentes, y emergían como sujetos políticos con epicentro en sus cabildos cabeceras. En sus nuevas reglamentaciones adoptaron formas republicanas de gobierno, estableciendo regímenes representativos de base electoral amplia (a excepción de Mendoza y Córdoba), ejecutivos unipersonales a cargo de gobernadores, autoridades administrativas y judiciales. A esta estructura se sumaba un sistema fiscal independiente. ${ }^{2}$

En Buenos Aires, la construcción del Estado autónomo provincial comenzó formalmente el 11 de febrero de 1820 cuando el Cabildo asumió el mando de la ciudad y su provincia, convocó al vecindario a Cabildo abierto y se formó el 16 del mismo mes la Honorable Junta de Representantes, que al día siguiente designó gobernador a Manuel de Sarratea, contando así con su primera Legislatura y su primer ejecutivo provincial. Con la ley que suprimió los Cabildos de Buenos Aires y Luján, el 24 de diciembre de 1821, se fijaron las bases de la organización judicial de la provincia, pues hasta entonces ellos tenían a su cargo la administración de justicia en primera instancia. ${ }^{3}$

Esta transformación, directamente relacionada con la extensión de las libertades individuales y los cambios en el derecho de propiedad, requirió de proyectos y ensayos, acompañados en lo relativo al concepto de justicia a lo largo del siglo XIX del abandono de la "arraigada virtud y guía de los gobernantes", para llegar a una concepción externa, legal, que tenía como finalidad la defensa

\footnotetext{
${ }^{1}$ Chiaramonte, 1997, op. cit; Goldman, Noemí, "Los orígenes del federalismo rioplatense”, en Goldman, 2005, op. cit. pp. 103-124. Dardo Pérez Guilhou sostiene que después de Cepeda en 1820, se produjo la crisis de autoridad del gobierno nacional. Se llegaba así al "proceso instrumentador contractual”, iniciado con el Tratado del Pilar, en el que "aparecieron por fin las provincias, definitivamente como sujetos con personería institucional y de derecho público para participar en la conformación de la nación estado... Se producía la histórica y nunca después derogada consagración, por un lado, del sistema federal que aceptaba la autonomía de las provincias y su participación en la organización; y por otro, se afirmaba el reconocimiento de la nacionalidad común dirigida por un gobierno central; sin dejar de recordar por su artículo tercero- a la heroica Provincia de Buenos Aires como cuna de la libertad de la Nación." Pérez Guilhou, Dardo, Las provincias y la organización nacional 1852-1853, Instituto Argentino de Estudios Constitucionales y Políticos, Mendoza, Editorial de la Facultad de Filosofía y Letras de la Universidad Nacional de Cuyo, 2003, pp. 13-14. Más allá de las ideas profundas y complejas en debate sobre la Nación, lo que aquí nos interesa destacar en función de nuestra tesis, es la coincidencia fundamental de que las provincias estaban en proceso de formación como Estados autónomos.

${ }^{2}$ Ternavasio, Marcela, Historia de la Argentina, 1806-1852, Buenos Aires, Siglo XXI, 2009; 120-121; 130

${ }^{3}$ Ibáñez Frocham, op. cit. 1938, pp. 163-164.
} 
de la seguridad individual antes que el bien común. Sin embargo esto requirió de un tiempo de maduración y el proceso político hasta Caseros se caracterizó por la concentración de poderes, ya que las garantías individuales enunciadas no llegaron a extenderse sobre todos los habitantes, pues no había una sociedad de iguales ante la ley y el poder de los gobernantes no se enfrentaba con un sujeto único de derecho. ${ }^{4}$

Visto el período como un todo, la aceptación de la división de poderes, la separación de la moral y de la religión del derecho, y el absolutismo de la ley, respondían al esquema racionalista donde la administración de justicia pasaba a concebirse como poder independiente. ${ }^{5}$ Sin embargo, el peso de la organización española mantuvo la dialéctica entre teoría y praxis, presente en la creación de todo Derecho y formadora no sólo de la organización judicial formal sino de la cultura jurídica dentro de un contexto histórico. ${ }^{6}$

Conocer esa cultura jurídica requiere desprenderse del presente para partir del pasado y una vez allí lograr que los juristas nos permitan aprehender y comprender el ordenamiento jurídico. Esta tarea implica asumir que el Derecho es toda una cultura, que presupone una concepción de la persona y del mundo y que para acceder al orden jurídico de determinada época se requiere acceder a las reglas, a su formulación y a su mecanismo de cumplimiento dentro de la cultura que les dio sentido. ${ }^{7}$

En este proceso es fundamental estudiar hasta qué punto continuó el predominio del derecho natural y de gentes -fundamento de las ideas políticas de la primera mitad del siglo XIX- para poder, a través de los ensayos y proyectos, conocer los intentos de cambio en la cultura jurídica que construirían la base de los debates de los próximos años. Juristas, magistrados y legisladores los llevarían adelante para resolver cuestiones tales como la descentralización judicial, la justicia lega o letrada, la inamovilidad de los jueces, la forma de su elección, la fundamentación de las sentencias, el juicio por jurado y la especialización, entre otras. Estos proyectos tenían como fondo la independencia del poder judicial y con ella la construcción de un Estado provincial autónomo,

\footnotetext{
${ }^{4}$ Cansanello, 2003, op. cit. pp. 171-196.

${ }^{5}$ Griselda Pressel estudió la implementación del principio de independencia del poder judicial para Entre Ríos a mediados del siglo XIX, concluyendo que a pesar de ir definiéndose reglamentos que establecían la independencia republicana entre los tres poderes, se generó entre la letra y la práctica un espacio de grises. A pesar de innovaciones modernizadoras introducidas en la estructura y el funcionamiento del poder judicial, no lograba desprenderse de la ingerencia del Ejecutivo, por el fortalecimiento logrado por éste por las guerras, la permanencia de las costumbres, la falta de recursos y de hombres letrados y el juego de lealtades en el nombramiento de los magistrados. Pressel, Griselda, "Hacia un sistema republicano. La justicia en el paso del Antiguo Régimen a la Modernidad. Entre Ríos a mediados del siglo XIX", en Barriera, Darío, (coord.) La justicia y las formas de autoridad. Organización política y justicias locales en territorios de frontera. El Río de la Plata, Córdoba, Cuyo y Tucumán, siglos XVIII y XIX, ISHIR CONICET-Red Columnaria, Rosario, 2010, pp. 193-207.

${ }^{6}$ Díaz Couselo, José María "Pensamiento jurídico y renovación legislativa", en Nueva Historia de la Nación Argentina, tomo 5, Academia Nacional de la Historia, Planeta, Buenos Aires, 2000, pp.363-403.

${ }^{7}$ Garriga, Carlos "Historia y derecho, historia del derecho" y "Orden jurídico y poder en el Antiguo Régimen”, en Istor, Revista de Historia Internacional, año IV, núm.16, México, primavera del 2004, pp.3-8; 13-44. En ambos trabajos el autor toma los conceptos metodológicos del enfoque histórico-jurídico crítico destacando a Antonio Manuel Hespanha y a Bartolomé Clavero.
} 
diferenciado del Estado nacional, impensable sin la división de poderes, que junto con una visión iusnaturalista racionalista fueron los pilares del texto constitucional. ${ }^{8}$

Estos intelectuales estaban decididos a modificar el sistema de administración de justicia, en mayor o menos medida, inspirados en nuevas corrientes de pensamiento y motivados por la opinión pública; pero la legislación y una estructura administrativa preexistente dificultaban la tarea. Partiendo del contenido de la ley que en 1821 modificó la organización judicial, nos proponemos indagar en los proyectos de organización judicial, la bibliografía académica, los mensajes de los gobernadores, leyes y decretos relacionados buscando determinar las ideas y conceptos liberales innovadores en el discurso político y jurídico sobre los que se pretendía estructurar y hacer funcionar el sistema judicial. Si bien en muchos casos no superaron la teoría y no llegaron a llevarse a la práctica, conformaron un legado sobre el que se organizó el poder judicial bonaerense entre la instalación definitiva de la primera instancia letrada a la campaña en 1853 y la ley orgánica judicial de 1881, sancionada para una provincia que había perdido su capital.

\section{La construcción del Estado autónomo provincial}

La organización del Estado provincial comenzó con un movimiento reformista iniciado en el gobierno de Martín Rodríguez entre 1821 y 1824, promovido por su ministro de gobierno Bernardino Rivadavia que, inspirado en Jeramy Bentham y Destutt de Tracy, devino en un importante movimiento político y cultural. En este proceso el Cabildo debía ser suprimido no solamente por la superposición de jurisdicciones, sino también porque su sustancia histórica lo hacía incompatible con un régimen representativo con equilibrio de poderes. ${ }^{9}$

La ley que terminó con los Cabildos dio origen a la estructura judicial basada en los jueces de primera instancia -letrados, rentados e inamovibles- y a la justicia de paz lega. Pero en 1826 Buenos Aires fue declarada capital del poder nacional recientemente creado, siendo diezmado el poder económico de la provincia y suprimidas la Sala de Representantes y las instituciones creadas en 1821. Después del fracaso de la "feliz experiencia rivadaviana”, se inició la reorganización de la provincia, pero sobre la base político-jurídica que aquella había dejado.

Ante la "novedad y felicidad" de la experiencia política que vivió Buenos Aires en 1820 de las ruinas dejadas por la crisis, Tulio Halperín Donghi se preguntaba si el nuevo ordenamiento era fruto de un preciso plan de reconstrucción política y económica surgido del talento de un hombre o de un equipo político. La "feliz experiencia” ¿se debía a la visión profética, al raro genio de Rivadavia? La respuesta le otorgó una mayor relevancia a la coyuntura y afirmó que "lo que

\footnotetext{
${ }^{8}$ Levaggi, 2005, op. cit.; Ternavasio, 2007, op. cit.

${ }^{9}$ Chiaramonte, 1997 , op. cit. pp. 180-184.
} 
hace la originalidad de la experiencia que comienza es que ella se da en un clima en el que la guerra ha dejado de ensombrecer."

En cambio, para Ricardo Piccirilli la obra gubernativa de Rivadavia después de 1820, permite demostrar que siguió los consejos de Jeremy Bentham en sus medidas administrativas, en la preocupación por el bien público y en la inquebrantable línea de conducta, que indicaban su clara identificación, de lo que se deduce un plan de acción. El modelo propuesto quedó inconcluso “en la medida que los principios resultaron foráneos al sentimiento de la colectividad.”11

Para Enrique Barba, el ideario de Rivadavia, continuado y perfeccionado por sus colaboradores y discípulos, "alentó y dio contenido doctrinario a quienes en larga y cruenta lucha bregaron por la organización constitucional de la patria." La influencia de Rivadavia propició cambios y creó instituciones que prepararon el camino de la obra que cumplió como ministro de Martín Rodríguez, con reformas unidas por el lazo de la cultura que las vinculó y las erigió, entre ellas la organización del poder judicial. ${ }^{12}$

Desde otra perspectiva más reciente, el grupo rivadaviano buscó dar coherencia y sentido teórico a las reformas a partir de algunas de las ideas centrales de corrientes filosóficas europeas, fundamentalmente el sensualismo, el utilitarismo y la idéologie. En especial las ideas de Bentham y el principio de utilidad, que determinaba que las acciones humanas debían ser juzgadas según el grado de daño o placer que provocaban a la comunidad. Este principio estaba especialmente destinado a los legisladores, considerados responsables de administrar la sociedad, teniendo a su alcance los medios más idóneos para ello: el premio y el castigo. ${ }^{13}$ Dentro del proyecto, la abolición del Cabildo llevaba implícita una reestructuración del sistema jurídico, que siguiendo el ideal benthamiano buscaba ser simplificado y separado de los otro dos poderes, aunque no se haya podido lograr. $^{14}$

El triunfo de los federales con Dorrego como gobernador en 1827 fue breve y su deposición profundizó el enfrentamiento con los unitarios que llevaría a Juan Manuel de Rosas al poder, con el proyecto de construir un orden social y político que, a pesar de la concentración de atribuciones del gobernador, mantendrían en vigencia la división de poderes y la ley electoral. Pero esto cobraría un nuevo sentido, legitimado en el sufragio y la opinión pública, que requirió de los sectores populares y el disciplinamiento de las elites políticas. ${ }^{15}$ Por ello es necesario seguir el desarrollo del proceso

\footnotetext{
${ }^{10}$ Halperin Donghi, Tulio, Revolución y Guerra. Formación de una élite dirigente en la Argentina criolla, México, Siglo XXI, 1979, p.352-379.

${ }^{11}$ Piccirilli, Ricardo, Rivadavia y su tiempo, Buenos Aires, Peuser, 1943, tomo II, p.22; 27.

${ }^{12}$ Barba, Enrique M. "Rivadavia y su tiempo", en Rivadavia, homenaje de la Facultad de Humanidades y Ciencias de la Educación, La Plata, UNLP, 1945, pp. 10; 14-15.

${ }^{13}$ Gallo, Klaus, op. cit., 2008, pp. 184-185, 193-194.

${ }^{14}$ Gallo, Klaus Bernardino Rivadavia: el primer presidente argentino, Buenos Aires, Edhesa, 2012, p. 77.

${ }^{15}$ Paganini Rosana, Souto Nora, Wasserman Fabio "El ascenso de Rosas al poder y el surgimiento de la Confederación (1827-1835)" en Goldman, 2005, op. cit., pp. 283-321.
} 
institucional en la campaña, que tomó ritmos diferentes y fue resultado de la centralización de mecanismos de poder por parte del Estado, como el intento fallido de establecer la primera instancia con tres jueces letrados, que fueron adquiriendo funciones que excedían notablemente las judiciales y fracasaron. ${ }^{16}$

Para lograr la paz social y construir un nuevo orden legítimo se requería de un aparato de contención construido por un cuerpo de funcionarios leales al gobierno, pero reconocidos y aceptados por la sociedad: los jueces de paz. ${ }^{17}$ La experiencia de los paisanos durante el rosismo reconstruyó la relación entre los subalternos y el Estado, agregando muy poco al cuerpo de leyes en vigencia y a las instituciones judiciales en funcionamiento. Lo que distinguió al período fue la "pedagogía de la ley", el esfuerzo por restaurar la autoridad de la ley como reguladora de las interacciones sociales. ${ }^{18}$ Esto ha generado un importante tema de debate, porque desde otro punto de vista no significó una alteración de los elementos esenciales que constituían el orden semántico de la vieja cultura jurídica, manteniéndose una dinámica de continuidad en el proceso de transición. ${ }^{19}$ De todas formas, la consolidación del Estado provincial a partir de 1852 estuvo signada por la continua presión que reclamaba la expansión del territorio -indispensable para la producción ganadera- y la búsqueda del Gobierno por alcanzar el control y la definición territorial.

\section{La administración de justicia desde 1820}

En 1820, establecido el gobierno provincial y terminado el conflicto generado por la coexistencia entre el gobierno central y el Cabildo, que representaba la soberanía de la ciudad capital, éste podía ser suprimido. Una vez dado este paso, la justicia ordinaria sería administrada por cinco jueces letrados, rentados e inamovibles denominados jueces de primera instancia, dos en la capital y tres en la campaña. Algunos de los pueblos rurales alcanzaron una mayor jerarquía institucional como cabecera de los departamentos judiciales de campaña o cabecera de partido,

\footnotetext{
${ }^{16}$ Sobre el tema del desarrollo institucional en la campaña véase Garavaglia, Juan Carlos, Poder, conflicto y relaciones sociales, Rosario, Homo Sapiens, 1999; Barral y Fradkin, 2005, op. cit., pp. 7-48; Fradkin, Raúl O. “¿Misión imposible? La fugaz experiencia de los jueces letrados de Primera Instancia en la campaña de Buenos Aires (18221824)", en Barriera, Darío G. (coord.) Justicias y Fronteras. Estudios sobre historia de la Justicia en el Río de la Plata, Murcia, Editum, 2009, pp. 143-164; Fradkin, Raúl O. (compilador), El poder y la vara. Estudios sobre la justicia y la construcción del estado en la Buenos Aires rural, Buenos Aires, Prometeo, 2008.

${ }^{17}$ Gelman, Jorge, "Crisis y reconstrucción del orden en la campaña de buenos Aires. Estado y sociedad en la primera mitad del siglo XIX” en Boletín del Instituto de Historia Argentina y Americana "Dr. Emilio Ravignani”, tercera serie, núm. 21, primer semestre de 2000, pp. 7-32.

${ }^{18}$ Salvatore, Ricardo D., Wandering Paysanos, Statae order and subaltern experience in Buenos Aires during Rosas era, Duke University Press, Durham and London, 2003.

${ }^{19}$ El estudio de la administración de justicia penal en Córdoba durante la primera mitad del siglo XIX ha demostrado que los pocos cambios observados no significaron una alteración de los "elementos esenciales que definían el orden semántico de la vieja cultura jurídica", demostrando la dinámica de continuidad en el largo proceso de transición, a partir del estudio de casos. La cultura jurídica que determinaba el lenguaje criminal de Córdoba afirma la coherencia y continuidad del período. Agüero, 2010, op. cit. En cambio para Buenos Aires, si bien es cierto que las tradiciones legales coloniales no desaparecieron de un día para el otro, el proceso revolucionario introdujo ideas liberales innovadoras visibles en el discurso político y jurídico. Barreneche, 2001, op. cit., p. 100-101.
} 
transformados por el crecimiento económico y demográfico en espacios de construcción del poder institucional. Pero esto no fue suficiente para sostener una estructura institucional intermedia, fracasando la primera instancia letrada en la campaña bonaerense. ${ }^{20}$ La inestabilidad política también implicó inseguridad laboral y precariedad en los cargos judiciales, aún en aquellos que se consideraban vitalicios, como los de jueces y fiscales, al estar sus carreras ligadas a las facciones políticas y correr en estos años su misma suerte. ${ }^{21}$

Ante la Junta de Representantes, Rivadavia explicó que el Cabildo era incompatible con un gobierno representativo, en que la autoridad había retrovertido a la sociedad y se ejercía por medio de quienes tenían la representación del pueblo. Sostenía que la administración de justicia de primera instancia no podía ser más viciosa, al ser ejercida por los hombres legos que confesaban su inhabilidad recurriendo a asesores, bajo cuyo juicio y responsabilidad juzgaban. Con estos fundamentos anunció que el Gobierno tenía en estudio un plan de reformas para la justicia -que demostraría al Cabildo innecesario- y otro para la policía. Según la correspondencia entre Bernardino Rivadavia y Jeremy Bentham -definido éste como trabajador incansable de la felicidad de la masa- el régimen tenía fallas que surgían del poder excesivo acordado a un solo individuo que podía anular la voluntad soberana de las asambleas representativas. Era Rivadavia quien mejor podía captar el pensamiento del utilitarista y desde una cuestión moral ajustarse a los principios políticos enunciados en su obra. ${ }^{22}$

Lo que nos interesa de los debates es que para Rivadavia los Cabildos eran contrarios a la representación provincial, es decir a la de la Sala de Representantes, ${ }^{23}$ mezclándose en las discusiones la esfera provincial con la municipal que quedó finalmente sin resolver, afirmando el carácter de provisionalidad que se daba a la reforma, lo que se repetirá en cada modificación, ya muy avanzado el siglo XIX. ${ }^{24}$ Esta provisionalidad significaba también indefinición respecto a rasgos sustanciales, como el de los fundamentos nacionales de los gobiernos centrales, los límites territoriales de su autoridad o sus atribuciones soberanas. ${ }^{25}$

Respecto al contenido de la ley, el carácter de letrados de los jueces de Buenos Aires la distinguía de otras provincias, pero hasta la sanción de los códigos sus atribuciones serían las de los alcaldes ordinarios capitulares. La preferencia por los jueces letrados fue dándose a lo largo del siglo XIX pero los fundamentos estaban casi todos presentes entre 1820 y 1852 . La creación de un sistema de derecho, con un juez vinculado a la ley y obligado a aplicarla, hacía necesario que

\footnotetext{
${ }^{20}$ Barral, y Fradkin, 2005, op. cit., pp.7-48.

${ }^{21}$ Barreneche, 2001, op. cit., pp. 110.

${ }^{22}$ Piccirilli, 1943, op. cit, tomo II, pp. 18.

${ }^{23}$ Acuerdos de la Honorable Junta de Representantes, Sesión del 18 de diciembre de 1821, II, p.353

${ }^{24}$ Art. $1^{\circ}$ "Quedan suprimidos los Cabildos hasta que la Representación crea oportuno establecer la ley general de Municipalidades." Ley del 24 de diciembre de 1821, ROPBA, 1821, pp. 124-125.

${ }^{25}$ Goldman, 2005, op. cit., pp. 57.
} 
conociera el orden legislativo para la aplicación técnica de una norma al caso planteado y no resolverlo según el buen saber y honradez de un lego. Este nuevo enfoque letrado de la administración de justicia encontró diversos escollos, pero el primero fue la necesidad de códigos racionalistas, expresión del nuevo sistema de derecho. También debía obedecerse a formas procesales, que aseguraran la seguridad individual respetando las garantías del ciudadano, comenzando a discutirse sobre la fundamentación legal de las sentencias. Además, avanzado el siglo una concepción dogmática y sistemática del derecho fue reservando a los juristas su monopolio, por lo que el arte de juzgar no podría estar ya en manos de jueces legos.

La orientación letrada encontró eco en todas las provincias como ideal a alcanzar, pero salvo en Buenos Aires se chocó con la falta de abogados y de fondos públicos para cubrir los cargos. La orientación lega se mantuvo y su protagonista fue el ciudadano de luces y conocida honradez o de ilustración y probidad. Se expresó en la justicia lega y popular, administrada por legos elegidos por el pueblo como los alcaldes de los cabildos del interior y jueces de campaña; jurado de imprenta; jueces nombrados por el gobernador; justicia gremial, como la mercantil y el intento del jurado criminal que no se concretó. Una solución intermedia fue la orientación letrada-lega manifestada en el juez lego con asesoramiento letrado obligatorio, el tribunal integrado con jueces legos y letrados y la existencia alternada de instancias legas y letrada. ${ }^{26}$

El intento de descentralización se manifestaba en la instalación de dos jueces en la capital y tres en la campaña; pero como no se conocía el territorio para establecer la división, se facultó al poder ejecutivo para que estableciera las respectivas jurisdicciones. Dividió entonces la campaña en tres departamentos con cabecera en San Vicente, instalada en Chascomús; Villa de Luján y San Nicolás, instalada en Arrecifes. Pero estos tuvieron corta vida, fueron eliminados en 1824 y nombrados dos jueces civiles y dos criminales en la capital, con la especialización por materia y fuero que aún perdura. ${ }^{27}$ Esos jueces serían rentados, con un sueldo de mil quinientos pesos anuales los de ciudad y de dos mil pesos los de campaña, mientras ejercieron la magistratura. Recordemos que si bien los alcaldes ordinarios no habían tenido sueldo, sí lo habían recibido sus asesores letrados, lo que se fundamentaba en que la preparación técnica para administrar justicia requería ahora de una remuneración, no bastando ya ser "homes buenos."

La inamovilidad significaba permanencia e independencia, la reforma debía ser consecuente con el sistema implantado por la Revolución de una justicia independiente, al menos en el texto de

\footnotetext{
${ }^{26}$ Tau Anzoátegui, 1973, op. cit., pp. 238-245. Manuel Antonio de Castro fue uno de los más férreos defensores de la idoneidad: "Si el atributo de la justicia es precisamente dar a cada uno su derecho, es muy claro que el distribuidor del derecho de cada uno debe tener copulativamente las partes de probidad y ciencia, y así como haría mal juez el ímprobo literato, tampoco será buen juez el iliterato probo. Está bien que se hayan de nombrar hombres buenos, según el valor del nombre; pero como no se han de librar pleitos, por la ley de buena intención, sino por las leyes positivas, se puede asegurar que la delicadeza de sus conciencias será puesta en tortor toda vez que hayan de votar pleitos implicados y oscuros." El Censor, 11 de febrero de 1812. Citado por Seghesso, 1989, op. cit., op. cit., pp. 68.

${ }^{27}$ Sobre el fracaso de estos juzgados véase Fradkin, 2009, op. cit., pp. 143-164.
} 
la ley. Sin embargo, Rivadavia consideraba que era necesario, para evitar la anarquía, declarar en comisión a los jueces para dar libertad al ejecutivo, pero no logró imponer su parecer. Se opuso firmemente Valentín Gómez, para quien declarar en comisión a los jueces era quitarles toda garantía a la inviolabilidad de sus juicios, haciendo imposible "conservar la independencia recíproca de los tres poderes.",28

Sería un letrado quien estuviera a cargo de la Defensoría de Pobres y Menores, que desempeñaría también la Procuración General de la Provincia. Hasta entonces era ejercida por un regidor elegido anualmente, que no tenía sueldo, recibiéndolo sí su asesor. El resto de los funcionarios de la justicia continuarían percibiendo sus emolumentos no del Estado, sino de los litigantes por medio de las costas de actuación hasta 1914. Por decreto del 13 de febrero de 1822 los oficiales de justicia (antes alguaciles mayores) tendrían sueldo; esos auxiliares, inclusive los secretarios, no serían letrados.

Según la ley, en cada parroquia había un juez de paz y en las parroquias de campaña el Gobierno debía establecer los que considerara necesario según la extensión. Sus atribuciones eran juzgar en las demandas que las leyes y las prácticas declaraban verbales y arbitrar en las diferencias. En la campaña reunía las de los alcaldes de hermandad, que quedaban suprimidos, incluyendo funciones administrativas y de policía. Adquiría así "extraordinario valor la persistencia del derecho consuetudinario español y la aplicación" en el territorio que en ese momento abarcaba la provincia de Buenos Aires. ${ }^{29}$ Este texto legislativo prometía las municipalidades, la codificación, el padrón, el plano de la provincia y la organización de la policía, transformándose en otra muestra de la naturaleza bifronte de las reformas republicanas, con una parte atada férreamente al pasado y otra en búsqueda de un orden liberal y moderno. ${ }^{30}$ Nos dedicaremos ahora a definir los caminos que se intentaron seguir para organizar el sistema judicial.

\footnotetext{
${ }^{28}$ Ibáñez Frocham, 1938, op. cit., pp. 177-179.

${ }^{29}$ Los artículos $10^{\circ}, 11^{\circ}$ y $12^{\circ}$ de la ley del 24 de diciembre de 1821 establecían que la policía, la inspección de mercados y abastos estaría a cargo en toda la provincia por un Jefe de Policía, seis comisarios para la ciudad y ocho para la campaña. Fijaban sus sueldos y las atribuciones quedaban a designar por el Gobierno hasta la sanción de las leyes correspondientes. Zorraquín Becú, 1952, op. cit., pp. 64; Díaz, 1959, op. cit., p. 53. Para un estudio detallado del funcionamiento de la justicia de paz en la campaña ver Garavaglia, Juan Carlos, "La justicia rural en Buenos Aires durante la primera mitad del siglo XIX (estructuras, funciones y poderes locales)”, en Garavaglia, 1999, op. cit., pp. 89121.

${ }^{30}$ Cansanello, 2003, op. cit., p. 67.
} 


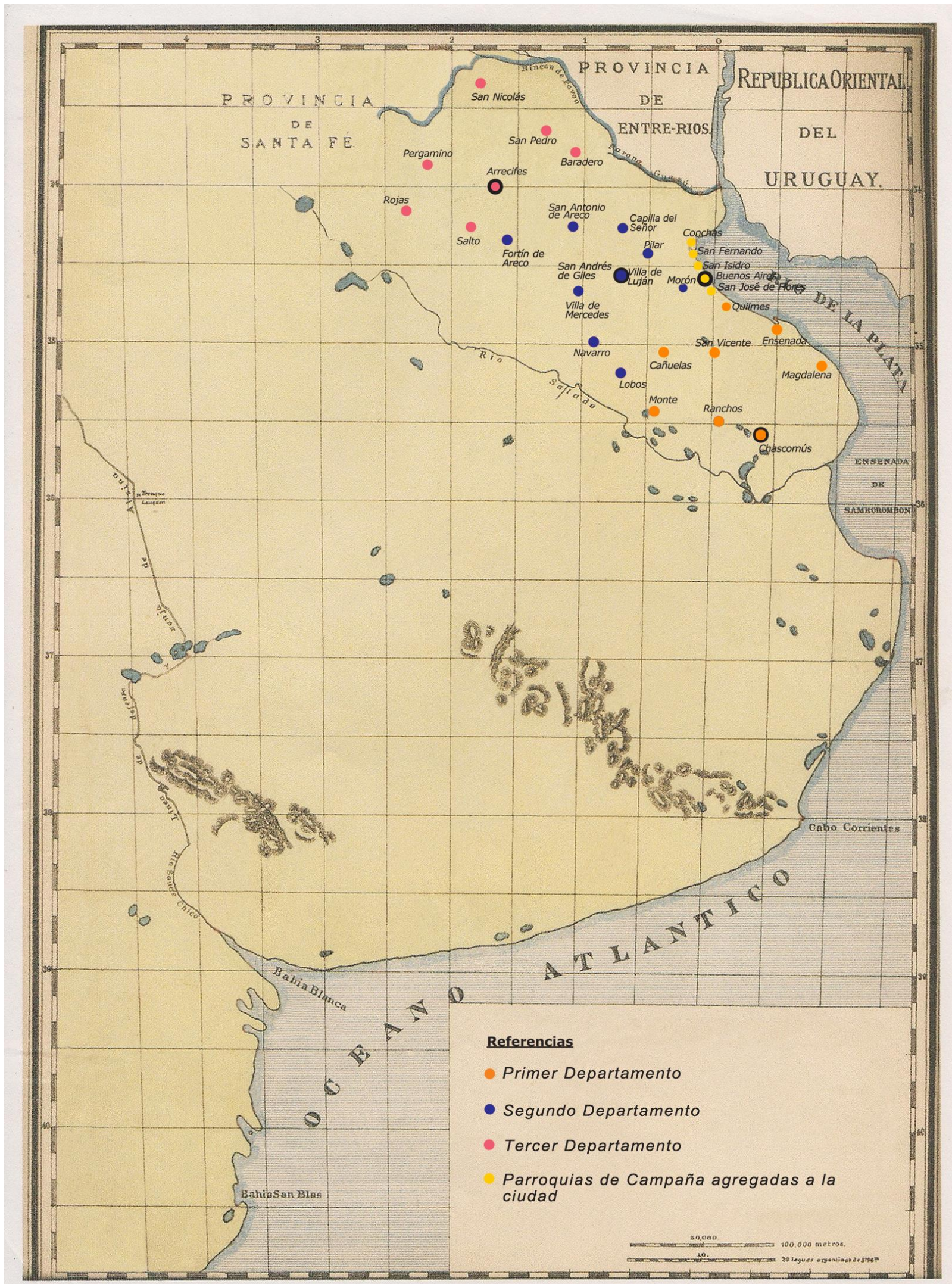

Mapa de la provincia de Buenos Aires según los partidos enunciados en la ley del 28 de diciembre de 1821, la ley del 22 de enero de 1822 de nombramiento de los jueces de paz en los tres departamentos de campaña y partidos agregados a la ciudad, y la ley del 7 de febrero de 1822 de cabeceras de Departamento. Según esta ley el partido de Quilmes quedó agregado finalmente al Departamento de la Capital. Elaboración propia a partir de los datos de ROPBA, 1821, p. 128; ROPBA, 1822, p. 16-17; p. 24. Diseño de Joaquín Aras. 


\section{Los proyectos}

\section{a. Los proyectos de la Cámara de Apelaciones}

Parte del movimiento que se había generado en Buenos Aires para organizar las instituciones se manifestó en los proyectos que la Cámara de Justicia presentó entre 1821 y 1833, que si bien no llegaron a sancionarse, muestran - junto con los reglamentos adoptados en las demás provincias- la variedad y riqueza de soluciones posibles para la administración de justicia y son prueba del empirismo de la organización judicial temprana, que respondía a las necesidades de cada provincia y comprobaba el protagonismo de las del interior. El contenido de los proyectos deja de manifiesto que no buscaban generar grandes cambios en el derecho, sino darle precisión y método moderno, reuniendo en ellos normas sobre la administración de justicia y el procedimiento civil, comercial y criminal, dado que la especialización temática fue el fruto de un proceso histórico y no de un modelo teórico previo. ${ }^{31}$

El 18 de agosto de 1821 Bernardino Rivadavia, ministro de gobierno y relaciones exteriores, dirigió un oficio a la Cámara de Justicia, presidida por Manuel Antonio de Castro, exponiendo la importancia de la administración de justicia en la reforma y organización de la provincia y afirmando que "las formas de los juicios y la provisión de jueces hábiles y proporcionados al número, gravedad y exigencia de los casos" eran los puntos que reclamaban más prontas correcciones y mejoras, y nadie como ese tribunal estaba capacitado para colaborar con tal obra.

El 6 de diciembre la Cámara remitió la primera parte de un proyecto de ley sobre la organización de los jueces y tribunales, firmado por Castro, Alejo Castex y Tomás Antonio Valle, acompañada por una nota del presidente. ${ }^{32}$ El objetivo era claro: “extirpar los abusos más notables en el ejercicio del poder judicial sin dar el paso peligroso de alterar sustancialmente el sistema de la ley." El número de magistrados era insuficiente y desproporcionada su distribución, dilatándose las causas y frustrando el efecto de las penas. Proponía dividir la provincia en siete departamentos (con asientos en Capital, San Nicolás, Luján, Morón, Ensenada, Chascomús y Villa del Carmen de Río Negro) con jueces de residencia permanentemente, que administraran justicia "con prontitud, con proporción y acierto y al mismo tiempo cuiden de la policía, y buen orden de los distritos.”

\footnotetext{
31 Abelardo Levaggi realizó un pormenorizado estudio sobre el origen del proceso codificador en las provincias demostrando que en este período el mayor esfuerzo en este sentido no lo había realizado Buenos Aires, sino las provincias del interior, y que las normas sobre la administración de justicia no fueron realizadas sobre el diseño ilustrado, sino que se desarrolló empíricamente a partir de la legislación indiana, adoptando dicho diseño con posterioridad. Estudiamos los textos de los proyectos, analizados por el autor, en los que nosotros destacamos o agregamos lo relacionado con el tema que nos ocupa. Nos hemos dedicado especialmente a las notas de presentación de los proyectos, pues allí se exponían los objetivos, las ideas y la síntesis de las reformas propuestas. Levaggi, 1995, op. cit., pp. 14-19; 58-72.

${ }^{32}$ Nota dirigida por el doctor Manuel Antonio de Castro, Presidente de la Excelentísima Cámara de Justicia, al Ministro secretario de Gobierno y relaciones exteriores adjuntando el proyecto de Ley para la provincia de Buenos Aires, sobre el establecimiento de las magistraturas que debe haber en ella, forma y orden de la administración de justicia, en Castro, Manuel Antonio de, [1834] Prontuario de práctica forense, Facultad de Derecho y Ciencias Sociales. Instituto de Historia del Derecho Argentino, Buenos Aires, 1945. Reedición facsimilar con apéndice documental, p. 1-4. 8. (en adelante Castro, Prontuario)
} 
El concepto de descentralización de Castro se basaba en que dos alcaldes en lo civil y uno en los criminal no podían cumplir con una buena administración de justicia para toda la provincia, con una campaña donde "los miserables labradores y hacendados están obligados a caminar 70 y 80 leguas en busca de justicia, fuera de su domicilio." A esto se sumaba que en materia criminal no se podían esclarecer los delitos a tan grandes distancias y la campaña quedaba infestada de malhechores. En la propuesta la justicia estaba reservada a la Cámara de Justicia y los juzgados de primera instancia, suprimiendo la Alzada de Provincia y los "casos de corte." Los magistrados debían ser letrados, pues los legos con asesores multiplicaban empleados y los sistemas judiciales europeos y la del propio tribunal habían demostrado la ventaja de un juez con más inmediata responsabilidad. $^{33}$

La segunda parte del proyecto fue presentada el 12 de marzo de 1822 y nuevamente Castro anunciaba que se había "evitado cuidadosamente hacer innovaciones sustanciales, porque toda reforma parcial en esta materia corre el riesgo de alterar o trastornar el sistema de las leyes sin mejorarlo." El objeto principal era abreviar los juicios civiles, cuyo retardo se debía a que uno de los litigantes poseía "la cosa" en disputa e intentaba eternizar el juicio, haciendo uso de todos los recursos disponibles, mientras el otro quería adquirirla o recuperarla en un rápido juicio. En los juicios criminales había procurado el Tribunal "conciliar todos los derechos de la seguridad individual y real con los de la justicia pública, a fin de que puesto el ciudadano a cubierto de toda violencia y arbitrariedad, no queden a este pretexto impunidos los delitos." 34

La preocupación del Gobierno por los robos de ganado en la campaña generó un nuevo pedido de proyecto de ley a la Cámara de Apelaciones, al que el 4 de mayo de 1825 contestó Castro luego de varios Acuerdos del Tribunal, de los que participaron el ministerio fiscal y los jueces del crimen de primera instancia. Nos interesa aquí destacar que se buscaba más la prevención de los delitos que el castigo, pero entendida como la prontitud y severidad en castigar al delincuente; la prontitud en manos de la policía del gobierno y la severidad a cargo del orden judiciario y de las buenas leyes penales. Desde su análisis la lentitud en los procesos era causada por la lentitud de los comisarios de policía en redactar sumarios largos y prolijos, la ratificación de los testigos en el estado plenario de la causa y la falta de procuradores que llevaran adelante las causas. Como solución a estos problemas se presentaba el proyecto de ley sobre procedimiento judicial en causas criminales, reglamento práctico que no se tradujo en ley.

Otra propuesta de la Cámara tuvo su origen en el decreto firmado por Juan Manuel de Rosas el 5 de marzo de 1830, justificado en la búsqueda del mejor desempeño de la administración de justicia y la protección de todos los derechos sociales. Eran urgentes las reformas que la opinión

\footnotetext{
${ }^{33}$ Era un proyecto que abordaba buena parte de las reformas que se fueron adoptando con el tiempo, pero que no fue tenido en cuenta en 1821. Ibáñez Frocham, 1938, op. cit., pp. 165-171.

${ }^{34}$ Castro, Prontuario, pp. 17-21.
} 
pública y la experiencia señalaban como necesarias y que nadie mejor que la Cámara de Justicia podría orientar. ${ }^{35}$ Por el trabajo que el tribunal tenía, el gobernador aumentaba de cinco a siete sus miembros, con dos fiscales (uno para lo civil y negocios de Hacienda y otro para lo criminal) y se les encargaba redactar un proyecto de reforma cuyos objetivos serían las magistraturas, el orden de los juicios, las oficinas bajo su inspección y las procuradurías.

Fue presentado el 12 de abril de 1833, luego del trabajo de una Comisión, que discutió en sesiones plenarias buscando disminuir y simplificar los pleitos. En la presentación puede observarse que el concepto de utilidad guiaba la tarea para la organización de la magistratura, la definición de su misión y la supresión de todo trámite superfluo y oneroso, logrando así “obtener cada uno lo suyo con el menor dispendio posible de tiempo, fortuna y sufrimiento." ${ }^{, 36}$ El poder judicial era declarado independiente y todo hombre tenía derecho a ser juzgado por sus jueces. No determinaba si los jueces eran temporales o permanentes, pero sí que no podían ser removidos sin juicio y sentencia, ni suspendidos sin sumario. Le quedaba asignada la superintendencia del Poder al Superior Tribunal y en caso de dudas, le consultaría al poder legislativo sobre la interpretación de las leyes. ${ }^{37}$

La idea era simplificar los juicios "sin desatender las garantías más escrupulosas que pueden desear los ciudadanos de que se les administrara sin vejamen recta justicia." ${ }^{38}$ Para Levaggi, este largo proyecto que era el mejor desde el aspecto técnico, estaba influenciado por el de 1821-1822 y la ley de Enjuiciamiento española sobre los Negocios y Causas de Comercio de 1830, destacándose la originalidad en la búsqueda de adaptarse a las circunstancias de la provincia. ${ }^{39}$ A esto agregamos que según el proyecto constitucional del mismo año, el poder judicial debía asegurar el honor, la vida y la propiedad de los ciudadanos, teniendo especial significado para nuestro estudio la publicidad definitiva de la votación de los jueces del Superior Tribunal y la falta de mención de la calidad de letrado como requisito para ser magistrado.

\section{b. Plan general de la organización judicial para Buenos Aires de Guret Bellemare ${ }^{40}$}

Guret Bellemare era un magistrado francés y ciudadano argentino, cuyo objetivo era lograr un sistema completo de legislación criminal en "armonía con la razón y los verdaderos principios de

\footnotetext{
${ }^{35}$ El texto completo del decreto se encuentra en el Archivo Histórico de la provincia de Buenos Aires, Cámara de Apelaciones, 9-1-2-154, porque en el texto publicado en el Registro Oficial faltan artículos. (en adelante AHP)

${ }^{36}$ Proyecto de ley sobre la Reforma Judicial elevado por la Cámara de Justicia al Gobierno el 12.4.1833, en Levaggi, op. cit., p. 84. (en adelante Proyecto de 1833)

${ }^{37}$ Ver para mayor detalle de las propuestas procesales: Levaggi, 1995, op. cit., pp. 69-71.

${ }^{38}$ Proyecto de 1833, Levaggi, 1995, op. cit., p. 87.

${ }^{39}$ Levaggi, 1995, op. cit., pp. 71-72.

${ }^{40}$ Bellemare, Guret, [1839] Plan general de organización judicial para Buenos Aires, "Noticia preliminar de Ricardo Levene", Facultad de derecho y ciencias sociales, Instituto de Historia del derecho, Colección de textos y documentos para la Historia del derecho Argentino VIII, Buenos Aires, Facultad de Derecho, UBA, 1949. (en adelante Plan Bellemare)
} 
humanidad", especialmente en estas tierras en que no se habían adquirido aún malos hábitos. Pretendía evitarlos inspirando principios y moral con buenas leyes criminales. Sus ideas coincidían con las de Florencio Varela, que en su tesis definía a la legislación vigente como "un oscuro laberinto en que los jueces se confunden y los ciudadanos no pueden conocer con exactitud los límites de sus derechos y de sus obligaciones." Varela criticaba la administración de justicia, los procedimientos criminales, la prolongación de los procesos y el estado de las cárceles, asegurando que la pena de muerte era un "asesinato legal", pero imposible de suprimir por mucho tiempo. ${ }^{41}$

En 1827, Bellemare proponía la creación de una cátedra de derecho criminal y el nombramiento de una comisión legislativa de los jurisconsultos más antiguos y experimentados para codificar. Ante estas ideas y por la necesidad del Gobierno de organizar la justicia, Manuel Dorrego le encargó escribir un plan con este fin, que resultó ser más teórico que práctico, inspirado en modelos de las instituciones norteamericanas, inglesas o francesas y no en la experiencia local. El plan fue presentado el 15 de agosto de 1828, aclarando que su inclinación al modelo francés era por su origen y formación, pero también por encontrar las costumbres de los americanos del Sud más cercanas a las francesas, salvando el jury que tomaba de Inglaterra y los Estados Unidos por haber sido alterado por el despotismo de Francia. ${ }^{42}$

Desde la perspectiva de Bellemare, el poder judicial debía ser el contrapeso del poder y la inamovilidad de los miembros que lo formaban le daba independencia, garantía de la libertad de los pueblos. Todo empezaba y terminaba en la división de poderes constituyentes, la inamovilidad de la magistratura y el establecimiento del jury, que formaba y fortalecía el espíritu público. ${ }^{43} \mathrm{Si}$ bien no se contaba con una Constitución, indispensable para servir de base al edificio social y establecer los tres poderes constituyentes, Buenos Aires "vive y existe en república”, con una cámara legislativa, y un poder ejecutivo, y era necesario constituir un poder judicial para equilibrarle. ${ }^{44}$

La propuesta organizativa partía de una pregunta-diagnóstico, cuya respuesta sería propuesta de solución: “¿Cuál es el estado de vuestra organización jurídica, civil y criminal, donde, a pesar de la magistratura, todo es lentitud y languidez? Y vuestra magistratura, con las leyes españolas, ¿puede servir de contrapeso al poder ejecutivo, ni servir a vuestras libertades públicas?” A esto respondía que una nueva administración de justicia, con nuevos atributos, sería la única tabla salvadora del naufragio. ${ }^{45}$ Debía estar conformada por magistrados letrados, reunidos en tribunales colegiados, nombrados por el cuerpo legislativo, sobre una lista de tres candidatos presentada por el

\footnotetext{
${ }^{41}$ Varela, Florencio, "Disertación sobre los delitos y las penas", 1827. Fue publicada en Revista de Legislación y Jurisprudencia, tomo V, Buenos Aires, 1870, p.43.

${ }^{42}$ Plan Bellemare, Noticia preliminar, pp. XXX-XXXI.

${ }^{43}$ Plan Bellemare, p. 116.

${ }^{44}$ Plan Bellemare, pp. 4; 153-157.

${ }^{45}$ Plan Bellemare, Noticia preliminar, pp. XIV, XXI.
} 
ejecutivo. ${ }^{46}$ Éste también propondría a los miembros del Ministerio Público, que si resultaban de una elección unánime de la Corte sería definitiva y si no se someterían al legislativo, siendo luego inamovibles. $^{47}$

El poder judicial estaría organizado en base a juzgados de paz, tribunales de primera instancia, Alta Corte, Ministerio Público y cárceles, que no debían ser casa de venganza para la sociedad, sino casa de corrección saludable. Para esto, debían estar divididas en una parte para hombres y otra para mujeres, subdividido según el grado de locura o culpabilidad, considerados como hospitales, con guardianes como enfermeros, médicos, maestros de artes, profesores y eclesiásticos. En Buenos Aires había advertido todos los defectos posibles para propagar la corrupción, aceptándose presos sin orden escrita y sin explicar por qué. ${ }^{48}$

\section{$\underline{\text { IV. La bibliografía académica }}$}

En 1821 fue creada la Universidad de Buenos Aires y por Edicto de Erección del 9 de agosto, el gobernador Martín Rodríguez instituía el Departamento de Jurisprudencia, con las cátedras de Derecho Civil, a cargo de Pedro Somellera, y Derecho Natural y de Gentes, encabezada por Antonio Sáenz, el primer Rector, que junto con profesores y personal eran solventados por el gobierno de Buenos Aires. Los estudios estaban organizados en dos etapas, una académica que se cursaba en la Universidad y de la que se obtenía el título de Doctor en Jurisprudencia, y otra práctica en la Academia de Jurisprudencia, llevando en total unos cinco o seis años; la tercera cátedra de Magistratura, propuesta por Sáenz, no prosperó por cuestiones económicas. ${ }^{49}$

La obligación de los profesores de preparar los cursos para la impresión nos permite conocer en parte la base doctrinaria con que los letrados salían de la Universidad y los lineamientos de los debates jurídicos. ${ }^{50}$ Los docentes debían elaborar la síntesis de una disciplina, esto implicaba una

\footnotetext{
${ }^{46}$ Plan Bellemare, pp. 3-4. El conocimiento del derecho debía ir acompañado de un carácter de rectitud reconocida y probada por una conducta regular, y por la edad madura "que es el sello de la prudencia y de la experiencia."

${ }^{47}$ Plan Bellemare., pp. 150-153. El Ministerio Público era amovible, considerado parte del Poder Ejecutivo y por él celado y destituido; pero estos eran principios defectuosos, pues debía ser "independiente, inamovible y libre de todo influjo gubernativo."

${ }^{48}$ Plan Bellemare, pp. 214-220.

${ }^{49}$ En 1826 se incorporaron las cátedras de Derecho Canónico y Economía Política, eliminada eat última en la década siguiente. Sobre la Facultad de Derecho de la Universidad de Buenos Aires véase Ortiz, Tulio, Historia de la Facultad de Derecho, Buenos Aires, Facultad de Derecho, UBA, 2004; Halperin Donghi, Tulio, Historia de la Universidad de Buenos Aires, Buenos Aires, EUdeBA, 2002. Sobre la enseñanza del derecho: Seoane, María Isabel, La enseñanza del derecho en la Argentina. Desde sus orígenes hasta la primera década del siglo XX, Buenos Aires, Perrot, 1981; Tau Anzoátegui, Víctor, "En torno a la mentalidad de nuestros juristas del ochocientos”, en Revista de Historia del Derecho, núm. 5, Buenos Aires, Instituto de Investigaciones de Historia del Derecho, 1977.

${ }^{50}$ Por el Reglamento del 6 de marzo de 1823 se debían arreglar los estudios, comprendiendo el plan general de las publicaciones docentes y universitarias. Los profesores tenían obligación inherente al cargo de preparar sus cursos para la impresión. El contenido estaría dedicado al texto de la teoría o ciencia que se enseñaba y una vez concluida la redacción del curso cada profesor se consagraría "a redactar con criterio y precisión la historia de su respectiva facultad..." El decreto del 17 de mayo de 1823 les reconocía la propiedad intelectual. ROPBA, 1823, pp. 25-26. La Magdalena Candioti estudió las ideas sobre derecho posrevolucionario en el marco de la Universidad de Buenos Aires y su importancia en la legitimación de la Revolución. Candioti, 2009, op. cit., p. 142.
} 
reacción contra el método de enseñanza imperante, según el cual los antiguos profesores se limitaban a referirse a autores "de volúmenes importantes que eran reverenciados y conocidos generalmente por las cubiertas."

\section{a. Instituciones elementales sobre el Derecho Natural y de Gentes de Antonio Sáenz}

La cátedra de Derecho Natural y de Gentes del Departamento de Jurisprudencia “significó con todo [se refiere a los elementos de procedencia escolástica] una manifiesta concesión a las ideas racionalistas y los nombres de Grocio y Pufendorf -inspiradores de aquel movimiento- alcanzaron por esta vía también notoriedad en el aula universitaria". ${ }^{52}$ En ella Antonio Sáenz enseñaba en el orden jurídico natural e inmutable, con muy pocas críticas y propuestas legislativas o de administración de justicia, sin pretender presentar un orden jurídico concreto. ${ }^{53}$

Su obra consta de dos partes, una sobre derecho natural y otra sobre derecho de gentes; la primera, del curso dictado en 1822, se ha extraviado pero se conserva el plan y los conceptos del autor en el Informe publicado en $1823 .{ }^{54}$ Para los censores, Sáenz abrazaba los principios fundamentales y sólidos del derecho natural, desenvolviéndolos con luminosa claridad y presentándolos con un método sintético y doctrinal. El derecho natural y el derecho positivo tenían el mismo origen, pero el primero era promulgado al hombre por la revelación y el segundo por la razón. El derecho natural distinguía lo justo de lo injusto, y la conciencia aprobaba o condenaba las propias acciones, pero el acto ajeno se discernía a través del cumplimiento de la ley y de allí nacía la imputabilidad.

El libro segundo, Del derecho de gentes, dictado en 1823 establecía en su Discurso preliminar que todos los hombres tenían la misma responsabilidad ante la ley y diferenciaba el derecho de gentes y el público. El derecho de gentes era universal y salía de la naturaleza, logrando su conocimiento por la recta razón; el derecho público reglaba el régimen interior de los Estados y las relaciones, tratados y usos de las naciones entre sí; por esto no era fijo, inmutable ni universal. ${ }^{55} \mathrm{~A}$ esto debía agregarse el derecho de costumbre, surgido del consentimiento de las naciones en orden a sus usos y ejercicios, que sólo generaba obligación entre las que lo habían adoptado o permitido y derivaba su fuerza del principio natural que prescribía la observancia de toda obligación.

\footnotetext{
${ }^{51}$ Sáenz, Antonio, "Instituciones elementales sobre el Derecho Natural y de Gentes. (Curso dictado en la Universidad de Buenos Aires en los años 1822-1823)", Buenos Aires, Instituto del Historia del Derecho, Facultad de Derecho y Ciencias Sociales, 1939. Introducción de Ricardo Levene, p. LII; LVII. (en adelante Sáenz)

52 Tau Anzoátegui, Víctor, [1977] La codificación en la Argentina (1810-1870) Mentalidad social e ideas jurídicas, 2da. Edición, Buenos Aires, Librería Histórica Emilio J. Perrot, 2008, p. 218.

${ }^{53}$ Candioti, 2009, op. cit., p. 129.

${ }^{54}$ Informe de la Comisión nombrada para censurar el curso de Derecho natural dictado por Doctor Antonio Sáenz y acuerdo de la muy Ilustre Sala de doctores de esta Universidad, Buenos Aires, Imprenta de la Independencia, 1823.

${ }^{55}$ Sáenz, pp. 56-58.
} 
La Sociedad, llamada también Nación y Estado, era la reunión de hombres que debían someterse voluntariamente a una suprema autoridad soberana, y aunque la soberanía se constituía por la reunión de los grandes derechos y deberes de un Estado, podía distribuirse su ejercicio y dividir su administración, quedando repartida entre las autoridades que tenían asignadas sus funciones. El supremo poder ejecutivo, y el judicial ejercían derechos magestativos o de primer orden no menos importantes que el legislativo, "así pues ni la soberanía es propia de este solo, ni sus funciones son intransmisibles cuando pasa frecuentemente de unas personas a otras su ejercicio por períodos señalados." 56

\section{b. Principios de derecho civil de Pedro Somellera ${ }^{57}$}

Esta obra desarrolló ideas básicas y elementales, destinadas a formar los cimientos del edificio que constituiría la educación de los jóvenes estudiantes. Siguiendo el modelo de Bentham, expresaba sus desacuerdos embebido en su contexto (medio ambiente, base cultural y grado de preparación de los alumnos) y con conocimiento de los problemas jurídicos para escribir un libro destinado a la educación, convencido que para ser jurista era indispensable saber unir teoría y práctica $^{58}$ A partir de allí, y sobre "los verdaderos principios de utilidad y conveniencia", sus objetivos fueron presentar los principios en que debían reposar las nuevas leyes y las normas, junto con las reglas indispensables para interpretar y aplicar correctamente las leyes que regían. ${ }^{59}$

Para Somellera el derecho tenía tres definiciones: la ciencia de lo justo y de lo injusto, esto era la Jurisprudencia; la colección de leyes de una misma especie; la facultad de hacer o de exigir alguna cosa, y en este sentido, su correlación con el deber. La Jurisprudencia era el "hábito práctico de interpretar las leyes rectamente, y aplicarlas con exactitud a los casos”, para ser jurista se debía conocer, interpretar y aplicar la ley. Interpretar la ley era "explicar su intento, su fuerza y poder", en tres formas: auténtica, (declaración del mismo legislador, consultado a causa de la oscuridad de la ley); práctica, (la que hacen los tribunales, según el uso observado en los juicios anteriores), doctrinal (la que dan los abogados según las reglas y principios del derecho).

Las funciones de la ley eran mantener la abundancia, crear la seguridad, favorecer la igualdad, elementos todos que componían la felicidad. ${ }^{60}$ Sobre esta base, los magistrados debían intervenir en el intervalo entre el principio y el fin del delito, imaginando la peor de las terminaciones,

\footnotetext{
${ }^{56}$ Los derechos magestativos también llamados soberanos y altos poderes. Sáenz, pp. 70-71.

57 Somellera, Pedro, Principios de derecho civil (curso dictado en la Universidad de Buenos Aires en el año 1824), Buenos Aires, Imprenta de los Expósitos, 1824. Reedición facsimilar. Noticia preliminar de Jesús H. Paz, Buenos Aires, Facultad de Derecho y Ciencias Sociales, Instituto de Historia del derecho argentino, 1939. El texto anuncia tres partes, de las que sólo escribe las dos primeras: sobre el derecho de las cosas y de las acciones, de los delitos, de los modos de precaverlos, de los jueces y de los juicios. (en adelante Somellera)

${ }^{58}$ Somellera, Noticia preliminar de Jesús H. Paz, pp. XIV-XVII.

${ }^{59}$ Somellera, Noticia preliminar de Jesús H. Paz, pp. III-V.

${ }^{60}$ Somellera, pp. 10-13.
} 
recurriendo al conocimiento de casos anteriores, para suprimir el delito con prontitud. Pero si tenía que aplicar la pena, debía disponer de muchas alternativas para recurrir a la más conducente, y poder "combinarlas, y mezclarlas, como los médicos combinan y mezclan los simples para componer un remedio apropiado a la enfermedad", sin llegar a la pena de muerte. ${ }^{61}$

La propiedad de las cosas (igualada con dominio, como dueño y propietario) era útil y necesaria, por lo que debía ser "religiosamente garantida", para producir tranquilidad, hacer progresar las ciencias y las artes, y formar la prosperidad de los individuos y la de la sociedad. Fundamentada en el trabajo del hombre, añadía a las cosas un valor particular, que no recibieron de la naturaleza, siendo la ley la que tenía el don de definir el "tuyo y mío."62

La posición utilitarista de Somellera fue abandonada en la Universidad en 1832 con Rafael Casagemas, que volvía a lo tradicional al inspirar su enseñanza en las "Instituciones del Derecho Real de España” de José María Álvarez, en una edición adaptada por Vélez Sarsfield en 1834, para agregar al texto original el derecho indiano mediante notas y adiciones. El utilitarismo, como corriente ideológica, decaía hacia los 30 y las visiones iusnaturalistas y romanistas ascendían. ${ }^{63}$ Sin el concepto de utilidad, plazos más cortos y costos más bajos reaparecían en los discursos, pero los objetivos de abundancia (como progreso), seguridad e igualdad reaparecerían. Tau demuestra que el fermento reformista se mantuvo a través del estudio de las tesis doctorales. ${ }^{64}$

\section{c. Prontuario de práctica forense de Manuel Antonio de Castro}

Manuel Antonio de Castro representaba una de las diferencias sustanciales en el grupo reformista, oponiéndose a las medidas de Rivadavia, a la división de la provincia y a la ley de enfiteusis, protegiendo los intereses de Buenos Aires y sus sectores más poderosos, adhiriendo a la organización de un Estado unitario o al confederacionismo como Estado soberano e independiente en pro de su liderazgo. ${ }^{65}$ Esto se refleja en su obra, en cuyo primer capítulo define el fin de la justicia como "dar a cada uno lo que es suyo". Quien iniciaba un pleito judicial tenía por objeto obtener lo que creía pertenecerle en justicia, por medio de la autoridad pública. El juicio, en sentido lato era todo procedimiento que resultaba de la audiencia, prueba y sentencia; y el juez era la tercera persona que necesariamente intervenía en el juicio. Las Partidas (L.1 ${ }^{\circ}$, tít. 4, Part. 3) lo definían como el home bueno que es puesto para mandar e facer derecho y este juez recibía de la ley la

\footnotetext{
${ }^{61}$ Somellera, p. 46.

${ }^{62}$ Somellera, pp. 115-117.

${ }^{63}$ Díaz Couselo, José María "La tradición indiana y la formación del derecho argentino", en Temas de historia argentina y americana núm. 7, julio-diciembre, UCA., Buenos Aires, 2005; Candioti, 2009, op. cit., p. 160.

${ }^{64}$ Tau Anzoátegui, 2008, op. cit., p. 220.

${ }^{65}$ Chiaramonte, 1997 , op. cit. p. 82.
} 
potestad pública para el conocimiento y decisión de las causas, siendo esta la jurisdicción (L.18; tít.4, Part.3). ${ }^{66}$

En la descripción de la organización judicial, presentaba cada instancia, fecha de origen, evolución y cambios, planta y competencia que tenía al momento. Es un magistrado que desde dentro del poder fue explicando la organización y el funcionamiento, haciendo breves observaciones sobre los agentes, no sobre la estructura. Las sugerencias sobre las reformas al sistema judicial las realizó desde los proyectos presentados al Gobierno y desde la prensa, donde definía la división de poderes, sin debatir sobre el origen o la naturaleza del pacto social. La soberanía se explicaba por tres atributos o maneras de obrar, que formaban los tres supremos poderes conocidos con la denominación de legislativo, ejecutivo y judicial. De la exactitud en su constitución, separación y equilibrio dependía la mayor o menor libertad civil de un Estado. ${ }^{67}$

\section{d. Tratado elemental de los procedimientos civiles en el foro de Buenos Aires de Miguel Esteves} Saguí $^{68}$

Miguel Esteves Saguí, jurista y catedrático, cuya relación con el rosismo fue rápidamente olvidada después de Caseros, se destacó por sus expresiones doctrinarias destinadas a lograr la fundamentación obligatoria de las sentencias y por éste Tratado, correcta sistematización y estudio de las instituciones procesales, con un detallado resumen de la legislación vigente y a la vez una visión de lo que ella significaba en el ejercicio del derecho de esos días.

Leyes patrias nacidas con nuestra República, como era necesario que brotasen; pero derogantes y derogadas; sobre una y mil materias; confundidas todas a la vez, para mayor penuria: leyes del tiempo del sistema colonial, aun a peor condición y oscuridad todavía, como las cédulas, órdenes, decretos, pragmáticas especiales al virreinato; y el indigesto código de Indias sin más origen y fundamento que otras tantas, salidas de la antigua corte: Leyes Recopiladas de Castilla, tipo vetusto de aquella otra Compilación: Código de las Partidas, Fuero Real, Fuero Juzgo: únicas piedras preciosas entremezcladas en los montones de aquel incendio: diversos códigos canónicos: otros comerciales: no sin un lugar importante el Romano -padre y fundador de todos los otros [...] ¡Santo Dios! ¡Cuanta mole inmensa para espantar al más atrevido! [...] Es un verdadero laberinto, donde nada falta, donde todo sobra... ${ }^{69}$

El autor encaraba este tratado elemental para poder entrar y salir con mayor facilidad de ese laberinto, hasta que se tuviera una legislación propia "adecuada a nuestras costumbres; digna en fin de esta Buenos Aires; hermosa parte de la Confederación Argentina, cuyo esplendor nacional brilla

\footnotetext{
${ }^{66}$ Castro, Prontuario, p. 3.

${ }^{67}$ Gaceta de Buenos Aires, 25 de octubre de 1820, "Reflexiones. Sobre la exactitud de los principios sociales y sobre los vicios que puedan alterarlos."

${ }^{68}$ Esteves Saguí, Miguel, Tratado elemental de los procedimientos civiles en el foro de Buenos Aires, adaptado al uso de los estudiantes de derecho, y obra útil para muchas otras personas que tengan por que intervenir en el foro, Imprenta Americana, Buenos Aires, 1850. (en adelante Esteves Saguí)

${ }^{69}$ Esteves Saguí, p.XII. Véase Tau Anzoátegui, Víctor "Los orígenes de la Jurisprudencia de los Tribunales en la Argentina", en Revista del Instituto de Investigaciones de Historia del Derecho, núm. 6, 1979, Buenos Aires, p. 323.
} 
hoy, al impulso de la poderosa cabeza del GRAN ROSAS, y a despecho de la vieja altanera Europa." 70

Con respecto a la forma y organización del poder judicial, comenzaba definiendo la jurisdicción, que tomada en general según las Partidas, era el conjunto de facultades y atribuciones concedidas por pública y competente autoridad a algún individuo o corporación, para conocer y vigilar sobre el cumplimiento de las leyes. Tomada en concreto, era la facultad de citar, oír, conocer y sentenciar en los asuntos litigiosos, o sujetos al castigo que las leyes imponían (L.18, tít.4, Part. $\left.3^{\circ}\right) .^{71}$

Era una facultad independiente del poder legislativo y ejecutivo, que residía originariamente en el pueblo, y quienes la desempeñaran en su nombre debían reunir condiciones y calidades que los hicieran dignos de un ministerio que el autor consideraba semejante en algo a la Divinidad. Estos funcionarios, reconocida la independencia en los tres poderes del Estado, deberían ser nombrados por el más alto Tribunal de la administración de justicia, lo mismo que sus empleados. La delegación de esta tarea en el poder ejecutivo devenía de los códigos españoles, en los cuales era el rey el encargado de nombrarlos como jefe y dispensador de justicia. Era para Saguí un elemento innegable de independencia que el mismo poder eligiera a sus miembros, necesario para concretar la división de poderes y terminar con el modelo español de organización judicial. Pero lo más interesante es que esto lo afirmaba cuando Rosas era el gobernador y tenía absoluta decisión sobre la elección y el nombramiento de los magistrados.

\section{Los Mensajes del Gobernador}

Para observar desde otra perspectiva el diagnóstico y las soluciones buscadas para la organización judicial, recurrimos a la lectura de los mensajes de los gobernadores en las sesiones de apertura de la Legislatura de la provincia de Buenos Aires. El 3 de mayo de 1824 el Gobierno se dirigía a la cuarta Legislatura de la provincia asegurando que la reforma de la administración de justicia era una de las primeras necesidades y también una de las más peligrosas y difíciles de realizar, reconociendo que la magistratura había aumentado su fuerza moral y se había dedicado a cortar y precaver los crímenes y los litigios, superando obstáculos surgidos muchas veces de la misma legislación. ${ }^{72}$

Tomás Manuel de Anchorena, aseguraba en el mensaje del 21 de mayo de 1831, que la Justicia no tenía alteraciones después de la nueva forma que se le había dado a su primer tribunal,

\footnotetext{
${ }^{70}$ Esteves Saguí, pp.XIV-XV. Después de realizar estas afirmaciones en 1850, fue "miembro conspicuo de la élite política post Caseros", Fasano, Juan Pablo, "Jueces, fiscales y escribanos: trayectorias profesionales dentro y fuera de la justicia penal (Buenos Aires 1840-1880)", Congreso 2009 de la Asociación de Estudios Latinoamericanos, Río de Janeiro, Brasil, del 11 al 14 de junio de 2009.

${ }^{71}$ Esteves Saguí, p. 1.

${ }^{72}$ ROPBA, 1824, pp.44-45.
} 
cuyos miembros eran acreedores de la consideración del Gobierno y el reconocimiento público, estando a la espera de que presentaran un proyecto. Informaba de los cambios introducidos, reuniendo los cargos de asesor y agente del defensor General de Pobres, "consultando en esta medida el bien de esta clase menesterosa." En pro de "la más preciosa de las libertades", el Gobierno provisoriamente en uso de sus facultades extraordinarias, había nombrado la lista de los ciudadanos elegibles en los juicios de imprenta, y pedía a la Legislatura que legislara al respecto. ${ }^{73}$

Cuando el tema fue abordado por Juan Manuel de Rosas, en su mensaje del 7 de mayo de 1832, justificó las demoras en los proyectos de reforma anunciados y la falta de cambios en la administración de justicia, en la enfermedad de algunos de los miembros del Tribunal. Nuevamente eran los Magistrados los acreedores de la consideración pública por su esfuerzo y el Gobernador declaraba su preocupación por garantir la seguridad y propiedad de los habitantes de la campaña. ${ }^{74}$

Según el mensaje de Juan Ramón Balcarce del 31 de mayo de 1833, en la Justicia no había más alteración que la de haber el Gobierno determinado que la Presidencia de la Cámara de Apelaciones fuese servida por el miembro que él nombrase anualmente, ínterin se estableciera una ley general sobre la materia, en la reforma que se preparaba. Se habían reunido las físcalías para lo civil y negocios de hacienda y para lo criminal en un solo individuo provisoriamente, y se habían incorporado del mismo modo las agencias fiscales en un letrado. Finalmente la Cámara de Justicia había presentado el proyecto, que sería oportunamente analizado; la redacción del Código mercantil estaba en marcha y el Gobierno prestaba especial atención a la cárcel pública, ${ }^{75}$

El gobernador Juan José Viamonte inauguraba la duodécima Legislatura provincial en mayo de 1834, trasmitiendo la necesidad de apoyar la quietud de que gozaban en la ley, que protegiera y subordinara los intereses de todos. Esto se lograría, como lo habían hecho hasta entonces, sosteniendo una marcha legal en los elemento del orden constitucional: "justicia e igualdad, pública y honradamente ejercida con todos los ciudadanos." 76 Pero nada decía de cómo se lograría este objetivo, a pesar de ser promotor de cambios importantes como la supresión de los recursos extraordinarios, dejando como suprema autoridad judicial a la Cámara de Justicia, a la se le asignó la facultad de proponer los abogados para ocupar las vacantes de jueces de primera instancia. ${ }^{77}$

A partir de aquí, los mensajes fueron pronunciados por Juan Manuel de Rosas hasta que el 9 de diciembre de 1851 fue exonerado de presentarlo, al igual que el presupuesto. ${ }^{78}$ El 31 de diciembre de 1835 Rosas celebraba haber realizado "una feliz transformación" de todos los ramos de la administración, habiéndose logrado "administrar justicia a todos, sin más consideración que la

\footnotetext{
${ }^{73}$ ROPBA, 1831, pp.55-56.

${ }^{74}$ ROPBA, 1832, p. 35.

${ }^{75}$ ROPBA, 1833, p.33.

${ }^{76}$ ROPBA, 1834, p.74.

${ }^{77}$ Ibañez Frocham, 1938, op. cit., pp. 194-208.

${ }^{78}$ ROGBA, 1851, p.17.
} 
debida razón de equidad." Fueron modificados los procesos penales, a causa de los reclamos que su lentitud ocasionaba, y en cuanto al cuidado de la propiedad, y en respuesta a la opinión pública, derogó las leyes que imponían la pena de confiscación de bienes. Sobre el cuidado de la vida, sostenía que el Gobierno respetaba la garantía inestimable de la seguridad individual "en cuanto le ha sido posible" aplicando sólo la pena de muerte a aquellos reos cuyo castigo era reclamado con urgencia por la vindicta pública. ${ }^{79}$

Un año después admitía que el ramo de Gobierno que requería de mayor atención era la justicia, pero también la que presentaba mayores dificultades. Era urgente tomar al menos medidas aisladas, como la eliminación de los juicios de quitas y esperas que "burlaba a los acreedores más privilegiados, distraía a los magistrados, corrompían a los subalternos, y todas las relaciones comerciales eran paralizadas." ${ }^{80}$ Instaba al Superior Tribunal a redoblar la vigilancia sobre los tribunales ordinarios, para que no cayeran en demoras "contrariando la mente y espíritu de las leyes"; pero a su vez justificaba los juicios de orden especial. Los malhechores eran "perseguidos en toda la vasta extensión de la provincia por las autoridades locales y tomados en sus guaridas”, y el gobernador los juzgaba a fin de que algunos ejemplos saludables asegurasen reposo a las familias y respeto a la propiedad. Según su discurso, con esa medida y el fomento dado a la religión se había logrado en la campaña habitar con tranquilidad y reducir los crímenes. ${ }^{81}$

Pero a fines de 1839 la administración de justicia seguía sin recibir "una reforma saludable", y la Legislatura no había podido dedicarse a brindar una "sólida y acabada garantía a la libertad y a los derechos civiles." Sin embargo, a su entender, los organismos judiciales funcionaban satisfactoriamente y los delitos habían disminuido en la ciudad y la campaña, ofreciendo "un lúcido comprobante de cultura social." ${ }^{, 82}$ A partir de 1840 los mensajes se convirtieron en una formalidad, enumerando las oficinas que desempeñaban sus tareas y anunciando que de las mejoras necesarias el Gobierno se ocuparía oportunamente, excusándose en "los vitales negocios de la guerra y a los delicados de Estado." ${ }^{83}$ Quedaba así de manifiesto un argumento que se mantendrá más allá de los cambios políticos: las reformas en la justicia eran indiscutiblemente necesarias y reclamadas, pero debían ser pospuestas por cuestiones más urgentes.

\footnotetext{
${ }^{79}$ ROPBA, 1835, pp. 175-176; 184.

${ }^{80}$ Sobre el tema véase Levaggi, Abelardo "El Supremo decreto de Rosas del 29 de marzo de 1836 sobre esperas y quita", en Revista del Instituto de Historia del Derecho Ricardo Levene, núm 26, Buenos Aires, Imprenta de la Universidad, 1980-1981.

${ }^{81}$ ROPBA, 1837, pp.7-10.

${ }^{82}$ ROPBA, 1839, pp. 73-74.

${ }^{83}$ ROPBA, 1842, pp. 36-37.
} 


\section{La legislación}

Durante estos años fueron numerosas las nuevas normas legales motivadas por la intención de modificar las leyes coloniales, pero muchas de ellas no se aplicaron y fueron codificadas en la segunda mitad del siglo XIX. Como pudimos observar en palabras de los propios protagonistas, la legislación era en esos años un "laberinto" en el que se combinaban códigos medievales, leyes coloniales, decretos del poder ejecutivo y leyes republicanas, que ningún acto jurídico abolió desde el comienzo. Es por esto necesario determinar la legislación sancionada (leyes, acuerdos, decretos), definida en una minuciosa lectura del Registro Oficial provincial y presentada según los temas que preocuparon a la hora de legislar, determinando con qué criterio lo hicieron. ${ }^{84}$

La primera cuestión fue la publicidad de la legislación, que dio origen al Registro Oficial bajo la dirección del Ministerio de Gobierno, suprimiendo bandos y circulares, que retardaban la comunicación y recargaban el trabajo de las oficinas. El objetivo era presentar a todo funcionario público una recopilación, donde encontrara reunidas las determinaciones cuyo cumplimiento le era encomendado. Pero además el Gobierno quería dar la mayor publicidad a su tarea, para que todos los ciudadanos pudieran juzgarlas. ${ }^{85}$

Con el mismo fin, el gobernador Juan Gregorio de Las Heras mandó realizar un extracto del Registro Oficial para fijarlo en lugares públicos de la provincia y periódicos de la ciudad. El día de fiesta más próximo, el juez de paz lo leería en las iglesias parroquiales después de la misa mayor. ${ }^{86}$ Rivadavia como presidente, ordenó fijar las sentencias contra reos de delitos graves en lugares públicos $^{87}$ y Rosas mandó años después, teniendo en cuenta lo expuesto por la Cámara de Apelaciones, "sobre la utilidad y conveniencia de adoptar un texto correcto, uniforme y metódico de las disposiciones vigentes", realizar la Recopilación de Leyes y Decretos publicada por la Imprenta del Estado, obligando a todos los empleados de la administración de justicia, profesores y estudiantes de derecho a tenerla. ${ }^{88}$

Sobre la organización del poder judicial, contamos con los nombramientos, que por no ser siempre publicados y por no asumir siempre el nombrado, no sirven de fuente única para construir los organigramas, pero sí dan un panorama del movimiento de personal, de la categoría de propietario -sustituto o en comisión-, de los sueldos, de las modificaciones estructurales (como por ejemplo el reemplazo del defensor particular de herencias transversales por el agente fiscal de lo

\footnotetext{
${ }^{84}$ Para conocer los cambios jurídicos del período: Ibañez Frocham, 1938, op. cit.; Méndez Calzada, L., La función judicial en las primeras épocas de la independencia, Losada, Buenos Aires, 1944; Díaz, 1959, op. cit.; Levene, Ricardo Historia del derecho argentino, Editorial Guillermo Kraft Lda., Buenos Aires, 1958; Tau Anzoátegui, 1973, op. cit.

${ }^{85}$ ROPBA, 1821, p. 3.

${ }^{86}$ Decreto del 21 de octubre de 1825, ROPBA, 1821, p. 43. El gobernador había mandado el 25 de febrero realizar una recopilación de las leyes y resoluciones dictadas desde el 25 de mayo de 1810 hasta la publicación del ROPBA, 1821 p. 11.

${ }^{87}$ Decreto del 5 de abril de 1826, Registro Nacional de las Provincias Unidas del Río de la Plata, Año 1826, p. 57.

${ }^{88}$ ROPBA, 1839, p.27.
} 
civil). ${ }^{89}$ Relacionadas con esto, encontramos las condiciones que se exigían a quienes ocuparían los cargos, enunciadas en los nombramientos. En 1822 se requería de "luces, conocimientos, patriotismo" 90 ; a los procuradores, cuyo cargo dejaba de ser vendible para ser nombrados por el Gobierno a propuesta en terna de la Cámara de Justicia, se les exigía "probidad, idoneidad y honradez." 91 En 1835 Vicente Maza era nombrado camarista por tener "a más de probidad y luces suficientes, distinguidos servicios y constante fidelidad a la causa Nacional de la Federación, que le hacen acreedor a la confianza del Gobierno, y de los verdaderos federales." $" 92$

Los nombramientos muestran momentos de mayor movimiento, generalmente unido a las modificaciones estructurales del poder. El primero se dio a continuación de la ley de 1821, que organizaba la justicia de primera instancia y de paz $^{93}$; siguiéndole la modificación de la Cámara de Justicia en $1830^{94}$ y la creación de los Tribunales de Recursos Extraordinarios en 1838. ${ }^{95}$ Durante todos los años en que Rosas fue Gobernador hubo nombramientos y despidos, como al camarista Miguel Villegas por haber traicionado la causa nacional de la Confederación, o al camarista Gregorio Tagle "para siempre", que se extendían a toda la administración. ${ }^{96}$ Los cambios también respondían al carácter de no rentados y temporarios de varios cargos, o los que pasaban a ser no letrados por la resistencia de los abogados a ocuparlos, como la defensoría de pobres y menores en $1840 . .^{97}$

En cuanto al funcionamiento, en los años rivadavianos observamos la intención de lograr una organización espacial de la administración de justicia, definiendo las jurisdicciones de los jueces de primera instancia y de paz, o cambiando los partidos de jurisdicción. ${ }^{98}$ Con Rosas las modificaciones espaciales atendían a un mayor control de la provincia, como en 1839 las distribuciones de los partidos de Monsalvo, Tandil y Dolores. ${ }^{99}$ En los primeros años se buscaba llevar un control pidiendo que los jueces de primera instancia pasaran razón mensual al Ministerio de Gobierno, de los procesos civiles y criminales iniciados, pendientes y concluidos en el mes vencido; igualmente debían hacerlo el procurador general, defensor de pobres y menores de sus

\footnotetext{
${ }^{89}$ ROPBA, 1821, p. 79.

${ }^{90}$ ROPBA, 1822, p. 21.

${ }^{91}$ ROPBA, 1825, p. 36.

${ }^{92}$ ROPBA, 1835, p. 38. Estas condiciones concordaban con las requeridas para obtener el grado de doctor, de "haber sido sumiso y obediente a sus superiores en la Universidad durante el curso de sus estudios, y de haber sido y ser notoriamente adicto a la causa nacional de la Federación”, ROPBA, 1836, p. 10.

${ }^{93}$ ROPBA, 1821, pp. 124-128; ROPBA, 1824, pp. 13; 21.

${ }^{94}$ ROPBA, 1830, pp. 16-17, el movimiento se nota durante todo el año, p. 45; p.82.

${ }^{95}$ ROPBA, 1838, pp. 55-57; 91.

${ }^{96}$ ROPBA, 1838 , p. 55; 1835, pp.32-33.

${ }^{97}$ ROPBA, 1840, pp.22-27.

${ }^{98}$ ROPBA, 1822, p. 24-25; 1824, p. 60.

${ }^{99}$ ROPBA, 1839, pp. 64-66.
} 
ministerios. ${ }^{100}$ Los jueces de paz requerían especial atención debido a su condición lega, que buscaba ser saneada por formularios y un Manual especialmente redactado. ${ }^{101}$ La observación de los formularios continuaba siendo un problema, más para un observador de las formas como Rosas, que en 1834 mandó a la Cámara y demás autoridades judiciales observar los decretos al respecto. ${ }^{102}$

Otra preocupación presente a través de los años fueron los procedimientos en causas criminales. Ya el 22 de agosto de 1821, se solicitaba al alcalde ordinario del crimen acelerar la conclusión de las causas de los ladrones aprehendidos por las partidas celadoras, ante el reclamo de la vindicta pública, de los criminales y la obligación de las autoridades de ejecutar las leyes. ${ }^{103} \mathrm{Al}$ año siguiente dos decretos establecieron, en pro del orden público y la seguridad de los individuos, los primeros procedimientos que la policía debía observar en crímenes, delitos y ebriedad, dejando al reo a disposición de la justicia ordinaria. ${ }^{104}$

Buscando dar solución al robo de ganado se organizaron "tribunales", para juzgar a los reos que no excedieran las seis cabezas, formados por el juez de paz y dos vecinos, de conocida honradez y propiedad, en juicios sumarios y verbales, dando cuenta al Tribunal de Justicia con acta, después de ejecutada la sentencia. ${ }^{105}$ En la misma línea, Anchorena pidió a la Cámara de Justicia propusiera medios extraordinarios para abreviar los juicios sobre robos, "que reduciéndose a los trámites muy preciso para comprobar el crimen y descubrir a su autor, facilite el pronto y ejemplar castigo, que se hace sobre manera necesario para consultar la seguridad y tranquilidad de los habitantes de esta ciudad."106

A partir de 1830, los sumarios quedaron a cargo de los jueces de primera instancias, al revocar el decreto que facultaba a los comisarios, pues era innecesario y perjudicial a la pronta y recta administración de justicia, y al mismo servicio de la policía. Los Comisarios debían dedicarse a recorrer diariamente a caballo sus secciones, dirigiendo partes claros y circunstanciados al Jefe de Policía por vago o mal entretenido, ebrio, no tener papeleta de conchavo o enrolamiento, cargar cuchillo o arma prohibida, por insultos o falta de respeto a la autoridad doméstica, riña sin heridas

\footnotetext{
${ }^{100}$ ROPBA, 1822, p. 3; insistían pidiendo remitan con el primer correo de cada mes la razón de las causas criminales pendientes, estado, nombre de los reos y tiempo de prisión, para la visita en las cárceles y la mejor y más pronta administración de justicia, p. 90.

${ }^{101}$ ROPBA, 1824, pp. 102-105; Manual para los jueces de paz de campaña, Imprenta de la Independencia, Buenos Aires, 1825, redactado por Manuel García.

${ }^{102}$ Decretos del 3 de noviembre de 1832 y 22 de mayo de 1835. ROPBA, 1835, pp.123-124. El 27 de agosto de 1838 Rosas ordenaba nuevamente que todo documento público y actuación judicial se ajustara al formulario correspondiente. ROPBA, 1838, p. 4. Antes había sido terminante con los escribanos sobre la forma de la escritura quedando amenazados de perder su oficio. Registro Oficial, 1830, p. 18.

${ }^{103}$ ROPBA, 1821, p. 21. Instalada la primera instancia, la Cámara de Justicia instaba a los jueces a abreviar los procesos de delitos graves, robos calificados y abigeatos, que iban en contra de la seguridad de las personas y sus bienes, para dar "satisfacción a la vindicta pública y escarmiento a los malhechores." Acuerdo ordinario de la Excelentísima Cámara de Justicia con asistencia del Fiscal, del 3 de julio de 1823, ROPBA, 1823, pp. 56-57.

${ }^{104}$ Decreto del 31 de mayo de 1822 y del 11 de junio de 1822 , ROPBA, 1822, pp. 101; 103.

${ }^{105}$ Decreto del 19 de enero de 1825. ROPBA, 1825, p.6.

${ }^{106}$ ROPBA, 1831, p.76.
} 
graves, deshonestidad pública, palabras obscenas en público, falta de cumplimiento de decretos o mandatos de la Policía, remitiéndolos a la cárcel de la policía y poniéndolos a disposición del Jefe. Si fuese por otro delito debía remitirlo preso a la cárcel pública a disposición del juez de primera instancia criminal. ${ }^{107}$

El Brigadier, en uso de sus facultades extraordinarias, recurrió -para detener el traslado de armas y provisiones de la capital a la campaña para los grupos de hombres armados que sostenían la rebelión- a la formación de una comisión especial permanente, que también juzgaba delitos de traición, con juicios breves y sumarios. ${ }^{108}$ También designó al camarista Maza para juzgar en forma especial la causa de reos existentes en la cárcel y en la campaña, ajustándose a las instrucciones que recibiere para conocer, concluir, sentenciar y darle cuenta, para satisfacer la vindicta pública y escarmentar a los criminales. ${ }^{109}$ Junto a la preocupación por las causas criminales estaban las cárceles, sobre las que se dictaron diversas medidas en pro de un mejor servicio, orden y economía. $^{110}$

Las causas comerciales fueron otra constante que se inició con las quejas por los procedimientos del Tribunal Consular y del desorden de la legislación que debía reglarlo, era urgente remediarlos. Mientras tanto el Gobierno recurría al buen juicio de los jueces, nombrando una comisión para la redacción del Código de comercio en 1824 y otra en $1832^{111}$ e instando a la responsabilidad de los comerciantes de responder al llamamiento para ocupar el Consulado. ${ }^{112}$

Pero no bastaba con obligar a los comerciantes a integrar los tribunales comerciales, también debieron definir el acto de comercio, a semejanza del Código francés. ${ }^{113}$ En los años liderados por Rosas se destacó en este campo mercantil el decreto en el que declaró abolidos los juicios de concurso de acreedores llamados de esperas o moratorias y de remisión o quitas. Ningún

\footnotetext{
${ }^{107}$ Decreto del 18 de diciembre de 1830. ROPBA, 1830, pp. 85-86.

108 ROPBA, 1829, pp. 33-34. Comisión: Dr. Gabriel Ocampo (fiscal civil); Dr. Bernardo Vélez (juez de primera instancia criminal), Dr. Manuel B. Gallardo (presidente de la comisión), Dr. Pedro Somellera (fiscal de la comisión, auditor de guerra).

${ }^{109}$ ROPBA, 1835, pp. 102-103.

${ }^{110}$ ROPBA, 1821, p.21; 1822, pp. 33-34; 1823, pp. 43-44.

111 ROPBA, 1821, pp. 67-68; 1824, pp. 62-63; 1832, p. 56.

${ }^{112}$ La Alzada de Comercio había sido puesta en manos de uno de los miembros del Tribunal de Justicia en 1822. ROPBA, 1822, p. 114. Véase Tjarks, Germán O El Consulado de Buenos Aires y sus proyecciones en la Historia del Río de la Plata, Facultad de Filosofía y Letras, Instituto de Historia Argentina Dr. Emilio Ravignani, Buenos Aires, 1962.

${ }^{113}$ ROPBA, 1822 , p. 55-56. Acto de comercio: "todo convenio por el cual se ha comprado una cosa para revenderla, o alquilar el uso de ella, bien sea en el mismo estado que se compró, o después de darle por el trabajo otra forma de mayor o menor valor. Toda operación sobre letras o cualquiera otro género de papel de comercio, de tesorería o fondos públicos. Todo sueldo, salario, compra de provisiones, útiles o materiales, y contratos pertenecientes a transportes por agua y por tierra."
} 
comerciante sería obligado en adelante a conceder una u otra franquicia, aunque una mayoría de capital y de número accediera. ${ }^{114}$

Las preocupaciones de la justicia civil contemplaron el matrimonio, buscando desde 1821 terminar con las uniones ocultas, para concretar uno de los cambios que al Gobierno le resultaría más difícil y requeriría mayor vigilancia, “establecer las buenas costumbres y mejorar la moral”, para lo que contaba con la cooperación del clero. ${ }^{115}$ El tema reapareció años después con disposiciones sobre los matrimonios de creencias distintas de la religión católica que debían presentarse ante el presidente de la Cámara de Justicia pidiendo permiso y cumpliendo los trámites pertinentes para que se les diera. Se trató la cuestión de los protestantes y se simplificó el modo de comprobar su soltería. ${ }^{116}$

Pero la preocupación realmente destacable en este fuero fue la propiedad, así como en el criminal se luchaba por protegerla de los robos, aquí se partía del principio de su inviolabilidad. ${ }^{117}$ Al tratar sobre los terrenos en pueblos de campaña el objetivo era fomentar la población para lo cual era primordial garantizar la propiedad, dando en ello un papel central a los jueces de primera instancia para la organización de los solares baldíos. ${ }^{118}$ Con Rosas sólo registramos leyes destinadas a la cesión de tierras por premio o a antiguos enfiteutas. ${ }^{119}$

\section{Conclusión}

Proyectos, textos, mensajes y leyes estuvieron atravesados por el concepto de felicidad. Era un objetivo a alcanzar para América Hispana, donde tanto O’Higgins en Chile, como Rivadavia en Buenos Aires, estaban convencidos de que el pueblo tenía que ser libre y feliz. Bolívar en Venezuela recomendaba la constitución británica, modelo de cuantos aspiraban al goce de los derechos del hombre y de toda felicidad política. ${ }^{120}$ Pero lo importante es descubrir que la idea de felicidad fue cambiando aunque siguiera siendo un objetivo a alcanzar, por ejemplo para Bellemare era en la moral y el trabajo donde se hallaba la felicidad.

\footnotetext{
${ }^{114}$ ROPBA, 1836, pp. 31-32. Véase Levaggi, Abelardo Manual de derecho argentino. (castellano-indiano/nacional) Tomo III, $2^{\circ}$ edición, actualizada y ampliada. Ediciones Depalma, Buenos Aires, 2001, p. 145; Levaggi, Abelardo, 1980, cit.

${ }^{115}$ ROPBA, 1821 , p. 50.

${ }^{116}$ ROPBA, 1833, pp. 104-106, 1834, p. 26; 79.

${ }^{117}$ ROPBA, 1822, p. 104. Zeberio, Blanca "Los derechos civiles en transición. Controversias jurídicas y proyectos políticos", en Bonaudo, Marta; Reguera, Andrea y Zeberio, Blanca (coordinadoras) Las escalas de la historia comparada, tomo I: "Dinámicas sociales, poderes políticos y sistemas jurídicos”, Buenos Aires, Miño y Dávila, 2008, pp. 285-307.

${ }_{118}$ ROPBA, 1824, pp. 60-61; 78-79.

${ }_{119}^{19}$ Valencia, Marta, Tierras públicas, tierras privadas, Buenos Aire 1852-1876, Edulp, La Plata, 2005.

120 Para comparar el tema de la felicidad con otros países latinoamericanos ver Lynch, John, Las revoluciones hispanoamericanas 1808-1826, Barcelona, Editorial Ariel, 1998. El autor trata el tema para Chile comparándolo con Argentina (p.160-161); Venezuela, siguiendo las ideas de felicidad, igualdad y libertad de Bolivar (pp.225; 237; 241) y Colombia (pp. 260-263).
} 
En cuanto a las cuestiones más claramente relacionadas con la organización del Estado y la administración de justicia, el principio primero y siempre presente era la independencia del poder judicial. Estaba enunciada en el Reglamento de 1833 y era condición indispensable de la división de poderes, sin embargo la dificultad residía en determinar su relación con los otros dos poderes, uno legislativo, hacedor e intérprete de las leyes, y otro ejecutivo, que avanzaba sobre la conquista de atribuciones judiciales, pero sabiendo que no le competían y que lo hacía en forma "extraordinaria." Esto significaba que se aspiraba a un poder independiente y que se sabía como lograrlo, pero las decisiones políticas marcaban otro rumbo, representado en las comisiones especiales dadas por Rosas, pero especialmente en el Tribunal de Recursos Extraordinarios, creadas ante su solicitud por la Junta de Representantes.

Había un acuerdo generalizado en que la legislación era un laberinto y que la codificación era ineludible; lo mismo sucedía con la administración de justicia, que para Rivadavia clamaba correcciones y mejoras, y para Rosas reformas saludables; pero ni una ni otra podían ser atendidas por demandas menos importantes, pero más apremiantes. Las reformas eran parciales, en defensa de la libertad, la propiedad y la seguridad, respondiendo a la vindicta pública y al escarmiento de los malhechores, resistiendo los cambios sustanciales, en algunos casos de forma explícita como en los proyectos de Castro.

Otro tema de larga resolución fue el carácter letrado o lego de los jueces, que llevaba consigo la primera explicación de la falta de profesionales, pero que se profundizaba en la opción del juicio por jurado o del magistrado formado en derecho, por la responsabilidad que tenía sobre la vida y la propiedad del soberano. A esto se sumaba la inamovilidad (que se dio a la Cámara de Justicia y primera instancia) o duración definida de los cargos (elegida para justicia de paz y defensores de pobres y menores), ligada a la garantía de independencia, cuestiones todas que seguirán siendo tema de debates.

La interpretación de la ley fue una de las cuestiones claves, pues afectaba directamente la administración de justicia a través de la sentencia, y era una atribución exclusiva del poder legislativo, no de los jueces. La seguridad individual implicaba dar seguridad frente al fallo judicial, desterrando la arbitrariedad del magistrado, de allí derivaba la estricta aplicación del texto de la ley y la formación de la jurisprudencia. La sentencia debía ser expresión del raciocinio con que el juez aplicaba la ley sin consideraciones ajenas a los hechos. Unida a la interpretación iba la jurisprudencia, definida por Somellera como el "hábito práctico de interpretar las leyes rectamente, y aplicarlas con exactitud a los casos”, a lo que Valentín Alsina y Esteves Saguí buscaban agregar la fundamentación obligatoria de las sentencias. ${ }^{121}$

\footnotetext{
${ }^{121}$ Tau Anzoátegui, Víctor “Acerca de la fundamentación de las sentencias en el derecho patrio", en Revista del Instituto de Historia del Derecho Ricardo Levene, núm. 13, Imprenta de la Universidad, Buenos Aires, 1962, pp.181-
} 
La estructura judicial establecida por la ley del 24 de diciembre de1821, fue de la que Rosas se valió para llevar adelante su proyecto, pudiendo observarse el desgaste producido entre el gobernador y los miembros del poder judicial. Cuando inició su Gobierno el rito de apertura del año judicial seguía obedeciendo a las leyes de Indias. Después de Pascuas, pasada las doce del mediodía, se reunía la Cámara de Apelaciones con los ministros subalternos, oficiales de justicia, escribanos, abogados de matrícula, procuradores, defensor general de pobres y menores, agente fiscal, alcalde de la cárcel de la ciudad y porteros, y se declaraba habilitado el año judicial. Pero la asistencia al acto fue disminuyendo en relación con la mayor intervención del Gobierno en la vida judicial y la migración de muchos abogados al exterior; en 1849 iniciaron el año sólo los miembros de la Cámara. ${ }^{122}$ Esto también se observa en la justicia de paz, reconocida como uno de los pilares de la permanencia de Rosas en el poder, que sin embargo en sus mensajes en la Legislatura a partir de 1848 , comenzaba a quejarse de la falta de cumplimiento de las obligaciones de los jueces de paz y a la imposibilidad de terminar con ese mal.

En los proyectos y en la literatura académica observamos una reiterada oposición a los tribunales de alzada, a las comisiones especiales, a los de recursos extraordinario, que gozaron de plena salud durante todos los años rosistas. Estos fueron abolidos por una ley del 18 de noviembre de 1852, que daba por extinguido el Tribunal de Recurso Extraordinarios, y otra del 19 de septiembre de 1854 que suprimía el juzgado de alzada. La superposición de cargos se mantuvo hasta 1874 , y la tarea judicial que ocupaba mucho tiempo, sumada a las funciones encargadas por la Cámara al comenzar cada año y las comisiones del Gobernador, más el desempeño en otros poderes del Estado, llevaba a designar conjueces para votar en los acuerdos de la Cámara, en algunos casos nombrados por el Gobierno. ${ }^{123}$

Lo cierto es que todas estas experimentaciones institucionales requerían de un paso previo, que terminara con las soluciones parciales a problemas urgentes, para organizar un poder independiente, que sirviera de contrapeso a los otros poderes, como defensor de los intereses sociales, pero que por sobre todas las cosas permitiera la formación de un Estado autónomo provincial. Sin embargo, lo novedoso del proceso iniciado a finales del siglo XVIII y terminado con

182; "Los comienzos de la fundamentación de las sentencias en la Argentina", en Revista de Historia del Derecho, núm. 10, Buenos Aires, Instituto de Investigaciones de Historia del Derecho, 1982. Levaggi, Abelardo "La interpretación del derecho en la Argentina en el siglo XIX”, en Revista de Historia del Derecho, núm. 7, Instituto de Investigaciones de Historia del Derecho, Buenos Aires, 1978.

${ }^{122}$ Leiva, 2005, op. cit. pp. 109-111.

${ }^{123}$ Leiva, 2005, op. cit. pp. 114-116. Los camaristas supernumerarios desaparecieron por decreto del 9 de marzo de 1852. 
la codificación fue el peso que adquirió la ley en la forma política y en el pacto que, dañado por toda conducta, rigió la convivencia, que organizó la sociedad. ${ }^{124}$

Ese paso era la redacción de un texto constitucional, que consagrara la división de poderes y estableciera las pautas para organizarlos. Esa Constitución fue sancionada en 1854, para comenzar un camino en el que muchos de los temas aquí planteados estaban por resolverse y que seguirían en debate hasta la sanción de la Constitución provincial de 1873, de la que proyectos, ensayos y legislación fueron piedras constructoras, aún como fracasos. Pero entre ambos textos constitucionales se promovieron y produjeron cambios en los organismos judiciales, que confluirán hasta definir la ley orgánica de 1881. Esto es lo que nos dedicaremos a estudiar, comenzando en el próximo capítulo por definir los códigos culturales de las elites intelectuales del siglo XIX, que definieron la formación y el funcionamiento del sistema judicial de la provincia.

124 Barriera, Darío "Saberes jurídicos, quehaceres judiciales y representaciones mentales: puntos de referencia para interpretar sus relaciones", en Avances del Cesor, Año VI, Nº, 2009, Escuela de Historia, Universidad Nacional de Rosario, p. 106. 


\section{Capítulo III}

\section{Ideas políticas y administración de justicia (1852-1881)}

\section{Introducción}

Si bien la historia intelectual no se practica con modelos teóricos obligados para analizar sus objetos, ni para interpretarlos, se puede "esbozar un programa de trabajo que comunique la historia política, la historia de las elites culturales y el análisis histórico de la literatura de ideas". ${ }^{1}$ Para ello se debe tener presente que las elites intelectuales del siglo XIX, letrados y pensadores, ordenaron sus escritos en torno a la política y a la vida pública, y a códigos culturales, pautas de sus relaciones. Con el objetivo de crear un observatorio de estos códigos culturales compartidos seleccionamos dos autores, a partir de cuyas miradas podremos conformar un repertorio con matices sobre el cual se iba a configurar la organización del poder judicial. Esto permitirá superar una división tajante entre una concepción del derecho pretérita y una nueva - científica - que buscaba imponerse.

Realizaremos entonces en este capítulo una cuidadosa lectura del pensamiento de dos políticos y juristas, Vicente Fidel López y Antonio E. Malaver, que expresaron sus ideas sobre la formación y el funcionamiento de los organismos judiciales de la provincia. Su estudio nos permitirá analizar en las ideas de estos intelectuales, los códigos culturales de la época que se abrió a partir del final del régimen político encarnado por Juan Manuel de Rosas. Organizar el Estado fue uno de los objetivos perseguidos entre 1852 y 1880; organizar la provincia de Buenos Aires en esos años fue un proyecto que generó profundas tensiones internas sumadas a las ya existentes con el resto del país; organizar la campaña desde la ciudad, provocó dudas, incertidumbres, avances y retrocesos.

Sin dejar de tener en cuenta las características propias de los movimientos nacionalista y autonomista, sabemos que en estos años no había partidos políticos organizados, por ello los debates eran extensos y las posturas de sus protagonistas no pueden ser agrupadas y definidas fácilmente. ${ }^{2}$ Sólo a finales de la década del 70 la figura del "partido político" comenzó a considerarse un ámbito apropiado para la definición de las candidaturas, y aunque se mantuvieron los "clubes" como institución típica de las décadas anteriores para realizar los trabajos electorales, el partido comenzaba a ser referencia última de cualquier candidatura. Pero antes que esto sucediera el escenario fue cambiando. A partir del Partido Liberal de Buenos Aires surgieron dos agrupaciones que, en torno al problema de la autonomía de la provincia, terminarían por

\footnotetext{
${ }^{1}$ Altamirano, Carlos, "Ideas para un programa de Historia Intelectual”, Prismas, Revista de historia intelectual, núm.3, Universidad Nacional de Quilmes, 1999, pp. 203-208.

${ }^{2}$ Melo, Carlos, "Historia de los partidos políticos argentinos entre 1862-1930”, en Historia Argentina Contemporánea 1862-1930, Vol. II., Buenos Aires, Edición de la Academia Nacional de la Historia, El Ateneo, 1964.
} 
configurarse como dos partidos (en el sentido laxo del término): el nacionalista dirigido por Bartolomé Mitre, y el autonomista, liderado por Adolfo Alsina. En Buenos Aires ser "mitrista" o ser "alsinista" constituía una marca política. Sin embargo, a la hora de debatir y resolver los límites entre ellos, estos eran débiles, generándose pases entre dirigentes y alianzas entre ambos grupos. ${ }^{3}$

En el período en estudio, el complejo proceso de la construcción del Estado debía resolver la división de poderes, la centralización del poder y el diseño de las instituciones de gobierno, entre las que las encargadas de la administración de justicia eran fundamentales. Pero, llegado el momento de tomar decisiones, la teoría seguía diversas interpretaciones y en la práctica política influía la tradición y los modelos foráneos, dando por resultado profundas diferencias de forma y de fondo al diseñar las instituciones judiciales. Concretamente en el grupo de los juristas, sus ideas

presiden la formación de su mentalidad, fijan el concepto del Derecho, establecen sus fuentes, precisan la interpretación jurídica y gravitan, por lo tanto, sobre una parte considerable de la esfera de acción del hombre sobre la sociedad...a menudo marchan unidas con el pensamiento filosófico, las creencias religiosas, los valores morales, el desarrollo de la ciencia y la técnica, las ideas o hechos políticos y económicos, y las expresiones de la cultura y del arte. ${ }^{4}$

Para estudiarlas se debe tener presente el mundo jurídico de tradición romano-canónica y buscar allí los grandes influjos ideológicos para finalmente construir la tradición jurídica propia.

Elegimos para encaminar esta tarea a dos abogados, presentes en buena parte de los debates, pero que en estos años no fueron magistrados. Vicente Fidel López, inspirado en el romanticismo, el historicismo jurídico y el eclecticismo filosófico de la generación del 37, proponía la construcción de un cuerpo inamovible, con derecho a renovarse a sí mismo según sus capacidades científicas y morales, que no dependiera de la opinión pública, como seguro de un pueblo libre y feliz que superara la conflictiva relación entre igualdad y jerarquía. Para Antonio Malaver, cultor del derecho científico basado en el modelo, la magistratura debía ser un cuerpo judicial que no fuera despreciado por el foro, formado por pocos hombres distinguidos, mejor pagos y más eficientes, garantía de una justicia más rápida y económica. Creía que dada las condiciones de los medios de comunicación, la descentralización espacial no produciría cambios inmediatos. Confiaba más en la descentralización ratione materiae, que consideraba altamente ventajosa al permitir a los jueces especializarse en una temática, lo que le daría mayor pericia. Según su punto de vista, la especialización por materias daría jueces no sólo íntegros sino también competentes. ${ }^{5}$ Ahora bien, estas ideas no estaban necesariamente enfrentadas y podían en muchos casos llegar a intercambiarse.

\footnotetext{
${ }^{3}$ Sábato, Hilda, Buenos Aires en armas. La revolución de 1880, Siglo XXI, Buenos Aires, 2008, pp. 24-26. Estos cambios políticos se harán visibles en la medida que avancemos en la tesis y surjan ideas y posturas frente a las diversas cuestiones en discusión, lo que nos permitirá observar y comprender estos movimientos.

${ }^{4}$ Tau Anzoátegui, op. cit., 1977, pp.13-14.

${ }^{5}$ Malaver, Antonio, Curso de procedimientos judiciales en materia civil y mercantil, Buenos Aires, Imprenta de Pablo E. Coni, , 1875, pp. 118-119.
} 


\section{La dimensión política provincial en el contexto nacional}

La derrota de Juan Manuel de Rosas en la batalla de Caseros el 3 de febrero de 1852 depositó todo el poder político "nacional" en manos de su vencedor, el general Justo José de Urquiza. El entrerriano nombró como gobernador provisorio de Buenos Aires a un ex rosista, Vicente López y Planes, en cuyo gabinete de conciliación figuraban desde antiguos rivadavianos como Valentín Alsina hasta federales como Gorostiaga a Escalada. ${ }^{6}$ Comenzaban "treinta años de discordia", como definió Tulio Halperín Donghi, durante los cuales una confederación de catorce provincias, cada una con su organización política, terminarían teniendo una organización política federal y representativa establecida en la Constitución de la República Argentina. ${ }^{7}$

En abril de 1852 Urquiza alentó la firma del Protocolo de Palermo, por el cual Corrientes, Entre Ríos y Buenos Aires invitaban a las demás provincias a que se reunieran en San Nicolás de los Arroyos y desde allí sentaran las bases de la organización nacional. El desafío que suponía la unidad política desembocó en el surgimiento de tres facciones con posturas diversas: los federales (o urquicistas) entre quienes se destacaban el citado López y Planes, su hijo Vicente Fidel López, Marcos Paz, Hilario Lagos, Francisco Pico y Juan María Gutiérrez; los aislacionistas como Valentín Alsina (que los convocaba), su hijo Adolfo, los Obligado, Nicolás Anchorena, Carlos Tejedor y José Mármol; los nacionalistas, que aceptaban la unidad pero guiada desde y por Buenos Aires y reunía a Bartolomé Mitre, Domingo F. Sarmiento, Rufino de Elizalde y Dalmacio Vélez Sarsfield.

En San Nicolás la principal oposición se generó en torno a las facultades otorgadas a Urquiza y por el carácter $a$ - porteño del acuerdo. La reacción de Urquiza frente a sus críticos les dio pie a que éstos vieran justificados sus temores, ya que desde su cargo de Director Provisorio el caudillo entrerriano disolvió la Legislatura provincial, encarceló a los diputados opositores y nacionalizó la Aduana. El resultado de esa radicalización de sus actos de gobierno fue la revolución del 11 de setiembre de 1852, que terminó con la secesión de Buenos Aires y su ruptura con la Confederación. Desde 1854 la provincia se dio una Constitución propia, por lo que la tendencia aislacionista quedaba reflejada en un orden institucional, con un Estado que ejercía el pleno derecho soberano en política interior y exterior.

\footnotetext{
${ }^{6}$ Floria, Carlos y García Belsunce, César, Historia de la argentinos, Buenos Aires, El Ateneo, 2009, p. 537. El objetivo de este apartado es brindar un contexto histórico provincial y nacional que ayude a la comprensión del contenido de la tesis y que puede ser profundizado entre otros autores en Gallo, Ezequiel y Cortés Conde, Roberto, Historia Argentina. La República conservadora, Buenos Aires, Paidós, 1972.; Halperín Donghi, 1995, op. cit.; Bonaudo, Marta (directora), Nueva Historia Argentina Liberalismo, estado y orden Burgués (1852-1880), Tomo IV, Buenos Aires, Editorial Sudamericana, 1999; Academia Nacional de la Historia, Nueva Historia de la Nación Argentina, La configuración de la República independiente, 1810-1914, tomos IV al VI, Buenos Aires, Planeta, 2000-2001; Sábato, Hilda, Historia de la Argentina, 1852-1890, Buenos Aires, Siglo XIX Editores, 2012.

${ }^{7}$ Sábato, 2012, op. cit. p. 11.
} 
Entre 1854 y 1859 se tensionaron las relaciones, tanto en el plano político y militar como económico. La Confederación redactó la Constitución en 1853, convirtiendo a Paraná en la ciudad capital. En Cepeda la derrota de Buenos Aires (conducido por Mitre) frente a la tropas de Urquiza obligó a los porteños a firmar el Pacto de Unión Nacional en San José de Flores. Pero Buenos Aires -que se veía obligada a integrar la Confederación - se arrogaba la potestad de discutir la Carta Magna de 1853 e introducirle las reformas que creyera necesarias. Para ello se reunió una Convención ad hoc que contó con la presencia de referentes claves en el proceso de organización nacional: Mitre, Sarmiento, Vélez Sarsfield, Ireneo Portela, Félix Frías y Nicolás Anchorena, entre otros.

La sucesión presidencial, con la fórmula Santiago Derqui- Pedernera, convivió con el ascenso político de Mitre como gobernador en Buenos Aires hasta la ruptura definitiva en la batalla de Pavón el 17 de septiembre de 1861. En ese interregno, la figura de Derqui se fue debilitando por su "subordinación" a Urquiza, que seguía siendo el jefe del partido federal, general del ejército y elegido como gobernador de Entre Ríos. Además, la posibilidad de que la legislatura de Buenos Aires revisara la Constitución se tradujo en que se reservaba el manejo de la Aduana y se estableciera como compensación un subsidio de un millón de pesos de la Provincia a la Nación.

Entre tanto, en la provincia de Buenos Aires luego de la revolución del 11 de septiembre de 1852, ocupó la gobernación Manuel G. Pinto, en su carácter de presidente de la Sala de Representantes. La misma nombró el 30 de octubre a Valentín Alsina como gobernador y capitán general de la provincia al mando de la revolución. Pero el $1^{\circ}$ de diciembre el coronel Hilario Lagos (comandante en jefe del Departamento del Centro) se pronunció en Luján en contra del gobierno y si bien Alsina renunció el 6 de diciembre esto no hizo cesar la rebelión. Lagos avanzó hasta el centro de Buenos Aires, donde fue detenido por Mitre, ministro de gobierno de Alsina, y nuevamente Pinto se hizo cargo del poder ejecutivo. El 9 de marzo de 1853 las tropas de Buenos Aires consiguieron la victoria, quedando así separada definitivamente de la Confederación. ${ }^{8}$

El Estado de Buenos Aires se organizó en torno a la Constitución provincial promulgada el 11 de abril de 1854 y la elección de Pastor Obligado como gobernador. Durante su gestión fue muy significativa la tarea educativa, la expansión territorial, apoyando la formación de nuevos pueblos y partidos, junto a la promoción del comercio y las comunicaciones ferroviarias. El 5 de mayo de 1857 asumió Valentín Alsina, que debió enfrentarse con las dificultades de una línea de fronteras en conflicto, tanto con los pueblos originarios como con la Confederación. La tensión se radicalizó hasta el enfrentamiento militar entre Urquiza y Mitre en la batalla de Cepeda el 22 de octubre de de 1859. El triunfo de Urquiza marcó la renuncia de Alsina y el acuerdo en San José de Flores. Dado

\footnotetext{
${ }^{8}$ Historia argentina contemporánea 1862-1930. Historia de las provincias y sus pueblos, volumen IV, primera sección, Buenos Aires, El Ateneo, 1967, capítulo I, "La provincia de Buenos Aires".
} 
que la Asamblea General provincial nombró a Mitre como gobernador el 2 de mayo de 1860 y debido a una nueva ruptura con la Confederación, se decidió en Pavón no sólo el triunfo final de Buenos Aires sino que el vencedor Mitre fuera quien asumiría provisoriamente las facultades del poder ejecutivo nacional.

En los días entre septiembre de 1861 y el 10 de octubre de 1862, cuando Mitre renunció como gobernador, las tensiones giraron en torno a la federalización de Buenos Aires. Se acordó que la ciudad fuera residencia del gobierno nacional hasta que el Congreso Nacional dictase una ley de capital permanente, la Ley de Compromiso que establecía que Buenos Aires fuera sede de autoridades nacionales por el lapso de cinco años.

Luego de Pavón, se convocaron a elecciones nacionales en abril de 1862, triunfando la fórmula Mitre- Marcos Paz, pero escindiéndose el llamado Partido Liberal entre autonomistas y nacionalistas. La presidencia de Mitre se estructuró sobre tres principios de su programa de gobierno: "Nacionalidad, Constitución, Libertad", que en la praxis se tradujo en Nación unida desde Buenos Aires y represión al caudillaje del Interior; Constitución federal con garantía de los derechos civiles y "libertad" económica, institucional y de crítica, bajo el "paraguas" del liberalismo y positivismo decimonónicos.

Una de las primeras cuestiones por resolver fue la reorganización de la Corte Suprema de Justicia, de los tribunales nacionales y de los códigos. Para integrar el tribunal máximo de justicia, Mitre convocó juristas de la talla de Salvador María del Carril, Gorostiaga, Carreras, Barros Pazos y Delgado. En cuanto a la codificación, se adoptó para la Nación el Código de Comercio de la provincia de Buenos Aires -obra de Acevedo y Vélez Sarsfield- y el Código Civil -que fue aprobado a libro cerrado y promulgado por Sarmiento en 1869-, encargándole a Carlos Tejedor la redacción del Código Penal. La sucesión presidencial entorpeció los débiles acuerdos de convivencia cuando Urquiza se presentó como el candidato del partido Federal, Adolfo Alsina como jefe de la fracción autonomista y Elizalde por los nacionalistas.

Entonces, Lucio Mansilla lanzó la candidatura de Domingo Sarmiento, quien se encontraba como ministro argentino en Estados Unidos y cuya figura resultaba conciliadora frente a los antagonismos de los otros potenciales candidatos. El acuerdo con Alsina y el apoyo del autonomismo porteño, más las simpatías de las provincias cuyanas, desembocó en la fórmula Sarmiento- Alsina, que dejó fuera de juego a la potencial candidatura de Urquiza y a la negativa de Mitre, en pleno campo de batalla por la guerra de la triple Alianza.

La presidencia de Sarmiento y luego la de Nicolás Avellaneda se inscribieron en un contexto de transformación política, económica y social. En el plano político, la línea Interior- federal y Buenos Aires- liberal dejaron de existir, las redes del federalismo se desarticularon y el liberalismo se dividió, generándose alianzas entre los dos troncos partidarios tradicionales. Desde el punto de 
vista económico, la irrupción del lanar, acompañando el desarrollo vacuno, junto a la expansión de las líneas férreas que delinearon el mapa económico primario- exportador se complementó con el ingreso de inmigrantes al mercado laboral, quienes dieron un nuevo matiz a la estructura poblacional, según quedó reflejado en el Censo de 1869. Las crisis de superproducción por stocks invendibles o las financieras (como la de 1873-1875), sufridas por la vulnerabilidad de los mercados europeos de capitales, fueron un rasgo común en el período 1868-1880.

Si bien Sarmiento era un presidente sin partido, no por ello carecía de un programa, sintetizado en su obsesión de educar al soberano. El fin de la guerra del Paraguay le permitió abocarse a un programa de modernización del Estado, que consideraba la extensión del ferrocarril y la colonización como pilares de su modelo de civilización. Avellaneda por su parte, gestó una política explícita de promoción a la inmigración con la llamada "Ley Avellaneda", extendió la frontera con la estrategia de avanzada sobre el desierto con la línea de fortines, consolidó el poder de las oligarquías del Interior con la Liga de Gobernadores y la formación del P.A.N., pero debió enfrentarse con la crisis financiera y la cuestión de la federalización de Buenos Aires, que sólo se resolvió con el enfrentamiento de la Nación y la provincia de Buenos Aires, durante la presidencia de Roca.

A partir de la unificación nacional, se sucedieron diversos gobernadores en la provincia de Buenos Aires que debieron asumir como escenario político la polarización entre autonomistas y nacionalistas. Mariano Saavedra (1862-1866) se encargó de una ardua tarea de extensión del territorio y del poblamiento al sur del Salado, alentando la construcción de nuevas líneas férreas), junto a una ardua tarea educativa y de organización administrativa de la burocracia provincial.

La gobernación de Adolfo Alsina (1866-1868) marcada por ser el líder del autonomismo, estuvo signada por la guerra del Paraguay y la epidemia del cólera; hizo obligatoria la educación y se crearon nuevos pueblos. Renunció a su cargo para acompañar como vicepresidente a Domingo Sarmiento, quedando la gobernación provisionalmente a cargo de Emilio Castro. Este fue electo gobernador (1869-1872) caracterizándose por las nuevas concesiones ferroviarias, una importante legislación sobre tierras públicas, las dificultades en las fronteras con el indio, nuevas epidemias de cólera y fiebre amarilla y la convocatoria en 1871 a una Convención para redactar una nueva Constitución provincial.

Entre 1872 y 1874 el autonomista Mariano Acosta fue gobernador. Durante su gestión se deben resaltar las pujas políticas frente al contexto de sucesión presidencial (Acosta renunció a su cargo en 1874 al ser electo como vicepresidente de Nicolás Avellaneda) y la redacción de la Constitución provincial de 1873, que establecía importantes reformas institucionales, como la elección del ejecutivo provincial por electores (surgidos del voto popular y no de la Asamblea 
Legislativa); la creación del cargo de vicegobernador y la representación de las minorías en base al criterio de proporcionalidad.

La salida de Acosta dejó el ejecutivo a cargo del presidente del Senado Álvaro Barros (18741875), quien debió resolver la revolución mitrista de 1874. Elegidos según la nueva Constitución, Carlos Casares y Luis Sáenz Peña (1875-1878) debieron enfrentar el desafío que supuso la crisis financiera (1873-1875) y la consolidación de la frontera provincial, con la estrategia de crear nuevos pueblos por el aliento a la colonización, a medida que se extendía el ferrocarril. Casares promulgó la ley de Educación Común de la provincia (antecedente de la ley 1.420). Las pujas internas del autonomismo, cuyos disidentes eran los republicanos, y las negociaciones con los nacionalistas dieron forma a la candidatura de Carlos Tejedor- José María Moreno.

Como gobernador provincial (1878-1881), Tejedor tuvo una importante actuación en reformas administrativas, pero su gestión quedó trunca por el enfrentamiento con el poder ejecutivo nacional que desembocó en la federalización de Buenos Aires. Su renuncia puso a Moreno a cargo de la gobernación, pero éste debió abandonarla por la intervención federal. Por ley nacional del 11 de agosto de 1880, el Congreso disolvió la Legislatura y el presidente Roca anunció el 6 de diciembre de 1880 la ley de capitalización de la ciudad de Buenos Aires. En las elecciones de ese mismo mes, triunfó la fórmula Dardo Rocha- Adolfo González Chaves como las nuevas autoridades bonaerenses para el período $1881-1884$.

\section{Vicente Fidel López: felicidad y libertad}

Vicente Fidel López nació en 1815 y fue su padre Alejandro Vicente López, quien se caracterizó por su habilidad de adaptación política, definida como "pragmatismo", heredado por su hijo y por su nieto, Lucio Vicente. ${ }^{9}$ Optando por las leyes como vocación profesional, integró la generación de 1837, junto a otras pocas figuras que dominaron la vida cultural argentina durante varias décadas. ${ }^{10}$ La bibliografía dedicada a este jurista, político e historiador es abundante, no sólo por lo atractivo de su historia, sino porque, representante de una generación, atravesó la era rosista amparado en el exilio, fracasó en su intento de protagonizar el proyecto nacional después de Caseros y finalmente tuvo una activa participación en los debates de la construcción del Estado, fundamentalmente en la década de 1870.

Ante el fracaso generacional de ser uno de los ideólogos de la nueva era, se trasladó en 1840 a Córdoba, donde contrajo matrimonio con Carmen Lozano Zamalloa e intentó expandir las ideas románticas. Luego inició en Chile un exilio de diez años, cuyo balance resulta contradictorio, pues

\footnotetext{
${ }^{9}$ Para conocer la vida y la acción política de Vicente Fidel López ver Lettieri, Alberto R., 1995, op. cit.

${ }^{10}$ Myers, Jorge, "La revolución de las ideas: la generación romántica de 1837 en la cultura y en la política argentinas", en Goldman, 2005, p. 383.
} 
pudo estudiar a fondo un modelo político que juzgaba aplicable, pero despertó en él un nacionalismo extremo, hasta entonces latente. ${ }^{11}$ Finalmente se trasladó a Montevideo, desde donde alimentó su proyecto de generar municipalidades fuertes en contacto con el ejecutivo nacional, que junto a su relación con Urquiza y su defensa del Acuerdo de San Nicolás, lo llevaron al descrédito y a un prolongado letargo hasta 1868. Durante su exilio, al igual que sus compañeros de generación, lo distinguió su avidez por estar al tanto de lo último surgido en Europa y en Estados Unidos. ${ }^{12}$

En ese año inició una fecunda etapa en la que colaboró en la "Revista de Buenos Aires", fundó con Juan María Gutiérrez y Andrés Lamas "La revista del Río de la Plata”, y dictó clases de Economía política en la Universidad de Buenos Aires, llegando a ocupar el Rectorado, actividad académica que le permitiría relacionarse con los jóvenes autonomistas reformistas, integrantes luego del Partido Republicano. ${ }^{13}$ Pero lo importante es que a toda esta actividad intelectual y académica, se sumó su retorno a la actividad política institucional de la provincia como convencional para la reforma constitucional, por la ciudad de Buenos Aires, y como senador provincial por el autonomismo en 1872. La Convención Constituyente fue el ámbito de expresión de la perspectiva teórico política de López ${ }^{14}$ y a través de su actividad en el Senado provincial y las páginas de la "Revista de Legislación y Jurisprudencia" manifestó los aspectos prácticos de su teoría, sin dejar de dar a sus propuestas el sustento ideológico elaborado a lo largo de todos estos años.

Fue en el inicio de esta etapa que López redactó un proyecto de organización para el poder judicial. El mismo no ha sido tenido particularmente en cuenta en los estudios realizados hasta el momento sobre su producción bibliográfica. La "Revista de Legislación y Jurisprudencia” presentó, con motivo de la reforma constitucional, el proyecto de Vicente Fidel López dedicado a la “Organización del Poder Judicial". ${ }^{15}$ Los editores, entre los que se encontraba Antonio Malaver, advertían sobre la imposibilidad de realizar un estudio detallado de las teorías y doctrinas expuestas, pues su crítica jurídica requería de largos estudios. También aseguraban que el proyecto no se convertiría en ley, por no responder a los requerimientos de una sociedad que necesitaba comprender y pedir una organización de la cual desconocía su objeto y sus funciones, pero rescataban la exposición sobre la amovilidad o inamovilidad de los jueces, y por ello decidieron honrar "las páginas de la publicación con tan notable trabajo". ${ }^{16}$

\footnotetext{
${ }^{11}$ Lettieri, 1995, op. cit., p.25.

${ }^{12}$ Myers, 2005, op. cit. p.385.

${ }^{13}$ Lettieri, 1995, op. cit., p.39.

${ }^{14}$ Lettieri, 1995, op. cit., p.40.

${ }^{15}$ Revista de Legislación y Jurisprudencia, tomo V, Buenos Aires, Imprenta de La Prensa, 1870, pp. 395-447. (en adelante RLJ)

${ }^{16}$ RLJ, p. 395.
} 
López dividió su proyecto en una parte teórica y otra práctica, sirviendo la primera de base a la segunda para que no se considerara su trabajo "una extravagancia deseosa de ser calificada de original". Para ello recurrió a los publicistas más acreditados y "a quienes el partido liberal tributa en todas partes mayor respeto y consideración". ${ }^{17}$ Las citas son extensas y las referencias a pie de página vagas, haciendo permanentes referencias al conocimiento que sus lectores debían tener sobre los textos y aconsejando que los leyeran y meditasen a la luz de la historia y de la experiencia. ${ }^{18}$ Esos libros dieron sustento a su proyecto, al acercarle la experiencia de pueblos "morales y felices" y las prácticas de pueblos libres como Estados Unidos, Bélgica, Inglaterra y Suiza.

Esta parte teórica podríamos nosotros dividirla en dos. La primera, en que cada uno de sus inspiradores teóricos fue brevemente introducido, para pasar luego a largas transcripciones relacionadas con la organización judicial; y la segunda, en la que López expresó sus opiniones. Inició la exposición con Eduardo Laboulaye ${ }^{19}$ y su libro Partido liberal (1869), del que rescató la inamovilidad del juez, fundamental desde el punto de vista político para la magistratura, una inamovilidad absoluta, basada en el modelo inglés. El juez no era despedido pero tampoco tenía una carrera judicial, por lo que no tenía nada que esperar del poder, pero tampoco nada que temer. Aquí el autor citado aludía a su vez a Benjamin Constant, para quien sí había posibilidad de ascenso la inamovilidad se tornaba ilusoria, el juez inglés no estaba expuesto ni al temor ni a la esperanza (aguijones del ser humano), pero tampoco a la política. ${ }^{20}$ En este contexto, expresó López los graves inconvenientes de la elección popular, manejada por los partidos o abandonada a la abstención del electorado, apoyándose en las ideas de autores aceptados por la elite intelectual de la que él había logrado formar parte.

La inamovilidad estaba ligada a la independencia del juez, a quien Laboulaye definía como representante de la justicia ante el pueblo y ante el gobierno, destacando que no debía ser sirviente del primero ni esclavo de la opinión del segundo. Esta idea fue reforzada por nuestro autor citando a Toqueville -para quien disminuir la independencia de los magistrados, no atentaba sólo contra la justicia sino contra la democracia misma- y con Stuart Mill que en El Gobierno Representativo, ${ }^{21}$

\footnotetext{
${ }^{17}$ RLJ, p.395.

${ }^{18}$ En el texto se hace referencia al autor sólo por su apellido y en la cita a pie de página se da el nombre del libro, a veces en forma incompleta, señalando siempre la página, por esto ha sido muy dificultoso -en algunos casos imposibleubicar a los autores y a las obras.

${ }^{19}$ Escritor y jurisconsulto francés, (1811-1883). Continuador de Benjamín Constant y Alexis de Tocqueville, escribió Historia de los Estados Unidos (4 tomos, Sevilla, Eduardo Perie, 1870). En el segundo tomo dedicó una lección al estudio del poder judicial, calificándolo como poder político debido a que tenía poder de declarar la inconstitucionalidad de las leyes. Sus estudios sobre la organización judicial y la Constitución de Estados Unidos jugaron un importante papel en el fortalecimiento del porfiriato mexicano, ver: Cabrera Acevedo, Lucio, La Suprema Corte durante el fortalecimiento del porfirismo, 1882-1888, México, Suprema Corte de Justicia de la Nación, 1991; Speckman Guerra, 2002, op. cit.

${ }^{20}$ Laboulaye, Eduardo, Le parti liberal, París, Charppentier, 1858, p. 227.

${ }^{21}$ Mill, J.S. Considerations on Representative Government, Londres, 1861 Esta obra es su tratado más extenso de filosofía política. López recomendaba su lectura en una carta a su amigo Félix Frías: "Leyendo el famosos libro sobre el Gobierno Representativo de Stuart Mill que aquí puedes encontrar traducido por Dupont White-1862, me acordé de ti
} 
destruyó el sofisma de la elección popular de los jueces, porque el pueblo no contaba con las calidades necesarias (calma e imparcialidad) para hacerlo, y criticó el sistema norteamericano. En medio de este profuso texto, que criticaba la opción francesa de jueces temporales elegidos por el pueblo, López aseguró que no bastaba la inamovilidad, también se requería de la formación profesional y de la experiencia.

Pidiendo permiso para emitir su opinión, López expresó con ironía que sí en los dos países del mundo mejor capacitados para elegir, fracasó la elección popular de los jueces, “imaginemos lo que ella sería entre nosotros". ${ }^{22}$ Sin embargo, no se podía seguir como hasta entonces. La elección del ejecutivo implicaba la elección de un amigo, o al menos conocido, pues nunca elegiría a un adversario, y esto era no por el defecto de una persona sino por la "naturaleza moral de las cosas humanas". No se trataba de un acto de corrupción en la elección de un allegado, sino un acto de afecto paternal de la autoridad. ${ }^{23}$ Por otro lado, la solución de confiar la elección al Senado traía dos problemas: la influencia del espíritu de partido y el desconocimiento que los legisladores podían tener sobre la administración de justicia.

La solución estaba en la Historia del Gobierno Representativo de Caine, para quien una buena Constitución debía repartir el poder electoral y el poder político en cada cuerpo de la Nación inherentes al servicio que debían prestar. Un cuerpo inamovible tenía el derecho de renovarse a sí mismo según las capacidades científicas y morales, sin ser dominados por la opinión popular; cuerpos moralmente, no políticamente, aristocráticos, distinguidos por la ciencia y el magisterio, sometidos a su dignidad y a su conciencia. Esta forma de elección era una garantía para un pueblo libre y feliz, que armonizaba igualdad y jerarquía, tan difíciles de conciliar.

Al llegar a este punto el texto pasó a estar dominado por la opinión de López, con citas que la fundamentaban, escribiendo otro tanto como lo que llevaba expuesto. Su propósito era destacar lo inadecuado de caer en la rutina electoral, de imitar el modelo francés, teniendo delante la experiencia inglesa que se sintetizaba en un objetivo: "Municipalidades políticas: justicia soberana e independiente encarnada en la misma acción del pueblo (no en su elección)". ${ }^{24}$ Para lograr una imagen más clara de lo que quería transmitir recurrió a una fábula, según la cual imitar a Francia o a España era comportarse como el negligente bondadoso que tenía dos pares de sábanas y los usaba alternativamente, dejando el que no estaba en uso debajo de la cama. Durante sesenta años estuvimos "durmiendo alternativamente con las sábanas de la revolución francesa o con las del

por dos motivos- el primero para recordarte esa lectura capital que no es por cierto como las tontas polémicas de pura especulación que te preocupan; y el otro es que recuerdo el espanto que te causó que una vez en nuestras discusiones te dijera yo que la Inglaterra había sido una confederación hasta ahora muy pocos años. Cosa o concepto que hallarás igualmente vertido en la página 365 de ese libro precioso." Archivo General de la Nación, Archivo "Los López", legajo 2368, carta $\mathrm{n}^{\circ}$ 4270. Carta de Vicente Fidel López a Félix Frías, Montevideo, 23-X-(sin año).

${ }^{22}$ RLJ, p.401.

${ }^{23}$ RLJ, p.401.

${ }^{24}$ RLJ, p.404. 
Virreinato, y cuando tiramos las unas es para agarrar las otras. Lavémoslas al menos, aún cuando nos cueste trabajo y sepamos ir al fondo, y sin pereza, de lo que queremos"25.

El objetivo fundamental era el "gobierno de lo propio", que consistía en funcionar, no en elegir. ${ }^{26}$ El pueblo podía funcionar como juez, como jurados o jueces de paz en situaciones extremas, aunque no eligiera a sus jueces. Los magistrados estarían sujetos a la jurisdicción provincial del jurado, sin fueros especiales que atentaran contra la igualdad ante la ley y la libertad que, a pesar de ser lo más importante, debía estar respaldada por esa ley. Pero no había ley si la justicia no era igual y escrita para todos, la ley era la regla de la conducta del juez, responsable y justiciable, sólo así la libertad se hacía efectiva. Estas conclusiones de López suponen la lectura de Alexis de Tocqueville, que descubrió en el arte político de los Estados Unidos, la solución al problema democrático de la centralización del poder, nacido de la pasión por la igualdad, enfrentada a la pasión por la igualdad en la libertad, ambas de fuerza desigual. La solución sugería "recursos democráticos" entre los que se encontraban el autogobierno local, la separación de la Iglesia y el Estado, la libertad de prensa, las elecciones indirectas, una justicia independiente y el fomento de las asociaciones. ${ }^{27}$

A su vez Tocqueville influyó en John Stuart Mill, leído por López, que aceptaba el inevitable avance de la igualdad en la democracia, inconveniente de quienes quisieran promover el progreso, pues la igualdad en extremo chocaba con la justicia y socavaba la libertad y el respeto a la excelencia intelectual y moral, condición de todo progreso. Por esto Mill, sosteniendo el núcleo del utilitarismo, introdujo algunas modificaciones, basadas fundamentalmente en que si bien el gobierno existía para producir la felicidad del mayor número, algunos tipos de placer eran mejores que otros, y era su responsabilidad educar al ciudadano de modo que tendiera a buscar los placeres más elevados en lugar de los más bajos. Esto se expresaba en la educación moral (por el gobierno o particular) dirigida al hombre no sólo como animal que busca placeres, sino como "ser progresista". ${ }^{28}$ De esto podemos entender que López tenía como modelo a los pueblos felices y libres, pero morales, y que la igualdad debía funcionar como garantía de la libertad en la letra de la ley para alcanzar el tan anhelado progreso.

Antes de adentrarse a los aspectos prácticos, López sintetizó el fundamento de su proyecto en dos ideas: su propuesta era un "corsé" del tejido de las prácticas inglesas que debía adaptarse a

\footnotetext{
${ }^{25}$ RLJ, p.405. Con respecto a los modelos, López creía que "no podemos tener la pretensión de hacer una ley perfecta, pero sí de imitar a aquellas que existen, que son reconocidas por buenas, y que dan todas las garantías indispensables para que todo hombre pueda ser atendido y pueda salvar sus derechos y sus garantías...". Sesión del 22 de junio de 1872. Senadores, 1873 , p.81.

${ }^{26}$ El "gobierno de lo propio" era para López el gobierno legítimo, contrario al "gobierno de lo ajeno". Este concepto lo desarrolló en su artículo "De la naturaleza y del mecanismo del Poder Ejecutivo en los Pueblos Libres" en la Revista del Río de la Plata, tomo .IV, núm. 14, 15 y 16. Ver Lettieri, 1995, op. cit., pp.41-42.

${ }^{27}$ Zetterbaum, Marvin, "Alexis de Tocqueville", en Strauss Leo y Cropsey, Joseph, Historia de la filosofía política, México, FCE, 1993, p.727.

${ }^{28}$ Magid, Henry M., “John Stuart Mill”, en Strauss y Cropsey, 1993, op. cit. pp. 741-742.
} 
nuestro cuerpo social y la administración de justicia debía ser soberana e independiente. Terminada la teoría, comenzaba el proyecto extenso y detallado, construido sobre bases generales para la administración de justicia que debía ser gratuita; los juicios serían públicos y contradictorios; quedaban prohibidos los grillos o ligaduras; no existirían los fueros; ninguna ley tendría fuerza retroactiva; los juicios criminales debían surgir de la denuncia escrita; la cárcel previa sólo podía ser correccional o por presunción de delito, nunca por presunciones políticas; ningún delincuente estaría obligado a declarar contra sí mismo; en los juicios criminales las averiguaciones en el vecindario serían garantía de la vida y libertad de los hombres; el proceso criminal no podía durar más de un mes en la ciudad y dos en la campaña; la justicia por mano propia no estaba permitida al pueblo, pero no estaba prohibida cuando "la haga en masa y en lugares de campaña donde no haya medios eficaces de escarmiento y de seguridad"; el extranjero que en duelo derramara sangre argentina sería desterrado; no podría ejercer cargo público el ciudadano que hubiere participado en duelo con efusión de sangre; la traición contra el Estado sería hacer la guerra contra él bajo otra bandera pero nunca su oposición a través de la prensa. ${ }^{29}$

La justicia sería administrada por tribunales ex aequo et bono (conforme a la equidad o según el leal saber o entender) y tribunales ex jure (de derecho). Los primeros eran los jurados civil y criminal, los jueces de paz, la Cámara Correccional y el Departamento Topográfico y de Ingenieros; los segundos, los que componían en su conjunto la Sala Jurídica de la Provincia de Buenos Aires integrada por diez y seis miembros titulares y otros tantos adjuntos, todos ellos abogados con ocho años de práctica. Los titulares serían nombrados la primera vez por el Senado y luego por mayoría en su seno; durarían en sus cargos tanto como su buena conducta. ${ }^{30}$ La Sala Jurídica en pleno sería consejo consultivo de derecho para el poder ejecutivo y el poder legislativo en los casos de conflictos administrativos o interprovinciales que requirieran ser arregladas en función de sus antecedentes, leyes vigentes y prácticas. ${ }^{31}$

Los juicios criminales podrían ser únicamente por jurados y las causas condenatorias serían revisadas por el tribunal del crimen, compuesto de seis miembros de la Sala; en las causas civiles el actor podría optar por el jurado o los tribunales letrados. La Sala funcionaría en primera instancia para los divorcios, disensos y la administración de bienes matrimoniales y dos de sus miembros se dedicarían a dirigir y redactar el Registro de la Jurisprudencia de las sentencias. Los jurados actuarían en el distrito municipal donde hubiere ocurrido el hecho y sería integrado por vecinos del mismo. Desaparecían los Fiscales y Agentes fiscales y sus funciones serían desempeñadas por personal nombrado para cada caso. ${ }^{32}$ Cada tres meses, tres jueces adjuntos recorrerían las

\footnotetext{
${ }^{29}$ RLJ, pp. 445.

${ }^{30}$ RLJ, pp. 414-415.

${ }^{31}$ RLJ, pp. 420.

${ }^{32}$ RLJ, pp. 416-421.
} 
Municipalidades de Campaña, para fallar en apelación las causas civiles resueltas en primera instancia por el Jurado; las criminales condenatorias irían directamente a la Sala Jurídica de la Capital y las sentencias de los jueces visitadores serían publicadas en el Registro de la Jurisprudencia con la interpretación de las leyes y circunstancias que se hubieren aplicado. Las Municipalidades con desenvolvimiento social y medios propios podrían solicitar a la Legislatura un Tribunal de Apelación propio. ${ }^{33}$

Como en 1862 fue eliminado el Consulado y establecidos los tribunales de comercio en la capital, dándosele jurisdicción comercial a los jueces de primera instancia de la campaña, López quería regresar a la justicia comercial ejercida por el propio gremio, para lo cual definía al comerciante, que por componer un gremio civil debían estar sujetos a su propia jurisdicción, pero en caso de apelación, la Cámara Comercial se formaría agregando tres abogados. ${ }^{34}$ El Departamento Topográfico constituiría un Jurado especial de obras públicas, ante el cual se debía consultar para emprender construcciones u obras públicas; podría imponer multas y proceder a expropiaciones autorizado por el ejecutivo. Si los particulares o empresas resistieran seis mandatos, lo contencioso se derivaría al Jurado y se podría apelar ante el Senado. ${ }^{35}$

El apartado de la justicia de paz establecía la relación entre las municipalidades y el poder ejecutivo. Los jueces serían nombrados por la autoridad local pero podían ser depuestos por el ejecutivo provincial, sin tener que exponer las causas, lo que no estaría permitido sería deponer a todos o a parte de ellos en forma general. La jurisdicción contenciosa del juez de paz correccional se ejercería sobre los casos sin gravedad que no merecieran más de diez duros de multa o de uno a diez días de prisión; en casos urgentes podría expedir medidas de arresto, para contener un desorden o prevenir un delito y si el hecho no correspondía a su jurisdicción, y si había procedido previamente, el juez de paz debía dirigirse al Presidente del municipio para que se instalara el jurado. El juez de paz correccional podría ejercer actos de policía preventiva y los agentes policiales debían prestarle obediencia; le estaría permitido inspeccionar lo relativo a la limpieza y salubridad del barrio, el estado de casas, empedrados y veredas y también recibiría denuncias sobre incidentes de vecindad ${ }^{36}$.

En lo que respecta al juez de paz civil, sería su jurisdicción el pago del impuesto de alumbrados y serenos, casos de conchabos, sirvientes y changas, salarios de peones, artesanos y casos de marineros contra capitanes y patrones de buques y viceversa, alimentos de hijos ilegítimos, incidentes y permisos para cazar y pescar; cuestiones de mercados de abastos, tratos y ventas al menudeo, alquileres de cosas raíces, o muebles, o bestias que no procedieran de trato escrito, pues si

\footnotetext{
${ }^{33}$ RLJ, pp. 417-418.

${ }^{34}$ RLJ, pp. 436-437.

${ }^{35}$ RLJ, p.438.

${ }^{36}$ Lo referente a la organización de la justicia de paz en RLJ, pp. 428-436.
} 
procedían les correspondían al jurado. Les correspondía también expedir medidas urgentes contra deudores, presuntos de fuga, o para embargos preventivos o para interdicciones momentáneas contra buques traspasados de valores, o de propiedades, pero estas órdenes no tendrían efecto sino por veinticuatro horas. Podría también en casos urgentes, autorizar casos civiles como testamentos, personerías, protestos, cargos de plazo fatal en las solicitudes que lo tuvieran, haciéndose atestiguar en todos estos actos con dos vecinos respetables del barrio. Si las partes querían apelar lo decidido por el juez de paz, deberían exponerlo verbalmente ante la Comisión de vecindad, la cual formaría un tribunal con los tres jueces de paz más inmediatos, la parte agraviada podría llamar un asesor letrado y en una sola audiencia verbal y sumaria se confirmaría o revocaría lo fallado, dando por concluida la causa.

Además de estos funcionarios, los dueños de estancia serían jueces de paz natos entre quienes poblaban su establecimiento, para causas civiles que requirieran fe pública y en las que no fueran parte (testamentos, tutelas, particiones), para lo cual deberían llevar un Registro Público que sería depositado anualmente en el Archivo de la Municipalidad. También podrían pedir a la Municipalidad título y comisión de jueces de paz supernumerarios, todo propietario argentino, de arraigo en la provincia de Buenos Aires y sus hijos mayores de 22 años, garantidos por el padre; graduados en derecho, arte y ciencias, hacendados, jefes de oficinas administrativas y jueces de derecho. Su competencia estaría limitada a casos premiosos y preventivos de naturaleza correccional o delito inminente y serían responsables ante el Jurado de todo abuso que cometieran.

López aspiraba a pueblos felices y libres, con jueces morales y científicos que formaran un cuerpo moralmente aristocrático en cuyo desempeño la jurisprudencia jugaba un importante papel, pero buscaba la descentralización judicial con el jurado, los jueces de paz, el tribunal comercial y el Departamento Topográfico. ${ }^{37}$ La descentralización administrativa era relativa, perfilando una figura que trascendiera lo jurídico y se convirtiera en un garante de la seguridad en la campaña, apoyándose en el fortalecimiento del municipio aunque para ello se mantuviera cierta centralización de funciones en los jueces de paz.

La mirada del autor estaba puesta en el control del poder político. En sus propias palabras, "se trata de hacer el Gobierno de lo propio, se trata del bien de esas localidades, y de darles entonces a los funcionarios todas aquellas atribuciones que le son indispensables, pero al mismo tiempo responsabilizándolos para que de ellos no abusen". ${ }^{38}$ Esto incluía a los funcionarios encargados de administrar justicia, sobre los que el ejecutivo tenía cierta disponibilidad, pero que eran garantes de los derechos como expresión incuestionable de la libertad.

\footnotetext{
${ }^{37}$ RLJ, p.403.

${ }^{38}$ Sesión del 3 de agosto, Senadores, 1872, pp.180-181.
} 
Aunque no lo mencionó en su propuesta, no escapaba a sus preocupaciones el lugar en que se administraba la justicia, demostradas como integrante de la Comisión de Legislación del Senado, donde estudió y modificó el proyecto sobre refacción de los tribunales de justicia, propuesto por el senador Rufino de Elizalde, que ordenaba al poder ejecutivo hacer levantar los planos y presupuesto para la construcción de la Casa de Justicia, permitiendo un gasto máximo. ${ }^{39}$ El nuevo Proyecto de la Comisión autorizaba al Poder Ejecutivo a hacer lo necesario para la ejecución de la obra, prefiriendo "las obras del ingeniero que presente el plano más adecuado y las condiciones más favorables de trabajo", planos y presupuesto debían ser aprobados por la Legislatura. Además mientras se efectuasen las refacciones, debía proveerse a los juzgados de primera instancia, con sus secretarios y archivos, de una casa adecuada. Elizalde llamó la atención sobre la "forma autoritativa" y solicitó mantener la "preceptiva", cambio aceptado por la Comisión ${ }^{40}$.

Podemos observar algunas cuestiones fundamentales en las modificaciones introducidas en la propuesta original. En primer lugar, la relación que establecía con el ejecutivo lo autorizaba a iniciar las obras, no sin que antes planos y presupuesto estuvieran autorizados por la Legislatura. Esto coincide con la idea que tenía el senador sobre la relación entre ejecutivo y legislativo. Presidente y ministros conformaban un gobierno de lo ajeno, saqueando las finanzas y menoscabando la influencia de la opinión pública, que no lograba participar de la administración de lo propio. La solución estaba en proveerla de mecanismos de participación en el gobierno, creando un ministerio parlamentario o consejo de ministros. ${ }^{41}$ En segundo lugar el concepto moderno de construcción pública, prácticamente una licitación, y finalmente el concepto de la necesidad, que debía ser resuelta mientras se ejecutaran las obras. ${ }^{42}$

También en la práctica legislativa, López introdujo su visión de la primacía de la libertad sobre la igualdad, al presentar un tema de fondo, como el proyecto del habeas corpus. En su opinión, el derecho criminal estaba en nuestro país abandonado a la eventualidad y la arbitrariedad de los jueces, por lo que era desequilibrada la relación entre los delitos y las faltas, con las penas y

\footnotetext{
${ }^{39}$ López fue senador provincial entre abril de 1872 y junio de 1873, integrando la Comisión de Legislación junto a Félix de Zéliz y Luis Sáenz Peña, participando de la revisión, elaboración y presentación de numerosos proyectos que ponían en práctica sus ideas.

${ }^{40}$ Sesión del 8 de junio, Senadores, 1873, p.65.

${ }^{41}$ Lettieri, 1995, op. cit., pp. 52-53. Ver Pérez Guilhou, Dardo, Liberales, radicales y conservadores. Convención constituyente de Buenos Aires 1870-1873, Buenos Aires, Editorial Plus Ultra, 1997.

${ }^{42}$ La cuestión sobre los edificios dedicados a la administración de justicia es todo un tema en sí mismo, que no sólo atañe a la arquitectura o al arte sino que forma parte de una "historia cultural urbana". Este concepto ha sido desarrollado por Adrián Gorelik atento al estudio del modo en que la ciudad y sus representaciones se producen mutuamente. El plano de una cuidad, sus calles, y en el caso que nos ocupa sus edificios son formas materiales en las que deben ser halladas les formas culturales que las producen y viceversa, es decir comprender como se producen unas en otras. Para esto ha encontrado un puente, entre cultura urbana e historia cultural, la "ciudad análoga", que "busca dar forma sintética a la visión exactamente opuesta de ciudad, mediante una visión alternativa de la relación entre ciudad y cultura, en el que los objetos de la historia, sus huellas culturales, están cargadas de un simbolismo mudo, fundante en la identidad social y cultural, que debe ser descifrado y reactivado". Gorelik, Adrián, "Historia de la ciudad e historia intelectual", en Prismas, Revista de Historia intelectual, núm. 3, Buenos Aires, Universidad Nacional de Quilmes, 1999, pp.209-223.
} 
los castigos. Debía abandonarse la pena aflictiva, pues era imposible la igualdad, dado que los hechos eran diferentes como también lo eran las personas. Para algunos, una prisión de tres meses no significaba nada y para otros podía significarle la ruina completa. La respuesta de los criminalistas modernos era el sistema de la pena correccional pecuniaria, que permitía una escala gradual adaptable a los hechos y a "la escala de las personas". En su exposición, como miembro informante de la Comisión de Legislación, López invocó tres fundamentos: los antecedentes ingleses, la garantía de la libertad (para argentinos y extranjeros) y la regularización de los procedimientos. $^{43}$

A principios de 1873, el senador fue nombrado miembro de una Comisión especial que el Senado formó para redactar un proyecto sobre administración de justicia en respuesta al notorio malestar en la justicia expresado por el Superior Tribunal en una nota dirigida al poder ejecutivo. En el debate de esta medida, López explicitó la necesidad de mantener claras las atribuciones de cada poder, el Senado no investigaría a los jueces ni a los tribunales sino a los hechos que estaban produciendo los males que el Tribunal no detallaba en su presentación. ${ }^{44}$

En oportunidad de discutir sobre la justicia de paz y la organización de la campaña, el jurista y político sintetizó sus ideas sobre la administración de justicia:

Una de las cuestiones más difíciles y serias, y sin embargo más esenciales para un país bien gobernado es la de tener buena justicia, y una buena justicia no puede tenerse cuando el país mismo no contribuye a mantenerla y formarla... Una de las grandes necesidades que tiene un país en las condiciones del nuestro es que todo hombre público conozca los resortes de la justicia, y estos no son los que verdaderamente aspiran. Es preciso que el ciudadano conozca no solamente el carácter, la índole de las instituciones, sino que conozca también la clase de los intereses que la institución tenga, porque como todos son diversos, no pueden gobernarse de la misma manera. Así el modo de tener hombres públicos y de tener una buena Administración de Justicia, es tener una justicia popular en que se administren y defiendan los intereses de la Sociedad. ${ }^{45}$

\section{Antonio Ezequiel Malaver: necesidad y competencia}

Al contrario de lo que hemos visto con López, es muy escasa la bibliografía sobre Antonio E. Malaver. Sabemos que nació en Buenos Aires el 9 de abril de 1835 y sus padres fueron Antonio Malaver y Pía Sánchez. ${ }^{46}$ En 1853 se recibió de agrimensor y como tal prestó servicios a las órdenes del General Paz en el sitio a Buenos Aires; estudió medicina un año y luego derecho hasta alcanzar el título de doctor en jurisprudencia en 1864. Dictó derecho procesal en la Universidad de Buenos Aires; fue diputado provincial entre 1865 y 1869; ocupó la cartera de Gobierno provincial

\footnotetext{
${ }^{43}$ Sesión del 22 de junio, Senadores, 1872, p.83. Ver sobre el tema de la relación entre libertad e igualdad Lettieri, 1995, op. cit., p.42.

${ }^{44}$ Sesión del 11 de marzo de 1873, Senadores, 1872, p. 406.

${ }^{45}$ Sesión del 24 de agosto 1872, Senadores, 1872, pp.207-208.

${ }^{46} \mathrm{Su}$ participación en la ley de educación común de 1875 fue tratada por Barba, 1982, op. cit.
} 
de 1869 a 1872, fue convencional entre 1872 y 1873, participó como vocal de la comisión redactora del Código de Procedimiento Penal de1885 y fue Procurador General de la Nación de 1890 a 1892; falleció en 1897.

En la Introducción de su Curso de procedimientos judiciales, ${ }^{47}$ firmada el 23 de septiembre de 1875, el autor explicó:

Encargados desde el año anterior de dar un Curso de Procedimientos Judiciales en la Universidad en una época en que esta parte de nuestra legislación entraba en la reforma, apenas principiada con la nueva organización que la Constitución de 1873 ha dado a los Tribunales de la Provincia, nuestra tarea era bien difícil; porque nos faltan aún, las leyes orgánicas de esos Tribunales y las reglamentarias de los juicios ${ }^{48}$

Esta declaración del autor nos permite tomar su obra como una síntesis de las ideas que surgieron, se enfrentaron y acordaron hasta lograr la organización de los tribunales y la legislación procesal.

Se trataba de una obra didáctica que, según el autor, venía a reemplazar otras fundamentales en la guía de los procedimientos vigentes y que se hallaban agotadas, como la de Esteves Saguí, la de Castro o la suya publicada en 1870 con otro compañero. ${ }^{49}$ Explicaba que el Procedimiento era una rama del derecho a la espera de la legislación que la nueva Constitución había encargado, por ello una vez que fueran dictadas las leyes correspondientes, habría otro tomo -que nunca se publicó- en el que haría "una exposición razonada, estudiándolas a la luz de los principios". Finalmente advirtió que su texto de enseñanza, reconocía la "más amplia libertad de doctrina, de método y exposición" y tenía como fin facilitar el estudio y la tramitación de los juicios. ${ }^{50}$

El Manual fue dividido en dos partes, una sobre la organización judicial y otra dedicada a los procedimientos. La que nos interesa ahora es la primera, a la que a su vez le fue dada una clara estructura interna dedicándose a definir la jurisdicción y sus diversas especies, siguiendo luego la

\footnotetext{
${ }^{47}$ Malaver, 1875, op. cit.

${ }^{48}$ Malaver, 1875, op. cit. p. 5. En su labor como senador provincial, Vicente López, junto a su compañero de Comisión Félix de Zéliz, aconsejaron a la Cámara la sanción del proyecto remitido en revisión por la Cámara de Diputado, de creación de la Cátedra de procedimientos Judiciales en el plan de estudios universitarios, para reemplazar la Academia Teórico-Práctica de Jurisprudencia, que no había producido los resultados esperados ni daba la instrucción práctica de jurisprudencia, pues las causas que allí se estudiaban no tenían las características necesarias para atender a los objetivos planteados. Consideraban que era necesario y urgente, y que terminaría con la enseñanza al estilo academia para dar al profesor la obligación de enseñar sobre la materia, Sesión del 3 de octubre, Senadores, 1872, pp. 306-307. La ley fue sancionada el 5 de octubre de 1872 y surgió de la propuesta presentada por del diputado Leandro N. Alem el 5 de agosto de ese año. Alem llegó a la Legislatura bonerense, como candidato del club Electoral, que representaba el sector joven y reformista del autonomismo. Ver Barba, 1982, op. cit., pp.27-29; Leiva, 2005, op. cit. pp.188-200.

${ }^{49} \mathrm{Al}$ igual que con López, las citas bibliográficas son vagas, en la mayoría de los casos colocó el apellido del autor, sin nombre, y parte del título, dando la clara impresión de estar dirigiéndose a un público reducido que debía manejar esa bibliografía extranjera, pues al especificar en todos los casos la página nos da la idea de buscar exactitud. Aquí se refería a dos que ya mencionadas en el capítulo anterior: Manuel Antonio de Castro y Esteves Saguí. La obra suya a la que hacía referencia es un trabajo realizado con su amigo y colega José María Moreno, publicado en partes en la Revista de Legislación y Jurisprudencia, núm. 4 y 5 de 1869 y 1870, “Apuntes sobre los Procedimientos civiles y comerciales”, resumen del libro de Esteves Saguí con las modificaciones introducidas desde 1852 y destinado a los estudiantes.

${ }^{50}$ Malaver, 1875, op. cit., p.6.
} 
forma que la Constitución provincial de 1873 le había asignado al poder judicial. Sobre esa estructura, Malaver realizó una exposición pormenorizada trabajando con la legislación vigente, los antecedentes legislativos y los autores europeos y norteamericanos. Nos detendremos en la expresión de sus opiniones, siempre fundamentadas en un autor extranjero y cimentadas en la idea de que la jurisdicción emanaba del pueblo y el ejercicio correspondía al poder judicial, que no tenía la facultad de hacer derecho (jurisditione), sino de declararlo o aplicarlo en casos particulares (jus dicere o juridictione). Las Partidas decían que los jueces "son omes buenos puestos para mandare fazer derecho" (L.1 $1^{\mathrm{a}}$, Tít. $4^{\mathrm{o}}$, Part. $3^{\mathrm{a}}$ ), sin embargo la Constitución determinaba claramente que sólo el poder ejecutivo podía dictar las leyes, a lo que se sumaba que todos los jueces eran ordinarios porque ejercían en tribunales con un territorio y causa determinada. ${ }^{51}$

Dentro de la cuestión de la jurisdicción, diferenció la administrativa, "principio fundamental de la separación e independencia de los poderes públicos”, que necesitaban de los medios para explicar sus actos, atender los reclamos y resolver las dudas sobre la ejecución de sus decisiones, pues sin libertad de acción no se les podía exigir responsabilidad política ni moral. ${ }^{52}$ Su referencia en este tema era el Derecho Administrativo de Manuel Colmeiro, abogado y economista, profesor de derecho administrativo en Madrid, que evolucionó en su postura teórica del proteccionismo hasta convertirse en un ferviente defensor del liberalismo. ${ }^{53}$

En el estudio de la jurisdicción voluntaria, expresada en el juicio de arbitraje, le dio lugar se dedicó al origen de la justicia, pues fue aquel la primera forma en que se expresó, la más natural y sencilla que podía tener lugar en la sociedad primitiva, sin jueces ni tribunales, donde una persona ajena, imparcial y de confianza podía decidir sobre el conflicto. El juicio por árbitros se remontaba al libro bíblico del Génesis, era anterior a las leyes y estas lo mantuvieron mientras se creaba la administración de justicia. Estuvo presente en el Fuero Juzgo, el Fuero Real, las Partidas y el Código de Comercio hacía obligatorio el arbitraje para determinados casos. Era una institución útil y necesaria, que no se contraponía con los adelantos de la ciencia de la legislación y lo analizó en base a la comparación de lo que el foro pensaba del arbitraje. Para algunos, el compromiso era una sátira de la administración de justicia y los ciudadanos sólo debían reconocer a sus ministros, los árbitros no conocían la ciencia del derecho, lo que podía dar paso a la parcialidad, al fraude, a la arbitrariedad, la lentitud de proceso y mayores gastos para la justicia ordinaria. En cambio, quienes

\footnotetext{
${ }^{51}$ Malaver, 1875, op. cit., p. 8-9. En su participación en los debates legislativos como diputado, Malaver reclamó permanentemente por el respeto de la Constitución con arreglo a las leyes que se dictaran y que los principios siempre presentes debían ser los que garantizaran la propiedad, la vida y el honor de los ciudadanos. Sesiones del 30 de junio y del 7 de octubre, Diputados, 1867, pp.242-243; p. LIV.

${ }_{52}$ Malaver, 1875, op. cit., pp.37-38.

${ }^{53}$ Colmeiro, Manuel, Derecho administrativo español, Madrid, 1850, Imprenta de Hilario Martínez, reeditado en 1995.
} 
lo defendían veían en él una justicia mejor instruida, de la que se eliminaban odios, escándalos, gastos y demoras. ${ }^{54}$

El autor intentó colocarse en el centro de las opiniones, apoyándose en Armand Dalloz ${ }^{55}$ y sosteniendo la incuestionable utilidad del arbitraje voluntario, siempre y cuando se simplificaran sus formas para abreviar los términos procesales. ${ }^{56}$ Respecto al arbitraje forzado, no se declaró en contra pero sostuvo que el Código de Comercio multiplicó los casos de su aplicación sin considerar la crítica de los jurisconsultos. En una minuciosa exposición sobre los árbitros, sus funciones y procedimientos, quedó defendida la actuación de la mujer como tal, pues a pesar de las prohibiciones establecidas en la Novísima Recopilación y las Partidas, a su entender, si se les prohibía esta actividad se le debía prohibir el ejercicio de todo acto civil. Pero, como decía Joaquín Escriche en la definición de árbitro, para aceptarlo requería del permiso del marido. ${ }^{57}$

$\mathrm{Al}$ ingresar en la jurisdicción ordinaria, sin salirse de la estructura determinada por la nueva Constitución, Malaver extendió sus opiniones sobre la nueva organización e introdujo las propuestas para la reglamentación pendiente, "sin la cual no hay verdadera responsabilidad en los Jueces, ni la garantía necesaria para ellos mismos". ${ }^{58}$ La sección dedicada a la justicia de paz es extensa, iniciando el capítulo con la evolución de la institución para poder señalar los cambios y luego llamar la atención sobre la falta de legislación que hubiera generado la transformación real. Al contrario de López, defendió el modelo francés de la elección popular que, a su entender, había fracasado por la falta de leyes adecuadas. Por esto, el objetivo fundamental de la sección era inspirar a los legisladores y señalar las situaciones que a su juicio requerían inmediata atención.

La Constitución Provincial de 1873 no definía si los juzgados de primera Instancia serían unipersonales o tribunales colegiados y la legislación no lo había resuelto aún, por ello, fundado en autor competente ${ }^{59}$, Malaver aprovechó a ponerse a favor de los primeros. Un menor número de jueces permitiría elegir hombres de alta moralidad y vasta instrucción, mejor retribuidos, con procedimientos más rápidos y con menor gasto. Las causas fáciles no requerían de un gran número

\footnotetext{
${ }^{54}$ Malaver, 1875, op. cit., pp. 43-94. Sobre el tema véase Díaz Couselo, José María, "La jurisdicción arbitral indiana. La continuidad después de la revolución en Buenos Aires (1810-1880)", en Biblioteca Jurídica del Instituto de Investigaciones Jurídicas, Universidad Nacional de México, 2007.

${ }^{55}$ Dalloz, Armand, Dictionnaire général et raisonné de législation, de doctrine et de jurisprudence en matière civile, commerciale, criminelle, administrative et de droit public , París, Jurisprudence Générale, 1835-1841 , 5 v. Jurisprudence générale du royaume. Répertoire méthodique et alphabétique de législation, de doctrine et de jurisprudence en matière de droit civil, commercial, criminel, administratif, de droit des gens et de droit public, nouvelle édition, considérablement augmentée et précédée d'un essai sur l'histoire générale du droit français; par M. D. Dalloz ainé, avec la collaboration de M. Armand Dalloz, son frère, a Paris, au Bureau de la Jurisprudence Générale du Royaume, 1845, 44 vols, ver, arbitre, n.37. Esta obra formaba parte de la biblioteca de José Diego Fernández, jurista del porfiriato, ver Fernández Sotelo, Rafael Diego "Don José Diego Fernández Torres semblanza, escritos y biblioteca de un jurista del porfiriato", Anuario Mexicano de Historia del Derecho, vol. XIV.

${ }^{56}$ Malaver, 1875, op. cit., p.45.

${ }^{57}$ Escriche, Joaquín, Diccionario razonado de legislación y jurisprudencia, Madrid, Biec y Droma Edición, 1874-1876, v. arbitro.

${ }^{58}$ Malaver, 1875, op. cit., p. 112.

${ }^{59}$ Rey, Instituciones judiciales de Inglaterra, t.2, p.141.
} 
de hombres y las difíciles serían más plausibles de error en manos de hombres mediocres y, fundamentalmente, pocos hombres distinguidos y mejor pagos formarían todo el cuerpo judicial por lo que los más notables del foro no despreciarían la magistratura dejándola para la última etapa de su vida profesional.

En la sección dedicada a las cámaras de apelación, Malaver pudo explicar lo que entendía como la base de la organización judicial: la descentralización, territorial y por la naturaleza de las causas, cuyo objetivo final era acercar la administración de justicia a quienes la necesitaran. Antes la justicia civil y comercial estaba radicada en la capital y aún los procesos criminales terminaban en ella por apelación o consulta. Hasta ese momento en que él está escribiendo, no notaba los beneficios del cambio, dado que las comunicaciones eran más fluidas entre los pueblos de campaña con la capital, que entre aquellos y las ciudades cabeceras de los Departamentos Judiciales; a esto se sumaba la falta de personal preparado para la defensa y representación de los litigantes. A pesar de esto, se mostraba esperanzado en que esas dificultades se resolverían y que recién entonces se podrían juzgar los resultados. ${ }^{60}$ A diferencia de la descentralización espacial que todavía no había producido cambios, a la descentralización ratione materiae, la consideraba altamente ventajosa al permitir a los jueces especializarse en una temática, lo que le daría mayor pericia, la especialización por materias daría jueces no sólo íntegros sino también competentes.

Otra cuestión que consideró digna de tratar fue la del nombramiento de los jueces, y para destacar las virtudes de la opción realizada por la Constitución de 1873 la comparó con la del 1854. En este último caso, el Senado debía proponer una terna al ejecutivo, de la que éste elegía al nuevo magistrado, de esta forma ni uno ni el otro se hacía responsable de la elección, el Senado por ser un cuerpo colegiado y numeroso, el ejecutivo por verse limitado a escoger entre tres candidatos supuestamente aptos. La nueva Constitución mandaba a que el ejecutivo eligiera cuidadosamente al futuro magistrado, que luego recibiría el acuerdo del Senado confirmando individualmente la elección aprobando al menos la honorabilidad del futuro juez. No era una forma perfecta, pero la consideraba la menos riesgosa a la hora de comprometer la elección de los más aptos al calor de la pasión política.

Los jueces debían ser letrados, rentados y elegidos por el ejecutivo, y según la Constitución durarían en el cargo tanto como su buena conducta, pero para el autor este era un tema debatible. El concepto sobre el que se apoyaban los defensores de la amovilidad era evitar que los jueces, movidos por su ambición pusieran en peligro las libertades públicas, según Bellot garantizaba confianza y fuerza moral, la elección periódica estimulaba a los hombres "capaces, íntegros e

\footnotetext{
${ }^{60}$ Malaver, 1875, op. cit., pp.118-119.
} 
independientes". ${ }^{61}$ En cuanto a la inamovilidad, Edmond Seligman sostenía que era una garantía de buena justicia, que aseguraba "la independencia del juez contra la voluntad de los poderosos que desprecian el freno saludable de las leyes", 62 el juez temeroso de perder su cargo cedería a las pasiones populares o a los miembros de los cuerpos electorales. Entre estas dos posturas, Malaver expuso que el texto constitucional optó por la inamovilidad, limitada sólo por la acusación fundada y la edad (de 35 a 70 años), y si bien no emitió opinión, parecía de acuerdo con esta opción al cerrar el tema citando a Bellot sobre el inconveniente de conservar jueces incapaces por su edad.

Sobre las atribuciones de la Suprema Corte se explayó, especialmente en los antecedentes históricos y la interpretación y aplicabilidad de las leyes. Sobre la primera, Malaver afirmó su postura utilizando palabras de Story,

la facultad de interpretar las leyes envuelve necesariamente la función de establecer si ellas son conformes a la Constitución, o no; y si no lo son, declararlas nulas y sin efecto. Como la Constitución es la ley suprema de la tierra, en un conflicto entre ella y las leyes, es el deber del poder judicial seguir aquella únicamente que es de suprema obligación. Esto resulta de la misma teoría de una constitución republicana de gobierno; pues de lo contrario los actos de la Legislatura y del Ejecutivo vendrían a ser en efecto supremos y sin restricciones, no obstante cualquiera de las prohibiciones contenidas en la Constitución; y podrían cometerse usurpaciones del carácter más equívoco, sin remedio ninguno al alcance de los ciudadanos. ${ }^{63}$

El costo de estas usurpaciones sería la destrucción de la libertad. Para fortalecer su opinión recurrió a las palabras de la Corte Suprema de los Estados Unidos y al Federalista, para quienes la Constitución era la ley fundamental y era deber de la justicia hacerla prevalecer por sobre cualquier acto particular procedente del cuerpo legislativo, es decir que "la Constitución debe ser preferida al estatuto; la intención del pueblo a la intención de sus agentes". ${ }^{64}$

Para Malaver era primordial el respeto de la división de poderes, para lo que era decisivo que la Corte, como jurisdicción originaria y exclusiva del más alto tribunal creado por la Constitución, decidiera cuando otro de los poderes públicos salía de la esfera de sus atribuciones propias y cuando

\footnotetext{
${ }^{61}$ Bellot, P. F., Loi sur la Procédure civile du Canton de Géneve, avec lèxposé des motifs, 3 a edición, 1870. Fue coautor en Francia de la ley que obligaba a los jueces a distinguir las cuestiones en las causas, es decir todo punto controvertido de hecho o de derecho cuya resolución influía en la sentencia. Ghirardi Olsen, A., Introducción al razonamiento forense, Universidad Nacional de Córdoba, 2002, p.19.

${ }^{62}$ Seligman, Edmond Quelles sont, au point de vue juridique et au point de vue philosophique, les réformes dont notre procédure civile est susceptible ?, Paris, A. Durand, 1855.

${ }^{63}$ Story, Joseph, Comentario a la Constitución federal de los Estados Unidos, libro 30 "Poder Judicial de los Estados Unidos de América", Boston, 1833; traducción de J.M.Cantilo, p.5. No dimos con la traducción que menciona Malaver, pero en 1860 realizó una Nicolás Calvo y la Biblioteca Central de la Suprema Corte de la provincia de Buenos Aires conserva la de Clodomiro Quiroga de 1891. Story (1789-1845) fue abogado y escritor jurídico norteamericano. Ejerció la profesión, fue profesor y decano de la Universidad de Harvard, legislador y en 1811 entró en la Corte Suprema de la que luego fue presidente hasta su muerte.

${ }^{64}$ Hamilton, Alexander, Madison, Santiago y Jay, John, El Federalista, artículos sobre la constitución de los Estados Unidos escritos en 1788, y corregidos por los mismos autores con un apéndice que contiene los artículos de Confederación y la Constitución de los Estados Unidos, Buenos Aires, Imprenta del Siglo, traducción de José María Cantilo, 1868, LXXVIII, p.630.
} 
un tribunal o juez excedía los límites de su competencia en el orden provincial. ${ }^{65}$ El desarrollo del texto, hace pensar que el autor tenía en su cabeza las palabras de El Federalista:

la gran seguridad contra la concentración gradual de los diversos poderes en un solo departamento, consiste en que tengan los que administran cada uno de estos, los necesarios medios constitucionales y motivos personales, para resistir a las usurpaciones de los otros. Los medios de defensa deben en este, como en todo otro caso, ser proporcionados al peligro del ataque. $^{66}$

El recurso de aplicabilidad de ley obedecía a la necesidad de mantener en la justicia provincial unidad de jurisprudencia, garantía de unidad e igualdad de la ley. En otros países se llamaba recurso de casación, remedio supremo fundado sobre la recta administración de justicia, pues

no es la ley escrita lo único que constituye el derecho: su interpretación, la manera de aplicarlo, la vida que recibe en el foro, es lo que lo completa. El legislador no debía ser casuista: si tuviera el loco empeño de prever todos los casos, de establecer reglas para todas las hipótesis, acometería una obra temeraria, una obra imposible. En el espíritu de generalidad con que tiene que concebir sus preceptos, se ve precisado inevitablemente a confiar su completo desarrollo a la jurisprudencia. Si la jurisprudencia, pues no es uniforme, si la ley es extendida y aplicada de diferente modo en las diversas divisiones del territorio, necesario es decir que, a pesar de la unidad de la ley no habrá unidad en el derecho. ${ }^{67}$

La inspección sería ejercida sobre la conducta de los jueces por el primer Tribunal del Estado, freno de abusos, doctrinas ilegales y prácticas absurdas, inspirada en el Sistema de Casación español, no en el francés, refundiendo los recursos de apelación y de casación, dado que la Corte “conoce y resuelve en grado de apelación". Lo importante de la práctica surgida de esta teoría era adoptar un sistema sencillo que garantizara la igualdad de la ley en toda la provincia y de la jurisprudencia en su aplicación. ${ }^{68}$

La jurisdicción especial y privativa de la justicia comercial había enfrentado a dos sectores, los que estaban a su favor, sostenían que los jueces comerciales debían conocer las operaciones mercantiles para lograr trámites rápidos y económicos, con las formalidades necesarias; ${ }^{69}$ los que estaban en contra aducían que con ese criterio todos los estados que constituían la sociedad civil tendrían derecho a querer juzgar sus conflictos con un tribunal especial, además la uniformidad de la legislación era contraria a tribunales especiales y siendo los jueces víctimas de la parcialidad al

\footnotetext{
${ }^{65}$ Malaver, 1875, op. cit., pp. 136-137.

${ }^{66}$ Madison, 1868, op. cit., LI, p.357.

${ }^{67}$ Gómez de la Serna, Pedro, Motivos de las variaciones principales que ha introducido en los procedimientos la Ley de Enjuiciamiento Civil, Madrid, Imprenta de la Revista de la Legislación, 1857, p. 185. Jurisconsulto y escritor español (1806-1871), considerado uno de los mejores juristas de su época, tuvo una destacada labor legislativa en la codificación española. Fue funcionario de Espartero, liberal progresista, por lo que fue al destierro durante tres años a Londres. En 1869 ocupó la presidencia del Tribunal Supremo de Justicia español.

${ }^{68}$ Malaver, 1875, op. cit., pp. 139; 148. Malaver desarrolló una detallada explicación de por qué el recurso de aplicabilidad se podía asimilar al recurso de casación.

${ }^{69}$ Vicente y Caravantes, José, Tratado histórico, crítico filosófico de los procedimientos judiciales en materia civil, tomo 1, p.186. La obra de este autor español (1820-1880), es considerada uno de los más valiosos frutos de la época procedimentalista de su país, cuyo valor se extendió en Europa y América.
} 
querer beneficiar a su sector dentro de la actividad comercial. ${ }^{70} \mathrm{Al}$ igual que con la Suprema Corte, recurrió a un pormenorizado relato de los orígenes y evolución de la institución, para explicar y justificar que a pesar de terminar con el Consulado y nombrar desde 1862 jueces de comercio letrados, esta competencia seguía siendo una jurisdicción privativa.

Finalmente, refiriéndose al ministerio fiscal, también recurrió a establecer sus orígenes, determinando que estaban ligados a los abogados fiscales del derecho romano, con antecedentes en las Partidas y en la organización judicial de Valencia, que en el siglo XIII tenía abogado fiscal y abogado patrimonial, a los que se sumaron procuradores fiscales que cuidaban de la denuncia de los delitos. Pero el ministerio fiscal, con la organización y las facultades que poseía, era una institución moderna y aunque el texto constitucional no lo había mencionado, Malaver lo consideraba indispensable y lo supuso librado a la acción de la legislatura. ${ }^{71}$

Hemos podido observar que el autor recurrió reiteradamente al concepto de necesario para respaldar sus ideas, y lo hizo no sólo al referirse a la justicia. Tratando la ley de patentes, como diputado provincial, argumentaba que "puede no ser esta ley la mejor, y evidentemente es mala...pero hemos dicho es necesaria, y ante la necesidad, hemos callado...he creído que era mala la ley, pero necesaria: he creído pues cumplir con mi deber". ${ }^{72}$

\section{Conclusión}

Los juristas analizados pertenecían al mismo grupo, una elite cultural compuesta por generaciones diferentes, de activa participación política, con las mismas preocupaciones a las que daban soluciones distintas o similares pero partiendo de diversos fundamentos teóricos. Al escribir, ambos se dirigían a un auditorio restringido, que tenía acceso a bibliografía extranjera, fundamento de sus ideas, generalmente en el idioma original. Encontramos aquí el primer código cultural: el acceso a obras extranjeras, de reciente publicación, y el manejo de las lenguas en que fueron escritas.

Vicente Fidel López traía consigo la experiencia de haber pertenecido a una generación que había hecho propias en su momento, nuevas corrientes de pensamiento como el romanticismo, el historicismo jurídico y el eclecticismo filosófico. Algo de las tres quedaba vivo y latente en él cuando se ocupó de diseñar la administración de justicia para la provincia de Buenos Aires, pero especialmente el historicismo, al recordar que los autores europeos y norteamericanos debían ser leídos y meditados a la luz de la propia historia y de la experiencia de cada sociedad.

\footnotetext{
${ }^{70}$ Meyer, Jonas Daniel Esprit, origine et progrès des institutions judiciaires des principaux pays de l'Europe, Paris, A.A. Renouard, 1818-1823; Paris, G. Dufour et Z. d'Ocagne, 1823, 5 vol, t.5, c.27, p.483. Abogado holandés.

${ }^{71}$ Tejedor, Carlos, Curso de Derecho Criminal, Primera parte: leyes de fondo, Segunda parte: leyes de forma, tomo 2 , p.64; Colmenares, Manual del promotor fiscal, capítulo1 ${ }^{\circ}$.

72 Sesión del 7 de junio, Diputados, 1867, p.48.
} 
Antonio Malaver perteneció a la generación que respondía al derecho científico, que basaba su tarea en el modelo; la obra legislativa de otros países y la doctrina de autores extranjeros inspiraba el diseño de las nuevas instituciones. El jurista José María Moreno fue el prototipo de esta corriente, colega y amigo de Malaver, con quien dirigía y editaba la Revista de Legislación y Jurisprudencia.

Pero lo interesante es que en sus obras, López recurrió al modelo y Malaver se remontó a los orígenes de las instituciones y a la experiencia que las mismas tuvieron en el Río de la Plata, para poder sugerir a los legisladores el marco legal necesario para poner en funcionamiento las reformas constitucionales. A esto se sumó la coincidencia en temas fundamentales para la organización de la justicia, tales como la inamovilidad de los magistrados. Para el primero, la construcción de un cuerpo inamovible, con derecho a renovarse a sí mismo según sus capacidades científicas y morales, que no dependiera de la opinión pública, aseguraba un pueblo libre y feliz y superaba la conflictiva relación entre igualdad y jerarquía. Para el segundo, un cuerpo judicial de jueces íntegros y capaces, que no fuera despreciado por el foro, pocos hombres distinguidos, mejor pagos y más eficientes, eran garantía de una justicia más rápida y económica. Encontramos aquí otro de los códigos culturales, tener la mirada puesta en los países que habían alcanzado a sus ojos el progreso, pero sin llegar a una ciega imitación, adaptando el modelo a la realidad con la que contaban, aceptando que el cuerpo social al que se le debía administrar justicia no era aún el pueblo libre y feliz al que aspiraba López.

Coincidían en el sistema de jurados, recurso democrático recomendado por Tocqueville para mantener la libertad, pero que debía estar acompañado de un cuerpo de jueces superiores, cuya calidad iría disminuyendo en relación a su número. De la calidad de esos hombres dependía que el sistema de jurados formara el juicio del pueblo y en él la conciencia de los requerimientos de la justicia. Era un recurso para descubrir los medios por los cuales moderar e instruir los gustos y las pasiones de los muchos. La preparación de los juristas les daba amor al orden, a las formas legales y políticas y a la conexión de las ideas, lo que los convertía en una aristocracia por sus pensamientos y preferencias (la aristocracia moral de López o el cuerpo judicial de alta moralidad y vasta instrucción de Malaver). Su función sería contener los impulsos de la mayoría en una sociedad donde casi toda cuestión política se transformaría en judicial. La ruptura con el nivel democrático era así parcial, porque los juristas por su cuna e intereses mantenían el nexo fundamental con el pueblo, por lo tanto no constituían una clase distinta. ${ }^{73} \mathrm{He}$ aquí otro código de grupo, los magistrados debían constituir una especie de reserva moral por su formación, pero sin dejar de ser parte del pueblo.

\footnotetext{
${ }^{73}$ Zetterbaum, 1993, op. cit., pp.728-729.
} 
Malaver era más consciente de la realidad económica y social, pudimos observarlo cuando hablaba de los efectos de la descentralización territorial y de los resultados de los nombramientos realizados por el jurado con acuerdo del Senado, serían al menos jueces honorables, pero no estaba garantizada la idoneidad. Su preocupación por la división de poderes se extendía a los riesgos de no dejar especificadas correctamente las atribuciones de la Suprema Corte, especialmente la de interpretación de la ley, límite contra el ejecutivo y el legislativo, y la de aplicabilidad de la ley, que garantizara la igualdad de la ley y de la aplicación de la jurisprudencia. El autor establecía los límites entre poderes y dentro del mismo poder judicial, mientras que López convertía a la Sala Jurídica en un consejo consultivo de derecho con atribuciones poco claras, a lo que se sumaba su rechazo a la formación de un Ministerio Público y a tribunales de comercio letrados.

Pero las diferencias entre López -que aspiraba a la felicidad- y Malaver -que se guiaba por la necesidad-, no les quitaban el privilegio de ser juristas que representaban a una elite con acceso a la última literatura jurídica, con una educación que les permitía leerla y comprenderla, convencidos que el pueblo debía participar de la justicia, siempre y cuando esta estuviera asegurada por un cuerpo de magistrados letrados, parte de su mismo grupo.

Los códigos culturales de López y Malaver fueron los de todo un grupo, y permiten acceder al contenido ideológico y a la comprensión de los debates que se irán suscitando en la formación de la estructura judicial provincial. El conocimiento de los códigos culturales de un grupo, cobrarían mayor significación en el contexto del proceso de constitución y consolidación del poder judicial, responsable de la administración de justicia, como integrante del Estado provincial, legitimador de su accionar político y mediador con la sociedad civil. 


\section{Capítulo IV}

\section{La justicia de paz lega (1852-1874)}

\section{Introducción}

Con sus raíces medievales en la Santa Hermandad de Burgos, creada en 1475 para vigilar los caminos despoblados y proteger a mercaderes y viandantes de los delincuentes -teniendo además funciones jurisdiccionales- y su origen en la ley provincial de 1821, los jueces de paz reunían en 1852 numerosas y diversas funciones administrativas y judiciales. ${ }^{1}$ A esto se sumaba la estrecha relación entre el avance de la frontera y la conformación del mapa judicial con la decisión del nombramiento de un juez de paz, pues seguía estando ligada, como la de los alcaldes de hermandad, a la configuración administrativa y política del territorio de un partido, aún sin tener el juez un pueblo en el cual residir y fijar el juzgado en su propia estancia.

Es por esto que estudiar los espacios de frontera, no sólo en su sentido físico sino como "lugar" donde el espacio físico y medio-ambiental se relacionaba con los diferentes actores sociales en una mutua interacción, aporta una nueva perspectiva al conocimiento de la construcción de la provincia de Buenos Aires. ${ }^{2}$ Después de 1852 se fortaleció la continua presión sobre la expansión territorial necesaria para la producción ganadera y la búsqueda del poder provincial de afianzarse en el control y la definición del territorio. El Registro Gráfico de 1864 manifiesta la situación formativa, aún precaria, de ese proceso que en el registro de 1890 parece cristalizar en

\footnotetext{
${ }^{1}$ Garavaglia, Juan Carlos, San Antonio de Areco, 1680-1880. Un pueblo de la campaña, del Antiguo Régimen a la "modernidad" argentina, Rosario, Prohistoria Ediciones, 2012, pp. 171-182.

${ }^{2}$ Nos basamos en la concepción de frontera de Carlos Mayo, que a partir de la definición de Frederick J. Turner concibió la frontera como experiencia que configuraba un mundo de vivencias y prácticas, que jugaba un papel ambiguo separando y ligando a la vez. No era una línea, era un área de tierras libres en continuo receso (abiertas a la apropiación de la sociedad hispano criolla), región de encuentro cultural entre indios y pueblos de origen europeo, límite extremo del asentamiento, sin excluir al territorio indio próximo. En su investigación le dio una definición espacial más amplia y laxa, aproximándose a las regiones que se convirtieron sucesivamente en los confines del poblamiento criollo y su retaguardia. Centrándose en los partidos de frontera y los próximos a esta, estudió con su equipo la casa, la dieta, la pulpería y la escuela de sus pobladores. En la introducción a la recopilación realizó una síntesis del proceso de constitución y ocupación del espacio fronterizo. Agotado el ganado cimarrón en la campaña en el siglo XVIII, los indios avanzaron sobre el ganado manso de las estancias fronterizas, iniciando grandes malones La frontera fue militarizada entonces, instalando fuertes y creando el cuerpo de blandengues. A partir de 1779 el virrey Vértiz fijó y reforzó la línea fronteriza en un marco de 155 leguas entre Chascomús y Melincué llegando casi al borde del río Salado. La paz con los indios consolidó la ocupación en las tierras de la depresión del Salado y estancieros y labradores avanzaron sobre tierras indígenas y efectuaron las denuncias. En 1817 se fundó Dolores iniciando una expansión durante la década del veinte de la frontera ganadera, fijándose la línea de fortines entre los fuertes Federación (al norte), Cruz de Guerra (cincuenta kilómetros al oeste de la actual ciudad de 25 de Mayo), Blanca Grande (en el partido de Olavarría) y Bahía Blanca. Los malones volvieron pero el poblamiento continuó. Rosas consolidó la frontera incorporando $182.655 \mathrm{Km}$ cuadrados de tierras. A mediados del siglo XIX el nuevo sur contaba con la cuarta parte de la población de la campaña bonaerense. Entre 1855 y 1857 recrudecieron los malones en una frontera mal defendida, que retrocedió hasta el Salado. Sarmiento intentó consolidar y expandir la línea de fortines pero el gran avance lo inspiró Adolfo Alsina que en 1877 expandió la frontera casi hasta los límites actuales. Mayo, Carlos A. (editor), Vivir la frontera. La casa, la dieta, la pulpería, la escuela (1770-1870), Buenos Aires, Biblos, 2000, Introducción, pp. 11-14.
} 
configuraciones territoriales que tendrán un despliegue posterior pero sin modificaciones sustanciales. $^{3}$

La expansión territorial debía realizarse avanzando sobre el "desierto", que Zusman y Minvielle han definido como una metáfora de interacción, que permitió ejercer cierto tipo de dominación, aún antes de emprender la ocupación. Se llamaba "desierto" -la tierra del indígena- a un espacio ajeno a la "civilización" que presentaba un estímulo para su conquista y dominación, secundada por una organización jurídico-administrativa que en la provincia de Buenos Aires estaría centrada en la figura del juez de paz y la creación de nuevos partidos. ${ }^{4}$

Esta expansión significaba el movimiento de la frontera, en un ciclo vital de ocupación, que comenzaría a cerrarse en la medida que la cantidad de tierra pública disponible fuera menor, encareciéndose el valor del recurso, cuya propiedad se convertía cada vez más en un factor de prosperidad y avance, en dimensión real y simbólica. ${ }^{5}$ Una revisión de la bibliografía más reciente dedicada a la campaña bonaerense ofrece una nueva visión entre mediados del siglo XVIII y XIX, según la cual, la frontera no era el desierto que describían los escritos de la generación del 37, sino que eran tierras ocupadas por una sociedad de familias enteras que tejían un denso entramado social. $^{6}$

El río Salado fue por muchos años frontera natural, económica y militar en la provincia, limitada en su avance por las condiciones ecológicas, la guerra con el indio y la precariedad del transporte. El dominio efectivo del territorio por parte de la sociedad hispano criolla se llevó a cabo creando guardias y fortines en torno a los cuales se instalaban pueblos de campaña, realizándose la apropiación privada de las tierras ganadas al indígena. El Estado adjudicó esas tierras a lo largo de los siglos XVIII y XIX por moderada composición, donaciones, enfiteusis, premios, arrendamientos y ventas. Pero también fue fundamental el rol de los ejidos para la ocupación territorial, la seguridad de los pobladores y la actividad agrícola que proveía el mercado interno de los pueblos. ${ }^{7}$

\footnotetext{
${ }^{3}$ Cacopardo, Fernando y Da Orden, María Liliana, "Territorio, sociedad y Estado en la provincia de Buenos Aires: una aproximación a partir de los Registros Gráficos, 1830-1890” en Registros, Revista anual de Investigación del Centro de Estudios Históricos Arquitectónico-Urbanos, "La transformación física del territorio en la constitución de la Argentina moderna", Facultad de Arquitectura, Urbanismo y Diseño, Universidad Nacional de La Plata, Año5, núm. 5, abril de 2008. Esta investigación realizó un detallado estudio de los Registros Gráficos de la provincia de 1830, 1831, 1864 y 1890 analizando el papel de los encargados de levantarlos y el rol de las reparticiones técnico-administrativas como instancias intermedias entre los niveles más elevados de poder y los distintos actores sociales, apuntando al proceso de apropiación territorial y lo que éste supuso para la consolidación del Estado.

${ }^{4}$ Zusman, Perla, y Minvielle Sandra, "Sociedades Geográficas y delimitación del territorio en la construcción del Estado-Nación argentino", Instituto de Geografía, Universidad de Buenos Aires. Documento descargado de http: //www. educ.ar. Consultado el 14 de junio de 2006.

${ }^{5}$ Mosse, op. cit., 2006.

${ }^{6}$ Banzato, Guillermo, y Valencia, Marta, "Los jueces de paz y la tierra en la frontera bonaerense, 1820-1885", en Anuario IEHS, Instituto de Estudios Histórico-Sociales, Tandil, Universidad Nacional del Centro de la Provincia de Buenos Aires, núm. 20, 2005, pp. 211-237.

${ }^{7}$ Barcos, María Fernanda, "Los ejidos de los pueblos de campaña: ocupación y acceso a la propiedad legal en Monte, 1829-1865", en Mundo Agrario, Revista de estudios rurales, núm. 14, $1^{\circ}$ sem., 2007. En el capítulo IX, en que realizamos un estudio de caso relacionado con la propiedad de la tierra detallamos la bibliografía sobre el tema.
} 
Entre la ciudad y el campo se fue estructurando el mundo de las quintas y las chacras, desafiando el límite administrativo entre lo urbano y lo rural, y haciendo difusa la delimitación jurisdiccional. ${ }^{8}$ Ese espacio fue definido por Garavaglia como una serie de anillos sucesivos que partían de la ciudad y concluían a campo abierto. El primer anillo incluía las quintas y chacras del ejido de la ciudad de Buenos Aires, el segundo eran las chacras de San Isidro, el tercero las tierras de Matanzas y Conchas, terminando con las chacras de campaña. ${ }^{9}$

Desde el punto de vista administrativo e incluso el judicial, el territorio provincial se dividía en la contradicción ciudad-campaña y las medidas que se tomaban para encarar reformas se fundaban en ella. El proceso de fundación de pueblos en el siglo XIX, sus planos, conflictos y crecimiento, no fue independientes de los aspectos jurisdiccionales, legales, disciplinares y técnicos en que se ocupó el espacio, donde el Estado no tenía control efectivo, aspectos al que se articula la cuestión frontera como "construcción, representación y experiencia práctica". ${ }^{10}$

Al igual que actualmente, la provincia se dividía en partidos, que como los definió el ministro de gobierno Nicolás Avellaneda en 1867, eran circunscripciones territoriales, creadas por declaraciones con fuerza de ley, en que se dividía la administración de la campaña, regidos por una municipalidad y por un juez. Pero para que un municipio existiera no bastaba una creación legislativa y lograba formarse donde se encontraban en realidad los elementos que lo constituían, donde había una comunidad de habitantes. ${ }^{11}$

A fines del período colonial había veinte partidos. Luego siguió una progresiva subdivisión avanzando según una lógica en una relativa relación con los movimientos de la frontera. ${ }^{12}$ En el año 1860 los partidos eran cuarenta y seis, llegando la provincia a estar dividida en 1881 en setenta y ocho partidos. El censo realizado en la provincia de Buenos Aires en $1881^{13}$ ofrece los siguientes datos comparativos:

\footnotetext{
${ }^{8}$ Fradkin, Raúl O., "Las quintas y el arrendamiento en Buenos Aires (siglos XVIII y XIX)", en Canedo, Mariana y Mateo, José -compiladores- Tierra, población y elaciones sociales en la campaña bonaerense (siglo XVIII y XIX), Grupo de Investigación en Historia Rural Rioplatense, Universidad Nacional de Mar del Plata, 1999, pp. 7-39.

${ }^{9}$ Garavaglia, Juan Carlos, "Las chacras y quintas de Buenos Aíres, ejido y campaña, 1750-1815”, en Mandrini, Raúl y Reguera, Andrea, Huellas en la tierra, Tandil, IEHS, pp. 121-146. El autor aclara que en las fuentes bajo la denominación "Matanza" quedaban incluidas Flores, Morón y Lobos.

${ }^{10}$ Cacopardo, Fernando, "El estado en la definición territorial de la Argentina del siglo XIX: construcciones legales, cuadrícula territorial y urbanística en la frontera de la provincia de Buenos Aires al sur del río Salado", en Revista Perspectivas Urbanas, nº 8, año 2007. En línea: <http://hdl.handle.net/2099/2763>, consultado el 31 de octubre de 2012.

${ }^{11}$ Memorias del Departamento de Gobierno de la Provincia de Buenos Aires 1866-1867, Buenos Aires, Imprenta del Siglo, 1867, p. LXII. (en adelante Memoria 1866-1867)

${ }_{12}$ Cacopardo, 2007, op. cit.

${ }^{13}$ Censo General de la provincia de Buenos Aires. Demográfico, agrícola, industrial, comercial. Verificado el 9 de octubre de 1881, bajo la administración del doctor don Dardo Rocha, Buenos aires, Imprenta de El Diario, 1883.
} 


\begin{tabular}{|l|c|c|c|c|c|c|c|c|}
\hline Año & Pueblos & Partidos & Parroquias & Escuelas & $\begin{array}{l}\text { Diarios y } \\
\text { periódicos }\end{array}$ & $\begin{array}{l}\text { Km de vías } \\
\text { férreas }\end{array}$ & $\begin{array}{l}\text { Km de hilos } \\
\text { telegráficos }\end{array}$ & $\begin{array}{l}\text { Valor de la } \\
\text { teirra } \\
\text { /legua2 }\end{array}$ \\
\hline 1860 & 46 & 50 & 40 & 331 & 42 & 40 & 40 & $\begin{array}{c}8000 \mathrm{a} \\
15000 \$\end{array}$ \\
\hline 1881 & 87 & 78 & 80 & 600 & 1000 & 1000 & 4000 & $\begin{array}{c}30000 \mathrm{a} \\
80000 \$\end{array}$ \\
\hline
\end{tabular}

Existe una tendencia plurisecular a la emergencia de la típica gran ciudad principal, concentradora de población y de funciones, de recursos y de poder con un carácter auto sostenido y auto acumulativo de la concentración urbana y del desequilibrio entre las regiones. ${ }^{14}$ Los liberales pensadores del sistema judicial que estamos estudiando, concebían a esa ciudad de Buenos Aires (aún lejana de ser "la gran ciudad" pero concentradora de poder y de funciones) como eje civilizador de la nación y motor que distanciaría la república progresista del retrazo colonial. ${ }^{15} \mathrm{La}$ "eficacia instrumental" urbana -definida por José Luis Romero- por la que concentraban las ciudades el poder de las instituciones ${ }^{16}$, se había manifestado en el fracaso del funcionamiento de la justicia letrada en la campaña y llegó en los años de nuestra investigación a manifestarse entre la nación y la provincia en la lucha por un espacio que las autoridades compartieron casi por veinte años y cuya ocupación debieron definir por la violencia.

En la provincia de Buenos Aires, la ciudad capital era un Municipio, dividido en juzgados de paz y parroquias, cuyos territorios fueron unificados en 1869 para lograr la conformidad de límites necesaria para determinar ambas jurisdicciones relativas a la administración de justicia y de los sacramentos que suministraba la Iglesia Católica. Eran entonces trece juzgados de paz y parroquias: Catedral Norte, Catedral Sud, San Telmo, Santa Lucía, San Cristóbal, de la Concepción, Monserrat, San Miguel, San Nicolás, del Socorro, del Pilar, de la Piedad, de Balvanera. ${ }^{17}$ El resto de la provincia era considerado como la "Campaña".

En este territorio urbano y rural así organizado, actuaban los jueces de paz a los que dedicamos este capítulo. Desde su instalación en 1822 hasta el fin del rosismo, han sido sumamente estudiados, no siendo tan así a partir del gobierno de Pastor Obligado, elegido en 1853. Uno de los historiadores que más ha escrito sobre la justicia de paz, estudiada y analizada desde diversos aspectos, es Juan Carlos Garavaglia que en su libro Construir el Estado e inventar la Nación,

\footnotetext{
${ }^{14}$ Kaplan, Marcos, "Prólogo", en Hardoy, Jorge, Las ciudades en América Latina, Buenos Aires, Paidós, 1972.

${ }^{15}$ La construcción física de esa ciudad y la construcción ideológica del Estado argentino se relacionaban en cuatro dimensiones: las bases urbanas de la acción popular, los mecanismos de control social, las bases materiales de las formas urbanas y las conexiones entre creencias políticas y creencias estéticas. Szuchman, Mark, "Construyendo la ciudad, construyendo el Estado: transición política y arquitectónica en la Argentina urbana, 1810-1860", en Naciones, gentes y territorios: ensayos de historia e historiografía comparada de América Latina y el Caribe, Medellín, Universidad de Antioquia, 2000.

${ }^{16}$ Romero, José Luis, "La ciudad latinoamericana y los movimientos políticos", en Hardoy, Jorge y Tobar, Carlos, (editores) La urbanización en América Latina, Buenos Aires, Editorial del Instituto Torcuato Di Tella, 1969, pp. 297310 .

${ }^{17}$ Ley del 28 de junio de 1869. ROPBA, 1869, pp. 301-311. La ley aprobaba un decreto elevado por el gobierno el 7 de octubre de 1868 .
} 
dedicó tres estudios al Estado de Buenos Aires en expansión, hasta que en 1861 la batalla de Pavón terminó con Buenos Aires como Estado autónomo. En estos artículos el autor se refiere a los juzgados de paz y a la función que ellos cumplieron en la campaña para el reclutamiento de campesinos y la organización de elecciones. La obra del autor dedicada a San Antonio de Areco entre 1680-1880 avanzó en el conocimiento de la justicia local. ${ }^{18}$

Desde otra perspectiva, el juez camarista Gualberto Lucas Sosa dedicó a los antecedentes históricos de la justicia de paz tres capítulos de su libro sobre las instituciones de la moderna justicia de paz letrada, escrito con motivo de la puesta en funcionamiento de la ley sobre juzgados de paz letrados de 1987. En nuestro estudio seguiremos los intentos por cambiar esta justicia de paz. Por ello, es de destacar que desde la perspectiva de un magistrado que escribe en el desempeño de sus funciones terminando el siglo XX, Sosa afirme que "la reforma implica desde el punto de vista de la descentralización y ampliación de los órganos judiciales del interior, un esfuerzo del legislador por facilitar a los consumidores jurídicos el ejercicio del derecho a la jurisdicción”. ${ }^{19}$ El concepto de descentralización al que se hace referencia estuvo permanentemente presente en las tres décadas de nuestro estudio, y su continuidad demuestra la resistencia de esta institución lega a entrar en el ámbito letrado, más allá de los límites temporales de este estudio. ${ }^{20}$

Leandro Di Gresia, en el contexto de una investigación más amplia dedicada a la justicia bonaerense, ha establecido la importancia de reconstruir el perfil de los sujetos que ejercieron el cargo de jueces de paz, para entender las lógicas que guiaron su designación como también para observar la dinámica y funcionamiento de la institución. Establecidas esas lógicas de designación, ha podido dilucidarse que fueron mudando en función al contexto y la situación de la ocupación del territorio. $^{21}$

\footnotetext{
${ }^{18}$ Garavaglia, Juan Carlos, "Ejercito y milicia: los campesinos bonaerenses y el peso de las exigencias militares (18101860); "De Caseros a la Guerra del paraguay: el disciplinamiento de la población campesina en el Buenos Aires posrosista (1852-1865)"; El despliegue del Estado en Buenos Aires: de Rosas a Mitre" en Garavaglia, 2007, op. cit; 2009, op. cit. La investigación fundacional sobre la justicia de paz en estos años fue la tesis doctoral de Benito Díaz. Diáz, 1959, op. cit.

${ }^{19}$ Sosa, Gualberto Lucas, Instituciones de la moderna justicia de paz letrada, La Plata, Librería Editora Platense, 1993.

${ }^{20}$ Entre los intentos más importantes por hacer letrada la justicia de paz se encuentran los proyectos presentados por los diputados provinciales Pedro A. Verde Tello y Mario Sibretti, en 1935; Julio A. Amoedo en 1939; Pedro González Bergez en 1943; Calabrese y García en 1946. Buscando la descentralización de la justicia letrada, Rafael R. Marino, Subsecretario de Justicia del gobernador Oscar Alende, propuso organizar la "Justicia de instancia local". Augusto M. Morello propuso en 1966, la instalación gradual de la Justicia de Paz Letrada, con una competencia cuantitativa limitada, jueces profesionales y Cámaras de Paz Letradas. En la Primera y Segunda Conferencia sobre la Reforma Judicial, realizadas en 1977 y 1978, quedó de manifiesto la necesidad de crear juzgados de paz letrados. En el año 1978 el gobierno de facto dictó el decreto ley 9229, que abrogaba la ley 1853 y organizaba la justicia de paz letrada estableciendo el objeto sustancial de revitalizarla y adecuar su jerarquía y funcionamiento a las necesidades de una mejor administración de justicia.

${ }^{21}$ Di Gresia, Leandro, “Jueces rústicos: saberes legos. Esbozo para un estudio de la formación judicial de los Jueces de Paz en el sudbonaerense (segunda mitad del siglo XIX), en XI Jornadas Interescuelas/ Departamentos de Historia, Tucumán, 19 a 22 de septiembre de 2007.; "Jueces de paz, masones y conservadores en la campaña bonaerense. Una aproximación a las redes vinculares en el sur de la provincia de Buenos Aires (Tres Arroyos, 1865-1910)", en Mundo Agrario, vol. 11, núm. 21, segundo semestre de 2010, UNLP.
} 
El estudio de esta justicia “capilar" permite contrastar las ideas y proyectos relacionados con la justicia bonaerense dinámica y heterogénea que, aun con toda su variedad, aporta elementos comunes que ayudan a ir definiendo el perfil de la organización judicial en estudio. De esta forma las continuidades y los cambios, lejos de presentarse como contradicciones se observan en el movimiento y la maduración de una institución. ${ }^{22}$

Con el objetivo de conocer y analizar la justicia de paz como organismo administrativo y judicial y su relación con el Gobierno y los otros órganos judiciales hemos dividido el capítulo en tres partes. En la primera determinaremos la concentración de funciones administrativas, policiales y judiciales en el juez de paz, que se prolongó más allá de la sanción de la Constitución provincial, y la ampliación de competencia de los jueces de paz en los distintos aspectos de la organización local. En la segunda nos introduciremos en un juzgado a través de sus notas, como estudio de caso para determinar su movimiento y sus relaciones administrativas y judiciales. Finalmente, describiremos la preocupación por la descentralización que manifestaban los hombres de Estado y que apuntaba, fundamentalmente, a lograr que el juez de paz se convirtiera en la base del sistema judicial provincial, terminando con su poder omnímodo.

\section{$\underline{\text { I. La concentración de funciones y la ampliación de competencia de los jueces de paz }}$}

\section{a. Las funciones administrativas y policiales}

En la provincia de Buenos Aires la ley promovida por Rivadavia en 1821 terminaba con los Cabildos, creaba jueces de primera instancia letrados, rentados e inamovibles y daba origen a la justicia de paz. En la campaña, a más de sus atribuciones judiciales, reunía las de los suprimidos alcaldes de hermandad que incluía funciones administrativas y de policía. ${ }^{23}$ En cuanto a la organización municipal, la ley la dejaba pendiente hasta que la representación lo creyera oportuno,

\footnotetext{
${ }^{22}$ Para la provincia de Córdoba véase Agüero, Alejandro, “Tradición jurídica y derecho local en época constitucional. El "Reglamento para la administración de justicia y policía en la campaña" de Córdoba", 1856, Revista de Historia del Derecho, Sección Investigaciones núm 41, Instituto de Investigaciones de Historia del Derecho, Buenos Aires, enerojunio 2011, pp. 1-43.

${ }^{23}$ ROPBA, 1821, pp. 124-125. La ley organizaba también la alta y baja policía, la inspección de mercados y abastos en toda la provincia, que quedaban a cargo de un jefe de policía, con seis comisarios para la capital y ocho para la campaña. En febrero de 1825 se restablecieron los cargos de comisarios de Policía de Campaña que habían sido suspendidos en noviembre del año anterior, asumiendo sus funciones los jueces de paz. Lo mismo sucedió con un decreto del 25 de enero de 1830 que restablecía los comisarios de campaña, eliminados del presupuesto. Pero en 1831, el juez de paz asumió las funciones policiales y el 17 de febrero el Gobierno acordó que los jueces de paz cobraran el salario de los comisarios. Esta situación se mantuvo hasta la creación de la Policía de la Provincia en 1880, pero con la paulatina creación de comisarías en puntos de frontera. Romay, Francisco, "Reseña histórica de la policía rural bonaerense", en Primer Congreso de Historia de los pueblos, Archivo Histórico de la provincia de Buenos Aires, 1950, pp. 108-138; Fradkin, Raúl, "Justicia, policía y sociedad rural en Buenos Aires, 1780-1830”, en Bonaudo, Marta, Reguera Andrea y Zeberio, Blanca, (coordinadoras) Las escalas de la historia comparada, tomo I: "Dinámicas sociales, poderes políticos y sistemas jurídicos”, Buenos Aires, Miño y Dávila, 2008, Las escalas de la historia comparada, pp. 247-284.
} 
por lo que el nombramiento del juez de paz en la campaña siguió determinando la formación de un partido, como lo hiciera el del alcalde de hermandad antes de $1821 .^{24}$

Los jueces de paz eran nombrados por el Gobierno provincial, de ternas que el jefe de policía elevaba, por informes de sus subalternos. El Tribunal Superior informaba y los salientes recibían juramento de los entrantes. Cuando las funciones de comisario fueron otorgadas a los jueces de paz, éstos quedaron a cargo de las ternas. En la ciudad se ordenó en 1847 al jefe de policía que elevara las ternas para la elección de los jueces. ${ }^{25}$

Instaladas las municipalidades en 1856, debían proponer una terna para que el juez de paz de su partido fuera nombrado por el Gobierno, que pocos años después no debía ya sujetarse a estas ternas. ${ }^{26}$ El proyecto fue presentado por el diputado Francisco Elizalde buscando "alejar de las elecciones municipales de campaña toda injerencia en la política, porque entiendo que las instituciones municipales, una vez que se mezclan con la política, se desvirtúan completamente”. El ministro de gobierno Bartolomé Mitre, presente en los debates, dio la clave del conflicto que se generaría años después, afirmando que o se elegían los jueces de paz popularmente o los elegía el Gobierno, pues cuando se trataba del mejor servicio público no podía haber idea política ninguna. ${ }^{27}$

Después de Caseros la concentración de funciones administrativas a nivel local se mantuvo, dado que la Constitución de 1854 que estableció el régimen municipal en todo el Estado, dejaba la elección, atribuciones y deberes a una ley específica. ${ }^{28}$ Esa ley, sancionada el 16 de octubre de 1854, determinaba que en la ciudad, el presidente nato de la Municipalidad -único conducto de comunicación con las autoridades, con otros jueces de paz y con los jefes militares- sería el ministro de gobierno y en los partidos de la campaña sería el juez de paz. Junto con cuatro vecinos propietarios, quedaba encargado del régimen económico y administrativo de su distrito. ${ }^{29} \mathrm{El}$

\footnotetext{
${ }^{24}$ Levene, Ricardo, Historia de la provincia de Buenos Aires y formación de sus pueblos, vol. I, La Plata, Talleres de impresiones oficiales, 1940, pp. 115-117. Los alcaldes de hermandad eran vecinos nombrados por el Cabildo, desde 1805 de una terna presentada por el alcalde que finalizaba sus funciones que duraban un año. Tenían jurisdicción sobre delitos menores y disputas civiles de poco monto y actuaban como sumariantes en casos graves. Nacieron con la doble vocación civil y criminal, pero fuertemente ligados a ésta. La apelación de las decisiones de los alcaldes de Hermandad quedaban a cargo de los jueces ordinarios. Garavaglia, op. cit., 2009.

${ }^{25}$ Para un estudio detallado de la justicia de paz en la campaña hasta 1852 véase Garavaglia, Juan Carlos, "La justicia rural en Buenos Aires durante la primera mitad del siglo XIX (estructuras, funciones y poderes locales)", en Poder, conflicto y relaciones sociales, Homo Sapiens, Rosario, 1999, pp. 89-121.

${ }^{26}$ La ley fue promulgada el 22 de septiembre de 1858 -también organizaba el cuerpo de serenos y el padrón de extranjeros- y en su último artículo establecía "Los jueces de paz serán nombrados por el Poder Ejecutivo, sin sujetarse a las ternas de la Municipalidad, quedando en esta parte derogado el artículo 61 de la indicada ley de octubre 11 de 1854". ROGBA, 1858, p. 85.

${ }^{27}$ Sesión del 4 de agosto de 1858, Diputados, 1858, pp. 366-393.

${ }^{28}$ ROGBA, 1854, pp.45-46.

${ }^{29}$ ROGBA, 1854, pp.107-117. La Municipalidad de Buenos Aires estaba formada por un consejo de 21 personas, elegidos por voto popular masculino, y su presidente, el ministro de gobierno. Los cambios respondían a la efervescencia municipalista que se había desatado en Argentina después de Caseros, en consonancia con otros países de la región. Pero no sólo la Legislatura buscaba convertir en derecho positivo el ideal positivista, también desde la prensa los intelectuales apoyaban la aspiración de establecer municipalidades. Este movimiento de organización municipal tuvo la influencia del libro de Alexis de Tocqueville, La democracia en América, y el papel de Esteban Echeverría como receptor de sus ideas en esta materia. Para Tocqueville, el municipio era el instrumento adecuado para combatir la
} 
municipio de la capital fue modificado en 1866 denominándose Comisión municipal y al año siguiente Consejo municipal, con un presidente por él elegido.

A pesar de todos los cambios que se anunciaban después de la caída de Rosas, el juez de paz siguió concentrando funciones militares, electorales, de escribano y se desempeñaba como agente del ejecutivo, por encargos del Gobierno -a través de sus ministros- y en su carácter de comisario, recibiendo órdenes del jefe de policía. ${ }^{30}$ En los partidos de frontera el juez de paz se transformó en comandante de milicias, aún después de 1852 cuando tomó el nombre de Guardia Nacional, hasta que un decreto, firmado en 1866 por el gobernador Valentín Alsina, dispuso que los jueces de paz no fuesen comandantes de campaña, por ser contrario a una buena administración.

La separación de la provincia del resto de la confederación terminó y la vida institucional comenzó a organizarse con un renacimiento de la vida cívica. ${ }^{31}$ Pero vigente la ley de elecciones de 1821, el decreto del 19 de marzo de 1852 ponía en manos de los jueces de paz el "orden y la libertad en el ejercicio del derecho de elección" y a partir de la década del sesenta fue una preocupación constante de algunos hombres de gobierno quitarles esa atribución, ya que violaba el supuesto básico de la "apoliticidad" del modelo municipal dominante. ${ }^{32}$

En cuanto a la función del juez de paz como escribano, los miembros del Superior Tribunal reunidos en acuerdo extraordinario, expresaron que en un partido donde residiese escribano con registro, no era indistinto que éste o el juez de paz otorgase instrumento público. Los jueces de paz sólo podían "reputarse autorizados", como un "medio supletorio en la falta de protocolo" y les mandaban que cesaran esa práctica para lo cual se les transcribía el texto del acuerdo. ${ }^{33}$ Una discusión entre el fiscal de gobierno y el Superior Tribunal, dejaba de manifiesto lo conflictivo de la cuestión, incluso en la postura entre los funcionarios. El juez de paz de Chascomús había realizado

centralización administrativa, objetivo perseguido al convertir al juez de paz en un funcionario exclusivamente judicial. Esto va directamente unido a la necesaria organización de la judicatura, para mantener la república democrática a través de la distribución de los poderes públicos en el tejido social. Echeverría definió a la comuna como pequeña patria y la escuela donde el pueblo aprendiera a conocer sus intereses y sus derechos, adquiriera costumbres cívicas y sociales, se educara paulatinamente para el gobierno de sí mismo o la democracia, bajo el ojo vigilante de los patriotas ilustrados y el espíritu de asociación. Abásolo, Ezequiel, "Elementos toquevilleanos en la formulación de proyectos políticos concretos: la génesis del municipalismo en la Argentina decimonónica" en Investigaciones y Ensayos, núm. 53, Academia Nacional de la Historia, Buenos Aires, 2003, pp. 91-113.

${ }^{30}$ Sobre la policía y su relación en el período previo: Rico, Alejandra, "Policía, soldados y vecinos. Las funciones policiales entre las reformas rivadavianas y la caída del régimen rosista". Tesis de maestría. Universidad Nacional de Luján.

${ }^{31}$ Sábato, op. cit, 1998.

${ }^{32}$ Ternavasio, Marcela, Municipio y política, un vínculo histórico conflictivo. La cuestión municipal en Argentina entre 1850 y 1920, Tesis de maestría en Ciencias Sociales, Rosario, FLACSO, 1991, p. 104. La autora plantea la dicotomía centralización-descentralización en el siglo XIX, p. 11-15. El conflicto nacía de la naturaleza doble y ambigua del sistema municipal en Hispanoamérica que generó una tensión entre la representación de los intereses locales y la subordinación al poder central, que no terminó con la modernidad política y el constitucionalismo moderno. El gobierno buscaba un municipio como órgano administrativo y los vecinos un instrumento de autogobierno local. A esto se sumaba la falta de una división entre la justicia y la administración, representada en los jueces de paz de los partidos de la provincia de Buenos Aires, que no lograba realizarse a pesar de los esfuerzos constitucionales. Morelli, Federica "Orígenes y valores del municipalismo iberoamericano", Arucaria, Universidad de Sevilla, Sevilla, España, 2007, pp. 116-129.

${ }^{33}$ Acuerdos y sentencias, tomo I, p. 261.6 de diciembre de 1858. 
una consulta al Gobierno sobre la forma en que debían extenderse las escrituras de contrato en su partido, encontrando el Tribunal en la respuesta del ejecutivo un grave error en el valor legal que el fiscal daba al documento. El juez que consultaba consideraba que actuando con dos testigos, desempeñaba las funciones de Escribano público, opinión "completamente equivocada" para los magistrados, pero que había sido asegurada por el Fiscal, "que cree también que los documentos o escrituras de contratos autorizados por los Jueces de Paz de Campaña valen como instrumentos públicos".

Los miembros del Tribunal explicaban que la ley que instituyó esos juzgados no les confería esa facultad y por ello no tenían registros de contratos, como sí los tenían los escribanos públicos. Pero por ser "costumbre pedir su intervención en el otorgamiento de documentos, como testigos más caracterizados que el común de los hombres", podían llevar registros, que servían como parte de prueba para fijar la fecha de la escritura que autorizaban como instrumentos simples. El instrumento público era solamente la escritura otorgada por escribano público, firmada y signada en un registro público. De acuerdo en esto el Fiscal y el Asesor, el Gobierno declaró que "las escrituras otorgadas ante los Jueces de Paz de Campaña no tienen fuerza de instrumentos públicos” y lo mandó a notificar a los jueces de paz. ${ }^{34}$ Este caso deja de manifiesto que el juez de paz no era escribano, sino que cumplía las funciones de escribano ante la imposibilidad de que estos estuvieran en todos los partidos. Muy distinto era su rol de comisario, al que nos dedicaremos antes de avanzar en la jurisdicción judicial.

Desde 1831 el juez de paz era comisario, pero en 1857 fue separado de todas las funciones policiales al ser creadas en la campaña veinticinco comisarías, que exceptuaban a Junín, Bahía Blanca y Patagones. La partida de once hombres asignada a los juzgados quedaba reducida a cuatro y las comisarías eran dotadas con partidas de diez a quince hombres. Este cambio surgía de la experiencia de dividir la provincia en ocho departamentos a cargo de prefectos, para descentralizar los servicios públicos y administrativos. En noviembre de 1859 se suprimieron prefecturas y comisarías, retornando las funciones originales a los jueces de paz, con la concentración de atribuciones, el control sobre su partido y el papel de nexo entre éste y el poder central que no podían ser modificados. ${ }^{35}$

Pero en el nuevo arte de gobernar moderno, según enseñaba Michel Foucault, la "policía será el cálculo y la técnica que van a permitir establecer una relación móvil, pero pese a todo estable y

\footnotetext{
${ }^{34}$ ROPBA, 1862, pp. 293-296.

35 Sobre la experiencia de las prefecturas en la provincia puede consultarse Díaz, Benito "La organización de prefecturas de campaña de Buenos Aires durante el gobierno de Valentín Alsina”, en Trabajos y comunicaciones, núm. 8, Facultad de Humanidades y Ciencias de la Educación de la Universidad Nacional de la Plata, 1959, pp. 37-68; Yangilevich, Melina "Crónicas de conflicto y desilusión. Prefecturas de campaña, juzgados de paz y comisarías (18571859)" en Barriera, Darío (coordinador) La justicia y las formas de autoridad. Organización política y justicias locales en territorios de frontera. El Río de la Plata, Córdoba, Cuyo y Tucumán, siglos XVIII y XIX, ISHIR CONICET-Red Columnaria, Rosario, 2010, pp. 129-154.
} 
controlable, entre el orden interior del Estado y el crecimiento de sus fuerzas". El Estado debía crecer al máximo pero a la vez mantenerse en orden, para lo cual requería evitar que la relación de fuerzas se inclinara en su contra, objetivo de una buena policía. Desde principios del siglo XVII "la idea de un poder de policía se distinguió de otro tipo de ejercicio del poder real: el poder de justicia, el poder judicial. Policía no es justicia [...] es sí, la actuación directa del monarca sobre sus súbditos pero en una forma no judicial". ${ }^{36}$ Entonces los liberales que trabajaban en la construcción del Estado provincial tenían que separar la justicia de la policía. ${ }^{37}$

El gobernador de la provincia, Emilio Castro, definió a la policía en 1870 como "el orden mismo que preside a un pueblo, y la perfección que ella alcanza se considera como el atributo de la civilización. En un sentido más limitado la Policía comprende todo lo que interesa al bienestar habitual y a la seguridad del pueblo; y a sí su dominio es tan extenso cuanto son los múltiples intereses con que se relaciona". ${ }^{38}$ Tras el fracaso de separar la justicia de paz de la policía en la década anterior, el Gobierno había comenzado a intentarlo nuevamente con la creación de comisarías, pero la situación de la campaña seguía siendo muy distante de lo que se aspiraba. Así lo describe el ministro de gobierno Antonio Malver al referirse a la estructura y el funcionamiento de los partidos de campaña en el capítulo "Administración de la Campaña” de la Memoria de su Departamento de gobierno en 1871:

Sus autoridades las constituyen un Juez de Paz, una Municipalidad que -como queda dichoes una simple dependencia del poder Ejecutivo- y algunos Alcaldes y tenientes Alcaldes. Existe también en todos ellos una Partida de Policía que obedece las órdenes del Juez de Paz; y en unos pocos, un Comisario de Policía y de Tablada que, con otra Partida de soldados se encuentra también a las órdenes de aquel funcionario. ${ }^{39}$

Esta primera descripción la profundizó, dividiendo el capítulo en jueces de paz, comisarías, alcaldes y tenientes alcaldes y policías. Enumeró las atribuciones de los jueces de paz, divididas en administrar justicia y desempeñarse como presidente de la Municipalidad, comisario, agente inmediato y directo del poder ejecutivo, recaudador de los impuestos que pagaba el partido. A lo conflictivo de la acumulación de facultades y funciones se sumaba la gratuidad de su servicio.

\footnotetext{
${ }^{36}$ Foucault, Michel, Seguridad, territorio, población. Curso en el Collège de France (1977-1978), Buenos Aires, Fondo de Cultura Económica, 2006, pp. 387-389.

37 Sobre las transformaciones del poder de policía en el siglo XIX: Sozzo, Máximo, "Usos de la violencia y construcción de la actividad policial en la Argentina” en Gayol, Sandra y Kessler Gabriel, (editores) Violencia, delitos y justicia en la Argentina, Buenos Aires, Manantial, 2002, pp. 225-258.

${ }_{38}$ Mensaje del Gobernador a la Legislatura. ROGBA, 1870, pp. 292-293.

${ }^{39}$ Memoria de los diversos Departamentos de la Administración de la Provincia de Buenos Aires. Departamento de Gobierno, 1871, Buenos Aires, Imprenta del Siglo, 1872. Los comisarios de Tablada tenían la función de garantir la propiedad de los frutos con las guías correspondientes para su conducción y los artículos 130 y 131 habilitaba al Gobierno a establecer las necesarias "destinadas en particular a vigilar las introducciones de animales y frutos, que hagan los indios amigos", como también en algunos puntos fronterizos de la provincia para "revisar la legalidad de las extracciones de animales y frutos, y a no consentir la de animales o cueros no contraherrados". Código Rural de la provincia de Buenos Aires, Buenos Aires, edición oficial, Imprenta de Buenos Aires, 1865.
} 
Las Comisarías de Policía y de Tablada habían comenzado a instalarse en Azul en $1867^{40}$ y entre 1869 y 1872 se fundaron las de San Nicolás de los Arroyos ${ }^{41}$, Pergamino, Tapalqué, Mercedes de Patagones, Rojas ${ }^{42}$ y Tandil ${ }^{43}$. Con sus partidas de soldados estaban regidas por el decreto del 19 de enero de $1870^{44}$, “fundadas para garantir mejor la seguridad de los habitantes y para cumplir con las disposiciones de los artículo 130 y 131 del Código Rural”. Tengamos presente que todas dependían de sus jueces de paz, y “concurren a hacer más eficaz la Policía en los Partidos mencionados y a impedir, en cuanto es posible, los robos de ganado y frutos por medio del examen prolijo que se hace de todas las extracciones." Si leemos con atención los fundamentos de la creación de cada una de estas comisarías, observaremos que su objetivo era asegurar la propiedad y el segundo lugar la vida.

Los principales auxiliares de la policía eran los alcaldes y tenientes alcaldes, a cargo de los cuarteles en que se dividían los partidos, nombrados por el Gobierno a propuesta de las municipalidades, sujetos al cumplimiento de las órdenes de ésta, sin ninguna remuneración, a pesar de ser responsables de cumplir las disposiciones vigentes para salvaguardar la vida y la propiedad, vigilando sus cuarteles. En la ciudad los alcaldes y tenientes de barrio estaban sujetos a la Municipalidad, encargados de la policía municipal. ${ }^{45}$

Las partidas de soldados - llamadas comúnmente Policías- asignadas a los jueces de paz en su función de comisarios, fueron organizadas por el decreto del 15 de junio de 1870, después de

\footnotetext{
${ }^{40}$ La Comisaría de Policía y de Tablada del partido de Azul se estableció "no tanto por ser fronterizo, como por encontrarse situado en él dos tribus de indios llamados amigos; y siendo repetidas las quejas que llegan al Gobierno sobre cuereadas, venta y compra de cueros robados" siendo necesaria una policía para reprimir esos abusos. El comisario nombrado era interino hasta que se sancionara la ley y las atribuciones eran las mismas que las de los Comisarios de la Capital. Decreto del 28 de mayo de 1867. ROPBA, 1867, pp. 214-215.

${ }^{41}$ Fue solicitada por el juez de paz de San Nicolás, en respuesta a las reiteradas quejas que recibía por los robos de hacienda de los cuatreros y deseando garantir la propiedad y las vidas de los habitantes de la campaña. En la nota proponía para el cargo a Pablo Cepeda, comisario municipal. Decreto del 21 de junio de 1869 y ley del 12 de agosto de 1869. ROGBA, 1869 , pp. 289-290; 381.

${ }^{42}$ Esta Comisaría de policía y Tablada de Rojas había sido solicitada por los hacendados del partido para vigilar esa sección de la frontera y ofrecer mayores garantías a la propiedad, impidiendo los continuos robos de hacienda que sufrían por la falta de vigilancia. Decreto del 25 de enero de 1871. ROGBA, 1871, pp. 13-14.

${ }^{43}$ El objetivo de la Comisaría de Tandil era dar a las autoridades locales elementos para una policía eficaz. El comisario tenía la función de "recorrer constantemente el Partido, aprehendiendo a los criminales y sometiéndolos a la autoridad criminal que les corresponda con el sumario que se les haya formado". Decreto del 20 de febrero de 1872. ROGBA, 1872, pp. 99.100.

${ }^{44}$ Con el objetivo de "facilitar y mejorar la administración de la Campaña, procurando por ese medio a sus habitantes y a sus propiedades todas las garantías posibles de seguridad" y habiendo aceptado la Legislatura en el presupuesto el establecimiento de Comisarías de Policía y de Tablada en Pergamino, Tapalqué y Patagones, el Gobierno acordó y decretó su establecimiento según las atribuciones designadas en los artículos 130 y 131 del Código Rural y los reglamentos que dictase cada partido. Se componían de un comisario, un oficial dos sargentos, veintidós soldados para Pergamino y Tapalqué y ocho para Patagones. Los comisarios quedaban bajo la dirección y vigilancia del juez de paz respectivo y la Municipalidad debía proponer el reglamento y las disposiciones para su mejor servicio, sujetándose a lo dispuesto por el Código Rural. Eran nombrados por el Gobierno a propuesta del juez de paz, que podía solicitar su remoción "toda vez que no llenare los deberes de su oficio". Los oficiales también los nombraba el Gobierno a propuesta del comisario y el juez; los soldados de la partida eran designados por el juez a propuesta del comisario. ROGBA, 1870, pp. 17-19.

${ }^{45}$ Ley de municipalidades art. 49. ROPBA, 1854, p. 113: "Quedan inmediatamente sujetos a la Municipalidad los alcaldes y tenientes de barrio, como autoridades encargadas de la policía municipal".
} 
consultar a los jueces de paz. Algunas estaban mandadas por un oficial, otras por un sargento y los soldados variaban entre cinco y trece. ${ }^{46}$ Pero la experiencia había demostrado que eran insuficientes para cumplir la función que en palabras de Malaver era la de "guardar el orden y para ejercer una activa y constante vigilancia en cada uno de los Partidos de Campaña”.

El ministro proponía que subieran a treinta o cuarenta soldados, según la extensión del partido, con uno o dos oficiales a su frente, para dividirlos en tres grupos destinando uno al cuidado de los pueblos y los otros dos a recorrer constantemente el partido "en persecución de los vagos, viciosos y criminales que cruzan nuestra Campaña”. El objetivo no era sólo la seguridad de los habitantes, sino la disminución de los delitos contra la propiedad que se observaban en la campaña, fuera de la ciudad capital.

El mensaje de Castro en 1872 adhería a la propuesta de su ministro. Y recomendaba aumentar las policías de campaña, "para dar a la vida y a la propiedad de los habitantes todas las garantías de seguridad" y proponía la sanción de un impuesto local para responder a los gastos que requería la mejora del servicio. ${ }^{47}$ En septiembre de ese mismo año se creó una Comisaría de Policía y Tablada en Bahía Blanca ${ }^{48}$ y otra en el partido fronterizo de 25 de mayo, instalada en La Verde, campos que había ocupado la tribu de Raninqueo. ${ }^{49}$

A partir del estudio del caso de Tandil, Gisela Sedeillán afirma que las comisarías creadas en estos años no formaban parte de un programa de Gobierno que buscaba limitar la función de los jueces de paz de campaña, sino que eran medidas improvisadas en respuesta a los reclamos de mayor seguridad. ${ }^{50} \mathrm{Si}$ bien es cierto que no se trataba de un proyecto planificado, la perspectiva que dan los motivos que llevaron a la creación de todas las comisarías entre 1867 y 1872 permite afirmar que estaban convencidos de que la solución a los reclamos por inseguridad estaba en la conformación de un cuerpo policial y que ya no bastaba el juez de paz, aunque quedara a cargo del nuevo funcionario.

\footnotetext{
${ }^{46}$ Acuerdo organizando definitivamente las partidas de policía de Campaña. ROPBA, 1870, pp. 449-462. El juez de paz estaba a cargo de arreglar el personal y el sueldo de las partidas.

${ }_{47}$ Mensaje del Gobernador Castro el 1 de mayo de 1872. ROPBA, 1872, pp. 225-240.

${ }^{48}$ ROPBA, 1872 , p. 358.

${ }^{49}$ ROPBA, 1872, p. 361. El argumento del decreto era que las tierras habían sido abandonadas por la tribu al igual que los edificios que el Estado les construía.

${ }^{50}$ Sedeillán, Gisela, "La conformación y consolidación de la institución judicial en Tandil, 1872-1901", Tesina de licenciatura, inédita, 2001; "La pérdida gradual de las funciones policiales del juzgado de paz: la creación de la institución policial en Tandil 1872-1900", en Anuario Segretti, Córdoba, 2005.
} 


\section{Cuadro 1}

Comisarías creadas entre 1867 y 1872 en la provincia de Buenos Aires

\begin{tabular}{|c|c|c|}
\hline Partido & $\begin{array}{l}\text { Año de } \\
\text { creación }\end{array}$ & Motivo \\
\hline Azul & 1867 & Por quejas por cuereadas y comercialización de cueros robados \\
\hline $\begin{array}{l}\text { San Nicolás } \\
\text { de los } \\
\text { Arroyos }\end{array}$ & 1869 & $\begin{array}{l}\text { Por quejas por robos de hacienda de los cuatreros y para garantir la } \\
\text { propiedad y las vidas de los habitantes de la campaña }\end{array}$ \\
\hline Pergamino & 1870 & $\begin{array}{l}\text { Para facilitar y mejorar la administración de la Campaña, procurando } \\
\text { garantir seguridad a los habitantes y a sus propiedades }\end{array}$ \\
\hline Tapalqué & 1870 & $\begin{array}{l}\text { Para facilitar y mejorar la administración de la Campaña, procurando } \\
\text { garantir seguridad a los habitantes y a sus propiedades }\end{array}$ \\
\hline Patagones & 1870 & $\begin{array}{l}\text { Para facilitar y mejorar la administración de la Campaña, procurando } \\
\text { garantir seguridad a los habitantes y a sus propiedades }\end{array}$ \\
\hline Rojas & 1871 & $\begin{array}{l}\text { Por pedido de los hacendados para vigilar la frontera y garantizar la } \\
\text { propiedad contra los robos de hacienda }\end{array}$ \\
\hline Tandil & 1872 & $\begin{array}{l}\text { Para dar a las autoridades locales elementos para una policía eficaz, } \\
\text { aprehendiendo a los criminales y sometiéndolos a la autoridad } \\
\text { criminal que les corresponda con el sumario que se les haya formado }\end{array}$ \\
\hline 25 de mayo & 1872 & $\begin{array}{l}\text { Abandono de tierras por la tribu al igual que los edificios que el } \\
\text { Estado les construía }\end{array}$ \\
\hline Bahía Blanca & 1872 & \\
\hline
\end{tabular}

Fuente: Registro Oficial de la provincia de Buenos Aires

Este breve repaso de las modificaciones generadas en la policía de la provincia, ofrece un panorama del lento proceso de definición en su función de "garantir mejor la seguridad de los habitantes", distinguiéndose de la administración municipal y de la justicia. Un paso más en este camino lo demuestra la medida tomada por el gobernador el 25 de enero de 1873, al separar de su cargo de comisario Juan J. Biedma por actividad política. Si bien éste negó haber tomado participación oficial, declaró que "ha sido y será acérrimo sostenedor del Comité Electoral, pero en su carácter particular, con sus amigos y su dinero". Estas expresiones eran para el Gobierno contrarias a lo impuesto a sus funcionarios de mantenerse ajenos a todo lo relacionado con el acto electoral, por lo que decidió despedirlo. ${ }^{51}$

Pero todavía faltaba mucho trecho para alcanzar la descentralización enunciada en los discursos y un buen ejemplo de la concentración de diversas funciones en la figura del juez de paz es el de Adolfo Tuñer, a cargo del juzgado de San Nicolás de los Arroyos, que en 1866 fue acusado por Julio Jonas de abuso de autoridad en el ejercicio de su empleo. El juez del crimen del Norte elevó el auto y sus antecedentes al Superior Tribunal, que de conformidad con lo solicitado por el Fiscal suspendió a Tuñer "en sus funciones judiciales”, devolviendo la causa al juez del crimen para que prosiguiera con arreglo a derecho. Pero el asesor de Gobierno, Carlos Tejedor, expresó que suspendido el funcionario en sus funciones judiciales "no sería moral, administrativamente hablando" que conservara sus demás funciones y "el mando como comisario de la fuerza pública". Por esto debía completarse la suspensión y así lo resolvió Alsina nombrando en calidad de interino

\footnotetext{
${ }^{51}$ ROPBA, 1873, pp. 22-23.
} 
a Marcelino Díaz Herrera. ${ }^{52}$ Una misma persona era juez y comisario, como veremos más adelante que podía ser juez y legislador o juez del crimen y juez de comercio.

\section{b. Las funciones judiciales}

La competencia judicial de los jueces de paz también fue ampliada en estos años, pues originariamente juzgaba en todas las demandas que las leyes y prácticas declaraban verbales y arbitraba en las diferencias, pero sus funciones judiciales se consolidaron con el fracaso de la organización policial y de la instalación de la justicia letrada en la campaña ${ }^{53}$ El procedimiento en las causas donde dictaba sentencia era verbal, con dos testigos, debiendo constar en el libro de actas la demanda, contestación, prueba y resolución.

Esto generó conflictos durante todos estos años y ya instalada la Suprema Corte en 1876 aconsejaba a los jueces de paz la supresión de lo escrito que no fuera indispensable, con arreglo a su jurisdicción y buscando evitar gastos en juicios "de tan exigua importancia". El mismo año, en respuesta a una consulta del juez de Cañuelas, el Tribunal explicaba que por la ley de 1821 el procedimiento era verbal, levantando acta de las causas, para todas las causas de competencia de los jueces de paz, "sean de la naturaleza que fueren", lo que había sido sostenido por la ley del 23 de septiembre de 1854 y la Constitución de $1873 .^{54}$

Estos jueces eran desde 1822 vecinos legos, es decir que no tenían formación profesional ni eran expertos en derecho. Quienes administraban justicia actuando como mediadores, resolviendo las causas de menor cuantía que la ley establecía -aunque cada vez fueran más- se basaban en un saber práctico; dominaban la tecnología de la escritura y "sabían hacer un proceso y esto era crucial para administrar justicia". 55 Para asistir a esos jueces de saberes legos, el Gobierno recurrió a manuales con una finalidad netamente práctica, como el redactado por el ministro Manuel García en $1825 .{ }^{56}$ Su texto establecía la jurisdicción civil, criminal $^{57}$ y las funciones de los jueces de paz en la

\footnotetext{
${ }^{52}$ ROPBA, 1866, pp. 102-104.

${ }^{53}$ En 1821, la justicia de primera instancia contaba con cinco jueces (dos para la ciudad y tres para la campaña) letrados, rentados e inamovibles, pero los de campaña fueron suprimidos en 1824 hasta 1853. Fradkin, 2009, op. cit., pp. 143-164.

${ }_{54}$ Acuerdos y sentencias, tomo I, p. 190: p. 445. El método verbal y actuado constituía sin excepción la regla del procedimiento.

${ }^{55}$ Barriera, Darío G., "Voces legas, letras de justicia. Culturas jurídicas de los legos en los lenguajes judiciales (Río de la Plata, siglos XVIII-XIX) en Montecón Movellán, Tomás, (editor) Bejtin y la historia de la cultura popular: cuarenta años de debate, PubliCan, Universidad de Cantabria, Santander, 2008, pp 347-368.

${ }^{56}$ Manual para los jueces de paz de campaña, Buenos Aires, Imprenta de la Independencia, 1825.

${ }^{57}$ Se refiere al ejercicio de la policía judiciaria, en lugar de los comisarios suprimidos, que debían combatir la vagancia, y a los procesos sumarios y verbales en los casos de uso de cuchillo, heridas leves, hurtos simples, palabras obscenas o insultos y el robo de ganado hasta seis cabezas. Sobre la construcción de la figura del vago véase Alonso, Fabián, Barral, María E., Fradkin, Raúl y Perri, Gladis, "Los vagos de la campaña bonaerense: la construcción histórica de una figura delictiva (1730-1830)", en Prohistoria, N5, Rosario, 2001, pp. 171-202; Casagrande, Agustín, Los vagabundos y la justicia de Buenos Aires durante el periodo tardo colonial (1875-1810). Construcciones jurídicas y criminalidad, Buenos Aires, Instituto de Investigaciones de Historia del Derecho, 2012, pp.91-104.
} 
campaña sobre delitos graves como sumariantes. ${ }^{58}$ Reproducía formularios de los trámites que el juez debía realizar en cumplimiento de sus atribuciones y el texto de las leyes necesarias.

La condición de lego no se modificó y Carlos Tejedor redactó dos manuales, uno para procesos criminales y otro para demandas civiles y asuntos administrativos. La intensión práctica y pedagógica de estos textos quedó de manifiesto en la devolución que el presidente del Superior Tribunal, Francisco de las Carreras, realizó del Manual para causas criminales al Gobernador, que le había sido entregado para que el Tribunal y su fiscal lo evaluaran. El manual ofrecía a los jueces de paz "una exposición clara, concisa y metódica" de las disposiciones legales que se encontraban en el Registro Oficial, "que por el considerable número de volúmenes de que se compone, hacía laborioso y difícil su conocimiento". El Tribunal no sólo aconsejaba su aprobación sino que también recomendaba la redacción del manual para causas civiles, firmando Bartolomé Mitre el decreto para ambas cosas.

Leandro Di Gresia estudió en estos manuales los mecanismos que llamó "transposición didáctica" entre el universo académico y la sociedad civil, representada en estos jueces legos. Su cultura jurídica -como noción de derecho- y judicial -como saber hacer en caso de procedimiento judicial- se fue conformando en el ejercicio del cargo por diversas vías: la lectura didáctica que el Estado ponía a su alcance y la formación práctica y casuística surgida del ejercicio del cargo. ${ }^{59}$

Es decir que un miembro de la comunidad, que debía responder a sus vecinos y al Gobierno aprendía en el ejercicio de su cargo, pero contando con dos textos didácticos, uno para orientar su función punitiva y otro para guiar su función mediadora, redactados por un abogado que dictaba el Curso de Derecho Criminal en la Universidad de Buenos Aires. Aunque el objetivo fuera netamente práctico, Tejedor pertenecía al mundo académico y lo que es más interesante, durante los años que estamos estudiando se resistió a aceptar un cargo en el poder judicial provincial, ejerciendo la profesión o desempeñándose en cargos de Gobierno o legislativos. Un caso similar fue el de los hermanos Elizalde, responsables de proyectos y activos protagonistas de los debates de leyes relacionadas con la administración de justicia.

El primer manual fue redactado en 1861 para servir de guía a los jueces de paz de campaña en el desempeño de la jurisdicción criminal de su competencia y en la ejecución de las diligencias que les encargaban los juzgados de primera instancia del crimen. ${ }^{60}$ El texto establecía la jurisdicción criminal de los jueces de paz, dividida en propia, delegada y sumariante. La jurisdicción propia era la que les atribuía la ley en ciertos casos para conocer y fallar en primera instancia y la delegada era

\footnotetext{
${ }^{58}$ Delitos graves: muerte, heridas, robo, violencia, incendio, etc.

${ }^{59}$ Di Gresia, 2007, op. cit.

${ }^{60}$ Tejedor, Carlos, Manual de Jueces de Paz en los procesos criminales, Buenos Aires, Imprenta Argentina "El Nacional", 1861. (en adelante Tejedor, Manual criminal) Con firma de Mitre y Pastor Obligado fue aprobado el Manual, se mandaron a imprimir 500 ejemplares para repartirlos en los juzgados de paz y se le encargó a Tejedor otro manual para la competencia civil.
} 
por la que los jueces de primera instancia los autorizaban a realizar actos y diligencias del proceso que no requirieran su presencia. ${ }^{61}$ Tenía también, en su calidad de comisario, la facultad de sumariar -exclusiva de la justicia ordinaria- pues "un instante perdido sería irreparable” para la resolución del delito. Pero no le daba competencia propia y terminado el sumario estaba obligado a remitirlo con los acusados a la justicia ordinaria.

En cuanto a las funciones judiciales propias, la jurisdicción contenciosa de los juzgados de paz en la ciudad y la campaña extendió su conocimiento y decisión a toda cuestión que no excediera los cuatro mil pesos moneda corriente, exceptuando aquellas surgidas por inventarios o tasaciones testamentarias, que pasarían a iniciarse ante los juzgados de primera instancia, sea cual fuera su importancia. ${ }^{62}$ Poco tiempo después un texto legislativo reiteró esta competencia, pero fue más explícito, el juez de paz debía atender las cuestiones de daños y perjuicios rurales hasta ocho mil pesos, las demandas reconvencionales y de la excepción de compensación, arrendamientos y desalojos con un alquiler urbano de mil quinientos pesos y un arrendamiento rural de quinientos, reparaciones y mejoras, asuntos de comercio hasta cuatro mil pesos, injurias verbales o difamaciones de palabra o por escrito, no siendo por prensa. Toda causa resuelta por el juez de paz hasta trescientos pesos era inapelable y debía el juez levantar acta de las causas en que conociera. ${ }^{63}$

Las funciones civiles y administrativas de los jueces de paz eran comunes a los de la ciudad y la campaña, pero los primeros recibían menos comisiones y su jurisdicción no requería ser extendida al no existir el problema de la distancia. En la resolución de los conflictos de su competencia debía ser amigable y conciliatorio y cuando cumplía las órdenes de un tribunal superior debía atenerse a su fiel ejecución. ${ }^{64}$

La función de sumariante fue asignada al juez de paz poco después de ser creada la institución en 1821, heredada de los Alcaldes de la Hermandad, quienes tenían a su cargo esa tarea en la etapa anterior. Un decreto del Gobierno de Las Heras, el 28 de febrero de 1825, establecía que:

\footnotetext{
${ }^{61}$ El juez de paz se desempeñaba en comisión cuando recibía algún despacho del Tribunal de Justicia, Consulado o Jueces de primera instancia. Otras diligencias asignadas al juez de paz eran el discernimiento de tutela, un inventario o tasación, un embargo, prisión o remisión de una persona, un desalojo o demolición, mensuras, etc. En acuerdo del 23 de abril de 1860 el Superior Tribunal mandaba a los jueces de paz la "breve expedición de las comisiones que se le confieran", porque estaban obligados a concluirlas s in demora, pudiendo hacerse efectivas las responsabilidades y represiones correspondientes según derecho. Acuerdos y sentencias, tomo I, pp. 292-293.

${ }^{62}$ Ley del 16 de septiembre de 1853. ROGBA, 1853, p. 90.

${ }^{63}$ Ley del 19 de septiembre de 1854. ROGBA, 1854, pp. 97-98. Otra ley del 27 de septiembre de 1854 incluyó luego el conocimiento en contratos de inmigrantes. ROGBA, 1854, pp. 101-103. El monto que fijaba la jurisdicción en lo civil y comercial fue elevado a veinte mil pesos en 1863. Ley del 30 de septiembre de 1863. ROGBA, 1863, p. 283. En las testamentarias que excedían los veinte mil pesos, el juez de paz se limitaba a inventariar los bienes, tasarlos y asegurarlos, previa citación de los herederos mayores y el procurador municipal, concurriendo dos testigos y realizándose las tasaciones por inteligentes nombrados de oficios. Finalmente se reconocían los papeles o declaraciones de herederos y se remitía todo con oficio al presidente de Superior Tribunal de Justicia en su Sala de lo Civil.

${ }^{64}$ Tejedor, Carlos, Manual de Jueces de Paz en las demandas civiles y asuntos administrativos, Buenos Aires, Imprenta de La Tribuna, 1861. (en adelante Tejedor, Manual civil)
} 
...siendo necesario proveer del mejor modo posible al servicio que rendían los comisarios de policía en campaña, suprimidos, el gobierno ha acordado y decreta: 1 . Las funciones de los comisarios de policía de campaña serán ejercidas por ahora, por los jueces de paz, tanto en la parte civil como en la criminal y judiciaria...

Para tal función contaba con una partida de tres milicianos, entregándosele una instrucción que determinaba las funciones de los jueces de paz de la campaña en delitos graves, mandándoles en su carácter de comisarios a levantar el sumario correspondiente. ${ }^{65}$ El juez de paz dirigía el sumario al presidente de la Cámara de Justicia y éste a su vez lo pasaba al juez de la capital que debía continuar la causa. ${ }^{66} \mathrm{El}$ juez de paz como comisario levantaba el sumario, parte del expediente judicial.

La situación cambió en parte después de la caída de Rosas y la instalación de la primera instancia en la campaña en dos Departamentos, Norte (con asiento en Arrecifes) y Sud (con asiento en Dolores). ${ }^{67}$ En cada uno había un juzgado de primera instancia en lo criminal, que era desempeñado por un letrado, teniendo adscripto un escribano. Los jueces eran nombrados por el poder ejecutivo a propuesta en terna de la Cámara y los escribanos a propuesta de los jueces. Los jueces de paz de los partidos que componían ambos Juzgados le remitían al juez correspondiente según su jurisdicción los sumarios y presos que hasta entonces enviaban a la Capital, sin perjuicio de notificar las remisiones a la Cámara de Justicia. ${ }^{6}$

Por tratarse de la investigación de un delito, el derecho de sumariar correspondía a la justicia criminal, que había sido acordado al jefe de policía y comisarios de la ciudad y la campaña, sin competencia propia, por lo que su misión terminaba allí, debiendo remitir inmediatamente a los acusados con la información levantada a la justicia ordinaria. ${ }^{69}$ Tejedor definía esta función del juez de paz como la más delicada dado que la inoperancia o ignorancia en la ejecución de los primeros procedimientos podrían ser decisivas para la vida y fortuna de los ciudadanos. El sumario tenía cinco objetivos básicos:

1. la comprobación de un hecho punible,

2. la reunión de datos que descubran o indiquen al delincuente,

3. las diligencias de su prisión y demás relativas a la resolución del juicio,

\footnotetext{
${ }^{65}$ Sobre la relación entre la policía y la función de sumariante véase Sedeillan, Gisela, "El papel de la policía de la provincia de Buenos Aires en la instrucción sumarial en el período de codificación del derecho", en Bohoslavsky, Ernesto, Caimari, Lila y Schettini, Cristiana, (organizadores) La policía en perspectiva histórica. Argentina y Brasil (del siglo XIX a la actualidad), 2009.

${ }^{66}$ Manual para los Jueces de Paz de campaña, 1825.

${ }^{67}$ Por inconvenientes en el pueblo de Arrecifes, el Juzgado se instaló en Mercedes. Molle, Alejandro, El Departamento Judicial Mercedes, Mercedes, 1997, p. 33.

${ }^{68}$ ROGBA, 1853, p. 155. En 1856 se agregó otro Departamento con un juzgado de primera instancia en lo criminal con asiento en San Nicolás. ROGBA, 1856, p. 114. Los Departamentos comprendían el del Norte, San Nicolás, San Pedro, Baradero, Arrecifes, Rojas, Pergamino; Centro, Junín, Salto, Fortín de Areco, San Antonio de Areco, Giles, Villa de Mercedes, Navarro, Lobos, Montes, Ranchos, Las Flores, 25 de Mayo, Chivilcoy, Bragado; Sud, los partidos situados al sur de Ranchos. Reparemos en la vaguedad de los límites para el Departamento del Sud.

${ }^{69}$ Tejedor, Carlos, Curso de derecho criminal. Segunda parte: leyes de formas. Buenos Aires, Librería de Cl. M. Joly, 1871, segunda edición, núm. 134. (en adelante Curso de Tejdor, II)
} 
4. la declaración indagatoria,

5. la confesión. ${ }^{70}$

Tanto la declaración indagatoria como la confesión no debían ser practicadas por el juez de paz dado que se trataba de una comunidad pequeña, donde generalmente había conocimiento previo del acusado que podía viciar el interrogatorio. Pero en 1859 se dejó sentado que en las indagaciones que en causas criminales levantasen los jueces de paz y comisarios de campaña se recibirían bajo juramento las declaraciones de los testigos y. tendría el mismo valor jurídico que los sumarios levantados por los jueces del crimen. ${ }^{71} \mathrm{El} \mathrm{juez} \mathrm{de} \mathrm{paz} \mathrm{como} \mathrm{sumariante} \mathrm{implicaba} \mathrm{una} \mathrm{relación} \mathrm{con}$ los jueces de primera instancia que no siempre era fluida y generaba llamados de atención por los procedimientos, las demoras o por no enviarlos al magistrado a cargo de la causa.

Mientras se atendía a un mejor funcionamiento de la jurisdicción contenciosa de los jueces de paz, la preocupación por la descentralización se manifestaba en intentos de lograr la división de poderes a nivel local, asegurando una justicia cercana y accesible, para que el litigio se resolviera allí donde se producía. El juez de paz debía convertirse en la base del sistema judicial provincial y para ello era indispensable descentralizar sus funciones y crear un poder municipal a cargo de las jurisdicciones locales. Es decir, para que el proceso de descentralización planificado y manifestado en palabras fuera llevado a la práctica, era fundamental convertirlos en funcionarios exclusivamente judiciales, pero sobre todo quitarle la dependencia política central a través de la elección popular. Funcionarios exclusivamente judiciales y elegidos por los vecinos.

La nueva Constitución provincial de 1873 puso las bases para el cambio en la organización pues los jueces de paz eran funcionarios exclusivamente judiciales y agentes de los Tribunales de Justicia, que para ser electos debían ser ciudadanos mayores de 25 años, contribuyentes, con dos años de residencia en el lugar donde fueran a desempeñar sus funciones y saber leer y escribir. Pero lo más importante era que serían elegidos en forma directa por electores calificados, esto es mayores de 22 años con residencia de un año. El procedimiento seguía siendo verbal y actuado y los recursos atendidos por los tribunales de vecindario organizados por la ley en la materia, de forma que las causas quedaran terminadas dentro del mismo distrito.

\section{El movimiento del juzgado}

Es un hecho que durante el tiempo que el juez estaba a cargo de su juzgado -que por ley era un año pero sin límite para ser nuevamente nombrado- debía atender una variedad de tareas en las que quedaban incluidas las funciones judiciales. Una fuente que demuestra el movimiento y las

\footnotetext{
${ }^{70}$ La declaración indagatoria es la que toma el juez al sospechoso de la comisión de un delito para averiguar la verdad de los hechos, la confesión es el acto por el cual una persona reconoce haber cometido un hecho punible. Ossorio, Manuel, Diccionario de Ciencias Jurídicas, Políticas y Sociales, 24a edición actualizada, corregida y aumentada por Guillermo Cabanellas de las Cuevas, Buenos Aires, Editorial Heliasta, 1997.

${ }^{71}$ Ley del 16 de septiembre de 1859, ROPBA, 1859, p. 91.
} 
relaciones del juzgado de paz son las notas recibidas. En este caso, elegido para trabajar las de Exaltación de la Cruz, pues al haber sido ordenadas en expedientes por su juez de paz Manuel F. de la Fuente en 1881, ofrecen cierta seguridad de estar completas. Hemos podido recuperar los expedientes de 1862 a 1881 (faltan de 1870 a 1872) y con esos documentos buscamos llevar el texto de leyes y decretos a la vida cotidiana del juzgado en las cuestiones que el funcionario debió atender. $^{72}$

Antes de dedicarnos a esta tarea creemos necesario exponer brevemente que sucedió en la primera década del período analizado, entre 1853 y 1861, que ha estudiado Juan Carlos Garavaglia. Partiendo de 1841 enfocó el "despliegue del Estado" en Buenos Aires, es decir la extensión de las funciones estatales, -analizando los cambios en la construcción de sus “instrumentos"- en dirección a reforzar la presencia estatal en el ámbito urbano y en la campaña, dándole a los jueces de paz un papel fundamental en el reclutamiento y el control de los ciudadanos para la Guardia Nacional y la realización de las elecciones legislativas. ${ }^{73}$

En estos años se marcó la diferencia entre los jueces de paz del rosismo y los de los años posteriores a Caseros, cuando los paisanos avecinados fueron destinatarios del accionar represivo de la justicia de paz, dadas las exigencias militares de las guerras civiles entre Buenos Aires y la Confederación y los requerimientos del servicio en la frontera. ${ }^{74}$ Sobre este accionar de los jueces de paz, el autor destacó la "autonomía jurídica" que recibieron para perseguir y juzgar en juicio oral a vagos y mal entretenidos por la ley del 30 de octubre de $1858 .{ }^{75}$ Los destinaban al servicio de las armas por un término de entre dos y cuatro años, con sentencia condenatoria apelable ante el juez del crimen, pero sin suspender los efectos de la sentencia, cosa prácticamente irrealizable para el condenado. $^{76}$

Unificadas la provincia de Buenos Aires y la Confederación, iniciamos la tarea con los documentos. En primer lugar realizamos un cuadro (cuadro 2) que permite observar los organismos de los que el juez de paz - cabeza del municipio, comisario y administrador de justicia- recibía todo

\footnotetext{
${ }^{72}$ Todas las notas citadas corresponden a la Correspondencia del juzgado de paz de Exaltación de la Cruz arreglada por el juez de paz Manuel F. de la Fuente en 1881. Expedientes núm. 23 de 1862; núm. 24 de 1863; núm. 25 de 1864 ; núm. 26 de 1865; núm. 27 de 1866; núm. 28 de 1867; núm. 29 de 1868; núm. 30 de 1869; núm. 34 de 1873 ; núm. 35 de 1874. El partido de Exaltación de la Cruz y su cabecera, Capilla del Señor -ubicada en el centro noreste de la provincia, a $83 \mathrm{~km}$. de la capital- fueron creados sobre las tierras pertenecientes al pago de la Cañada de la Cruz. En 1785 fue nombrado alcalde de hermandad Francisco Casco y en 1822 juez de paz Justo Fonseca. En 1856 se instaló la primera municipalidad de elección popular.

${ }_{73}$ Garavaglia, 2007, op. cit., pp. 343-356.

${ }^{74}$ Garavaglia, 2007, op. cit., 309.

75 Art. $2^{\circ}$ Los vagos y mal entretenidos, los que en días de labor se encuentren habitualmente en casa de juego o tabernas, los que usen cuchillo o arma blanca, en la Capital o en los Pueblos de Campaña, los que cometan hurtos simples, o los que infieran heridas leves, serán destinados al servicio de las armas, por un término que no baje de dos años, ni exceda de cuatro. Art. $3^{\circ} \mathrm{El}$ conocimiento de las causas de que habla el artículo anterior, corresponderá en la Ciudad al Juez Correccional, y en la Campaña a los Jueces de paz, por medio de proceso verbal, sin apelación, en el efecto suspensivo. De esta apelación conocerá en la Campaña el Juez del crimen sin más recurso. ROPBA, 1858, p. 133. Por la ley del 26 de octubre de 1864 se derogan los artículos $2^{\circ}$ y $3^{\circ}$. ROPBA, p. 115 .

${ }^{76}$ Garavaglia, 2007, op. cit., pp. 332-333.
} 
tipo de demandas, recomendaciones y reclamos, pudiendo observar la evolución de esa relación a lo largo de los años.

Cuadro 2: Correspondencia recibida en el juzgado de paz de Exaltación de la Cruz entre 1862 y 1874

\begin{tabular}{|c|c|c|c|c|c|c|c|c|c|c|}
\hline Origen & 1862 & 1863 & 1864 & 1865 & 1866 & 1867 & 1868 & 1869 & 1873 & 1874 \\
\hline Ministro de Gobierno & 20 & 25 & 22 & 25 & 31 & 17 & 11 & 39 & 37 & 20 \\
\hline Ministerio de Hacienda & 5 & 8 & & 4 & 5 & 13 & 11 & 4 & 8 & 3 \\
\hline Ministerio de Guerra y Marina & 26 & & & & & & & & & \\
\hline Departamento General de Policía & 36 & 22 & 19 & 7 & 1 & 6 & 3 & 4 & 3 & 3 \\
\hline Administración General de Sellos & 4 & & & & & & & 7 & & \\
\hline Colector de Rentas & 5 & & & & & & & & & \\
\hline Inspección de Caballadas & 19 & & & & & & & & & \\
\hline Subdelegación de Marina & 1 & & & & & & & & & \\
\hline Superior Tribunal de Justicia & 2 & & 2 & & & & & & & \\
\hline Juzgados de primera instancia & & 1 & & 1 & & 1 & 8 & 2 & 7 & 20 \\
\hline Juzgado de Paz & 44 & 42 & 31 & 23 & 28 & 16 & 25 & 31 & 37 & 50 \\
\hline Administración Gral de Correos & & 1 & & & & & & & 4 & \\
\hline Colecturía Contribución Directa & & 1 & 7 & 3 & 3 & & 4 & & & 5 \\
\hline Consejo de Higiene & & 1 & & 1 & & 1 & & & & \\
\hline Inspección de la Guardia Nacional & & & 7 & 18 & & 1 & & & 1 & \\
\hline Sociedad de Beneficencia & & & 1 & 3 & 1 & 2 & 2 & & 3 & 1 \\
\hline Defensoría General de Menores & & & 3 & & 3 & & 2 & & & \\
\hline Oficina de Estadística & & & & & 2 & 1 & & & 7 & 5 \\
\hline Oficina de tierras públicas & & & & & 1 & & & & & 6 \\
\hline Agrimensores & & & & & 5 & & & & & \\
\hline Secretaría del Senado & & & & & & 1 & & & & \\
\hline Alcalde de la cárcel & & & & & & 2 & & & & \\
\hline Resguardo de Campana & & & & & & 1 & 1 & & & \\
\hline Oficina de patentes & & & & & & & 7 & & 12 & 5 \\
\hline Comisario de censo & & & & & & & & 1 & & \\
\hline Sub-inspección del Norte & & & & & & & & & 3 & \\
\hline Dirección General de Telégrafos & & & & & & & & & 1 & \\
\hline Dirección General de Rentas & & & & & & & & & 2 & 10 \\
\hline Comisario de Censo de Escuelas & & & & & & & & & 2 & \\
\hline Sociedad Rural Argentina & & & & & & & & & 1 & \\
\hline Cámara Legislativa provincial & & & & & & & & & 1 & \\
\hline Tablada Central & & & & & & & & & & 1 \\
\hline $\begin{array}{l}\text { Comisión Protectora de } \\
\text { Bibliotecas Populares }\end{array}$ & & & & & & & & & & 2 \\
\hline $\begin{array}{l}\text { Administrador Anales de } \\
\text { Agricultura }\end{array}$ & & & & & & & & & & 1 \\
\hline Total & 162 & 101 & 92 & 85 & 80 & 62 & 74 & 110 & 154 & 143 \\
\hline
\end{tabular}

Fuente: Correspondencia arreglada por el juez de paz Manuel F. de la Fuente en 1881

Inventario $\mathrm{N}^{\circ} 23$ al 30; 34 y 35 
Cuando se trataba de circulares que solicitaban el cumplimiento de un decreto o ley, iban acompañadas de su texto, pidiendo publicidad y mandando fijarlo en parajes públicos. El juez actuaba como medio de conexión con organismos de su partido, como por ejemplo la sucursal del Banco Provincia, a quien debía pedir prontitud en los trámites solicitados por los juzgados de primera instancia. En cuanto a las solicitudes que el juez de paz realizaba al Gobierno, el ministro de gobierno mandaba que enviara una nota por cada asunto a la oficina correspondiente y recomendaba que no se expidiera documento alguno sin sello.

Se le informaba al juez sobre nombramientos, toma de posesión o renuncias de funcionarios de Gobierno, ya fuera el gobernador, ministros, legisladores, inspectoras de escuelas o preceptores. Se le solicitaba y expedía recibo de contribución directa, patente a casa de negocios, industrias y mercachifles e impuesto de saladeros y graserías, que tuvo su propia oficina de recaudación en 1874. Le enviaban todas las determinaciones relativas a marca de ganado, arrendamientos (por ejemplo la "Revista" del 1 de septiembre de 1862 con el decreto sobre quintas y chacras en pueblos de campaña), datos sobre terrenos de propiedad pública, cuestiones de tierras y relación con el Departamento Topográfico.

En cuanto al ganado se le pedía que tomara medidas contra el abigeato (tales como lograr que no quitaran el cuero de las ovejas sin orejas el 13 de febrero de 1873), y el registro de firmas para evitar la falsificación en las guías. Respondiendo a una consulta del juez de paz de 25 de mayo, y según dictamen del fiscal, el Gobierno decretó que las guías otorgadas por los jueces de paz de campaña debían llevar su firma, sello del juzgado y un contrasello común a todos los juzgados. Para evitar las falsificaciones el juez cuando asumía el cargo, junto con el procurador municipal -que era su sustituto- debía enviar una nota a sus colegas y a los comisarios de Tablada con los sellos y firmas que utilizaban en los actos oficiales. Cuando el Código Rural fue sancionado se les envió y dos años después les solicitaron una memoria con las dificultades para su aplicación. ${ }^{77}$

Unas de las cuestiones permanentemente presentes en las notas eran las relacionadas con la Guardia Nacional: enrolamiento, cooperación con las partidas para activar la aprehensión de desertores y la recolección de las caballadas, determinando las expropiaciones y lo que se pagaba por ellas; sobre las raciones que debía darse a las familias de la Guardia cuando marchaban a campaña y la revista de inválidos para remitirlos a la Comisaría General de Guerra; sobre

\footnotetext{
${ }^{77}$ El código rural de la provincia de Buenos Aires fue sancionado en 1865. Valentín Alsina, elaboró en 1856 una encuesta de la que participaron estancieros, labradores y arrendatarios, que brindaron su parecer y las posibles soluciones a los problemas que aquejaban al mundo rural. Uno de los temas más conflictivos, que puso de manifiesto la contraposición de intereses, fue el límite del derecho de propiedad y de uso de bienes comunes. Fue así que Alsina al elevar el proyecto de Código Rural, buscó mediar entre las voces, optando por la costumbre frente a los principios del derecho. Pero también dio prioridad a la búsqueda de un principio de ley que reforzara los derechos de propiedad privados o públicos. El código fue muy difícil de aplicar por el débil desarrollo institucional del estado provincial. Zeberio, Blanca, "Los derechos civiles en transición. Controversias jurídicas y proyectos políticos", en Bonaudo, Marta; Reguera, Andrea y Zeberio, Blanca (coordinadoras) Las escalas de la historia comparada, tomo I: "Dinámicas sociales, poderes políticos y sistemas jurídicos”, Buenos Aires, Miño y Dávila, 2008, pp. 285-307.
} 
expedición de pases de licenciados del ejército, que no debían exceder los 15 días fuera del partido; para que recogieran el armamento en manos de particulares.

Otra constante eran las filiaciones enviadas por el Departamento General de Policía o jueces del crimen por delitos, deserción o fuga, y las circulares sobre la conducción de presos y oficios de urgencia. Presentamos un ejemplo de los datos que debía registrar una filiación, en este caso del prófugo criminal Nicanor:

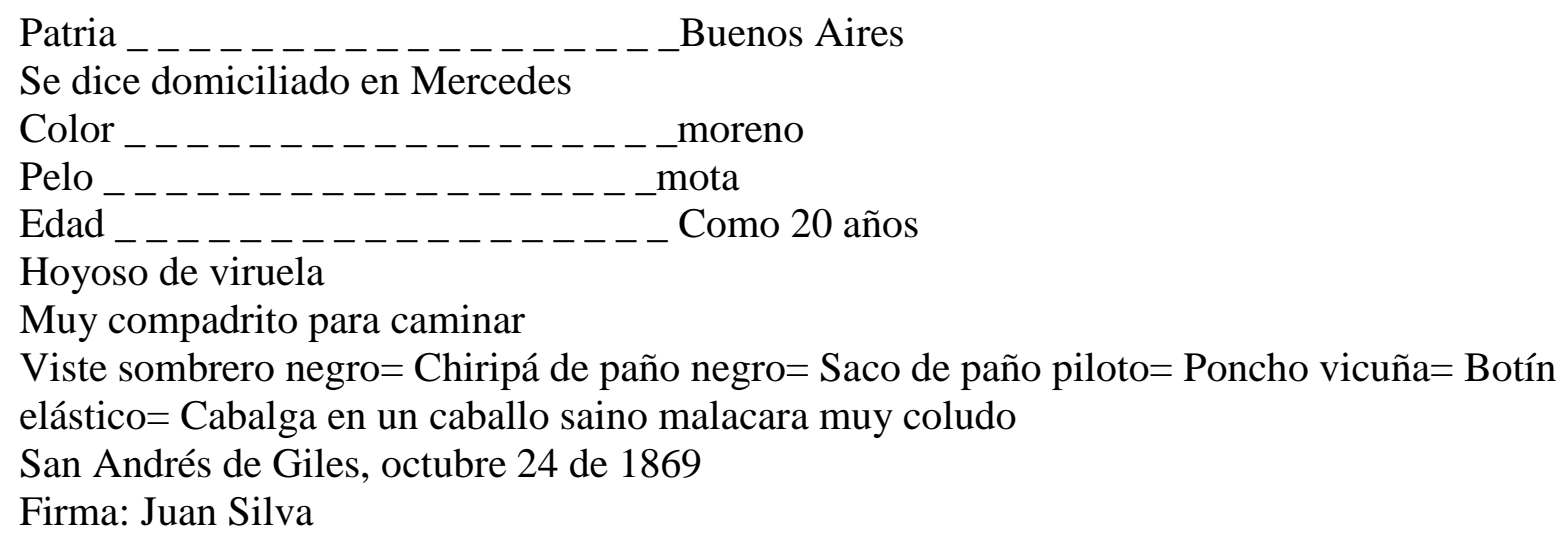

En los primeros años, la ocupación del Gobierno respecto a la policía se manifestaba pidiendo la relación del vestuario y armamento que tenía el juzgado y en que estado se hallaba. Después de 1873 se observa mayor preocupación en la organización del servicio de policía, con la exoneración de un oficial de la partida policial por no cumplir con sus deberes y la aprobación de la propuesta de Manuel Fernández para su reemplazo Le comunicaban también el pedido a contaduría del ajuste de haberes correspondientes para el oficial nombrado de la partida de policía del juzgado, Braulio Burgos, desde el 1 de abril.

Las oficinas de Gobierno aumentaban y con ellas las tareas y responsabilidades del juez de paz. En cuanto a la estadística provincial, debían participar con los datos de su partido enviándolos en cuadros con planillas modelos y datos censales. Respecto a la salud registraban la nómina de profesores de medicina, mandaban quemar cuerpos de animales enfermos, aplicaban las recomendaciones sobre el cólera en 1874 y sobre epizootias según el código rural. Debían también vigilar de circulación de billetes falsos en la campaña, asegurarse de que enterraran a los protestantes en los cementerios e informar a la Comisión protectora de las bibliotecas populares sobre el movimiento de libros.

Toda una faena era la de los pasaportes, a los que el juez de la Fuente dedicó un expediente especial. Pero recordemos que desde 1822 en la campaña "la expedición y administración del ramo de pasaportes" correspondía al Departamento General de Policía y ningún juez podía expedirlos, lo 
que significaba que el juez lo hacía como comisario. ${ }^{78}$ Por ejemplo, unos pasaportes correspondían a los soldados de policía Valentín San Martín y Nicolás Sánchez que conducían un preso a San Andrés de Giles en 1862. En el pasaporte debía constar la fecha de emisión, destino, objetivo del traslado, firma autorizante, fecha de entrega y el receptor. Estos son los números que pueden dar una idea de la circulación en el partido.

Cuadro 3

Juzgado de paz de Exaltación de la Cruz

Pasaportes

\begin{tabular}{|c|c|}
\hline Año & pasaportes \\
\hline 1861 & 41 \\
\hline 1862 & 26 \\
\hline 1863 & 12 \\
\hline 1864 & 11 \\
\hline 1865 & 31 \\
\hline 1866 & 44 \\
\hline 1867 & 26 \\
\hline 1868 & 15 \\
\hline 1869 & 8 \\
\hline 1870 & 7 \\
\hline 1871 & 9 \\
\hline 1872 & 5 \\
\hline 1873 & 10 \\
\hline 1874 & 22 \\
\hline 1875 & 15 \\
\hline 1876 & 9 \\
\hline 1877 & 13 \\
\hline 1878 & 10 \\
\hline 1879 & 9 \\
\hline 1880 & 2 \\
\hline
\end{tabular}

Fuente: Correspondencia arreglada por el juez de paz Manuel F. de la Fuente en 1881 Caja 2 Inventario $\mathrm{N}^{\circ} 4$

En cuanto a la función judicial, los jueces de paz eran, según la definición de Carlos Tejedor, magistrados que podían conocer de la acción civil de ciertos delitos, de la vagancia y en primera instancia del abigeato en la campaña. Eran capaces de ejercer jurisdicción criminal en los robos de ganado que no excediera las seis cabezas, acompañados de dos vecinos, por un decreto de 1825, en el que podían imponer la pena de azotes. Pero en la década del setenta la jurisdicción criminal estaba en deceso y el juez de paz tenía solamente "cierta jurisdicción correccional". ${ }^{79}$

Sobre las funciones judiciales delegadas, ${ }^{80}$ las notas de juzgados de primera instancia eran pocas y mínimas las del Superior Tribunal (cinco en los años trabajados). De las últimas, dos eran

\footnotetext{
${ }^{78}$ ROPBA, 1822, p. 136.

${ }^{79}$ Curso de Tejedor, II, núm. 106, 107 y 431.

${ }^{80}$ Podían ser "infinitas las ordenes que el juez de paz" recibiera y debiera cumplir "al pie de la letra". Por ejemplo recibir despacho del Tribunal Superior o tribunal de primera instancia o tribunal de comercio para citación o emplazamiento de alguna persona a comparecer sobre cuestión de justicia o contestar demanda, tomar declaración reconocer documento, absolver posiciones o ratificar declaración anterior. Otras diligencias eran un discernimiento de tutela, un inventario o tasación, que podía realizar por medio de su alcalde más cercano, un embargo, la prisión o
} 
de 1862, una de ellas una circular explicitando los casos en que debían conocer los jueces correccionales y otra citando a Catalina Sosa. En 1864, por fallecimiento del español José Vivas, le recordaban al juez el decreto relativo a testamentaria del 19 de noviembre de 1862 e informaban el nombramiento de Tomás Castro como secretario del Superior Tribunal. El 5 de mayo de 1874 el Superior Tribunal pidió informe acerca de la solicitud del escribano Rufino Acosta de extender su jurisdicción de Pilar hasta Exaltación de la Cruz, pedido que se relacionaba con el movimiento de descentralización de las funciones del juez de paz, que como hemos visto se desempeñaba como escribano en los partidos que no lo tenía.

Los jueces de primera instancia en sus notas solicitaban la mensura de terrenos públicos y privados (en algunos casos a través de otros jueces de paz), trámites en testamentarias (pedido de partidas de defunción y tasación de bienes, permisos para transportar hacienda, envío de martilleros para la venta de los bienes) y concursos. Pedía al juzgado de paz la filiación de prófugos (como solicitaba la de Juan Moreira en 1873 el secretario del Juzgado del crimen del Centro, Laurentino Cruz) o su captura (como el 25 de abril del año siguiente el juez Antonio Benguria pedía la de Moreira por varios delitos). Mandaban tomar declaración por homicidio, consultaban sobre el estado de detenidos y pedían sus antecedentes. Estarán más presentes las funciones delegadas de primera instancia en la relación entre los juzgados de paz.

También enviaban los jueces indicaciones sobre cómo realizar sus funciones, como la circular del 27 de septiembre de 1873 redactada por Antonio Benguria, juez del crimen del Departamento del Centro, enviando desde Mercedes las reglas para la instrucción de sumarios. ${ }^{81}$ Lo curioso es que se refería a "los jueces de este Departamento" y Exaltación pertenecía, según la ley, al Departamento Capital. Al respecto podemos afirmar que el movimiento de los juzgados, especialmente en la relación entre los jueces de paz, no manifiesta en estos años la pertenencia a un departamento judicial determinado, sino más bien se relacionaba con la cercanía, de hecho no aparece en ningún momento nada relacionado con el Departamento Sud. ${ }^{82}$ Como podemos observar

remisión de una persona, desalojo o demolición por fuerza contra arrendatario que no cumplió orden anterior. Tejedor, Manual civil, pp. 19-21.

${ }^{81}$ El 27 de septiembre de 1873 Antonio Benguria envía una nota al juez de Paz del Partido de la Exaltación de la Cruz diciendo: "Como en algunos de los sumarios criminales que levantan los jueces de este Departamento, ha observado el suscrito muchas deficiencias que alargan las causas que se siguen ante este juzgado como supresión de careos, rueda de presos; se recomienda a V. practicar en los sumarios criminales todas las diligencias prescritas en el Manual de los Jueces de Paz para lo Criminal hasta dejar claramente probado quien o quienes son los autores de cada delito y claramente constatado cual sea este, o bien hasta constatar evidentemente la imposibilidad de averiguarlo, con cuyo motivo se previene a Ud. que por una acordada dictada por el Superior tribunal de Justicia está mandado que en las declaraciones se debe hacer constar además de la edad, profesión o ejercicio, el domicilio de cada uno de los declarantes." Correspondencia del Juzgado de Paz de Exaltación de la Cruz, año 1873, No inventario 34, p.174. Reglas para la instrucción de sumarios.

${ }^{82}$ En cuanto a las causas competencia de primera instancia, podemos afirmar basándonos en el Departamento Sud, -por contar con su catálogo y haber trabajado en su elaboración- que se respetaba la jurisdicción, pues si bien encontramos expedientes correspondientes a los otros tres Departamentos, no son más de dos y puede deberse al reemplazo del juez a cargo. Sólo llama la atención General Alvear, pues nueve causas fueron atendidas por Julián S. Aguirre entre 1875 y 1879 . 
en el cuadro 4 la mayor cantidad de notas las recibía Exaltación de la Cruz de Zárate y de Pilar, los más cercanos del Departamento Capital, siguiéndole en número San Andrés de Giles del Departamento del Norte.

Esta relación más estrecha entre algunos jueces de paz podemos confirmarla en otro tipo de notas que se enviaban. Por ejemplo el 5 de octubre de 1868 el juez de Pilar invitaba al de Exaltación con la familia a la fiesta del pueblo (por la fecha se refería a la celebración de Nuestra Señora del Pilar el 12 de octubre). El 14 de enero de 1863 el juez de paz de San Andrés de Giles, Eustaquio Sosa, ofrecía sus servicios a los jueces de paz lindantes al asumir su cargo. El 28 de noviembre de 1864 el juez de paz de Zárate le pedía prestados a su colega de Exaltación los Registros Oficiales de 1860 y 1861. Pero la nota más llamativa al respecto fue una invitación que recibió el 24 de agosto de 1874 a un meeting en Mercedes para exigir a los diputados las reformas que acordaba a la campaña la nueva Constitución. Esto manifestaba que los jueces de paz de la campaña, o al menos algunos de ellos, eran conscientes de la necesidad de descentralizar el municipio convirtiendo a los jueces de paz en funcionarios exclusivamente judiciales, tal como decía el texto constitucional.

Para constatar las funciones que los jueces de paz cumplían en relación a justicia a nivel local trabajamos con la correspondencia que recibían de diversos juzgados, y a partir de 1866 notamos que entre ellas estaban también las copias de las que Exaltación enviaba a otros jueces. Antes de dedicarnos a su contenido, es importante aclarar que estamos tomando un ejemplo en años que los partidos de la provincia aumentaron al mismo ritmo que se extendió su territorio. El objetivo no es generalizar los datos (cosa imposible en tierras tan extensas, con tan distintos tiempos de colonización y posibilidades de transporte) sino observar de qué forma la legislación dictada se aplicaba en un caso concreto, en definitiva como laboratorio del funcionamiento judicial de un juzgado.

Las copias de notas enviadas por el juez de paz de Exaltación de la Cruz que encontramos desde 1866 acompañan envío o acusan recibo de presos; piden a un médico reconocer un cadáver en una pulpería, evaluar la idoneidad de un vecino para aplicar ventosas y realizar sangrado, reconocer y curar mordedura de perro o informar sobre una clase de lesión. También intimaban a contestar demandas, notificaba sobre trámites cumplidos del proceso, citaba herederos para testamentaria o a mayores con menores a cargo para que se presentaran a la Defensoría de Menores local. Notificaba al agrimensor público comisionado por el juez de primera instancia para medir terrenos y notificar a los linderos.

Con la lectura de las notas recibidas en el juzgado, en primer lugar realizamos un cuadro para establecer el partido de origen y la cantidad por año para tener una idea de la magnitud de la relación entre juzgados. 


\section{Cuadro 4}

Cantidad de notas enviadas por los jueces de paz al juzgado de paz de Exaltación de la Cruz entre 1862 y 1874 ordenadas por partido

\begin{tabular}{|c|c|c|c|c|c|c|c|c|c|c|c|}
\hline Partido & Departamento & 1862 & 1863 & 1864 & 1865 & 1866 & 1867 & 1868 & 1869 & 1873 & 1874 \\
\hline Arrecifes & Norte & & 1 & & & & & & & & \\
\hline Baradero & Norte & 2 & 4 & & & 1 & & & & & \\
\hline $\begin{array}{l}\text { Carmen de } \\
\text { Areco }\end{array}$ & Centro & & & & & & & & & 1 & 1 \\
\hline Chivilcoy & Centro & & & & & & 1 & & & 1 & \\
\hline Conchas & Capital & & 1 & & & & & & & & 2 \\
\hline Mercedes & Centro & & & & 1 & & & & & 1 & \\
\hline Moreno & Capital & & & & & & 1 & 1 & & 1 & 2 \\
\hline Morón & Capital & 1 & & & & & & & & & \\
\hline Pilar & Capital & 16 & 10 & 8 & 6 & 9 & 3 & 4 & 8 & 6 & 1 \\
\hline Rojas & Norte & & & & & & & & & & 1 \\
\hline $\begin{array}{l}\text { San Andrés } \\
\text { de Giles }\end{array}$ & Centro & 9 & 9 & & 4 & 1 & & 1 & 2 & & \\
\hline $\begin{array}{l}\text { San } \\
\text { Antonio de } \\
\text { Areco }\end{array}$ & Centro & 1 & & & & 1 & 1 & & 2 & 4 & 8 \\
\hline $\begin{array}{l}\text { San } \\
\text { Fernando }\end{array}$ & Capital & 1 & 1 & & & 1 & & & & & \\
\hline San Martín & Capital & & & & & & & & & & 1 \\
\hline $\begin{array}{l}\text { Villa de } \\
\text { Luján }\end{array}$ & Capital & 2 & & 1 & 2 & 3 & 3 & & 4 & 5 & \\
\hline Zárate & Capital & 11 & 16 & 22 & 10 & 8 & 7 & 16 & 9 & 13 & 9 \\
\hline
\end{tabular}

Fuente: Correspondencia arreglada por el juez de paz Manuel F. de la Fuente en 1881 Inventario $\mathrm{N}^{\circ} 23$ a 30,34 y 35

El segundo paso fue determinar las funciones relacionadas con la administración de justicia que los jueces de paz cumplían en estos años. El recibo y la remisión de presos era de las más frecuentes, en algunos casos aclaraban que acompañaba el sumario, al juzgado criminal del Centro, de la Capital o del Norte. Los presos eran llevados desde un juzgado de paz o el Departamento de Policía al juzgado de primera instancia dónde serían juzgados, deteniéndose en los juzgados en tránsito. Por ejemplo el 4 de noviembre de 1866 llegó de Pilar el preso Juan García, procedente de Las Conchas con destino al Departamento del Norte en San Nicolás. El 1 de abril de 1867 el juez de Pilar remitió un preso recibido de Las Conchas, originario de San Isidro con destino a Zárate. El 18 de agosto de 1869 de Pilar llegaron cuatro presos que por orden del jefe de policía eran remitidos para el juez del crimen del Departamento del Norte (habían pasado por Belgrano, San Isidro, San Fernando y Las Conchas) El 12 de mayo de 1874 de Zárate fueron remitidos los presos Andrés Flores y Margarita Olloa al juzgado de Mercedes del juez Antonio Benguria, con el sumario correspondiente. 
Otra correspondencia pedía o respondía a pedidos sobre averiguación de domicilio, informe sobre paradero de jóvenes, capturas, robos, lesiones, carreras organizadas en pulpería, daños de animales (mucho más presentes en estos juzgados que el hurto), disparo en casa de negocios. Realizaban citaciones a contestar demandas o ser testigos, pedidos de declaración, interrogatorio acompañados de las preguntas o informes médicos, solicitud de noticias de familiares herederos de heridos en la batalla de Pavón. Informaban sobre la libertad de un preso, pedían la remisión de menores. Solicitaban informes sobre demanda de cobro de pesos, ejecuciones de pagares, mensuras de terrenos de propiedad pública, inventario de bienes para testamentaria, preguntando por paradero de un individuo, reconocimiento de cadáver, sumario de homicidio o heridas.

También informaban las sentencias dictadas o detenciones. Veamos algunos ejemplos: El juez de Zárate el 12 de enero de 1869 notificó la prisión de Nicolás Polleri, maquinista, que reparando el órgano del templo de Exaltación inutilizó tres registros con un hacha. El 21 de agosto de 1869 solicitó ordenar al vecino José Olivera el pago de $\$ 300 \mathrm{~m} / \mathrm{c}$ por daño de sus animales en los sembrados de Pablo Rodríguez, con tres días de plazo. El 30 de enero de 1869 el juez de San Antonio de Giles informó la captura de varios hombres en la pulpería de Pedro Martínez puestos en la cárcel pública del pueblo. El 24 de abril de 1873 el juez de San Antonio de Areco enviaba el pedido de captura de Eusebio Alvarez que debía marchar a la Inspección General de Milicias por robo a vecina con arma en mano. Otra vez desde Zárate, el 30 de abril de 1873 se pedía la retención de $\$ 120$ del sueldo del vigilante Miguel Cardoso que adeudaba por arreglo de cuentas pendientes y el 25 de julio de 1874 solicitaba el embargo de carro a Valentín San Martín por falta de patente.

Como podemos observar en estos ejemplos las cuestiones eran muy variadas y se pretendía que el juez de paz respondiera a todas ellas, en esta posición de tensión entre la pertenencia a un partido y la obediencia a un Gobierno. Respecto a esto último, el juez debía acompañar la resolución de los conflictos internos y cotidianos de su partido y los de la provincia, como lo prueban dos notas enviadas desde Zárate el 27 y 30 de noviembre de 1874. En la primera adjuntaba la copia del telegrama del ministro del interior felicitando al juez de paz por el "nuevo triunfo sobre la rebelión"; en la segunda remitía el telegrama del comandante de la Guardia Nacional Gervasio Capello que expresaba la gloria de haber triunfado y felicitaba al juez de paz y al Comandante de ese pueblo.

\section{La preocupación por la descentralización}

La división de poderes era una cuestión por todos aceptada, sin embargo este consenso no se dio de la noche a la mañana y tampoco su discusión se generó en una sola línea o siguiendo un único modelo. Como afirma Oreste Cansanello la división de poderes resultó de las transformaciones requeridas por el mundo moderno, como parte del proceso de extensión de 
libertades individuales y de cambios radicales en el derecho de propiedad y el proceso político hasta Caseros se destacó por la concentración de poderes ${ }^{83}$ Específicamente en la justicia, el proceso tendiente a la formación de un poder judicial independiente fue largo y penoso cruzando el umbral del medio siglo. ${ }^{84}$

Esta concentración tuvo su base en la pervivencia de la Real Ordenanza de Intendentes de 1782, que como ordenamiento político y administrativo del Virreinato del Río de la Plata, prolongó su influencia después de mayo de 1810 en el ámbito nacional y provincial. Las cuatro causas justicia, hacienda, guerra y gobierno- se ejercían por los nuevos funcionarios, configurando poco a poco las secretarías o ministerios y las modificaciones no alteraron fundamentalmente la estructura hasta 1820 y siguió presente en la organización que intentaron darse las provincias. Los reglamentos y constituciones que se dictaron tenían inspiración ideológica pero fallaban al confrontarse con la realidad, eran reformas parciales cuya teoría superaba los conflictos por resolver y la división de poderes no lograba concluirse. ${ }^{85}$

Una vez formada la provincia, las reformas republicanas se caracterizaron por su naturaleza bifronte, una parte atada férreamente al pasado y otra en búsqueda de un orden liberal y moderno. ${ }^{86}$ La solución “inventada” por Rivadavia en 1821 combinaba nociones modernas de representación política, centralización y división de funciones en los espacios locales, con la tradición hispánica, representada en las jurisdicciones territoriales coloniales, los partidos de campaña y en las atribuciones de los alcaldes de hermandad que se prolongaban en los jueces de paz. ${ }^{87}$

La división de funciones no logró en varios aspectos superar la letra de la ley y a pesar de reiterados intentos estos funcionarios sumaron atribuciones y competencias que los liberales, según sus propias palabras, buscaban “descentralizar”. La preocupación por la descentralización había comenzado antes de 1873 y fue puesta de manifiesto el 9 de octubre de 1867, cuando el poder ejecutivo provincial elevó un proyecto de ley a la Honorable Asamblea General Legislativa, firmado por Nicolás Avellaneda -ministro de gobierno- y Mariano Varela -ministro de hacienda y el gobernador Adolfo Alsina.

El documento partía de la necesidad imperiosa de separar las funciones judiciales de las administrativas que se hallaban resumidas en los jueces de paz y el primer paso era "dar formas regulares a la organización de la Campaña”. En el mensaje del poder ejecutivo a la Asamblea Legislativa, en mayo del mismo año, la urgencia del cambio había sido expresada con firmeza, asegurando que la campaña tenía una necesidad apremiante que era preciso llenar a todo trance: "su

\footnotetext{
${ }^{83}$ Cansanello, 2003, op. cit., cap. V.

${ }^{84}$ Levaggi, Abelardo, "Espíritu del constitucionalismo argentino de la primera mitad del siglo XIX", en Revista de Historia del derecho, núm.9, Buenos Aires, Instituto de Investigaciones de Historia del Derecho, 1981, p.284.

${ }^{85}$ Díaz Couselo, 1995, op. cit., p. 233-234.

${ }^{86}$ Cansanello, 2003, op. cit., p.67.

${ }^{87}$ Ternavasio, 1999, op. cit..
} 
reforma administrativa, aunque, hablando con propiedad, más que reformar la Administración, es preciso crearla, porque lo que hoy existe es tan irregular y tan monstruoso, que ni el nombre de Administración merece". ${ }^{88}$

La propuesta de ley enumeraba los objetivos que debían alcanzarse:

...procurar que el ejercicio de todos los derechos esté sólidamente garantido, que la seguridad individual sea un hecho, que la responsabilidad de los funcionarios pueda hacerse efectiva, que no haya autoridades sin contrapeso, que se de a las Municipalidades elementos de vida propia, para que dejen de ser tributarias, que la acción del Gobierno se haga sentir en ellas más para fiscalizar que para administrar, la uniformidad de un sistema de contabilidad, reglamentación del juicio administrativo para averiguar y castigar los abusos de autoridad.

En la presentación del proyecto se sostenía que la división de funciones, sumada a la nueva organización de los tribunales también proyectada, sería la base para aproximar el litigante a su juez. Esta voluntad de descentralizar la administración había quedado de manifiesto en un decreto del mismo Gobierno, que establecía que no se atendería en las oficinas de Gobierno ningún escrito que tuviera por objeto denunciar abusos de los jueces de paz, cuando estos hubieren procedido como funcionarios de la administración de justicia. ${ }^{89}$

El ministro de gobierno Nicolás Avellaneda dedicó en las Memorias de su Departamento un largo capítulo a la organización de la campaña, abocándose especialmente al poder judicial y al sistema municipal. Un primer diagnóstico de la situación lo llevó a concluir que "el principio de la separación y de la independencia respectiva de los poderes públicos sobre el que reposa nuestra constitución política, no ha penetrado en la campaña...La regla americana que proclama la necesidad de establecer tantos funcionarios, cuantas son las funciones, para emplear el mayor número en la gestión de los intereses comunes, y para que la autoridad pueda ser grande, siendo el funcionario pequeño, encuentra igualmente su negación más completa". 90

La solución radicaba en que el ejecutivo tuviera sus agentes propios, que no fueran los jueces, para evitar así la arbitrariedad logrando "la aplicación severa e imparcial de la ley, que sólo se opera por el ministerios de la justicia”. ${ }^{91}$ La administración de justicia debía descentralizarse, aumentando el número de jueces y ampliando sus facultades para lograr el acceso a la justicia, a la que renunciaban muchos habitantes de la campaña por la distancia y los costos.

Pero Avellaneda no se detuvo en el diagnóstico y la posible solución, sino que realizó una dura crítica al poder judicial, cuya organización -en palabras del ministro-era "inadecuada y deficiente. Estaba centrada en la ciudad, distante de trescientos mil habitantes que reclamaban una intervención

\footnotetext{
${ }^{88}$ ROPBA, 1867, Buenos Aires, Imprenta Argentina El Nacional, 1868, p.163.

${ }^{89}$ Decreto del 2 de Setiembre de 1867, "Sobre quejas o denuncias de abusos de los Jueces de Paz ante el Gobierno". ROPBA de 1867, Buenos Aires, Imprenta Argentina de El Nacional, 1868, p.399.

${ }^{90}$ Memorias del Departamento de Gobierno de la Provincia de Buenos Aires 1866-1867. (en adelante Memoria de Gobierno 1866-1867) Para la afirmación sobre las funciones y el funcionario citó a Kent

${ }^{91}$ Memoria de Gobierno 1866-1867, p. XXXVIII.
} 
inmediata y pronta que les permitiera vivir bajo el amparo de la ley". El Superior Tribunal era numeroso, y sus miembros -más que los de la Corte Suprema de los Estados Unidos- estaban “inmóviles en sus asientos, esperando que venga el litigante con su pleito y el delincuente con su delito desde los confines de la Provincia, para decidir la contienda del uno y la culpabilidad del otro, con su sentencia justa sin duda, pero tardía, costosa e ineficaz". ${ }^{92}$ Después de arrojar el guante al rostro de los magistrados, lo recoge buscando dejar claro que el problema no estaba en su incapacidad sino en el sistema judicial, poniendo como ejemplo al juez americano o inglés que dejaba la sede de sus tribunales para trasladarse allí donde se producía el litigio o el delito.

Estas ideas las concluye en un párrafo que consideramos una oportuna síntesis de la relación entre ciudad y campaña en lo que se refería a la administración de justicia, yendo aún más allá y definiendo lo que consideraba que significaba la justicia y la ley en una sociedad:

Apenas hay una materia que deba preocupar más a nuestros hombres públicos, como la adecuada distribución del Poder Judicial. Acumular sistemáticamente los jueces en la ciudad, para que no abandonen jamás su recinto, es poner fuera de la ley civil a la campaña, sujetando a sus moradores a ser perdurablemente víctimas del desorden, de la injusticia y de la violencia. La centralización administrativa hiere de esterilidad cuanto toca; comprime el desarrollo de las poblaciones, ahoga su iniciativa; pero no introduce al menos en ella la perturbación de los vínculos sociales, que viene fatalmente aparejada con la ausencia del juez y de la ley que sólo tiene vida, cuando éste la aplica y la imprime a las relaciones de los hombres. ${ }^{93}$

Pero a su entender, aumentar el presupuesto y el número de funcionarios no era suficiente, pues aún se hallaban "ante los umbrales de la vieja Audiencia" y se conservaban procedimientos judiciales que eternizaban los litigios manteniendo errores que la ciencia del derecho había superado. Era entonces indispensable aplicar el juicio por jurados, superando al "juez del antiguo régimen" y "el absurdo sistema de las pruebas legales", que en muchos casos hacían de sus fallos un acto mecánico y ciego. ${ }^{94}$ Pedía que se eliminara la necesidad de la firma de un letrado para peticionar ente la justicia y que se diera publicidad a las sentencias para que el juez de los jueces fuera la opinión pública. Estas eran las reformas que el poder judicial necesitaba pues "si la libertad es el derecho, la justicia es la garantía y no acierta a vivir sino por su aplicación rápida y eficaz". 95

Ciertamente esta exposición de Avellaneda iba más allá de la justicia de paz y esto se explica en que su reforma local debía insertarse en otro poder judicial y en un espíritu comunal que apenas existía, para poder "formar pueblos y crear hombres aptos para los fines de la República y para el gobierno de sí mismos [...] Si la educación da al hombre el conocimiento de sus derechos, si la justicia los garante, el municipio le presenta el primer teatro en que debe ejercitarlos". ${ }^{96}$ He aquí las instituciones que la Constitución había impuesto al régimen provincial, donde el ciudadano se

\footnotetext{
${ }^{92}$ Memoria de Gobierno 1866-1867, p. XL.

93 Memoria de Gobierno 1866-1867, p. XLI.

${ }^{94}$ Memoria, de Gobierno 1866-1867, p. XLIII.

${ }^{95}$ Memoria, de Gobierno 1866-1867, p. XLIV-XLV.

${ }^{96}$ Memoria de Gobierno 1866-1867, p. XLVI-XLVII.
} 
vinculaba con la comunidad y que Buenos Aires estaba aún lejos de alcanzar, y que sería imposible con un juez de paz presidente de la municipalidad. Las instituciones políticas debían cimentarse en una triple base, fundamento de la organización social, que tuvieran por objeto: “...iluminar la inteligencia del hombre en la Escuela, desenvolver su personalidad en el Municipio, y darle seguridad bajo el amparo de la Justicia". ${ }^{97}$

Unos años después, en la Memoria que Antonio Malaver redactó en 1872, insistía en que se debía quitarles a los jueces de paz las municipalidades y toda influencia en los actos electorales, pero había que esperar a que en el pueblo se generalizaran los principios del gobierno propio, para que la elección de los jueces fuera popular, dándole tiempo al municipio para que actuara como escuela donde el pueblo aprendiera conocer sus intereses y sus derechos.

\section{Conclusión}

El estudio de la justicia de paz lleva al ejercicio de pensar a la provincia de Buenos Aires como un todo que atraviesa el río Salado y extendiéndose hacia el sur y hacia el oeste. Estas tierras son ocupadas por nueva población, en buena medida inmigrantes, que reclaman seguridad para sus haciendas y sus vidas. Los protagonistas del proceso de formación del Estado provincial concebían ese crecimiento en la dicotomía desierto-civilización y ciudad-campaña, queriendo superarlas en el texto constitucional de 1873, como quedó expresado en las elocuentes palabras de José Manuel Estrada:

...La palabra campaña ha sido suprimida por la Convención Constituyente del vocabulario político de este país. Valdría la pena de haber empleado tres años de trabajo y un puñado de dinero que muchos lloran con las lágrimas de Shylock, sólo por adquirir esta modificación del lenguaje. No lo dudéis. El soplo de un nuevo espíritu borra esa palabra, símbolo de la desigualdad, doloroso emblema de contradicciones atroces y de rivalidades brutales. ${ }^{98}$

Cierto es que la aspiración de este grupo de intelectuales de eliminar la contradicción ciudadcampaña sólo quedó en borrar la palabra del vocabulario y que aún hoy influye en la organización política provincial, con inmanejables concentraciones urbanas y campos cada vez más despoblados y con graves problemas de comunicación, que Antonio Malaver suponía en los años setenta del siglo XIX que estarían prontamente resueltos.

La organización provincial tenía una profunda diferencia entre los juzgados de paz de la ciudad y de la campaña, con la grave concentración de funciones que se daban en estos últimos, pero que lógicamente no se daría en los barrios de Buenos Aires, dirigidos directamente por el

\footnotetext{
${ }^{97}$ Memoria de Gobierno 1866-1867, p. LXXVI. Avellaneda termina el texto reiterando la necesidad de la descentralización judicial y poniendo como ejemplo para la organización municipal los cuerpos comunales de Bélgica y la Unión Americana.

${ }_{98}$ En Obras Completas, tomo X, Buenos Aires, Librería del Colegio, 1904. Citado por Halperín Donghi, Tulio Proyecto y construcción de una nación (1846-1880), Buenos Aires, Biblioteca del Pensamiento Argentino II, Ariel Historia, 1995.
} 
poder central. Aceptada esta situación, confirmada en el movimiento del juzgado de Exaltación de la Cruz, lo importante es comprender por qué las leyes y decretos que buscaban la descentralización, en muchos casos logrando aplicarse, no podían quebrar esa estructura política, administrativa y judicial que tenían los partidos provinciales, realizando marchas y contramarchas, claramente observables en los intentos de separar la función policial de la función judicial.

Una explicación, que aunque obvia no puede ignorarse, es la dificultad de encontrar hombres capacitados y en los que se pudiera confiar, no porque no existieran sino porque la concepción tutelar de esta elite intelectual les imposibilitaba reconocer talentos por fuera de sus propios círculos. Los hombres de gobierno del siglo XIX resolvían este problema unificando en una persona diversas funciones, pero, y esto es lo más interesante, logrando desdoblar la persona que obedecía a la autoridad correspondiente en cada una de las tareas asignadas.

El juez de paz era juez y respondía al Superior Tribunal; era comisario y obedecía al jefe de policía; era presidente de la municipalidad y daba cuenta al Gobernador; era comandante de campaña bajo las órdenes de la autoridad militar. ${ }^{99}$ Era una persona pero era varios funcionarios y el Gobierno le exigía que enviara una nota por cada asunto a la oficina correspondiente. ${ }^{100}$ Como la excepción confirma la regla, este "desdoblamiento funcional" queda confirmado al comprobar que el juez de paz no era escribano, expedía un documento que daba cierta garantía pero que no era escritura. Sin dudas, esta superposición de funciones y funcionarios podía darse en hombres con una cultura jurídica que preservaba la posibilidad del control a distancia superponiendo funciones y funcionarios.

La otra explicación es que el Estado de la provincia se estaba formando y si bien a nivel provincial los tres poderes estaban divididos y organizados, todavía no lograba determinarse con claridad el límite de sus competencias y continuamente se originaban conflictos entre ellos buscando establecer quien tenía el poder. Entonces, si a nivel provincial la división de funciones no estaba resuelta, difícil sería que pudiera encontrarse una respuesta a nivel local, donde la ley que lo formó depositaba buena parte de las atribuciones en el juez de paz. A esto se sumaba lo conflictivo de esa figura ambigua de un poder representante de los intereses de su comunidad y brazo territorial del Estado.

La Constitución Provincial de 1873 descentralizó las funciones administrativas a escala local pero sin fuertes debates, tal vez porque otras cuestiones requerían mayor atención y la opinión pública exigía la organización municipal que no podía dilatarse. La preocupación por la justicia de

\footnotetext{
${ }^{99}$ Cuando se organizó el gabinete de la provincia de Buenos Aires fue nombrado ministro de Guerra y Marina Francisco Fernández de la Cruz, ministerio que se mantuvo (con un cambio de nominación por Guerra y Relaciones Exteriores entre 1828 y 1829) hasta que el 14 de octubre de 1862 resolvieron disolverlo. Entonces se les envío a los jueces de paz una circular redactada el 26 de noviembre de 1862 solicitándoles que se dirigieran al Inspector General de Milicias.

${ }^{100}$ Correspondencia recibida en el juzgado de paz de Exaltación de la Cruz entre 1862 y 1874, expediente número de inventario $27,1866$.
} 
paz estaba ligada a dos problemas, uno político y otro que afectaba la organización judicial. Respecto al primero, coincidían en que la división de poderes era la única garantía de libertad y la justicia de paz - tal y como funcionaba- sólo garantizaba centralización administrativa y un gobierno provincial prácticamente sin límites. En cuanto al sistema judicial, un funcionario sin formación profesional, sin sueldo, inestable y con una competencia excesivamente extendida, no podía administrar justicia.

Desde el discurso se coincidía en la necesidad de una justicia independiente y accesible a todos, como garantía de libertad y seguridad individual. La elección popular de los jueces de paz era un tema que ya en la década del sesenta había enunciado Adolfo Alsina y que para los abogados tenía dos aspectos favorables, era garantía de una justicia popular y cercana, a la vez que servía para limitar el poder del Gobierno, al quitarle una atribución por años explotada. También al juez surgido de la elección popular, sin formación jurídica, era posible asignarle una competencia menor que dejara una jurisdicción más amplia a la justicia ordinaria.

En la decisión constitucional no hubo diferencias, pero sería la Legislatura la encargada de dictar la ley orgánica de la Justicia de Paz, y si la elección directa no podía organizarse en ese año el poder ejecutivo nombraría los funcionarios para 1874. Ésta fue la piedra del escándalo que no se resolvió y los jueces de paz nunca fueron elegidos por el pueblo y pasaron doce años hasta que un texto legislativo los definió funcionarios exclusivamente judiciales. ${ }^{101}$

${ }^{101}$ Constitución de la provincia de Buenos Aires de 1873, artículos 178-183 y Disposición transitoria artículo 227. Corbetta, Juan Carlos, Textos constitucionales de Buenos Aires, Buenos Aires, Suprema Corte de Justicia, 1984, pp. 115; 128-129. (en adelante Constitución provincial de 1873) El artículo que disponía la elección directa de los jueces de paz era el art. 180, pero por el artículo 227, en el resto de ese año, mientras no estuviera dictada la ley orgánica, el Poder Ejecutivo seguiría nombrando a esos funcionarios para el año 1874. Agreguemos aquí que este artículo incluía la salvedad también de que seguiría funcionando la justicia correccional como hasta el momento, a cargo de los jueces de paz en la campaña, pues en la ciudad la ejercía un juez letrado desde 1857. 


\section{Capítulo V}

\section{La primera instancia letrada civil, penal, correccional y comercial (1853-1874)}

\section{Introducción}

Al suprimirse el Cabildo de Buenos Aires en 1820, la justicia ordinaria fue organizada y administrada por cinco jueces letrados, rentados e inamovibles denominados jueces de primera instancia letrados, dos en la Capital y tres en la campaña. Algunos de los pueblos rurales como "sedes" -región física que interviene como escenario de la acción social, con fronteras que contribuyen a concentrarla y permite fijar las instituciones- alcanzaron una mayor jerarquía institucional como cabecera de los Departamentos Judiciales de campaña o cabecera de partido. El crecimiento económico y demográfico los transformó en espacios de construcción del poder institucional, que no alcanzó para sostener una estructura institucional intermedia; claro ejemplo de ello fue el fracaso de la primera instancia letrada en la campaña bonaerense. ${ }^{1}$

Durante el régimen de Rosas los nombramientos en la justicia se simplificaron en la práctica, siendo la lealtad a la causa federal, certificada por el gobernador y sus acólitos, el requisito principal para obtener el puesto. Así la legitimidad de la justicia no derivaba de la división de poderes sino de la adhesión a los objetivos del régimen rosista. ${ }^{2}$ La ley se convirtió en la llave simbólica que permitió a los subalternos entender el significado del Estado y su orden, constituyéndose también en fuente de resistencia subalterna y acortando la distancia que separaba al subalterno del sistema de justicia. ${ }^{3}$ En la campaña de Buenos Aires, después del intento frustrado de instalar jueces letrados, los jueces de paz fueron los representantes del poder judicial y cualquier demanda o delito que excediese su competencia debía resolverse ante los jueces de primera instancia letrados de la Capital.

Después de Caseros, la formación del Estado y de sus instituciones, el proceso de construcción de la autoridad y de la obligación política, se concentraron en dos cuestiones fundamentales: la producción de una nueva legitimidad política y de un nuevo consenso sociopolítico. En la administración de justicia, “...espacio clave de la vida institucional...”4, uno de los desafíos fundamentales fue la descentralización judicial. Por ello, aún antes de sancionada la Constitución provincial de 1854, Valentín Alsina promovió la creación de dos juzgados en el

\footnotetext{
${ }^{1}$ Barral, y Fradkin, op. cit. Los autores tomaron la definición de "sedes" de Anthony Giddens. Las causas esgrimidas para la instalación de los tres departamentos judiciales eran castigar los delitos y resolver los pleitos allí donde se producían, controlar y vigilar la campaña y suplir la falta de municipalidades. Ésta última fue en gran parte la semilla del fracaso de estos magistrados al resultar excedidos en sus funciones judiciales. Fradkin, 2009, op. cit., pp. 143-164

${ }^{2}$ Myers, 1995, op. cit., pp. 73-84.

${ }^{3}$ Salvatore, 2010, op. cit.

${ }^{4}$ Lettieri, 2006, op. cit.
} 
interior de la provincia, con jurisdicción criminal y opción por parte de los particulares a litigar causas civiles.

Esta decisión significaba extender la frontera política hacia la campaña, buscando el control y la seguridad a través de los magistrados letrados. A partir de allí la preocupación sobre la administración de justicia giró en torno a la organización del más alto tribunal, la descentralización judicial, la formación técnica de los magistrados, la fundamentación legal de las sentencias y la codificación. Resolver estas cuestiones significaba la conformación de otra frontera, la del poder judicial, con los otros poderes. Para la provincia, el proceso de constitución y consolidación del poder judicial como parte constitutiva del Estado, legitimador de su accionar político y mediador con la sociedad civil, ha sido poco estudiado después de 1852, menos aún la conformación de su primera instancia. ${ }^{5}$

Los abogados, que fueron instrumentales en la emergencia de una embrionaria "esfera política" dentro de las nacientes naciones independientes, ya sea como partícipes en las instituciones que dieron forma a una nueva sociabilidad política, ya sea como promotores de una transformación ideológica que los llevaría a presentarse como los nuevos políticos frente a la opinión pública, ${ }^{6}$ comenzaron entonces a formar en Buenos Aires una elite, que compartía códigos culturales pero que iba en su interior delimitando los roles del litigante, el político, el legislador y el magistrado.

Esto no sólo implicaba definir la figura del magistrado sino también establecer las condiciones que debería reunir. El Reglamento de justicia de 1812 determinaba que la primera obligación del magistrado era su integridad y la segunda, pero no menos exigente, la laboriosidad y contracción a los objetos de su cargo. ${ }^{7}$ Dicho Reglamento no mencionaba siquiera la idoneidad, que en la década de 1860 comenzó a ser un tema de preocupación y debate con el objetivo de que la justicia fuera administrada por magistrados "íntegros y competentes”.

Este capítulo está dedicado a estudiar en primer lugar cómo se conformó la primera instancia en todos sus fueros y para toda la provincia. Luego nos dedicaremos a las características de la magistratura, para finalmente determinar quiénes la ocuparon en esa primera instancia. Esto se dio en un proceso que tuvo su cúspide en 1874, cuando cambió la formación de los abogados, al crearse la Facultad de Derecho, sancionándose la ley sobre acumulación de cargos, por lo que los jueces

\footnotetext{
${ }^{5}$ Fasano, 2009, op. cit.; Yangilevich, Melina y Míguez, Eduardo, "Justicia criminal y Estado en la frontera de Buenos Aires, 1852-1880” en Boletín del Instituto de Historia Argentina y Americana Dr. Emilio Ravignani, número 32, Buenos Aires, ene./jun. 2010; Yangilevich, 2012, op. cit.; Sedeillan, 2012, op. cit. Para otras provincias Piazzi, 2010, op. cit.; 2011, op. cit.; Ramírez Braschi, 2008, op. cit.

${ }^{6}$ Uribe-Uran, Víctor, "Colonial Lawyers, Republican Layers and the Administration of Justice in Spanish America", en Zimmerman, Eduardo (editor), Judicial Institutions in Nineteenth-Century Latin America, Institute of Latin American Studies, University of London, 1999, pp. 25-48.

${ }^{7}$ Reglamento de institución y administración de justicia del Gobierno Superior Provisional de las provincias del Río de la Plata, Supresión de la Audiencia y creación de la Cámara de Apelaciones en Acuerdos y Sentencias, tomo I, pp. 144148.
} 
sólo debían atender sus juzgados, y fue organizado el poder judicial, encabezado por la Suprema Corte de Justicia, cumpliendo las pautas establecidas por la Constitución aprobada en 1873. Entre 1853 y 1874 se sentaron las bases para la formación de la carrera judicial, con abogados dedicados a la magistratura que comenzaban a dejar la vida política para dedicarse a una formación específica que se expresaría en la especialización del derecho positivo de los años siguientes.

\section{La justicia letrada en toda la provincia}

Antes de la instalación definitiva de jueces letrados en la campaña, Hilario Lagos mientras tenía sitiada a Buenos Aires y haciendo uso de las facultades que "espontáneamente le confirieron la mayoría de los habitantes de la campaña”, instaló el Consejo de Administración el 25 de mayo de $1853 .{ }^{8}$ Este Consejo, presidido por Francisco Pico, envió una circular a los jueces de paz el 4 de junio de 1853, por la que les informaba del decreto que establecía cuatro distritos judiciales, a cargo cada uno de un juez letrado, a constituirse en San Nicolás, Guardia de Luján, Dolores y San José de Flores, residencia oficial del Comandante del Ejército y del Consejo de Administración. ${ }^{9}$ Si bien estos juzgados nunca se instalaron, la resolución ponía de manifiesto que quien quisiera legitimar su poder en la campaña, debía asegurar la presencia de la justicia letrada en ella.

Así lo consideró Valentín Alsina -simultáneamente legislador y presidente de la Cámara de Justicia- que aún antes de la sanción de la Constitución presentó a la Honorable Sala de Representantes el proyecto sobre el nombramiento de dos jueces letrados del crimen en la campaña. ${ }^{10}$ Esta aclaración tiene sentido en función de comprender sus palabras al presentar su proyecto:

En el puesto en que me hallo, he tocado una verdad dolorosa, y es que sea por el estado del país, sea por las pasiones de los hombres, son innumerables los presos que se remiten; esto me ha movido a presentar el proyecto para evitar los graves perjuicios que causa, ya que por la larga distancia, ya por la ubicación de la capital que no es central, por las formas que es preciso observar, porque esta ubicación de proceso no puede ser atendida solo por dos jueces,

\footnotetext{
${ }^{8}$ El original de este decreto puede verse en el Archivo Municipal de Cañuelas, Nota N ${ }^{\circ} 84$ del Juzgado de Paz.

${ }^{9}$ Saldías, Adolfo, Un siglo de instituciones, tomo II, La Plata, Impresiones Oficiales, 1910, pp. 57-59.

${ }^{10}$ Valentín Alsina fue el nuevo arquetipo del abogado porteño. Llegado del exilio integró el foro de Buenos Aires que contaba en 1855 con cincuenta abogados. Fue penalista, profesor universitario, político, estadista y codificador. Inauguró el primer Colegio de abogados en 1858 Como camarista se ocupó de organizar la estadística judicial, mejoró las cárceles y estableció la práctica de fundar las sentencias. Fue quien primero abordó el tema, en 1829, sosteniendo que fundar las sentencias evitaba errores y arbitrariedades, hacía efectiva la más absoluta responsabilidad judicial partiendo del principio republicano de que dar el motivo de los actos era regla común de todos los poderes de la sociedad y reducía las cuestiones complejas a puntos determinados, obligando a los magistrados a examinar separadamente las cuestiones. Durante su gestión la Cámara promovió la ley sobre sustanciación de los juicios civiles, el arancel de honorarios y derechos de empleados de la administración de justicia y la tramitación de testamentarias en la Campaña. Dentro de las presentaciones realizadas por la Cámara no podemos obviar la referida a la pena capital, que no solo se defendió (recordemos que Alsina presentó en 1828 ante la Academia de Jurisprudencia una tesis a favor de la pena de muerte) sino que se destacó como resarcimiento de la ofensa sufrida por la sociedad y escarmiento para quienes quisieran cometer igual delito. ROPBA, 1853, pp. 170-171.
} 
y por otra parte convendría que los Juzgados estuviesen a corta distancia del teatro de los delitos para poder castigarlos o evitarlos. ${ }^{11}$

Cuando Alsina dijo en "el puesto en que me hallo", sin duda se refería a la presidencia de la Cámara de Justicia. Esto se confirma y cobra más sentido al leer una serie de expedientes de primera instancia de la Capital de $1853 .{ }^{12}$ Hasta mediados de septiembre, el juez de paz de la campaña elevaba el sumario al jefe de Policía y este al juez de primera instancia. A partir de allí esto cambió y el expediente tuvo una escala intermedia entre el jefe de Policía y el juez, el despacho del presidente del Tribunal, que veía pasar las causas que procedían del interior, siendo éste uno de los motivos que llevaron a la presentación del proyecto. La demora en la resolución de las causas hacía que hubiera detenidos sin sentencia por demasiado tiempo, originando gastos y durante la instrucción de un caso.

El proyecto fue apoyado y encomendado a la Comisión de Legislación. En la sesión de la Sala de Representantes del 16 de noviembre de 1853, comenzó el tratamiento del texto legislativo sobre la instalación de juzgados de primera instancia en lo criminal en la campaña redactado por la Comisión en veintiún artículos. ${ }^{13}$ El debate se extendió hasta el 28 de noviembre y las cuestiones en discusión fueron fundamentalmente la necesidad de la ley para la provincia, la cantidad de juzgados y la jurisdicción de los jueces criminal, civil, o ambas. ${ }^{14}$

En cuanto a la necesidad de la ley, Miguel Esteves Saguí destacó su utilidad a pesar de los inconvenientes que podía ocasionar, pues era necesaria "la acción presta de los jueces para evitar la tardanza que necesariamente trae la gran distancia de los lugares”. Tomás Anchorena se opuso a la ley considerando que los males serían mayores que las ventajas pues

Un Juzgado que ha de disponer de la vida, honor y propiedad de los ciudadanos no presta suficiente garantía siempre que se coloque lejano de un pueblo culto, capaz de conocer y criticar sus actos; y lejano también de superiores inmediatos que le contengan en sus abusos; y mucho más en la campaña donde no hay defensores ni letrados, quedando por el hecho los juicios sin el principal elemento cuanto necesario. Por otra parte, si hay muchos asuntos que despachar, póngasenos jueces, divídanse los juzgados de paz en estas áreas, pues estos son los que deben aquietar la campaña inspirando confianza y son los que conocen la verdadera policía del lugar.

Trabájese en adelante la ilustración y espérese mucho de las Municipalidades. Entonces será que convenga el establecimiento de que se trata y para el que ahora no habrá abogados que quieran admitir el cargo sino los muy mediocres. ${ }^{15}$

Los juzgados letrados no debían instalarse en la campaña porque, según Anchorena allí no había "pueblo culto" y los conflictos que se generaran podían ser resueltos por jueces legos, que

\footnotetext{
${ }^{11}$ Diario de Sesiones de la Sala de Representantes de la Provincia de Buenos Aires de 1853, p.88.

${ }^{12}$ AHP, Juzgado del crimen, legajo 152.

${ }^{13}$ El debate fue seguido día a día por el periódico El Nacional.

${ }_{15}^{14}$ AHP, Legislatura, Cámara de diputados 1853, 48-5-69 No 112.

${ }^{15}$ Sesión del 16 de noviembre de 1853. Diario de Sesiones de la Sala de Representantes de la Provincia de Buenos Aires de 1853.
} 
ciertamente actuaban más como policía que como magistrados. Esta opinión era emitida por un hacendado, para quien los litigios contra la propiedad podían ser resueltos, como hasta entonces, por los jueces letrados que residían en la capital. Jueces mediocres y sin control no cumplirían con su objetivo de salvaguardar la vida, el honor y fundamentalmente la propiedad. Pero Alsina le respondió que, aunque los jueces no eran nombrados para ilustrar a la campaña, su presencia y ejemplo podrían ayudar a ello. Dalmacio Vélez Sarsfield apoyaba el proyecto, desmereciendo totalmente la falta de abogados y basándose en la necesidad de castigar los delitos leves que por su multiplicidad "hacen la ruina de los vecinos". ${ }^{16}$

Admitido el proyecto de la Comisión, se procedió a la discusión en particular y el punto que llevó mayor discusión fue el de la jurisdicción civil. La Comisión había incluido un artículo autorizando a los jueces criminales de la campaña a atender y resolver asuntos civiles después de dos meses de instalados, pero Carlos Tejedor insistió en establecer jueces civiles. Sostenía que el tema del gasto no era excusa valedera y que la opción de atender causas civiles terminaría siendo una trampa, pues quien quisiera demorar el expediente recurriría al juez de la Capital, opinión apoyada por Torres asegurando que la demanda civil requería más inteligencia de derecho y los abogados irían donde pudieran ganar con mayor facilidad.

Pero Alsina insistió en que la jurisdicción civil distraería la atención del juez, asegurando que "primero es necesario fundar y después ensanchar”. Estevez Saguí reforzó estos argumentos, pues era urgente hacer sentir en la campaña la acción de la autoridad con jueces criminales, dado que la ley debía buscar a los delincuentes y los individuos se cuidaban de buscar la ley. Ante lo inevitable de la aprobación de la ley, Anchorena se colocó a favor de Alsina diciendo que la orden del día era la jurisdicción criminal. Estos argumentos lograron la instalación de juzgados criminales que a dos meses de instalados podrían atender causas civiles, a pesar de que Bartolomé Mitre, en una fugaz intervención apoyando la jurisdicción civil de los jueces, afirmó que el proyecto tenía por objeto una ley para reprimir al pueblo, pero que debía ser reparadora. Los ricos se oponían a la jurisdicción civil de la campaña, pero eran pocos y las leyes estaban destinadas al pueblo. Lo cierto es que el trabajo con los expedientes del juzgado criminal que fue instalado en Dolores en 1854, nos permitió corroborar que las causas civiles tramitadas allí fueron muy pocas y que los propietarios seguían recurriendo a los jueces civiles de la Capital. ${ }^{17}$

La ley sancionada el 29 de noviembre de 1853 constaba de diecinueve artículos, cuyo contenido hemos esquematizado en función de la organización que la administración de justicia de la provincia de Buenos Aires.

\footnotetext{
${ }^{16}$ Sesión del 16 de noviembre de 1853. Diario de Sesiones de la Sala de Representantes de la Provincia de Buenos Aires de 1853.

${ }^{17}$ Sección Histórica Judicial de Dolores, SCBA, Juzgado del crimen de Dolores, 1853-1881.
} 
a) Jurisdicción: en primera instancia criminal con opción por parte de los particulares para litigar causas civiles; en grado de apelación de las causas resueltas por los jueces de paz

b) Competencia territorial: tres departamentos judiciales con asiento en

- Departamento del Norte: Arrecifes (fue Mercedes)

- Departamento Capital: Buenos Aires

- Departamento del Sud: Dolores.

c) Magistrados:

- letrados,

- nombrados por el poder ejecutivo a propuesta en terna por la Cámara de Justicia, al igual que los escribanos adscriptos

- rentados: $\$ 4000$ mensuales

- recibirían de los jueces de paz los sumarios y los reos

d) Personal del juzgado:

- escribano adscripto

- agente fiscal

- defensor de pobres ${ }^{18}$

- Ordenanza a caballo

e) Normas procesales

f) El Gobierno se comprometía a facilitar todo lo referente a la instalación del juzgado.

El primer intento por cubrir los cargos fue realizado con un decreto del 22 de diciembre de 1853 fracasó; designaba a Felipe José Coronel para el Departamento del Norte y a Fernando Arca para el del Sur y ninguno aceptó la propuesta. Ante la insistencia del gobernador Obligado, Coronel cedió, pero para el juzgado del sur. Marcelino Ugarte, Felipe Sánchez de Zéliz, Eduardo Carranza y Francisco de Elizalde, integrantes de ambas ternas, rechazaron el cargo para el norte, al igual que los propuestos el 13 de febrero de 1854, Tiburcio de la Cárcova, Ángel Medina y Osvaldo Piñero. Finalmente, el 27 de marzo de 1854 fue nombrado José María Juan Climarco Irigoyen, que no instaló su juzgado en Arrecifes, tal como determinaba la ley, sino en la Villa de Luján. ${ }^{19}$

El 20 de octubre de 1856 se debatió en la Cámara de Diputados la creación de un nuevo departamento judicial con sede en San Nicolás, aprobada el 21 de octubre de $1856 .{ }^{20}$ Este proyecto, según el diputado Pica, era la continuación del de 1853 que había demostrado resultados respecto a la conclusión de las causas criminales, a la disminución de los delitos y a la moralización de la campaña, palpables en la administración de justicia. Hizo alusión a las demoras que había antes por las distancias, retrasando el castigo o dejando crímenes impunes. La elección del pueblo de San Nicolás para cabecera del Departamento del Norte quedó justificado en que tenía mil casas de material, más de cien negocios, superaba los doscientos hacendados y los diez mil habitantes.

Esta población tan numerosa y rica, parece que exige, por las necesidades que introducen naturalmente las transacciones sociales, algo más que un Juez de Paz, un juez que tenga jurisdicción criminal para conocer de los delitos que allí se cometan, y de algunos ramos de competencia civil, porque estos juzgados de campaña no están circunscriptos puramente a la

\footnotetext{
${ }^{18} \mathrm{Al}$ agente fiscal y al defensor de pobres los nombraba el Gobierno, no debían ser letrados y eran rentados.

${ }^{19}$ Los nombramientos se realizaron por decreto del 5 de enero de 1854 . ROPBA 1854, p.5.

${ }^{20}$ La ley fue promulgada el 24 de octubre. ROPBA, 1856, p. 114.
} 
órbita de la jurisdicción criminal, sino que entienden también en algunos casos en asuntos civiles. $^{21}$

La decisión sobre la instalación de la justicia letrada en la campaña resultó decisiva para la conformación del mapa judicial, pues los diecinueve departamentos judiciales en que está dividida hoy la provincia, resultaron de la extensión en competencia y la división jurisdiccional de esa estructura original en cuatro departamentos judiciales. El proceso que derivó en ese mapa judicial fue seguido por la prensa, que era formadora y articuladora de una opinión pública que ampliada se convirtió en la fuente de la nueva legitimidad política. ${ }^{22}$

La Tribuna, a cargo de los hermanos Varela, publicó una síntesis del debate y el texto de la ley como documento oficial. Pero durante los meses de discusión insistieron en el papel que la policía y las municipalidades debían desempeñar para lograr el orden en la campaña. Criticaba la ley de municipalidades por aumentar el poder de los jueces de paz, dándoles mayor dependencia del poder oficial. Un editorial sobre descentralización administrativa sostenía que

la reforma de las leyes a fin de producir un cambio saludable en las costumbres, ha de ser radical para que satisfaga la necesidad sentida de aumentar la fuerza del ciudadano sin disminuir la energía legal que siempre debe rodear a los poderes públicos. La centralización aleja toda idea de independencia y voluntad en la campaña. ${ }^{23}$

El diario apoyaba a los vecinos de Zárate, que en una carta al diario solicitaban autoridades propias pues dependían de Exaltación de la Cruz. La sentencia de los redactores era terminante y dejaba ver que poco esperaban de la ley recientemente sancionada,

pero en tanto que las poblaciones de la campaña permanezcan en el abandono que hoy se hallan, y en el estado que con tanta moderación y verdad describen los vecinos de Zárate, no esperamos hallar en ellas más que tolderías de cristianos bajo el pomposo y ridículo nombre de pueblos y ciudades. ${ }^{24}$

El Nacional siguió más de cerca la evolución de la ley. Dos días antes de la presentación del proyecto de Alsina el editorial "La legislatura de 1853", reclamaba para la campaña organización judicial y hacía hincapié en la codificación. ${ }^{25}$ Rescataba la labor de la Cámara de Justicia sobre la práctica de fundar las sentencias "que estaba abolida en ese Superior Tribunal, y es altamente honorífico para los miembros que hoy la componen haberla restaurado, como la única y verdadera garantía de sus resoluciones y la prueba más evidente de la rectitud y justicia de sus fallos". ${ }^{26}$

El diario trascribía cada día los debates y el 18 de noviembre con el largo editorial “Judicaturas en la Campaña" se expresó sobre el tema asegurando que la administración de justicia

\footnotetext{
${ }^{21}$ Diputados, 1856, pp. 537-538

${ }^{22}$ Lettieri, 1999, op. cit.; Leiva, 1997, op. cit.

${ }^{23}$ La Tribuna, 13 de noviembre de 1853.

${ }^{24}$ La Tribuna, 29 de noviembre de 1853.

${ }^{25}$ El Nacional, 5 de octubre de 1853.

${ }^{26}$ El Nacional, 7 de octubre de 1853 .
} 
se encontraba atrasada respecto a los años previos a la revolución en que había municipalidades elegidas por el pueblo, autoridades locales con atribuciones claras y precisas, jueces ordinarios civiles y criminales en la campaña. ${ }^{27}$

¿Qué es lo que tenemos hoy en materia de administración provincial? Un Gobernador, tres Ministros, un jefe de Policía en la capital, 50 jueces de paz con atribuciones enciclopédicas; y una administración de justicia circunscripta a los límites de la capital. En la ciudad rige el sistema republicano, en la campaña rige el sistema de la arbitrariedad. En la ciudad hay garantías judiciales, en la campaña no hay garantías judiciales, ni tribunales que conozcan los crímenes y delitos, en una palabra no hay justicia de ninguna especie.

El periódico rescataba la labor de Alsina al frente de la Cámara de Justicia, buscando remediar el mal por el camino de la justicia y de la ley generalizando la administración de justicia en toda la provincia. Pero difería en la aplicación de la ley, ya que dos jueces serían insuficientes, y la represión no debía ser el único fin pues era su obligación amparar la libertad civil del ciudadano, palabras seguramente escritas por Mitre que coincidían con las expresadas en la Legislatura. En coincidencia con La Tribuna, a pesar de sus enfrentamientos, creía que un sistema republicano debía instalar municipalidades y dotar de justicia local a la campaña, pues el juez de paz no era en ese momento miembro del poder judicial presente en la campaña.

Los comentarios expresados por la prensa a favor de la organización municipal y judicial previas a 1810, eran una manifestación de lo complejo y conflictivo que resultaba romper los moldes de la estructura colonial. Sin embargo el cambio estaba en marcha y la conformación de los poderes del Estado ya había comenzado en el período anterior y ahora venía a consolidarse. ${ }^{28}$ Nadie discutía ya la necesidad de atender los requerimientos judiciales de la campaña, pero la propuesta de Alsina era una solución de emergencia que no obedecía a un plan de organización basado en las municipalidades como expresión y ejercicio de la soberanía del pueblo. Los objetivos inmediatos eran resolver las causas pendientes del rosismo y comenzar a construir una estructura de legitimación del poder.

Como sea, así quedó constituida la primera instancia de la provincia, en la que los magistrados trabajaban en sus juzgados con los escribanos, autoridad pública que verificaba los actos del juez y sin cuya presencia resultaba nulo todo lo actuado. ${ }^{29}$ Los oficiales de justicia, cuyo antecedente eran los alguaciles, debían cumplir las órdenes de los jueces con prontitud. ${ }^{30}$ Para completar el sistema

\footnotetext{
${ }^{27}$ Los Alcaldes ordinarios del Cabildo porteño, miembros de la elite, en el cumplimento de sus funciones judiciales y policiales se habían ganado el recelo de la gente por su fama de rudos y violentos, la Audiencia lejos de dar respuesta a los reclamos por los abusos de autoridad de los Alcaldes, estaba preocupada por afianzar su autoridad. Barreneche, 2001, op. cit., pp. 72.

${ }^{28}$ Halperín Donghi, 1995, op. cit., 1952.

${ }^{29}$ Tejedor, Carlos, [1860] Curso de derecho criminal. Segunda parte: leyes de formas. Buenos Aires, Librería de Cl. M. Joly, 1871, segunda edición, núm. 128. (en adelnate Curso de Tejedor, II)

${ }^{30}$ Curso de Tejedor, II, núm. 129.
} 
judicial haremos una breve referencia al Ministerio Fiscal, las Defensorías de Menores y de pobres, para conocer el origen y las atribuciones de los funcionarios a cargo. ${ }^{31}$

El Ministerio Fiscal o Ministerio Público era una magistratura particular que tenía por objeto velar por el interés del Estado y de la sociedad ante los tribunales. Tenía el encargo de promover la represión de los delitos, la defensa judicial de los intereses del Estado. En el siglo XIII aparecieron por primera vez en Valencia dos funcionarios, el abogado fiscal -encargado de acusar los delitos, cuidar de la ejecución de las penas y defender la jurisdicción real- y el abogado patrimonial -que debía defender las cuestiones del real patrimonio y del erario, los derechos del monarca en los asuntos civiles y la recaudación de impuestos. A estos se agregaron los procuradores fiscales, que dirigidos por aquellos abogados cuidaban la denuncia de los delitos.

En las leyes de Indias se determinaban las funciones del fiscal del Consejo de Indias y de dos solicitantes fiscales. ${ }^{32}$ Las audiencias de Lima y México tenían cada una dos fiscales, uno para causas civiles y otro para las criminales, con asiento en seguida de los oidores y que debían asistir diariamente tres horas a la audiencia. Los fiscales no podían abogar, dedicándose sólo a lo relativo de su oficio, sin recibir nada de los litigantes o negociantes ni escribir cartas de recomendación. ${ }^{33}$ Por el artículo 19 del Reglamento de 1813 cada cámara tendría un agente, con las funciones que hasta entonces tenían los fiscales, con un auxiliar, nombrado por el gobierno a propuesta suya. El Reglamento provisorio de 1817 estableció un fiscal en las Cámaras de Apelación y dos agentes auxiliares, uno civil y otro criminal, repartiéndose los asuntos de hacienda.

Después de varias modificaciones, la ley que organizó el Superior Tribunal le asignó un fiscal y el Ministerio Público quedó dividido en dos, uno del físcal de Gobierno que obedecía al poder ejecutivo y atendía todas las cuestiones económicas y administrativas- y otro del adscrito al Tribunal -que recibía sus órdenes, atendiendo las funciones judiciales de los antiguos fiscales. Los agentes fiscales representaban la acción pública en los juzgados inferiores y eran los jueces los que debían dar cuenta al Tribunal de cualquier retardo en la agencia.

El fiscal tenía el tratamiento de los ministros del Tribunal, era parte en toda causa criminal sobre delito público o de responsabilidad oficial y en las mismas civiles y sobre delitos privados, se le oía cuando interesaran a la causa pública, a la defensa de la jurisdicción ordinaria o de derechos del Estado. No podía ejercer la abogacía, ni dar su patrocinio, perdiendo su empleo si lo hacía. Malaver llamaba la atención en que la Constitución de 1873 nada decía sobre el Ministerio Público,

\footnotetext{
${ }^{31}$ Para esto nos hemos basado en Malaver, Antonio Curso de procedimientos judiciales en materia civil y mercantil, Buenos Aires, Imprenta Especial para obras de Pablo E. Coni, 1875. (en adelnate Curso de Malaver)La primera parte está dedicada a la organización judicial. Ministerio fiscal, pp.198-209. Este manual fue escrito para los alumnos de la carrera de derecho, reconociendo el autor "la más amplia libertad de doctrina, método y exposición" del sistema universitario.

${ }^{32}$ Recopilación de Indias, Leyes 1, 5, 14 y 16, Tit. 5, lib. 2.

${ }^{33}$ Recopilación de Indias, Leyes 1 a 6, Tit. 18, lib. 2.
} 
sin oponerse a su subsistencia y reglamentación. Por una ley de 1874, que fue sancionada para su organización provisoria, sería desempeñado en la Capital por un procurador general, un fiscal en cada Cámara de Apelación, dos agentes fiscales en los civil y uno en lo criminal. El los otros departamentos judiciales habría un agente fiscal en lo civil y criminal. ${ }^{34}$

Antes de la supresión de los Cabildos el 24 de diciembre de 1821 había cargos de defensor de pobres y defensor de menores, que desempeñaban dos de los capitulares. Dicha ley refundió ambos cargos en uno hasta que fueron nuevamente separados el 31 de diciembre de 1824 . El 29 de diciembre de 1829 se reunieron, agregándole al defensor de pobres y menores el título de Protector de Naturales, que debía estar a cargo de un ciudadano de fortuna y probidad acreditadas. ${ }^{35}$ Era un cargo gratuito y de honor, nombrado por el ejecutivo, que lo comunicaba a la Cámara de Justicia, ante la cual juraba. Tenía un asesor por él propuesto y nombrado por el Gobierno, un escribiente y dos ordenanzas. Con la instalación de los jueces letrados en la campaña, se determinó que cada juzgado tendría un agente fiscal y un defensor de pobres, ambos rentados.

El Ministerio de menores era "parte legítima y esencial en todo asunto judicial o extrajudicial, de jurisdicción voluntaria o contenciosa, en que los incapaces demanden o sean demandados, o en que se trate de las personas o bienes de ellos, so pena de nulidad de todo juicio que hubiere lugar sin su participación, exceptuándose solo de esta representación a las mujeres casadas."36 Por el "Reglamento de la Defensuría de Menores" en el Departamento Capital había dos defensores, cada uno con un asesor letrado, un escribiente y un ordenanza, todos nombrados por el poder ejecutivo cada año. En los partidos de campaña las atribuciones del defensor de menores las tendría el procurador municipal, bajo la dirección del defensor de turno de la Capital. Tendría un letrado como asesor, que se presentaría en los asuntos ante los juzgados de primera y segunda instancia. ${ }^{37}$

El defensor de menores era el abogado nato, en la primera y ulteriores instancias, de todos los que solicitaran declaratoria de pobreza. Podía visitar las cárceles, tomando los conocimientos necesarios sobre el tratamiento de los presos y estado de sus causas, para quejarse ante quien correspondiera de las faltas observadas. ${ }^{38}$

\footnotetext{
${ }^{34}$ ROPB, 1874, p. 367.

${ }^{35}$ ROPBA, 1829, pp. 119; 145-146

${ }^{36}$ Curso de Malaver, pp. 209- 213. Enumera todas las funciones del Ministerio de Menores.

37 "Reglamento de la Defensuría de Menores", ROPBA, 1864, pp. 137-142. Organización confirmada en la ley del 30 de junio de 1874. ROPBA, 1874, p. 368. En la campaña bonaerense, los alcaldes de la hermandad participaron en la protección de los menores. La defensuría estaba a cargo de dos capitulares (ordenanza 21 de octubre de 1814). La ley de 1821 estableció el cargo de defensor de pobres y menores. Las funciones serían reglamentadas por un decreto de 1840. En la campaña, la ley de Municipalidades de 1854, contempló entre las funciones del procurador municipal la de desempeñar la de defensor de pobres y menores, cuidando los intereses y derechos de los mismos, interviniendo en todo inventario o asunto en que se tratasen temas de aquellos. Esto fue reafirmado por el decreto del 23 de noviembre de 1864, firmado por Saavedra y Cárdenas, en el que se estableció que el procurador municipal quedaba bajo la dirección del Defensor de turno de la capital y explicaba los libros que debía llevar y los informes anuales que debía elevar.

${ }^{38}$ Curso de Malaver, pp. 216- 217.
} 


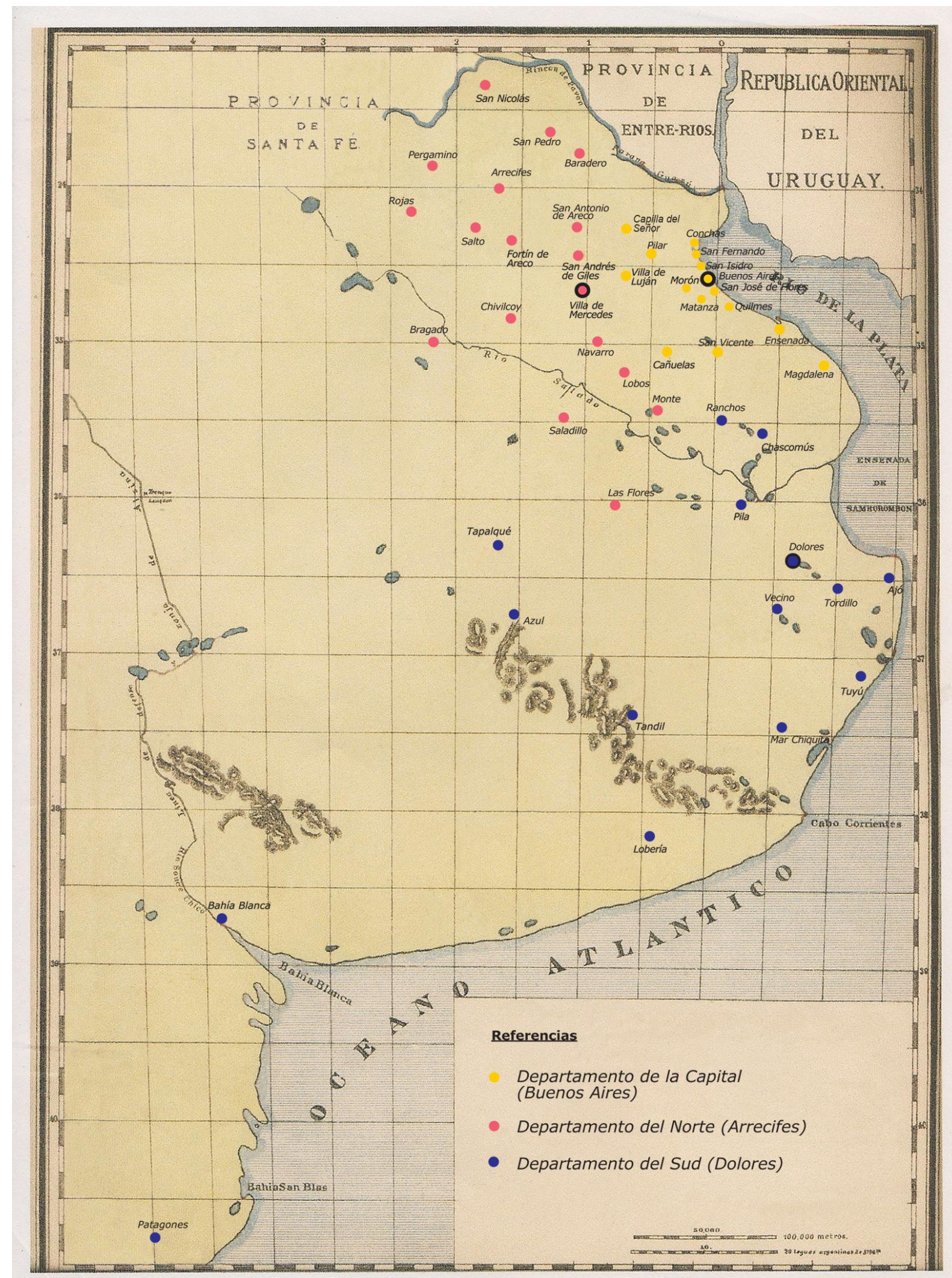

Mapa de la provincia de Buenos Aires según la ley del 28 de noviembre de 1853 sobre establecimientos de juzgados del crimen. Los puntos en color indican los partidos con juez de paz a cargo. La cabecera del Departamento del Norte debía ser Arrecifes pero fue la Villa de Mercedes. Elaboración propia a partir de los datos del ROGBA, pp. 155-156. Diseño de Joaquín Aras. 


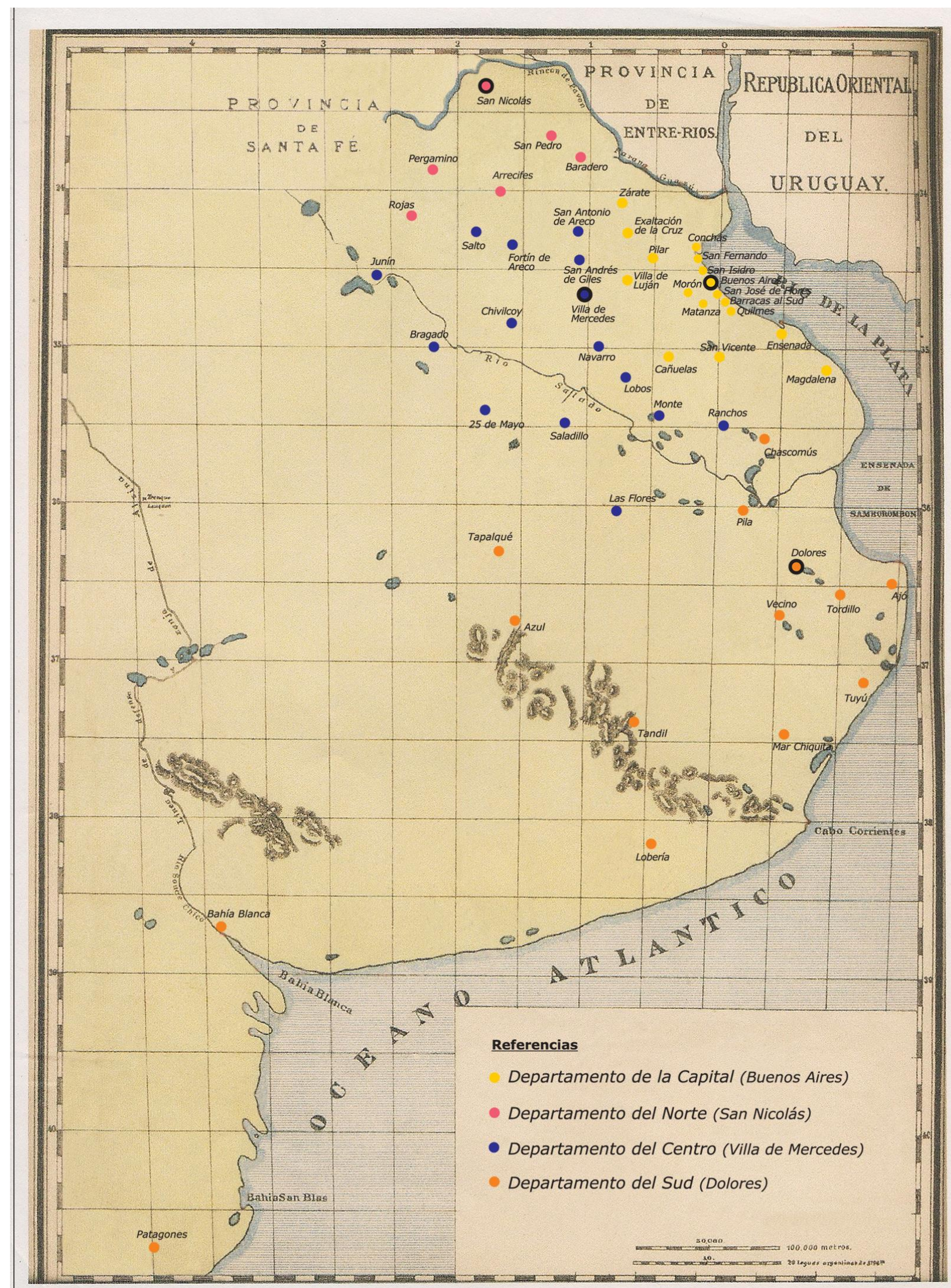

Mapa de la provincia de Buenos Aires según la ley del 24 de octubre de 1856 que dividió la jurisdicción de los jueces del crimen de la campaña en tres departamentos judiciales. Los puntos en color indican los partidos con juez de paz a cargo. Por ley del 27 de julio de 1863 los partidos de Patagones y Bahía Blanca pasaron a ser competencia de los jueces del crimen del Departamento Capital. Elaboración propia a partir de los datos del ROGBA, 1856, p.114. Diseño de Joaquín Aras. 


\section{La justicia comercial}

El Real Consulado de Buenos Aires fue creado por Carlos IV el 30 de enero de 1794 e instalado el 28 de mayo del mismo año, integrado por un prior, dos cónsules, nueve conciliarios y un síndico con sus tenientes, secretario, contador y tesorero. Fue creado con dos finalidades, la protección y fomento del comercio en todos sus ramos (Junta del Consulado) y la más breve y fácil administración de justicia (Tribunal del Consulado). ${ }^{39}$ Respecto a esta última la Cédula determinaba que

La administración de justicia estará a cargo del Tribunal que sólo se compondrá del Prior y Cónsules, y conocerán privativamente en todos los pleitos y diferencias que ocurran entre comerciantes ó mercaderes, sus compañeros y factores sobre sus negociaciones de comercio, compras, ventas, cambios, seguros, cuentas de compañía, fletamentos de naos, factorías y demás de que conoce y debe conocer el Consulado de Bilbao conforme á sus Ordenanzas; las cuales han de servir de regla á este nuevo Tribunal por ahora, para la substanciación y determinación de los pleitos en todo lo que no haya prevenido por esta Cédula; y lo que ni ella ni en dichas Ordenanzas este prevenido, se decidirá por las Leyes de Indias, ó en su defecto, por las de Castilla: no habiendo pragmáticas, reales cédulas, órdenes ó reglamentos expedidos posteriormente que deban gobernar en las respectivas materias. ${ }^{40}$

Después de la crisis de 1820 la jurisdicción mercantil fue reducida al crear cada provincia sus tribunales de comercio y quedar el Consulado limitado a la provincia de Buenos Aires. En 1821, el

\footnotetext{
${ }^{39}$ El texto completo de la Real Cédula del Consulado de Buenos Aires puede consultarse en Acuerdos y sentencias, tomo I, pp. 266-273. El aumento y extensión del comercio de América con la libertad concedida por Reglamento de 1778 y otras gracias y franquicias dadas posteriormente, generó en varias ciudades y puertos la solicitud de Consulados para la protección del tráfico y la resolución breve y sumaria de los pleitos mercantiles. Más allá de los reclamos, el movimiento comercial de los puertos americanos podía volver insuficientes los Consulados de Lima y México y el tema fue puesto en estudio de los Ministros de Estado y el despacho Real, a fin de proveer "lo que más conviniese al bien y prosperidad del comercio". Sus conclusiones, junto a las recomendaciones del Virrey Arredondo, llevaron al Rey a erigir el Consulado de Buenos Aires que hasta tanto se le dieran ordenanzas propias, se regiría por las reglas establecidas por la Cédula. Las funciones económicas y generales fueron agregadas al Consulado en el siglo XVIII, originariamente su función era principalmente judicial. Tjarks, Germán O., El Consulado de Buenos Aires y sus proyecciones en la Historia del Río de la Plata, Buenos Aires, Facultad de Filosofía y Letras, Instituto de Historia Argentina Dr. Emilio Ravignani, 1962.

${ }^{40}$ Acuerdos y sentencias, tomo I, p. 266. Formado el tribunal con el prior y los cónsules, debían "proceder siempre a estilo llano, verdad sabida y buena fe guardada", sin intervención de letrados y evitando "todo lo que huela a sutileza y formalidades de derecho", y las faltas no justificadas a sus tareas estaban penadas con una multa de cuatro pesos diarios. Completaba el personal presente en las audiencias un escribano, que autorizaba los juicios, y dos porteros alguaciles, encargados de cuidar los estrados y realizar las citaciones. Oídas las partes, con los testigos y las pruebas que presentaban, se debía buscar "ya la transacción voluntaria, ya el compromiso en arbitradores y amigables componedores". De no avenir las partes se concretaba el juicio verbal y se votaba la sentencia, para la cual eran necesarios dos votos. Si el negocio era de difícil prueba se podía realizar juicio escrito con un plazo máximo de ocho días, si ocurría grave dificultad de derecho debía recurrirse al asesor titular, letrado. Cuando el pleito superaba los mil pesos se podía apelar la sentencia ante la Alzada de Comercio, un tribunal formado por un oidor de la Real Audiencia y dos comerciantes elegidos por él entre quienes proponían las partes. Contra el fallo del tribunal de Alzada cabía, en algunos casos, el recurso de nulidad o de injusticia notoria ante el Consejo de Indias. Por la Real Orden del 21 de septiembre de 1796 y la Real Cédula del 7 de marzo de 1800 fueron aceptadas las apelaciones de sentencias menores, cuando se comprometía el honor o interés de los individuos de comercio. Tjarks, 1962, op. cit., p. 67. El Consulado creó dieciséis diputaciones en el interior del Virreinato en las ciudades de mayor actividad comercial, en delegación de sus funciones fundamentalmente para la administración de justicia. Guillamondegui, Julio César, "Notas para el estudio de la justicia mercantil patria de las provincias argentinas", en Revista del Instituto de Historia del Derecho, núm.20, 1992.
} 
Consulado dejó de cumplir con su misión administrativa pero siguió funcionando como Tribunal de Comercio, mientras que se intentaba sancionar el Código de Comercio y organizar la justicia mercantil. Entretanto Rivadavia generó un decreto definiendo el acto de comercio, marcando un hito fundamental en la legislación mercantil. Apuntando a la proscripción de los fueros y privilegios y conformando un concepto objetivo del acto de comercio, en un derecho subjetivo desde su más embrionario, elaborado y aplicado por los comerciantes y basado en la costumbre. ${ }^{41}$

La construcción del modelo basado en la producción de bienes primarios para la exportación, a partir de la segunda mitad del siglo XIX, movilizó el circuito comercial (almacenes, agencias y casas), el circuito financiero (bancos, agencias de cambio y seguro) que requerían de un cambio en la legislación que controlara y reglamentara las nuevas relaciones, así como también de los tribunales apropiados para aplicarla. También resultaron enfrentados a comerciantes y ciudadanos no pertenecientes al gremio en conflictos de otra magnitud, surgidos de las actividades de acumulación y reproducción económica y de generación de capital social. En la provincia de Buenos Aires fueron necesarias nuevas soluciones y garantías que la legislación indiana y posindependiente aplicada por el Consulado no podía brindar. ${ }^{42}$

La instalación de jueces letrados para atender esos pleitos mercantiles generaba dos cuestiones cuya resolución implicaba una clara postura respecto al derecho mercantil. Por un lado, daría fin a una institución colonial que había sobrevivido más de cuatro décadas de vida independiente. Por el otro, planteaba la disyuntiva entre dar origen a juzgados puramente mercantiles o agregar esa competencia al fuero civil. El primer intento que se realizó para instalarlos en 1858, aún antes que entrara en vigencia el Código, fracasó. Se había avanzado logrando que los abogados pudieran intervenir libremente en las causas comerciales y que las apelaciones se realizaran ante el máximo Tribunal, pero sin embargo las causas seguían siendo resueltas por los comerciantes. ${ }^{43}$

\footnotetext{
${ }^{41}$ Decreto del 25 de abril de 1822, ROPBA, 1822, p.88. Este concepto fue tomado años más tarde por el Código de Comercio de la provincia de Buenos Aires y por el Reglamento tucumano de Justicia en 1860. Para Díaz Couselo, este decreto significó el abandono del criterio subjetivo y la adopción del objetivo, teniendo en cuenta el acto de comercio y no quien lo realizaba. Díaz Couselo, 2005a, p. 70. El Código napoleónico en Francia, y el decreto de Rivadavia años más tarde en Buenos Aires, incorporaron el concepto de acto de comercio para objetivar al derecho mercantil. Sin embargo los jueces seguirían siendo comerciantes, el derecho objetivo definido por el acto y no por las personas, sería aplicado por los integrantes del gremio, nombrados por el Estado pero elegidos por ellos. El desarrollo doctrinario sobre el acto de comercio trató de dar una justificación objetiva a una jurisdicción subjetiva, pero no logró dar una explicación racional por lo que muchos autores las definen como categorías históricas. Otaegui, Julio C., "La codificación comercial en América Latina”, en La codificación: raíces y perspectivas I. El Código Napoleón, Buenos Aires, Educa, Colección Prudentia Iuris, 2003.

${ }^{42}$ Fernández, Sandra, Pons, Adriana, Videla, Oscar, “Las burguesías regionales”, en Bonaudo, 1999, pp. 423-481.

${ }^{43}$ Ante la demora en sancionar el Código y la necesidad de comenzar a dar respuesta a la incertidumbre legal en la que se encontraba el capital mercantil, se eliminó la Alzada de Comercio, pasando las apelaciones a ser resueltas por el Superior Tribunal. Ley del 21 de octubre de 1857. ROPBA, 1857, p. 156-157. Por la ley del 8 de julio de 1859 los recursos se interpondrían anta las Salas de lo Civil y del Crimen del Superior Tribunal alternándose mensualmente. ROPBA, 1859, p.72. Adelman, 1999, p. 244. El proyecto de Código de Comercio fue presentado el 7 de mayo de 1857 y sancionado dos años después. Se sometió a una Comisión revisora integrada por Francisco Balbín, Amancio Alcorta, Ambrosio Lezica, Andrés Somellera y Miguel Valencia y fue sancionado por ambas cámaras el 6 de octubre de 1859. Santa Fe lo adoptó en 1861, Entre Ríos lo declaró aplicable en su territorio en 1862 y para San Juan fue legislación
} 
En la sesión de la Cámara de Diputados del 23 de junio de 1858, Marcelino Ugarte (padre) presentó el proyecto y explicó con claridad los motivos de la presentación. El Tribunal del Consulado sería reemplazado por un juez de primera instancia en lo comercial, que gozaría del mismo sueldo que los jueces de primera instancia en lo civil. Ugarte comenzó justificando la inversión que representaba la nueva ley, consciente del déficit de las rentas generales. Pero los comerciantes electos para desempeñar los cargos en el Consulado se excusaban, lo cual daba una clara oportunidad para introducir el cambio y el Tribunal del Consulado no satisfacía las exigencias de la jurisdicción mercantil, reuniéndose sólo tres veces por semana, con un despacho lento en función de las cuestiones comerciales que requerían celeridad. El sistema de jurado no guardaba armonía con la administración de justicia y la forma de nombramiento entraba en contradicción con el artículo 121 de la Constitución, según el cual los miembros de los juzgados inferiores debían ser nombrados por el Gobernador del Estado, a propuesta en terna del Tribunal Superior. ${ }^{44}$

La Cédula del Consulado establecía un máximo de ocho días para la justicia de los comerciantes, justificado por la conveniencia práctica de la prontitud en el despacho de las causas. ${ }^{45}$ Para 1855, "El Judicial”46 publicaba estadísticas que más que de retardo hablaban de la paralización del tribunal mercantil. ${ }^{47}$ El desarrollo de Buenos Aires, las grandes empresas, la Casa de la Moneda primero y el Banco de la Provincia después y la formación de sociedades aumentaron las causas mercantiles que sin una legislación actualizada y con la intervención inevitable del asesor letrado se volvían interminables.

Una carta publicada en "El Nacional" abundaba sobre el papel de los asesores en la administración de justicia,

...ya que tenemos la fatalidad de que, aun subsista esta institución, a pesar de estar sancionada por la Sala de Representantes su anulación (que a la verdad triste cosa es ver hombres legos juzgando según las leyes) nos atrevemos á suplicar a los señores que lo componen, anden con cautela en la elección de las persona a quienes saben consultar sobre los puntos en que ellos son ignorantes, pues sabido es que aunque todos los asuntos que se ventilan ante el Tribunal son dirigidos por letrados, estos no firman los escritos, y no sería extraño que consultado alguno de ellos aconseje torcidamente a lo que le convenga á sus miras. Esto no carece de antecedentes; y es por esto que se lo hacemos presente á los señores del Tribunal, para que no sean sorprendidos y con la mejor buena fe del mundo pongan sentencias inicuas que puedan traer el despojo y la ruina de los litigantes. Dicen por ahí los conocedores de la materia, que en la calle antiguamente titulada del "Restaurador" hay un letrado muy vivo y práctico en la materia. Firma uno de los 9,000 desgraciados que piden justicia. ${ }^{48}$

subsidiaria del Código español. El 12 de septiembre de 1862 se lo fue adoptó como Código de Comercio de la República. Díaz Couselo, José María, Código de Comercio Argentino. Estructura. Relaciones con el Código Civil. Unificación, Buenos Aires, 1988.

${ }^{44}$ Diputados, 1858, p.193.

${ }^{45}$ Acevedo, Carlos Alberto, Ensayo histórico sobre la legislación comercial argentina. Tesis para optar al grado de doctor en Jurisprudencia a la Facultad de Derecho, Imprenta Alsina, Buenos Aires, 1914, pp. 63-71.

${ }^{46}$ El Judicial, periódico dirigido por los camaristas Valentín Alsina y Domingo Pica que publicaba los datos que los tribunales debían elevar a la Cámara de Justicia según la acordada del 5 de noviembre de 1853.

${ }^{47}$ Por ejemplo, en septiembre de 1855 había 1158 causas pendientes, mientras que las iniciadas en el mismo mes eran 114. En los años 1855 y 1856 el promedio de causas pendientes por mes era de 768 y de causas iniciadas 30.

${ }^{48}$ El Nacional, 9 de septiembre de 1858. "Crónica local. Tribunal de Comercio." 
Volviendo al proyecto de Ugarte, fue apoyado y pasó a la Comisión de Legislación, cuyo proyecto, presentado por el miembro informante Francisco de Elizalde, comenzó a debatirse el 26 de julio de 1858. Esta propuesta era más terminante. Comenzaba dando por suprimido el Tribunal del Consulado y establecía algunas pautas de funcionamiento para el nuevo organismo. Elizalde, al tomar la palabra, atacó directamente a la práctica jurisdiccional que hasta entonces se había llevado, afirmando que el gremio de los comerciantes no era el más idóneo para conocer y decidir sobre las causas del ramo. En la práctica del Consulado los abogados intervenían para todo, tanto como defensores de los litigantes o como consejeros de los jueces. La reforma buscaba dar uniformidad a la administración de justicia, terminando con los jueces especiales y liberando a los comerciantes de tan pesada carga, que les exigía tiempo y abandono de los negocios sin retribución alguna. ${ }^{49} \mathrm{El}$ proyecto entró en discusión y quedó finalmente aprobado.

El tratamiento en la Cámara de Senadores en la sesión del 16 de octubre de 1858, partía del informe de la Comisión de Legislación ${ }^{50}$, que aconsejaba la adopción del proyecto de Diputados, pero agregando que la ley no tendría ejecución hasta la promulgación del Código de Comercio del Estado. ${ }^{51}$ Todas las opiniones apuntaban en el mismo sentido, podía discreparse en algunos detalles, pero básicamente el Consulado debía ser reemplazado.

Sin embargo, faltaba Vélez Sarsfield, que sin rastros de diplomacia expresó que la ley en diputados fue ligeramente sancionada y que los motivos que daba el miembro informante tampoco eran de importancia. El Consulado marchaba bien y debía ser conservado a pesar del empeño de los "abogados jóvenes por inventar cosas nuevas" y destruir lo existente sin prever sus consecuencias. $\mathrm{Su}$ postura se respaldaba en el concepto de universalidad del derecho mercantil, sostenido por la experiencia de naciones europeas y la necesidad de separar las cuestiones comerciales del derecho civil y sus procedimientos.

El origen del derecho mercantil era consuetudinario, el interés común de los comerciantes hizo nacer las instituciones y las leyes requeridas para cada nueva necesidad. Para Vélez, era vano el esfuerzo de los juristas por acomodar esas leyes y costumbres a la ciencia del derecho de Justiniano. La especialidad de las leyes comerciales hacía innecesaria la ciencia de los abogados. El tribunal Consular era un completo jurado que debía juzgar sólo por su conciencia, los abogados no tenían escuela en derecho comercial y los defectos del Consulado podían solucionarse con pequeñas reformas.

El jurista Amancio Alcorta, miembro del Consulado, creía que la institución se hallaba desprestigiada por los abogados que seguían las causas con errores de procedimiento sujetándose a las reglas de los jueces ordinarios, en lugar de seguir las del Consulado que debía resolver a verdad sabida y buena fe guardada. Él proponía que Vélez se reuniera con la Comisión de Legislación de Diputados y presentaran un proyecto de organización del Tribunal de Comercio como ley adicional

\footnotetext{
${ }^{49}$ Diputados, 1858 , p.303.

${ }^{50}$ Integrada por Juan José Alsina, Andrés Somellera (ambos camaristas) y Sarmiento.

${ }^{51}$ Senadores, 1858, p.452.
} 
al Código de Comercio. La moción fue apoyada y el proyecto volvió a la Comisión, pero nada más pasó hasta 1862.

Ese año, entre el 23 y el 28 de octubre, fue aprobado el proyecto redactado por las Comisiones de Legislación de ambas Cámaras y los abogados de Diputados. ${ }^{52}$ De sus breves debates, vale destacar la opinión del senador Francisco Pico, vocal de la comisión redactora del Código de Comercio de 1852, para quien el proyecto sancionado cuatro años atrás no logró convertirse en ley porque aún se tenía más fe en los comerciantes que en los jueces letrados. Subyacía temor de destruir una institución antigua, que había sido representada en Buenos Aires por personas honorables, contra cuyo proceder nada se alegaba. Entonces Pico explicó que las cosas habían cambiado y la opinión pública pedía la reforma, los comerciantes no concurrían a las elecciones del Consulado y los que eran electos no querían hacerse cargo. Regía un código al que los comerciantes debían ajustarse y de los juicios participaban los asesores que no eran elegidos por el pueblo y no tenían responsabilidad ostensible.

Por todo esto la Comisión aceptó el proyecto incorporándole las variaciones necesarias, considerando mejor que los casos mercantiles, que estaban siendo resueltos como las causas civiles, fueran decididos por jueces que llevarán su responsabilidad con su firma y tuvieran audiencia diaria. En realidad, los motivos expuestos por Pico no eran muy diferentes de los utilizados en 1858. La única diferencia, no menor, residía en la vigencia del Código. Sin embargo, se levantó aún una voz en defensa del Consulado, la del senador Manuel Guerrico para quien el juicio de comerciantes hecho a verdad sabida y buena fe guardada, valía indudablemente mucho a esa sociedad y a ese comercio y la solución no era eliminar el Tribunal sino duplicar sus miembros.

Finalmente, el 29 de octubre de 1862 el gobernador de la provincia, Mariano Saavedra firmó el cúmplase a la ley que daba origen a los Tribunales letrados de comercio. Quedaba suprimido el Tribunal del Consulado, reemplazado por dos jueces letrados en primera instancia en lo comercial, nombrados en la forma que prescribía el artículo 121 de la Constitución. Los jueces tendrían audiencia diaria y observarían en sus procedimientos y resoluciones el Código de Comercio y leyes vigentes en éste género de causas. ${ }^{53}$ Pero la ley nada decía de los departamentos judiciales de la campaña y el tema no resultaba claro, al punto que un Acuerdo de la Suprema Corte de 1879

\footnotetext{
${ }^{52}$ Senadores, 1862, p.173. Diputados, 1862, p.146.

${ }^{53}$ Los dos Jueces reunidos, formarían al fin de cada año la lista de comerciantes de que habla el artículo 1556 del Código de Comercio, para desempeñar las funciones de Síndicos Provisorios de las quiebras. Anualmente se elegirían diez comerciantes para desempeñar cargos de Jueces comisarios en las quiebras, electos en la misma forma que prescribía la Cédula Ereccional del Consulado y demás leyes vigentes, desempeñando las funciones a que se refería el Código de Comercio. La nueva ley dejaba en vigencia la cláusula de la Real Cédula que autorizaba a los jueces de comercio a entender y resolver "a verdad sabida y buena fe guardada", lo que demostraba la influencia que seguían teniendo las fuentes indianas. Guillamondegui, Julio César, "La justicia consular en Buenos Aires (1794-1810)", en Boletín de la Academia Nacional de la Historia, volumen XXXIII (1962) 2a edición, Buenos Aires, 1963, pp.795-838, p. 36. En la prensa no hubo mayor repercusión, El Nacional del 24 de octubre de 1862, reprodujo un resumen del debate y el texto de la ley, tal vez porque era la caída de un fruto maduro.
} 
enunciaba que los jueces en el interior eran civiles y comerciales. ${ }^{54}$ El alto tribunal sostenía en un dictamen que en los tribunales departamentales de campaña la jurisdicción civil y comercial se encontraban reunidas. ${ }^{55}$

A partir de los nombramientos publicados en el Registro Oficial, confirmados minuciosamente en los expedientes preservados en el Archivo General de la Nación, ${ }^{56}$ hemos reconstruido el listado de los jueces de comercio que actuaron en el Departamento Capital entre 1863 y 1881: Mariano S. Pinedo, Juan E. Barra, Tomás Isla, Enrique Martínez, Juan A. Areco, Carlos Dimet, Juan Carlos Lagos, Julio Fonrouge.

Por la ley orgánica de 1881 del poder judicial, los juzgados de primera instancia pasaron a ser en toda la provincia de competencia criminal o civil y comercial. La Capital quedaba en las mismas condiciones de población, comercio y movimiento judicial que los otros tres Departamentos y podía, según los legisladores que reducían el problema a una cuestión de números, arreglarse con la misma cantidad de personal.

\section{La justicia correccional}

Los alcaldes de hermandad tenían facultades policiales y administrativas en su jurisdicción y con frecuencia actuaban como delegados de los otros magistrados para perseguir a los delincuentes, instruir el sumario o juzgar en causas correccionales. ${ }^{57}$ A partir de la organización judicial resuelta en 1821, los jueces de paz en la campaña y los jueces del crimen en la ciudad atendían la jurisdicción correccional. ${ }^{58} \mathrm{El}$ juez de paz era privativo en el huerto de ganado que no excediera seis animales, la vagancia, el uso de cuchillo o arma blanca, los hurtos simples y las heridas leves. ${ }^{59} \mathrm{En}$ la Capital la jurisdicción correccional correspondió, a partir del 7 de agosto de 1857, a un juez letrado especial, magistrado surgido de un proyecto remitido por el poder ejecutivo a la Legislatura con el objetivo de reprimir la vagancia y proveer el reclutamiento del ejército.

Francisco de Elizalde explicó las razones por las que la Comisión de Legislación aconsejaba la adopción del proyecto que el ejecutivo había sometido a consideración de las Cámaras. ${ }^{60} \mathrm{El}$

\footnotetext{
${ }_{54}^{54}$ Acuerdos y sentencias, tomo II, p. 493.

${ }^{55}$ Acuerdos y sentencias, II, Causa DCXLIX, del 22 de enero de 1880. p. 585. Los expedientes del Departamento Judicial del Sud tenían dos carátulas, una de Juzgado de primera instancia en lo civil y otra en lo comercial. El mismo magistrado firmaba como juez civil o como juez de comercio Es decir que dentro del juzgado estaba marcada la división jurisdiccional aunque el mismo funcionario impartiera justicia en uno u otro caso.

${ }^{56}$ Archivo General de la Nación, Fondos documentales, Archivo de Tribunales y protocolos, Tribunal comercial.

${ }^{57}$ Ibañez Frocham, 1938, op. cit.., pp. 6-7.

${ }^{58}$ Ley del 17 de diciembre de 1823 estableció el enjuiciamiento de quienes fueran reputados vagos atribuyendo la competencia a los jueces de paz y a los jueces del crimen. ROPBA, 1823, p. 98. En el Manual para los Jueces de Paz de Campaña de 1825 está transcripta la ley en el punto 8, p. 18.

${ }_{59}$ Tejedor, Carlos, Manual de Jueces de Paz en los procesos criminales, Buenos Aires, Imprenta Argentina "El Nacional", 1861, pp. 6-7. (en adelante, Manual criminal)

${ }^{60}$ El proyecto fue debatido en la Cámara de Diputados en Sesión del 3 de agosto. Diputados, 1857, pp. $345-355$. Aprobado, pasó a la Cámara de Senadores, dónde después de ser tratado por la Comisión de Legislación fue presentado el 1 de septiembre de 1857 y pasó a un extenso debate de tres sesiones La Cámara de Senadores debatió en sesión del 1
} 
objeto del proyecto era reprimir la vagancia, tanto en la ciudad como en la campaña, al mismo tiempo que remontar el ejército permanente, a lo que se recurría como medio pronto y eficaz "rechazada la ley de conscripción, en que se conciliaba la igualdad de los ciudadanos". La ley de 1823 había asignado a los jueces de primera instancia en la ciudad y de paz en la campaña las causas de vagancia, pero sin dar garantías para los enjuiciados.

Presentaban entonces un texto que creaba una autoridad especial para este tipo de causas, que eran muchas y que en ese momento no se atendían. Se establecía un juez de policía correccional para conocer en los delitos de vagancia, hurtos simples y todas aquellas faltas leves que atendían los comisarios de policía y sus resoluciones tendrían apelación ante los jueces del crimen. Pero la Comisión creía que a ese juez se le debían dar más atribuciones, creando un juez de instrucción criminal en todas las causas que así lo demandasen. Pero no había incorporado al proyecto esa reforma, porque lo urgente era que fuese votado como "un medio muy eficaz de obtener soldados, de hombres que hoy están en medio del vicio y que serán útiles al país". ${ }^{61}$ Elizalde termina dando su apoyo a la propuesta del ejecutivo, aunque de su presentación surgiera que otros mecanismos eran más favorables a la igualdad de los ciudadanos y la necesidad de garantir a los enjuiciados.

José Barros Pazos, ministro de gobierno presente en el debate, expuso que la legislación vigente sobre vagancia era confusa y verdaderamente vaga, lo que dificultaba su aplicación; las penalidades eran diversas y el sistema de procedimientos poco conforme con el que se observaba en los tribunales. Por esta "el Gobierno ha querido reunir en una sola Ley todas esas disposiciones dispersas para facilitar su conocimiento y aplicación y también para que el procedimiento sea más conforme con los principios liberales que nos rigen y de garantías a la libertad y seguridad que la Constitución acuerda a los ciudadanos". ${ }^{62}$

La ley del Gobierno proponía modificaciones importantes sobre la penalidad, estableciendo como pena el servicio de armas desde uno a cuatro años. En la capital atribuía la jurisdicción de esas causas al juez de policía correccional, con apelación al juez del crimen en turno. En la campaña debían ser juzgadas por el juez de paz, con apelación al juez de primera instancia del departamento en el que fuera aprehendido el vago. Según palabras del ministro, disminuían la penalidad y aumentaban las garantías, pues en la práctica la apelación no existía en el sistema de enjuiciamiento.

La propuesta fue aprobada y sin grandes cambios pasó a Senadores dónde se profundizó la discusión, modificando el texto y su objetivo pues se limitó a crear la justicia correccional letrada. Cuando regresó a Diputados, Francisco de Elizalde explicó que el proyecto era muy distinto en sus

de septiembre de 1857. Senadores, 1857, pp. 263-277; sesión del 3 de septiembre, Senadores, 1857, pp. 279-281; sesión del 17 de septiembre, Senadores 1857, pp. 345-360.

${ }^{61}$ Diputados, 1857, p. 345.

${ }^{62}$ Diputados, 1857, p. 346. 
detalles pero en el fondo era el mismo al enviado al Senado sobre represión de la vagancia y juez de policía correccional. En el proyecto original se hacía referencia a las disposiciones anteriores y se clasificaba la vagancia o el delito de vagancia, el actual hacía una declaración general "sin entrar a clasificar cuales son los delitos de vagancia”. El ministerio de gobierno estaba conforme y la ley fue aprobada. ${ }^{63}$ A continuación expondremos las ideas más importantes en debate, especialmente las relacionadas con el sistema de justicia.

Planteado el proyecto, surgieron en los debates de ambas Cámaras cuestiones de forma y de fondo que ponían de manifiesto los tiempos de transición que se estaban viviendo, los cambios profundos en cuanto a la concepción de la justicia y el papel del magistrado y la dificultad en aceptarlos o aplicarlos. Uno de los problemas, que ya hemos tratado al estudiar la justicia de paz, se basaba en "la separación de la justicia ordinaria de los asuntos que deben pertenecer a la Policía", según lo manifestó Rufino de Elizalde, aclarando las aristas del conflicto. Constantemente había motivos de desinteligencia entre la policía y los tribunales ordinarios y un solo juez no podría resolver todas esas causas. Era necesario que en una población tan grande como la de Buenos Aires el juez estuviera cerca del lugar donde se cometían esas faltas, por lo que era "casi indispensable y conveniente que los Comisarios sean los que conozcan de estos delitos de policía correccional, concediendo cuando más apelación ante un Juez de Policía correccional que se establezca" ${ }^{64}$

El miembro informante de Senadores, Juan José Alsina - que simultáneamente era juez del crimen de la Capital y que un mes después pasó a ser miembro de la Cámara de Apelacionesexplicó que no se podía poner en duda la necesidad y la urgencia de la adopción del proyecto. En la capital la población aumentaba a diario y en proporción los crímenes, en especial los leves. Los sumarios de esas causas quitaban demasiado tiempo a los jueces del crimen, ocupados también en delitos más graves cuyo castigo exigía la salud pública del modo más breve posible. Los delitos leves tenían una íntima relación con los reglamentos de policía y el juez correccional podría dedicarse a ellos. ${ }^{65}$

Pero aceptada la idea de que Buenos Aires tuviera un juez correccional, había una cuestión teórica mucho más profunda que debía resolverse, planteada en los debates por Carlos Tejedor: “¿La vagancia es verdaderamente un delito?”. El concepto de vagancia fue mutando y el cambio fundamental para su represión se generó entre el siglo XVII-XVIII cuando del carácter cristiano de la caridad se pasó a la utilidad pública. Este cambio de paradigma dio fundamentación a la pena y a la legislación contra los vagabundos. En la criminalidad como construcción jurídica el concepto de vagancia daba participación a la policía (seleccionando) y la justicia (juzgando y castigando). Se cruzó así un delito grave, juzgado por el juez letrado, con la pretensión de llevarlo hacia una

\footnotetext{
${ }^{63}$ Sesión del 5 de octubre de 1857. Diputados, 1857, pp. 541-542

${ }^{64}$ Diputados, 1857 , pp. 346-347.

${ }^{65}$ Senadores, 1857, p. 263.
} 
conducta ilícita de poca entidad, una resuelta por los jueces legos. ${ }^{66}$ Esta transformación era la que se estaba debatiendo en la legislatura porteña.

Tejedor, estaba de acuerdo con la creación de un juzgado correccional pero no con el objeto de perseguir la vagancia y remontar un ejército con los vagos. No había delito en no tener ocupación alguna, "para que esto fuera un delito era necesario que las sociedades hubiéramos reconocido el deber del trabajo que no está aceptado, que fue el principio de algunas repúblicas antiguas, pero que no ha pasado a las modernas". ${ }^{67}$

La vagancia era un estado que preparaba al delito, continúa Tejedor, aunque no era un delito en sí misma los que no tenían ocupación estaban más dispuestos a entregarse a los vicios, pero no merecía la pena grave del servicio de las armas. Eso se daba en España, pero en Brasil la vagancia se castigaba con ocho días de trabajo, lo mismo que en Francia, Inglaterra y Estados Unidos. Esto se agravaba al llamar vagancia a lo que era delito, como cargar armas prohibidas, fugar o emanciparse de su patria potestad, realizados por delincuentes vagos que debían hacerse soldados. Los vagos tenían suficiente castigo en la Carta constitucional que les quitaba los derechos civiles. ${ }^{68}$

Pero para el Ministro la vagancia era considerada por todas las legislaciones del mundo como un delito, los códigos de todas las naciones civilizadas lo consideraban así, por reunir los dos caracteres que constituían toda delincuencia: ser contraria a la moral -porque contraría el precepto divino que mandaba al hombre vivir de su trabajo- y perniciosa a la sociedad -porque es contraria al mejoramiento, a su progreso y riqueza-, por esto era considerada un verdadero delito y como tal reprimida y castigada por todas las legislaciones del mundo. ${ }^{69}$

Pero además el funcionario tenía su justificación. Cuando el ejecutivo presentó un proyecto en Diputados estableciendo la conscripción o el sorteo para la remonta del ejército, la Cámara se pronunció en contra, porque el Gobierno tenía en sus medios ordinarios como proveer el reclutamiento del ejército, haciendo hincapié en la facultad que tenían los agentes administrativos de destinar a los vagos a las armas. Por eso debieron recurrir a este proyecto para reglamentar lo relativo a la legislación sobre el vago y para dar más garantías a los ciudadanos que fuesen acusados

\footnotetext{
${ }^{66}$ Casagrande, Agustín E., Los vagabundos y la justicia de Buenos Aires durante el período tardo colonial (1785-1810) Construcciones jurídicas y criminalidad, Buenos Aires, Instituto de Investigaciones de Historia del Derecho, 2012.

${ }^{67}$ Unos años después, cuando redactó los Manuales para los jueces de paz, Tejedor había cambiado de idea y quienes no tenían trabajo eran vagos. "Los elementos esenciales de la vagancia son, la falta de domicilio, de oficio o profesión, y de medios de subsistencia. Decretos hay sin embargo que llaman vagos a los peones que transitan la Campaña sin papeleta de su patrón, o pase del Juez, los ociosos, los jugadores, los hijos de familia sustraídos de la obediencia de sus padres y los que usan cuchillo. La ley sin definir la palabra menciona expresamente a los que en días de trabajo se encuentran habitualmente en casa de juego o tabernas. Así es que los Jueces de Paz deben siempre considerarlos como vagos. Tejedor, Manual criminal, 1861, pp. 7-8.

${ }^{68}$ Diputados, 1857, pp. 348-349. Para Vélez Sarsfield tampoco había delito de ociosidad. Senadores, 1857 , p. 264.

${ }^{69}$ Diputados, 1857, p. 349. Barros Pazos hacía referencia al texto bíblico del Génesis 3, 19: “Ganarás el pan con el sudor de tu frente". Bernard de Mandeville (1670-1733) en su obra La fábula de las abejas, vicios privados, beneficios públicos de 1714, desarrolló y resolvió una nueva relación entre lo económico (la desocupación) y la moralidad (la vagancia) subordinando esta última a las acciones económicas. de Mandeville, Bernard, La fábula de las abejas, o cómo los vicios privados hacen la prosperidad pública. Madrid, Fondo de Cultura Económica, 1982.
} 
de esos delitos. Según el artículo 161 de la Constitución ningún habitante del Estado podía ser penado sin previo juicio y sentencia legal, y no eran estas las formalidades con las que se destinaba a los habitantes de Buenos Aires al servicio de las armas. ${ }^{70}$ La idea del Gobierno era que el vago estaba cometiendo un delito, por el que podía ser destinado a las armas pero con garantías constitucionales.

Entre estas dos posturas estaba la de Bartolomé Mitre, que no reconocía la vagancia como delito, pero que sí coincidía con el destino al ejército, que debía componerse "de aquellos elementos cuya ausencia sea menos perjudicial a la sociedad". Las armas debían manejarlas los menos ocupados o más bien los que no tuvieran ocupación alguna, de modo que el llevar hombres al ejército no significara arrebatar brazos a la industria. ${ }^{71}$ De esto puede interpretarse el destino al ejército no como castigo por un delito sino como alternativa o solución para un problema que la provincia debía afrontar. Llevado esto a un punto extremo, para José Eusebio Agüero -canónigo y abogado- ir un hombre a formar parte del ejército de línea no era una pena sino una carrera de honor, con un sueldo y un medio honorable de vivir, que no se podía equiparar a la prisión. Por lo tanto la pena leve que se daba a un vago, para evitar que se pusiera en la carrera del crimen era destinarlo al ejército. $^{72}$

Unido al debate sobre la vagancia surgió el principio de libertad, en palabras de Ireneo Portela, al observar en el proyecto una intervención activa de los jueces sobre el modo de ser y la conducta de cada ciudadano. Esto era contrario a los sanos principios de libertad, que consistían "en hacer lo que las leyes no prohíben, ni ofender los derechos de los demás hombres”. Otros senadores lo consideraban contradictorio con las garantías constitucionales, pues "se rompía la papeleta de hombres útiles y trabajadores para llevarlos a ser soldados”. La solución propuesta era repartir las tierras para hacerlo ciudadano útil al país y a su familia, y si ese hombre no se ocupaba de cultivar esas tierras, entonces debía ser corregido por sus compatriotas igualmente beneficiados, clasificado de mal vecino y ocioso y puesto en una casa de corrección. ${ }^{73}$

Se aceptara o no la vagancia como delito se creaba un juez correccional y el conflicto estaba en la definición de los delitos atendidos por esa jurisdicción. Vélez, que se oponía a la jurisdicción de un juez especial quitada a los jueces del crimen, explicaba que en los códigos extranjeros determinaban los delitos y las penas correccionales, pero esta ley no permitía conocerlos y sin código criminal era imposible determinar las jurisdicciones de los jueces ${ }^{74}$, y lo que era peor definir las penas, cuestión sobre la que interrogaba a los jueces.

\footnotetext{
${ }^{70}$ Senadores, 1857, p. 350.

${ }^{71}$ Diputados, 1857, p. 352.

${ }^{72}$ Senadores, 1857, p. 353.

${ }^{73}$ Senadores, 1857, pp. 264-267.

${ }^{74}$ Senadores, 1857, p. 264.
} 
Yo preguntaría a los señores jueces ¿por dónde se guían para castigar el robo? ¿Por sólo su conciencia? ¿Por dónde se guían para castigar las injurias graves? Por las circunstancias de la persona y de los hechos, porque las leyes criminales no pueden aplicarse. Queda todo en nuestras costumbres, a la equidad de los jueces, para disponer la pena. Un juez puede condenar a un reo a 600 azotes o a 200, porque todo es arbitrario en el juez; pues si fuera a aplicar las Leyes de partida, tendría que hacer cortar la mano al delincuente o sacarle los dientes. Lo mismo digo con relación a los hijos de familia, pues que eso será según la familia, según el joven. No veo, pues, la necesidad de hacer esta clasificación, seguro que no aplicará el juez las Leyes anteriores, porque llaman vago al hombre que anda vendiendo melcochas, al que anda con instrumentos de música, cosa que hoy está perfectamente tolerada. Es mejor dejar las Leyes como están. ${ }^{75}$

Establecer las penas generó un debate en el que algunos diputados proponían un máximo y un mínimo, dejando al juez apreciar la gravedad de los casos para imponer la pena y otros consideraban indispensable calificar el delito para aplicar la pena. Se decidió que los reos del delito de vagancia fueran castigados con una pena de arresto que no excediera los seis meses, o con el servicio a las armas en el ejército de línea por el término de uno a cuatro años, según la gravedad del caso. Lo difícil de superar el arbitrio del juez lo manifestó Mitre, asegurando que "todos los sistemas se encuentran frente a frente y los criminalistas no se han entendido todavía sobre cual es el mejor. Así es que por el proyecto se acepta uno de ellos, el que establece el mínimo y el máximo de la pena, dejando al buen juicio del juez la apreciación de la más o menos gravedad del delito" 76

Pero había legisladores contrarios a los límites de la pena, como Agüero para quien era preciso que siempre que se pudiera y hasta donde se pudiera los delitos y las penas fueran definidos y clasificados, para que la ley clasificara al delincuente y le aplicara la pena quitando el arbitrio del juez, pues

en materia criminal es un principio que para consultar la seguridad individual y los derechos sociales que deben tener los hombres, no se deje nada al arbitrio de los jueces, porque es bien sabido que todo juez es hombre, y que si hoy hay un juez recto y de una conciencia pura y delicada, mañana puede haber otro malo, sanguinario y perverso, y que si se deja al arbitrio de los jueces hacer la clasificación de los delitos como la de la pena que se ha de aplicar, la administración de justicia no tendría base fija por qué guiarse, y sería tan vario como son los hombres y sus ideas. ${ }^{77}$

Debía recopilarse todo lo que ya estaba en el Registro Oficial y conformar el Código del juez correccional, para "formarle un círculo de hierro de donde no pueda salir" y asegurar que la seguridad individual de la persona está garantida.

En el texto de la ley sancionada la palabra vagancia había desaparecido y sólo creaba la jurisdicción correccional en el distrito señalado a los jueces del crimen de la ciudad de Buenos

\footnotetext{
${ }^{75}$ Senadores, 1857, p. 270.

${ }^{76}$ Diputados, 1857, p. 353 . "Pero la distinción entre graves y leves debe ser determinada por la ley, ciega e imparcial, y no mediante la peligrosa y arbitraria prudencia de los jueces". Beccaria, Cesare, [1764] De los delitos y de las penas, edición crítica bilingüe y estudio preliminar por Francisco P. Laplaza, Ediciones Arayú, Buenos Aires, 1955, p. 281.

${ }^{77}$ Senadores, 1857, p. 270.
} 
Aires, con un juez letrado especial que tendría un sueldo de cuatro mil pesos mensuales, su asiento en la capital y despacho en el Departamento General de Policía, actuando con un escribano público con el sueldo de los escribanos del crimen ${ }^{78}$ y disponiendo de un ordenanza. Los delitos fueron definidos como aquellos que por su naturaleza daban lugar a una pena correccional, que eran de ocho días hasta tres años de detención, prisión o servicio en el ejército y las multas desde quinientos pesos.

En tanto fuera posible, juez correccional debía proceder en actuaciones verbales y su resolución podía apelarse dentro de tres días para ante el tribunal que conozca de las apelaciones de los jueces del crimen, sin más recursos. ${ }^{79}$ El primer juez de policía correccional fue Carlos Eguía nombrado el 13 de octubre de 1857, reemplazado el 18 de diciembre por José Boneo, por haber sido nombrado juez de primera instancia civil. ${ }^{80}$

Al año siguiente fue sancionada una ley que contenía todo lo que se había evitado en la primera, determinado el conocimiento de las causas de vagos y mal entretenidos. ${ }^{81}$ Pero en 1864 la Legislatura derogaba sus artículos $2^{\circ}$ y $3^{\circ}$, inhibiendo a los jueces de paz para conocer en delitos correccionales, debiendo limitarse a sumariar y someter al fallo de la justicia ordinaria a los detenidos. Podrían sólo conocer en faltas policiales y delitos que las leyes sometieran a su jurisdicción. El gobernador Saavedra envió una circular con el texto de los artículos derogados, pidiendo que los alcaldes y tenientes dieran lectura al vecindario. ${ }^{82}$

\section{$\underline{\text { IV. La Magistratura }}$}

El texto constitucional del Estado de Buenos Aires terminaba de dar forma en 1854 a la magistratura de primera instancia de la provincia de Buenos Aires, como parte de un poder judicial independiente en el ejercicio de sus funciones, desempeñada por jueces nombrados por el Gobernador, de una terna propuesta por el Superior Tribunal de Justicia, formada por abogados en ejercicio de la ciudadanía, mayores de 25 años y con dos años de ejercicio de la profesión. ${ }^{83}$ Eran magistrados letrados, que gozarían de la compensación que la ley les designara y que no podían ser

\footnotetext{
${ }_{78}^{78}$ El sueldo al escribano se le asigno por ley del 5 de agosto de 1876. ROPBA, 1876, pp.197-198.

${ }^{79}$ Ley del 6 de octubre de 1857, ROPBA, 1857, p. 135. Al año siguiente fue sancionada una ley que contenía todo lo que se había evitado en ésta, determinado el conocimiento de las causas de vagos y mal entretenidos. Ley del 5 de noviembre de 1858 . ROPBA, p.133. Pero en 1864, la Legislatura derogaba los artículos $2^{\circ}$ y $3^{\circ}$ de la ley, inhibiendo a los jueces de paz para conocer en delitos correccionales, debiendo limitarse a sumariar y someter al fallo de la justicia ordinaria a los detenidos. Podrían sólo conocer en faltas policiales y delitos que las leyes sometieran a su jurisdicción. El gobernador Saavedra envió una circular con el texto de los artículos derogados, pidiendo que los alcaldes y tenientes dieran lectura al vecindario. ROPBA, 1864, segundo semestre, pp. 115-116.

${ }^{80}$ ROPBA, 1857, p. 145; 309-310.

${ }^{81}$ Ley del 5 de noviembre de 1858. ROPBA, p.133.

${ }^{82}$ ROPBA, 1864, segundo semestre, pp. 115-116

${ }^{83}$ Constitución del Estado de Buenos Aires de 1854, Sección VI Del Poder Judicial, en Corbetta, Juan Carlos Textos constitucionales de Buenos Aires, SCBA, La Plata, 1984, pp. 73-74.
} 
removidos sin causa y sentencia legal. Nos dedicaremos a definir y a analizar que significaba que estos jueces fueran letrados, rentados e inamovibles. ${ }^{84}$

\section{a. La formación de los abogados}

El Estado moderno era Estado de derecho, Estado de leyes y el juez debía ser un hombre bueno, pero poco valía su virtud sin formación para aplicar e interpretar el derecho, que ya no estaba en las costumbres sino en las leyes y que no se podía conocer con la sola experiencia. ${ }^{85} \mathrm{La}$ instalación de los estudios jurídicos en Buenos Aires pasó por un intento frustrado a fines del siglo XVIII, y se concretó en 1814 con la creación de la Academia Teórico Práctica de Jurisprudencia, integrada por abogados registrados en la Cámara de Apelaciones, pero también doctores, licenciados y bachilleres de otras universidades. Sus cursos duraban tres años y el examen final se rendía ante la Cámara. ${ }^{86}$

Desde 1821, los estudios en el Departamento de Jurisprudencia de la Universidad de Buenos Aires estaban organizados en dos etapas, una académica que se cursaba en la Universidad y de la que se obtenía el título de Doctor en Jurisprudencia, y otra práctica en la Academia de Jurisprudencia, llevando en total unos cinco o seis años. Este proceso se mantuvo a pesar de los cambios políticos hasta 1872, sufriendo dos modificaciones con Rosas, al perder el apoyo financiero y requerir para alcanzar el título de abogado obtener del gobierno la “...declaratoria de haber sido sumiso y obediente a sus superiores en la Universidad durante el curso de sus estudios, y de haber sido notoriamente adicto a la causa nacional de la Federación...”, de otra forma el título otorgado sería nulo y la infracción a este decreto castigada. ${ }^{87}$

La Academia Teórico-Práctica de Jurisprudencia fue reemplazada por la Cátedra de Procedimientos judiciales en el plan de estudios universitarios, a partir de la propuesta realizada por del diputado Leandro N. Alem el 5 de agosto de $1872 .{ }^{88}$ Alem definía el estado de la Academia como una mera fórmula, cuyos integrantes no se reunían y los interesados en ser examinados tenían que buscarlos por todas partes, hasta en carruaje para que se presentaran, pues no bastaba la teoría para aprender incidentes y detalles que sólo se aprendían en el ejercicio de la abogacía. La Comisión de Legislación aconsejó su sanción con algunas modificaciones, aprobadas por el autor

\footnotetext{
${ }^{84}$ Todas estas cuestiones relacionadas con la magistratura son debatidas en la actualidad, como por ejemplo la inamovilidad de los jueces, el salario, la forma de elección o la jubilación. En el siglo XIX fue crucial la resolución de estas cuestiones, pues definieron el perfil de la magistratura que ha perdurado en el tiempo y hoy vuelven a la escena pública en forma de debate.

${ }^{85}$ Levaggi, Abelardo Manual de historia del derecho argentino, II, Depalma, Buenos Aires, 1987, p.10.

${ }^{86}$ Levene, Ricardo Historia del Derecho Argentino, VI, Kraft, Buenos Aires, 1951. La evolución de los estudios jurídicos la hemos seguido con Ortiz, 2004.

${ }^{87}$ Decreto del 27 de enero de 1836. ROPBA, 1836, p. 10.

${ }^{88}$ Diputados, pp. 293-295. Alem llegó a la Legislatura bonaerense como candidato del club Electoral, que representaba el sector joven y reformista del autonomismo. Barba, Fernando Los autonomistas del 70, Centro Editor de América Latina, Buenos Aires, 1982, pp.27-29; Leiva, 2005, pp. 188-200.
} 
del proyecto, no sin antes destacar el valor que había tenido la Academia en la formación de alumnos y profesores. Los diputados estaban de acuerdo en la necesidad del cambio y los debates se centraron en el sueldo que recibiría el profesor a cargo y en la duración de la materia. El senador provincial, Vicente F. López, junto a su compañero de Comisión Félix de Zéliz, aconsejaron a la Cámara la sanción del proyecto ${ }^{89}$ y la ley fue sancionada el 5 de octubre de 1872.

Según el artículo cuarto de la ley, una vez terminados los cursos teóricos, el alumno aprobado podría ingresar a cursar Procedimientos. Aprobado el curso, rendía un examen general teórico práctico de Jurisprudencia según lo determinaba el Consejo de la Universidad, debiendo presentar la tesis para obtener el diploma que lo acreditase en su carácter de Doctor en Jurisprudencia y solicitar el examen de abogado ante el Superior Tribunal de Justicia. ${ }^{90}$

El cambio se completó en 1874, al crearse la Facultad de Derecho de la Universidad de Buenos Aires, obedeciendo a lo establecido por la Constitución provincial de 1873. El decreto orgánico fue redactado por Juan María Gutiérrez, Pedro Goyena y José María Moreno y firmado por el gobernador Mariano Acosta, con su ministro de gobierno Amancio Alcorta. Esta decisión ha sido atribuida a un acontecimiento acaecido en diciembre de 1871, durante la época de exámenes en el Departamento de Jurisprudencia, cuando Roberto M. Sánchez, estudiante sanjuanino, se suicidó tras ser aplazado en Derecho Romano, generándose el Movimiento 13 de diciembre, liderado por Estanislao Zeballos, que con asambleas y peticiones a las autoridades universitarias y provinciales instalaron los debates en la reforma constitucional. ${ }^{91}$

A la comprensión del contenido de la reforma, ayuda comparar los discursos pronunciados al inaugurar la Academia en 1855 y el pronunciado al abrir la Cátedra de Procedimiento en 1872. En el primer caso, Octavio Garrigós, instaba a unir el conocimiento de la teoría del derecho con la práctica de la jurisprudencia, para formar al abogado y al jurisconsulto. En la Universidad habían aprendido los principios de la ciencia sin atender la vida del pueblo y las modificaciones que esos principios sufrían en la sociedad, en la Academia debían estudiar las aplicaciones prácticas de los principios, su desenvolvimiento e inconvenientes en la vida del pueblo, pues ambas juntas eran parte de la verdadera ciencia, el derecho no era una abstracción, era la vida misma, el orden entero de la sociedad. El teórico perfecto debía vivificar su teoría con “...una experiencia completa de la vida real, de los juicios y del resultado de los pleitos; que abrazara con un golpe de vista las combinaciones entre las costumbres, la religión, la Política y los intereses económicos de los pueblos." 92

\footnotetext{
${ }^{89}$ Senadores, 1872 , pp. 306-307.

${ }^{90}$ ROPBA, 1872 , p. 382-384.

${ }^{91}$ Ortiz, 2004, pp. 18-19.

92 "Disertación leída por el Dr. Octavio Garrigós en la apertura de la Academia de Jurisprudencia, 1 de marzo de 1855", en Revista de Legislación y Jurisprudencia, III, Buenos Aires, Imprenta de Buenos Aires, 1869, pp. 201-208.
} 
Daniel María Cazón, diecisiete años después, fundamentaba la poca atención prestada al procedimiento en una sociedad ocupada “...por sus hábitos de vida colonial, o inconsciente por mucho tiempo de los medios adecuados para aumentar sus libertades y garantir el derecho de cada uno sobre la propiedad y la vida...", lo que había vuelto inorgánico el mecanismo de la justicia, “...abstraídos por una evolución constante y sin descanso en las regiones de la política.” La consecuencia había sido el retardo en los juicios y un sistema “...vejatorio e inquisitorial...”, sobre el que reclamaba la sociedad un procedimiento que fuera “...resultado práctico del derecho, protegiendo el cumplimiento de las obligaciones y el sagrado de la propiedad, del honor y de la vida." Es decir que la ciencia del derecho no servía de nada sin una administración de justicia que lo aplicara, se vislumbra aquí la preocupación por formar abogados que supieran llevar adelante las causas, pero fundamentalmente que supieran aplicar la ley para resolverlas. ${ }^{93}$

\section{b. La inamovilidad y la buena conducta}

La Constitución de 1873 determinaba que el juez mantendría su empleo mientras durara su buena conducta, reafirmando lo que en 1854 se había enunciado como la imposibilidad de removerlos sin causa y sentencia legal. Los jueces de las Cámaras de Apelación y de primera instancia podían ser acusados por cualquiera del pueblo, por delitos o faltas cometidas en el desempeño de sus funciones ante un Jury calificado, formado por siete diputados y cinco senadores profesores de derecho, o en su defecto letrados con las condiciones necesarias para ser senador. El juez acusado quedaba suspendido en el desempeño de su cargo desde que era admitida la acusación. El Jury declaraba al acusado culpable o no culpable de los hechos imputados y pronunciado el veredicto de culpabilidad la causa seguía en manos del juez ordinario penal ${ }^{94}$. Una ley debía determinar los delitos y faltas acusables y reglamentar el procedimiento a seguir, pero la ley de Jury de enjuiciamiento de magistrados fue sancionada el 12 de octubre de 1878. Era jurisdicción del Jury, acorde al texto constitucional, suspender al juez en el ejercicio de su cargo desde que se hacía lugar a la acusación y a declararlo culpable o no culpable de los hechos que se le imputaban. Debía atender también las demandas contra jueces por mala conducta o incapacidad legal, física o mental, para desempeñar el puesto. El Jury una vez conformado debía reunirse en la sala de audiencia del Superior Tribunal. ${ }^{95}$

\footnotetext{
93 "Discurso pronunciado por el Dr. Daniel María Cazón en la apertura del aula de Procedimientos de la Universidad de Buenos Aires" en Revista de Legislación y Jurisprudencia, VIII, Buenas Aires, Imprenta de Pablo E. Coni, 1872, pp. 373-381.

${ }^{94}$ Constitución de la provincia de Buenos Aires de 1873, Sección V Del Poder Judicial, en Corbetta, Juan Carlos Textos constitucionales de Buenos Aires, SCBA, La Plata, 1984, pp. 111-118. Cap.II, Elección, duración y responsabilidad de los miembros del Poder Judicial, art.190-193, pp.116-117. (en adelante Constitución provincial de 1873)

${ }^{95}$ ROPBA, 1878, pp.253-264.
} 
Hasta que esta institución fue organizada seguía vigente el antiguo procedimiento de superintendencia, preservado por la misma Constitución ${ }^{96}$, y por tal se entendía el gobierno judicial conferido por la Constitución provincial de 1854 al Superior Tribunal ${ }^{97}$, que ejerció constantemente aplicando "la corrección disciplinaria, la suspensión, mandato de enjuiciamiento y pena del delito o falta grave, o bien la adopción de otra medida administrativa". Teniendo siempre presente la idea de preservar la dignidad de la magistratura, los miembros de la Suprema Corte aclaraban que

esta atribución, que es inherente a la constitución de todo poder, que lo ejerce la generalidad de los tribunales, y especialmente el Tribunal Supremo Español, cuya organización hemos tomado en gran parte, no es depresiva de la dignidad del magistrado, que fuerte en la convicción de su derecho y en la legalidad de sus procederes, debe ver en ella el medio legítimo de levantar hasta la más leve sombra de acusaciones injustificadas. ${ }^{98}$

El Tribunal sostenía que esta atribución constitucional no se perdería completamente con la ley de jury porque las faltas disciplinarias seguirían correspondiendo a su jurisdicción.

Uno de los casos más significativos en que tuvo que actuar el Superior Tribunal en ejercicio de la superintendencia fue el del juez Emilio Agrelo acusado de sustracciones indebidas de depósitos en el Banco Provincia de la sucesión de Santiago Donohag. El escribano Paulino R. Speratti preso por esta causa y ante la ausencia de asistencia del juez Agrelo, mandó a publicar artículos, primero en el diario La Prensa y luego La Pampa, involucrándolo. Esto bastó para que la máxima autoridad judicial de la provincia tomara intervención:

Habiéndose publicado en el Diario "La Pampa" del 29 de diciembre de 1872, un artículo denunciando delitos imputados al Dr. Agrelo en su carácter de Juez de primera instancia, consignándose datos y ofreciéndose justificativos cuya existencia e importancia es necesario investigar, siendo un deber del Tribunal de Justicia proceder a la indagación respectiva para esclarecer hechos que tan profundamente afectan al crédito de la Administración, el mismo Superior Tribunal reunido en Acuerdo Extraordinario, ha resuelto que el señor vocal Dr. Tomás Isla, proceda inmediatamente a esa investigación dando cuenta con toda brevedad del resultado. ${ }^{99}$

\footnotetext{
${ }^{96}$ Constitución provincial de 1873, art. 220, "Las funciones de que se hace mención especial en esta Constitución y que hoy son desempeñadas por el Tribunal de Justicia en sala plena, lo serán por la Corte Suprema una vez instalada y mientras no se dicten las leyes orgánicas y de procedimiento", p.127. El artículo 158 determinaba que "La Suprema Corte hará su reglamento y podrá establecer las medidas disciplinarias que considere convenientes a la mejor administración de justicia", Textos Constitucionales, p.112. Según su reglamento "la Corte puede llamar a su seno, a cualquier Magistrado Judicial, a fin de prevenirle por faltas u omisiones...", Reglamento para la Suprema Corte de Justicia de la provincia de Buenos Aires, art.25, en Acuerdos y sentencias, p.26.

${ }^{97}$ Constitución de la provincia de Buenos Aires de 1854, art. 125, "El Tribunal Superior tendrá la superintendencia en toda la Administración de Justicia”, en Textos Constitucionales, p.74. Esto fue confirmado por la ley que amplió el Superior Tribunal a diez miembros y un fiscal. El Superior Tribunal Pleno "tendrá la superintendencia de toda la administración de justicia”, ley del 29 de setiembre de 1857, artículo 9, inc.4º, ROPBA, 1857, pp.113-114.

${ }^{98}$ Resoluciones dictadas con motivo de la venida a la capital sin licencia, del camarista Dr. Benítez, y de los sucesos ocurridos en la casa de Justicia del departamento del Norte en 28 de setiembre de 1877, en Acuerdos y Sentencias, tomo I, pp. 641-643.

99 Causa criminal contra el Juez de Primera Instancia Emilio Agrelo y otros, por delitos graves, denunciados públicamente en el diario "La Prensa", lunes 27 y martes 28 de abril de 1872, por denuncias del escribano Paulino R. Speratti (que se halla detenido en la cárcel pública) y del Dr. Ramón Posse. Archivo Histórico de la provincia de Buenos Aires, Cuerpo 38, Anaquel 5, legajo 316, expediente 13. En el mismo documento mandó a suspender el traslado de Speratti a Patagones
} 
El 9 de enero de 1873, el presidente y vocales del Superior Tribunal distribuyeron las causas correspondientes al juzgado de Agrelo entre los demás jueces civiles por hallarse suspendido en sus funciones. ${ }^{100} \mathrm{La}$ causa criminal fue iniciada en primera instancia en el juzgado del crimen de Damián Hudson que lo declaró culpable el 31 de enero de 1874 en el proceso por defraudación de fondos pertenecientes a testamentarias en tramitación, condenándolo a prisión por cinco años, inhabilitación para el cargo público, indemnización civil y pago de costas.

La sentencia fue apelada y el 15 de junio de 1877 la Cámara del Crimen derogó el delito de hurto de Agrelo, pero confirmó su culpabilidad disminuyendo la condena. El fallo no fue unánime, uno de los jueces no encontró culpa alguna, otro acusó omisiones que lo hacían punible por faltas graves y el último halló conducta culpable, culpabilidad punible y grave culpabilidad. La sentencia de culpabilidad de faltas graves quedó compurgada por la prisión e inhabilidad sufridas. El recurso de inaplicabilidad de ley interpuesto ante la Suprema Corte fue fallado improcedente el 11 de abril de 1878. En los antecedentes del fallo, Sixto Villegas hizo referencia a la "criminalidad, negligencia, sospechosa indolencia, la responsabilidad penal, que clasifica la culpabilidad, usando las palabras de ley $1^{\text {a }}$, tít. 31 , part.7”, de la sentencia de primera instancia. ${ }^{101}$

\section{c. Magistrados rentados}

La cuestión de la retribución monetaria generó en estos años nuevos conflictos en torno a la acumulación de sueldos y de las jubilaciones. La primera cuestión pasó por diversas instancias hasta que finalmente los magistrados, que solían desempeñarse como legisladores a la vez que formaban parte del poder judicial, debieron optar entre una u otra actividad pública. En 1859 Rufino Elizalde presentó un proyecto por la Comisión de Hacienda, para fijar una regla que resolviera todas las cuestiones sobre acumulación de sueldos, ya establecida en 1821, pero arbitrariamente aplicada. ${ }^{102}$ Remitido por la Cámara de Diputados, el proyecto fue tratado por los senadores, aprobado en general y en particular, centrando el debate en torno a la cuestión económica. ${ }^{103}$

El tema reapareció en 1872, pero en otro contexto y con otros fundamentos, el proyecto sobre acumulación de empleos fue presentado por Aristóbulo del Valle y tratado por la Comisión de Negocios Constitucionales, con el fin de

...organizar el servicio público de una manera que responda a las verdaderas necesidades del país y acabar con la práctica perniciosa de los gobiernos, de acumular en una o dos personas mayor número de empleos de los que pueden desempeñar con arreglo a sus aptitudes, sin consultar a los verdaderos intereses del país, sino los intereses personales. Es una doctrina incontestable de buena administración, que cada empleo requiere su

\footnotetext{
${ }^{100}$ Acuerdo y sentencias, tomo I, pp.552.

${ }^{101}$ Acuerdos y sentencias, tomo II, Causa CCCLXI, pp.124-126.

${ }^{102}$ Sesión del 31 de agosto. Diputados, 1859, pp. 315- 316.

${ }^{103}$ Sesión del $1^{\circ}$ de setiembre. Senadores, 1859, pp. 147-150.
} 
empleado, y que sólo se tiene los empleos bien servidos cuando ellos están atendidos por personas que hacen de esa ocupación, el objeto principal de su vida. ${ }^{104}$

En el debate para algunos seguía siendo una cuestión económica, sin embargo se impuso la postura de quienes veían como objetivo el buen servicio de la administración - mucho más elevado que los sueldos- y también los inconvenientes políticos que de la acumulación de empleos infaliblemente resultaba.

La maduración del proceso llevó a que la Comisión de Negocios Constitucionales de Diputados presentara el proyecto sobre compatibilidad de empleos enviado por el Senado y aconsejara la sanción de esta ley por la que los jueces no serían más legisladores en forma simultánea, como lo hacían hasta entonces. La solución, para quienes defendían el proyecto, estaba en llamar al servicio público mayor número de ciudadanos en vez de reconcentrarlos en pequeños núcleos que se repartieran todos los puestos públicos pagándoseles tres o cuatro sueldos a cada uno. Era cuestión de tomar la decisión, pues aseguraban que poco se necesitaba conocer a Buenos Aires para comprender que no eran hombres competentes, con inteligencia e ilustración lo que faltaba. Los argumentos habían superado el plano económico y la mera eficiencia para centrase en la independencia de poderes, conquista que garantizaba las libertades públicas a la vez que facilitaba la acción del Poder en beneficio del servicio público. ${ }^{105}$

El tema de las jubilaciones no tenía pautas claras y la Legislatura resolvía cada caso en particular, por ejemplo el 28 octubre de 1868 se le acordó a Ana B. de Cárdenas, viuda de Jacinto Cárdenas, la tercera parte del sueldo que gozaba éste como juez de primera instancia, por vía de pensión graciable. ${ }^{106}$ La comisión de peticiones la presentó sosteniendo que en este cómo en otros casos análogos, no habían tenido presente sino razones de equidad, porque no habiendo ley de pensiones todo cuanto se hiciera sobre la materia era arbitrario. El mismo año se le acordó la pensión graciable de la mitad del sueldo de que disfrutaba como camarista, a la viuda e hijos de Tiburcio de la Cárcova que dejó ocho hijos menores sin recurso para la subsistencia. ${ }^{107}$ En octubre de 1870 se aprobó la jubilación de Mario J. Beascoechea, relator del Superior Tribunal de Justicia, con sueldo íntegro. ${ }^{108}$ En 1872 se le acordaron a Juan José Alsina, en su condición de miembro del Superior Tribunal, diez mil pesos moneda corriente mensuales. ${ }^{109}$

Previendo que en la implementación de la nueva organización judicial, prescripta por la Constitución de 1873, algunos magistrados no serían reelectos, se les acordó a los que hubieran

\footnotetext{
${ }^{104}$ Sesión del 18 de octubre. Diputados, 1872, p.562-563.

${ }^{105}$ Sesión del 7 de agosto. Diputados, 1874, pp. 450-473.

${ }^{106}$ Ketzelman, Federico y De Souza, Rodolfo Colección completa de leyes del estado y Provincia de Buenos Aires desde 1854 a 1881, Editorial Lex, Buenos Aires, 1930, tomo III, p. 524.

${ }^{107}$ Sesión del 28 de octubre, Diputados, 1868, pp. 501-502.

${ }^{108}$ ROPBA, 1870, p. 711.

${ }^{109}$ Ketzelman y De Souza, 1930, tomo IV, p.236.
} 
desempeñado cargos en la administración de justicia con inhibición del ejercicio de su profesión, por el espacio de más de diez años, cuya renta no excediera de seis mil pesos al mes, la mitad del sueldo de que gozaban, y a los que lo habían hecho por más de quince años, las dos terceras partes de sus sueldos. Lo interesante de estos debates fue como comenzó a destacarse la figura del magistrado distinta de la del litigante,

...entre el abogado y el juez hay, una distancia inmensa, que el juez ha formado sus hábitos, hábitos que no son los hábitos del abogado, que el juez tiene su manera de ver que no es la manera de ver del abogado, que el juez tiene su modo de estudiar que no es el modo de estudiar del abogado y en fin señor Presidente, el ser juez es un estado; y cuando se han pasado diez, doce, quince años ejerciendo esto que yo llamo sacerdocio, al hombre que abandona su puesto es muy difícil que baje a la arena de la lucha, se necesita, un hombre de espíritu y cuerpo vigoroso para que después de pasado un tiempo tal en la judicatura pueda decir yo voy a abogar, yo voy a volver a ser lo que he sido. ${ }^{110}$

La jubilación en estos términos fue acordada a Joaquín Cueto y a García Fernández, pero las medidas restrictivas del presupuesto, fruto de la difícil situación que atravesaba el erario público, consecuencia de la crisis, hicieron que la partida correspondiente a ambas pensiones fuera suspendida para 1876. Ambos ex jueces recurrieron a la Corte y la ley fue declarada inconstitucional, dejando en claro la nueva relación que se había generado entre los tres poderes. El poder judicial no podía decidir sobre su presupuesto pero si podía frenar los avances de los otros poderes sobre sus atribuciones fijando una frontera política.

El siguiente cuadro sintetiza los salarios recibidos por magistrados y funcionarios en funciones por año, realizado en base a los Presupuestos anuales.

${ }^{110}$ Sesión del 24 de octubre. Diputados, 1873, pp. 347-352. 


\begin{tabular}{|c|c|c|c|c|c|c|c|c|c|}
\hline Cargos & $1857^{111}$ & $\mathbf{1 8 6 0}^{112}$ & $\mathbf{1 8 6 3}^{113}$ & $\mathbf{1 8 6 4}^{114}$ & $1867^{115}$ & $\mathbf{1 8 6 8}^{116}$ & $\mathbf{1 8 7 4}^{117}$ & $1877^{118}$ & $\mathbf{1 8 7 9}^{119}$ \\
\hline $\begin{array}{l}\text { Juez en lo } \\
\text { civil de la } \\
\text { ciudad }\end{array}$ & 4300 & 5000 & 6000 & 7200 & 8500 & 8500 & 12000 & 11700 & 11700 \\
\hline $\begin{array}{l}\text { Juez en lo } \\
\text { criminal de } \\
\text { la ciudad }\end{array}$ & 4500 & 5000 & 6000 & 7200 & 8500 & 8500 & 12000 & 11700 & 11700 \\
\hline $\begin{array}{l}\text { Juez de } \\
\text { policía } \\
\text { correccional }\end{array}$ & 4000 & 5000 & 6000 & 7200 & 8500 & 8500 & 12000 & 11700 & 11700 \\
\hline $\begin{array}{l}\text { Agente } \\
\text { fiscal del } \\
\text { crimen }\end{array}$ & 2750 & 2750 & 2750 & 3300 & 4000 & 4000 & 10000 & 9000 & 9000 \\
\hline $\begin{array}{l}\text { Agente } \\
\text { fiscal en lo } \\
\text { civil }\end{array}$ & 1650 & 2000 & 2000 & 2400 & & 2500 & 10000 & 9000 & 9000 \\
\hline $\begin{array}{l}\text { Oficiales de } \\
\text { justicia }\end{array}$ & 600 & 600 & 600 & & & & & & \\
\hline $\begin{array}{l}\text { Escribanos } \\
\text { del crimen }\end{array}$ & 1650 & 1650 & 1650 & 1980 & 2500 & 2500 & 4000 & 4500 & 4500 \\
\hline Portero & 440 & 440 & 440 & & & & & 500 & 500 \\
\hline Ordenanzas & 170 & 170 & 250 & 300 & 300 & 300 & 500 & & \\
\hline $\begin{array}{l}\text { Juez del } \\
\text { crimen de } \\
\text { campaña }\end{array}$ & 4500 & 5000 & 6000 & 7200 & 8500 & 8500 & 12000 & 11700 & 11700 \\
\hline $\begin{array}{l}\text { Agente } \\
\text { fiscal }\end{array}$ & 1100 & 1100 & 1100 & 1320 & 1400 & 1400 & 2000 & 9000 & 9000 \\
\hline $\begin{array}{l}\text { Defensor de } \\
\text { pobres }\end{array}$ & 880 & 880 & 880 & 1055 & 1100 & 1100 & 2000 & 4000 & 4000 \\
\hline $\begin{array}{l}\text { Juez de } \\
\text { comercio }\end{array}$ & & & 6000 & 7200 & 8500 & 8500 & 12000 & 11700 & 11700 \\
\hline
\end{tabular}

\footnotetext{
${ }^{111}$ Presupuesto general de sueldos y gastos de la Administración para el año 1858, 30 de noviembre de 1857. ROPBA, 1857, pp.188-265. Los salarios de los miembros del Superior Tribunal, su fiscal y los jueces de primera instancia fueron establecidos por una ley del 1 de junio de 1857, ROPBA, p.52.

${ }^{112}$ Presupuesto general de sueldos y gastos de la Administración para el año 1861, 22 de noviembre de 1860, ROPBA, 1860, pp.170-254.

${ }_{113}$ Presupuesto de la Administración general para el año de 1863, mayo de 1863, ROPBA, 1863, pp.145-179.

114 Presupuesto General de la provincia de Buenos Aires para el año 1864. ROPBA, 1864, pp.152-190. Este presupuesto sancionado el 9 de octubre de 1863, firmado por Saavedra y Luis L. Domínguez acuerda los siguientes cambios con respecto al de 1863: aumento del 20 por ciento sobre los sueldos, jubilaciones y pensiones, con excepción de los sueldos de Gobernador e Inspección de Milicias, que serán los mismos que rigen; de los sueldos de Relatores del Superior Tribunal de Justicia, que se fijan en $\$ 5000$ pesos mensuales.

${ }^{115}$ Ley del presupuesto general para el año de 1867, 19 de junio de 1867. ROPBA, 1867, pp.241-276.

${ }^{116}$ Presupuesto general de gastos de la provincia de Buenos Aires para el año 1868, 20 de noviembre de 1867. ROPBA, 1867, pp. 524-567.

${ }^{117}$ Presupuesto general de gastos de la provincia de Buenos Aires para el año 1874, 23 de febrero de 1874, ROPBA, 1874, pp. 83-128.

${ }^{118}$ ROPBA, 1878, pp.53-91. Podemos observar un descuesto del 10\% que obedece la ley de presupuesto de 1876, Art. 12 Desde la promulgación de la presente ley todos los presupuestos votados por leyes especiales para las diversas reparticiones de la Administración, serán reducidos en un diez por ciento en los sueldos que excedan los mil pesos mensuales. Art.13 Las pensiones y jubilaciones que excedan los mil pesos, se ajustarán con una rebaja del $10 \%$ con excepción de las de Monte-pio. ROPBA, 1876, p.103. Esa ley asigna 11.700 pesos a cada juez de primera instancia.

${ }^{119}$ ROPBA, 1879, pp. 1-44.
} 


\section{$\underline{\text { V. Los Magistrados }}$}

Para definir quiénes eran los magistrados, el primer paso fue recurrir a sus nombramientos, que debían aparecer publicados en el Registro Oficial como decretos del poder ejecutivo, presentados por el Ministro de Gobierno. El Superior Tribunal elevaba una terna y el gobernador elegía al postulante que cubría la magistratura vacante. ${ }^{120}$ Pero lo cierto es que los nombramientos no siempre eran publicados y en algunos casos los abogados nombrados no asumían el cargo, por ello debimos por un lado completar la lista de los jueces y por otro confirmar su actividad.

Para ambas cosas la solución más efectiva fue consultar los fondos documentales de los juzgados que tuvieron a su cargo, es decir verlos a los jueces en acción, pero esto no siempre fue posible. Recordemos que al inicio del período en estudio funcionaban dos juzgados civiles y dos criminales en la Capital y uno criminal en cada nuevo Departamento creado, el Norte y el Sud en 1853 y el Centro en 1856. En 1854 se creó otro juzgado civil para la Capital y tres más en 1871. Dos juzgados comerciales reemplazaron al Consulados en 1862, (en la campaña el juez del crimen funcionaba como juez mercantil) y finalmente en 1873 se creó un juzgado criminal para la Capital. De todos estos juzgados se conservan los expedientes del Departamento del Sud, del Centro, el Criminal Capital y los mercantiles. Buena parte de los expedientes civiles de Capital también se conservan porque no pueden ser destruidos (familia, sucesiones, etc.). Pero al rastrear los jueces actuantes en estas causas se debe tener la precaución de no confundir a los que pertenecían a otro juzgado porque estaban a cargo temporariamente, por enfermedad, ausencia o vacancia.

Otra alternativa son los papeles de los juzgados de paz, pues tenían jurisdicción propia y delegada, que era aquella por la que el juez de primera instancia le autorizaba a realizar actos y diligencias del proceso que no requerían su presencia. Esto generaba un intercambio de notas, firmadas por el juez, archivadas en el juzgado, como las de Exaltación de la Cruz que hemos consultado en esta oportunidad.

Otra cuestión a tener en cuenta son los abogados nombrados pero que no aceptaron los cargos. En uno de estos casos, Martín Matheu, hijo de Domingo, presentó la nota de rechazo al Juzgado del Crimen del Departamento Capital, en la que puede observarse la diferencia que se fue estableciendo entre el ejercicio de la profesión y de la magistratura.

...no me es posible aceptar esta distinción, por cuanto habitudes de estudio y trabajo, en más de 26 años, me han constituido inadecuado para sobrellevar la gran responsabilidad de ese cargo: hábitos a mi pesar contraídos, que harían resentir el buen desempeño que requiere el servicio público. Esto mismo expliqué al Sr. Presidente del Superior Tribunal de Justicia, quien bondadosamente atendió como plausibles las razones prolijas de mi excusación. Agradezco a S.E. como debo la designación con que me ha elegido; pero suplico igualmente,

\footnotetext{
${ }^{120}$ Constitución del Estado de Buenos Aires de 1854, Sección VI del Poder Judicial, art.121, Corbetta, 1984, op. cit., p.
} 74. 
por el órgano de Ud., se sirva dejarme en el ejercicio de mi profesión de Abogado, defiriendo a le expuesto. ${ }^{121}$

Cubrir los cargos no fue tarea sencilla durante todo el período, pero hubo momentos especialmente conflictivos, uno de ellos fue el de los nombramientos para los nuevos juzgados del crimen de campaña. Los postulados aducían escasa instrucción, falta de experiencia, delicada salud o no contar con la edad exigida. Finalmente, el 27 de marzo de 1854 fue nombrado José María Juan Climarco Irigoyen en el Departamento del Norte, que no instaló su juzgado en Arrecifes tal como determinaba la ley, sino en la Guardia de Luján (Mercedes), según se lo indicó el ministro Irineo Portela.

...en virtud de los inconvenientes que obstan al presente la instalación del Juzgado al cargo de V.S. en el pueblo de Arrecifes, según lo resuelto por la Honorable Sala, el Gobierno a fin de que no se demore más tiempo la instalación de dicho Juzgado, tan urgentemente reclamada para el buen servicio de la administración de justicia, ha resuelto que, por ahora, y mientras se adopten las medidas necesarias a fin de cumplir lo dispuesto por la H. Sala, para V.S. para la Guardia de Luján, a establecer allí su Juzgado... ${ }^{122}$

La decisión unilateral del poder ejecutivo, tal vez fue fruto del conocimiento que Pastor Obligado adquirió de la zona en la recorrida que realizó por los pueblos del norte y centro de la provincia entre el 20 de marzo y el 8 de mayo de $1854 .{ }^{123}$

Irigoyen representaba el modelo de muchos otros jueces que durante su formación en la Academia, practicaba en un estudio prestigioso y trabajaba en los Ministerios como oficial, así lo manifestó cuando se presentó ante la Cámara de Justicia a solicitar su matrícula,

...cerca de dos años que me hallo incorporado en la matrícula de practicantes a juristas y más de un año antes he asistido diariamente con tal objeto al estudio del Dr. Roque Pérez, donde con la mayor contracción y estudio me he dedicado enteramente a la práctica de la jurisprudencia. Allí bajo su dirección y con un excesivo empeño he aprendido cuanto ha sido posible, y mi continua asistencia a la Academia de Jurisprudencia a pesar de mis inconvenientes que me ofrece mi calidad de empleado en uno de los Ministerios, me ha puesto hoy día en estado de poder optar al honor de pertenecer a la matrícula de Abogados de esta Excma. Cámara... ${ }^{124}$

Manifestaba también la relación del juez con el poder ejecutivo en estos primeros años de organización de la magistratura en función de pautas constitucionales, considerada un servicio al Gobierno, no una carrera diferenciada del ejercicio de la profesión que tardearía en darse. Cuando fue nombrado juez llevaba nueve años de libre ejercicio de la profesión y dijo que sólo aceptaba por tres meses, pero finalmente lo hizo sin límite de tiempo, considerándose feliz si conseguía

\footnotetext{
${ }^{121}$ Nota presentada el 13 de noviembre de 1863, ROPBA, 1863, p. 325.

${ }_{122}$ Nota del Ministro Portela al Juez Irigoyen, AGN, Buenos Aires, Sala X, 28-5-1, fs. 272, 12 de junio de 1854.

${ }^{123}$ Molle, Alejandro El Departamento Judicial de Mercedes (Bs.As.), Mercedes, 1997.

${ }^{124}$ Sobre la práctica en estudios jurídicos Leiva, 2005, op. cit., p. 158.
} 
“...desempeñar el Juzgado referido a satisfacción del Excmo. Gobierno para lo cual no omitirá sacrificio ninguno esforzando su contracción a fin de suplir su falta de luces..."125 En el primer mes de trabajo (agosto de 1854) Irigoyen atendió tres causas, dos contra las personas y tres contra la propiedad, según constó en el informe presentado a la Cámara de Justicia el $1^{\circ}$ de setiembre de $1854 .^{126}$

Después de 1872 volvió a tornarse dificultoso lograr que los abogados aceptaran los cargos de juez, esto podía ser por los bajos salarios, la inestabilidad económica y política y los cambios que se avecinaban con motivo de la sanción de la nueva Constitución, a lo que se sumaba el aumento del número de juzgados de cinco en 1854 a once para la Capital y tres para la Campaña, en 1873.

Las siguientes conclusiones fueron obtenidas partir de una muestra de cuarenta y nueve abogados, de los pudimos obtener información. ${ }^{127}$ Las fechas de nacimiento van de 1799 a1844. La mayor cantidad se da entre 1830 y 1840 (doce abogados) y descienden a la mitad para la década siguiente. Esto significa que un buen número de ellos nació y creció durante el rosismo, en varios casos sufriendo el destierro propio o por sus padres, como Juan José Alsina, Benito Carrasco, Carlos E. Eguía, Juan Agustín García, Claudio Martínez, Miguel Navarro Viola, Ventura Pondal y Andrés Somellera. Una manifestación del exilio fue en algunos casos la diferencia de años entre la obtención del título de doctor y la inscripción en la matrícula.

Otros formaron parte del gobierno de Rosas, que a pesar de haber sido reemplazados en sus cargos en un primer momento después de 1852, retornaron a la administración de justicia. Eustaquio Torres fue nombrado nuevamente juez del crimen de la Capital; Mariano Beascoechea, que fue secretario del Departamento General de Escuelas y salió a campaña con Rosas, se jubiló como relator del Superior Tribunal en 1870; Miguel Estevez Saguí fue rosista en su juventud y

\footnotetext{
${ }^{125}$ Molle, 1997, op. cit., p. 46, AGN;28-5-1, fs.276-277.

${ }^{126}$ Molle, 1997, op. cit., p.38. Datos según la relación y estado pendiente de las causas, iniciadas y concluidas en cada mes, que debían. Valentín Alsina como camarista se ocupó de organizar la estadística judicial. "Acuerdo extraordinario del 5 de noviembre de 1853, Estableciendo y reglamentando la estadística judicial.” Según Alsina la estadística era indispensable para planificar las reformas en el orden judicial, Acuerdos y sentencias, tomo I, pp.183-184,

${ }^{127} \mathrm{Si}$ los registros oficiales son tan poco precisos para estos años, imaginemos cuanto más dificultoso es aproximarse a las vidas públicas y privadas de estos hombres. Existen sin duda varias vías, pero necesitábamos en esta ocasión de una que nos diera una vista lo más completa posible de todos ellos. De nada serviría ahora tener detalles precisos de algunos e ignorar la vida del resto, por ello recurrimos a los diccionarios biográficos. Los datos allí encontrados los volcamos en una planilla tipo y los confirmábamos o completábamos con los datos hallados en los fondos documentales. Una vez completadas estas planillas construimos un cuadro combinando los datos biográficos con los obtenidos sobre su desempeño como jueces, las columnas contiene: Abogado: nombre de todos los abogados que aceptaron el cargo y lo ejercieron aunque fuera por pocos días; Nacimiento: año en que nació; Lugar: ciudad de nacimiento; Título: año en que le fue otorgado el título de doctor en jurisprudencia; Matrícula: año en que se presentaron ante el más alto Tribunal a rendir el examen para obtener el título de abogado y ser inscripto en la matrícula. Recordemos que hasta 1812 fue la Real Audiencia, luego la Cámara de Apelación hasta 1857 que la reemplazó el Superior Tribunal de Justicia (Constitución de 1854) y finalmente desde 1875 la Suprema Corte de Justicia (Constitución provincial de 1873). El listado de los abogados recibidos e incorporados por la Real Audiencia, Cámara de Apelaciones, Superior Tribunal y Suprema Corte de Justicia de la provincia de Buenos Aires pueden consultarse en Acuerdos y sentencias, tomo I, pp. 766-774; Magistrado: años en que fue juez de primera instancia en la provincia de Buenos Aires; Departamento: departamento judicial en que ejerció la magistratura de $1^{a}$ instancia; Poder Judicial: otros cargos previos o posteriores a la primera instancia; Período: años en que los ejerció; Otros cargos: ejercidos en la administración pública de la provincia en forma simultánea con la magistratura; Período: años en que los ejerció.
} 
luego nombrado juez del crimen; el famoso Emilio Agrelo, que tiró del carro de Manuelita, renunció a la magistratura en 1873. Daniel María Cazón expresó la experiencia de esos años, asegurando que “...por lo que a mí respecta puedo asegurar que más de una vez he sentido el peso abrumador de mis primeros años bajo el respeto del falseamiento en las ideas, de la estrechez de nuestros estudios y de la poca o ninguna expansión de nuestro espíritu..." ${ }^{128}$ Esto fue otra muestra de la unión entre ex rosistas y emigrados porteños ante un enemigo común para rechazar el Tratado de San Nicolás. ${ }^{129}$

El magistrado más joven fue Navarro Viola con 25 años, que cumplía con las leyes mencionadas por Francisco de Elizalde al rechazar el Juzgado del Norte en 1853. Seguía un grupo de nueve abogados que habían asumido con menos de 30 años en los extremos del período, antes de 1858 o después de 1872. Los de menos de 40 eran diez y ya algunos eran nombrados en la década del 60, mayormente ocupada por los nueve que tenían más de 40 años. Juan José Alsina y José Antonio Zavalía ocuparon la magistratura con 58 y 59 años respectivamente, siendo los dos únicos que no habían estudiado en Buenos Aires. Podríamos concluir que en los años críticos no se reparaba en la edad de los postulantes, prefiriendo los de 40 cuando se podía elegir.

Conocemos el lugar de nacimiento de trente y tres de ellos siendo el 75\% de Buenos Aires, el $15 \%$ de provincias argentinas y el resto de Asunción, Luro y Montevideo. Como dijimos antes, todos estudiaron en Buenos Aires, a excepción de Juan José Alsina que lo hizo en Córdoba y José Antonio Zavalía en Chuquisaca. Alsina había nacido en Montevideo y su padre murió en la defensa de Buenos Aires en la segunda Invasión inglesa, quedando su madre sin recurso alguno. Entre el clero realizaron una suscripción para socorrer a cuatro viudas que pudieran costear las carreras de sus hijos, realizado el sorteo en la plaza de la Victoria. Alsina resultó favorecido y partió a Córdoba a estudiar recibiéndose de doctor en teología en 1816. Regresó a Buenos Aires a cuidar a su madre y luego retornó a Córdoba a continuar estudiando por su cuenta, llevando consigo a su hermano Valentín, se recibió y rindió el examen para la matrícula en Buenos Aires. Fue por cinco meses juez de primera instancia, pasando luego a integrar el Superior Tribunal. El caso de Zabalía resulta lógico por haber nacido en Tucumán, fue camarista en Salta y magistrado en Mercedes por siete años hasta su muerte.

La cantidad de años que fueron jueces y cómo se desarrollaron sus carreras es un innegable aporte al estudio de la magistratura, porque si bien algunos de ellos eran legisladores simultáneamente, nos habla del desarrollo de carreras judiciales, que hasta ese momento no se había experimentado. El caso de Tiburcio de la Cárcova preanuncia lo dicho, atravesando los cambios posteriores a Caseros, inició sus años en tribunales como agente fiscal en 1841, en 1844 fue

\footnotetext{
128 “Discurso pronunciado por el Dr. Daniel María Cazón...”, op. cit.

${ }^{129}$ Lettieri, 1999, op. cit., p. 69.
} 
ascendido a juez del crimen y formó parte del primer Superior Tribunal hasta su muerte en 1868, recibiendo su viuda pensión por su actividad judicial.

La carrera comenzaba como agente fiscal o relator, pasaban a juez de primera instancia, para luego ascender al Superior Tribunal, seguir con la carrera política o volver a ser relator hasta la jubilación. Cuando se produce el cambio de 1875 algunos integrantes del Tribunal formaron las Cámaras de Apelación. Otra alternativa era el paso por la campaña para acceder a la Capital, como Alejandro Heredia, Tomás Isla (que llegó hasta la Suprema Corte) y Ventura Pondal, jueces del Departamento del Norte; Jacinto Cárdenas y Joaquín Cueto del Sud; Jorge Echevarría, Manuel H. Langhenheim, del Centro. Este último fue el prototipo de una carrera judicial, militante masón y defensor de la enseñanza laica.

Con respecto a la simultaneidad de la magistratura y de la tarea de legislador que observamos en dieciséis de los jueces, concluimos que la misma no estaba reñida con la concepción de servicio público y de la relación entre judicatura y política de esos años. Los cargos de diputado y senador no tenían salario. La dieta se estableció en 1874 como dijera Luis V. Varela “...no como una compensación al empleo sino simplemente para hacerles comprender que el nombramiento de diputado o senador no importa un título de honorabilidad, sino que impone deberes, desde entonces como todo empleado a sueldo...", buscando un remedio a la falta de número en las sesiones. La compensación sería de 50.000 pesos anuales divididos en cuatro mensualidades, descontándose lo proporcional a las faltas en que hubiera incurrido. Sumado esto a la ley de compatibilidades, los jueces dejaron de ser legisladores. ${ }^{130}$

El recorrido vital de estos magistrados refleja la heterogeneidad en la edad y participación en la carrera judicial, que se hace menor respecto a la ciudad de procedencia y de formación, donde prevalece Buenos Aires en la medida que avanzan los años.

\section{Conclusiones}

Los tribunales de primera instancia conformaban el poder judicial en un momento en que el complejo proceso de la construcción del Estado debía resolver la división de poderes y el diseño de las instituciones de gobierno, entre las que eran fundamentales las encargadas de la administración de justicia Estas instituciones se inscribían en el marco más amplio de la justicia como valor, sobre cuya concepción fue construido el ordenamiento jurídico del Estado, su legitimidad y la relación que se estableció con la sociedad. El concepto de justicia se iba reduciendo de virtud a ley aplicada en los tribunales, y si bien el derecho natural seguía vigente, el derecho positivo avanzaba apoyado en el eclecticismo jurídico.

\footnotetext{
${ }^{130}$ ROPBA, 1874, p. 371.
} 
En este contexto, y para acceder a su orden jurídico, recurrimos en este capítulo a los debates parlamentarios y a la legislación para comprender cómo surgieron y cuáles fueron las raíces de la justicia de primera instancia civil, criminal y correccional, teniendo en cuenta todo el territorio provincia y las diferencias que se establecieron entre capital y campaña. Pero esta pesquisa quedaba incompleta si no conocíamos a los hombres que fueron los jueces de esos juzgados, qué condiciones debían cumplir para ocuparlos y cómo fue el movimiento dentro del poder judicial en estos años, en que se estaba consolidado la carrera judicial de hombres "íntegros y competentes".

Respecto a la justicia de primera instancia, nadie discutía ya la necesidad de atender los requerimientos judiciales de la campaña, pero se enfrentaban una propuesta de emergencia, con un plan de organización basado en las municipalidades como expresión y ejercicio de la soberanía del pueblo. Los objetivos inmediatos eran resolver las causas pendientes del rosismo y comenzar a construir una estructura de legitimación del poder. Quizá por esto la ley siguió adelante y el mapa judicial continuó creciendo, más allá de los cambios institucionales que el poder judicial tuvo a lo largo de los años.

Hemos seguido el camino que recorrió la justicia mercantil lega hasta convertirse en letrada, para unirse finalmente con la justicia civil. El cambio se generó en un escenario diferente, en el que los comerciantes eran protagonistas de un proyecto orientado por el progreso, que les generaba riesgos, por lo que ellos exigían garantías. Los comerciantes no querían el cargo en el Consulado, la justicia estaba atrasada, los abogados actuaban de todas formas en los juicios, todo esto era cierto, pero lo más importante era que los conflictos suscitados por las sociedades anónimas no podían ser resueltos por jueces legos, pares de quienes recurrían a la justicia para resolverlos. Sí, como dice Tau Anzóategui, la justicia gremial había logrado hasta entonces "zafarse de las garras letradas", 131 era ya impostergable la instalación de la justicia mercantil letrada.

En esta jurisdicción, no pudieron instalarse jueces letrados que tuvieran que juzgar con las Ordenanzas de Bilbao. Primero debió sancionarse el Código de Comercio y esto llama la atención pues los otros fueros tuvieron sus jueces letrados mucho antes de la codificación. El derecho comercial basado en el acto de comercio se convertía en un derecho de todos, constituido por actos civiles, competencia del derecho civil, en una jurisdicción exclusivamente comercial, aunque la aplicara un juez que también juzgaba causas civiles. ${ }^{132}$

La creación del juzgado correccional tuvo como objetivo reprimir la vagancia y proveer el reclutamiento del ejército. Fue por esto que a pesar de tratarse de un juzgado que atendía causas menores generó los profundos debates en torno a la vagancia y el arbitrio jurídico, que no lograron

\footnotetext{
${ }^{131}$ Tau Anzóategui, op. cit., 1973.

${ }^{132}$ En nuestro país, a partir de 1986, se inició en el ámbito legislativo la tendencia unificadora de la legislación civil y comercial. El 15 de julio de 1999 fue presentado un proyecto de unificación de los códigos civil y de comercio en un único código, elaborado por la comisión integrada por los doctores Alegría, Alterini, Méndez Costa, Rivera, Roitman y Zannoni.
} 
resolverse, dejando establecida una diferencia -que desde el discurso buscaba eliminarse- entre la justicia letrada de la ciudad y la justicia lega de la campaña.

Más allá de determinar si la vagancia era o no un delito, lo más importante es que en ningún momento aparece la idea de pecado, sino de contrario a la moral, porque el que la practicaba no trabajaba. Entonces la discusión más profunda era si a los "vagos" era mejor mandarlos al ejército, para no quitar brazos a la industria, o ponerlos a trabajar con ese mismo objetivo. Una moralidad basada en lo económico y no en lo religioso.

En cuanto los magistrados, comenzamos a investigar convencidos de encarar la construcción de un gran rompecabezas, pero dados los primeros pasos descubrimos que buena parte de las piezas se habían extraviado y no claudicamos porque suponíamos que podríamos rearmarlas con la información de las piezas de alrededor. Sin embargo, a medida que avanzábamos debimos aceptar que no era un rompecabezas, pues los integrantes de la administración de justicia eran hombres y sus conductas no encajarían unas con otra, ni siquiera las de un mismo hombre a través de los años. Pero las partes no encajaban sobre todo porque quienes estaban "armando" la administración de justicia a lo largo de estos años disentían en sus opiniones y buena parte de los momentos en que había que tomar decisiones disentían profundamente. Estábamos frente a la constitución de un poder estatal que reconoció múltiples influencias y se conformó con personas de las más variadas procedencias e ideas. Sólo por tomar dos ejemplos extremos, Francisco de Elizalde solía encabezar las propuestas de cambio y Dalmiro Vélez Sarsfield insistía justificadamente en dejar las cosas como estaban, hasta lograr la codificación. En el medio, tal como quedó reflejado en los ejemplos señalados, existieron diversos contrapuntos y matices de opinión.

Una frontera se había expandido, - el acceso a la justicia, la defensa de la vida y de la propiedad había llegado a la campaña, sin abandonar el objetivo de controlar a su población-, y otra frontera intentaba fijarse, -la independencia del poder judicial con respecto a los demás poderes. Pero esas fronteras se estaban construyendo y requerían de la organización del poder, de la conformación de sus límites internos, para lo que era fundamental su cabeza, que en estos años sufrirá la transición de la Cámara de Apelaciones al Superior Tribunal de Justicia, con todo lo que esto implicaba en la superintendencia del poder judicial y su relación con el legislativo y el ejecutivo. 
Cuadro de magistrados de primera instancia de los departamentos judiciales de la provincia de Buenos Aires

1853-1874

\begin{tabular}{|c|c|c|c|c|c|c|c|c|c|c|}
\hline Abogado & Nacimiento & Lugar & Título & Matrícula & Magistrado & Departamento & Poder Judicial & Período & Otros cargos & Período \\
\hline Acosta, José Antonio & 1823 & Bs. As. & & 1848 & $1854-1857$ & Capital- civil & Superior Tribunal & $1857-60$ & diputado & $1854-57 / 62-64$ \\
\hline Agrelo, Emilo A. & 1821 & Bs.As. & 1843 & 1846 & $1868-1873$ & Capital- civil & Agente fiscal & & senador & $1871-73$ \\
\hline \multirow[t]{2}{*}{ Alsina, Juan José } & 1799 & Montevideo & Cba & 1826 & 1857 & Capital- criminal & Superior Tribunal & $1857-72$ & senador & $1857-1860$ \\
\hline & & & & & & & & & diputado & $1869-1870$ \\
\hline Areco, Isaac Paulino & 1839 & Bs. As. & & 1868 & $1871-1873$ & Capital- civil & & & & \\
\hline Barra, Juan Eulogio & 1832 & Bs.As. & 1857 & 1860 & 1863 & Capital- comercial & & & & \\
\hline Baescorchea, Mariano José & 1812 & Bs.As. & 1838 & 1855 & 1857 & Capital- criminal & Relator STJ & $1855-57$ & & \\
\hline \multirow[t]{2}{*}{\begin{tabular}{|l|} 
Belaústegui, Luis V. \\
\end{tabular}} & 1842 & Bs.As. & & 1869 & $1872-1875$ & Capital- civil & Relator STJ & $1870-72$ & & \\
\hline & & & & & & & Cámara civil Capital & 1875 & & \\
\hline Benguria, Antonio & & & & 1865 & $1870-1875$ & Centro- criminal & Cámara del Centro & 1875 & & \\
\hline \begin{tabular}{|l|} 
Benítez, Félix Amadeo \\
\end{tabular} & & . & & 1865 & $1872-1875$ & Norte- criminal & Cámara del Norte & 1875 & & \\
\hline \multirow[t]{2}{*}{ Bunge, Octavio } & 1844 & Bs.As. & 1867 & 1869 & $1873-1875$ & Capital- criminal & Relator STJ & $1870-71$ & & \\
\hline & & & & & & & Fiscal en la Civil & 1872 & & \\
\hline \multirow[t]{2}{*}{ Cárdenas, Jacinto } & 1832 & Bs.As. & 1852 & 1856 & $1858-1860$ & Sud- criminal & & & Diputado & 1860-66 \\
\hline & & & & & 1860-1868 & Capital- civil & & & & \\
\hline \multirow[t]{2}{*}{ Carrasco, Benito } & 1815 & Bs. As & 1837 & 1841 & $1855-1857$ & Capital- civil & $\begin{array}{l}\text { Asesor Tribunal de } \\
\text { Comercio }\end{array}$ & 1855 & Diputado & $1858-60$ \\
\hline & & & & & & & STJ & $1857-68$ & & \\
\hline \multirow[t]{2}{*}{\begin{tabular}{|l|} 
Cazón, Daniel María \\
\end{tabular}} & 1826 & Bs. As. & 1845 & 1849 & 1853-1854 & Capital- civil & & & Diputado & 1854-1858 \\
\hline & & & & & $1863-1866$ & Capital- civil & & & Senador & 1869-1873 \\
\hline Coronel, Felipe & & & & 1849 & $1855-1856$ & Sud- criminal & & & & \\
\hline Correa, Carlos & & & & 1835 & $1856-1858$ & Sud- criminal & & & & \\
\hline \multirow[t]{2}{*}{ Cueto, Joaquín Justiniano } & & Bs. As. & 1853 & 1858 & $1860-1867$ & Sud- criminal & & & & \\
\hline & & & & & $1867-1874$ & Capital- criminal & & & & \\
\hline \multirow{2}{*}{ De la Cárcova Sáenz, Tiburcio } & 1809 & Bs. As. & 1834 & 1835 & $1844-1857$ & Capital- criminal & Agente fiscal & $1841-44$ & & \\
\hline & & & & & & & STJ & $1857-68$ & & \\
\hline Del Carril , Salvador María (h) & & & & 1869 & $1873-1875$ & Capital- civil & Cámara civil Capital & 1875 & & \\
\hline \multirow[t]{2}{*}{ Echevarría, Jorge } & 1830 & & & 1858 & 1862-63 & Norte- criminal & Relator STJ & -1862 & Diputado & $1865-67$ \\
\hline & & & & & $1863-1868$ & Capital- civil & & & & \\
\hline
\end{tabular}




\begin{tabular}{|c|c|c|c|c|c|c|c|c|c|c|}
\hline Eguía, Carlos Enrique & 1809 & Bs. As. & 1835 & 1857 & 1857 & $\begin{array}{l}\text { Capital- } \\
\text { correccional }\end{array}$ & STJ & $1868-75$ & Diputado & $1858-62$ \\
\hline & & & & & $1857-1863$ & Capital- civil & & & & \\
\hline & & & & & & & Cámara civil Capital & 1875 & & \\
\hline \multirow[t]{2}{*}{ Escalada, Manuel María de } & 1823 & & & 1846 & $1853-1855$ & Capital- criminal & Agente fiscal civil & & Diputado & $1852-56$ \\
\hline & & & & & & & \begin{tabular}{|l|} 
STJ-SCJ \\
\end{tabular} & $1872-84$ & & \\
\hline Estevez Saguí, Miguel & 1814 & Bs.As. & 1837 & 1840 & $1852-1853$ & Capital- criminal & & & & \\
\hline Font, Pablo & 1810 & & & 1835 & 1859 & Capital- civil & STJ & 1859-71 & & \\
\hline \multirow[t]{2}{*}{ García, Juan Agustín } & 1831 & Bs. As. & 1849 & 1854 & $1857-1862$ & Capital- civil & Relator STJ & & diputado & $1858-74$ \\
\hline & & & & & & & Agente fiscal civil & & Consejero M. & $1856-57 / 59-60$ \\
\hline García, Manuel Rafael & 1826 & Bs. As. & 1846 & 1849 & 1855 & Capital- civil & Agente fiscal & 1852 & diputado & \\
\hline \multirow[t]{4}{*}{ González Garaño, Alejo B. } & 1833 & Bs. As. & & 1856 & a 1863 & Capital- civil & Agente fiscal & 1857 & diputado & $1860-74$ \\
\hline & & & & & & & Relator Cámara de J. & 1857 & & \\
\hline & & & & & & & STJ- sala civil & \begin{tabular}{|l|}
$1863-75$ \\
\end{tabular} & & \\
\hline & & & & & & & SCJ & $1875-84$ & & \\
\hline \begin{tabular}{|l|} 
González, Diego \\
\end{tabular} & 1843 & & & 1869 & 1873 & Capital- civil & Relator STJ & $1870-72$ & & \\
\hline \multirow[t]{2}{*}{ Heredia, Alejandro } & 1830 & & & 1855 & $1857-1862$ & Norte- criminal & & & & \\
\hline & & & & & $1862-1863$ & Capital- civil & & & & \\
\hline Hudson, Damián H. & & & & 1867 & $1873-1875$ & Capital- criminal & & & & \\
\hline Irigoyen, José María & & & & 1845 & $1854-1858$ & Centro- criminal & & & & \\
\hline \multirow[t]{3}{*}{ Irigoyen, Manuel Bernardo de } & 1819 & & 1841 & 1844 & $1867-1875$ & Sud- criminal & Agente fiscal civil & 1854 & & \\
\hline & & & & & & & Relator STJ & 1855 & & \\
\hline & & & & & & & $\begin{array}{l}\text { Cámara Apelación } \\
\text { del Sud }\end{array}$ & 1875 & & \\
\hline \multirow[t]{4}{*}{ Isla, Tomás } & 1821 & Bs. As. & 1849 & 1852 & $1862-1865$ & Norte- criminal & STJ & $1872-75$ & & \\
\hline & & & & & $1865-1872$ & Capital- comercial & $\begin{array}{l}\text { Cámara de } \\
\text { Apelación criminal y } \\
\text { mercantil }\end{array}$ & 1875 & & \\
\hline & & & & & & & Procurador SCJ & $1880-85$ & & \\
\hline & & & & & & & SCJ & $1885-87$ & & \\
\hline \multirow{3}{*}{ Langenheim, Manuel H. } & 1832 & & 1852 & 1856 & $1858-1862$ & Centro- criminal & Relator STJ & 1857 & & \\
\hline & & & & & $1862-1868$ & Capital- criminal & Asesor de menores & 1857 & & \\
\hline & & & & & & & STJ & \begin{tabular}{|l|}
$1868-75$ \\
\end{tabular} & & \\
\hline
\end{tabular}




\begin{tabular}{|c|c|c|c|c|c|c|c|c|c|c|}
\hline & & & & & & & $\begin{array}{l}\text { Cámara de } \\
\text { Apelación Civil de } \\
\text { la Capital }\end{array}$ & $1878-81$ & & \\
\hline & & & & & & & SCJ & $1881-87$ & & \\
\hline \multirow[t]{2}{*}{ Martínez, Claudio } & & Bs. As. & 1837 & 1851 & $1853-1854$ & Capital- criminal & & & diputado & $1855-1859$ \\
\hline & & & & & 1854 & Capital- civil & & & & \\
\hline \multirow[t]{2}{*}{ Martínez, Enrique } & 1844 & Bs. As. & 1866 & 1869 & $1872-1875$ & Capital- comercial & & & & \\
\hline & & & & & & & $\begin{array}{l}\text { Cámara de } \\
\text { Apelación Civil de } \\
\text { la Capital }\end{array}$ & 1875 & & \\
\hline \multirow{2}{*}{ Medina, Ángel } & 1811 & Bs. As. & 1832 & 1836 & 1854 & Capital- criminal & STJ & $1857-72$ & diputado & $1861-63$ \\
\hline & & & & & & & & & Senador & $1865-66$ \\
\hline Navarro Viola, Miguel & 1830 & Bs. As. & 1848 & 1852 & $1855-56$ & Sud- criminal & & & & \\
\hline Pacheco, Wenceslao & 1838 & Mendoza & 1864 & 1864 & 1873 & Capital- civil & & & & \\
\hline Pardo, Amancio & 1834 & Salta & 1855 & 1859 & 1873 & Capital- civil & & & & \\
\hline \multirow[t]{2}{*}{ Pica, Domingo } & 1810 & & 1844 & 1846 & $1852-53$ & Capital- civil & STJ & $1857-75$ & diputado & $1856-58$ \\
\hline & & & & & 1853 & Capital- criminal & & & & \\
\hline \multirow[t]{2}{*}{ Pondal, Ventura } & 1830 & Paraná & 1855 & 1864 & $1866-1872$ & Norte- criminal & $\begin{array}{l}\begin{array}{l}\text { Agente fiscal } \\
\text { criminal }\end{array} \\
\end{array}$ & $1873-74$ & & \\
\hline & & & & & & & \begin{tabular}{|l|} 
Agente fiscal de \\
Cámara criminal \\
\end{tabular} & 1875 & & \\
\hline Prado y Rojas, Aurelio & 1842 & Bs. As. & 1867 & 1869 & $1873-1875$ & Capital- civil & Secretario de SCJ & 1875 & & \\
\hline \multirow[t]{2}{*}{ Salas, Basilio } & & & & 1852 & 1852 & Capital- civil & ECJ & 1855 & & \\
\hline & & & & & & & STJ & $1857-74$ & & \\
\hline \multirow[t]{3}{*}{ Somellera, Andrés } & 1810 & $\begin{array}{l}\text { Asunción } \\
\text { del } \\
\text { Paraguay }\end{array}$ & 1835 & 1852 & 1853 & Capital- civil & STJ & $1857-74$ & & \\
\hline & & & & & $1853-56$ & Capital- criminal & SCJ & $1875-79$ & diputado & $1854-56 / 59-65$ \\
\hline & & & & & & & & & senador & $\begin{array}{l}\text { 1856-59/65- } \\
67 / 68-71 / 73-74\end{array}$ \\
\hline \multirow[t]{2}{*}{ Torres, Eustaquio J. } & & Bs. As. & 1831 & 1834 & 1841-1852 & Capital- criminal & Agente fiscal & & diputado & $1845-51 / 54-58$ \\
\hline & & & & & $1852-1853$ & Capital- criminal & ECJ & $\begin{array}{l}1853-54 \\
156-57\end{array}$ & & \\
\hline Zavalía, José Antonio & 1804 & Tucumán & $\begin{array}{l}1826, \\
\text { Chuqu } \\
\text { isaca }\end{array}$ & 1863 & $1863-1870$ & Centro- criminal & Camarista- Salta & 1854 & & \\
\hline
\end{tabular}




\section{Capítulo VI}

\section{El Superior Tribunal de Justicia de la provincia de Buenos Aires (1857-1874)}

\section{Introducción}

La primera etapa del estudio del poder judicial de la provincia de Buenos Aires estuvo dedicada a la organización de la magistratura de primera instancia rentada, letrada e inamovible, en un proceso que entre 1853 y 1874 sentó las bases para la formación de la carrera judicial y abrió paso a la especialización. Sigue ahora investigar la reforma de la Cámara de Justicia que dio como resultado la constitución del Superior Tribunal, que encabezaría la administración de justicia provincial desde 1857, con el objetivo de saber si se trató de una nueva institución, conocer las ideas que guiaron su organización y establecer el grado de dependencia con los demás poderes.

En este capítulo será de especial interés definir las atribuciones del Tribunal, centrándonos en lo referido a la corrección disciplinaria y de enjuiciamiento, y a la competencia en los conflictos entre el poder ejecutivo y los particulares. Basados en los debates de los legisladores provinciales, definiremos qué papel jugaba el poder judicial como parte fundamental del proyecto liberal, asentado sobre la autoridad de la ley y la división de poderes del Estado provincial.

Si bien no se han realizado investigaciones sobre el Superior Tribunal, en algunas obras generales aparecen reseñas sobre el tema. ${ }^{1}$ Otras obras tratan los antecedentes del Superior Tribunal, Real Audiencia y Cámara de Apelaciones, como la de Víctor Uribe-Uran² en la que plantea que el número de profesionales en una sociedad, en especial ingenieros o abogados, ha sido considerado síntoma del tipo y grado de su desarrollo económico y político. La cantidad de abogados demostraba la importancia dada a la administración estatal como ocupación y al Estado como agente histórico y fuente de empleo. ${ }^{3}$ Desde aquí el autor plantea su trabajo dividido en tres partes, las dos primeras, dedicadas fundamentalmente a asuntos demográficos y políticos, se ocupan de la profesión legal en Nueva Granada y en los epicentros de los otros tres virreinatos españoles Nueva España, Perú y Río de la Plata- y la supuesta abundancia de abogados coloniales. Luego expone sobre el ínfimo número de abogados durante la primera mitad del siglo XIX republicano y las enormes dificultades que causaba a la proyectada reorganización de los sistemas judiciales

\footnotetext{
${ }^{1}$ Por ejemplo Levene, 1945-1958, op. cit.; Tau Anzoátegui, 1977 op. cit.; La codificación en la Argentina (1810-1870) Mentalidad social e ideas jurídicas, Buenos Aires, Imprenta de la Universidad, 1977; Corbetta, Juan Carlos (coordinador), Suprema Corte de Justicia de la provincia de Buenos Aires. Historia. Organización. Competencia, Buenos Aires, Función Pública, 1997.

${ }^{2}$ Uribe-Uran, 2000, op. cit., pp. 141-174.

${ }^{3}$ Víctor Uribe comprobó que los jueces ocupaban cargos en el sistema político al estudiar la historia de los abogados y concluir que fueron quienes controlaron el Estado y sus recursos, siendo éste el principal recurso de trabajo, honor, poder, prestigio y patronazgo. Uribe-Uran, Víctor M. "Elites, construcción del Estado y negocios. El cambio de significado del Honor, Status y Clase: los letrados y burócratas de Nueva Granada en el período tardo colonial y temprano post-colonial", en Uribe-Uran, 2001, op. cit., pp.59-88.
} 
vigentes. En el caso del Río de la Plata se buscó desde un principio separar las funciones judiciales, como quedó de manifiesto en los Reglamentos del 22 de octubre de 1811 y del 3 de diciembre de 1817. Especialmente el Reglamento de Institución y administración de Justicia, promulgado el 23 de enero de 1812, suprimió el Tribunal de la Real Audiencia y lo sustituyó por la Cámara de Apelaciones para los "negocios de grave importancia". 4

Respecto a instituciones de última instancia en América Latina, contamos con la investigación de Pilar Domingo dedicada al estudio de los cambios de la Suprema Corte de México y su relación con el poder ejecutivo. En ésta destaca la importancia de ver la naturaleza del sistema político y las peculiaridades de la forma del desarrollo constitucional. La construcción de las biografías de los integrantes del alto tribunal le permitió observar las estrategias e incidencias en el sistema presidencial y su pesquisa consideró los factores sociales y políticos en el análisis de la administración de justicia, concluyendo que el papel de la Suprema Corte en el desenvolvimiento del sistema político mexicano sirvió a la consolidación del estado de legalidad y el poder judicial estuvo políticamente subordinado a la lógica de dominación. ${ }^{5}$

También para México, Linda Arnold sostuvo que no fue creado rápidamente un orden jurídico republicano porque no existía una visión de consenso de una ideología crítica mexicana en relación con los valores políticos y con una sociedad política republicanos. El consenso nació con la guerra civil y se consagró en la Constitución de 1857, cuando quienes buscaban justicia descubrieron la necesidad de un orden jurídico innovador. ${ }^{6}$ Para la autora, se puede observar a partir de los amparos y los pedidos de anticonstitucionalidad de las leyes ante la Suprema Corte de Justicia, el contenido de los parámetros fundamentales de la matriz política mexicana "que surgió de y respondió a las condiciones políticas y los problemas sociales dentro de la sociedad mexicana."7

La ley es, en palabras de Salvatore y Aguirre, el "terreno" en donde los diferentes intereses individuales y grupales, sus recursos y sus "cuotas de poder" confrontan entre sí y tratan de "trabajar el sistema" (Hobsbawm), en pos de sus propios intereses. Pero existe el "eslabón previo", las normas legales que deben ser escritas y promulgadas, proceso (que los autores reconocen poco estudiado por los historiadores) en el cual la elite y los intereses del Estado son preponderantes, aunque no omnipotentes ni uniformes. ${ }^{8}$ Por esto nos dedicaremos especialmente en este capítulo a

\footnotetext{
${ }^{4}$ Reglamento de institución y administración de justicia del Gobierno Superior Provisional de las provincias del Río de la Plata. Supresión de la Audiencia y creación de la Cámara de Apelaciones, en Acuerdos y Sentencias, tomo I, pp. 144-148.

${ }^{5}$ Domingo, 2000, op. cit., pp.705-735.

${ }^{6}$ Arnold, Linda, "Política y justicia. La Suprema Corte de Justicia mexicana (1824-1855)" en Estudios históricos, Instituto de investigaciones jurídicas, serie C, núm.62, UNAM, México, 1996; "The Suprema Corte de Justicia in México: its First Step, 1825-1826), en Anuario Mexicano de Historia del Derecho, №1, 1989, pp. 3-14.

${ }^{7}$ Arnold, Linda, "Buscando a México: conflictos, jurisprudencia y la Suprema Corte mexicana (1825-1853), en Anuario Mexicano de Historia del Derecho, N4, 1992, pp. 252-268.

${ }^{8}$ Salvatore, Ricardo, Aguirre, Carlos, Joseph, Gilbert M. (editors) Crime and Punishment in Latin America. Law and society Since Colonial Times, Duke University Press, Durham, 2001, Introducción, p13.
} 
los debates de las leyes que sostuvieron el proceso de conformación del Superior Tribunal, sus atribuciones e integración.

\section{$\underline{\text { I. Los antecedentes }}$}

Si bien la Real Audiencia y la Cámara de Apelaciones son bien conocidas, consideramos importante recordar aquí algunas características para percibir y comprender las continuidades y cambios de la institución en estudio. La función judicial colonial integraba la compleja actividad gubernativa y era considerada como un deber de conciencia y un altísimo honor, basada en un ideal de justicia fundado en las normas morales y religiosas cuya misión era procurar el bien común. En este marco, las Audiencias, organismos colegiados, formados por oidores y cuya jurisdicción se ejercía en segunda o tercera instancia, eran los supremos tribunales indianos, en representación directa del monarca en cuyo nombre actuaban.

En Buenos Aires, entre 1663 y 1671 funcionó la Primera Real Audiencia. La segunda, creada en 1783, fue una Audiencia pretorial por ser presidida por un Virrey (si la presidía un Gobernador era subordinada). Su distrito fue todo el Virreinato del Río de la Plata, incluyendo las provincias de Buenos Aires, Paraguay, Tucumán y Cuyo, además de las gobernaciones y capitanías correspondientes. El Tribunal se instaló en Buenos Aires en 1784 compuesto por un presidente (el Virrey), un regente, cuatro oidores, un fiscal, con las funciones de tribunal superior de justicia, que entendía en tercera instancia de las apelaciones que se interponían contra los fallos de los gobernadores o Intendentes u otros jueces de su jurisdicción. ${ }^{9}$ Tenían la superintendencia de tribunales y cárceles y toda la materia llamada de subalternaría, por la cual el presidente de la Audiencia debía nombrar un Oidor cada año para que fuera visitador de sus Ministros y Oficiales. Por la Recopilación de Indias, la Real Audiencia tenía competencia para juzgar de los perjuicios que hubiesen podido sufrir los particulares por actos de gobierno de Presidentes o Virreyes. ${ }^{10}$

Según Ricardo Levene, "la Audiencia, con los conjueces criollos nombrados en junio de 1810 a inspiraciones de Mariano Moreno y la Cámara de Apelaciones de 1812, que es su continuación, concebida por Bernardino Rivadavia, es la misma institución creada y renovada bajo el signo de esos dos espíritus superiores."11 Más allá de las inspiraciones, lo interesante es la afirmación sobre la continuidad institucional, que podemos observar en el artículo de creación, “el tribunal Supremo

\footnotetext{
${ }^{9}$ Para mayor información sobre las Audiencias en el periodo tardocolonial, véase Burkholder, Mark y Chandler, D. S., De la impotencia a la autoridad. La Corona española y las audiencias en América 1687-1808, México, Fondo de Cultura Económica, 1984.

${ }^{10}$ Leyes de Indias, libro II, título XV, ley XXXV: "Declaramos y mandamos que sintiéndose algunas personas agraviadas de cualquier auto, o determinación que proveyeren u ordenaran los Virreyes o Presidentes por vía de gobierno, puedan apelar a nuestras Audiencias, donde se les haga justicia, conforme a leyes y ordenanzas, y los Virreyes y Presidentes no les impidan la apelación, ni puedan hallar, ni hallen presentes a la vista y determinación de estas causas y se abstengan de ellas."

${ }^{11}$ Levene, Ricardo Historia del Derecho Argentino, tomo IV: El derecho patrio argentino desde la Revolución de Mayo a la Asamblea General Constituyente de 1813-1815, Editorial Guillermo Kraft Ltda., Buenos Aires, 1948, p. 326.
} 
de Justicia que hasta ahora ha sido la Real Audiencia, se llamará en adelante Cámara de Apelaciones, consiguientemente queda desde la fecha disuelto y extinguido el precitado tribunal de la real audiencia.” Esta decisión obedecía al deseo de alcanzar la libertad y la felicidad, mejorando las instituciones políticas, "simplificando la administración de justicia que debía ser buena y sencilla, con magistrados sabios y confiables" y que resolvieran "tribunales numerosos, complicados e instituidos para colocar y sostener la mejor elevación a los agentes del despotismo." 12

La Cámara estaba integrada por cinco individuos, empeñados en sostener la libertad de su patria. Tres de ellos eran letrados y los otros dos vecinos sin esta calidad, pero con "buen juicio, costumbres y opinión." Desaparecieron los cargos de chanciller y registrador y fue creado el cargo de agente de la Cámara, sin voto y con las funciones que hasta entonces ejercían los fiscales ${ }^{13}$. El letrado redactor fue instalado "para que relacionando breve y substancialmente los asuntos acelere lo posible el despacho." El nombramiento de todos los funcionarios los realizaba el Gobierno Superior cada bienio, pudiendo continuar el que se creyera necesario; por ausencia o enfermedad, el Gobierno designaba al reemplazante.

El Presidente de la Cámara debía cuidar de la policía interior del cuerpo y de la "pureza y exactitud en las funciones respectivas de los subalternos", rotando entre los cinco miembros de la Cámara cada cuatro meses empezando por el orden de su nombramiento. El Reglamento aconsejaba a los camaristas sobre su comportamiento "penetrados de que los principios del Gobierno, en su institución son mantener en equilibrio los derechos de todo ciudadano por medio de una administración la más breve y simplificada que sea posible; pero la que menos margen de al arbitrio de los jueces."14 Queda de manifiesto en este texto, la intención que se ponía de modificar la práctica de la justicia (en este caso de eliminar el arbitrio), pero que llevaría muchos años llevarla a la práctica.

El Reglamento de 1813 establecía que los Camaristas durarían en su cargo mientras durara su buena conducta y que la Presidencia se turnaría cada cuatro meses empezando por el orden del nombramiento. El Reglamento provisorio de 1817 determinaba que la Cámara de Justicia sería compuesta por cinco vocales y fijaba la edad para asumir como camarista en 25 años, letrado recibido con seis años de ejercicio público. El nombramiento era realizado por el Director del

\footnotetext{
${ }^{12}$ Reglamento de institución y administración de justicia del Gobierno Superior Provisional de las provincias del Río de la Plata, Supresión de la Audiencia y creación de la Cámara de Apelaciones, en Acuerdos y Sentencias I, pp. 144148. Debe tenerse en cuenta que en la normativa se utilizaba indistintamente Cámara de Apelaciones, Cámara de Justicia o Tribunal Supremo.

${ }^{13}$ Los fiscales tenían a su cargo el patrocinio de las causas que activa o pasivamente afectaban al fisco. Eran protectores de los indios para alcanzar justicia conforme a derecho, alegando por ellos en todos los pleitos civiles y criminales; concurrirían a los acuerdos de la Audiencia por derecho propio. Ibáñez Frocham, Manuel La organización judicial argentina, La Facultad, Buenos Aires, 1938, p.17.

${ }^{14}$ Art.39 del Reglamento de 1812.
} 
Estado en propuesta de cuatro letrados de los mismos tribunales por juicio comparativo de la mayor aptitud y servicios de los abogados del distrito. El Tribunal quedaba constituido por los magistrados, dos relatores, dos agentes auxiliares, uno en lo civil y otro en lo criminal, repartiéndose los asuntos de Hacienda, dos porteros, desempeñando alternativamente por semana el oficio de alguacil, seis procuradores, que intervendrían cuando las partes quisieran nombrarlos, y dos escribanos. ${ }^{15}$

Cuando la Cámara pasó a formar parte del Estado provincial y la justicia comenzó a organizarse, sus transformaciones fueron superficiales y los problemas que presentaba obedecían más a la falta de legislación de forma y de fondo que a la institución. Los cambios fundamentales fueron atribuirle la Alzada de Comercio, facultarla para formar las ternas para el nombramiento de los jueces de primera instancia y suprimir los recursos extraordinarios de nulidad e injusticia notoria y de segunda suplicación. Creaban el recurso de revisión y desaparecían las comisiones eventuales de cinco letrados nombrados por el Gobierno, dejando como suprema autoridad judicial a la Cámara de Justicia. $^{16}$

Juan Manuel de Rosas aumentó, por decreto del 5 de marzo de 1830, el número de los jueces de la Cámara de Justicia a siete, con dos fiscales (uno para lo civil y negocios de Hacienda y otro para lo criminal) previendo la formación de dos salas y derogando de hecho la inamovilidad. ${ }^{17} \mathrm{La}$ modificación surgió de una propuesta del Tribunal y el Gobernador la justificaba en obtener un mejor desempeño de la administración de justicia y la protección de todos los derechos sociales. ${ }^{18}$ En diciembre de 1838 fue creado el Tribunal de Recursos Extraordinarios, resurgiendo los recursos extraordinarios de nulidad e injusticia notoria y de segunda suplicación. ${ }^{19}$

\section{EI Poder Judicial en la Constitución de 1854}

El 8 de agosto de 1853, por decreto del gobernador Pastor Obligado, se redujo el número de camaristas a cinco, nombrando a Valentín Alsina (presidente de ese año), Marcelo Gamboa, Dalmacio Vélez Sarsfield y confirmando a Juan José Cernadas y Alejo Villegas. Esta modificación fue encarada considerando el Gobierno

... que el desafío exacto de todos los deberes en los funcionarios públicos en la administración de justicia, es una de las bases fundamentales en que debe apoyarse un buen Gobierno, y una de las primeras garantías del Ciudadano, muy especialmente en circunstancias como las presentes en que acaba de salir el país del profundo caos a que han

\footnotetext{
${ }^{15}$ Reglamento Provisorio de 1817, Sección IV, Del Poder Judicial, en Nueva recopilación de Leyes y Decretos de la provincia de Buenos Aires 1810-1876, Dr. Aurelio Prado y Rojas, Buenos Aires, 1877, Tomo I, pp. 416-424.

${ }^{16}$ Ibáñez Frocham, 1938, op. cit., pp.193-208.

${ }^{17}$ Ibáñez Frocham, 1938, op. cit., pp. 212-216.

${ }^{18}$ El texto completo del decreto se encuentra en el Archivo Histórico de la provincia de Buenos Aires, Cámara de Apelaciones, 9-1-2-154, porque en el Registro Oficial faltan artículos.

${ }^{19}$ ROPBA, 1838, pp. 55-57.
} 
querido precipitarlo los rebeldes, atacando de un modo inmoral las vidas y las propiedades.

Era necesario castigar los crímenes cometidos por la impunidad de que gozaron los delincuentes, con una pronta y severa justicia que no podía ser ejercida por camaristas de edad avanzada y con frecuentes dolencias. Los distintos ramos de la administración debían ser “desempeñados por personas que, a su idoneidad notoria, reúnan en si una conocida adhesión a los principios que acaban de triunfar por el esfuerzo y sacrificios de los buenos ciudadanos. ${ }^{, 20}$ Este considerando atentaba contra el principio de inamovilidad de los jueces y sonaba al argumento de adhesión a la causa con el que se intentaba terminar.

Un decreto anterior ya había ignorado la inmovilidad de los jueces, cuando el gobernador provisorio, Vicente López separó de sus cargos a los camaristas Manuel Insiarte, Felipe Arana y Baldomero García, dejando confirmados a Bernardo Pereda, Roque Sáenz Peña, Eduardo Lahitte y Cayetano Campana. En su reemplazo fueron designados Juan García Cossio, Juan José Cernadas (a quien Rosas había exonerado en 1838) y Alejo Villegas. ${ }^{21}$ Ante un reclamo de Baldomero García, Justo José de Urquiza, director provisional de la Confederación y a cargo del gobierno de Buenos Aires, resolvió el 31 de julio de 1852 revocar el decreto anterior asegurándole al magistrado que volvería a ocupar su asiento en la primera vacante asegurando que

...el principio de inamovilidad de los jueces es la garantía de la recta administración de justicia. Los jueces no pueden ser separados mientras no den motivo a que se les declare, por los trámites establecidos, incapaces o indignos de ejercer sus funciones. ${ }^{22}$

Esta resolución dejaba de manifiesto la incidencia del poder político en la conformación del poder judicial y la temprana tensión entre los hombres de Buenos Aires y la Confederación.

Mientras estos cambios se ponían en funcionamiento y se instalaban los jueces del crimen en la campaña, comenzaron los debates para la sanción de la Constitución del Estado de Buenos Aires de 1854, que declaró al poder judicial independiente de todo otro en el ejercicio de sus funciones. El 6 de abril de 1854 se inició el tratamiento de la sección judicial criticando Nicolás Anchorena el proyecto, que en su opinión dejaba "inconstituido" el poder judicial. En el estado de aislamiento en que se encontraba la provincia era indispensable crear un Tribunal Superior, afirmaba Anchorena, agregando que en un sistema democrático los jueces no podían tener carácter de inamovibles. ${ }^{23}$

En respuesta, Valentín Alsina aseguraba que el poder judicial estaba constituido hacía cuarenta años y el proyecto establecía los tribunales con las atribuciones que les designaban las

\footnotetext{
${ }^{20}$ ROGBA, 1853, pp.62-63. No es un detalle menor, en miras a las futuras reformas judiciales, la "necesidad de disminuir el número de empleados por el estado en que ha quedado el Tesoro Público" como otro argumento utilizado en la reorganización de la Cámara.

${ }^{21}$ Decreto por del el 9 de marzo de 1852. El Ministerio de Gobierno estaba a cargo de Valentín Alsina.

${ }^{22}$ Ibañez Frocham, op. cit. p.253.

${ }^{23}$ Diario de sesiones de la Sala de Representantes de la Provincia de Buenos Aires de 1854, Imprenta de la Sociedad Tipográfica Bonaerense, Buenos Aires, 1863.
} 
leyes vigentes y podían señalarles las leyes ulteriores. Los jueces no eran inamovibles pues no podían "ser removidos sin causa y sentencia legal durante el tiempo que según la ley deben ejercer sus funciones." La alta Corte de Justicia era incompatible con un Estado que era parte de una Nación. Existía en los Estados de la Unión Americana, pero en Buenos Aires no tenía ese significado, pues allí era un Tribunal Superior en lo judicial y aquí se le quería dar ese carácter y también el político.

En el proyecto de Anchorena, aseguraba Alsina, algunas de las atribuciones anexas a la alta Corte se oponían a lo ya sancionado en la Constitución y otras nunca se aplicarían, bastando para ciertos casos establecer un tribunal eventual. El país no contaba con los suficientes jurisconsultos para elevarlos a esta alta dignidad y los gastos de una alta Corte de Justicia no justificaban su utilidad. El presidente de la Cámara de Justicia reforzaba sus fundamentos teóricos enumerando los impedimentos prácticos que tenía el Estado provincial para crear un Alto Tribunal.

Pero Anchorena pretendía que el poder judicial fuera constituido como los otros poderes, estableciendo la duración de sus miembros. Además, sobraban los jurisconsultos y los gastos producidos por el establecimiento de un Tribunal quedaban compensados con sus ventajas. El oponente reiteró que bastaba la Cámara de Justicia, con un Tribunal eventual, ad hoc; insistiendo su contrincante en la necesidad de la creación de un Superior Tribunal de Justicia para la resolución de ciertos casos.

A esta altura del debate intervino Marcelo Gamboa (miembro de la Cámara) adhiriendo a la postura de Anchorena. Sostuvo la necesidad de una Alta Corte de Justicia, sin la cual estaba el poder judicial incompleto hasta que la Legislatura creara el Tribunal competente. En relación a esta cuestión, Carlos Tejedor señaló la necesidad de proveer a la Constitución de una sección que resolviera los casos contenciosos de Hacienda y los que nacieran de contratos entre particulares y el Gobierno, para lo cual proponía crear un artículo al final de la sección.

Finalmente, el texto constitucional declaraba al poder judicial independiente en el ejercicio de sus funciones, desempeñado por los tribunales y juzgados designados por la ley. Sus miembros no podrían ser removidos sin causa y sentencia legal, siendo suspendidos desde que fueran enjuiciados. Los miembros del Tribunal Superior de Justicia, nombrados por el Gobernador a propuesta en terna del Senado, requerían estar en ejercicio de la ciudadanía, ser mayor de 30 años, con seis al menos de ejercicio en la facultad. No se creaban tribunales de segunda instancia y las causas contenciosas de hacienda y las que nacieran de contratos entre particulares y el Gobierno serían juzgadas por un Tribunal especial, cuyas formas y atribuciones las determinaría la ley.

El Tribunal Superior debía fundar sus sentencias "en el texto expreso de la ley o en los principios y doctrinas de la materia." Tendría la superintendencia en toda la administración de justicia y podría informar al cuerpo legislativo de todo lo concerniente a las medidas que se podrían 
tomar para mejorarla. Cualquiera del pueblo tenía derecho a acusar a los depositarios de la judicatura, por los delitos de cohecho, prevaricato, procedimientos injustos contra la libertad de las personas, contra la propiedad y seguridad del domicilio. ${ }^{24}$

\section{La organización del Superior Tribunal de Justicia}

Tres años después, el Superior Tribunal de Justicia fue organizado por la ley de del 30 de setiembre de $1857^{25}$, nombrando el Gobierno la mitad de sus miembros el 8 de octubre. Era el fruto de largas discusiones de diputados y senadores, algunos a su vez integrantes del Tribunal. La Comisión de Legislación presentó en la Cámara de Senadores un proyecto sobre "reforma” del tribunal de justicia, al que se sumaron el de Dalmacio Vélez Sarsfield y el del Gobierno. Juan José Alsina pidió que por tratarse de un asunto de "suma gravedad y urgencia pública", fuera puesto como orden del día, presentando el proyecto "como un trabajo concienzudo."26

El resultado de estos debates fue una ley de catorce artículos que determinaba la composición y organización del Tribunal, sus atribuciones y el funcionamiento de la Alzada de Comercio. El Superior Tribunal de Justicia se compondría en adelante de diez jueces y un fiscal, es decir que no se trataba de una nueva institución sino de la renovación de la Cámara que ampliaba el número de miembros. De hecho en el texto constitucional no se hablaba de una nueva institución. Para resolver las causas quedaba dividido en dos salas, una civil, compuesta de los cinco jueces más antiguos (uno de los cuales sería el presidente del Tribunal, elegido por el Gobernador), y otra criminal con los cinco jueces nombrados, presidida por el más antiguo, requiriendo al menos de tres miembros la resolución definitiva de todo asunto. Arribar a esta organización generó arduos debates que pusieron de manifiesto las diversas posturas referentes a la administración de justicia.

La primera cuestión que se planteó fue el alcance que la institución tendría. Marcelo Gamboa, que había participado del tema en los debates constitucionales, preguntó si se estaba organizando una Suprema Corte como centro de la jurisprudencia, con la inspección de los magistrados y empleados, o un tribunal inferior. Según el informante, Juan José Alsina, no se podía definir como una Alta Corte de Justicia, que nunca había existido, pero era el último tribunal de justicia que conocía el país con funciones de tal -después de la supresión de las audiencias monárquicas- y mantenía las atribuciones que tenía en ese momento, aumentando su personal y reteniendo la

\footnotetext{
${ }^{24}$ Constitución del Estado de Buenos Aires de 1854, Sección IV del Poder Judicial, en Corbetta, Juan Carlos Textos constitucionales de Buenos Aires, SCBA, La Plata, 1984, pp. 73-74.

${ }^{25}$ ROEBA, 1857, pp.115-116. La ley fue sancionada por el Senado y la Cámara de Representantes del Estado de Buenos Aires, reunidos en Asamblea general el 29 de setiembre de 1857.

${ }^{26}$ En la confección del proyecto participaron dos Comisiones de Legislación, la primera formada el 7 de mayo de 1857 por Marcelo F. Gamboa, Francisco de las Carreras y José E. Agüero. Carreras renunció el 6 de junio, justificando su falta de asistencia "en el deber que tengo de asistir al despacho de la Cámara de Justicia que se recarga cada día más, que consume todo el tiempo de que puedo disponer y me impide atender a la Comisión"; la renuncia fue aceptada el 9 de junio y lo reemplazó Juan José Alsina el 27 de junio, Senadores, 1857, pp. 55; 57; 80. Los debates en Senadores comenzaron el 17 y terminaron el 22 de septiembre de 1857, Senadores, 1857, pp. 345-375.
} 
superintendencia. Gamboa le respondió que en un país constituido no se podía presentar un "proyecto decapitado", sin Suprema Corte de Justicia, "fuente donde los demás tribunales beben sus juicios" y resuelven sus dudas.

Los argumentos de quienes presentaban el proyecto se basaban en la práctica y la necesidad. Para instalar un Alto Tribunal faltaban de abogados, limitándose a lo que tenían y podían, buscando por el momento dar garantías al ciudadano. Pero Vélez Sarsfield aseguraba que no hacía falta un Alto Tribunal en una provincia, y la Corte de la Confederación en Paraná estaba ociosa, sin un sólo expediente, convirtiéndose en Tribunal de apelaciones del territorio de la provincia de Entre Ríos. Francisco de las Carreras, senador y juez camarista, recordaba que en la discusión del texto constitucional se había acordado que la Cámara de Justicia fuera el Tribunal de Justicia. Gamboa se conformó con que ambas salas integraran el Superior Tribunal de Justicia, opción que llevó finalmente a fijar en diez el número de miembros para el mejor funcionamiento del Tribunal pleno.

Sobre la composición del Tribunal se destacaban dos cuestiones. En primer lugar la permanencia de los miembros de la Cámara de Apelaciones para conformar la sala civil y en segundo lugar la definición de los fueros que se establecían al realizar esta opción, que se fundamentó en considerar más difícil de resolver las cuestiones civiles que las penales. Pero quienes no coincidían con esto sostenían que el derecho criminal respondía por la vida de los hombres y su honor, más valiosos que sus bienes, y que debían ser garantidos por la antigüedad. Sin embargo, el valor de la antigüedad no era el mismo para todos y no garantizaba siempre ciencia, tan sólo dignidad. Entonces surgió otra cuestión: ¿el Tribunal era nuevo o ya estaba creado? Para Gamboa, el existente no era constitucional, pero le respondieron que la Cámara Constituyente lo declaró como tal, siendo su continuación el Tribunal que estaban organizando.

En medio de los debates sobre la continuidad del Tribunal, Vélez Sarsfield definió el papel de su presidente, explicando las adaptaciones que habían sido necesarias.

En España y en América la sala que tenía nueve jueces, se componía de dos salas y cinco oidores del crimen que se llamaban alcaldes, y dejaba cuatro para lo civil. Yo hice presente a la Comisión que en este sistema quedaba número par en alguna sala; pero era que el regente andaba por todas las salas votando donde hacía falta, era una espacie de comodín por todas las salas; faltaba un juez en alguna, allí iba el regente y votaba. Entre nosotros ha sido preciso y conveniente crear un presidente que tenga la administración interna del tribunal y que sea un juez como todos los demás, no dándole la autoridad que tenían los regentes, y por eso se compone la sala de cuatro jueces y un Presidente. No podemos componer la sala de cuatro miembros y que el presidente anduviera votando en la sala que quisiese. ${ }^{27}$

Con respecto a la competencia de las salas, que no tuvo debate entre los senadores, la civil conocía de todos los recursos de apelación de las sentencias pronunciadas por los jueces de primera instancia en lo civil. La del crimen, por su lado, las de todos los recursos de apelación o de consulta,

\footnotetext{
${ }^{27}$ Senadores, 1857 , p. 366.
} 
en las sentencias de los jueces del crimen y del juez correccional. Dos sentencias conformes, tanto en lo civil como en lo criminal, hacían cosa juzgada, con excepción de las sentencias en que hubiese condenación a muerte. Aquí Gamboa solicitó que se estableciera diferencia entre las causas de mayor o menor cuantía, "porque parece que la prudencia enseña que cuanto mayor es la pérdida que puede ocasionarse a un ciudadano, tanto mayor garantía debe dársele a la posesión y seguridad de sus derechos." 28

Si bien no se hizo lugar a su propuesta, es de destacar la respuesta ofrecida por Vélez Sarsfield, haciendo referencia a las leyes vigentes en Buenos Aires, a las Audiencias de España, a los Códigos de América y al sistema de jurados de Gran Bretaña, afirmando que no se debían buscar la mejor administración de justicia multiplicando instancias. Aseguraba que la justicia había tenido una continuidad en su aplicación, más allá de los cambios en los gobiernos, basándose en la calidad de los abogados. En su experiencia profesional durante el rosismo, cuando

...en los tiempos más desgraciados de Buenos Aires, hasta 1850, mientras he sido abogado, no he encontrado mala administración de justicia en los tribunales, sino por el contrario han administrado bien la justicia en todo el tiempo de Rosas, y que no he podido quejarme de injusticia sino en una o dos sentencias: en todas las demás, las sentencias me han advertido que el defecto era mío. No digo esto por hacer honor a los miembros que la componían, sino para decir que la Cámara de Justicia la ha administrado bien, y que debe suponerse que la ha administrado igualmente antes de Rosas cuando la componían hombres como Castro, Castex, Valle, Pico, Escarranea, hombres respetables todos y acreditados en el foro. Y sin embargo se pensó que estos jueces podían hacer una injusticia revocando las sentencias de los jueces de primera instancia, y crearon una Cámara eventual de recursos de injusticia notoria. ${ }^{29}$

En el proyecto, este concepto de acortar instancias, no valía para la pena de muerte, diferenciada del resto de las sentencias, pues se le otorgaba el recurso a la otra Sala cualquiera fuera la naturaleza del delito. El objetivo era que, sin eliminar la pena máxima, se redujeran las sentencias a muerte, corriendo por más trámites que aseguraran la verdad, aún si la sentencia era dejar al reo libre. Esta medida estaba acorde con la tendencia restrictiva a la aplicación de la pena de muerte, que no lograba terminar en la aprobación de un proyecto formal de abolición. ${ }^{30}$

La apelación de las sentencias de cualquiera de las dos salas, revocando o alterando las sentencias de los jueces de primera instancia en lo civil o criminal, correspondía a la otra sala, haciendo de la sentencia cosa juzgada. En las causas criminales, la sentencia pasaba en consulta a la otra sala, aún si no se interponía apelación. Esto generó una discusión entre Juan José Alsina y Andrés Somellera (ambos camaristas) en torno al término apelación, considerando el primero que

...apelación no se entiende sino cuando se recurre de un juez inferior a otro mayor; no vamos a introducir una novedad que alarme a los rigoristas del derecho. Creo que está llenado el objeto de este recurso, desde que se diga de "revisión" porque tal es el objeto para que se

\footnotetext{
${ }^{28}$ Senadores, 1857 , p. 369.

${ }^{29}$ Senadores, 1857 , p. 370.

${ }^{30}$ Levaggi, 1977, p. 137.
} 
revocara la sentencia, no por los que la han dado, sino por los miembros que componen la otra sala. Así es que puede establecerse que habrá recurso de revisión. ${ }^{31}$

Para Somellera, este artículo establecía una tercera instancia, que sería más segura y ofrecería mayores garantías al ciudadano, si la conformaba todo el Tribunal, ${ }^{32}$ pero la opinión de Alsina fue respaldada por la de Carreras y el artículo quedó como en el proyecto original.

El Superior Tribunal Pleno se formaba, cuanto menos, de siete jueces y conocía:

$\left.1^{\circ}\right)$ de todo recurso de apelación que se interpusiese de resoluciones del Gobierno, en asuntos con particulares, mientras no se estableciera el Tribunal especial, enunciado en el art. 129 de la Constitución;

$2^{\circ}$ ) de los recursos de fuerza y protección de los Juzgados y tribunales eclesiásticos;

$3^{\circ}$ ) de los negocios contenciosos, pertenecientes al patronato de las iglesias;

$4^{\circ}$ ) de la superintendencia de toda la administración de justicia.

Alsina explicó que el Superior Tribunal tenía consignadas atribuciones que ya ejercía la Cámara de Justicia, innovando la primera en que daba garantías en el país de un modo más sólido en las violaciones del Gobierno en los asuntos sobre contratos de particulares y todo lo demás en que tenga lugar el interés individual del Gobierno, preparando la creación de un tribunal de hacienda. La superintendencia de la administración de justicia, confería las atribuciones al Tribunal Superior para juzgar a los jueces inferiores y demás subalternos del tribunal y otras atribuciones que tendían a conservar la moral y el orden de los juicios. Este artículo y el referido a la competencia del Presidente del Superior Tribunal, fueron aprobados sin debate.

En lo referido a la recusación, se buscaba dar garantía a los interesados del acierto de las resoluciones de las salas, pudiendo recusar un miembro de cada sala sin expresar causa. Esto era para Alsina

una novedad completa en nuestro derecho; todas las Leyes vigentes daban tal responsabilidad a los miembros de las audiencias, hoy de la Cámara de Justicia, que era preciso expresar la causa de recusación y probarla bajo una multa que tenía que pagarse sino se probaba. Así es que lo que ahora se concede, prueba hasta donde puede llegar la liberalidad del proyecto, tendiendo siempre a dar garantías a las partes del acierto y rectitud de las resoluciones. ${ }^{33}$

La Alzada de Comercio continuaba como hasta entonces, compuesta por dos comerciantes elegidos al azar y un integrante del Alto tribunal, que se turnaría anualmente por el orden inverso de antigüedad. ${ }^{34}$ Francisco de Elizalde explicó que por el momento no se reformaría dado que la Comisión ${ }^{35}$ presentaría un proyecto aparte, por considerar que la Alzada de Comercio debía ir a una

\footnotetext{
${ }^{31}$ Senadores, 1857 , p. 372.

${ }^{32}$ Senadores, 1857 , p. 373.

${ }^{33}$ Senadores, 1857 , p. 374.

${ }^{34}$ Ley del 30 de setiembre de 1857 organizando el Superior Tribunal de Justicia, art. 12, ROEBA, 1857, p. 115-116.

${ }^{35}$ Comisión de Legislación, nombrada por el Sr. Presidente de la Cámara de Diputados para 1857, en la sesión del 8 de mayo: Eduardo Costa, Carlos Tejedor, Francisco Elizalde, Emilio Agrelo, Claudio Martínez. Diputados, 1857 p. 17-18.
} 
de las Salas en que estaba dividido el Tribunal de Justicia, ofreciendo mayores garantías en las causas tan graves como las comerciales.

Al mes siguiente fue tratada esa ley que eliminaba la Alzada de Comercio, y según la cual las resoluciones del Tribunal de Comercio (que seguía compuesto por comerciantes) serían apeladas ante la Sala del Crimen del Superior Tribunal de Justicia, por suponer que sería la que tendría menos trabajo. Si su sentencia revocaba o alteraba la pronunciada por el Tribunal de Comercio, habría recurso de apelación ante la Sala de lo Civil y su sentencia sería definitiva. ${ }^{36}$

Volviendo al proyecto, este fue presentado el 28 de septiembre por Francisco de Elizalde en la Cámara de Diputados, explicando que la Comisión de esa Cámara ${ }^{37}$ tuvo el honor de ser invitada por la de Senadores para conferenciar sobre esa importante materia. Después de varias reuniones en que tomaron parte algunos senadores, entre ellos miembros de la Cámara de Justicia y el Ministro de Gobierno, José Barros Pazos, redactaron la propuesta. La presentación del proyecto sintetizaba lo que se había discutido, manifestando el objetivo de "arreglar de un modo conveniente los vicios que se notaban hasta ahora en los Tribunales de Justicia."

Por el régimen que se seguía hasta entonces, no había una verdadera garantía para el litigante, puesto que la Cámara que resolvía en apelación era la que conocía en súplica, es decir que los mismos hombres resolvían en uno y otro recurso. Así es que se ha considerado siempre que el recurso de súplica tal cual estaba establecido, era un recurso ilusorio. Era necesario pues proceder a la reforma del Superior Tribunal de Justicia y las comisiones habían partido del principio de que dos sentencias conformes hacían cosas juzgada. A esta introducción, seguía una síntesis del proyecto.

La Comisión, pues, ha establecido este Superior Tribunal con diez miembros, y lo ha dividido en dos salas. La sala de lo civil conocerá de las apelaciones de las causas de los jueces de primera instancia y resuelve en última instancia todas las causas criminales graves en las que hay condenación de muerte. De consiguiente la Comisión creyó que en la Sala de lo Civil debían estar los jueces más antiguos, no obstante que siempre se ha considerado la jurisdicción criminal de más categoría; pero generalmente las causas civiles son las de más importancia, y además los jueces de esta sala van a conocer en grado de apelación y consulta de las sentencias de los jueces de primera instancia en lo criminal, y también del Juez Correccional; y en el caso que alguna de las dos salas revoque o altera la sentencia de los Tribunales inferiores, es que se concede el recurso a la otra Sala. ${ }^{38}$

Aprobado el proyecto en general, no ofreció conflictos en particular hasta llegar a las atribuciones, y más específicamente se generó debate en torno a la definición de los asuntos contencioso-administrativos que irían a Sala plena. La ley fue finalmente aprobada y establecido el

\footnotetext{
${ }^{36}$ Ley del 21 de octubre de 1857, ROEBA, 1857, p. 156-157. Diputados, 1857, p.541; Senadores, 1857, p. 508. Por ley del 8 de julio de 1859 los recursos se interpondrían anta las Salas de lo Civil y del Crimen del Superior Tribunal alternándose mensualmente. ROGBA, 1859, p.72.

${ }^{37}$ Comisión de Legislación nombrada por el Presidente de la Cámara de Diputados, Montes de Oca, el 8 de Mayo de 1857: Eduardo Costa, Carlos Tejedor, Francisco Elizalde; Emilio Agrelo; Claudio Martínez.

${ }^{38}$ Diputados, 1857, pp. 525-526.
} 
Superior Tribunal. De las cuatro cuestiones en que conocía el Superior Tribunal Pleno, nos dedicaremos a las no relacionadas con temas eclesiásticos, que fueron perfilando los cambios hasta la conformación de la Suprema Corte en 1875. En primer lugar estudiaremos los recursos de apelación interpuestos ante resoluciones del gobierno a través de los cuales puede accederse a su competencia contencioso-administrativa, inconcebible -en palabras de Garriga- en el marco de la cultura jurisdiccional del antiguo régimen. ${ }^{39}$ Luego nos dedicaremos a la superintendencia del Superior Tribunal sobre toda la administración de justicia, atribución fundamental en la conformación de un poder y la definición de su independencia.

\section{Los conflictos entre los particulares y el Estado}

Cuando hablamos de contencioso administrativo nos referimos a la "protección de los derechos de los administrados frente a los actos del Estado provincial, mediante el control de la legalidad de su actividad, a través de acciones - muchas veces denominadas recursos- de plena jurisdicción y anulación”, cuya instauración y desarrollo en la provincia de Buenos Aires tuvo decisiva importancia en el Derecho público de esa y otras provincias, encontrando en ella el origen de la institución en la Argentina. ${ }^{40}$

La justicia administrativa al término del período hispano tenía sus propios tribunales, que no se confundían con la jurisdicción ordinaria, y continuó rigiéndose durante el primer medio siglo de vida independiente por las mismas normas, con modificaciones que se introdujeron paulatinamente. ${ }^{41}$ El Reglamento de 1817 otorgó a la Cámara de Apelaciones conocer en grado de apelación y primera súplica en los pleitos de contrabando y demás ramos y negocios de hacienda, con excepción de las relativas a "los apresamientos y detenciones de buques por los bajeles de guerra del Estado, o por corsarios particulares”, iniciando la evolución tendiente a la intervención de la justicia ordinaria en los pleitos administrativos.

La Constitución de 1854 intentó modificar la estructura vigente con un nuevo sistema político, jurídico y administrativo. Según el art.129, incluido en la sección sexta dedicada al Poder Judicial, "las causas contenciosas de hacienda y las que nacen de los contratos entre los particulares y el gobierno, serán juzgadas por un tribunal especial, cuyas formas y atribuciones las determinará la ley de la materia.” Esto fue reafirmado con la ley que organizó el Superior Tribunal, otorgándole el pleno conocimiento "de todo recurso de apelación que se interpusiese de resoluciones de gobierno

\footnotetext{
${ }^{39}$ Garriga, Carlos, "Gobierno y Justicia: el Gobierno de la Justicia”, en Lorente Sariñena (directora), La jurisdicción contenciosa-administrativa en España. Una Historia de los orígenes, Cuadernos de Derecho Judicial VII, Madrid, Consejo del Poder Judicial, Centro de Documentación Judicial, 2009.

${ }^{40}$ Díaz Couselo, José María, "Origen y consolidación del contencioso administrativo en la provincia de Buenos Aires (1854-1906) y su influencia en el derecho público de las demás provincias” en Revista de Historia del Derecho, núm. 22, Instituto de Historia del Derecho, Buenos Aires, 1994, p.52.

${ }^{41}$ Zorraquín, 1952, op. cit., p.207.
} 
en asuntos con particulares mientras no se establezca el tribunal especial de que habla el art.129 de la Constitución". 42

Cuando fue presentado el proyecto de ley del Superior Tribunal, Vélez Sarsfield destacó que era una gran novedad, surgida del juicio de todos los abogados que participaron en su elaboración, en la jurisdicción que hasta el momento ejercía el Gobierno. El objetivo había sido "conceder algún recurso a las resoluciones del Gobierno que perjudicaran a un tercero en las cuestiones entre particulares con el mismo Gobierno." ${ }^{43}$ Explicó a la Cámara que esa jurisdicción había existido en el país por las leyes de Indias. Siempre que la causa perjudicara a un tercero se podía apelar ante las Audiencias, desapareciendo los recursos con las facultades extraordinarias, no habiendo en ese momento en los asuntos más graves con el mismo Gobierno, adonde apelar.

En la letra existía un asesor, pero para Vélez el Gobierno muchas veces resolvía en contra de éste, sin ser sus miembros abogados. El problema estaba en que

...declara caídos, por ejemplo en comiso, cuantiosas mercaderías, contra la opinión del asesor, y de sus dictámenes no hay apelación ni recurso alguno, por consiguiente la justicia no está bien administrada, los hombres no tienen garantías en sus derechos, ni de una resolución única y dañosa a grandes intereses de particulares, no hay un tribunal que juzgue, que la modifique o la revoque. Respecto a los derechos individuales, siempre las Leyes se han abstenido de librar al juicio del Poder Ejecutivo los derechos individuales, ni la imposición de las penas, aunque fuesen pecuniarias en algunos asuntos. ${ }^{44}$

En base a este diagnóstico, que demostraba indefenso al particular, los abogados que planificaban la nueva organización judicial creyeron necesario que toda resolución sobre un acto del Gobierno que perjudicara a terceros fuera apelable ante un tribunal superior. Así se cumpliría con la declaración constitucional de independencia de la administración de justicia respecto al Gobierno, quedando a la espera de la creación del Tribunal prometido. Alsina reafirmó esta idea, diciendo que por primera vez se garantizaba de un modo más sólido la defensa "en las violaciones del Gobierno en los asuntos sobre contratos de particulares, y todo lo demás en que tenga lugar el interés individual del Gobierno." 45

Cuando el tema llegó a Diputados se generó un conflicto en torno a la definición de asuntos puramente administrativos y los contenciosos de hacienda, desatado por Manuel Rafael García para quien esa atribución generaría graves dificultades. Francisco de Elizalde reconoció las dificultades para la definición de los asuntos, optándose por llevar a Sala plena todas las cuestiones entre el Gobierno y particulares, tratando de ofrecer una garantía más al ciudadano. Pero para García se trataba de un "gravísimo error" que terminaría por paralizar la acción del Gobierno poniendo en

\footnotetext{
${ }^{42}$ Constitución del Estado de Buenos Aires de 1854, art. 9, inc. 1.

${ }^{43}$ Senadores, 1857, p. 365.

${ }^{44}$ Senadores, 1857, p. 366.

${ }^{45}$ Senadores, 1857, p. 374.
} 
conflicto cualquier asunto administrativo. A su entender, las causas apelables estaban "perfectamente deslindadas" en las Ordenanzas de Intendentes.

Emilio Agrelo intentó mediar en la disputa, llevando su resolución al momento en que se creara el Tribunal contencioso de Hacienda y se determinara claramente su jurisdicción, y aunque esto no conformó a García, el inciso resultó aprobado veintiséis contra dos. ${ }^{46}$ Más allá de la cuestión en debate, se dejan ver aquí dos posturas que se repetían respecto a conflictos por resolver en la organización judicial. Una era la de no modificar la estructura establecida por la legislación colonial y la otra, reconociendo la necesidad del cambio, dejar la resolución a leyes futuras.

Pero lo más interesante y que se debe comprender, es que se estaba discutiendo sobre la apelación de los conflictos entre los particulares y el Estado. La resolución en primera instancia quedaba en manos del Gobierno, por lo que poco tiempo después se generó un conflicto. El 2 de octubre se presentó al Senado un pedido para dar preferencia a una ley sobre los casos en que el Gobernador se hallara impedido. El poder ejecutivo había mandado el 30 de junio una nota, explicando que el gobernador Valentín Alsina se encontraba en grandes dificultades para despachar asuntos pendientes e importantes "por haber tenido que intervenir como abogado en ellos antes de ser Gobernador [...] y que deseaba que en aquellos casos el Gobernador del estado se considerase inhabilitado para entender negocios entre particulares y el Gobierno." Para aquel solo acto, se buscaba que el gobernador delegase la atribución en el presidente del Senado, y que si éste a su vez se encontraba impedido, transmitiera su delegación al presidente de la Cámara de Diputados. ${ }^{47}$

Para la Comisión de Negocios Constitucionales esto era inconstitucional, pues no se trataba de un caso en el que el poder ejecutivo pudiera delegar su poder en el presidente del Senado. Por ello la comisión buscó solucionar el problema de otra forma, entrevistándose el senador José Mármol con el Ministro de Gobierno José Barros Pazos y con el Gobernador Valentín Alsina. Resolvieron que para esos casos se reunieran los Ministros y con acuerdo de estos, el Gobernador despachara, entendiendo en los casos ordinarios sólo el ministro del ramo. Para los casos especiales se acordó resolver con acuerdo general de los Ministros, al que asistiría el Gobernador. No puede dejarse de observar la relación que se establecía entre el ejecutivo y el legislativo para resolver una cuestión relacionada con la administración de justicia.

Para Sarmiento, en estos casos, el gobernador no debía tener voto, sólo presidir a los Ministros, en quienes delegaba las atribuciones judiciales que le daba la Constitución y que tenía el poder ejecutivo en Buenos Aires. Pero a su entender, el Senado tenía en casi todas las Constituciones, y en esta especialmente, ciertas facultades administrativas. Por ello el presidente del

\footnotetext{
${ }^{46}$ Diputados, 1857, p. 526-527.

${ }^{47}$ Senadores, 1857, p. 422.
} 
Senado podía suplir al gobernador en esos casos, pues los Ministros estaban legítimamente impedidos para ejercer delegación que tampoco podía darles una ley. ${ }^{48}$

Pero Vélez Sarsfield volvió al principio, no encontrando inconveniente en que Alsina resolviera pues

por las Leyes generales, abogado de unas de las partes, no puede ser juez de la causa; pero un abogado que ha dejado de ser abogado del pleito, no hay inconveniente, habiendo ascendido al alto puesto de Gobernador en que juzgue el mismo negocio, como muchas veces sucede que las partes nombren de jueces padrinos a los mismos abogados. Entonces ya se ve la causa con otros ojos; es el juez y no el abogado empeñado en sostener las pretensiones del litigante, sino el Gobernador del Estado que tiene por delante los intereses públicos, y mucho más debiendo fallar con tres Ministros. ${ }^{49}$

En cambio para José E. Agüero el gobernador estaba más expuesto a la censura pública, debiendo cuidar su conducta y medir sus pasos. Además, las resoluciones no eran definitivas y contaba la parte agraviada con recurrir ante el Superior Tribunal de Justicia, por lo que el Gobierno sería más cuidadoso en su resolución "para no ver humillada la autoridad pública, y arrastrada a un tribunal donde va a ser quizá revocada su sentencia." Por estas causas el Gobernador no debía excusarse salvo en aquellas "inhabilidades que nacen del derecho natural, como es en negocios propios, como sería por ejemplo los negocios de un padre o un hermano, estos en que habla la naturaleza y callan todas las Leyes, y la autoridad debe declararse inhabilitada."50

El proyecto fue aprobado, lo mismo que en Diputados, donde Rufino de Elizalde expresó la necesidad de abrirle un camino al gobernador para esos casos en que creía indispensable o conveniente excusarse. Se resolvía así la posición del gobernador, pero los conflictos entre un particular y el Estado, seguían siendo en definitiva dirimido una de las partes, aunque pudiera luego la otra apelar ante el Superior Tribunal.

\section{$\underline{\text { V. La Superintendencia sobre la administración de justicia }}$}

Una resolución de la Suprema Corte del 22 de enero de 1877, relacionada con la asistencia al despacho de un juez de comercio, nos ofrece una síntesis sobre el significado de la superintendencia.

La asistencia diaria es un deber del juez: todo deber impuesto es una obligación a cumplir; y toda obligación a cumplir responde a la existencia de medios para hacerla efectiva, a fin de que no quede ilusoria en casos dados. Esas facultades coercitivas que residían primitivamente en la antigua audiencia pasaron plenas a las Cámaras de apelación por los Reglamentos de 1813 y 1817. La Constitución de 1854 la conservó en el poder respectivo, bajo el nombre lato de superintendencia, que significa el gobierno judicial; y este mismo concepto se lee en la del 73, después de haberle dado a la Suprema Corte la facultad inalterable de hacer su reglamento

\footnotetext{
${ }^{48}$ Senadores, 1857, pp. 422-423.

${ }^{49}$ Senadores, 1857, p. 423.

${ }^{50}$ Senadores, 1857, p. 424.
} 
y de "establecer las medidas disciplinarias que considere convenientes a al mejor administración de justicia. ${ }^{51}$

La Superintendencia confería "las atribuciones del Tribunal Superior, para juzgar a los jueces inferiores y demás subalternos del tribunal, y otras atribuciones que tienden a conservar la moral y el orden de los juicios. ${ }^{„ 52}$ Era el gobierno judicial que implicaba no sólo apercibir a los jueces por el incumplimiento de su deber sino también, hasta la ley de enjuiciamiento, suspender, investigar y mandar a enjuiciar criminalmente a los que aparecieron refractarios de aquellos. Esta atribución, tomada en gran parte del Tribunal Supremo Español, "no es depresiva de la dignidad del magistrado, que fuerte en la convicción de su derecho y en la legalidad de sus procederes, debe ver en ella el medio legítimo de levantar hasta la más leve sombra de acusaciones injustificadas."

El caso de Emilio Agrelo nos permite conocer los alcances de la superintendencia cuando como juez civil de la Capital, presentó una nota al Superior Tribunal el 11 de agosto de 1869 realizando un reclamo publicado por la Revista de Legislación y Jurisprudencia, junto con la respuesta recibida. ${ }^{54} \mathrm{~A}$ la presentación el magistrado adjuntaba el número de la "Gaceta de los Tribunales" en la que su redactor, el procurador Coronado, le dirigía insultos personales, con el pretexto de tachar sus procedimientos como juez.

Si la censura de los funcionarios públicos es no sólo permitida sino conveniente para la buena administración, si es lícito denunciar arbitrariedades de los Jueces, la violación de la Ley, y todos los actos que revelen la falta de cumplimiento a sus deberes, porque esta es la verdadera garantía que asiste al ciudadano, que tiene que someter al fallo de los Jueces las cuestiones en que se debate tal vez su honor o su fortuna, ese derecho no puede confundirse jamás con el abuso indigno de la prensa, cuando ella se constituye en detractora, y no tiene otro propósito ostensible que satisfacer pasiones vulnerables. ${ }^{55}$

\footnotetext{
${ }_{51}^{51}$ Acuerdos y Sentencias, tomo I, pp. 408-411.

52 Senadores, 1857, p. 374. El ejercicio de la superintendencia fue conflictivo siempre desde la Audiencia. Las instancias superiores tuvieron serias dificultades respecto a los jueces y funcionarios judiciales, que solían responder a la autoridad ejecutiva de turno que daban prioridad a las fuerzas policiales ante una sociedad que reclamaba por la inseguridad. El poder judicial no tenía autonomía para el desempeño de sus tareas y la superintendencia del Tribunal se veía mermada por cuestionamientos y disputas dentro del mismo poder. El Ejecutivo nombraba a los empleados judiciales que le reclamaban cuando la Cámara de Justicia quería imponerle otras tareas o no coincidían en cuestiones técnicas. La administración de justicia pedía por reformas constitucionales y no por leyes parciales que terminaban dando mayor poder al poder ejecutivo. Barreneche, 2001, op. cit., p. 136. Esta situación se mantuvo con los jueces de paz que además de ser presidentes de la municipalidad hasta 1884, ejercían "una de estas formas de pequeña resistencia cotidiana, donde los actores sociales recurrían en busca de una solución, dado el importante papel conciliador de esta instancia, es decir que actuaba como mediadora entre los actores involucrados y el Estado en formación, posibilitando la resolución de la causa allí donde se iniciaba". El alejamiento del Tribunal Superior se agravaba porque esta instancia judicial capilar estaba regida por una legislación que "dejaba intersticios para el ejercicio del cargo de una manera u otra”. De Paz Trueba, Yolanda, Mujeres y esfera pública entre 1880 y 1910, Rosario, Prehistoria Ediciones, 2010, pp. 33-36.

${ }_{53}$ Acuerdos y Sentencias, tomo I, pp. 669-670.

54 "Superintendencia del Superior Tribunal de Justicia. No compete al Tribunal en virtud de la superintendencia conocer de oficio injurias o calumnias dirigidas a los Jueces por medio de la prensa", en Revista de Legislación y Jurisprudencia, t. IV, 1870, Buenos Aires, pp.38-42.

55 "Superintendencia del Superior Tribunal de Justicia..., op. cit.
} 
El procurador Coronado era dependiente subalterno de la administración de justicia y contratista de la publicación de los documentos judiciales y, para Agrelo, de él "nada podía esperarse, sino fuera porque bajar hasta él" era indispensable para atender a esta cuestión donde un juez debía olvidarse de su condición de hombre, insultado en un diario creado y pagado para conveniencia de administración de justicia y no para "escarceo a los Magistrados", cumplidores fieles de sus deberes. El juez le pedía al Superior Tribunal adoptara una medida conveniente y justa, "como poder mayor en la Magistratura", asistido por el derecho de superintendencia, con el que debía protección directa a los subalternos y cuidado al decoro de la administración.

El Superior Tribunal dio vista a su fiscal, Marcelino Ugarte, enviándole los números de la "Gaceta de los Tribunales" donde estaban los artículos a que se hacía referencia. El Fiscal comenzó explicando que la superintendencia asignada por el artículo 125 de la Constitución provincial, no tenía la extensión que se le atribuía. Esta se reducía a los actos puramente económicos de la administración de justicia y a la vigilancia con que debía procurar que los funcionarios cumplieran “empeñosamente" los deberes de su cargo. Esto no implicaba facultades extraordinarias para resolver en causas sin respetar formas y recursos legales, ni para dar a los magistrados una protección para lo que no estaba habilitado.

La ofensa alcanzaba al magistrado y a la magistratura, pero debía mostrarse superior a las agresiones, "confiando en la honrada rectitud de su conducta" y el respeto que la opinión profesa a los que se conducen bien; o debía seguir el procedimiento acordado por las leyes para lograr el desagravio. Los miembros de la Judicatura estaban sujetos a la censura como todos aquellos integrantes de poderes en que se encontraba delegada la soberanía popular y su conducta debía ser el escudo y el bálsamo que los curara, si no llegaba a preservarlos. ${ }^{56}$

El Superior Tribunal no era juez correccional para juzgar una publicación como injuria, más allá del instrumento utilizado, no podía basarse en denuncias sin hechos propicios. Quien tuviera motivos para quejarse de los jueces inferiores, podía hacerlo al Superior Tribunal por apelación de los actos que considerara abusivos.

Si es necesario garantir a todos los miembros de la sociedad contra el error o el abuso de los Jueces, no es menos necesario garantir a los jueces contra los efectos de las pasiones y de los intereses que tienen que herir a cada instante en el cumplimiento de sus deberes y la mejor garantía que se les puede dar a este respecto es no prestar atención a denuncias desautorizadas o vagas. ${ }^{57}$

\footnotetext{
${ }^{56}$ Véase: Bonaudo, Marta, "La libertad de opinión y el honor de los hombres. Diálogo entre lo público y lo privado (Santa Fe, 1850-1890), en Bonaudo, Marta, Reguera Andrea y Zeberio, Blanca, (coordinadoras) Las escalas de la historia comparada, tomo I: "Dinámicas sociales, poderes políticos y sistemas jurídicos", Buenos Aires, Miño y Dávila, 2008.

57 "Superintendencia del Superior Tribunal de Justicia..., op. cit.
} 
Por todo esto el Fiscal recomendó no hacer lugar a la queja interpuesta, dejando su derecho a salvo. El 26 de agosto el Superior Tribunal resolvió “en todo como dice el Fiscal” mandándolo a publicar en la "Gaceta de los Tribunales.

Por ejemplo, el 23 de abril de 1852 los camaristas fijaron las obligaciones de los oficiales subalternos de la administración de justicia, recordándoles sus respectivos deberes, "según las leyes en aquella parte en que su observancia aparece estar descuidada, por exigirlo así no sólo el buen servicio público y los fines saludables de la justicia, sino el crédito de las personas a quienes están encomendados aquellos oficios y el general de la administración.” Específicamente les hacía hincapié en el deber de estar presentes en la Casa de Justicia a las horas del despacho de los señores jueces; en la prohibición legal de pedir derechos o ni gratificaciones a las partes por las diligencias judiciales encargadas y en el deber de practicar los actos dentro de las veinticuatro horas hasta ocho cuadras de la casa de justicia y cuarenta y ocho a distancia mayor en los términos de la ciudad, anotando en el expediente, cuando hubiese impedimento para verificarlo, el motivo que lo ocasionaba. Los jueces de primer instancia debían informar a la Cámara de Justicia sobre las faltas "probadas en que incurriesen los subalternos". 58

Esta obligación de los magistrados fue reiterada en 1861 por el Superior Tribunal que mandaba, en cumplimiento de su deber de velar por la buena administración de Justicia, que los jueces de primera instancia de la Capital, informaran sobre el desempeño y aptitudes de los Oficiales de Justicia. La orden se había originado en las noticias que les habían llegado sobre la sesión de la Cámara de Representantes del 22 de mayo. En ella, el juez en lo civil, Juan Agustín García, fundaba un proyecto sobre oficiales de justicia, asegurando que de los tres de esta clase, sólo uno de ellos estaba en aptitud de cumplir con las obligaciones de su cargo. ${ }^{59}$

En los años previos a la Constitución de 1873, el desprestigio sufrido por el poder judicial, hizo que los miembros del Superior Tribunal enviaran una circular a los magistrados pidiéndoles que les elevaran mensualmente una estadística del movimiento de su despacho Esta era una disposición que había caído en desuso y que eran indispensable para hacer conocer al público las tareas que pesaban sobre los tribunales y la contracción con que cada juez desempeñaba las que les correspondía "poniéndolos a cubierto de juicios y apreciaciones desfavorables fundadas en malos informes". También servirían de base para proponer las reformas convenientes a una mejor administración de justicia. Los informes de las causas iniciadas debían ser quincenales, con nombre, nacionalidad, edad, estado y ejercicio del procesado y el delito que se le atribuía. También debían informar las causas concluidas, con el nombre del procesado, indicando sobreseimiento, sentencia

\footnotetext{
${ }^{58}$ Acuerdos y sentencias, tomo I, pp. 179-180.

${ }^{59}$ Acuerdo extraordinario del 27 de mayo de 1861. Reunidos los Señores Presidente y Vocales del Superior Tribunal de Justicia Francisco de las Carreras, Domingo Pica, Basilio Salas, Andrés Somellera, Tiburcio de la Cárcova, Juan José Alsina, Benito Carrasco, Angel Medina, Pablo Font y José Barros Pazos. Acuerdos y sentencias, tomo I, p. 307.
} 
definitiva o absolutoria de culpa y cargo, absolutoria de la instancia o condenatoria y si había sido consentida o apelada. ${ }^{60}$

Estos ejemplos permiten observar la diversidad de cuestiones ligadas con la superintendencia relacionados con los conflictos internos del poder, que daban intervención a los otros poderes, como cuando un juez de primera instancia, que simultáneamente era diputado provincial, recurría a proyecto de ley en la Legislatura para resolver un conflicto de funcionamiento del poder del que era miembro con atribuciones para administrar justicia. Pero también se relacionaban con problemas hacia fuera, en que la cabeza del poder debía mejorar la recepción que hacía la sociedad del funcionamiento de la administración de justicia. Quedaba así de manifiesto la capacidad o incapacidad de la justicia en formación, de ejercer su autoridad de manera autónoma y con capacidad de cumplimiento.

\section{Conclusión}

El seguimiento de la organización del Superior Tribunal de Justicia de la provincia de Buenos Aires nos ha permitido arribar a algunas conclusiones que a su vez permitirán comprender las discusiones que se dieron para las reformas de la administración de justicia en la Constitución provincial de 1873. En primer lugar, si bien este Tribunal no fue una nueva institución y hubo continuidad con sus antecesores -la Audiencia y la Cámara de Apelación- se formó y funcionó sobre diferentes concepciones para organizar la justicia, en una cultura jurídica en cambio.

En la institución colonial (que sobrevivió dos años después de 1810) se trataba de normas morales y religiosas cuya misión era procurar el bien común. Cuando se organizó la provincia y la Cámara de Justicia pasó a encabezar el poder judicial del Estado provincial los cambios fueron lentos y fue en la segunda mitad del siglo XIX cuando la aceptación de la división de poderes, la separación de la moral y de la religión del derecho, y el absolutismo de la ley, respondían a un proyecto donde lo justo estaba siendo definido por la legislación y la administración de justicia buscaba concebirse como poder independiente. La legislación y la organización del sistema judicial que había dejado España hizo muy difícil superar la distancia entre teoría y práctica, pero la división de poderes había empezado y el desafío es comprender como se adaptaron las viejas instituciones a las nuevas necesidad y requerimientos.

Sobre esta teoría, el poder judicial debía alcanzar una independencia que en este período pudimos ver muy obstaculizada por el poder legislativo, que defendía su derecho de legislar. Según Antonio Malaver la jurisdicción emanaba del pueblo y el ejercicio correspondía al poder judicial, que no representaba la facultad de hacer derecho (jurisditione), sino de declararlo o aplicarlo en

\footnotetext{
60 "Circular del Superior Tribunal mandando 7 de febrero de 1870", Acuerdos y sentencias, tomo I, p.443. A. Somellera, Domingo Pica, Basilio Salas, Juan José Alsina, Angel Medina, Pablo Font, Alejo B. González, José Domínguez, Manuel H. Langenheim, Carlos Eguía.
} 
casos particulares (jus dicere o juridictione).$^{61}$ Pero la dependencia de la justicia se manifestaba fuertemente con el poder ejecutivo, que se había reservado el nombramiento no sólo de los miembros sino del presidente. Intervenía de modo indirecto en la elección del presidente de la sala del crimen, y participaba de los conflictos contencioso administrativos, en los cuales no perdía su jurisdicción y sólo dejaba la posibilidad de apelar ante el Superior Tribunal. A este juego entre poderes se sumaba el papel de la prensa en la relación entre el poder judicial y la sociedad.

El proyecto liberal debía resolver varias cuestiones, logrando hacerlo en algunos casos y en otros no. Por ejemplo el alcance de las leyes, que si bien eran provinciales, en muchos momentos de los debates aspiraban a cubrir el país. Otro tema permanente fue la necesidad de las "garantías de acierto y rectitud" que los magistrados debían brindar, afianzadas en la especialización por materias, que enfrentaba la primacía de la vida y la libertad con la de la propiedad. También estaba presente la preocupación por la pena de muerte, de la que sólo se buscó asegurar su sentencia sin eliminarla, terminando la decisión en los jueces de la sala civil.

Esta instancia judicial superior tuvo un rol específico en la conformación del poder judicial bonaerense, que se manifestó en cuatro aspectos primordiales: los preludios de la competencia originaria y exclusiva, la configuración y la afirmación de la superintendencia como gobierno judicial, los ensayos inmediatos del jury y la presentación de proyectos que comenzaron a concretarse aún antes de 1875 y que conoceremos en el próximo capítulo. El Superior Tribunal reunido a sala plena anticipó algunas de las atribuciones que después tuvo la Suprema Corte y sus salas civiles y criminal funcionaron como la segunda instancia que luego quedaría a cargo de las Cámaras de apelaciones constitucionales. Desde esta perspectiva confirmamos que toda institución tiene sus antecedentes y sus ensayos, aún cuando finalmente se concreten de forma diferente o incluso se configuren basadas en ideas diferentes.

La esfera legal es un "teatro" en el que la ley es un sistema de referencia en el cual la gente apela en defensa de sus derechos y donde la elite es preponderante pero no omnipotente. ${ }^{62}$ Esto es cierto, pero nuestra investigación nos ha permitido sumar a esta idea que esa elite no era homogénea, que en ella no todos pensaban igual y que en temas decisivos para la nueva organización liberal, como la administración de justicia, existieron posturas en muchos ocasiones diferentes y enfrentadas, que se manifestarán claramente al debatir la Constitución provincial de 1873.

\footnotetext{
${ }^{61}$ Malaver, Antonio E., Curso de procedimientos judiciales en materia civil y mercantil, t. I, Imprenta de Pablo E. Coni, Buenos Aires, 1875.

${ }^{62}$ Salvatore, Aguirre, y Joseph, op. cit., 2001, p.13.
} 


\section{Capítulo VII}

\section{El Poder Judicial de la provincia de Buenos Aires en la Constitución de 1873}

\section{$\underline{\text { Introducción }}$}

El protagonismo que han cobrado los sistemas judiciales de América Latina ha hecho renacer en gran parte de los países de la región un interés académico por la administración de justicia en los últimos años. ${ }^{1}$ A partir de aquí ha quedado demostrado que es primordial determinar la organización de las distintas instancias judiciales y sus competencias, junto con las normas que regularon la resolución de los conflictos. Este universo emergente estuvo sometido a una triple tensión de la primacía de la costumbre, la legislación aún vigente del Antiguo Régimen y la codificación que estaba surgiendo a partir del pacto constitutivo que intentaba imponer una nueva lógica de legitimidad, de la cual sus gestores se consideraban garantes. Los debates dejaban ver los complejos vínculos e identificaciones de los viejos integrantes de esos espacios jurídicos y los nuevos actores con sus resistencias a legitimar lo propuesto como normalidad y su esfuerzo por ubicarse en una comunidad política asentada en la soberanía del pueblo. ${ }^{2}$

Esto pudo verse en la formación de la magistratura en la provincia de Buenos Aires entre 1853 y 1874, momento cúspide en que fue creada la Facultad de Derecho, se sancionó la ley sobre acumulación de cargos, por lo que los jueces sólo debían atender sus juzgados, y se organizó el poder judicial. Éste, encabezado por la Suprema Corte de Justicia, cumplía las pautas establecidas por la Constitución sancionada en 1873, sentándose las bases para la formación de la carrera judicial.

Surgen entonces nuevas preguntas, específicamente relacionada con el concepto de garantía; garantías para el magistrado como administrador de justicia y para el pueblo como receptor de esa justicia. Éstas implicaban la responsabilidad que el poder judicial asumía como poder del Estado moderno en gestación y la del pueblo en el ejercicio de las garantías constitucionales (derecho de petición, recurso a la justicia y sufragio). Las respuestas a esas preguntas, que indagaremos en los debates constitucionales que se desarrollaron entre 1870 y 1873, deberán tener presente la relación entre lo político y lo jurídico, permanentemente puesto de manifiesto en los discursos de las sesiones de la Convención.

Los hombres que debatían, habitués de espacios comunes de sociabilidad, de formación profesional e incluso de trabajo, compartían el proyecto liberal. Este proyecto ponía en evidencia el esfuerzo de las elites en favor del constitucionalismo, la codificación y la construcción de nuevos

\footnotetext{
${ }^{1}$ Palacio, y Candioti, , op. cit., p. 11

${ }^{2}$ Bonaudo, 2005, op. cit., p. 215.
} 
sistemas judiciales, locales y nacionales. ${ }^{3}$ Para sostener sus posturas recurrieron a ideas políticas "importadas" de tres o cuatro países centrales, en lo referido a los principios básicos de las doctrinas políticas y a las características generales de los cambios institucionales propuestos, pero no se puede negar la originalidad del pensamiento político global argentino y la existencia de una tradición jurídica propia.

Esta tradición se fue gestando como consecuencia de la adaptación de esas ideas a la realidad con la que estos actores se encontraron. Ellos mismos, de diversas maneras, habían convivido con un país y un Estado en formación donde las transferencias e intentos de aplicación lisa y llana de normas y principios de otras latitudes, dieron lugar a grandes enfrentamientos y violencia. ${ }^{4}$ En la universidad donde estudiaron se iniciaron en los debates no sólo académicos sino también sobre la formación del sistema judicial que iluminaban, a su vez, los intercambios de la elite para posicionarse en la organización constitucional del país. ${ }^{5}$

El Estado no tuvo una expresión de acuerdo monolítico sobre las cuestiones a resolver, sino que fue expresión de conflictos sociales comprensibles en un tiempo determinado, que se deben tener en cuenta a la hora de analizar la creación y producción de leyes, constituciones, códigos e instituciones judiciales. ${ }^{6}$ Quienes discutieron el texto constitucional tenían un acuerdo sobre los principios doctrinarios de fondo, que partían de los presupuestos jurídico-políticos del estado liberal. No entraron en discusión la declaración de derechos, la organización tripartita del poder y la necesidad de contar con una norma superior que garantizara el principio de legalidad, pero sí se debatieron, y mucho, los fundamentos generadores del nuevo programa, de los que nos interesa especialmente los relacionados con la organización judicial. ${ }^{7}$

Los modelos propuestos se guiaban por la inspiración extranjera, la propia tradición, la experiencia histórica y las necesidades, ${ }^{8}$ surgiendo tres tendencias dentro del liberalismo, con sus propios "programas" de organización de los órganos estatales. Los liberales buscaban la supremacía del órgano legislativo bicameral, el sufragio con voto calificado por la inteligencia y la riqueza, con elección indirecta para asegurar la calificación. El órgano ejecutivo lo preferían colegiado para debilitarlo frente al legislativo y la administración de justicia debía ser independiente, con un cuerpo más técnico que político, con capacidad de control sobre los otros órganos para poder actuar como freno frente a los abusos. Los radicales democráticos también defendían la supremacía del

\footnotetext{
${ }^{3}$ Bonaudo, 2005, op. cit., p.200.

${ }^{4}$ Gallo, Ezequiel, "Liberalismo, centralismo y federalismo. Alberdi y Alem en el 80", en Investigaciones y Ensayos, 45, enero-diciembre de 1995, p. 386; Tau Anzoátegui, Víctor, Las ideas jurídicas en la Argentina (siglos XIX y XX), Editorial Perrot, Buenos Aires, 1977.

${ }^{5}$ Zimmermann, Eduardo, "The Education of Lawyers and Judges in Argentina`s Organización Nacional (1860-1880), en Eduardo Zimmermann (editor), Judicial Institutions in Nineteenth-Century Latin America, Institute of Latin American Studies, University of London, 1999.

${ }^{6}$ Palacio y Candioti, 2007, op. cit., p. 18.

${ }^{7}$ Pérez Guilhou, 1997, op. cit., p.16.

${ }^{8}$ Tau Anzoátegui, 1977, op. cit.
} 
legislativo, pero unicameral y surgido del sufragio universal directo periódico y sin reelección. El ejecutivo debía ser colegiado, por elección directa y subordinado al legislativo. El órgano judicial se integraba con participación popular, preferentemente subordinado al legislativo. Sus jueces no interpretan la ley y debían acatarla sin discusión, recurriendo en caso de duda al legislador. Los conservadores defendían la supremacía del ejecutivo unipersonal, colegislador y fruto de la elección indirecta de colegios electorales. El ejecutivo era bicameral, de sufragio calificado y facultades limitadas. El poder judicial independiente debía integrarse por abogados respaldados por la continuidad en la función y con fuerte control sobre el legislativo. ${ }^{9}$

Con esta perspectiva, luego de haber seguido todo lo relativo a la conformación del poder judicial, elegimos los temas que consideramos generarían una determinada relación entre éste y la sociedad civil: su independencia, la elección y duración de los magistrados en sus cargos, el Jury de enjuiciamiento, el juicio por jurado y la libre defensa y representación, poniendo especial atención a la responsabilidad de los magistrados y las garantías que se buscaba brindarles en el ejercicio de su función. ${ }^{10}$ Para poder comprender mejor los debates, hemos seguido a pie de página la evolución de los tres proyectos previos y el de la Constitución desde el primero, presentado por la Comisión dedicada al poder judicial. ${ }^{11}$

Luego de acceder a la conformación del poder judicial en sus distintos niveles, analizaremos los debates de la Constitución provincial, concluida en 1873. Este acontecimiento puede definirse como un "momento bisagra", en que se articularon un punto de llegada y otro de partida. Terminaban con años de discusiones y enfrentamientos en pro de definir, al menos en la letra, el Estado de la provincia de Buenos Aires, pero comenzaban con un proceso de codificación, legislación y organización de los poderes republicanos en base a las ideas recibidas del exterior y procesadas por los intelectuales locales y los proyectos experimentados hasta el momento, hubieran llegado o no a concretarse.

\footnotetext{
${ }^{9}$ Egües, Carlos "Las ideas políticas en el constitucionalismo argentino del siglo XIX. Un aporte metodológico", en Revista de Historia del Derecho núm. 24, Instituto de Investigaciones de Historia del Derecho, Buenos Aires, 1996; Pérez Guilhou, 1997, op. cit.

${ }^{10}$ Todos estos temas tiene absoluta vigencia en un momento que la presidente de la Nación Cristina Fernández de Kichner anunció una amplia reforma judicial, bajo el título de "democratización del Poder Judicial". La propuesta consta de los proyectos de seis leyes presentados al Congreso de la Nación, tres a Diputados y tres a Senadores. Las leyes tratan de la ampliación y elección popular de los miembros del Consejo de la Magistratura, órgano encargado de seleccionar y remover a los jueces; el ingreso democrático al Poder Judicial y al Ministerio Público Fiscal; la publicidad de los actos del Poder Judicial; la creación de tres Cámaras de Casación; la publicidad y acceso directo a las declaraciones juradas de magistrados y funcionarios; la regulación de medidas cautelares contra el Estado. Diario La Nación, 8 de abril de 2013.

${ }^{11}$ De los debates parlamentarios de la Convención Constituyente llevada adelante entre 1870 y 1873 faltan todos los textos tomados por el taquígrafo Camaña que intentamos cubrir con los resúmenes.
} 


\section{La definición del Poder Judicial en la Constitución provincial de 1873}

El 31 de mayo de 1869 el gobernador Emilio Castro, a poco de ser electo, se dirigió a la Legislatura propiciando la reforma de la Constitución de la provincia. ${ }^{12}$ El 10 de marzo del año siguiente se convocaron las elecciones de convencionales y finalmente la Convención inició sus sesiones ordinarias el 23 de mayo de 1870, presidida por Manuel Quintana, en cuyo discurso quedó definida la visión que ellos tenían de ese acontecimiento, afirmando que en el seno de la Convención se encontraban diseminados los hombres más notables de la Provincia. En unos se distinguía la práctica de la administración en todos sus ramos, en otros el sello de la ciencia más adelantada; en estos sobresalía la prudencia de la edad madura, en aquellos el generoso ardor de los primeros años. ${ }^{13}$ Intentaba transmitirse que se abría un franco diálogo entre todas las fuerzas, sin embargo en los debates eran claros los enfrentamientos, que si bien respetaban el proyecto liberal que los unía, determinaban modelos de organización judicial muy diferentes.

Cincuenta años después Adrián Becar Varela, en la introducción de a una nueva edición de los debates de la Convención Constituyente de 1870-1873, afirmaba que los hombres más destacados del escenario político, social y científico del país, se habían reunido con el propósito de discutir una constitución científica, expresión de sus vastos conocimientos jurídicos. Habían perfeccionado su saber en el destierro, en las cárceles, en el gobierno del país, pero "sin contaminarse directamente con los horrores de la tiranía." Era una Asamblea dedicada a la reconstrucción que tanto necesitaba el país, "para poder gozar de la paz interna y entrar de lleno al trabajo y al ejercicio de los derechos ciudadanos, para cimentar sus liberales instituciones y afianzar el progreso y adelanto moral y material del Pueblo Argentino, a quien la naturaleza ha brindado un suelo inagotable de riquezas". ${ }^{4}$

Autonomistas y nacionalistas participaron de los debates junto a sus líderes, doblando en número las bancas de los primeros, incluyendo a los hombres principales del partido federal. ${ }^{15}$ Las tareas de la Comisión reformadora terminaron el 14 de noviembre de 1873, con Mariano Acosta como gobernador, siendo el fruto de un largo y discontinuo trabajo la Constitución de la provincia de Buenos Aires de 1873 que fijaba las bases para la descentralización administrativa. La tarea comenzó con la designación de cinco comisiones especiales encargadas de redactar los capítulos

\footnotetext{
${ }^{12}$ Sanucci, 1964, op. cit.

${ }^{13}$ Debates de la Convención Constituyente de Buenos Aires, 1870-1873. Publicación Oficial hecha bajo la dirección del convencional Luis V. Varela, reimpresión con índice alfabético y cronológico confeccionado por Adrián Becar Varela, Taller de Impresiones Oficiales, La Plata, 1920 (en adelante DCC), p. 11.

${ }_{15}^{14} \mathrm{DCC}$, Antecedentes justificativos de la reimpresión, p.VII.

15 Sadías, 1910, op. cit., t. II, p. 221. Para acceder a las complejas imágenes de la formación del sistema político nacional desde la experiencia de las provincias véase Bragoni y Míguez, 2010, op. cit.
} 
referentes a Declaraciones de Derechos y Garantías, Poder Legislativo, Poder Ejecutivo, Poder Municipal y Poder Judicial. ${ }^{16}$

Los proyectos parciales que surgieron de esas comisiones fueron estudiados por una Comisión general, que presentó el texto definitivo de la nueva Constitución, sobre el cual se llevarían adelante los debates. Sin embargo las cosas no fueron sencillas y el camino hacia el capítulo dedicado a la organización judicial fue largo y sinuoso. La base del texto no fue el de la primera Comisión nombrada al efecto, sino de otra que redactó el "Despacho de la última Comisión del Poder Judicial". ${ }^{17}$ Para comprender el debate y las decisiones que se tomaron, es indispensable saber cómo se formó esta última Comisión y quienes intervinieron en ella. Todo un itinerario a través del último año de la Convención Constituyente.

A poco de iniciados los debates sobre el poder judicial en base al proyecto presentado por la Comisión central, el 14 de marzo de 1873 surgió la propuesta de formar dos Comisiones especiales, una para tratar los artículos 174 (independencia y conformación del poder judicial) y 177 (publicidad de las audiencias) ${ }^{18}$, y otra para el artículo 175 (el juicio por jurado). ${ }^{19}$ En la sesión del 26 de marzo Luis Sáenz Peña explicó que las dos comisiones habían tenido conferencias laboriosas buscando armonizar su trabajo, encontrando necesario expedirse colectivamente. Por esto requerían autorización para modificar otros artículos que estuvieran ligados a los que se había puesto a su consideración. ${ }^{20}$

Con referencia al artículo 174 sobre la estructura constitucional de los tribunales de la provincia, consideraban indispensable determinar por separado las atribuciones de cada uno de los Tribunales en que se dividía el poder judicial. La provincia debía tener un Tribunal Superior o Suprema Corte y establecer cuáles serían las atribuciones constitucionales que debía tener. Por esto pedían autorización para sacar algunos artículos de la Sección Poder Judicial y colocarlos en otro capítulo, propuesta que fue aceptada. ${ }^{21}$

\footnotetext{
${ }^{16}$ La Comisión nombrada por la Convención Constituyente para proyectar la parte de la Constitución de la Provincia referente al Poder Judicial estaba integrada por Andrés Somellera, Aristóbulo del Valle, Rufino de Elizalde, José Antonio Ocantos y Octavio Garrigós, DCC, pp. 100- 102.

${ }^{17}$ DCC, pp. 1381-1384. Ezequiel Pereyra, José María Moreno, Vicente F. López, Francisco Alcobendas, Antonio E. Malaver, Luis Sáenz Peña, Dardo Rocha, Pedro Goyena, Miguel Navarro Viola.

${ }^{18}$ El Presidente procedió a nombrar para la Comisión encargada de los artículos 174 y 177 a los convencionales Eduardo Costa, Luis Sáenz Peña, Miguel Navarro Viola, Antonio E. Malaver y Francisco Alcobendas. DCC, 17 de marzo de 1873, p. 1056.

${ }^{19}$ Comisión: Vicente F. López, Ezequiel Pereyra, Dardo Rocha, José María Moreno y Pedro Goyena. DCC, 17 de marzo de 1873, p. 1056.

${ }^{20}$ DCC, 26 de marzo de 1873, pp. 1091-1102.

${ }^{21}$ Proyecto de Constitución coordinado por la Comisión Central, sobre la base de los cinco proyectos presentados por las Comisiones parciales DCC, pp.104-126. Firmado por López, Villegas, Garrigós, Rocha y Mitre. Art. 174 “El Poder Judicial es independiente, en el ejercicio de sus funciones, de los demás Poderes creados por esta Constitución. Será desempeñado por un Tribunal Superior y por los demás Tribunales y Juzgados permanentes que esta Constitución y leyes reglamentarias designe, estableciendo su número, organización, jurisdicción y competencia, bajo la base de la descentralización, en cuanto fuere posible".
} 
En la sesión del 20 de junio entró en discusión la Sección Quinta "Poder Judicial” en base al proyecto de la última Comisión. La primera parte del debate estaba en los textos extraviados del taquígrafo Camaña, pero según la síntesis de la sesión, ésta comenzó con la exposición de Ezequiel Pereyra sobre el nuevo proyecto con un pormenorizado detalle de las reformas, analizadas y fundadas. Quien se opuso a la creación de una Suprema Corte fue José T. Guido ${ }^{22}$, afirmando que no había razones para ampliar de ese modo el poder judicial, bastando con aumentar algunas atribuciones del Tribunal Superior. Pero el artículo 174 fue votado y aprobado, quedando constituida la Suprema Corte. ${ }^{23}$

En el curso del debate, Vicente F. López explicó que lo importante del nuevo proyecto era que establecía el Tribunal de constitucionalidad. Ese Tribunal resolvía no solamente los conflictos de la ley o competencia entre los Poderes públicos de la provincia, sino también los conflictos que tuvieran los tribunales ordinarios de la provincia, porque ese Tribunal no pertenecía al orden regular de los jueces que decidían las causas. Los tribunales ordinarios podían estar en conflicto unos con otros y esos conflictos no se resolvían por el tribunal ordinario superior sino por este Tribunal de constitucionalidad, que era el que decidía cuál era la ley superior de la provincia, en una materia dada o en un conflicto dado.

En este proyecto se establecía una Corte Suprema de Justicia como Tribunal de constitucionalidad que, como explicaba Bernardo de Irigoyen, cuando resolvía la constitucionalidad de los procedimientos, no obraba como parte del poder judicial, sino como Tribunal Constitucional creado expresamente con el objeto de resolver los conflictos entre el poder judicial y el poder ejecutivo o entre el poder judicial y el poder legislativo. Esto lo reafirmó López diciendo que además de ser un Tribunal de Justicia era un Tribunal político. ${ }^{24}$

\section{La conformación del Poder Judicial: garantía y responsabilidad del magistrado}

\section{a. La independencia del Poder Judicial}

El primer artículo dedicado al Poder Judicial en el proyecto de la Comisión establecía que éste sería independiente "en el ejercicio de sus funciones, de los demás Poderes creados por esta Constitución" y la Comisión central mantuvo esta declaración especificando los tribunales que lo

\footnotetext{
${ }^{22}$ José T. Guido, definido conservador en Pérez Guilhou, 1997, op. cit., p. 129. En adelante mencionaremos el grupo del convencional según este texto.

${ }^{23}$ DCC, 20 de junio de 1873, pp. 1213-1222. Art. 174 "El Poder Judicial será desempeñado por una Suprema Corte de Justicia, Cámaras de Apelación, y demás Tribunal, Jueces y Jurados, que esta Constitución establece y autoriza consultando la descentralización posible en su jurisdicción territorial y en la de su competencia por materia o naturaleza de las causas que dan origen al procedimiento.” (art. 155 de la Constitución provincial de 1873)

${ }^{24}$ DCC, 20 de junio de 1873, pp. 1218-1220. López e Irigoyen fueron como Guido definidos conservadores, sin embargo estaban aquí en una postura enfrentada. Lettieri, 1995, op. cit. Esta discusión en torno a la más alta autoridad del Poder Judicial ya se había dado con la Constitución de 1854 para el Estado de Buenos Aires.
} 
conformarían, conformados bajo el principio de la descentralización "en cuanto fuere posible." ${ }^{25}$ En los debates, Miguel Navarro Viola ${ }^{26}$ consideró superfluo declararlo en sus funciones, independiente de los otros poderes. Fue apoyado por Vicente Fidel López y Rufino de Elizalde, ${ }^{27}$ pero José A. Ocantos sostuvo la redacción original porque los poderes emanaban del pueblo, y era preciso fijar esa independencia de aquellos de quienes él nacía. ${ }^{28}$

El concepto de independencia de Ocantos incluía la intangibilidad de los sueldos, impidiendo la dependencia de la Legislatura para que los sueldos de los jueces fuesen aumentados o disminuidos durante el tiempo que estuvieren funcionando. Fortaleció su postura asegurando que todos los tratadistas que se habían ocupado de la independencia de los poderes, aconsejaban que quedaran completamente desligados de las influencias más o menos legítimas que pudieran ejercer los otros Poderes. ${ }^{29}$

Este enfrentamiento no consistía solamente en una declaración, sino en la definición del origen del poder judicial, que volvió a hacerse presente cuando se establecieron las pautas de nombramiento de los magistrados. El artículo fue aprobado sin la declaración de poder independiente, pero mantuvo el concepto de descentralización que en el artículo constitucional especificará su competencia territorial (hoy jurisdicción) y por materia o naturaleza de la causa. Esta no es una cuestión menor, ya que en estos años hablar de descentralización podía hacer referencia indistintamente a tres aspectos: terminar con la dicotomía entre ciudad y campaña; establecer la división de poderes en el ámbito local separando las funciones judiciales de las administrativas; o generar los cambios en la administración de justicia que permitieran que el litigio se resolviera allí donde se producía, ya fuera a través de la desconcentración espacial o por materias. $^{30}$

\footnotetext{
${ }^{25}$ Comisión Poder Judicial: Art. $1^{\text {o: }}$ "El Poder Judicial es independiente, en el ejercicio de sus funciones, de los demás Poderes creados por esta Constitución. Comisión central: Art. 174 "El Poder Judicial es independiente, en el ejercicio de sus funciones, de los demás Poderes creados por esta Constitución. Será desempeñado por un Tribunal Superior y por los demás Tribunales y Juzgados permanentes que esta Constitución y leyes reglamentarias designe, estableciendo su número, organización, jurisdicción y competencia, bajo la base de la descentralización, en cuanto fuere posible". Despacho de la última Comisión del Poder Judicial: Art. 174 "El Poder Judicial será desempeñado por una Suprema Corte de Justicia, Cámaras de Apelación, y demás Tribunal, Jueces y Jurados, que esta Constitución establece y autoriza consultando la descentralización posible en su jurisdicción territorial y en la de su competencia por materia o naturaleza de las causas que dan origen al procedimiento" (art. 155 de la Constitución provincial de 1873).

${ }^{26}$ Conservador.

${ }^{27}$ Elizalde y Ocantos definidos como ortodoxos, pero enfrentados durante todo el debate.

${ }^{28}$ DCC, 14 de marzo de 1873, p. 1045.

${ }^{29}$ DCC, 14 de marzo de 1873, p. 1052. Esta cuestión provocará un conflicto entre poderes cuando el presupuesto para 1876 rebajó el diez por ciento los sueldos de los jueces en actividad, que se presentaron a reclamar ante la Suprema Corte, generando un debate en torno al principio de inamovilidad con que la Constitución de la Provincia había tratado de garantir la independencia del poder judicial. Corva, María Angélica, "Los magistrados de la provincia de Buenos Aires: sueldos, jubilaciones y pensiones (1854-1881), en Revista de Historia del Derecho $\mathrm{N}^{\circ} 36$, Buenos Aires, Instituto de Historia del Derecho, 2008, pp. 13-42.

${ }^{30}$ López, conservador, definió la descentralización al debatir con José Antonio Ocantos, liberal ortodoxo, en la Convención el 17 de marzo de 1873: "Yo comprendo por descentralización la completa separación de los tribunales, mientras que el señor convencional entiende por descentralización la creación de distintos tribunales para distintas materias jurídicas. Pero esto no es descentralización. La descentralización consiste en la separación de los tribunales
} 


\section{b. La elección de los magistrados}

Este fue uno de los temas que llevó más debates en tres largas sesiones y de los que sufrió un cambio más abrupto entre el proyecto original y el artículo finalmente sancionado. ${ }^{31}$ La Comisión del Poder Judicial había votado en disidencia y antes de entrar a tratar el tema Sáenz Peña quería saber los motivos, siendo Ocantos el que inició las explicaciones, generándose un debate público de la comisión redactora. La mayoría de la Comisión aceptaba el artículo, él incluido, a pesar de que no expresara sus ideas radicales en la materia. Había cedido en la redacción como transacción con los dos miembros de la Comisión, Somellera y Garrigós, que no que se aproximaban a sus ideas, dado que los otros dos, Elizalde y del Valle, eran radicalmente opuestos a la elección de segundo grado y estaban por la elección directa. ${ }^{32}$ Dar al pueblo la elección directa de los magistrados era una facultad perjudicial y contraria a las ideas que predominaban en la Constitución Nacional, por la que el poder ejecutivo nombraba los magistrados de la Corte Suprema y de los demás tribunales federales inferiores, con acuerdo del Senado, por lo que sería una felicidad para él que triunfara la idea de consignar en la Constitución de Buenos Aires un artículo análogo a éste.

Los países tomados por maestros en la ciencia del derecho federal habían aplicado el principio de nombramiento de los jueces de una y otra manera, demostrando que lo importante era tener en cuenta lo que convenía en la situación que se encontraban y cuál era el estado de civilización al que habían llegado. En Estados Unidos, por ejemplo, tratadistas tales como Lieber ${ }^{33}$ (que dio la última palabra sobre ciencia del derecho federal), Keen, Story Grink ${ }^{34}$, se inclinaron por el sistema nacional, y demostraban, especialmente el último, que a pesar del éxito que había tenido la elección popular en Nueva York, pudiendo resultar la más ancha base sobre la que podría fundarse el sistema federal, el ensayo era tan peligroso que debía "hacerse con toda circunspección y prudencia".

\footnotetext{
que han de conocer en las distintas materias, de tal modo que cuando se haya pronunciado sobre cualquiera de las materias, que le están atribuidas, la sentencia del tribunal que se reúna sea la última palabra que pueda pronunciarse sobre las materias, y que no dependa de otro tribunal la última palabra, porque entonces no sería descentralización [...] Es completamente contradictorio establecer que haya un Tribunal Superior en que han de centralizarse todos los demás". DCC, p. 1061. Hoy podríamos decir que Ocantos estaba a favor de la desconcentración por competencia y jurisdicción, y López por la descentralización espacial que asegurara el fin de la causa allí donde fuera iniciada, cerca de los actores. Sin embargo, tanto para uno como para el otro se estaba hablando de descentralizar la función judicial. Corva, María Angélica, "La Justicia de Paz en la Constitución de la Provincia de Buenos Aires de 1873", en Revista de Historia del Derecho núm. 33, Instituto de Investigaciones de Historia del Derecho, 2005, pp. 69-129.

${ }^{31}$ La elección estaba determinada por los artículos 180 -"Los miembros del Superior Tribunal serán elegidos por la Asamblea Legislativa a pluralidad absoluta de votos; y si ésta no resultase después de verificada la votación, se votarán nuevamente los dos candidatos que haya resultado en mayoría relativa, decidiendo el Presidente en caso de empate"-, y 181 - "Los Jueces letrados de los Tribunales inferiores serán nombrados por el Poder Ejecutivo con acuerdo del Senado"-, de la Comisión central, que coincidían con los artículos $9^{\circ}$ y $10^{\circ}$ de la Comisión Poder Judicial. En el texto constitucional se redujo a "Los Jueces letrados serán elegidos por el Poder Ejecutivo con acuerdo del Senado" (art. 184).

${ }^{32}$ En este artículo entra en la discusión Aristóbulo del Valle, a quien Pérez Guilhou lo califica como demócrata radicalizado, alineado con Elizalde, definido como ortodoxo.

${ }^{33}$ Francis Lieber (1800-1872) escribió On civil liberty and self-government (1853) traducida del inglés al español por Florentino González como La libertad civil y el gobierno propio publicada en 1872. La edición tiene un apéndice con las Constituciones de Inglaterra, Francia, Estados Unidos.

${ }^{34}$ Se refiere a Joseph Story (1779-1845) abogado y escritor jurídico norteamericano, autor del Comentario sobre el conflicto de las leyes, publicado en 1834 y traducido por Clodomiro Quiroga.
} 
Era casi imposible que diera resultados prácticos, pues el sistema podía aplicarse sólo

...en un Estado cuya población estuviera muy adelantada, cuyos habitantes estuvieran todos en un sistema de civilización tal que comprendieran perfectamente sus derechos y pudieran ejercer esta facultad sin comprometer los intereses permanentes del país, en el presente y en el futuro; que pudiera comprender la magnitud de la facultad que se les daba, y sobre todo, que su capacidad e inteligencia estuvieren tan bien preparadas que pudiesen hacerse cargo, no solamente de las altas funciones que tienen que desempeñar los magistrados, sino que los habilitara también para discernir las condiciones que deben tener esos magistrados, respecto a su capacidad, inteligencia y honorabilidad.

Si le daban un pueblo en esas condiciones para ensayar la propuesta de Elizalde y del Valle él la aceptaría, seguro de encontrar el verdadero ser del sistema representativo, base sobre la que podía fundarse la verdadera magistratura del país. Pero no eran esas las características del pueblo de la provincia y la Convención no debía "alucinarse" creyendo que estaba la sociedad en condiciones de adoptar ese sistema. ${ }^{35}$

Terminados los argumentos del presentador, del Valle respondió que los inconvenientes dentro de la Comisión se habían presentado no por cuestiones prácticas, sino a partir de dos ideas contrapuestas: un poder judicial que emanaba de los otros poderes públicos, o que debía surgir directamente del pueblo como los demás poderes del Estado. Su contrincante se declaró partidario de la elección popular, inaplicable por la deserción del pueblo en los comicios. Sin embargo el problema no era ese, sino la razón por la que el pueblo no concurría a sufragar cuando era llamado a ejercer su derecho en los actos electorales. El pueblo no concurría jamás a los comicios cuando un interés del momento no lo agitaba, afirmaba del Valle, pero cuando se tratara de la elección de los jueces responsables de decidir de la honra, de la fortuna, de la vida y del honor de todos los habitantes de la Provincia, el espíritu público habría de reaccionar. ${ }^{36}$

A las cuestiones ya presentadas, José Manuel Estrada agregó que según las Leyes de Indias "Juez ninguno podía ser emanación del interesado, ni tampoco estar bajo su influencia”. Por esto los jueces siempre habían tomado su investidura de un Poder superior, o más bien dicho de la soberanía, y ésta en su más lata abstracción, era una de dos cosas: o un hombre o un pueblo. Si era un pueblo, entonces eran los interesados los que nombraban sus propios jueces y se exponían a sufrir las consecuencias; pero tampoco podía ser nombrado por un solo Poder porque dependería de él. Entonces el poder judicial debía ser elegido por la soberanía representada por órganos dotados del criterio suficiente, como se suponía que reunían el poder ejecutivo y el poder legislativos combinados. Su propuesta concreta era que el Superior Tribunal de Justicia fuera nombrado por el poder ejecutivo, con consulta del Tribunal que tenía la vacante, y de la Asamblea Legislativa. ${ }^{37}$

\footnotetext{
${ }^{35}$ DCC, 19 de marzo de 1873, pp. 1070-1071.

${ }^{36}$ DCC, 19 de marzo de 1873, pp. 1072-1073.

${ }^{37}$ DCC, 19 de marzo de 1873, pp. 1074- 1075.
} 
Siguiendo la misma línea, Ezequiel A. Pereyra se declaró de acuerdo con Estrada y con Goyena $^{38}$ y advertía que se estaba confundiendo derecho con aptitud, pues si bien todos tenían derecho no todos tenían aptitud para ejercerlo. El juez requería de probidad, moralidad, inteligencia y ciencia, pero también de juicio, que nacía de la reflexión y "cierto criterio especial." Por esto ninguna elección respondería plenamente, ni la popular, ni los electores calificados, ni la hecha por el poder ejecutivo con acuerdo de las Cámaras Legislativas.

En Francia eran nombrados en base al informe de funcionarios caracterizados. En otros lugares se realizaba el concurso, cosa poco menos que imposible en Buenos Aires por el modo de ser y el estado en que se encontraban, pues no se presentarían los hombres más competentes, que ganaban mucho más en sus estudios. En Prusia y en Alemania los abogados daban un examen ante los Tribunales para ser juez, inaplicable entre nosotros. Aquí no había más remedio que recurrir al nombramiento del poder ejecutivo, que daba cierta garantía moral, con acuerdo de las Cámaras Legislativas y la opinión de los Tribunales. ${ }^{39}$

Cuando Elizalde encaró una fuerte defensa de la elección popular, surgió en la argumentación un tema muy poco discutido en la Convención: la justicia de paz. ${ }^{40}$ Los jueces de paz debían ser agentes de la justicia y criticaba duramente la forma de su elección, pus si el Gobierno lo elegía de una terna presentada por la Municipalidad, los móviles podían ser cuanto menos el desconocimiento del candidato y cuanto más los fines electorales. El verdadero principio ya estaba conquistado haciendo del juez de paz la base en que reposaba la Justicia, cuya jurisdicción -con la apelación que se concedía a los Tribunales de Apelación- "venía a formar una garantía sólida de la buena Administración de Justicia”.

Las causas de menor cuantía eran resueltas por jueces elegidos por el pueblo, entonces faltaba resolver qué sucedería con las de mayor cuantía.

A este respecto prevalecen dos ideas verdaderamente científicas y prácticas bajo el sistema que queremos sancionar: la descentralización en cuanto territorio a fin de poner a la Justicia al alcance de todos los que la necesiten, y la descentralización sobre las materias a fin de formar competencias y jurisprudencias, lo que no se hace actualmente entre nosotros. ${ }^{41}$

Elizalde aseguraba que no se la podía rechazar sin falsear el sistema republicano representativo y que la deficiencia en el criterio del pueblo era un argumento contradictorio, pues se le concedía suficiencia para la elección de los otros Poderes, que eran de menos importancia que el

\footnotetext{
${ }^{38}$ Goyena y Estrada se autocalificaban como liberales católicos.

3919 de marzo de 1873 , DCC, p. 1076.

${ }^{40}$ Podemos suponer que la descentralización administrativa se daba por resuelta en el proyecto del Poder Municipal, que dividía el territorio del Estado en distritos a cargo de municipalidades, con miembros elegidos por dos años, pública y directamente por el pueblo, encargados de las funciones que antes desempeñaban los jueces de paz. Los seis artículos que conformaron el capítulo "Justicia de Paz" resultaron del despacho de la última Comisión del Poder Judicial, sancionado sin debate. Los artículos segundo y tercero, relacionados con la elección popular, tuvieron uno y dos votos en contra respectivamente, el resto se aprobó por afirmativa general. DCC, 27 de junio de 1873, p.1119.

${ }^{41}$ DCC, p. 1081. Elizalde definió la descentralización tanto para referirse a cambios espaciales como de competencia.
} 
poder judicial. El pueblo podía elegir quien debía juzgarlo y hasta administrarse él mismo la justicia, demostrado esto en la adopción del jurado y la elección de los jueces de paz. Si el pueblo de Buenos Aires no tenía capacidad ni ciencia para elegir juez, tampoco lo tenía para elegir los otros poderes y si bien era cierto que se requería de hombres adecuados para ejercer las funciones judiciales y científicas del juez, no se necesitaba de hombres adecuados para ejercer las funciones electorales. Bajo el sistema representativo, republicano, federal, la división de Poderes era un principio fundamental, que exigía que el pueblo nombrase directamente sus mandatarios, pues los poderes públicos no podían derivar unos de otros. ${ }^{42}$

Respecto al argumento de incapacidad del pueblo para elegir los magistrados, Ezequiel N. Paz no entendía porque podía ser menos sabio que el Gobernador, o los abogados que formaban el Tribunal o el Senado, o porque se quería hacer incapaz a un pueblo capaz de pagar los impuestos y de matarse en las fronteras. Si esa era la justificación, la comparaba con la que sostenía que el ferrocarril era malo porque mataba a los sordos, a las vacas y a los bueyes que estaban en el camino. La elección de jueces era en una esfera limitada, entre 350 abogados de los que se podía marcar con el dedo quienes eran buenos y quienes eran malos, los hombres distinguidos podían ser separados de los traficantes de pleitos. ${ }^{43}$

Podríamos seguir con los debates, de inagotables argumentos, fundados en teoría jurídica, ejemplos de Estados Unidos, Francia e Inglaterra y expresados con impecable oratoria. Sin embargo, luego de un nuevo embate de Ocantos sosteniendo que por la elección popular no se pondría como magistrados a hombres que merecerían serlo, pues "las masas populares" no podían distinguir las condiciones que requerían los jueces científicos, se votó la elección por el poder ejecutivo con acuerdo del Senado. De nada sirvió que del Valle reconociera en el pueblo la fuente de todo poder sobre los principios republicanos, ${ }^{44}$ y que Vicente G. Quesada fuera terminante sosteniendo la elección popular y afirmando que las otras formas propuestas darían por resultado un poder judicial de origen bastardo. ${ }^{45}$

\footnotetext{
${ }^{42}$ DCC, 21 de marzo de 1873, pp. 1080-1083. "La división de poderes fue el resultado de las transformaciones requeridas por el mundo moderno, como parte del proceso de extensión de libertades individuales y de cambios radicales en el derecho de propiedad" y "la característica saliente del proceso político hasta Caseros fue la concentración de poderes" Cansanello, 2003, capítulo V, op. cit. Esta concentración tuvo su base en la pervivencia de la Real Ordenanza de Intendente, de 1782, que "como ordenamiento político y administrativo del Virreinato del Río de la Plata, prolongará su influencia después de mayo de 1810, no sólo en el ámbito nacional, sino también en el provincial. Sus disposiciones continuarán vigentes y las cuatro causas (Justicia, hacienda, guerra y policía) se ejercerán por los nuevos funcionarios, configurando poco a poco las secretarías o ministerios, dejando ese cuerpo normativo sedimentos en nuestra tradición histórica. En efecto, seguirá rigiendo, con modificaciones que no alteran fundamentalmente su estructura hasta 1820 y luego estará presente en la organización que intentan darse las provincias en el largo período en que la Nación carece de autoridad central" Díaz Couselo, 1995, op. cit., p. 233.

${ }^{43}$ DCC, 21 de marzo de 1873, pp. 1087-1088.

${ }^{44}$ DCC, 21 de marzo de 1873, p. 1080.

${ }^{45}$ DCC, 26 de marzo de 1873, pp. 1090.
} 


\section{c. La duración en el cargo}

Definida la forma en que los magistrados serían elegidos, pasaron a debatir sobre la duración en el cargo, produciéndose un enfrentamiento que llevó desde el proyecto original de elección por seis años con renovaciones parciales a la declaración de inamovilidad. ${ }^{46}$ Elizalde combatió el artículo propuesto sosteniendo la inamovilidad de los jueces y proponiendo la primera parte del artículo de la Constitución Nacional en su reemplazo. ${ }^{47}$ Luis V. Varela era partidario de la amovilidad, pero dado el deseo de sus electores y del país entero, votaría la inamovilidad. Ocantos optó por la amovilidad y fijó los precedentes históricos de España, Francia y otros países, haciendo notar que se trataba más de una cuestión práctica y de buen sentido que de principios. La inamovilidad estaba consagrada en la Constitución de Estados Unidos por un espíritu de imitación de las prácticas inglesas. ${ }^{48}$

Lo destacable del discurso de Ocantos era que la inamovilidad de los jueces en su origen no se había establecido como una garantía para ellos sino como una garantía contra la corona, una conquista contra ella, tratando de impedir que el rey fuera juez. Una de las forma de impedirlo era que una vez nombrado el magistrado no pudiera ser removido sin causa justa. La Constitución norteamericana consagraba la inamovilidad pero no debían ser serviles imitadores, pues ellos mismos reconocían sus errores. Uno de los redactores de "El Federalista” y Joseph Story, habían dicho que esa Constitución había sido inspirada en gran parte en Inglaterra, siendo el principio de inamovilidad resultado de esa imitación y no condición indispensable del sistema democráticorepresentativo. La reacción se había manifestado en las Constituciones de los Estados particulares que fueron reformadas estableciendo el principio de amovilidad de los jueces (California, Illinois, Pensilvania, Nueva York, Nueva Jersey, Indiana, Ohio, Connecticut y otras) A nivel nacional Jefferson, como vicepresidente, promovió la reforma de la Constitución, deseando que los jueces fueran amovibles, que duraran cuatro años en ejercicio y que fuesen reelectos. ${ }^{49}$

\footnotetext{
${ }^{46}$ Artículo 182 del proyecto de la Comisión central, que coincidía con el artículo $11^{\circ}$ de la Comisión Poder Judicial "Los Jueces letrados del Tribunal Superior e inferiores serán electos por el término de seis años, renovándose su número por terceras partes cada dos años. La suerte decidirá los que deban concluir en el primero y segundo bienio". El artículo 185 sancionado para el texto constitucional afirmaba "Los Jueces letrados conservarán sus empleos mientras dure su buena conducta".

47 Art. 93 de la Constitución de la Confederación de 1853: "Los jueces de la Corte Suprema y de los tribunales inferiores de la Confederación conservarán sus empleos mientras dure su buena conducta; y recibirán por sus servicios una compensación que determinará la ley, y que no podrá ser disminuida en manera alguna mientras permanezcan en funciones".

${ }^{48}$ DCC, 28 de marzo de 1873, pp. 1103-1104.

${ }^{49}$ En su libro sobre la doctrina de la separación de poderes, Maurice Vile realizó un pormenorizado análisis de una corriente de pensamiento constitucional que intentaba equilibrar la libertad de los ciudadanos con el ejercicio del poder estatal. Al exponer el pensamiento de Thomas Jefferson, explicaba que según su defensa del sistema de frenos y contrapesos, el único correctivo eficaz contra los abusos de poder era el poder de los electores, aplicado a los tres departamentos del Estado, legislativo, ejecutivo y judicial, cuyos miembros debían ser elegidos por votación de periodicidad frecuente. Uno de los más prominentes jeffersonianos, John Taylor, fue más lejos, sosteniendo que la manera más adecuada de elevar al Poder Judicial a la categoría de rama del Estado, acorde al principios de división que
} 
Si en los pueblos representativos todos los poderes eran amovibles, por qué no lo sería el poder judicial, lo contrario iba en contradicción con el principio de renovación de Poderes. De esta forma "el abogado que cerraba su estudio para abrazar el sacerdocio de la magistratura, para ser sacerdote de la ley, deberá ser recto y bueno so pena de morirse de hambre". A su entender el abogado que dejaba de ser abogado para ser magistrado sólo buscaba un retiro honroso de su profesión, a quien no se le podía pedir que estudiara las causas ni se lo podía juzgar por sus fallos, y esto se solucionaba con la amovilidad. El remedio era la renovación de los jueces, que debían estar a la altura de la ciencia, conocer sus ideas dominantes y sus progresos, para lo que debían tener estímulo, dando paso a inteligencias nuevas y creando un estorbo para la ignorancia. ${ }^{50}$

Juan José Montes de Oca contestó que no era por servilismo que la inamovilidad existía en Estados Unidos, sino por el adelanto que encarnaba el principio. Rebatió a Ocantos y terminó con las palabras de Royer-Collard tendientes a establecer para el juez las garantías de duración que requerían sus delicadas funciones. Pero Navarro Viola insistió con las virtudes de la amovilidad y observó que el gran punto práctico de la cuestión residía en la reelección, garantía contra los malos jueces, proponiendo tres años de duración en lugar de seis. A lo que Adolfo Rawson contestó que la cuestión de inamovilidad o amovilidad de los jueces afectaba en mucho el sistema republicano, y le parecía que la defensa de la amovilidad había sido "desconociendo en cierto modo cual era el carácter que representa al poder judicial en el orden de nuestras instituciones."

Lo que distinguía al sistema americano era haberle dado al poder judicial un carácter que no tenía en los países monárquicos, que velara por los intereses y las libertades particulares, que contuviera los abusos de los Poderes políticos de la Nación. ${ }^{52}$ Entonces era requisito indispensable para la organización de un país republicano, garantir a todos la independencia del juez que

...es garante, no tanto por la seguridad, por el salario, por la fórmula de su nombramiento y por las garantías personales que se acuerdan, sino principalmente por la duración de su empleo mientras ese Juez responda a la confianza del país, mientras sepa hacer justicia a sus ciudadanos, interpretando la ley y la Constitución para desempeñar fielmente los deberes que le han sido confiados. Al durar tres años y ser elegidos por el Gobernador, los jueces quedarían en manos de las fracciones políticas y de los partidos que se disputaban el triunfo en la lucha electoral. ${ }^{53}$

La inamovilidad también respondía a una de las funciones más importantes del poder judicial: la aplicación de las leyes en relación a su constitucionalidad o inconstitucionalidad. Entonces si los

ellos sostenían, era hacer que sus miembros lo fueran por cargos electos, de modo que tuvieran que rendir cuentas ante al pueblo. Vile, 2007, op. cit., pp. 185; 191.

${ }^{50}$ DCC, 28 de marzo de 1873, pp. 1106-1108.

${ }^{51}$ DCC, 1109.

${ }^{52}$ La opción de los países americanos por la senda republicana, mientras Europa se volcaba a la monarquía, implicaba una legitimación del poder político fundado en la soberanía popular. Sin embargo esto no implicó un camino único para la construcción del orden, sino que abrió alternativas y proyectos diversos, con formas muy distintas de ejercicio de la autoridad y conflictos sobre la definición y el control del poder. Sábato, 2008, op. cit., pp. 9-10.

${ }^{53}$ DCC, 28 de marzo de 1873, pp. 1110. 
partidos políticos tenían la elección periódica de los jueces, era imposible que muchas de las cuestiones en que estaban interesados los partidos, o las facciones políticas, determinadas por las leyes que la Legislatura dictase, o por los decretos que los Gobiernos expidieran, contrarios a la Constitución, pudieran ser llevados a juicio de esos Tribunales, los cuales no tendrían bastante independencia y bastante fuerza para condenar esas leyes o esos decretos contrarios a la Constitución. El poder judicial era la única salvaguarda y garante de los pueblos contra los abusos de las autoridades, por lo cual la propuesta de Rawson, como la de Elizalde, era el artículo de la Constitución Nacional por el cual los jueces durarían en el ejercicio de sus funciones mientras durara su buena conducta. ${ }^{54}$

Insistiendo sobre la figura del poder judicial como hijo de los otros dos poderes, Varela recordaba que Navarro Viola, en la última sesión, había dicho que el artículo importaba un matrimonio entre el poder ejecutivo y el Senado. El poder judicial era uno de los tres altos Poderes del Estado, y era de esperar que el pueblo soberano ejerciera la suma del Poder originariamente delegado, también en esa rama del Poder. Pero el artículo relacionado con la elección de los jueces había dado por tierra con la soberanía del pueblo, estableciendo el matrimonio que "lo divorcia de tiempo en tiempo, o lo restablece de cuando en cuando para que el poder ejecutivo y el Senado engendre en el poder judicial." 55

Rechazado el artículo de la Comisión se dio lectura al artículo de la Constitución Nacional, la discusión se prolongó y terminó con un incidente entre Ocantos, Navarro Viola y del Valle, haciéndose moción, no apoyada, para que el último fuera llamado al orden. Se aprobó el artículo propuesto por Elizalde, a favor de la inamovilidad pidiendo Quesada que se hiciera constar su voto por la amovilidad. Pero nada se decía sobre la intangibilidad de los sueldos, quitando la segunda parte del artículo que se había tomado de modelo.

\section{d. El enjuiciamiento de los magistrados}

Este tema incluía más de un artículo que sufrieron numerosos cambios desde el Proyecto del Poder Judicial $^{56}$ y el de la Comisión central ${ }^{57}$ hasta el texto constitucional que retiró la posibilidad

\footnotetext{
${ }^{54}$ DCC, 28 de marzo de 1873, pp. 1109-1110. El orden basado en nuevos principios suponía establecer normas y mecanismos de vinculación entre el pueblo y quienes ejercían el poder en su representación, Sábato, 2008, op. cit., p. 11.

${ }^{55}$ DCC, 28 de marzo de 1873, p. 1112.

${ }^{56}$ Proyecto de la Comisión Poder Judicial: Art. 16 : "Los miembros de Poder Judicial no podrán ser removidos ni suspendidos durante el tiempo por que hayan sido electos, sino en el caso de acusación y con arreglo en lo que se dispone en el artículo 18". Art. 17: "Los miembros de Superior Tribunal de Justicia y de los Tribunales inferiores, pueden ser acusados por cualquier habitante de la Provincia ante la Cámara de Diputados, por delito en el desempeño de sus funciones o por falta de cumplimiento de los deberes de su cargo. Esta acusación se llevará ante el Senado, por la Cámara de Diputados en la forma establecida por el juicio político de los Altos Magistrados de la Provincia". Art. 18: "Desde en día en que la Cámara de Diputados resuelva deducir la acusación de un Juez ante el Senado, quedará suspendido dicho funcionario hasta la completa terminación del juicio". Art. 19: "Los Jueces acusados de delitos
} 
de que cualquier habitante de la provincia pudiera acusar a los magistrados, asimilándolo al juicio político, al que sólo quedó sujeta la Suprema Corte. Los debates partieron del Despacho de la última Comisión del Poder Judicial. ${ }^{58}$ El artículo sobre la acusación de los miembros de la Suprema Corte, Cámara de Apelación y de primera instancia fue combatido por Sáez Peña y Elizalde y sostenido por Pereyra y Moreno, ocasionando una fuerte discusión. Los motivos que Elizalde daba para votar en contra del artículo se basaban fundamentalmente en que establecía la garantía de que los miembros del poder judicial no podían ser llevados a juicio ordinario sin que precediera el juicio político, lo que importaba la supresión, el desafuero o la destitución del empleo, pero lo que se proponía implicaba tres juicios: 1) el Senado que acepta la acusación y suspende al magistrado; 2) el Jury que declara culpable o inocente; 3) el tribunal ordinario que juzga al juez culpable, mientras

ajenos a sus funciones, serán juzgados en la misma forma que los demás habitantes de la provincia, quedando suspendidos desde el día en que se haga lugar a la acusación".

${ }^{57}$ Proyecto de la Comisión central: Art. 187 "Los miembros del Poder Judicial no podrán ser removidos ni suspendidos durante el tiempo por que hayan sido electos, sino en el caso de acusación y con arreglo en lo que se dispone en el artículo 18". Art. 188 "Los miembros de Superior Tribunal de Justicia y de los Tribunales inferiores, pueden ser acusados por delitos en el desempeño de sus funciones o por falta de cumplimiento de los deberes de su cargo. En la forma prescripta en el artículo 76, inciso $2^{\circ}$ de esta Constitución”. Modificado en concordancia con el artículo 76, inc. $1^{\circ}$ de su referencia que también ha sido reformado con sujeción a las reglas generales para el juicio político establecido en este proyecto de Constitución. Art.76: "Es de competencia exclusiva de la Cámara de Diputados: $1^{\circ}$ La iniciativa de la creación de contribuciones e impuestos generales de la Provincia; $2^{\mathbf{o}}$ Acusar ante el Senado al gobernador de la Provincia y a sus ministros, a los miembros de Superior Tribunal de Justicia y de los Tribunales inferiores, por delitos en desempeño de sus funciones o falta de cumplimiento a los deberes de su cargo. Para usar de esta atribución deberá proceder una sanción de esta cámara, por dos tercios de votos, que declare que hay lugar a la formación de cargos. Cualquier habitante de la Provincia tiene acción para denunciar ante la Cámara de Diputados el delito o falta a efecto de que se promueva la acusación. La ley determinará el procedimiento de estos juicios.” El artículo 10 fue suprimido por estar en contradicción con lo establecido en el Poder Judicial que no establece la superintendencia. Art. 189 "Desde en día en que la Cámara de Diputados resuelva deducir la acusación de un Juez ante el Senado, quedará suspendido dicho funcionario hasta la completa terminación del juicio". Art. 190 "Los Jueces acusados a delitos ajenos a sus funciones, serán juzgados en la misma forma que los demás habitantes de la provincia, quedando suspendidos desde el día en que se haga lugar a la acusación".

58 "Los Jueces de la Suprema Corte, Cámaras de Apelación y de primera instancia no pueden ser suspendidos en el ejercicio de sus cargos sino en el caso de acusación y con sujeción a lo que se dispone en esta Constitución". (art. 189) "Los miembros de la Suprema Corte de Justicia, Cámaras de Apelación y de primera Instancia pueden ser acusados por delitos o faltas cometidas en el desempeño de sus funciones ante un Jury calificado compuesto de siete diputados y cinco senadores abogados y cuando no los haya se integrará con letrados que tengan las consideraciones necesarias para ser electos senadores". (Este será el art. 190 pero con este texto: "Los Jueces de las Cámaras de Apelación y de primera instancia pueden ser acusados por cualquiera del pueblo, por delitos o faltas cometidas en el desempeño de sus funciones ante un Jury calificado, compuesto de siete diputados y cinco senadores profesores de Derecho, y cuando no los haya se integrará con letrados que tengan las condiciones necesarias para ser electos senadores". La acusación a los jueces de la Suprema Corte quedó incluida en la competencia exclusiva de la Cámara de Diputados en el art. 66, inc. $2^{\circ}$ : "Acusar ante el Senado al Gobernador de la Provincia y sus Ministros, al Vicegobernador y a los miembros de la Suprema Corte, por delitos en el desempeño de sus funciones, o falta de cumplimiento a los deberes de su cargo". Art. 73 "Es atribución exclusiva del Senado, juzgar en juicio público a los acusados por la Cámara de Diputados, constituyéndose al efecto en Tribunal y prestando sus miembros juramento o afirmación para estos casos") "El Juez acusado quedará suspendido en el ejercicio de su cargo desde el día que el Jury admita la acusación” (art. 191) "El Jury dará su veredicto declarando al Juez acusado culpable o no culpable del hecho o hechos que se le imputen" (art. 192). "Pronunciado el veredicto, de culpabilidad la causa se remitirá al Juez ordinario competente para que aplique la ley penal" (art. 193) "La ley determinará los delitos y faltas de los jueces acusables ante el Jury y reglamentará el procedimiento que ante él debe observarse". (art. 194) "Los Jueces acusados de delitos ajenos a sus funciones serán juzgados en la misma forma que los demás habitantes de la provincia, quedando suspendidos desde el día en que se haga lugar a la acusación”. (art. 195) "La ley determinará el modo y forma cómo deben ser nombrados los demás funcionarios que interviene en los juicios, la duración de sus funciones, organizará el Jury que debe conocer y resolver en las acusaciones que contra ellos se establezca por delitos o faltas cometidas en el ejercicio de sus cargos respectivos y el procedimiento que ante dicho Jury debe guardarse". (art. 196) 
que bastaba el juicio político y después el juicio común, como en todas las causas que importaban un delito. Ese Tribunal especial no era conveniente y menos aún que estuviera compuesto de senadores y diputados, que conocían de la cuestión y que estaban ligados por sus opiniones. ${ }^{59}$

A esto Moreno opuso los motivos por los cuales la Comisión había establecido el Jury especial para juzgar los delitos de los magistrados. En primer lugar, el respeto y la consideración que se debía a la magistratura exigía que, al establecer la Justicia ordinaria, que debiera resolver y decidir en las faltas y delitos que cometieron en su carácter de magistrados en el ejercicio de sus funciones, revistiera alguna garantía de elevado carácter, de perfecta imparcialidad y de reconocida competencia. No eran delitos o actos de los criminales ordinarios los que un juez habría de hacer en el ejercicio de su puesto. Si violaba las leyes especiales de procedimiento, se requería de una persona constituida en autoridad para apreciar los hechos de ese magistrado y con perfecto conocimiento de esas leyes, es decir, de derecho para declarar si había sido o no culpable. Por esta razón, se formó un Jury con letrados, a lo que para sumar garantía de rectitud y de severidad imparcial se agregó que fueran del cuerpo legislativo, esto mantenía la misma soberanía popular sin afectar la jurisdicción del juicio político. ${ }^{60}$

El juicio político, según el artículo sancionado por la Convención, ofrecía a la Suprema Corte una doble garantía, de que no disfrutaban los miembros de la Cámara de Apelación y de los Juzgados de primera instancia: tenían en primer lugar el fallo de dos Cámaras por una gran mayoría, tenían la garantía de la imparcialidad del más alto Cuerpo del Estado que habría de apreciar en definitiva si había o no lugar a la acusación. Tenía en seguida que ir al Jurado calificado, si se trataba de un delito cometido en el ejercicio de sus funciones, o al Jurado común si se trataba de un delito cometido en el fuero común. En cambio toda la garantía ofrecida a los miembros de la Cámara de Apelación y a los de los Tribunales inferiores era que fueran juzgados por los miembros de la Cámara de Diputados y los del Senado. ${ }^{61}$

Otra era la visión de Navarro Viola para quien las Cámaras y Tribunales inferiores debían ser denunciados por cualquier habitante de la provincia, pues nadie mejor que el mismo damnificado estaría en condiciones de hacerlo. Proponía entonces que se agregara que el Jury debía ser presidido por un abogado y que cualquiera del pueblo podía denunciar a miembros de Cámaras y Tribunales inferiores por delitos cometidos en el ejercicio de sus funciones, pues era diferente la responsabilidad de acusar y de denunciar. En cambio para Montes de Oca el artículo tenía que quedar como estaba -porque la denuncia hecha por cualquiera del pueblo tendría un efecto más extenso-, igual que para Estrada porque los integrantes del Jury debían ser letrados y la garantía de todo Gobierno libre era la igualdad ante la ley, para los débiles y para los fuertes. El hecho de ser

\footnotetext{
${ }^{59}$ DCC, 27 de junio de 1873, pp. 1228-1229.

${ }^{60}$ DCC, 27 de junio de 1873, pp. 1229-1230.

${ }^{61}$ DCC, 1 de julio de 1873, pp. 1236-1237.
} 
diputado o senador no constituía a un hombre perito en la ciencia del derecho, poniendo de esta forma a los jueces de los tribunales en peor condición que al último ciudadano. ${ }^{62}$

La insistencia de que fueran abogados los que juzgaran los actos de los jueces, se hacía presente en el discurso de Malaver, por tratarse de una violación de la tramitación y una falta en la aplicación del derecho, y de Pereyra, para quién los jueces y los abogados serían los únicos capaces de juzgar y condenar a otros jueces, porque el común de los hombres contaban sólo con la inducción, que no bastaba para averiguar si un juez había faltado o no a la ley. Contra esto luchaban Alcobendas, que pidió reconsiderar el artículo, y Mariano Marín aplaudido al afirmar que la condición de ser abogados los miembros del Jury en lugar de ser una garantía, determinaba que a su amparo podrían contar los jueces con la impunidad en los delitos que cometiera. Los vínculos de compañerismo entre el acusado y los jueces serían una

...especie de pararrayo que se quiere levantar sobre cada uno de los Tribunales para que los Jueces puedan contar con la impunidad del delito que lleguen a cometer por espíritu de compañerismo. El honor mal entendido de las profesiones, y muy especialmente en las relaciones íntimas que se forman entre los abogados y los Jueces con motivo de los nombramientos de oficio que ellos hacen y los favores que les pueden dispensar en las apreciaciones de los honorarios, son causales más que suficientes para sospechar de su rectitud y de su imparcialidad. Dada la condición de la naturaleza humana no es posible, señor, esperar que estos señores tengan demasiada abnegación y demasiada voluntad para sacrificar para siempre esos vínculos y mantener con mano firme la balanza de la Justicia cuando tengan que decidir la causa de un compañero, de un amigo de profesión, tal vez del más generoso de su protectores. ${ }^{63}$

Como había dicho López, el Jury resolvería cuestiones de hecho, culpa o delito cometido por los jueces en el ejercicio de sus funciones, para lo que no se necesitaba ni de la capacidad ni de la inteligencia que se suponía en los maestros de la ciencia. Pero para Pereyra para declarar a un juez culpable era necesario entrar en la cuestión legal y resolver cuáles eran los elementos o las circunstancias que habían preparado el delito. Recurría al ejemplo de un envenenamiento, para lo cual -le explicaba a Marín- el más idóneo para determinarlo era el químico, a lo que éste respondió otra vez seguido de aplausos, que mejor sería el que administró el veneno. Pero Pereyra continuó:

¿Cree acaso el señor convencional que el título de abogado es una deshonra, que el que lo lleva no tiene conciencia, que son todos malos, o que es la más mala de todas las plagas y que el Jurado se desnaturaliza por el mero hecho de ser abogados los que lo componen? Si así fuera, deberíamos mandar sacar a todos los abogados de los Tribunales y mandar a los señores convencionales que entienden mucho de derecho para que vayan a hacer justicia y aplicar la ley con mejor imparcialidad. ${ }^{64}$

\footnotetext{
${ }^{62}$ DCC, 1 de julio de 1873, pp. 1233-1235.

${ }^{63}$ DCC, 4 de julio de 1873, pp. 1245. Mariano Marín era abogado.

${ }^{64}$ DCC, 4 de julio de 1873, p. 1246.
} 
Con el apoyo de Navarro Viola, de Estrada y de Pereyra los Jurys estuvieron finalmente integrados de siete diputados y cinco senadores profesores de Derecho y el resto de los artículos fueron aprobados por unanimidad cambiando en algunos casos parte del texto.

\section{e. El juicio por jurado}

Este artículo fue fundado por Elizalde y combatido por el conservador Luis Sáenz Peña, Irigoyen, Ocantos, Montes de Oca y Navarro Viola, que se enfrentaron duramente. El juicio por jurado se aprobó pero no dentro del capítulo Poder Judicial y su definición fue muy breve y terminante. ${ }^{65}$ Nos detendremos en algunos puntos relativos al tema que iluminan su definición y la concepción que tenían del mismo. ${ }^{66}$ Según Elizalde, miembro informante de la Comisión, habían puesto en ejecución un principio ya admitido, que era el Jurado en materia criminal. Pero decidieron ir un poco más "adelante" poniendo el Jurado civil como voluntario, ya que el país no lo admitiría como obligatorio. El texto presentado incluía una cuestión muy compleja, relativa a la denegación de justicia, que Sáenz Peña pidió que aclarara si lo abarcaba en toda su amplitud. La respuesta definía la garantía en el Tribunal popular contra los abusos que cometían los jueces en el ejercicio de sus funciones.

La idea es someter la declaratoria de los Poderes Públicos a la acción del Jurado en las reclamaciones que se entablen, o en la acción que se deduzca contra ellos por daños y perjuicios hechos por tales poderes o jueces. Es decir, que cuando el Juez comete una injusticia o hace denegación de justicia, o comete una tropelía o violencia en el ejercicio de sus funciones, comete un delito común, y por consiguiente, no debe ser la justicia ordinaria sino el Jurado que conozca en ese caso. ${ }^{67}$

\footnotetext{
${ }^{65}$ Comisión Poder Judicial: Art. $3^{\circ}$ : "Serán juzgados por Jurados todos los delitos de imprenta, los delitos comunes, exceptuándose sólo los leves y las infracciones de los reglamentos policiales o municipales, que serán juzgados por los jueces permanentes que las leyes designen; las cuestiones civiles entre partes, siempre que éstas así lo soliciten. La Legislatura, por medio de una ley, determinará a la mayor brevedad la organización y forma de enjuiciamiento del Jurado". Comisión central: Art. 175: "Serán juzgados por Jurados, bajo el procedimiento que dicte la ley de la materia: $1^{\circ}$ Todas las causas por injurias y por ofensas de cualquier clase que sean y cualquiera que sea la forma en que fuesen inferidas; $2^{\circ}$ Todas las causas por delitos comunes en que no se tratase de la destitución o pena infamante de funcionarios y que requieran acusación pública, pudiendo para las leves establecerse por la ley otra forma de juicio; $3^{\circ}$ Todas las causas por actos ilícitos en que se tratase de reparación de daños o penas pecuniarias por tropelías o denegaciones de justicia; $4^{\circ}$ Las causas civiles, cuando las partes comenzasen por solicitarlo de común acuerdo ante el Juez ordinario". Este artículo fue modificado por hallarse en contradicción con lo que estatuía el artículo 19 de la "Declaraciones", especialmente en lo relativo a la aplicación del jurado en materias civiles. Se modificó en la $8^{\circ}$ Reunión de la Comisión Central, (DCC, p. 1381), pues en la $5^{\circ}$ Reunión se había establecido el juicio por jurado como regla general, (DCC, p. 1380) Este artículo decía en el proyecto de la Comisión: "Se asegura para siempre a todos el juicio por Jurado (con arreglo a la ley de la materia), pudiendo este derecho ser renunciado por las partes en las causas civiles, del modo que la misma lo prescriba; exceptuándose únicamente de esta regla el caso del enjuiciamiento político para los funcionarios públicos, y el de la jurisdicción militar para la Guardia Nacional movilizada por el Congreso en tiempo de guerra o en servicio de campaña", (DCC, p. 84) En el proyecto de la Comisión central quedó: "Se asegura para siempre a todos el juicio por Jurado, con arreglo a las prescripciones de la Constitución" por entrar en contradicción con el artículo $3^{\circ}$, Capítulo I del Poder Judicial. (DCC, 106) Este fue el artículo constitucional 14.

${ }^{66}$ Sobre los antecedentes del juicio por jurado en Buenos Aires Barreneche, Osvaldo “¿Lega o letrada? Discusiones sobre la participación ciudadana en la justicia de la ciudad de Buenos Aires durante las primeras décadas de independencia y experiencia republicana" en Palacio y Candioti, 2007, op. cit., pp. 197-202.

${ }^{67}$ DCC, 14 de marzo de 1873, p. 1049.
} 
Pero para Sáenz Peña el artículo era oscuro porque se interpretaba como materia del Jurado la retardación de justicia, siendo en materia civil voluntario someterse o no al Jurado, no asegurando al damnificado la reparación que correspondía. En cambio Elizalde comprendía que venía aparejada la acción por daños y perjuicios, pues cuando un juez negaba el recurso establecido por la ley obligaba al ciudadano a realizar gastos, cometiendo el juez un acto ilícito y debiendo dar cuenta el Tribunal popular de si actuó bien o mal. Según Irigoyen traería aparejada una gran complicación en la secuela de los pleitos ante los jurados populares, y para Ocanto se debía ser muy cautos en las atribuciones conferidas a la institución, de modo que no se desnaturalizara dando origen a conflictos con los demás Poderes. ${ }^{68}$

Se ponía así en juego la definición de la denegación de justicia y su competencia, pues parte de la Sala sostenía que si era un acto ilícito debía ser llevado ante los jueces superiores, quienes sabrían si había habido o no denegación de justicia y si era o no punible el juez. De otra forma el Jurado sería juez en materia de derecho de los actos jurídicos verificados por un juez letrado, cosa a lo que no estaba llamado, sino a juzgar con arreglo a los hechos y aplicar la pena que establecía la ley. En definitiva, lo que se debía evitar era que fueran al Jurado los pleitos que hubieran sido del resorte de los jueces letrado.

Cuestionando el espíritu del artículo, López advertía que los actos del Gobierno y los actos de los jueces juzgando, no podían ser materia del Jurado, no podían ser materia de otra cosa que de una acusación por un delito político, o de una destitución o acusación ante los superiores. Si un juez había abusado de su poder cometiendo una tropelía, era un acto personal, no era un acto del juez juzgando, como la injuria. Los actos de los jueces juzgando eran materia de los Tribunales ordinarios, de otro modo se vendría a echar por tierra todo el orden judicial. Otra cuestión fue la de las causas por injurias u ofensas, objetadas por Montes de Oca como competencia del Jurado. Elizalde estaba de acuerdo pero, como quisieron establecer el Jurado como institución salvadora de la libertad de imprenta, no podían hacer distinción de las injurias hechas de cualquier manera.

El Despacho de la última Comisión en el capítulo referente a la “Administración de Justicia en lo Criminal" definió que "toda causa por hecho calificado de crimen por la ley, será juzgada con la intervención de dos Jurys: uno que declare si hay lugar o no a la acusación, otro que decida si el acusado es o no culpable del hecho que se le imputa", siendo sancionado por unanimidad. Pero otro artículo revestía de vulnerabilidad al jurado al establecer que "la Legislatura puede modificar las bases establecidas en el artículo para el enjuiciamiento por dos Jurys, en las causas criminales, por mayoría de votos, si en la práctica ofreciese graves inconvenientes; y limitarlo o suprimirlo, por dos terceras partes de votos, si diese resultados desfavorables y previo informe motivado de la Suprema

${ }^{68}$ DCC, 14 de marzo de 1873 , p. 1050. 
Corte de Justicia”. Pedro Goyena pidió que se votara el artículo por partes y se aprobó quitando la palabra "suprimirlos". 69

Lo mismo sucedió con la "Administración de Justicia en Materia Civil y Comercial”, donde un artículo establecía que la Legislatura quedaba autorizada para suprimir o limitar el procedimiento de la prueba por Jurados, si en la práctica no diese resultados favorables, previos informes o indagaciones de la Suprema Corte de Justicia. Pereyra aclaró que la palabra suprimir había generado debate en la Comisión por eso sugería votar hasta allí y luego el resto, eliminando la palabra suprimir. $^{70}$

Para Ocantos esta innovación consistía en la atribución dada a la Legislatura provincial para suprimir los juicios por Jurado, contrario a la Constitución Nacional que establecía que todos los habitantes de la República tenían derecho a ser juzgados por Jurados (art. 99); "que no hay delito que no pueda juzgarse sin que un Jurado lo declare, que no hay reo que pueda ser penado sin que un Jurado designe o aplique la pena designada por la ley”. El Congreso no podía eliminar esta garantía constitucional, por lo que menos podía ser esta facultad de la Legislatura Provincial. ${ }^{71}$

El juicio por jurado, sancionado en la Constitución Nacional y en la Provincial, nunca se concretó, pues este pilar de la justicia lega había sido tratado más como un fin que como un instrumento de mayor participación ciudadana en la administración de justicia. La figura aparece luego como "cláusula programática", es decir, una que se incluye en la Constitución, pero que se aplicará, no inmediatamente, si no cuando se den las circunstancias. ${ }^{72}$

\section{f. La libre defensa y representación}

Curiosamente este artículo $^{73}$ que se mantuvo sin cambios desde el primer proyecto hasta el texto constitucional llevó dos sesiones de debates, abiertos por Sáenz Peña que encontraba inconveniente el absolutismo de la frase, pues dejaba libre la representación pero también la defensa, y ningún Cuerpo Constituyente tenían facultad ni atribución de darle ciencia a quien no la tenía. Comprendía que, como en otros países, todo habitante tenía derecho a defenderse ante los tribunales del país por sí o por medio de un letrado, pero no que se dijera que todo el mundo podía defender, pues era una exageración de la libertad, inaplicable, comparándolo con decir que todo el mundo podía curar. Daba el ejemplo de los americanos que habían encontrado una fórmula que

\footnotetext{
${ }^{69}$ DDC, 27 de junio de 1873, p. 1228.

${ }^{70}$ DDC, 27 de junio de 1873, pp. 1226-1227.

${ }^{71}$ DDC, 20 de junio de 1873, pp. 1217-1218.

${ }^{72}$ Barreneche, 2007, op. cit. p. 202.

${ }^{73}$ El artículo $8^{\circ}$ : "Queda establecida ante todos los Tribunales de la Provincia la libre defensa y la libre representación”, fue redactado por la Comisión Poder Judicial, se mantuvo en el proyecto de la Central y en el texto constitucional, por haber sido votado antes de la presentación del Despacho de la última Comisión del Poder Judicial. Artículo 173.
} 
reconocía a todos sus habitantes el derecho de defensa por sí mismo pero no el de ir a defender a otro.

A esto agregaba Navarro Viola que el artículo era anfibológico, que se prestaba al doble sentido o interpretación, a lo que Elizalde consintió, pues a su entender todo hombre tenía "derecho de defenderse, por sí o elegir defensor, pero no puede venir la ley a decirle a un hombre que no tiene los medios de qué valerse, que no puede defenderse por sí, sino por medio de letrado."74 Idea que reafirmó en la siguiente sesión explicando que libre representación significaba nombrar a quien uno quisiera como su apoderado, sea o no procurador de números, era "el derecho de nombrar el apoderado que le de la gana, y el no negar a nadie el derecho de defenderse por sí mismo". Recurría también al ejemplo de las Constituciones de los Estados Unidos que consignaban el derecho de la libre defensa, por sí o por medio de abogado.

En base a esto proponía que se aceptara el artículo como lo había redactado la Comisión, agregando "con arreglo a lo que determine la ley", lo que estaría en armonía con "los principios que hemos establecido con las profesiones liberales. A este respecto hemos reconocido que las Universidades tienen derecho de dar títulos de suficiencia que la Legislatura, por medio de una ley, determinará las condiciones y requisitos para el ejercicio de las profesiones.",75

Para el reconocido jurista y personaje político José María Moreno, en los hechos la libertad de defensa existía ya hipócritamente, cubierta con el misterio de una forma que se pagaba con poco dinero y se prestaba con facilidad, y no había razón para que no existiera clara y abiertamente. Había abogados para que firmaran los escritos de los que no lo eran, pero qué necesidad había de sujetar al que hacía esos escritos al visto bueno de un abogado a fin de que fuera recibido por el juez. Era mejor que fuera presentado con la firma del que lo había hecho, a fin de que aceptase la responsabilidad a que tales escritos daban lugar. Estaba consignada la defensa libre en los asuntos contencioso-administrativos y ante los Tribunales nacionales, donde se exigía la firma de letrado y aún en los Tribunales comerciales, donde una porción de personas que dirigían los asuntos, sobre todo de concurso, sólo hacían firmar los escritos cuando se trataba de practicar la regulación.

Para reafirmar su postura hizo una comparación con la libertad de curar, que había quedado demostrada en un discurso del diputado Garrigós, según el cual

...el individuo que se hace curar como quiera, tomando los remedios que le parezca, no hace mal a nadie, sino usa de un derecho o de una libertad que ninguna ley escrita tiene el deber de privarle. La prueba está en que, a pesar de todos los reglamentos y las penas establecidas por el Consejo de Higiene, a pesar de la vigilancia que se despliega para evitarla, esa libertad existe, y existen los curanderos por más que se persiguen. Tan es así que de tiempo en tiempo el mismo Consejo de Higiene nos hace saber que existen una porción de personas que viven de curar. Y la razón es muy sencilla: porque es imposible que la autoridad pueda seguir en sus actos a un individuo hasta la cabecera de su cama

\footnotetext{
${ }^{74}$ DCC, 14 de marzo de 1873, pp. 1053-1054.

${ }^{75}$ DCC, 17 de marzo de 1873, p. 1064.
} 
para privarle en las horas solitarias y en el silencia de su hogar, que no tomen los remedios que suministran los curanderos.

Al mismo plano llevaba la libertad del individuo de defenderse por sí mismo, pues el interés particular era bastante vigilante para precaverse contra los males que pudieran sobrevenirle, sobre todo, en los casos que un hombre no quisiera admitir otro defensor aceptando sufrir las consecuencias. $^{76}$

Ante semejante elocución, Sáenz Peña buscó un punto intermedio, aceptando que después de un régimen exagerado de intervención de los abogados para presentarse en juicio, se estaba yendo al extremo opuesto de hacer completamente innecesaria la intervención de los abogados. Por esto le preguntaba a Moreno “¿qué haría el Tribunal de Justicia el día que amparado en ese artículo constitucional fuese un menor de edad a defenderse a sí mismo en los estrados del Tribunal? ¿Podría despedirlo el Tribunal? No, señor; porque es la libre defensa sin restricciones. El día que fuese una mujer a defender una causa en nombre de otra persona ¿en virtud de qué ley podría despedirla el Tribunal? Yo creo que la libre defensa, sin limitaciones, como la sostiene el señor convencional, es imposible de aceptarla". ${ }^{77}$ Estas fueron las dos posturas extremas y como hemos dicho quedó "establecida ante todos los Tribunales de la Provincia la libre defensa y la libre representación.",78

\section{Conclusión}

Si bien es cierto que los estudios sobre la ley y la justicia se realizan hoy desde una nueva mirada dirigida a los actores y las prácticas, para lo que los archivos judiciales se han transformado en "espacios privilegiados de observación", no debe olvidarse que para acceder a ellos y comprenderlos son indispensable nuevos estudios de leyes, constituciones e instituciones judiciales que permitan esa perspectiva renovada, ${ }^{79}$ y a esto hemos buscado contribuir con este capítulo.

Establecer explícitamente en el texto constitucional que el poder judicial era independiente, no era un detalle menor, pues luego tendría relación directa con la forma de elección y la duración en el cargo de sus magistrados. Quienes consideraban superfluo declararlo independiente, insistieron en las virtudes de la amovilidad y la reelección, garantía contra los malos jueces. Bajo el sistema representativo, republicano, federal, la división de poderes era un principio fundamental, que exigía que el pueblo nombrase directamente sus mandatarios, pues los poderes públicos no podían derivar unos de otros. Quienes insistían en la declaración de independencia específicamente, lo hacían en defensa del poder judicial, frente a poderes emanados directamente del pueblo.

\footnotetext{
${ }^{76}$ DCC, 17 de marzo de 1873 , p. 1065.

${ }^{77}$ DCC, 17 de marzo de 1873, p. 1066.

${ }^{78}$ Artículo 173 de la Constitución provincial de 1873.

${ }^{79}$ Palacio y Candioti, 2007, op. cit., pp. 17-18.
} 
Entonces, el enfrentamiento ante la forma de elección de los magistrados se debía a dos principios diferentes, relacionado con lo anterior. ¿De quién emanaba el Poder encargado de administrar justicia? ¿De los otros Poderes públicos o directamente del pueblo? La respuesta a estas preguntas parte del concepto de soberanía ${ }^{80}$ y de su ejercicio, aunque se le quisiera dar a la opción por la elección en segundo grado un perfil práctico, basado en la falta de capacidad del pueblo elector para discernir sobre la idoneidad, inteligencia y honorabilidad de los jueces. Observemos que ambas posturas buscaban responder a la garantía de justicia, una en la libertad de la sociedad civil para elegir quién la impartiera, otra haciendo que ese acto fuera realizado por quienes tuvieran aptitud para ejercerlo, pero siempre relacionada con la responsabilidad del magistrado al ejercer su función.

En cambio cuando se trató la duración del magistrado en el ejercicio de sus funciones, se enfrentaron aquellas garantías con las garantías para el juez. La amovilidad o la inamovilidad iban en relación con un poder judicial que velara por los intereses y las libertades particulares y que contuviera los abusos de los Poderes políticos, pero también debía garantizar a todos la independencia del juez por la duración de su empleo mientras respondiera a la confianza depositada en él. Esto podía asegurarse a través de elecciones periódicas o de la permanencia en su cargo mientras durara su buena conducta. Pero en el primer caso los jueces quedarían en manos de las fracciones políticas y en el segundo no tendrían estímulo para estar a la altura de la ciencia, conocer sus ideas dominantes y sus progresos.

Haber optado por la inamovilidad requería de un jurado específico para juzgar al magistrado en ejercicio y el camino hacia su conformación significó diferenciar entre juicio político y Jury, lo que a su vez determinaba el grado de responsabilidad de quienes ejercían la magistratura. Las opciones fueron hasta invocar la inutilidad del Jury, pero una vez aceptado se debía establecer su conformación; el estar integrado por letrados del cuerpo legislativo representaba para unos una garantía para el juez y para otros un "pararrayos" sobre los Tribunales. La buena conducta era el límite de la inamovilidad del juez y una vez cruzado éste cualquiera del pueblo podría acusarlo, y serían legisladores letrados quienes determinarían su incompetencia o inconducta. ${ }^{81}$ Esta discusión implicó la valoración de la función del abogado en el cumplimiento de las garantías para el juez, como en los debates sobre la libre defensa y representación lo fue para las garantías del ciudadano.

El juicio por jurado si bien no se concretó, su discusión fue central, pues en ella estuvo en juego la competencia de ese jurado, en primer lugar sobre los juicios civiles y fundamentalmente sobre la denegación de justicia, sostenida en su definición como delito común y en un sentido

\footnotetext{
${ }^{80}$ El ejercicio intelectual de pensar al soberano debía definir qué papel darle sin poner en riesgo el control del orden social. Bonaudo, Marta y Sonzogni, Élida, "Los grupos dominantes entre la legitimidad y el control”, en Bonaudo, op. cit., 1999.

${ }^{81}$ Parry, Adolfo E. Responsabilidad de los Magistrados de la provincia de Buenos Aires, Taller de Impresiones Oficiales, La Plata, 1923.
} 
amplio de garantía que brindaba el Tribunal popular contra los abusos que cometían los jueces en el ejercicio de sus funciones. A través de esta institución planteada en forma más teórica que práctica la cuestión que se debate en definitiva es el acceso a la justicia y la participación popular en su sistema de administración.

El texto constitucional estaba terminado y comenzaba una nueva etapa de instalación de las instituciones judiciales y su reglamentación. La organización de la Suprema Corte de Justicia, los tribunales letrados, la justicia de paz, el enjuiciamiento de magistrados, la organización de la policía y de las cárceles, comenzaron a legislarse y a ponerse en marcha, junto con la legislación de fondo y de procedimiento, en una provincia que luchaba por no perder su capital y con ésta su supremacía política. Algunas de estas medidas se concretaron y otras quedaron en el camino -como las leyes de municipalidades y de justicia de paz- o se dejaron por aplicar-como el juicio por jurado. Pero había quedaba demostrado que sin las instituciones judiciales sancionadas en la Constitución no habría, como afirmaba Antonio E. Malaver, "verdadera responsabilidad en los Jueces, ni la garantía necesaria para ellos mismos". 


\section{Capítulo VIII}

\section{El Poder Judicial después de la Constitución de 1873 de la provincia de Buenos Aires (1875-1881)}

\section{Introducción}

La Constitución de la provincia de Buenos Aires, sancionada en 1873, fijó la organización de un poder judicial diferente al que se había propuesto originariamente, estableciendo una Suprema Corte, Cámaras de Apelación, Juzgados de primera Instancia Civiles, Criminales y de Comercio y Juzgados de Paz de elección popular. ${ }^{1}$ Los cambios determinados por el texto constitucional se profundizaron al año siguiente con la creación de la facultad de Derecho de la Universidad de Buenos Aires y el fortalecimiento de la carrera judicial con la prohibición de la acumulación de cargos para los magistrados.

Al momento de reglamentar la organización judicial establecida, el Estado no tuvo una expresión de acuerdo monolítico sobre las cuestiones a resolver, sino que manifestó los conflictos sociales comprensibles en un tiempo determinado, que se deben tener en cuenta a la hora de analizar la producción de leyes y códigos que definieron las instituciones judiciales. ${ }^{2}$ Esto se refleja en al estudiar los debates parlamentarios que ponen de manifiesto la división entre los grupos políticos $^{3}$ y el eclecticismo que dominaba el clima ideológico y los modelos propuestos guiados por la propia tradición, la experiencia histórica y las necesidades. ${ }^{4}$

Todo esto puede observarse en la interacción entre el mundo legal y el amplio proceso político, económico, social y cultural a través del cual tuvo lugar la transición del status colonial a la nación independiente durante el siglo XIX en América Latina. La creación de una sociedad liberal requería, entre otras cosas, el establecimiento de la igualdad legal, con el ideal de la autoridad de la ley y un compromiso a la protección de derechos individuales, propiedad privada y la ejecución de contratos. Esta relación se hizo visible en la cantidad de legisladores y ministros abogados, en un proceso que no fue homogéneo y estuvo diferenciado por las características

\footnotetext{
${ }^{1}$ Tal como se explicó en el capítulo 2, y según la ley promovida por Bernardino Rivadavia y acordada por la Sala de Representantes el 28 de diciembre de 1821, la justicia ordinaria, a cargo hasta entonces de los Cabildos suprimidos, era administrada por cinco letrados denominados jueces de $1^{\circ}$ instancia, dos en la Capital y tres en la Campaña (eliminados estos en 1824). Sus atribuciones, hasta el establecimiento de los códigos, eran las mismas en lo civil y criminal que las de los alcaldes ordinarios de los Cabildos. Un letrado desempeñaba las funciones de defensor de pobres y menores y de procurador general de la provincia. En cada parroquia había un juez de paz, estableciendo el Gobierno en las de la Campaña, los que considerara necesarios según su extensión. Sin embargo, fue después de Caseros cuando la primera instancia se instaló definitivamente en todo el territorio provincial y la Cámara de Apelaciones, el más alto Tribunal creado en 1812, fue reemplazado por el Superior Tribunal de Justicia. Véase Ley del 24 de diciembre de 1821, ROPBA, 1821, pp. 124-128.

${ }^{2}$ Palacio, y Candioti, op. cit., 2007, p. 18.

${ }^{3}$ Sábato, 2008, op. cit., pp. 24-26.

${ }^{4}$ Tau Anzoátegui, 1977, op. cit., p. 87.
} 
particulares del espacio donde tuvo lugar en la dinámica de las sociedades latinoamericanas del siglo XIX, particularmente en la evolución de las instituciones judiciales. ${ }^{5}$

Cuando el texto constitucional no estaba aún sancionado, el gobernador Mariano Acosta inició su Mensaje a la Asamblea Legislativa del $1^{\circ}$ de mayo de 1873, transmitiendo su preocupación por la administración de justicia que no había sido modificada, por no haber concluido la Convención constitucional con sus tareas y seguir sin sancionarse la mayoría de las leyes propuestas, especialmente las dirigidas a responder a los intereses de la campaña.

Se había cumplido con la legislación destinada al servicio a las armas, la creación de un nuevo juzgado del crimen en la ciudad y la abolición de prisión por deudas, pero estas no alcanzaban para remediar los males. Sostenía que las nubes agrupadas sobre la justicia debían ser disipadas, y eso requería de la concreción de los proyectos, pues "sólo así podéis hacer desaparecer la desconfianza que viene amenazando destruir su base inconmovible, y evitar que el litigante no vea tras el Juez sino la justicia, esa Justicia severa, pero ante cuya majestad callan los intereses heridos". 6

Pero a pesar de quedar definida la estructura de la "nueva institución judicial" en el texto constitucional de 1873, el poder judicial continuó funcionando como hasta entonces, tal como puede observarse en el presupuesto de $1874 .{ }^{8}$ Recién a partir de enero de 1875 se puso en vigencia la renovada organización de la justicia bonaerense.

En el caso concreto de la estructura judicial de la provincia de Buenos Aires, se han realizado investigaciones relacionadas especialmente con el fuero criminal, ${ }^{9}$ pero nos proponemos aquí determinar cómo se organizó el poder judicial en general, después de la Constitución provincial de 1873, y establecer la participación de los tres poderes en la organización del nuevo poder. El objetivo es, desde una perspectiva institucional, determinar el significado de la división de poderes en el Estado provincial y el papel que el poder judicial jugó en ella.

\section{$\underline{\text { I. La importancia de las reformas previas a la organización judicial }}$}

La estructura que el texto constitucional dio a la organización judicial se basó en modificaciones previas, que respondieron a las necesidades y requerimientos que no podían esperar y que habían tenido intentos anteriores. Esto quedó de manifiesto en las palabras de Daniel María Cazón, abogado de activa participación política, que al inaugurar la cátedra de Procedimientos en

\footnotetext{
${ }^{5}$ Zimmermann, 1999, op. cit., pp. 1-7.

6 "Mensaje del Poder Ejecutivo de la provincia de Buenos Aires a la Honorable Asamblea Legislativa", en ROPBA, 1873, p.243.

${ }^{7}$ Así definían al Poder Judicial la Suprema Corte de Justicia de la provincia en su "Memoria y proyectos presentados al Poder Legislativo, 1876", en Acuerdos y Sentencias, tomo I, pp. 187-190 (en adelante Memoria de la Suprema Corte, 1876).

8 "Presupuesto General de gastos en la provincia de Buenos Aires para el año 1874" Presentado el 23 de febrero de 1874. ROPBA, 1874, pp. 83-128.

${ }^{9}$ Por ejemplo Fasano, 2009, op. cit; Yangilevich, y Míguez, 2010, op. cit.; Sedeillan, 2012, op. cit.; Yangilevich, 2012, op. cit.
} 
1872, explicaba que la sociedad ocupada "por sus hábitos de vida colonial, o inconsciente por mucho tiempo de los medios adecuados para aumentar sus libertades y garantir el derecho de cada uno sobre la propiedad y la vida", había dejado inorgánico el mecanismo de la justicia.

La consecuencia de esta inconciencia había sido el retardo en los juicios y un sistema "vejatorio e inquisitorial", cuando el procedimiento era indispensable para dar a la sociedad un resultado práctico, que protegiera el cumplimiento de las obligaciones y los derechos sagrados de la propiedad, del honor y de la vida. El profesor estaba convencido de que la ciencia del derecho no servía de nada sin una administración de justicia que lo aplicara, y enunciaba la preocupación por formar abogados que supieran llevar adelante las causas, pero fundamentalmente con idoneidad para aplicar la ley en su resolución. ${ }^{10}$

En este contexto, el 18 de febrero de 1870 el ministro de gobierno Antonio E. Malaver, dirigió una nota a los magistrados del Superior Tribunal, expresándoles su preocupación por las últimas acordadas y por la circular dirigida a los jueces de primera instancia. ${ }^{11}$ Las acordadas a que hacía referencia estaban relacionadas con la venta de bienes raíces y el nombramiento de martilleros para actuar en ellas, y las estadísticas que los magistrados debían pasar mensualmente al Tribunal. Esto último había caído "en completa inobservancia" y era indispensable para dar a conocer al público "con exactitud las tareas que pesan sobre los tribunales y la contracción con que cada juez desempeña las que le corresponden, poniéndolos a cubierto de juicios y apreciaciones desfavorables". La comunicación fue realizada por una circular a los jueces, afirmando lo indispensable y urgente de tomar otras medidas que evitaran en el futuro el desprestigio de la magistratura, salvando la dignidad de los que la ejercían y las exigencias de la justicia. ${ }^{12}$

En la nota, Malaver solicitaba al Tribunal proyectos de ley que resolvieran la situación descripta, dejando de manifiesto como participaban en su concreción los tres poderes. El ejecutivo los pedía, el Judicial los formulaba y el legislativo los sancionaba. Esto debía ser así porque el gobernador, que consideraba absoluta y completamente independiente a los poderes públicos de la provincia, creía que nada podía hacer constitucionalmente para encontrar el remedio oportuno al mal que sentía. La solución que consideraba posible era entonces dirigirse a la cabeza del poder judicial -que ejercía su superintendencia- recurriendo a su celo y patriotismo para que formulara los proyectos, ofreciéndole incluirlos inmediatamente entre los asuntos de convocatoria extraordinaria de la Legislatura.

\footnotetext{
10 “Discurso pronunciado por el Dr. Daniel María Cazón en la apertura del aula de Procedimientos de la Universidad de Buenos Aires", en Revista de Legislación y Jurisprudencia, tomo VIII, 1872, Buenos Aires, Imprenta de Pablo E. Coni, 1872, pp.373-381.

11 "Nota al Superior Tribunal, incitando su celo para que formule proyectos de Ley, relativos a la mejora de la Administración de Justicia y su contestación", en ROPBA, 1870, pp. 99-108. (En adelante Nota al Superior Tribunal)

12 “Autos acordados el 7 de febrero de 1870", Acuerdos y Sentencias, tomo I, pp. 443-444.
} 
Según el criterio del gobernador, los magistrados tenían la ciencia y la experiencia que les daba la superintendencia y podían proponer el remedio pronto y eficaz a males que nadie como ellos conocían y apreciaban. Además, constitucionalmente por el artículo 126, debían informar al poder legislativo de todo lo concerniente a la mejora de la administración de justicia. La invitación de Emilio Castro a través de su ministro permite observar el juego de los tres poderes ante la conflictiva situación de la justicia, que se iría agravando. ${ }^{13}$ El poder ejecutivo sabía que constitucionalmente no podía imponer reformas que debían ser sancionadas por el poder legislativo, pero sí esperar que el poder judicial informara "al Cuerpo Legislativo de todo lo concerniente a la mejora de la Administración de Justicia”, según el texto constitucional de 1854.

Es decir que constitucionalmente la invitación no era necesaria, pero el 21 de febrero el presidente del Superior Tribunal, Andrés Somellera, le respondió a Malaver agradeciendo la nota recibida y pidiendo que comunicara al gobernador que aceptaba la propuesta. El Tribunal ya había reclamado esas medidas en 1867 al poder ejecutivo, logrando por las Cámaras ser autorizado para reorganizar los tribunales y reformar el enjuiciamiento civil, pero al año siguiente todo había pasado a los archivos. Según el magistrado, se había intentado sostener una institución vieja y carcomida la Real Audiencia- que no podía existir en el seno de una república. Protestaba contra los que habían propuesto como medida salvadora el reemplazo de los jueces actuales y los que buscaban "luego de indagaciones inquisitoriales, la exhumación de pleitos muertos, por comisiones ad-hoc y otras cosas capaces de conmover hasta en sus cimientos a la sociedad más sólidamente construida". ${ }^{14}$

En su nota encaraba la defensa del Tribunal, explicando que la Real Audiencia había desaparecido hacía muchos años y en ese momento sólo había jueces de primera instancia y un tribunal de apelaciones instituido y organizado por las leyes patrias. El origen del Superior Tribunal, que era lo que más caracterizaba a una institución, era popular y democrático, aunque no emanara sino indirectamente del pueblo. Era similar a los tribunales nacionales y de los Estados Unidos, que no podían ser tachados de añejos o anti-republicanos. Se podrían hacer las reformas necesarias, alterar los procedimientos, atrasados e inconvenientes, pero la institución se mantendría mucho tiempo porque respondía a las exigencias de la ciencia democrática moderna. Y según su perspectiva, cuando se instalara el jurado más que nunca se requeriría de esos magistrados letrados, aunque habían sido denunciados como incompatibles con otras instituciones democráticas, pues los

\footnotetext{
${ }^{13}$ Después de 1872 volvió a tornarse dificultoso lograr que los abogados aceptaran los cargos de juez, esto podía ser por los bajos salarios, la inestabilidad económica y política y los cambios que se avecinaban con motivo de la sanción de la nueva Constitución, a lo que se sumaba el aumento del número de juzgados de cinco a once entre 1854 y 1873 para la Capital, permaneciendo los tres para la Campaña. Es decir que en veinte años (1852-1872) los juzgados de primera instancia pasaron de ser cuatro a catorce.

${ }^{14}$ Nota al Superior Tribunal, p. 105.
} 
vicios y los fraudes cometidos contra una institución, no probaban nada contra la institución misma y las reformas propuestas por el Superior Tribunal.

Esas reformas eran la libre defensa y representación; la designación de jueces para lo civil y lo comercial en la campaña; la separación e independencia absoluta de los escribanos con registro y los que actuaran en los juicios, limitando su número; la creación de un archivo para cada juzgado hasta que se estableciera un archivo general; la abolición de la prisión por deudas que no procedieran de delito o fraude; la implementación de un breve medio provisorio para enjuiciar a los jueces y hacer efectiva la responsabilidad penal y civil; la abolición de la prueba secreta; el establecimiento de un procedimiento específico para una justicia fácil, pronta y poco gravosa para los que la pedían; la obligación de que los jueces lo fueran exclusivamente sin otra función pública; la institución del juicio por jurado; y la puesta en práctica de reglas equitativas para la estimación de honorarios.

Algunos de estos cambios buscaron convertirse en las leyes propuestas y debatidas a lo largo de estos años, mientras que otros fueron sancionados en la Constitución y algunos no llegaron a feliz término. Pero dos de ellos fueron logros fundamentales para alcanzar la organización judicial constitucional en 1875: la creación de secretarías para el Superior Tribunal y los juzgados de primera instancia, y la ley sobre incompatibilidad de empleos.

\section{a. Las secretarías de primera instancia}

Esta propuesta del Tribunal buscaba la separación e independencia absoluta de los escribanos que tuvieran registro y los que fueran a actuar en los juicios, a lo que se sumaba que estos, como secretarios de actuación, tuvieran un número reducido y que más adelante fueran rentados para evitar los problemas de su relación con los litigantes. ${ }^{15}$ El proyecto se concretó el 30 de septiembre de 1871 con la creación de las secretarías de primera instancia civil y comercial, y del Superior Tribunal, siendo éste un cambio fundamental en relación a la organización de la estructura judicial y su funcionamiento. ${ }^{16}$

Según el proyecto, el Superior Tribunal de Justicia tendría para su despacho tres secretarios escribanos, uno para cada sala. El secretario de la sala del crimen actuaría en los asuntos del Tribunal pleno y los de las salas de lo civil, por turno en los asuntos de las dos salas reunidas. Los Juzgados de lo Civil y los de Comercio de la Capital contarían con cuatro escribanos, únicos habilitados para actuar en dichos juzgados, pero autorizados para tener otros adscriptos para las

\footnotetext{
15 Sobre escribanos criminales ver Barrenache, 2001, op. cit.; Fasano, 2009, op. cit. Para la justicia federal: Zimmermann, Eduardo, "Centralización, justicia federal y construcción del Estado en la organización nacional”, en Revista de Instituciones, Ideas y Mercados Número 46, mayo 2007, pp. 265-292.

16 "Ley de creación de escribanos secretarios", ROPBA, 1871, pp. 574-575.
} 
diligencias externas, bajo su responsabilidad y con conocimiento y aprobación del juez. ${ }^{17}$ El resto de los jueces letrados, en la capital y en la campaña, tendrían un escribano para su despacho. Todos los escribanos serían nombrados por el Tribunal Superior, a propuesta de los jueces letrados de sus respectivos juzgados y el mismo Tribunal podía decretar el reemplazo por el pedido del juez o cuando lo juzgase oportuno "para el mejor servicio público". ${ }^{18}$ Los expedientes en curso continuaban a cargo de los escribanos que ya actuaban en ellos, cuestión que generó conflictos por muchos años.

Llegar al texto legal no fue tarea sencilla y llevó más de un año a partir de un proyecto que comenzó a debatirse en la Cámara de Senadores el 28 de junio de $1870 .{ }^{19}$ En su presentación, Rufino de Elizalde informaba que desde 1852 la administración de justicia había comenzado una gran trasformación, pero que los intentos por reformar el sistema de escribanos había fracasado y cuantas más causas había en la provincia, más se notaban los inconvenientes del sistema del notariado. $^{20}$ A pesar de la resistencia del Superior Tribunal de Justicia, el poder ejecutivo había aumentado el número de escribanos "al extremo de producir una gravísima confusión”, por lo que José Domínguez, encargado por el Gobierno del proyecto sobre la organización de los Tribunales, había propuesto la mayor parte de la reforma.

La idea fundamental de la propuesta era acabar con lo que ellos consideraban abusos inmorales, pues "los escribanos que tenían registro no deben, no pueden, no conviene que sean al mismo tiempo los que actúen en expedientes ante los Jueces”. Y, desde su perspectiva, eso no tenía discusión, pudiendo sólo discutirse la reglamentación, aunque enunciaba un punto que, como ya dijimos, sería de controversia. En diálogo con algunos escribanos de diligencias, había comprendido que debían respetarse derechos adquiridos de quienes compraron oficinas contando con expedientes radicados en ellas, pues no sería justo ni equitativo que se les sacasen, más tratándose de reformas fundamentales a las que poco afectarían la continuidad por unos meses más de "un sistema que creemos irregular". 21

El proyecto fue aprobado en general y las discusiones comenzaron con el artículo $2^{\circ}$, que establecía la responsabilidad del escribano de actuación sobre los escribanos adscriptos, lo que para

\footnotetext{
${ }^{17}$ El escribano de actuación que mandase practicar una diligencia externa por dependiente que no fuera de los escribanos adscriptos, sufriría la pena de suspensión por uno o dos años, según la gravedad del caso, sin perjuicio de las demás responsabilidades establecidas por las leyes vigentes.

${ }^{18}$ Es interesante observar que según la ley, que tenía por objetivo distinguir escribanos de actuación y de registro, sólo podía ser nombrado uno de estos en un juzgado si ponía su registro bajo la dirección de otro profesional y con autorización del Superior Tribunal.

${ }^{19}$ Senadores, 1870, pp. 93-97. El proyecto estaba firmado por Rufino de Elizalde, Emilio Agrelo, Daniel María Cazón, Federico Agustín Pinedo, todos abogados.

${ }^{20}$ Hace aquí referencia a un proyecto previo propuesto también por Elizalde como diputado en 1859, que terminó siendo rechazado. En su presentación aseguraba que sin esos cambios la vida y la propiedad no podían ser garantidas, pues de ello dependía el estado de la familia, la seguridad y el reposo de los ciudadanos. Sesión del 10 de octubre de 1859, Diputados, 1859, pp. 201-202; 371-377.

${ }^{21}$ Senadores, 1870, p. 94.
} 
el senador y juez civil de la Capital Emilio Agrelo, no era ni justo ni conveniente, pues no se podía poner al escribano actuario la responsabilidad del escribano adscrito, que podía cometer un delito, debiendo atenerse cada uno a las responsabilidades que le imponía la ley. Su compañero de Comisión, Rufino de Elizalde, aceptaba la modificación aclarando que lo que se había buscado era que el escribano actuario no esquivase su responsabilidad, valiéndose de "manos subalternas". En cambio, para Federico Agustín Pinedo, si el escribano actuario se valía de un dependiente debía responder por sus actos, a lo que Agrelo respondía que tanto el actuario como el de diligencias eran escribanos y las notificaciones corrían por su cuenta y riesgo. Pero Pinedo junto con José Domínguez, miembro del Superior Tribunal, creían que también la notificación era responsabilidad civil del secretario.

Pero el texto original fue aprobado modificando sólo lo referido a los expediente en trámite, que continuarían a cargo de los escribanos a su cargo. Con estas controversias irresueltas, aún dentro del poder judicial, el proyecto fue llevado a la Cámara de Diputados y tratado el 6 de septiembre de $1871 .^{22}$ En la presentación, José María Moreno, catedrático de derecho civil y fiscal general de gobierno, ofreció una imagen de la situación, asegurando que la necesidad de contar con más secretarios se debía a que la mayor cantidad de juzgados no resolvía el problema pues "la aglomeración constante de escribanos en derredor del despacho del juez retardaba necesariamente esa celeridad". El proyecto fue aprobado, pero el diputado Leopoldo Basavilbaso, que iniciaba su carrera política, pidió a la comisión que aceptara la introducción de un artículo por el cual se prohibiera terminantemente que las diligencias se hicieran por medio de dependientes, penando al escribano que no verificase personalmente las notificaciones.

El tema se trató en la siguiente sesión planteándose la diferencia entre cuestiones de organización y cuestiones de procedimiento. Así, la exposición de Alejo González Garaño, presidente de la Cámara de Diputados y juez del Superior Tribunal, hacía referencia al valor de la ley sobre la costumbre en relación al artículo que mandaba a los escribanos verificar personalmente las diligencias de notificaciones. Exponía que se trataba de una prescripción impuesta no sólo por las antiguas leyes españolas sino por las propias leyes patrias, como constaba en el reglamento de administración de justicia del año 1817, que ninguna ley posterior había derogado ni desvirtuado:

Las leyes están siempre en observancia según las reglas generales de legislación, y la costumbre no ha podido prevalecer contra sus disposiciones; por el contrario puedo asegurar que el tribunal ha encargado siempre el fiel cumplimiento de esas disposiciones y cuando su violación ha sido denunciada y justificada, ha sido reprimida como correspondía. ${ }^{23}$

\footnotetext{
${ }^{22}$ Diputados, 1871, pp.446-451.

${ }^{23}$ Sesión del 18 de septiembre, Diputados, 1871, p. 517.
} 
Modificado el proyecto por Diputados, y aceptadas las reformas por Senadores, ${ }^{24}$ fue sancionado el 22 de septiembre. El proyecto establecía que el escribano de la sala del crimen actuaría en los asuntos del tribunal pleno y de dos salas reunidas, pero según la ley el secretario de la sala del crimen actuaba en los asuntos del Tribunal pleno y los de la salas de lo civil, por turno, en los asuntos de dos salas reunidas. $\mathrm{Al}$ artículo $2^{\circ}$ se le agregó que el escribano de actuación que mandase practicar una diligencia externa por dependiente que no fuera de los escribanos adscriptos, sufriría la pena de suspensión por uno o dos años. Finalmente incorporaba la posibilidad de que el juez de primera instancia pudiera solicitar el reemplazo de su escribano al Superior Tribunal.

\section{b. Incompatibilidad de empleos}

Al año siguiente de sancionada la Constitución provincial se resolvió una cuestión conflictiva que había comenzado a tratarse muchos años antes. Según una de las peticiones del Tribunal, los jueces debían ejercer la magistratura exclusivamente sin otra función pública, pero no porque ocupar simultáneamente cargos en dos poderes diferentes implicara una contradicción con la división de poderes -incompatibilidad teórica o en principio- sino por razones de conveniencia y de material incompatibilidad. ${ }^{25}$

Tan es así que las discusiones sobre el tema habían comenzado en la década de 1850 en relación a la retribución monetaria, presentado por la Comisión de Hacienda, que generó en estos años nuevos conflictos en torno a la acumulación de sueldos. Con los años el debate avanzó, hasta que finalmente, iniciado por la Comisión de Negocios Constitucionales, terminó por obligar a los magistrados, que solían desempeñarse como legisladores a la vez que formaban parte del poder judicial, a optar entre una u otra actividad pública a partir de la ley sobre incompatibilidad de empleos del 11 de agosto de $1874 .{ }^{26}$ La opción no era menor, pues en definitiva se trataba de elegir entre la política o la carrera judicial.

En 1859 Rufino de Elizalde presentó un proyecto por la Comisión de Hacienda, para fijar una regla que resolviera todas las cuestiones sobre acumulación de sueldos, ya establecida en 1821, pero arbitrariamente aplicada. El tema reapareció en el campo legislativo en 1872, pero en otro contexto y con otros fundamentos, con un proyecto sobre acumulación de empleos que fue presentado por Aristóbulo del Valle y tratado por la Comisión de Negocios Constitucionales. La razón dominante que influyó en su espíritu para presentarlo fue

...la de organizar el servicio público de una manera que responda a las verdaderas necesidades del país y acabar con la práctica perniciosa de los gobiernos, de acumular en una o dos personas mayor número de empleos de los que pueden desempeñar con arreglo a sus

\footnotetext{
${ }^{24}$ Senadores, 1871 , pp. 259-260.

${ }^{25}$ Nota al Superior Tribunal, pp. 107-108.

${ }^{26}$ ROPBA, 1874, pp.398-399. La ley se refería a la incompatibilidad de empleos entre los tres poderes, pero aquí hacemos especial referencia a los magistrados como legisladores, que era lo que más solía ocurrir.
} 
aptitudes, sin consultar a los verdaderos intereses del país, sino los intereses personales. Es una doctrina incontestable de buena administración, que cada empleo requiere su empleado, y que sólo se tiene los empleos bien servidos cuando ellos están atendidos por personas que hacen de esa ocupación, el objeto principal de su vida. ${ }^{27}$

Pero la cuestión económica seguía presente, contra la postura de quienes veían un objetivo mucho más elevado que los sueldos, buscando el buen servicio de la administración y denunciando los inconvenientes políticos que de la acumulación de empleos infaliblemente resultaba. ${ }^{28} \mathrm{La}$ maduración del proceso llevó a que la Comisión de Negocios Constitucionales de Diputados presentara el proyecto sobre compatibilidad de empleos enviado por el Senado y aconsejara la sanción de esta ley, por la que los jueces no serían más legisladores en forma simultánea, como lo hacían hasta entonces. La solución, para quienes sostenían esta postura, estaba en llamar al servicio público mayor número de ciudadanos, en vez de reconcentrarlos en pequeños núcleos que se repartieran todos los puestos públicos pagándoseles tres o cuatro sueldos, asegurando que no era hombres competentes, con inteligencia e ilustración lo que faltaba. ${ }^{29}$

Algunos legisladores mantenían el argumento económico y la mera eficiencia, pero otros lo habían superado para centrase en la independencia de poderes, conquista que para sus defensores garantizaba las libertades públicas en beneficio del servicio público. ${ }^{30}$ Bonifacio Lastra, abogado, legislador y ministro de hacienda del gobierno de Carlos Casares, fue el más firme en este aspecto

En nuestro sistema de gobierno, la independencia de Poderes es una conquista que tiende a garantir las libertades públicas a la vez que facilita la acción del Poder en beneficio del servicio público. Independencia de Poderes no quiere decir, Señor Presidente, división en la orden de sus funciones, independencia de Poderes quiere decir: completa y absoluta prescindencia en las funciones de unos en sus relaciones con el ejercicio de los otros: es la división de facultades, y esta división de facultades no tendría razón de ser si viniere a confundirse en una misma persona, y de ahí yo sostengo que no hay independencia de Poderes cuando por la ley que quiere sancionarse se establece que un miembro del cuerpo legislativo puede ser parte del Cuerpo Administrativo. ${ }^{31}$

Se había profundizado el problema, llevándolo del campo económico al constitucional, sustentándolo primero en la mera práctica y finalmente en la teoría de la división de poderes. Sancionada la ley, se había logrado separar los poderes, al menos en quienes los ejercían. En la justicia federal la superposición entre las funciones judiciales y los cargos políticos tuvieron otro

\footnotetext{
${ }^{27}$ Sesión del 18 de octubre, Diputados, 1872, p.562-563

${ }^{28}$ Sesión del 29 de octubre, Senadores, 1872, p.346.

${ }^{29}$ La cuestión de superar los "pequeños núcleos" al servicio público con un mayor número de ciudadanos competentes, con inteligencia e ilustración ha estado presente y sigue estándolo en la formación de los poderes públicos. En los primeros años, el Estado provincial estaba lejos de contar con una burocracia judicial y policial sólida y era fundamental definir el papel de la burocracia, "institución”, forma de estructuración social que tendía a ritualizar conductas y comportamientos de acuerdo a ciertos códigos compartidos, exigiendo a la sociedad una adecuación creciente a esos códigos. Fradkin, 2005, op. cit.; Garavaglia, 2007, op. cit. Después de Caseros se puso como objetivo la carrera judicial pero a pesar de lograrse sigue siendo un tema de plena actualidad.

${ }^{30}$ Sesión del 7 de agosto, Diputados, 1874, pp.450-473

${ }^{31}$ Diputados, 1874, pp. 455-456.
} 
origen y otra connotación. Los abogados en las provincias eran escasos y estaban llamados a ocupar cargos políticos. Esto llevaba a dificultar el proceso de diferenciación de las funciones judiciales y así garantizar la independencia de los jueces. ${ }^{32}$

\section{La participación de los Poderes en la conformación del Poder Judicial}

\section{a. El Poder Ejecutivo}

Pilar Domingo consideró que, a pesar de haberse incrementado las investigaciones sobre política institucional, la mayor parte de los trabajos sobre el sistema de justicia han sido realizados por juristas. Entonces su tarea fue dedicada al estudio de los cambios constitucionales de la Suprema Corte de México, entre 1917 y 1994, con particular énfasis en aquellas reformas que alteraron su diseño y modificaron su relación con el poder ejecutivo. El objetivo estaba puesto en determinar la naturaleza del sistema político y las peculiaridades de la forma del desarrollo constitucional. ${ }^{33}$ Como una vía para establecer la relación entre la Suprema Corte de la provincia de Buenos Aires y el gobernador, consideramos fundamental determinar las cuestiones que preocupaban a éste último en relación a la administración de justicia, para lo cual recurrimos a los mensajes que anualmente dirigía a la Asamblea Legislativa.

Una vez en vigencia la Constitución de la provincia, el desafío era organizar y poner en funcionamiento el poder judicial, lo que se hizo entre agosto de 1874 y enero de 1875. Sin embargo la legislación reglamentaria tardó muchos años en sancionarse, llegando en algunos casos a no realizarse nunca, como el juicio por jurados, o a vetarse, como la de justicia de paz. A esto debe agregarse que para el gobernador no era en estos años una cuestión prioritaria, como quedó reflejado en sus mensajes a la Asamblea Legislativa entre 1875 y 1880, a pesar de sucederse distintos gobernadores y haber atravesado críticas situaciones hasta la pérdida de la capital. El tema no estaba ausente, pero el primer mandatario provincial debía atender cuestiones más apremiantes revolución política, crisis económica, organización municipal y policial, etc.- y esperaba que los legisladores pusieran en marcha esa organización judicial, cuya estructura había sido establecida en el texto constitucional. Por esto se limitaba a reclamar la pronta sanción de leyes de procedimiento y funcionamiento judicial. ${ }^{34}$

\footnotetext{
${ }^{32}$ Zimmermann, Eduardo, "El Poder Judicial, la construcción del estado y el federalismo: Argentina, 1860-1880", en: Eduardo Posada-Carbó (ed.) In Search of a New Order: Essays on the Politics of Nineteenth-Century Latin America. Londres: ILAS, 1998, pp. 131-152.

${ }_{33}^{33}$ Domingo, 2000, op. cit., pp. 705-735.

${ }^{34}$ De hecho, ya en el Mensaje de 1874, Mariano Acosta había explicado que la administración de justicia no sufrió cambios en el desempeño de sus funciones, a pesar de las modificaciones radicales que introdujo la Constitución. Aseguraba que esas reformas las debía llevar a cabo el poder legislativo, pero le pedía que autorizase el nombramiento de una Comisión de personas reconocidas que las estudiaran. "Mensaje del Poder Ejecutivo de la Provincia de Buenos Aires", ROPBA, 1874, p. 250.
} 
En 1874 Mariano Acosta renunció a la gobernación para completar la fórmula presidencial con Nicolás Avellaneda y el 12 de septiembre en su reemplazo asumió el presidente del Senado, Álvaro Barros. El $1^{\circ}$ de mayo de 1875, día en que juraron el gobernador electo Carlos Casares y el vice gobernador Luis Sáenz Peña, Barros dirigió el mensaje a la Asamblea Legislativa. En él dejaba de manifiesto que durante la transitoriedad de su administración, los tribunales permanentes, creados por la nueva Constitución, habían sido instalados y reclamaba la necesidad de las leyes de procedimiento para la nueva organización. ${ }^{35}$

Durante los años que siguieron hasta 1880, divididos entre los mandatos de Casares y Carlos Tejedor -que no lo completó - la atención fue desplazándose de lo necesario a lo urgente, pasando de reiterados pedidos de leyes reglamentarias, que consagraran "el derecho de todos, sobre las bases más amplias de la libertad civil y política", a la preocupación más específica por la propiedad y la vida, ${ }^{36}$ expresada ésta en la conmutación de penas, la excarcelación bajo fianza y la construcción de una casa correccional de menores. ${ }^{37}$

En los primeros años se reiteraba la necesidad de organizar la justicia de paz, para terminar con la acumulación de funciones en jueces que simultáneamente eran presidentes de las municipalidades, encargados de la policía, agentes del poder ejecutivo y también de los tribunales. Esto era interpretado como causa suficiente de mala administración y no debía demorarse la ley para dotar a la campaña de magistrados electivos sin otra misión que la de administrar justicia. ${ }^{38}$

Una vez que estuviera organizada la justicia de paz y legislados los procedimientos judiciales, era indispensable atender al tema edilicio. Proponía que, terminada la penitenciaría y desocupada la cárcel del Cabildo, fuera utilizada como casa de Justicia para economizar los alquileres del edificio que ocupaban los juzgados. Pero lo que el gobernador consideraba más valioso era que se concentraran en un solo punto todos los tribunales y escribanías, quedando los intereses privados comprometidos en los pleitos y garantidos en los registros de contratos públicos, resguardados y a cubierto de cualquier accidente. Se comprometía a presentarles el proyecto una vez realizados los estudios necesarios para la reedificación de la cárcel. ${ }^{39}$

\footnotetext{
35 “Mensaje del Poder Ejecutivo de la provincia de Buenos Aires a la Honorable Asamblea Legislativa", ROPBA, 1875, pp.132-146.

${ }^{36}$ Casares buscaba responder a "la necesidad de dar las mayores garantías a la propiedad y a la vida de los habitantes de la ciudad y de la campaña", para lo que el Ejecutivo se comprometía a mandar proyectos, dependiendo lo demás de los legisladores. "El Poder Ejecutivo de la provincia a la Honorable Asamblea Legislativa", Senadores, 1877, pp. 43-51. ${ }^{37}$ El poder ejecutivo fue autorizado el 7 de junio de 1878 a mantener una casa correccional de menores varones con el producido de las multas de policía. ROPBA, 1878, p. 267. Según Tejedor, era necesaria porque los juzgados que tenían menores bajo su amparo no encontraban donde colocarlos, y los que eran delincuentes se enviciaban más en la Cárcel de policía. "Mensaje del Poder Ejecutivo de la provincia de Buenos Aires a la Honorable Asamblea Legislativa". ROPBA, 1879, p. 253.

38 "Mensaje del Poder Ejecutivo de la provincia de Buenos Aires a la Honorable Asamblea Legislativa", en ROPBA, 1876, pp. 70-85.

${ }^{39}$ Senadores, 1877, pp. 43-51.
} 
El objetivo de economizar, mencionado en relación a los edificios, se fue considerando fundamental y las propuestas se tornaron más profundas, porque ya no se trataba sólo de cuestiones de infraestructura sino de la organización del poder y de los magistrados que lo componían. Consideraban que una vez organizadas y llevadas a ejecución las nuevas leyes de jueces de paz y tribunales de vecindario, podrían reducirse en la campaña a una las tres Cámaras de Apelación que determinaba la Constitución, dado que no eran consideradas verdaderamente necesarias. ${ }^{40}$ Decimos que es un tema más grave pues ponía en desigualdad la conformación de los Departamentos Judiciales, cuestión que había sido defendida en sucesivos debates desde el principio de la organización judicial. ${ }^{41}$

La atención comenzó luego a desplazarse hacia la cuestión preocupante del derecho del gobernador a conmutar penas, pues consideraban que una sociedad culta y cristiana no podía estar privada del derecho de gracia. Si castigar era justo, conmutar a veces las penas era caritativo, por eso el ejecutivo pedía al legislativo que dictara una ley reglamentando el artículo de la Constitución. ${ }^{42}$ Esto se acentuó en el discurso de Carlos Tejedor, al destacar que el código penal, proyectado por él y puesto en vigencia a partir del 1 de enero de 1878 , dejaba al condenado la esperanza de merecer la libertad, dando pruebas de reforma positiva, después de sufrir su condena por un tiempo que variaba según el delito. ${ }^{43}$

Años más tarde, relataba un caso en que el penado había solicitado su libertad por el gobernador del establecimiento en septiembre de 1879. Había sido condenado por falsificación de moneda a siete años de presidio y llevaba cumplidos seis, y el encargado de la Penitenciaría lo recomendaba a la consideración del Gobierno por haber observado una conducta intachable, con gran aplicación al trabajo. Se daba la ocasión de ejercer el derecho de gracia con arreglo a aquellas disposiciones, pero como no establecía quien debía ejercerlo, el poder ejecutivo solicitó opinión a la Suprema Corte, según la cual le correspondía al gobernador. La solicitud fue tomada en consideración y el penado obtuvo la libertad. Otros penados pidieron igual gracia directamente o

\footnotetext{
${ }^{40}$ ROPBA, 1879, pp. 236-237.

41 La justicia federal contaba con una sola Cámara de Apelación instalada en Buenos Aires, afectando el funcionamiento de los juzgados. Zimmermann, 1998, op. cit. p. 138.

${ }^{42}$ Senadores, 1877, p.43-51. Art. 142, inc. $3^{\circ}$ de la Constitución: "El Gobernador podrá conmutar las penas impuestas por delitos sujetos a la jurisdicción provincial, previo informe motivado del Tribunal Superior correspondiente, sobre la oportunidad y conveniencia de la conmutación, y con arreglo a la ley reglamentaria que determinará los casos y la forma en que pueda solicitarse, debiendo ponerse en conocimiento de la Asamblea Legislativa las razones que hayan motivado en cada caso la conmutación de la pena." Sobre el tema véase Levaggi, Abelardo, "La pena de muerte en el derecho argentino precodificado. Un capítulo de la historia de las ideas penales", en: Revista del Instituto de Historia del Derecho Ricardo Levene núm. 23, Buenos Aires, Imprenta de la Universidad, 1972, pp. 17-91; Caimari, Lila, "Castigar civilizadamente. Rasgos de la modernización punitiva en la Argentina (1827-1930)", en Gayol, Sandra y Kessler, Gabriel (comp.), Violencias, delitos y justicias en la Argentina, Buenos Aires, Manantial, 2002; Salvatore, Ricardo, Subalternos, derechos y justicia penal. Ensayos de historia social y cultural argentina, 1829-1940, Barcelona, Gedisa, 2010, en especial el capítulo cuarto.

${ }^{43} \mathrm{La}$ ley sobre conmutación de penas fue sancionada el 17 de octubre de 1877. ROPBA, 1877, pp. 357-358.
} 
por sus defensores, siendo concedidas algunas y negando otras, según el informe del gobernador de la Penitenciaría y lo aconsejado por la Corte, consultada en cada caso. ${ }^{44}$

Pero entre la sanción del Código penal y ese mensaje de Tejedor, surgió otra preocupación cuando Carlos Casares había destacado la ley reglamentaria de la policía, como "una de las principales instituciones sobre la que reposa el orden, la seguridad pública y el ejercicio de los derechos individuales". La Policía tanto de la ciudad como de la campaña había visto ilusorios sus esfuerzos "por la exagerada facilidad con que se concede la excarcelación bajo fianza. Los elevados propósitos en que ese derecho se funda, no deben convertirse en fuente de impunidad que fomenta el crimen, al mismo tiempo que desalienta a los encargados de reprimirlo”. Por ello pedía que se dedicaran al proyecto de ley sobre reglamentación de la excarcelación bajo fianza, que él había sometido a su consideración. ${ }^{45}$

Cuando Juan José Romero, a cargo del poder ejecutivo recibió la administración el 11 de octubre de 1880, dio cuenta de su gestión y sentenció que a pesar de las frecuentes leyes dictadas, la administración de justicia no mejoraba como debiera, no adquiría la rapidez indispensable para su crédito y "la justicia criminal sobre todo, se hace odiosa por su lentitud. Toda demora en las causas criminales no sólo entraña una injusticia, sino que aumenta los gastos de la justicia y la desacredita". Pero a más de continuar con la preocupación por el fuero criminal introdujo un nuevo ítem en su informe, sobre la provisión de las vacantes de la judicatura, en la que aseguraba haber procedido con la más ejemplar severidad, teniendo en cuenta únicamente la competencia, rectitud, honorabilidad y antigüedad de servicios con prescindencia absoluta de toda otra consideración. ${ }^{46}$

Si recordamos las reformas propuestas por el Superior Tribunal a demanda del ejecutivo, ni la conmutación de penas ni el funcionamiento del fuero penal estaban presentes. ${ }^{47}$ Sin embargo, diez años después estas cuestiones fueron surgiendo en las preocupaciones de los gobernadores, tal vez porque las garantías constitucionales enunciadas a favor de la vida y de la propiedad, se habían inclinado definitivamente hacia ésta y “el control de la violencia formó parte de las preocupaciones de las mismas dirigencias que recurrían a ella en sus luchas por el poder". ${ }^{48}$ Entonces reglamentar la conmutación de penas, la excarcelación bajo fianza, la contención de los menores y asegurar una

\footnotetext{
44 "Mensaje del Poder Ejecutivo de la provincia de Buenos Aires a la Honorable Asamblea Legislativa. $1^{\circ}$ Sesión de Asamblea del $1^{\circ}$ de Mayo de 1880”. Senadores, 1880, pp. 29-49.

45 "Mensaje del Poder Ejecutivo de la provincia de Buenos Aires a la Honorable Asamblea Legislativa". ROPBA, 1878, pp. 189-202. La ley de excarcelación bajo fianza fue sancionada el 4 de julio de 1878. ROPBA, 1878, pp. 8-11. Sobre la policía en este período en la provincia de Buenos Aires véase Seidellan, 2005, op. cit.; 2009, op. cit.; 2012 op. cit.; Gayol, Sandra, "Sargentos, cabos y vigilantes: perfil de un plantel inestable en ele Buenos Aires de la segunda mitad del siglo XIX”, en Boletín Americanista, V. 36, N 46, Barcelona, 1996.

${ }^{46}$ Mensaje del Gobernador de la provincia de Buenos Aires a la Honorable Asamblea Legislativa de Buenos Aires, el $1^{\circ}$ de mayo de 1881. ROPBA, 1881, pp. 245-270.

${ }^{47}$ En la respuesta de Somellera se hacía referencia a la necesidad del Código Penal y se prometía su proyecto. Nota al Superior Tribunal, p. 108. Lo cierto fue que el 15 de junio de 1881 nombraron una comisión para la redacción de proyecto de código de procedimientos criminal. ROPBA, 1881, pp. 359-360.

${ }^{48}$ Sábato, 2008, op. cit., pp. 296.
} 
justicia penal más ágil, protegerían al acusado y a la víctima, transmitiendo a la sociedad porteña el compromiso de sus gobernantes por cumplir con la defensa de la vida.

\section{b. El Poder Judicial}

Por una disposición constitucional "sabia y previsora", la Suprema Corte debía presentar a la Asamblea Legislativa una Memoria anual, informando el estado de la administración judicial y proponiendo los proyectos de reforma de procedimiento y organización para mejorarla. ${ }^{49} \mathrm{El} 10$ de junio de 1876 la Suprema Corte ponía en manos de la Asamblea "la primera página en la historia de la nueva institución judicial”, en la que el poder judicial se pensaba a sí mismo. ${ }^{50}$

Dos años más tarde la Corte concluía que la justicia era rectamente administrada, la pureza y competencia de sus administradores no era cuestionada y sus acuerdos y sentencias hacían honor a la jurisprudencia satisfaciendo la opinión ilustrada. Entonces, se preguntaban los altos magistrados, ¿dónde se originaban las quejas ante los tribunales y el cansancio del litigante de buena fe?, ¿por qué el descreimiento en la autoridad y la falta de fe en el castigo rápido y ejemplar de la delincuencia? Según su conclusión, el problema radicaba en la dificultad de alcanzar una recta y pronta justicia, primer deber de los poderes públicos, que afianzaba la paz por el bienestar de "pueblos justamente administrados" que pagaban con respeto y consideración a la autoridad. ${ }^{51}$

Las Memorias entre 1876 y 1878 reclamaban la falta de legislación reglamentaria de la Constitución sancionada, sin la que tuvieron que comenzar su tarea, debiendo su acción de superintendencia enfrentar los conflictos surgidos por la diferencia de personal, la división de jurisdicciones, la descentralización y la prueba pública, en un divorcio entre los principios que los sostenían, la ley y los intereses individuales. Pero aún así habían podido ejercitar la acción judicial con las garantías y plenitud del nuevo mecanismo de jurisdicción y procedimiento. ${ }^{52} \mathrm{~A}$ partir de este reclamo los proyectos presentados seguían los deberes primordiales de la administración de justicia: rapidez del procedimiento, disminución de honorarios y costas, reglamentación de los recursos y responsabilidad de los magistrados. Las causas principales del descontento general eran la lentitud y los altos costos de los procesos y desde el Superior Tribunal venían buscándose los medios de superarlo.

\footnotetext{
${ }^{49}$ Memoria de la Suprema Corte de Justicia, presentada el 21 de mayo de 1878. Acuerdos y Sentencias, tomo II, pp. $77-$ 82. (en adelante Memoria de la Suprema Corte, 1878).

${ }^{50}$ Memoria de la Suprema Corte, 1876, pp. 187-190.

${ }_{51}^{51}$ Memoria de la Suprema Corte, 1878, p. 77.

${ }^{52}$ Tomemos como ejemplo la inasistencia de un magistrado: "La Constitución de 1873 organizó el Poder Judicial como una sección de la soberanía, independiente de las otras, dando a los magistrados que la forman garantías de independencia en el ejercicio de sus funciones. Pero esa independencia no podía ser absoluta sin caer en lo arbitrario: era necesario que, como la de los otros poderes estuviese sometida al rígido imperio de las leyes orgánicas" .Resoluciones dictadas con motivo de la venida a la capital, sin licencia (según art. 24 de su reglamento), del camarista Dr. Benítez, y de los sucesos ocurridos en la casa de Justicia del departamento del Norte en 28 de septiembre último, 18 de octubre de 1877. Acuerdos y sentencias, tomo I, pp. 641-643.
} 
Siete mil trescientas quince causas habían sido finalizadas, haciendo desaparecer las críticas contra los magistrados, pero las reformas en los sistemas de procedimiento fueron parciales, deslizando aquí una crítica al poder legislativo que "creyó más útil que la brevedad, un campo lato y moroso de garantías que prodiga las apelaciones, los términos, etc." ${ }^{, 53}$ La raíz del mal debía extraerse con la sanción del proyecto de ley de procedimiento civil que la Corte había elevado el 12 de agosto de 1875, sancionada finalmente el 31 de octubre de 1878.

Pero en el fuero penal la reforma partía "de otro origen y de otras necesidades." El juicio por jurado era una solución que no había sido terminada, “y el sentimiento popular siente faltar su expresión, que atribuye al Jury, en la declaración de los hechos que garanten su seguridad". ${ }^{54}$ Pero pedían esa ley sin desconocer lo delicado de acomodar las costumbres y condiciones, y la deficiencia en la organización municipal, que formaría parte de la composición de esos Tribunales, por ello no presentaban ningún proyecto. Como podemos observar aquí, y en otras situaciones en que se hace referencia al juicio por jurado, sancionado en la Constitución Nacional y en la Provincial, este nunca se concretó, pues este pilar de la justicia lega había sido tratado más como un fin que como un instrumento de mayor participación ciudadana en la administración de justicia. ${ }^{55}$

Lo que preocupaba a la Corte era la pena, que por el tipo de cárceles no cumplía con el fin de mejoramiento del penado por medio de la educación y tampoco era ejemplo para la sociedad por medio del conocimiento público que "dejando penetrar la persuasión de la impunidad, eleva el número de delitos". ${ }^{56}$ Esos problemas terminarían con "el edificio de la más notable penitenciaría de la América Latina, en donde la corrección moral y el conocimiento del mal impuesto, hará extraordinaria disminución en el hoy alto número de penados". 57

Esa obra material, proporcionaría un adelanto necesario, pues al desalojarse locales de la casa de Justicia, podrían destinarse a los juzgados de la Capital que se encontraban diseminados y "reconcentrar bajo un solo edificio seguro los numerosos y valiosos intereses depositados en las oficinas públicas, repartidas con poca seguridad en las calles de la ciudad" ${ }^{58}$ Reaparece la doble preocupación del edificio como cárcel y como solución a la concentración de los juzgados y sus

\footnotetext{
${ }^{53}$ Memoria de la Suprema Corte, 1876, p. 187.

${ }^{54}$ Memoria de la Suprema Corte, 1876, p. 187.

${ }^{55}$ Barrenache, 2007, op. cit. pp. 202.

${ }^{56} \mathrm{Al}$ respecto Beccaria consideraba un error "tan común como contrario al fin social de salvaguardar la opinión de la propia seguridad" que el magistrado ejecutor de las leyes pudiera a su arbitrio poner en prisión a un ciudadano, privando de libertad a un enemigo o liberando a un amigo pese a indicios de culpabilidad." La prisión era una pena que debía preceder a la declaración de delito y sólo la ley, no el juez, determinaba los casos en que un hombre era digno de custodia e interrogatorio y pena. El acusado encarcelado y luego absuelto no debía llevar marca alguna de infamia en la medida que "la humanidad pase a través de los barrotes." Pero la prisión era más un suplicio que un lugar de custodia. Beccaria, Cesare, De los delitos y las pena, edición crítica bilingüe y estudio preliminar, Buenos Aires, Ediciones Arayú, 1955, pp. 261-262

${ }^{57}$ Memoria de la Suprema Corte, 1876, p. 187. Para una aproximación a las cuestiones del sistema carcelario en el siglo XIX ver Levaggi, Abelardo, Las cárceles argentinas de antaño, Buenos Aires, Editorial Ad-Hoc, 2002; Caimari, 2004, op. cit.

${ }^{58}$ Memoria de la Suprema Corte, 1876, pp. 187-188.
} 
empleados, presente en el ejecutivo. Desde la perspectiva judicial se le daba mayor solidez a la idea de que, con la desocupación de la antigua cárcel, pudiera construirse un edificio con asiento cómodo y digno a todos los tribunales de la Capital, para concentrar con la seguridad requerida los archivos y registros públicos. ${ }^{59}$ Además, como decía el gobernador, esa construcción economizaría crecidos gastos, “con una renta para el erario al eliminar el alquiler que deberían satisfacer las escribanías diseminadas en varias calles de la ciudad". ${ }^{60}$

La breve expedición de la justicia era, para los jueces, eficaz garantía de los derechos individuales y requería de diversas reformas que imprimieran a la tramitación de los juicios un movimiento más simple, rápido y económico. Había cuestiones de procedimiento, como la reglamentación de los recursos sobre inaplicabilidad de ley, que debía asegurar la apelación en casos excepcionales y extraordinarios, dado que por la falta de regulación se habían convertido en una instancia ordinaria. Lo mismo sucedía con la función que ejercía uno de los miembros de la Corte en disensos, venias supletorias y dispensas de impedimentos por diversidad de cultos, que consideraban surgida de la tirantez en el sistema religioso y el espíritu centralizador. La moral del matrimonio debía tender un camino más fácil en toda la provincia y con ese objetivo se presentaba el proyecto de ley, para satisfacer los deseos que desde 1814 se manifestaron en las leyes patrias. ${ }^{61}$

Desde la perspectiva de los jurisconsultos que integraban el alto tribunal, lograr que los jueces letrados administraran pronta justicia, requería quitar de su jurisdicción los pleitos de menor cuantía, “despojados por la insignificancia de su valor e interés jurídico, de todo aliciente para los profesores letrados", que les quitaban tiempo para la meditación y estudio de los asuntos más graves. El aumento de jueces no solucionaría el problema; debían encomendarse estas causas a los jueces de paz, con procedimiento verbal, para descentralizarlos entre las catorce parroquias de la

\footnotetext{
${ }^{59} \mathrm{El}$ tema de los archivos, conflictivo hoy en el sistema judicial, recién se presentaba y fue resuelto en ese momento por los Acuerdos $\mathrm{N}^{\mathrm{o}} 13$ y N 35 de la Suprema Corte, según el artículo 4 de la ley del 21 de octubre de 1873, por el que los expedientes concluidos serían archivados en los juzgados respectivos, en un archivo a cargo de uno de los secretarios nombrado por el Superior Tribunal. ROPBA, 1873, pp. 522-523.

60 "Memoria presentada al Poder Legislativo por la Suprema Corte de Justicia, el 28 de julio de 1877." Acuerdos y sentencias, tomo I, pp. 581-587. (En adelante Memoria de la Suprema Corte, 1877). La creación de la Penitenciaria Nacional fue parte de ese intento de optimización edilicia, pero también marcó la aplicación de las nuevas ideas penales sobre encierro. En 1877 se estrenaron las prisiones de San Nicolás, Dolores y Mercedes. En el mismo año se erigió la Penitenciaría en Buenos Aires, prueba del compromiso de la dirigencia con la reforma punitiva y modelo de referencia para Argentina y América Latina. Caimari, 2004, op. cit. pp. 50-62.

${ }^{61}$ Se refiere a las Ordenanzas Provisionales del Exmo. Cabildo, Justicia y Regimiento de la ciudad de Buenos Aires, del 20 de octubre de 1814. Registro Nacional de la República Argentina. Primera parte, pp. 289-297. El capítulo XI, Del Defensor General de Menores, "inmediatamente encargado del cuidado de los huérfanos y pupilos, de la defensa de sus derechos, y seguridad de sus intereses." Sería función del Defensor de Menores en el Departamento Capital y al juez de paz del partido local en la campaña, otorgar las venias supletorias para celebrar matrimonio los menores huérfanos sin tutor y decidir las cuestiones de disenso, con recurso al juez de $1^{\mathrm{a}}$ instancia respectivo. Las declaraciones de soltura se harían en Capital ante el juez de $1^{\circ}$ instancia civil y en la campaña ante el juez de paz, según la ley del 1 de agosto de 1876. ROPBA, 1876, pp. 187-188.
} 
Capital y los setenta y cuatro partidos de campaña y reducir las costas. Librados los jueces de esta carga, el despacho diario se agilizaría. ${ }^{62}$

Otra cuestión que retardaba el funcionamiento de la justicia era el servicio de subalternaría, asignado a las Cámaras de Apelación por la Corte, extraño a la función de juzgar y que les tomaba mucho tiempo. ${ }^{63}$ Se proponía que, sin cambiar el presupuesto ni el personal, se asignara la tarea a otro empleado, para lo cual los agentes fiscales de la Capital fueran dispensados de gestionar los intereses de la Municipalidad y del Departamento de Escuelas, que tenían por ley su representación propia, asignándoles las funciones de subalternaría, llevando una vigilancia más eficaz sobre los protocolos y procesos.

En cuanto a la estructura judicial, el Tribunal proponía una ley dedicada a los secretarios de los juzgados, que además de la limitación, apuntaba fundamentalmente a que los secretarios de actuación dejaran de cobrar costas, que eran altas e iban en contra del objetivo de economía de la buena administración de justicia. La Corte buscaba eliminar todo comercio entre el litigante y el secretario, rentando a éste con el producto que diera un recargo en el sello de actuación, sin un gravamen notable para el público.

Le daban al secretario otro rango, considerándolo funcionario público, convencidos de que sometidos a un arancel no se extirparía el abuso y ofrecían el ejemplo satisfactorio de las secretarías rentadas de los tribunales superiores. Así se desligaría a los litigantes de toda relación de interés con el actuario, "sabiendo que este está obligado a servirle en virtud de la renta con que el Estado remunera sus funciones". Pero para regularizar el buen servicio público debían finalmente reunirse en las secretarías todos los expedientes en tramitación, terminando con lo provisorio del artículo 7 de la ley del 30 de septiembre de 1871, que dejaba los expedientes a cargo del escribano actuante al crearse los escribanos de actuación. ${ }^{64}$

Sin embargo, no bastaba con que la justicia fuera rápida y organizada, la responsabilidad de los magistrados debía ser prontamente legislada -por la urgente necesidad de mantener la dignidad y

\footnotetext{
${ }^{62}$ Memoria de la Suprema Corte, 1878, p. 78.

${ }^{63}$ Los jueces de subalternos tienen su origen en las Leyes de Indias, ley 169, Título XV, Libro II. El presidente de la Audiencia tenía la superintendencia de tribunales y cárceles y toda la materia llamada de subalternaría, por la cual debía nombrar un Oidor cada año para que fuera visitador de sus Ministros y Oficiales. Reemplazada la Real Audiencia por la Cámara de Apelaciones, su Presidente debía cuidar de la policía interior del cuerpo y de la "pureza y exactitud en las funciones respectivas de los subalternos", rotando entre los cinco miembros de la Cámara cada cuatro meses empezando por el orden de su nombramiento. Según el Reglamento de las obligaciones de los subalternos del 23 de abril de 1852 estos eran los escribanos, procuradores y oficiales de justicia. Según el art. 25 del Acuerdo № 5 , Reglamento para las Cámaras de Apelación, “interin no se dicta la ley orgánica de los Tribunales, el Juzgado de subalternos será desempeñado anualmente en el Departamento de la Capital por miembros de las Cámaras de Apelación. Dos de las en lo Civil servirán todo lo relativo a este ramo y un miembro de la en lo Criminal y Correccional lo referente a éstos últimos. El turno principiará por el de menor edad.” Por el artículo $9^{\circ}$ de la Reglamentación de la visita de jueces de subalternos de 1882 la visita debía comprender las Oficinas Departamentales del "Registro de la Propiedad, embargos e inhibiciones", las Secretarías de los Juzgados de $1^{\circ}$ Instancia, Cámaras de Apelación y de la Suprema Corte y las Alcaidías de las Cárceles de Departamento.

${ }^{64}$ Memoria de la Suprema Corte, 1877.
} 
el respeto de la administración de justicia- en la función del jury calificado. ${ }^{65}$ En este pedido el Tribunal aprovechaba la oportunidad de aclarar, en función de su independencia, que no todas las violaciones de deberes cometidas por los magistrados debían ser llevadas al juzgamiento del jury, pues existían faltas para cuya corrección bastaba el poder disciplinario, que la Constitución había atribuido al primer tribunal de la provincia. La Corte pensaba que, de acuerdo con el espíritu constitucional, debían reservar a su jurisdicción el conocimiento de todas aquellas faltas de naturaleza leve, que encontrarían así pronta resolución, dejando las faltas graves, los delitos verdaderos en el ejercicio de la magistratura, al Jury. ${ }^{66}$

\section{c. El Poder Legislativo}

De los temas propuestos por la Suprema Corte, algunos tuvieron respuesta antes de organizado el poder judicial, como la creación de las secretarias, la incompatibilidad de cargos y la abolición de la prisión por deudas. ${ }^{67}$ Otros fueron resueltos en el texto constitucional y organizados en 1875, como los juzgados civiles y comerciales para la campaña. Algunas de estas propuestas fueron sancionadas más tarde, como la abolición de la prueba secreta en junio de $1875,{ }^{68}$ y la ley de jury de enjuiciamiento de magistrados, sancionada el 12 de octubre de 1878, después de largo debate. ${ }^{69}$ La ley de justicia de paz, tan pedida por la Corte, fue sancionada en mayo de 1878, y suspendidos sus efectos en septiembre del mismo año. ${ }^{70}$ Estos ejemplos parecen reforzar la idea de que había una intención de proteger a la propiedad y al propietario, más aún cuando la ley de

\footnotetext{
${ }^{65}$ Memoria de la Suprema Corte, 1876.

66 "La Suprema Corte tiene jurisdicción sobre los delitos y faltas de los magistrados en ejercicio de sus cargos, mientras no se dicten las leyes orgánicas y reglamentarais del artículo 190 de la Constitución, y aún después dictadas, en aquellos casos que no estén comprendidos en ellos”. Resolución en queja del Dr. L.F. López sobre un incidente personal con el juez de comercio Dr. Areco, 14 de julio de 1877, Causa CCXXVIII, en Acuerdo y sentencias, tomo I, pp.669-670.

67 “Abolición de la prisión por deudas, exceptuando los casos por quiebra," ley sancionada el 9 de octubre de 1872. ROPBA, 1872, p. 387.

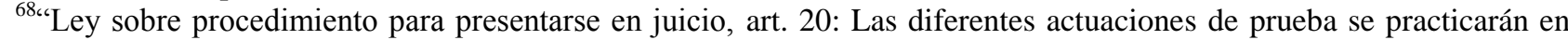
audiencia pública, salvo cuando fuese necesario guardar reserva para evitar escándalo”, 28 de junio de 1875. ROPBA, 1875 , p. 223.

${ }^{69}$ ROPBA, 1878, pp.253-264.

${ }^{70}$ El juez de paz debía convertirse en la base del sistema judicial provincial y para ello era indispensable descentralizar sus funciones y crear un poder municipal a cargo de las jurisdicciones locales. Para esto el texto constitucional establecía que los jueces de paz eran funcionarios exclusivamente judiciales y agentes de los tribunales de justicia - es decir que ya no eran presidentes de las municipalidades de la campaña - y debían ser electos directamente por electores calificados. La forma y tiempo de elección, así como la duración en funciones, debía ser establecida por una ley, que fue promulgada el 23 de mayo de 1878, pero cuyos efectos fueron suspendidos con los de la ley de Municipalidades, el 4 de septiembre, junto con las elecciones de municipales y jueces de paz. ROPBA, 1878, pp. 100-101. Los motivos de la suspensión no fueron expresados pero quedaron de manifiesto en el conflicto que se generó entre el poder ejecutivo y el poder legislativo, sobre la forma alternativa de elección a la que se recurriría hasta que la Justicia de Paz tuviera su ley orgánica. La Legislatura promulgó una ley por la cual mientras se organizara la justicia de paz con arreglo al texto constitucional, los jueces de paz serían nombrados por el poder ejecutivo, a propuesta en terna de la Cámara de Diputados y el Gobierno la vetó. El conflicto fue resuelto por un fallo de la Suprema Corte a favor del Ejecutivo el 24 de enero de 1880. "Poder Ejecutivo Provincial con la Honorable Legislatura sobre un conflicto suscitado con motivo de la sanción de una Ley sobre nombramiento de Jueces de Paz". Archivo de Demandas Originarias de la Suprema Corte de Justicia de la provincia de Buenos Aires, legajo 17, expediente B 1965, año 1880.
} 
enjuiciamiento civil y comercial fue promulgada en $1878,{ }^{71}$ mientras el código de procedimientos criminal se mandaba a redactar en 1881.

Al mes siguiente de presentada la Memoria de la Suprema Corte de 1876, en la sesión del 6 de julio, la Comisión de Legislación de la Cámara de Senadores se había ocupado del proyecto presentado sobre venias supletorias y declaraciones de soltura, aconsejando su adopción con modificaciones. ${ }^{72}$ Según la presentación, el Defensor de Menores en Capital y los jueces de paz en campaña otorgarían las venias supletorias para matrimonios de menores huérfanos sin tutor, y los disensos con recurso a primera instancia. Las declaraciones de soltura las haría el juez de primera instancia en Capital y los jueces de paz en campaña. Pero la Comisión proponía que las venias y las solturas fueran dados en primera instancia, como los disensos, con apelación a la Cámara respectiva, ya que antes eran atribución de la Cámara de Justicia, lo que manifestaba su importancia y la necesidad de ser competencia de jueces letrados, pues podían afectar "intereses trascendentales en el orden de las familias", logrando igualmente la descentralización que buscaba la Corte. Así fue votado y aprobado en general y en particular. ${ }^{73}$

El 28 de julio la Comisión de Legislación de Diputados ${ }^{74}$ se ocupó del proyecto remitido por el Senado, aconsejando la sanción; pero el diputado Juan Manuel Ortiz de Rozas, que iniciaba una profusa carrera legislativa y política, consideraba "más liberal" el proyecto de la Suprema Corte pues

para llegar a los centros de los departamentos judiciales, en muchos casos hay que recorrer diez, quince o veinte leguas y más, y que, por consiguiente, podría suceder que muchas personas, que podrían llegar a la unión legítima pudiendo fácilmente obtener la venia para casarse, continúan viviendo en concubinato, porque no hay facilidad para obtener esa venia, ni los medios para costear las actuaciones ante un juez letrado. ${ }^{75}$

Los menores que caían bajo esa ley eran los pobres, los desheredados, ya que aquellos que tuvieran bienes, seguramente tendrían tutor y así se le facilitarían las cosas para llegar a la unión legítima.

De este planteo relativo al acceso a la justicia, pasamos al conocimiento del jurista Roque Suárez, que recordaba que en la letra del código civil ambos juicios, venia y soltura, requerían de antecedentes y un juicio informativo, por lo que era necesario que interviniera un juez letrado. Pero Rozas insistía en las ventajas de poner al juez al alcance del interesado y por eso votaba por el artículo propuesto por la Suprema Corte, que consideraba tribunal muy competente en el asunto. Finalmente fue aprobado el proyecto de la Comisión, y el 1 de agosto sancionada la ley, lo cual

\footnotetext{
${ }^{71}$ ROPBA, 1878, pp. 317-429.

${ }^{72}$ La comisión estaba compuesta por Alfredo Lahitte y Rafael Ruíz de los Llanos. Senadores, 1876, pp. 236-237.

${ }^{73}$ Senadores, 1876, p. 236.

${ }^{74}$ Comisión de Legislación: Roque Sáenz Peña, Carlos L. Marenco, Vicente Villamayor, Roque Suárez.. Diputados, 1876, pp. 420-422.

${ }^{75}$ Diputados, 1876 , pp. $420-421$.
} 
tuvo varias implicancias. ${ }^{76}$ Por un lado prevaleció la justicia letrada sobre la lega y el concepto de acceso fácil y rápido a los tribunales no fue considerado. Pero fundamentalmente, en un proyecto presentado por la Corte, los abogados del poder legislativo se imponían al criterio de los abogados que llevaban años formando parte del poder judicial.

Esto era así quizás porque en Argentina la relación entre el mundo de la ley y la composición de las elites políticas se hicieron visibles en los abogados que fueron legisladores o jueces ${ }^{77}$, pero una vez sancionada la ley que impedía que los magistrados fueran legisladores, estaba en juego no sólo la división de poderes sino el posicionamiento doctrinario respecto a su modelo, los legisladores sancionaban las leyes y los jueces las aplicaban teniendo sus propuestas poco peso a la hora de decidir. ${ }^{78}$

Respondiendo a otra cuestión, el cuerpo legislativo trató el pedido de creación de dos secretarías para cada uno de los juzgados civiles y comerciales, a partir de un proyecto presentado por un joven diputado abogado, Carlos Molina Arrotea, ampliando la ley del 30 de septiembre de 1871 que creaba los escribanos secretarios. ${ }^{79}$ El 11 de agosto de 1876 la Comisión de Legislación ${ }^{80}$ presentó el proyecto y en la sesión del 25 de agosto Suárez explicó que la propuesta buscaba aliviar el trabajo extraordinario que pesaba sobre los jueces, que no podían aumentarse por consideraciones económicas, remediando esos inconvenientes en gran parte al facilitar el despacho con más secretarios.

En el debate Lucio Vicente López ofreció una magnífica descripción de la tarea que realizaban los secretarios en los juzgados:

...ejercen funciones propiamente de escribanos, pues ponen todos los despachos en que no es necesaria la intervención del Juez ¿Por qué? Porque no tienen la práctica que les da suficiente competencia para proponer al juez la fórmula de sus despachos. Esto lo vemos diariamente; no hay día que un Secretario no tenga un cúmulo inmenso de despachos; está en perfecto conocimiento de las causas que por el Juzgado tramitan, circunstancia que los habilita para dar a las partes los antecedentes necesario, lo que contribuye a regularizar y a acelerar el movimiento de la administración. Se trata sencillamente de distribuir el trabajo, y no hay sino que hacer esta deducción: si un juez con cuatro escribanos marcha regularmente, con ocho tiene que marchar con más regularidad. ${ }^{81}$

La discusión se centró, una vez aceptado el proyecto, en la inclusión de las dos secretarías de los juzgados comerciales del proyecto original, que Julio Fonrouge ${ }^{82}$ quería que se mantuvieran,

\footnotetext{
${ }^{76}$ ROPBA, 1876, pp. 187-188.

${ }^{77}$ Zimmermann, 1999, pp. 104-123.

${ }^{78}$ Un estudio de los modelos posibles de división de poderes en Egües, Carlos, "Las ideas políticas en el constitucionalismo argentino del siglo XIX. Un aporte metodológico", en Revista de Historia del Derecho del Instituto de Investigaciones de Historia del Derecho, No 24, 1996, Buenos Aires, pp. 45-62; Pérez Guilhou, 1997, op. cit..

79 "Ley de creación de secretarías para los juzgados de $1^{\circ}$ instancia”. ROPBA, 1876, pp. 231-232.

${ }^{80}$ Comisión de Legislación: Roque Suárez, Rafael Cobo, Marcos Paz. Diputados, 1876, pp. 577-581.

${ }^{81}$ Diputados, 1876 , pp. 578.

${ }^{82}$ El 31 de enero de 1877 Julio Fonrouge fue nombrado juez de $1^{\circ}$ instancia comercial del Departamento de la Capital en lugar de Juan C. Lagos. ROPBA, 1877, p. 35.
} 
porque cada juzgado tenía un despacho de quinientos expedientes diarios y la demora en los asuntos comerciales hacía perder millones de pesos, agregándose finalmente al texto "y comercial”. El segundo artículo presentó un problema que a lo largo de estos años sería muy difícil de resolver, mientras los secretarios fueran retribuidos por las costas de los pleitos: el reparto de las causas pendientes.

Para algunos diputados, como Roque Sáenz Peña también del foro y apoyado por Fonrouge y López, se trataba de una cuestión de administración judicial, que debía ser reglamentada por la Suprema Corte, desde la superintendencia que ejercía sobre el Poder. Además, quitarle los expedientes en trámite a un escribano era una usurpación, definiéndolos como algo que les pertenecía, que era de su propiedad, elegidos por su crédito y honorabilidad. A esto Molina Arrotea respondió que no se arrebataba nada, pues antes de trasladar el expediente era tasado y sus costas pagadas. La ley aprobada fue presentada en sesión del 21 de septiembre en Senadores, sin el artículo que establecía el reparto proporcional y equitativo de las causas en tramitación, entre los secretarios en funciones y los creados por la nueva ley. ${ }^{83}$ Aquí primaba el interés de los abogados de lograr un más rápido despacho, sin perjudicar a los escribanos que ya tenían sus causas en tramitación.

El reparto de las causas era muy conflictivo y se basaba en el concepto -para algunos legisladores juristas- del expediente como una especie de propiedad privada. Esta surgía de la libre elección que habían hecho de su trabajo los litigantes y tal vez porque se trataba de escribanos con su propio registro, que vivían de las costas que esos litigios les dejaban. Para otros era propiedad privada, pero quedaba saldada con la liquidación de costas. Desde la perspectiva del mejor servicio público, el abogado diputado Luis María Sarmiento presentó un proyecto el 30 de mayo de 1877 , derogando el artículo $7^{\circ}$ de la ley del 30 de septiembre de 1871. Había sido adoptado en su momento como medida de circunstancia, inconveniente a la administración y al buen despacho, pero era necesario completar la ley, concentrando todos los expedientes en las secretarías que existían para regularizar el trabajo.

Según la propuesta de la Corte, el proyecto mandaba a repartir proporcionalmente los expedientes de los escribanos que no fueran secretarios, por los jueces entre sus secretarios, previa regulación de costas. ${ }^{84}$ Apoyado, pasó a la Comisión de Legislación ${ }^{85}$ y el 6 de junio Suárez lo presentó, recordando que estaba en la Memoria de la Suprema Corte, y lo recomendaba

\footnotetext{
${ }^{83}$ Senadores, 1876, pp.493-496.

${ }^{84}$ Artículo $1^{\circ}$ "Los expedientes servidos por escribanos que no sean secretarios, serán repartidos proporcionalmente por los jueces que conocen de ellos entre sus secretarios, previa regulación y testimonio de las costas y planillas que podrán expedirse en papel común con cargo de reposición cuando el pago se efectuare". Artículo $2^{\circ}$ "Queda derogado el artículo $7^{\circ}$ de la ley de 30 de Septiembre de 1871'. Luis M. Sarmiento. Diputados, 1877, tomo I, pp. 136-137

${ }^{85}$ Diputados, 1877, pp.180-187.
} 
encarecidamente, pues respondía a una conveniencia pública y una necesidad de buen servicio, agregando una descripción de los cambios en el trabajo judicial:

....antes de la ley de 1871, que creó las Secretarías, los asuntos civiles o comerciales se iniciaban indistintamente por cualquiera de los Escribanos, y estos desempeñaban a la vez las funciones de Escribanos de Registro y de Actuación. Cualquiera de estos Escribanos llevaba al despacho el expediente que se iniciaba en su oficina a fin de obtener las providencias necesarias. La ley de 1871, al crear las Secretarías, tuvo dos objetos: separar las funciones de Escribano de Registro de las Escribanías de Actuación, funciones que aglomeradas en la misma persona, perjudicaban el buen servicio público, dificultando la pronta tramitación de los expedientes y dificultando también las propias funciones de los Escribanos de Registro. Además tuvo en vista otro objeto, y fue el siguiente: los escribanos que actúen serán de reconocida competencia y de aptitudes apreciadas por el mismo juez que despacha o conoce en el asunto. Por eso se autoriza a los jueces para que propongan el nombramiento de estos escribanos, debiendo la Corte Suprema aprobar las propuestas que se le hicieran. ${ }^{86}$

El objetivo fundamental era reconcentrar los expedientes en las secretarías, para que el despacho diario se regularizara. Pero además, se determinaba con claridad quienes serían los escribanos secretarios, teniendo en cuenta la relación que se establecía con el juez, al facultarlo para la elección. Pero la discusión continuó entre una y otra postura, y el proyecto fue desechado.

Otra cuestión de difícil solución, que se resolvió finalmente cuando la capital ya no pertenecía a la provincia, fue el de la casa de justicia, que implicaba la idea de que jueces y secretarios ocuparan un mismo lugar, dedicados exclusivamente a tramitar los expedientes. El tema del edificio había comenzado antes de la Constitución, cuando al decidirse la construcción de una cárcel, por ley del 3 de agosto de 1872, se mandó la realización de planos y presupuestos para la refacción de la casa de justicia y cárcel. El poder ejecutivo debía ocuparse para que funcionaran allí todas las salas del Superior Tribunal y juzgados inferiores con sus secretarías y archivos, expresión espacial de la voluntad de construir un poder judicial. La obra sería dirigida por el ingeniero que presentara los planos más adecuados y las condiciones de trabajo más favorables, y hasta que se realizara debía darse a los juzgados de primera instancia una casa invirtiendo hasta veinticinco mil pesos mensuales. $^{87}$

Pero el proyecto no avanzó, tal vez por falta de apoyo económico del poder ejecutivo, o negligencia para comprender lo que significaba la cuestión edilicia en el funcionamiento de la administración de justicia. ${ }^{88}$ Este fue un conflicto recurrente desde el inicio de la organización judicial provincial. En los primeros años la Cámara de Apelaciones no contaba con medios operativos, llegando a convertirse la provisión de pluma y papel en una decisión política. La precariedad edilicia quedó reflejada en los pedidos de los jueces que iban desde la construcción de

\footnotetext{
${ }^{86}$ Diputados, 1877, p. 181.

${ }^{87}$ ROPBA, $1872,317$.

${ }^{88}$ Sobre los problemas que generaba la escasez de recursos materiales en la justicia federal ver Zimmermann, 1998, pp. 135-140; 2007, pp. 278-279.
} 
un baño, hasta reformas indispensables para hacer habitables los lugares de trabajo, que definían como un páramo. Durante los gobiernos de Rosas la situación no mejoró, multiplicándose las demandas del Tribunal Superior, magistrados y otros funcionarios en pro de más presupuesto y mejoras estructurales. ${ }^{89}$

Pasaron algunos años hasta que el Departamento de Ingenieros recibió la orden de proyectar las refacciones necesarias para la instalación de los tribunales en la antigua cárcel, poniéndose de acuerdo con el presidente de la Suprema Corte. Terminados los planos y presupuestos de las obras, el poder ejecutivo debía remitirlos al legislativo para la resolución correspondiente. ${ }^{90}$ El 24 de octubre de 1879 se sancionó la ley autorizando invertir hasta dos millones de pesos moneda corriente para continuar las obras de arreglo y dotar al edificio de mobiliario, obteniendo los fondos necesarios de la venta de tierras públicas. Las escribanías de registro y los secretarios de actuación debían tener oficina allí y abonar a Rentas generales el alquiler mensual determinado por el ejecutivo. $^{91}$

El pago de alquiler era una cuestión altamente conflictiva, que encerraba una disyuntiva no resuelta sobre el papel de los secretarios escribanos. Para el senador Juan Carlos Lagos, que había sido juez de comercio, los secretarios de un juzgado eran tan empleados "como el último de los escribientes del Ministerio de Gobierno", y fijarles una renta era injusto, como era ya impropio que su sueldo, que debía fijarse en el presupuesto, surgiera de sus costas. Para Rufino Jacobo Varela, el escribano de actuación tenía las costas y eso no era propiamente un sueldo, era una utilidad industrial, era como escribano que podía ser secretario de actuación, y era como escribano que tenía un arancel, que le asignaba una remuneración para esa industria. Estas eran las posturas más extremas en relación a estos funcionarios judiciales que hasta 1914 no fueron incorporados al

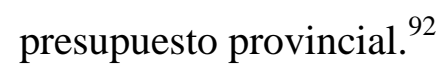

De la mano del conflicto edilicio se presentaba en el debate la preocupación por el archivo general, que debía ocupar el mismo edificio, fundado esto por Varela en que no podían estar esos documentos esparcidos en las oficinas dejando "los protocolos que contienen documentos valiosísimos, [...] a merced de cualquier pillastre que se le ocurra horadar un muro y alzarse con ellos, o que se incendie la casa y se acabó el archivo".93

Terminadas las obras de la casa de justicia, por decreto del gobernador Rocha del 6 de agosto de 1881, se dispuso su distribución y administración. Nombró una Comisión compuesta por Manuel H. Langenheim, José Fernández y Ambrosio Lezica, que de acuerdo con la Suprema Corte, por la

\footnotetext{
${ }^{89}$ Barreneche, 2001, op. cit., p. 106-108.

${ }^{90}$ Ley del 18 de septiembre de 1877. ROPBA, 1877, pp. 311-312.

${ }^{91}$ ROPBA, 1879, pp. 508-509.

${ }^{92}$ Ley No 3545 del 26 de enero de 1914 suprimiendo las costas de secretaría e incorporando el cargo de secretario al presupuesto provincial. ROPBA, enero-junio 1914, pp. 105-110.

${ }^{93}$ Senadores, 1879 , pp. 787-792.
} 
superintendencia del poder judicial, redactó el reglamento y distribuyó la casa. ${ }^{94}$ Pero esto fue en carácter de préstamo, pues Buenos Aires, cedida el 6 de diciembre de 1881 para capital de la República, ya no era la capital provincial y los magistrados se instalaron allí hasta que en 1884 fue terminado el Palacio de Justicia en la ciudad de La Plata, flamante ciudad capital de la provincia.

\section{Conclusión}

Para establecer cómo se organizó el poder judicial después de la Constitución provincial de 1873 y analizar la participación de los tres poderes en la organización del nuevo poder, comenzamos este capítulo conociendo los cambios que se habían producido entre el inicio de la Convención Constituyente y la instalación de la Suprema Corte. De este modo, pudimos saber no sólo cómo era el poder judicial al momento de su instalación, sino fundamentalmente cuáles eran las cuestiones prioritarias desde la perspectiva de quienes tenían en sus manos los cambios estructurales.

La creación de las secretarías de primera instancia marcó un primer paso fundamental, que de la mano de la incompatibilidad de empleos, fijaban el perfil del profesional que dejaría las escribanías de registro o la actividad política, para dedicarse exclusivamente a la administración de justicia. El cargo de secretario de primera instancia iría luego, incluso más allá del período de nuestro estudio, definiéndose y profundizándose con el sueldo fijo y la especialización por fuero. Por ejemplo, la Suprema Corte aspiraba a un secretario de primera instancia con exclusividad en la función de actuación, con un espacio físico común con su juez y un sueldo que eliminara las costas, propiedades que se alcanzarán paso a paso y luego de largas discusiones. A su vez, el juez a cargo de la secretaría debía también estar dedicado exclusivamente a la justicia, dejando toda actividad política.

Una vez sancionada la Constitución provincial era necesario determinar y aceptar qué rol jugaría cada uno de los poderes, incluso el mismo "nuevo Poder Judicial” en su conformación. Había temas en común, pero lo que variaba era la forma de resolverlos, la urgencia en hacerlo y los medios para alcanzarlos, que no eran siempre los mismos para cada poder. Incluso dentro del mismo poder legislativo, que corría con la última responsabilidad al ser quien sancionaba las leyes, aunque le quedara al gobernador la atribución del veto. Los legisladores siguieron las cuestiones propuestas de la Suprema Corte, pero no siempre respetaron el contenido del proyecto y de hecho, en el caso de la distribución de expedientes entre los secretarios, ni siquiera lo sancionaron.

El gobernador solicitaba los proyectos al Tribunal Superior, pero nada les aseguraba que fueran así sancionados, ni tampoco había en el camino legislativo ninguna consulta o pedido de opinión. Lo que sucedió finalmente con las leyes lo hemos visto a lo largo del capítulo, pero es

\footnotetext{
${ }^{94}$ ROPBA, 1881, pp. 461-463; 495-501.
} 
importante destacar tres cuestiones que emergieron en los debates y que resurgirían a la hora de decidir la organización y funcionamiento de la justicia: el concepto de administración de justicia como buen servicio público, el expediente como propiedad o trabajo del escribano y el alcance de la superintendencia de la Suprema Corte, que se relacionaba directamente con la independencia del poder judicial.

La justicia, en las Partidas españolas, estaba definida como "una de las cosas porque mejor y más encarecidamente se mantenía el mundo, haciendo vivir a cada uno en paz, según su estado".95 Llevado a la legislación indiana, "la buena administración de justicia es el medio en que consisten la seguridad, quietud y sosiego de todos los estados". ${ }^{96}$ Ese concepto medieval de justicia como virtud había guiado la organización judicial y política indiana, pero en el siglo XIX la tendencia fue recortarlo, en base a la separación de moral y religión del derecho, las concepciones individualistas, la aceptación de la división de poderes y el absolutismo de la ley. Surgió así una justicia externa, legal, propia de un poder del Estado, que más que buscar el bien de la comunidad iba tras la defensa de la seguridad individual. ${ }^{97}$ Este cambio se fue produciendo lentamente y como pudimos apreciar, llegando a su fin los años de la “organización nacional”, la administración de justicia se identificaba con el buen servicio público, concepto de una cultura legal que superaba los argumentos económicos y de mera eficiencia, centrándose en la independencia de poderes, que garantizaba las libertades públicas.

Esta concepción de la administración de justicia, que pasó de estar basada en una virtud a convertirse en un servicio, nos explica la enorme dificultad en definir el valor del expediente judicial y de quiénes debían participar de su resolución, cosa que en estos años no logró resolverse. Pero no se trataba de una disyuntiva, sino de la evolución del expediente como propiedad, trabajo o industria del escribano, que las partes le habían encomendado y que no le podía ser quitado, aún mediando el pago de las costas. Durante este recorrido histórico, dichas piezas jurídicas terminaron siendo un documento público de carácter privado, llevado adelante por funcionarios judiciales formalmente incorporados a la estructura administrativa del gobierno provincial y con renta permanente contemplada en el presupuesto estatal.

La superintendencia de la Suprema Corte habilitaba y obligaba a sus magistrados a enfrentar los conflictos internos, debiendo ejercer control y poder disciplinario, y surge aquí en relación a diversas cuestiones. Para el gobernador, la cabeza del poder judicial ejercía su superintendencia como responsable de formular proyectos que lo pusieran en funcionamiento. Para algunos legisladores, abarcaba cuestiones de la administración de justicia que incluía el reparto de los

\footnotetext{
${ }^{95}$ Part. $3^{\text {a }}$, tít. I, proemio y ley 2.

${ }^{96}$ Recopilación, I, X, 2. Zorraquín Becú, 1952, op. cit., pp. 7-9.

${ }^{97}$ Tau Anzoátegui, 1973, p. 211.
} 
expedientes y el mismo poder hizo uso de ella al reglamentar y distribuir el uso de la casa de justicia. Pero ciertamente, la Constitución de 1873 fue limitando el uso de la superintendencia de la Suprema Corte, siendo el ejemplo más importante el enjuiciamiento de los magistrados considerado necesario por los mismos jueces- que hasta ser organizado, siguió rigiéndose por el antiguo procedimiento de superintendencia, que comprendía la corrección disciplinaria, la suspensión, mandato de enjuiciamiento y pena del delito o falta grave, o bien la adopción de otra medida administrativa". 98

Penetrando en los proyectos, debates y propuestas de los diversos funcionarios provinciales durante este tiempo de puesta en marcha de la nueva estructura judicial bonaerense, contribuimos también en la discusión historiográfica sobre la naturaleza de los cambios y continuidades de la justicia decimonónica. Entre la mirada general del jurista o el legislador, rescatada por el historiador del derecho, y aquella de la praxis y aplicación de las normas en la sociedad, que han interesado al historiador social, nos encontramos frente al despliegue de un amplio repertorio de ideas y proposiciones encarnadas por diversos actores que intervienen en darle forma al poder judicial en estudio. Quienes las enuncian, no parecen seguir un único libreto. De allí que la cuestión de qué cambia y qué sigue en la justicia que los bonaerenses van a heredar en el siglo XX, no puede ser resuelta con simples generalizaciones. La complejidad del momento histórico analizado así lo indica, o al menos eso es lo que hemos querido remarcar.

\footnotetext{
${ }^{98}$ Resoluciones dictadas con motivo de la venida a la capital, sin licencia (según art. 24 de su reglamento), del camarista Dr. Benítez, y de los sucesos ocurridos en la casa de Justicia del departamento del Norte en 28 de septiembre último, 18 de octubre de 1877. Acuerdos y sentencias, tomo I, pp. 641-643.
} 


\section{Capítulo IX}

\section{EI “nuevo" Poder Judicial en funcionamiento (1875-1881)}

\section{Introducción}

El texto constitucional provincial de 1873 estaba sancionado y el poder judicial que de él surgió debía ser puesto en funcionamiento. Las leyes reglamentarias que la Constitución dejaba a los legisladores tuvieron distintos tiempos de maduración y en muchos casos no llegaron a concretarse, pero lo cierto es que después de casi dos años, el 23 de enero de 1875, el gobernador de la provincia Álvaro Barros dejaba sentada la instalación de la primera Suprema Corte de Justicia. Sus miembros, Sixto Villegas, Alejo B. González, Sabiniano Kier, con la ausencia autorizada de Carlos Tejedor y bajo la presidencia de Manuel María Escalada, prestaron juramento en audiencia pública. Debían entonces organizarse los demás tribunales y juzgados, nombrándose magistrados y funcionarios. ${ }^{1}$

El Alto Tribunal se estableció en la capital de la provincia con cinco jueces y un secretario letrado, nombrado de igual manera que los miembros de la Corte. El Departamento Capital tenía dos Cámaras de Apelación en lo civil y una para lo criminal y comercial. En la campaña se organizaron tres Cámaras de Apelación en los Departamentos del Sud, del Centro y del Norte, cada una con jurisdicción civil, mercantil y criminal, con residencia en las tres ciudades cabecera, Dolores, Mercedes y San Nicolás. Cada Cámara se integraba con tres jueces letrados y un secretario letrado, nombrados de igual manera. El poder ejecutivo designaba cuatro jueces de primera instancia en lo civil, tres en lo criminal y dos en lo comercial, con residencia en la ciudad capital, y para la campaña un juez con jurisdicción civil y comercial y otro con jurisdicción criminal para cada Departamento.

Según la Constitución los jueces letrados debían ser elegidos por el poder ejecutivo con acuerdo del Senado (art. 184) ${ }^{2}$ y conservarían sus empleos mientras durase su buena conducta (art. 185). Para ser juez de la Suprema Corte se requería ciudadanía en ejercicio, título de abogado, entre treinta y setenta años de edad, seis de ejercicio en la profesión en alguna magistratura o empleo judicial, bastando cuatro para las Cámaras de Apelación (art. 186). Para ser elegido juez de primera instancia era necesario ciudadanía en ejercicio, título de abogado y veinticinco años de edad.

Una vez instalada la Legislatura en 1874, debía dictar las leyes orgánicas y reglamentos, pero si no lo hacía, la Suprema Corte propondría los proyectos correspondientes para el período 1875.

\footnotetext{
${ }^{1}$ Para distintos lugares de la provincia, no para su totalidad, trabajaron sobre los mecanismos institucionales de acceso, promoción y alejamiento de la magistratura Fasano, Juan Pablo, 2009, op. cit.; Sedeillan, 2012, op. cit.; Yangilevich, 2012, op. cit.

2 "Constitución de la provincia de Buenos Aires de 1873", en Corbetta, Juan Carlos, Textos constitucionales de Buenos Aires, Suprema Corte de Justicia de la provincia de Buenos Aires, 1984.
} 
Durante el receso de las Cámaras, el poder ejecutivo podía llenar las vacantes sin acuerdo del Senado, por nombramientos en comisión que cesarían treinta días después de abiertas las sesiones ordinarias (art.142, inc. 14). Pero a estas condiciones para los nombramientos se sumaban las dispuestas en las "Disposiciones transitorias", por las cuales si la Legislatura no dictaba las leyes indicadas antes de marzo de 1874, el poder ejecutivo, después de ser instalada la Legislatura en el mes de mayo, nombraría todos los jueces de los Tribunales de Justicia, determinando las condiciones en que debían realizarse (art. 217).

Con respecto a la justicia de paz, la Legislatura tendría que dictar su ley orgánica y organizar la elección directa que esa Constitución disponía, pero entre tanto el poder ejecutivo seguía nombrando sus funcionarios y la justicia correccional continuaba igual hasta que aquella ley fuera sancionada. Esto generó un fuerte conflicto entre poderes pues el 4 de junio de 1879 fue sancionada una ley por la cual se establecía que mientras no se pusiesen en vigencia las leyes Orgánicas de Municipalidades y de Justicia de Paz, el nombramiento de los jueces de paz sería hecho por el poder ejecutivo de ternas que le presentaría la Cámara de Diputados. Para el Gobierno, las disposiciones de la ley importaban una violación a la carta fundamental. Ante la insistencia de las Cámaras el caso fue sometido a la Suprema Corte, para que resolviese el conflicto entre los dos Poderes, en virtud a las atribuciones que le confería el artículo 156 de la Constitución, y la ley fue declarada inconstitucional.

Las leyes del 30 de junio de 1874 organizaron en forma provisoria el Ministerio Fiscal y el Ministerio de Pobres y Menores. Mientras se dictaran las leyes orgánicas del poder judicial, el Ministerio Fiscal sería desempeñado en el Departamento de la Capital por un Procurador General de la Suprema Corte, un fiscal de las Cámaras de apelación, dos agentes fiscales en lo civil y uno en lo criminal. En los demás departamentos judiciales estaría a cargo de un agente fiscal en lo civil y criminal para ambas instancias. El Procurador y el fiscal tendrían las mismas condiciones de los tribunales de los que formaban parte y serían nombrados de igual manera. Los agentes fiscales requerirían las condiciones del juez de primera instancia y serían nombrados directamente por el poder ejecutivo. Todos tendrían el sueldo señalado por la ley y no podrían abogar. ${ }^{3}$

Los Ministerios de Pobres y Menores se mantendrían igual en el Departamento Capital, con dos defensores de menores y dos asesores, y un defensor de pobres con un asesor. En los demás departamentos judiciales la ley disponía que en los partidos que los componían, el procurador municipal se ocuparía de todos los asuntos extra-judiciales relativos al cuidado de la persona y bienes de los menores, y en los judiciales los representaría ante el juez de paz. En los asuntos tramitados ante los tribunales de primera y segunda instancia sería un letrado que no podría abogar,

\footnotetext{
${ }^{3}$ ROPBA, 1874, p. 367.
} 
quien representaría al menor siendo también asesor de los defensores de los partidos en todo caso de consulta o consejo. ${ }^{4}$ Los defensores de pobres y de menores eran nombrados anualmente por decreto del gobernador.

Conociendo la estructura que el sistema judicial tendría, el objetivo de este capítulo es determinar entre 1875 y 1881 quienes lo conformarían, reflejando todos los movimientos de personal (nombramientos, renuncias, fallecimientos, reemplazos, etc.). Es por esto que volcamos la investigación en cuadros comenzando por los primeros nombramientos realizados el 27 de agosto de 1874 por decreto del poder ejecutivo en cumplimiento de lo dispuesto en el art. 217 de la Constitución provincial de 1873 y en la ley del 30 de junio de 1874, con acuerdo del Senado del 26 de agosto de 1874.

La información recopilada presenta un potencial de pesquisa superlativo. A la vista de los datos que están sintetizados en los cuadros, pueden surgir numerosos interrogantes y sugerencias. Una de ellas, sin duda, es la posibilidad de realizar un estudio prosopográfico, centrado en este momento histórico en el que maduró la conformación inicial del poder judicial bonaerense. Desde esta perspectiva, la compilación hecha resultaría insuficiente. Sin embargo, debemos señalar que llevar a cabo una investigación de este orden puede resultar un trabajo muy empeñativo que, por si solo, amerita otra tesis doctoral.

Queda clara la importancia de tal emprendimiento. Casi todas las antologías que reúnen trabajos sobre la denominada Nueva Historia de la Justicia, así lo sugieren. ${ }^{5}$ Conocer la procedencia, perfil social, formación profesional, trayectoria de vida de estos magistrados, aportaría un abanico de información cuyas consecuencias analíticas e historiográficas serían importantísimas. Sin embargo, pocos han podido llevar a cabo estas biografías colectivas. En este contexto, consideramos que esta "instantánea" tomada al poder judicial bonaerense en la segunda mitad de la década de 1870, resulta un (imprescindible) primer paso que puede devenir en la base para una indagación ulterior.

\footnotetext{
${ }^{4}$ ROPBA, 1874, p. 368. El desempeño del Procurador municipal como defensor de menores en la campaña podemos confirmarlo en una consulta realizada por el juez de paz de Azul, Florencio Andrade, el 3 de julio de 1885 al ministro de gobierno Nicolás Achával, pidiéndole que deslindara las atribuciones del procurador municipal sobre gestiones relacionadas con menores o sus intereses. El ministro la elevó al fiscal que aconsejó elevarla a la Suprema Corte. Esta respondió que por la ley del 16 de octubre de 1854 (art. 65 "Desempeñará las funciones de Defensor de Pobres y Menores y cuidará de la defensa y seguridad de los intereses y derechos de éstos, interviniendo en todo inventario, y en todo asunto en que versen intereses de aquellos. Cuidará de la educación y bienestar de todo huérfano, ejerciendo por su Ministerio la falta de los padres naturales"), como por el Reglamento de la Defensoría General de Menores del 4 de agosto de 1884, el Procurador Municipal, "tiene como Defensor de Menores en los partidos de campaña las mismas atribuciones y deberes que corresponden al Defensor General en la Capital." Archivo de la Suprema Corte, expediente A-8084, 1885.

${ }^{5}$ Véanse, por ejemplo, las compilaciones de Zimmermann, 1999, op. cit.; Salvatore, Aguirre, ,Joseph, 2001, op. cit.; Gayol, y Kessler, 2006, op. cit.; Fradkin, 2007, op. cit.; Palacio, Juan Manuel y Candioti, Magdalena, -compiladoresJusticia, política y derechos en América Latina, Buenos Aires, Prometeo Libros, 2007; Caimari, Lila, (compiladora) La ley de los profanos. Delito, justicia y cultura en Buenos Aires (1870-1940), Buenos Aires, FCE, 2007; Barriera, 2009, op. cit.; Barriera, 2010, op. cit.; y, recientemente, Salvatore, Ricardo y Barreneche, Osvaldo, El delito y el orden en perspectiva histórica, Rosario, Prohistoria Ediciones, 2013.
} 
Los nombramientos de muchos de estos magistrados y funcionarios se concluyeron el 18 de enero de 1875, con acuerdo del Senado, y con nombramientos individuales cuyas fechas señalamos en cada caso. Una vez que completamos un cuadro básico para 1875, lo cotejamos con los listados publicados por el secretario de la Suprema Corte, Aurelio Prado y Rojas, para 1876 y $1879 .{ }^{6}$ A partir de esta estructura básica fuimos revisando los nombramientos en los Registros Oficiales, buscando definir quien dejaba el cargo, por qué razón y poder judicial por quién era reemplazado. Además agregamos las leyes que modificaban la estructura del poder judicial y los presupuestos anuales nos permitieron confirmar los cambios estructurales. Como puede observarse, la única forma de expresar en forma clara y completa esta estructura y sus modificaciones era a través de cuadros, especialmente porque el objetivo no es solo dar nombres sino determinar el origen y la organización de los órganos que conformaron el poder.

Con estos datos presentamos al poder judicial a partir de su instalación según la estructura determinada por la Constitución provincial de 1873, dividido en Suprema Corte de Justicia y los cuatro departamentos judiciales. A su vez, estos se dividen en cámaras de apelación, juzgados de primera instancia y ministerio público. Las cuatro columnas de los cuadros contienen:

Cargo: nombre del cargo explicando a pie de página las modificaciones que lo afectaron y en caso de corresponder, cómo se determinaban las presidencias. En qué consistía la tarea de los empleados y quién los nombraba.

Nombre: del primer magistrado, funcionario o empleado que ocupó el cargo desde 1875. En el caso de haber tenido antecedentes en la administración de justicia se indicarán a pie de página.

Fecha de nombramiento: a pie de página se indica la ley o decreto y las observaciones necesarias. En caso de ser nombramientos colectivos las indicaciones se realizan una sola vez. En el caso de los escribanos secretarios contamos con muy pocas fechas.

Modificaciones: aquí se indica, según los datos de que se dispone, por qué dejó el cargo (renuncia, cambio de cargo, muerte, exoneración); a dónde va; quien lo reemplaza; de dónde viene el nuevo funcionario; fecha.

Terminamos con un cuadro que muestra cómo termina conformándose el poder judicial según la ley de organización de la administración de Justicia del 29 de diciembre de 1881. Fue nombrado nuevamente todo su personal, permaneciendo gran parte del ya que estaba en funciones. ${ }^{7}$

\footnotetext{
${ }^{6}$ Acuerdos y Sentencias, tomo II, pp. 493-495.

${ }^{7}$ ROPBA, 1881, pp. 586-588; 859-861.
} 


\section{La Suprema Corte de Justicia}

\begin{tabular}{|c|c|c|c|}
\hline Cargo & Nombre & $\begin{array}{l}\text { Fecha de } \\
\text { nombramiento }\end{array}$ & Modificaciones \\
\hline Presidente $^{8}$ & Manuel María Escalada ${ }^{9}$ & 27 de agosto de $1874^{10}$ & \\
\hline Vocal & Sixto Villegas ${ }^{11}$ & 27 de agosto de 1874 & $\begin{array}{l}\text { Reemplazado por Luis } \\
\text { Sáenz Peña } 29 \text { de } \\
\text { diciembre de } 1881 .\end{array}$ \\
\hline Vocal & $\begin{array}{l}\text { Alejo B. González } \\
\text { Garaño }\end{array}$ & 27 de agosto de 1874 & \\
\hline Vocal & Sabiniano Kier ${ }^{13}$ & $\begin{array}{l}14 \text { de diciembre de } \\
1874^{14}\end{array}$ & \\
\hline Vocal & Andrés Somellera $^{15}$ & 25 de agosto de $1875^{16}$ & $\begin{array}{l}\text { Renunció y fue } \\
\text { reemplazado por Víctor } \\
\text { Martínez } 24 \text { de } \\
\text { noviembre de } 1879^{17} \text {. } \\
\text { Reemplazado por } \\
\text { Manuel Langenheim el } \\
29 \text { de diciembre de } \\
1881 \text {. }\end{array}$ \\
\hline Procurador $^{18}$ & Tomás Isla & 20 de octubre de $1880^{19}$ & \\
\hline
\end{tabular}

${ }^{8}$ La presidencia de la Suprema Corte tiene la duración de un año. En 1876 y 1880 fue presidente Sixto Villegas; 1877 y 1881: Alejo B. González Garaño; 1878: Sabiniano Kier; 1879: Andrés Somellera.

${ }^{9}$ Manuel María Escalada fue nombrado agente fiscal en lo civil el 28 de diciembre de 1854. ROGBA, 1854, p. 152. El 13 de septiembre de 1871, en terna con Federico Pinedo y Daniel M. Cazón, reemplazó a Pablo Font en el Superior Tribunal. ROPBA, 1871, p. 546.

${ }^{10}$ Los nombramientos con esta fecha corresponden a la Organización de los Tribunales de la Provincia, por decreto del 27 de agosto de 1874, con acuerdo del Senado del 26 de agosto de 1874. Confirmados en los juramentos del 22 y 23 de enero de 1875. ROPBA, 1874, pp. 436 y 440.

${ }^{11}$ Sixto Villegas fue nombrado fiscal del Superior Tribunal de Justicia el 14 de julio de 1870, dejando el cargo de agente fiscal y permaneció como fiscal hasta la creación del Suprema Corte. ROPBA, 1870, pp. 519-520.

${ }^{12}$ Alejo B. González Garaño fue relator de la Cámara de Justicia y el 22 de octubre de 1857 fue nombrado agente fiscal en lo civil. ROGBA, 1857, p. 161. Después fue juez civil de la Capital y el 14 de octubre de 1863 el Presidente del Senado presentó la terna para elegir miembro del Superior Tribunal de Justicia integrada por Alejandro Heredia, José A. Acosta y Alejo B. González Garaño, quien fue nombrado el mismo día por el Gobierno, dejando el cargo de juez en lo civil de la Capital. ROPBA, 1863, pp. 296-297.

${ }^{13}$ Sabiniano Kier era miembro del Superior Tribunal desde el 18 de mayo de 1872. ROPBA, 1872, p. 248.

${ }^{14}$ En el decreto del 27 de agosto de 1874 fueron nombrados Procurador General Sabiniano Kier y dos vocales que no asumieron, Federico Pinedo y Ezequiel Pereyra. En la sesión del Senado les fue negado el acuerdo a Amancio Pardo y Wenceslao Pacheco para la Cámaras de Apelación de la Capital; José María Cantilo, secretario de la Cámara del Centro; Adolfo Cano, camarista del Norte; Nemesio Rojo y Vicente Peralta, camaristas del Sud y Federico Igarzabal para su secretario; Luis María Sarmiento para juez de primera instancia del Sud. ROPBA, 1874, pp. 436 y 440. Por decreto del 18 de diciembre de 1874, con acuerdo del Senado del 14 de diciembre, Kier junto con Carlos Tejedor fueron nombrados vocales y José María Moreno Procurador General. ROPBA, 1874, pp. 511-512.

${ }^{15}$ Andrés Somellera fue juez en lo civil el 8 de agosto de 1853. ROGBA, 1853, p. 61. Como miembro de la Cámara de Justicia, el 30 de septiembre de 1857 pasó a formar parte del Superior Tribunal. ROGBA, 1857, p. 115-116.

${ }^{16}$ Andrés Somellera fue nombrado miembro de la Suprema Corte por decreto del 24 de agosto de 1875 , con acuerdo del Senado del 14 de agosto de 1875. ROPBA, 1875, pp. 304-305.

${ }^{17}$ Víctor Martínez fue nombrado por decreto del 24 de noviembre de 1879, con acuerdo del Senado, en reemplazo de Andrés Somellera que por enfermedad había renunciado y falleció el 13 de agosto de 1881. ROPBA, 1879, pp. 555-556.

${ }^{18}$ El primer Procurador nombrado, José María Moreno, no asumió, al igual que Antonio E. Malaver el 24 de noviembre de 1879. Desde enero de 1875 hasta octubre de 1880 el cargo estuvo vacante y se desempeñó como Procurador General Interino Benjamín Victorica, designado como tal por el acuerdo extraordinario de la Suprema Corte del 4 de marzo de 1879. Acuerdos y Sentencias, tomo II, pp. 423-424.

${ }^{19}$ Tomás Isla fue nombrado con acuerdo del Senado por decreto del 20 de octubre de 1880. ROPBA, 1880 , p. 618. 


\begin{tabular}{|l|l|l|l|}
\hline Secretario & Aurelio Prado y Rojas & 27 de agosto de 1874 & $\begin{array}{l}\text { Reemplazado por } \\
\text { Miguel Esteves Saguí } \\
\text { (hijo) el 22 de mayo de } \\
1878^{21}\end{array}$ \\
\hline Ujier $^{22}$ & Emilio Miliavaca & & \\
\hline
\end{tabular}

\section{Los Departamentos Judiciales}

\section{a. Departamento Capital}

Cámaras de Apelación

$1^{\circ}$ Cámara en lo civil de la Capital

\begin{tabular}{|c|c|c|c|}
\hline Cargo & Nombre & $\begin{array}{l}\text { Fecha de } \\
\text { nombramiento }\end{array}$ & Modificaciones \\
\hline Presidente $^{23}$ & Carlos Eguía $^{24}$ & 27 de agosto de 1874 & $\begin{array}{l}\text { Por su jubilación fue } \\
\text { nombrado Félix } \\
\text { Benítez el } 24 \text { de } \\
\text { noviembre de } 1879,{ }^{25} \\
\text { juez de la Cámara del } \\
\text { Departamento del } \\
\text { Centro }\end{array}$ \\
\hline Vocal & Enrique Martínez $^{26}$ & 27 de agosto de 1874 & \\
\hline Vocal & Leopoldo Basavilbaso & 18 de enero de $1875^{27}$ & \\
\hline Secretario & Carlos M. Pérez & 27 de agosto de 1874 & \\
\hline
\end{tabular}

${ }^{20}$ Aurelio Prado y Rojas fue nombrado juez de primera instancia en lo civil el 21 de abril de 1873. ROPBA, 1873, p. 231.

${ }^{21}$ Miguel Esteves Saguí (hijo) fue nombrado secretario de la Suprema Corte con acuerdo del Senado por decreto del 22 de mayo de 1878. ROPBA, 1878, p.232.

${ }^{22}$ Según el Reglamento para la Suprema Corte, dictado por la misma en su Acuerdo No 2 del 26 de enero de 1875 , Título IV, art. 46, eran las obligaciones del ujier " $1^{\circ}$ hacer emplazamientos, citaciones, notificaciones, embargos y demás diligencias que se practiquen de orden de la Suprema Corte, fuera de la Audiencia y Secretaría; $2^{\circ}$ ejecutar las ordenes que le diere el Presidente relativas al despacho; $3^{\circ}$ cuidar de que el Portero y Ordenanza cumplan estrictamente con sus obligaciones". Por el art. 47 el ujier no podría percibir costas algunas. Las funciones del portero y el ordenanza estaban definidas en el título VI, arts. 51-55 “el Portero asistirá a las audiencias públicas y hará guardar en ellas el orden y compostura debidos; tendrá a su cargo y responsabilidad las llaves de las puertas exteriores de la Casa de Justicia y las de las Salas de la Suprema Corte. El Portero de la Corte cuidará del aseo y limpieza diaria de la Casa de Justicia para cuyo efecto tendrá bajo sus inmediatas órdenes a las Ordenanzas de la Corte Suprema y Cámaras de Apelación. El Portero y la Ordenanza desempeñarán todas las diligencias que con relación al servicio les fuesen ordenadas por los Vocales o el Secretario de la Corte. Podrán ser removidos por el Presidente”. Según el Presupuesto general de gasto y plan de recursos para el año 1876 (sancionado el 29 de mayo de 1876) la Suprema Corte contaba con dos oficiales $3^{\circ}$, un oficial $4^{\circ}$, celador, ordenanza y portero general. ROPBA, 1876, pp. 100-142.

${ }^{23}$ Los presidentes de sus respectivas Cámaras de Apelación fueron nombrados por decreto del 22 de enero de 1875 , interín se dictase la ley orgánica de los Tribunales, que determinara la forma de elección y duración de los Presidentes de Cámara. ROPBA, 1875, p 14. En 1879 Leopoldo Basavilbaso fue presidente de la Cámara.

${ }^{24}$ Carlos Eguía fue juez de policía correccional en 1857, pero ese mismo año fue nombrado juez de primera instancia en lo civil de la Capital hasta 1863. ROEBA, 1857, p. 309. Desde 1868 hasta 1874 fue miembro del Superior Tribunal de Justicia, elegido de la terna con Agrelo y Cazón, en lugar del juez Carrasco. ROPBA, 1868, p. 471.

${ }^{25}$ ROPBA, 1879 , p. 556.

${ }^{26}$ Enrique Martínez fue juez de primera instancia en lo Comercial entre 1872 y 1874, nombrado por decreto del 8 de noviembre de 1872. ROPBA, 1872, p. 460.

${ }^{27}$ Los magistrados nombrados por decreto del 18 de enero de 1875 tuvieron acuerdo del Senado del 16 de enero de 1875. ROPBA, 1875 , pp. 12-14. 


\begin{tabular}{|l|l|l|l|}
\hline Ujier $^{28}$ & Manuel Garay & $\begin{array}{l}\text { Reemplazado por } \\
\text { Eduardo Reyes en } \\
1879 .\end{array}$ \\
\hline
\end{tabular}

\section{$2^{\circ}$ Cámara en lo civil de la Capital}

\begin{tabular}{|l|l|l|l|}
\hline Cargo & Nombre & $\begin{array}{l}\text { Fecha de } \\
\text { nombramiento }\end{array}$ & Modificaciones \\
\hline Presidente & Luis Beláustegui & 27 de agosto de 1874 & $\begin{array}{l}\text { Reemplazado por } \\
\text { Manuel H. } \\
\text { Langenheim, } \\
\text { presidente de la } \\
\text { Cámara de Apelación } \\
\text { del Centro, el 10 de } \\
\text { abril de 1878. }\end{array}$ \\
\hline Vocal & $\begin{array}{l}\text { Salvador María del Carril } \\
\text { (hijo) }^{30}\end{array}$ & 27 de agosto de 1874 & \\
\hline Vocal & Jorge Damianoviche & 18 de enero de 1875 & \\
\hline Secretario & Omar Landivar & 27 de agosto de 1874 & \\
\hline Ujier & Manuel M. Benítez & & \\
\hline
\end{tabular}

\section{Cámara criminal y comercial}

\begin{tabular}{|l|l|l|l|}
\hline Cargo & Nombre & $\begin{array}{l}\text { Fecha de } \\
\text { nombramiento }\end{array}$ & Modificaciones \\
\hline Presidente & Tomás Isla $^{31}$ & 27 de agosto de 1874 & $\begin{array}{l}\text { Pasó a Procurador } \\
\text { General y fue } \\
\text { nombrado Néstor } \\
\text { French, juez del } \\
\text { crimen del } \\
\text { Departamento Capital, } \\
\text { el 20 de octubre de } \\
1880 . .^{32}\end{array}$ \\
\hline Vocal & Juan E. Barra \\
\hline Vocal & Octavio Bunge $^{34}$ & 27 de agosto de 1874 & \\
\hline
\end{tabular}

\footnotetext{
${ }^{28}$ Según el Reglamento para las Cámaras de Apelación, dictado por la Suprema Corte en su Acuerdo № 5 del 27 de enero de 1875, Título IV, art. 47, eran las obligaciones del ujier " $1{ }^{\circ}$ hacer emplazamientos, citaciones, notificaciones, embargos y demás diligencias que se practiquen de orden de las Cámaras de Apelación, fuera de la Audiencia y Secretaría; $2^{\circ}$ ejecutar las ordenes que le diere el Presidente relativas al despacho; $3^{\circ}$ cuidar de que el Portero y Ordenanza cumplan estrictamente con sus obligaciones”. Por el art. 48 el ujier no podría percibir costas algunas.

${ }^{29}$ ROPBA, 1878, pp. 161-162. Jorge Damianoviche fue entonces presidente de la Cámara.

${ }^{30}$ Salvador María del Carril (hijo) fue juez de primera instancia en lo civil de la Capital entre 1873 y 1874 , nombrado por decreto del 5 de mayo de 1873, sobre la terna presentada por el Superior Tribunal el 3 de mayo con Juan S.

Fernández y Manuel Escobar. ROPBA, 1873, pp. 278-279.

${ }^{31}$ Tomás Isla fue juez del crimen del Departamento del Norte entre 1862 y 1866 . El 19 de marzo de ese año fue elegido su reemplazante por ser removido a juez comercial de la Capital, ocupando ese cargo hasta 1872. El 2 de noviembre de 1872 pasó a ser miembro del Superior Tribunal. ROPBA, 1866, p.33-34 y ROPBA, 1872, p. 447.

${ }^{32}$ ROPBA, 1880 , p. 618.

${ }^{33}$ En 1863 fue juez en lo comercial de la Capital.

${ }^{34}$ Octavio Bunge fue relator del Superior Tribunal entre 1870 y 1871, nombrado por el gobernador a propuesta del Tribunal, ROPBA, 1870, p. 11; fiscal civil en 1872 y entre 1873 y 1874 fue juez de primera instancia en lo criminal de la Capital. ROPBA, 1873, p. 96.
} 


\begin{tabular}{|l|l|l|l|}
\hline Secretario & Rafael Jorge Corvalan & 27 de agosto de 1874 & \\
\hline Ujier & Ignacio Lasota & & \\
\hline
\end{tabular}

\section{Jueces de primera instancia de la capital}

\begin{tabular}{|c|c|c|c|}
\hline Cargo & Nombre & $\begin{array}{l}\text { Fecha de } \\
\text { nombramiento }\end{array}$ & Modificaciones \\
\hline $\begin{array}{l}\text { Juez de } \\
\text { primera } \\
\text { instancia en } \\
\text { lo civil }\end{array}$ & Carlos Marenco & 27 de agosto de 1874 & $\begin{array}{l}\text { Renunció y fue } \\
\text { reemplazado el } 31 \text { de } \\
\text { marzo de } 1876 \text { por } \\
\text { Miguel L. Noguera, } \\
\text { asesor del Ministerio } \\
\text { de Menores de la } \\
\text { Capital. }{ }^{35} \text { Renunció y } \\
\text { fue reemplazado el } 4 \text { de } \\
\text { agosto de } 1881 \text { por } \\
\text { Luis A. Sauze, agente } \\
\text { fiscal de la Capital. }\end{array}$ \\
\hline $\begin{array}{l}\text { Escribano } \\
\text { secretario }^{37}\end{array}$ & Clodomiro Gallardo & & \\
\hline $\begin{array}{l}\text { Escribano } \\
\text { secretario }\end{array}$ & Manuel Llames Oliver & & $\begin{array}{l}\text { Reemplazado por } \\
\text { Sebastián Martínez en } \\
1879\end{array}$ \\
\hline $\begin{array}{l}\text { Escribano } \\
\text { secretario }\end{array}$ & Juan E. Coronado & & \\
\hline $\begin{array}{l}\text { Escribano } \\
\text { secretario }\end{array}$ & Natalio A. Ponce & & \\
\hline $\begin{array}{l}\text { Escribano } \\
\text { secretario }\end{array}$ & Juan Rodríguez & 1879 & \\
\hline $\begin{array}{l}\text { Escribano } \\
\text { secretario }\end{array}$ & Estanislao López & 1879 & \\
\hline $\begin{array}{l}\text { Juez de } \\
\text { primera } \\
\text { instancia en } \\
\text { lo civil }\end{array}$ & José María Rosa & 27 de agosto de 1874 & $\begin{array}{l}\text { Renunció y fue } \\
\text { reemplazado por el } \\
\text { juez civil y comercial } \\
\text { del Departamento del } \\
\text { Centro Virgilio Tedin } \\
\text { el } 20 \text { de octubre de } \\
1880 .^{38}\end{array}$ \\
\hline $\begin{array}{l}\text { Escribano } \\
\text { secretario }\end{array}$ & Bartolomé Martín & & \\
\hline $\begin{array}{l}\text { Escribano } \\
\text { secretario }\end{array}$ & Manuel Lacasa & & \\
\hline
\end{tabular}

\footnotetext{
${ }^{35}$ ROPBA, 1876, p. 47.

${ }^{36}$ ROPBA, 1881, Buenos Aires, 1881, p. 458.

${ }^{37}$ Los jueces ponían en conocimiento del Presidente de la Suprema Corte de Justicia que tomaban posesión del juzgado y proponían al secretario, que en algunos casos era el que ya estaba. Las secretarías fueron creadas por ley del 30 de septiembre de 1871, según la cual los escribanos secretarios serían nombrados por el Superior Tribunal a propuesta del juez letrado del respectivo juzgado. Al año siguiente de la puesta en funcionamiento de la nueva estructura judicial se agregaron a los juzgados de primera instancia civil y comercial de la Capital dos secretarías. Ley del 23 de septiembre de 1876. ROPBA, 1876, pp. 231-232. En 1879 fueron nombrados esos nuevos secretarios.

${ }^{38}$ ROPBA, 1880, p. 619.
} 


\begin{tabular}{|c|c|c|c|}
\hline $\begin{array}{l}\text { Escribano } \\
\text { secretario }\end{array}$ & Mariano Andrade & & \\
\hline $\begin{array}{l}\text { Escribano } \\
\text { secretario }\end{array}$ & Nicanor Repetto & & \\
\hline $\begin{array}{l}\text { Escribano } \\
\text { secretario }\end{array}$ & José Martín & 1879 & \\
\hline $\begin{array}{l}\text { Escribano } \\
\text { secretario }\end{array}$ & Tristán M. Almandos & 1879 & \\
\hline $\begin{array}{l}\text { Juez de } \\
\text { primera } \\
\text { instancia en } \\
\text { lo civil }\end{array}$ & Julián Balbín & 27 de agosto de 1874 & $\begin{array}{l}\text { Renunció y fue } \\
\text { reemplazado por Juan } \\
\text { Carlos Belgrano, juez } \\
\text { de primera instancia } \\
\text { civil en el } \\
\text { Departamento del } \\
\text { Centro, el } 22 \text { de } \\
\text { septiembre de } 1876 .{ }^{39} \\
\text { Renunció y fue } \\
\text { reemplazado el } 16 \text { de } \\
\text { abril de } 1877 \text { por } \\
\text { Salustiano J. Zavalía }\end{array}$ \\
\hline $\begin{array}{l}\text { Escribano } \\
\text { secretario }\end{array}$ & Félix Sagasta & & \\
\hline $\begin{array}{l}\text { Escribano } \\
\text { secretario }\end{array}$ & Miguel Repetto & & \\
\hline $\begin{array}{l}\text { Escribano } \\
\text { secretario }\end{array}$ & Manuel Victorica & & \\
\hline $\begin{array}{l}\text { Escribano } \\
\text { secretario }\end{array}$ & Darío Baccar & & \\
\hline $\begin{array}{l}\text { Escribano } \\
\text { secretario }\end{array}$ & Eduardo Munilla & 1879 & \\
\hline $\begin{array}{l}\text { Escribano } \\
\text { secretario }\end{array}$ & Félix Romero & 1879 & \\
\hline $\begin{array}{l}\text { Juez de } \\
\text { primera } \\
\text { instancia en } \\
\text { lo civil }\end{array}$ & Ángel E. Casares & 27 de agosto de 1874 & $\begin{array}{l}\text { Fue reemplazado por } \\
\text { Martín Bustos, el } 28 \text { de } \\
\text { enero de } 1878 .{ }^{41}\end{array}$ \\
\hline $\begin{array}{l}\text { Escribano } \\
\text { secretario }\end{array}$ & Manuel Pérez Gomar & & \\
\hline $\begin{array}{l}\text { Escribano } \\
\text { secretario }\end{array}$ & Gregorio Carballo & & \\
\hline $\begin{array}{l}\text { Escribano } \\
\text { secretario }\end{array}$ & Faustino Miñones & & \\
\hline $\begin{array}{l}\text { Escribano } \\
\text { secretario }\end{array}$ & Federico Méndez & & \\
\hline $\begin{array}{l}\text { Escribano } \\
\text { secretario }\end{array}$ & Ramón Wrigh & 1879 & \\
\hline $\begin{array}{l}\text { Escribano } \\
\text { secretario }\end{array}$ & Saturnino García & 1879 & \\
\hline
\end{tabular}

\footnotetext{
${ }^{39}$ ROPBA, 1876, p. 228.

${ }^{40}$ ROPBA, 1877, p. 145.

${ }^{41}$ ROPBA, 1878, p. 24.
} 


\begin{tabular}{|l|l|l|l|}
\hline $\begin{array}{l}\text { Juez de } \\
\text { primera } \\
\text { instancia en } \\
\text { lo comercial }\end{array}$ & Juan A. Areco & 27 de agosto de 1874 & $\begin{array}{l}\text { Lo reemplaza Carlos } \\
\text { Dimet, agente fiscal en } \\
\text { lo civil de la Capital, el } \\
\text { 31 de julio de 1878. }\end{array}$ \\
\hline $\begin{array}{l}\text { Escribano } \\
\text { secretario }\end{array}$ & Eugenio Blanco & \\
\hline $\begin{array}{l}\text { Escribano } \\
\text { secretario }\end{array}$ & Pedro Sicouret & & \\
\hline $\begin{array}{l}\text { Escribano } \\
\text { secretario }\end{array}$ & Isidoro Campos & & \\
\hline $\begin{array}{l}\text { Escribano } \\
\text { secretario }\end{array}$ & Bernardo Folkenand & & $\begin{array}{l}\text { Renunció y fue } \\
\text { reemplazado por Julio } \\
\text { Fonrouge, el 31 de } \\
\text { enero de 1877. }\end{array}$ \\
\hline $\begin{array}{l}\text { Escribano } \\
\text { secretario }\end{array}$ & Carlos N. González & 1879 & \\
\hline $\begin{array}{l}\text { Escribano } \\
\text { secretario }\end{array}$ & Pedro Cedrés & 1879 & \\
\hline $\begin{array}{l}\text { Juez de } \\
\text { primera } \\
\text { instancia en } \\
\text { lo comercial }\end{array}$ & Juan Carlos Lagos & 27 de agosto de 1874 & \\
\hline $\begin{array}{l}\text { Escribano } \\
\text { secretario }\end{array}$ & Joaquín Lijó & & \\
\hline $\begin{array}{l}\text { Escribano } \\
\text { secretario }\end{array}$ & Joaquín Reynoso & & \\
\hline $\begin{array}{l}\text { Escribano } \\
\text { secretario }\end{array}$ & Juan González & & \\
\hline $\begin{array}{l}\text { Escribano } \\
\text { secretario }\end{array}$ & Ramón Peralta & & \\
\hline $\begin{array}{l}\text { Escribano } \\
\text { secretario }\end{array}$ & Ángel J. Blanco & & \\
\hline $\begin{array}{l}\text { Escribano } \\
\text { secretario }\end{array}$ & Fernando M. Miranda & & \\
\hline
\end{tabular}

\begin{tabular}{|l|l|l|l|}
\hline $\begin{array}{l}\text { Juez de } \\
\text { policía } \\
\text { correccional }^{44}\end{array}$ & José Boneo & & \\
\hline $\begin{array}{l}\text { Escribano } \\
\text { secretario }\end{array}$ & Antonio Vieytes & & \\
\hline
\end{tabular}

\begin{tabular}{|l|l|l|l|}
\hline $\begin{array}{l}\text { Juez de } \\
\text { primera } \\
\text { instancia en } \\
\text { lo criminal }\end{array}$ & Damián Hudson $^{45}$ & 27 de agosto de 1874 & $\begin{array}{l}\text { Murió y lo reemplazó } \\
\text { Adolfo Insiarte }^{46}\end{array}$ \\
\hline
\end{tabular}

\footnotetext{
${ }^{42}$ ROPBA, 1878, p.48.

${ }^{43}$ ROPBA, 1877 , p. 35.

${ }^{44}$ Este juzgado fue creado por ley del 6 de octubre de 1857. ROGBA, 1857, p. 135. El 5 de agosto de 1876 una ley le asignó un sueldo al secretario del juzgado correccional. ROPBA, 1876, p. 197.

${ }^{45}$ Damián Hudson era juez de primera instancia en lo criminal desde el 12 de enero de 1873. ROPBA, 1873, p. 430.

${ }^{46}$ Ante la muerte de Damián Hudson, el reemplazo fue realizado por Adolfo Insiarte, primero por decreto en comisión (por falta de quórum en el Senado) y luego con nombramiento por decreto, con acuerdo del Senado, del 16 de abril de 1877. ROPBA, 1877, pp. 144-145.
} 


\begin{tabular}{|c|c|c|c|}
\hline $\begin{array}{l}\text { Escribano } \\
\text { secretario }\end{array}$ & Pastor Lacasa & & \\
\hline $\begin{array}{l}\text { Juez de } \\
\text { primera } \\
\text { instancia en } \\
\text { lo criminal }\end{array}$ & Pedro Passo & 27 de agosto de 1874 & $\begin{array}{l}\text { Pasó a Fiscal de } \\
\text { Cámara del } \\
\text { Departamento Capital y } \\
\text { fue reemplazado por } \\
\text { Julián Aguirre, juez del } \\
\text { crimen del } \\
\text { Departamento del Sud } \\
\text { el } 20 \text { de octubre de } \\
1880 .{ }^{47}\end{array}$ \\
\hline $\begin{array}{l}\text { Escribano } \\
\text { secretario }\end{array}$ & Pedro Miliavaca & & $\begin{array}{l}\text { Reemplazado por } \\
\text { Diego Pombo en } 1879 .\end{array}$ \\
\hline $\begin{array}{l}\text { Juez de } \\
\text { primera } \\
\text { instancia en } \\
\text { lo criminal }\end{array}$ & Mariano Demaria & 27 de agosto de 1874 & $\begin{array}{l}\text { Fue reemplazado por } \\
\text { Eduardo Carranza } \\
\text { Viamont el } 20 \text { de mayo } \\
\text { de } 1877 .^{48} \text { En su lugar } \\
\text { fue nombrado el juez } \\
\text { de primera instancia } \\
\text { del crimen del } \\
\text { Departamento del } \\
\text { Centro, Néstor French, } \\
\text { el } 3 \text { de julio de } 1877^{49} \text {, } \\
\text { que pasó a miembro de } \\
\text { la Cámara criminal del } \\
\text { Departamento Capital y } \\
\text { fue reemplazado por el } \\
\text { agente fiscal civil de la } \\
\text { Capital Luis Sauze el } \\
20 \text { de octubre de } \\
1880{ }^{50} \text { No asumió y fue } \\
\text { nombrado Francisco } \\
\text { Ramos Mejía el } 27 \text { de } \\
\text { octubre de } 1880 . .^{51}\end{array}$ \\
\hline $\begin{array}{l}\text { Escribano } \\
\text { secretario }\end{array}$ & Diego Pombo & & $\begin{array}{l}\text { Reemplazado por } \\
\text { Ramón Victorica en } \\
1879\end{array}$ \\
\hline
\end{tabular}

Ministerio Público

\begin{tabular}{|l|l|l|l|}
\hline Cargo & Nombre & $\begin{array}{l}\text { Fecha de } \\
\text { nombramiento }\end{array}$ & Modificaciones \\
\hline $\begin{array}{l}\text { Fiscal } \\
\text { General de las } \\
\text { Cámaras de } \\
\text { Apelación }\end{array}$ & Benjamín Victorica $^{52}$ & 18 de enero de 1875 & $\begin{array}{l}\text { Reemplazado por } \\
\text { Pedro Passo, juez del } \\
\text { crimen del } \\
\text { Departamento Capital, }\end{array}$ \\
\hline
\end{tabular}

\footnotetext{
${ }^{47}$ ROPBA, 1880, p. 618.

${ }^{48}$ ROPBA, 1877, p. 196.

${ }^{49}$ ROPBA, 1877, p. 237.

${ }^{50}$ ROPBA, 1880 , p. 619.

${ }^{51}$ ROPBA, 1880, p. 629.

${ }^{52}$ En el decreto del 27 de agosto de 1874 había sido nombrado Ceferino Araujo.
} 


\begin{tabular}{|c|c|c|c|}
\hline & & & $\begin{array}{l}\text { el } 20 \text { de octubre de } \\
1880 .\end{array}$ \\
\hline $\begin{array}{l}\text { Agente fiscal } \\
\text { en lo Civil y } \\
\text { comercial }\end{array}$ & Luis A. Sauze & 23 de enero de $1875^{54}$ & $\begin{array}{l}\text { Pasó a juez civil y fue } \\
\text { reemplazado por } \\
\text { Valentín Curuchet, el } 4 \\
\text { de agosto de } 1881.55\end{array}$ \\
\hline $\begin{array}{l}\text { Agente fiscal } \\
\text { en lo Civil y } \\
\text { comercial }\end{array}$ & Carlos Dimet & 27 de agosto de 1874 & $\begin{array}{l}\text { Pasó a juez comercial } \\
\text { de la Capital y fue } \\
\text { reemplazado por Pastor } \\
\text { Servando Obligado el } \\
31 \text { de julio de } 1878 .{ }^{56}\end{array}$ \\
\hline $\begin{array}{l}\text { Agente fiscal } \\
\text { en lo } \\
\text { Criminal }\end{array}$ & Ventura Pondal & 27 de agosto de 1874 & $\begin{array}{l}\text { Fue separado de su } \\
\text { cargo y reemplazado } \\
\text { por José M. Calderón } \\
\text { el } 19 \text { de octubre de } \\
1880.57\end{array}$ \\
\hline $\begin{array}{l}\text { Defensor de } \\
\text { menores }\end{array}$ & Eugenio Blanco & 18 de enero de $1875^{58}$ & $\begin{array}{l}\text { Reemplazado por } \\
\text { Pedro A. Carrasco el } \\
10 \text { de enero de } 1879^{59}\end{array}$ \\
\hline $\begin{array}{l}\text { Defensor de } \\
\text { menores }\end{array}$ & $\begin{array}{l}\text { Ambrosio del Molino } \\
\text { Torres }\end{array}$ & 18 de enero de 1875 & $\begin{array}{l}\text { Falleció y fue } \\
\text { reemplazado por } \\
\text { Francisco Rodríguez el } \\
6 \text { de julio de } 1875 .^{60} \\
\text { Falleció y fue } \\
\text { reemplazado por Pedro } \\
\text { Bernet el } 5 \text { de enero de } \\
1881^{61}\end{array}$ \\
\hline $\begin{array}{l}\text { Asesor de } \\
\text { menores }\end{array}$ & Juan Raíces & 11 de febrero de $1875^{62}$ & \\
\hline $\begin{array}{l}\text { Asesor de } \\
\text { menores }\end{array}$ & Miguel N. Nogueras & 30 de abril de $1875^{63}$ & $\begin{array}{l}\text { Pasó a juez civil del } \\
\text { Departamento Capital y } \\
\text { fue reemplazado por } \\
\text { Alberto Diana el } 31 \text { de } \\
\text { marzo de } 1876 .{ }^{64} \\
\text { Renunció y fue } \\
\text { reemplazado por }\end{array}$ \\
\hline
\end{tabular}

\footnotetext{
${ }^{53}$ ROPBA, 1880, p. 618.

${ }^{54}$ El 23 de enero de 1875 el poder ejecutivo, según ley del 30 de junio de 1874, acordó y decretó nombrar los agentes fiscales en lo civil y criminal. ROPBA, 1875, p. 15.

${ }^{55}$ ROPBA, 1881, p. 458.

${ }^{56}$ ROPBA, 1878, p.48.

${ }^{57}$ Ventura Pondal fue nombrado juez del crimen del Departamento del Norte el 19 de marzo de 1866. ROPBA, 1866, p. 33. Agente fiscal en lo Crimina. Ya era agente fiscal en lo criminal desde el 11 de enero de 1873 (ROPBA, 1873, pp. 12-13) y fue separado de su cargo "consultando el mejor servicio público" por decreto del 19 de octubre de 1880 . El mismo día fue nombrado Calderón. ROPBA, 1880, p. 617.

${ }^{58}$ Decreto del 18 de enero de 1875. ROPBA, 1875, p. 12.

${ }^{59}$ ROPBA, 1879 , p. 50.

${ }^{60}$ ROPBA, 1875, p. 231.

${ }^{61}$ ROPBA, 1881, p. 6.

${ }^{62}$ ROPBA, 1875, pp. 27-28.

${ }^{63}$ ROPBA, 1875, p. 131.

${ }^{64}$ ROPBA, 1876, p. 48.
} 


\begin{tabular}{|l|l|l|l|}
\hline & & & $\begin{array}{l}\text { Mariano de Gainza el } \\
\text { 31 de mayo de 1879. }\end{array}$ \\
\hline $\begin{array}{l}\text { Defensor de } \\
\text { pobres }\end{array}$ & $\begin{array}{l}\text { Alejo de Nevares Tres } \\
\text { Palacios }\end{array}$ & 18 de enero de 1875 & \\
\hline $\begin{array}{l}\text { Asesor de } \\
\text { pobres }\end{array}$ & Marcelino Aguirre & & \\
\hline
\end{tabular}

\section{b. Departamento del Norte}

\section{Cámara de Apelación}

\begin{tabular}{|c|c|c|c|}
\hline Cargo & Nombre & $\begin{array}{l}\text { Fecha de } \\
\text { nombramiento }\end{array}$ & Modificaciones \\
\hline Presidente & Félix A. Benítez ${ }^{66}$ & 27 de agosto de 1874 & $\begin{array}{l}\text { Pasó a ser juez de la } \\
\text { Cámara del } \\
\text { Departamento del } \\
\text { Centro y fue } \\
\text { reemplazado por } \\
\text { Manuel Escobar, } \\
\text { presidente de la } \\
\text { Cámara de Apelación } \\
\text { del Sud, el } 10 \text { de abril } \\
\text { de } 1878.67\end{array}$ \\
\hline Vocal & Eduardo Guido & 27 de agosto de 1874 & \\
\hline Vocal & Mariano Castellanos & 18 de enero de 1875 & Presidente en 1879 \\
\hline Secretario & Dalmiro Sáenz & 27 de agosto de 1874 & $\begin{array}{l}\text { Pasó a juez del crimen } \\
\text { del Departamento del } \\
\text { Sud y lo reemplazó } \\
\text { Próspero Gazzolo el } 27 \\
\text { de octubre de } 1880 .^{68}\end{array}$ \\
\hline Ujier & Meliton Nuñez & & $\begin{array}{l}\text { Reemplazado en } 1879 \\
\text { por Casiano R. } \\
\text { Huidogo }\end{array}$ \\
\hline
\end{tabular}

\section{Jueces de primera instancia}

\begin{tabular}{|l|l|l|l|}
\hline Cargo & Nombre & $\begin{array}{l}\text { Fecha de } \\
\text { nombramiento }\end{array}$ & Modificaciones \\
\hline $\begin{array}{l}\text { Juez de } \\
\text { primera } \\
\text { instancia en } \\
\begin{array}{l}\text { lo civil y } \\
\text { comercial }\end{array}\end{array}$ & Lorenzo Saborido & 27 de agosto de 1874 & $\begin{array}{l}\text { Renunció y fue } \\
\text { reemplazado por Juan } \\
\text { Igarzábal, asesor de } \\
\text { menores y de pobres } \\
\text { del Departamento del } \\
\text { Centro, el 17 de febrero } \\
\text { de 1881. }\end{array}$ \\
\hline
\end{tabular}

${ }^{65}$ ROPBA, 1879, p. 289.

${ }^{66}$ Félix Amadeo Benítez fue juez criminal del norte entre 1872 y 1874 . El nombramiento fue realizado por decreto del 2 de noviembre de 1872, a partir de la terna elevada por el Superior Tribunal el 31 de octubre, integrada con Victoriano de la Plaza y Carlos Saavedra Zavaleta. ROPBA, 1872, p. 445.

${ }^{67}$ ROPBA, 1878, pp. 161-162.

${ }^{68}$ ROPBA, 1880 , p. 629.

${ }^{69}$ ROPBA, 1881 , p. 81. 


\begin{tabular}{|l|l|l|l|}
\hline $\begin{array}{l}\text { Escribano } \\
\text { secretario }\end{array}$ & Pedro N. Pizarro & & $\begin{array}{l}\text { Reemplazado en 1879 } \\
\text { por Juan G. Araujo }\end{array}$ \\
\hline $\begin{array}{l}\text { Juez de } \\
\text { primera } \\
\text { instancia en } \\
\text { lo criminal }\end{array}$ & Luis Méndez Paz & 27 de agosto de 1874 & $\begin{array}{l}\text { Reemplazado por José } \\
\text { María Rojas el 20 de } \\
\text { junio de 1876. }\end{array}$ \\
\hline $\begin{array}{l}\text { Escribano } \\
\text { secretario }\end{array}$ & Bernabé Navarro & & \\
\hline
\end{tabular}

\section{Ministerio público}

\begin{tabular}{|l|l|l|l|}
\hline $\begin{array}{l}\text { Agente fiscal } \\
\text { ante todos los } \\
\text { Tribunales }\end{array}$ & David de Tesano Pintos & 23 de enero de 1875 & $\begin{array}{l}\text { Se excusó del cargo y } \\
\text { fue nombrado Nicolás } \\
\text { de Arredondo el 13 de } \\
\text { marzo de 1875. }\end{array}$ \\
\hline Defensor & José V. Urdapilleta & & \\
\hline
\end{tabular}

\section{c. Departamento del Centro}

\section{Cámara de Apelación}

\begin{tabular}{|c|c|c|c|}
\hline Cargo & Nombre & $\begin{array}{l}\text { Fecha de } \\
\text { nombramiento }\end{array}$ & Modificaciones \\
\hline Presidente & Manuel H. Langenheim ${ }^{72}$ & 27 de agosto de 1874 & $\begin{array}{l}\text { Pasó a juez de la sala } \\
2^{\circ} \text { de la Cámara del } \\
\text { Departamento Capital y } \\
\text { fue reemplazado por } \\
\text { Félix A. Benítez, } \\
\text { presidente de la } \\
\text { Cámara del Norte, el } \\
10 \text { de abril de } 1878 .{ }^{73} \\
\text { Reemplazado por } \\
\text { Amancio Pardo el } 5 \text { de } \\
\text { abril de } 1880 .{ }^{74}\end{array}$ \\
\hline Vocal & Antonio Benguria $^{75}$ & 27 de agosto de 1874 & \\
\hline Vocal & Fortunato Souza & 27 de agosto de 1874 & Fue presidente en 1879 \\
\hline Secretario & José J. Zeballos & 18 de enero de 1875 & $\begin{array}{l}\text { Pasó a asesor de pobres } \\
\text { y menores del } \\
\text { Departamento del }\end{array}$ \\
\hline
\end{tabular}

\footnotetext{
${ }^{70}$ ROPBA, 1876 , p. 160.

${ }^{71}$ ROPBA, 1875 , p. 81.

${ }^{72}$ Manuel H. Langenheim inició su carrera judicial el 22 de octubre de 1857 como relator del Superior Tribunal (ROPBA, 1857, p. 162). Ese mismo año fue asesor de menores y el año siguiente juez del crimen del Departamento del Centro, hasta el 20 de junio de 1862 que pasó a ser juez del crimen de la Capital. El 24 de enero de 1868 pasó a integrar el Superior Tribunal de Justicia por decreto del gobierno de la terna propuesta por el Senado. ROPBA, 1868, pp. 12-13.

${ }^{73}$ ROPBA, 1878, pp. 161-162.

${ }^{74}$ ROPBA, 1880, p. 142. Recordemos que en 1874 le había sido negado el acuerdo del Senado para la Cámara de Apelación de la Capital.

${ }^{75}$ Antonio Benguria fue entre 1870 y 1873 juez criminal del Departamento del Centro. Habiendo fallecido el juez José Antonio de Zavalía, el Superior Tribunal presentó el 28 de enero de 1870 la terna compuesta por Sixto Villegas, Juan José Montes de Oca y Antonio Benguria, siendo éste nombrado el 28 de enero. ROPBA, 1870, p. 30 . El 27 de marzo de 1873 fue nombrado juez de primera instancia en lo civil, a partir de la terna integrada con Eduardo Basavilbaso y Manuel Obarrio. ROPBA, 1873, pp. 181-182, pero en abril de 1874 seguía en Mercedes.
} 


\begin{tabular}{|l|l|l|l|}
\hline & & & $\begin{array}{l}\text { Centro y lo reemplazó } \\
\text { Arístides Martínez. }^{76}\end{array}$ \\
\hline Ujier & Nicolás Leguizamón & & \\
\hline
\end{tabular}

Jueces de primera instancia

\begin{tabular}{|c|c|c|c|}
\hline Cargo & Nombre & $\begin{array}{l}\text { Fecha de } \\
\text { nombramiento }\end{array}$ & Modificaciones \\
\hline \multirow[t]{5}{*}{$\begin{array}{l}\text { Juez de } \\
\text { primera } \\
\text { instancia en } \\
\text { lo civil y } \\
\text { comercial }\end{array}$} & Juan Carlos Belgrano & 27 de agosto de 1874 & $\begin{array}{l}\text { Pasó a juez civil del } \\
\text { Departamento Capital y } \\
\text { fue reemplazado por } \\
\text { Virgilio Tedin, asesor } \\
\text { de pobres y menores } \\
\text { del mismo } \\
\text { Departamento, el } 27 \text { de } \\
{\text { septiembre de } 1876 .{ }^{77}} \text { Nombrado juez civil } \\
\text { del Departamento } \\
\text { Capital fue } \\
\text { reemplazado por Juan } \\
\text { San Martín, agente } \\
\text { fiscal el } 20 \text { de octubre } \\
\text { de } 1880 .{ }^{78}\end{array}$ \\
\hline & Manuel Malmierca & & \\
\hline & Valentín Piñero & & \\
\hline & Agustín López Camelo & 1879 & \\
\hline & Carlos D. Giménez & 1879 & \\
\hline $\begin{array}{l}\text { Juez de } \\
\text { primera } \\
\text { instancia en } \\
\text { lo criminal }\end{array}$ & Néstor French & 27 de agosto de 1874 & $\begin{array}{l}\text { Fue nombrado juez } \\
\text { criminal de la Capital y } \\
\text { lo reemplazó Francisco } \\
\text { Ramos Mejía el } 3 \text { de } \\
\text { julio de } 1877 .{ }^{79} \text { Pasó a } \\
\text { juez criminal del } \\
\text { Departamento de la } \\
\text { Capital y lo reemplazó } \\
\text { el } 27 \text { de octubre de } \\
1880 \text { Octavio } \\
\text { Amadeo. }\end{array}$ \\
\hline $\begin{array}{l}\text { Escribano } \\
\text { secretario }\end{array}$ & Julián Byron & & \\
\hline
\end{tabular}

\section{Ministerio Público}

\begin{tabular}{|l|l|l|}
\hline $\begin{array}{l}\text { Agente fiscal } \\
\text { ante todos los } \\
\text { tribunales }\end{array}$ & San Martín & $\begin{array}{l}\text { Pasó a juez civil y fue } \\
\text { reemplazado por José } \\
\text { Antonio Capdevila. } 81\end{array}$ \\
\hline
\end{tabular}

\footnotetext{
${ }^{76}$ ROPBA, 1881, pp. 145-146.

${ }^{77}$ ROPBA, 1876, p. 235.

${ }^{78}$ ROPBA, 1880, p. 619.

${ }^{79}$ ROPBA, 1877, p. 237.

${ }^{80}$ ROPBA, 1880, p. 629.

${ }^{81}$ ROPBA, 1880, p. 619.
} 


\begin{tabular}{|c|c|c|}
\hline $\begin{array}{l}\text { Asesor de } \\
\text { pobres y } \\
\text { menores }\end{array}$ & Virgilio Tedin & $\begin{array}{l}\text { Pasó a juez civil y } \\
\text { comercial y fue } \\
\text { reemplazado por Juan } \\
\text { Igarzábal, agente fiscal } \\
\text { del Departamento del } \\
\text { Sud, el } 23 \text { de octubre } \\
\text { de } 1876 .{ }^{82} \text { Pasó a juez } \\
\text { de primera instancia } \\
\text { civil y comercial del } \\
\text { Departamento del } \\
\text { Norte y fue } \\
\text { reemplazado por José I. } \\
\text { Zeballos, secretario de } \\
\text { la Cámara de } \\
\text { Apelación del } \\
\text { Departamento del } \\
\text { Centro, el } 22 \text { de febrero } \\
\text { de } 1881 .{ }^{83}\end{array}$ \\
\hline
\end{tabular}

\section{d. Departamento del Sud}

\section{Cámara de Apelación}

\begin{tabular}{|l|l|l|l|}
\hline Cargo & Nombre & $\begin{array}{l}\text { Fecha de } \\
\text { nombramiento }\end{array}$ & Modificaciones \\
\hline Presidente & Manuel Escobar & 18 de enero de 1875 & $\begin{array}{l}\text { Fue nombrado juez de } \\
\text { la Cámara del Norte y } \\
\text { reemplazado por } \\
\text { Virgilio Tedin el 10 de } \\
\text { abril de 1878 } \\
\text { renunció al cargo y fue } \\
\text { nombrado Agustín } \\
\text { Justo el 10 de junio de } \\
1879 .^{85}\end{array}$ \\
\hline Vocal & $\begin{array}{l}\text { Buenaventura Ruiz de los } \\
\text { Llanos }\end{array}$ & 18 de enero de 1875 & Pasó a ser presidente \\
\hline Vocal & Manuel Irigoyen & & \\
\hline Secretario & Zoilo Invaldi & 27 de agosto de 1874 & \\
\hline Ujier & Daniel J. Casagrande & 18 de enero de 1875 & \\
\hline
\end{tabular}

Jueces de primera instancia

\begin{tabular}{|l|l|l|l|}
\hline Cargo & Nombre & $\begin{array}{l}\text { Fecha de } \\
\text { nombramiento }\end{array}$ & Modificaciones \\
\hline $\begin{array}{l}\text { Juez de } \\
\text { primera } \\
\text { instancia en }\end{array}$ & Justo P. Ortiz & 18 de enero de 1875 & \\
\hline
\end{tabular}

${ }^{82}$ ROPBA, 1876, p. 261.

${ }^{83}$ ROPBA, 1881, p. 84.

${ }^{84}$ ROPBA, 1878, pp. 161-162.

${ }^{85}$ ROPBA, 1879, p. 321.

${ }^{86}$ Manuel Bernardo de Irigoyen fue nombrado agente fiscal civil el 28 de diciembre de 1854, ROPBA, 1854, p. 152. Luego fue nombrado relator del Superior Tribunal de Justicia el 13 de marzo de 1855 pero renunció y fue elegido el 23 de marzo de 1867 juez del crimen del departamento del Sud. ROGBA, 1856, p. 40; ROPBA, 1867, p. 139. 


\begin{tabular}{|l|l|l|l|}
\hline $\begin{array}{l}\text { lo civil y } \\
\text { comercial } \\
\text { secretario }\end{array}$ & Severo F. Crespo & & \\
\hline $\begin{array}{l}\text { Escribano } \\
\text { secretario }\end{array}$ & Alejandro Villabrile & & \\
\hline $\begin{array}{l}\text { Juez de } \\
\text { primera } \\
\text { instancia en } \\
\text { lo criminal }\end{array}$ & Julián S. Aguirre & 27 de agosto de 1874 & $\begin{array}{l}\text { Pasó a juez del crimen } \\
\text { del Departamento } \\
\text { Capital y fue } \\
\text { reemplazado por } \\
\text { Dalmiro Sáenz, } \\
\text { secretario de Cámara } \\
\text { del Departamento del } \\
\text { Norte el 20 de octubre } \\
\text { de 1880. }\end{array}$ \\
\hline $\begin{array}{l}\text { Escribano } \\
\text { secretario }\end{array}$ & Pedro Lara & $\begin{array}{l}\text { Lo reemplazó en 1879 } \\
\text { Ramón Bourel }\end{array}$ \\
\hline
\end{tabular}

\section{Ministerio público}

\begin{tabular}{|c|c|c|}
\hline $\begin{array}{l}\text { Agente fiscal } \\
\text { ante todos los } \\
\text { tribunales }\end{array}$ & Juan Igarzábal & $\begin{array}{l}\text { Pasó a asesor de } \\
\text { menores del } \\
\text { Departamento del } \\
\text { Centro y fue } \\
\text { reemplazado por Juan } \\
\text { J. Amaral el } 23 \text { de } \\
\text { octubre de } 1876 .^{88}\end{array}$ \\
\hline $\begin{array}{l}\text { Asesor de } \\
\text { pobres y } \\
\text { menores }\end{array}$ & Juan G. Lecot & $\begin{array}{l}\text { Renunció y fue } \\
\text { reemplazado por } \\
\text { Octavio Amadeo el } 13 \\
\text { de enero de } 1877 .^{89} \\
\text { Pasó a juez del crimen } \\
\text { del Departamento del } \\
\text { Centro y fue } \\
\text { reemplazado por } \\
\text { Remigio Molinas el } 27 \\
\text { de octubre de } 1880 .^{90}\end{array}$ \\
\hline
\end{tabular}

${ }^{87}$ ROPBA, 1880, p. 619.

${ }^{90}$ ROPBA, 1880 , p. 629. 
Estructura del Poder Judicial según la ley de Organización de la Administración de Justicia de la Provincia del 26 de octubre de $1881^{91}$ y nombramientos del 29 de diciembre de $1881^{92}$

\begin{tabular}{|c|c|c|}
\hline Organismo & Cargo & Nombre \\
\hline \multirow[t]{7}{*}{ Suprema Corte de Justicia } & vocal & Alejo B. González \\
\hline & vocal & Sabiniano Kier \\
\hline & vocal & Manuel M. Escalada \\
\hline & vocal & Luis Sáenz Peña \\
\hline & vocal & Manuel H. Langenheim \\
\hline & Procurador General & Tomás Isla \\
\hline & secretario & Miguel Esteves \\
\hline \multicolumn{3}{|l|}{ Departamento de la Capital } \\
\hline \multirow[t]{4}{*}{ Cámara de apelaciones } & vocal & Pedro Passo \\
\hline & vocal & Leopoldo Basavilbaso \\
\hline & vocal & Néstor French \\
\hline & secretario & Rafael J. Corvalán \\
\hline Juzgado civil y comercial & juez & Aditardo Herdia \\
\hline Juzgado en lo criminal & juez & Francisco Ramos Mejía \\
\hline \multirow{2}{*}{ Ministerio público } & Asesor de menores & Valentín Curuchet \\
\hline & Agente fiscal & José A. Capdevila \\
\hline Defensoría General de Menores ${ }^{93}$ & Defensor & Pedro Bernet \\
\hline \multicolumn{3}{|l|}{ Departamento del Norte } \\
\hline \multirow[t]{4}{*}{ Cámara de apelaciones } & vocal & Eduardo Guido \\
\hline & vocal & Mariano Castellanos \\
\hline & vocal & Manuel Escobar \\
\hline & secretario & Próspero Gázzolo \\
\hline Juzgado civil y comercial & juez & Federico Igarzabal \\
\hline Juzgado en lo criminal & juez & José M. Rojas \\
\hline \multirow[t]{2}{*}{ Ministerio público } & Asesor de menores & José V. Urdapilleta \\
\hline & Agente fiscal & Nicolás Arredondo \\
\hline \multicolumn{3}{|l|}{ Departamento del Centro } \\
\hline \multirow[t]{4}{*}{ Cámara de apelaciones } & vocal & Manuel Irigoyen \\
\hline & vocal & Antonio Benguria \\
\hline & vocal & Fortunato Souza \\
\hline & secretario & Arístides Martínez \\
\hline Juzgado civil y comercial & juez & Julián Barranquero \\
\hline Juzgado en lo criminal & juez & Octavio Amdeo \\
\hline \multirow[t]{2}{*}{ Ministerio público } & Asesor de menores & José J. Zeballos \\
\hline & Agente fiscal & Federico García Alberdi \\
\hline \multicolumn{3}{|l|}{ Departamento del Sur } \\
\hline \multirow[t]{4}{*}{ Cámara de apelaciones } & vocal & Ventura Ruíz de los Llanos \\
\hline & vocal & Dalmiro Sáenz \\
\hline & vocal & José M. Calderón \\
\hline & secretario & Daniel Ocampo \\
\hline Juzgado civil y comercial & juez & Remigio Molinas \\
\hline Juzgado en lo criminal & juez & Juan J. Amaral \\
\hline \multirow[t]{2}{*}{ Ministerio público } & Asesor de menores & Ramón Victorica \\
\hline & Agente fiscal & Pedro Uriburu \\
\hline
\end{tabular}

\footnotetext{
${ }^{91}$ ROPBA, 1881, pp. 587-588.

${ }^{92}$ ROPBA, 1881, pp. 859-861. Los cargos del ministerio público no tenían acuerdo del Senado.

${ }^{93}$ El Defensor General de Menores tenía jurisdicción sobre toda la provincia con asiento en la Capital, asesorado por el Asesor del Departamento Capital.
} 


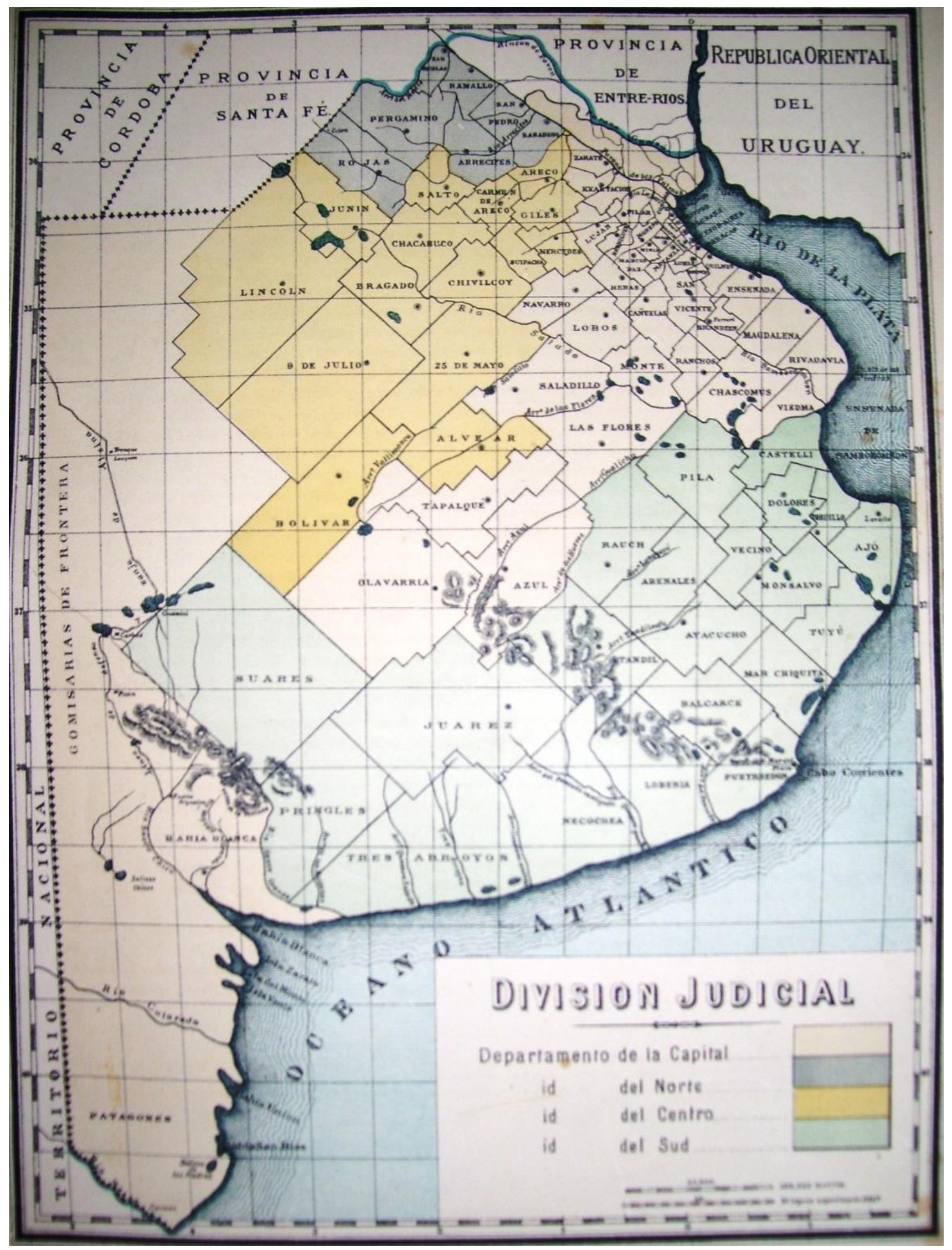

Mapa de la división judicial de la provincia de Buenos Aires según la ley del 10 de noviembre sobre división de los departamentos judiciales. ROPBA, 1879, pp. 544-545.

Fuente: Censo de la provincia de Buenos Aires de 1881. 


\section{Conclusión}

De la observación de los cuadros construidos a partir de las transformaciones institucionales y los nombramientos de magistrados y funcionarios, lo primero que surge es que los cinco miembros de la Suprema Corte pertenecían a su antecesor, el Superior Tribunal de Justicia (Sixto Villegas como fiscal y el resto como vocales). Carlos Tejedor fue nombrado, pero nunca asumió, lo que podemos entender conociendo su posterior carrera política a la gobernación. Esta conformación puede cuestionar el calificativo de "nuevo" que los mismos miembros daban a su tribunal que, como había sucedido con parte del anterior Tribunal, no había cambiado sus protagonistas.

$\mathrm{Al}$ ser sus integrantes los mismos, sin dudas se generaba una continuidad en las ideas. ${ }^{94}$ Pero no debe obviarse el cambio fundamental que se había dado en la competencia del Tribunal, definido por Vicente F. López como Tribunal de constitucionalidad, que resolvía los conflictos de la ley o competencia entre los poderes públicos de la provincia, y los conflictos entre los tribunales ordinarios de la provincia, porque ese Tribunal no pertenecía al orden regular de los jueces que decidían las causas. Decidía cuál era la ley superior de la provincia, en una materia dada o en un conflicto dado. Era un cambio orientado a lograr la independencia del poder judicial de los otros poderes.

Aunque López lo definió como un "tribunal político", durante estos años siguió ligado a la carrera judicial, pues los reemplazos fueron realizados por abogados que pertenecían al poder. Dos de ellos eran miembros del Superior Tribunal que llegaron a la Corte, pero después de pasar por las Cámaras de apelación. Carlos Eguía fue primero camarista civil de la Capital y Manuel Langenheim debió pasar por la Cámara del Centro y luego por la Capital. Víctor Martínez, nombrado en lugar de Somellera a fines de 1879, fue asesor del Tribunal de Comercio en 1852, pero fue más activa su actuación legislativa. Incluso el secretario Prado había sido juez de primera instancia, recorrido hoy impensable.

En las Cámaras de apelación, al menos sus presidentes tenían antecedentes judiciales y dentro de la estabilidad que tuvieron durante el período, los reemplazos seguían cierta prioridad entre las Cámaras de los departamentos judiciales. Los camarista del Centro pasaban a la Capital, los del Norte al Centro y los del Sud al Norte, aunque no se mantenía ese recorrido si venían de primera instancia. Por ejemplo Virgilio Tedin comenzó su carrera como asesor de pobres y menores en el Departamento del Centro, de donde pasó a juez civil y comercial. Con el mismo cargo fue nombrado en el Departamento del Norte, pasando de allí a presidente de la Cámara del Departamento del Sud.

\footnotetext{
${ }^{94}$ No continuaron en el poder judicial Domingo Pica y Basilio Salas, que conformaron el Superior Tribunal desde 1857 , y Ceferino Araujo nombrado en 1873.
} 
Los magistrados de primera instancia son un ejemplo del fortalecimiento de la carrera judicial, que entre 1852 y 1874 había sentado sus bases con abogados dedicados a la magistratura que comenzaban a dejar la vida política para entregarse a una formación específica que se expresaría en la especialización del derecho positivo que ya podía vislumbrarse. Procedían en algunos casos de cargos del Ministerio Público, como asesor de menores o agente fiscal y generalmente mantenían la movilidad del Centro a Capital, pero lo más importante es que comenzaba a definirse la exclusividad del fuero ya que no observamos jueces civiles que pasen a ser del crimen o viceversa, como si sucedía en los años previos a la Constitución.

Este poder buscaba definirse y establecer su independencia en la práctica, como lo hacía con la superintendencia. En su reglamento la Suprema Corte había dejado sentado que podía llamar a su seno a cualquier magistrado judicial a fin de prevenirle por faltas $\mathrm{u}$ omisiones $\mathrm{y}$, a fin de mantener el decoro de la administración de justicia, podía corregir las faltas que se cometieren con multas. Si la falta o desacato merecía pena mayor eran arrestados los jueces y puestos a disposición del juez competente. ${ }^{95}$ Ciertamente se fundaban en la ley 169 , título 15 , lib. $2^{\circ}$, de la Recopilación de Indias, que dio al camarista juez de subalternos la facultad de conocer en las faltas cometidas por los subalternos al ejercer sus funciones, "para que entiendan, que no procediendo con la justificación que deben han de ser castigados, y los que reciban agravio sepan a quien han de ocurrir en particular". Pero esa jurisdicción disciplinaria se mantuvo sin menoscabo de las prescripciones constitucionales, respecto de faltas cometidas en el ejercicio de un cargo público, incorporada a la organización de los tribunales por el art. 225 de la Constitución. ${ }^{96}$

Más aún, en la Memoria del 28 de julio de 1877 presentada por la Corte al poder legislativo, reclamaba la ley sobre responsabilidad de los miembros del poder judicial, haciendo hincapié en diferenciar las faltas leves a su cargo, de las graves que irían a jury. Según el texto constitucional, "no todas las violaciones de deberes cometidas por los magistrados, deben ser llevadas al juzgamiento del jury. Existen faltas para cuya corrección basta el poder disciplinario, que la misma Constitución ha atribuido al primer tribunal de la provincia. "97

Con esto queremos demostrar que el "nuevo" Tribunal, que no lo era completamente, se adaptaba a un nuevo orden en búsqueda de su legitimidad, con un concepto de justicia en transformación que ubicaba a la ley accesible y aplicable por encima de todo. Gran parte de las modificaciones planteadas e incluso sancionadas en el texto constitucional quedaron en la letra y otras se concretaron pero cargando con el peso de la legislación indiana. Ciertamente el cambio no estaba ni por mucho concluido, pero estaba sin dudas comenzado.

\footnotetext{
${ }^{95}$ Artículo 25 y 26 del Reglamento de la Suprema Corte de Justicia. Acuerdos y sentencias, tomo I, pp. 25-29.

${ }^{96}$ Causa CXLIII, 28 de noviembre de 1876. Acuerdos y sentencias, tomo I, p. 526.

${ }^{97}$ Acuerdos y sentencias, tomo I, p. 582.
} 


\section{Capítulo X}

\section{La vida: pena de muerte, indulto y división de poderes. El caso de Clorinda Sarracán}

\section{Introducción}

Dentro de la historia de la justicia es indispensable el estudio de la organización y funcionamiento institucional del ámbito judicial, desde una perspectiva social, sin vaciarlo de lo jurídico. Esto incluye las normas que le dieron origen, el funcionamiento de las instituciones (duración de los procesos, acceso, nivel de corrupción), su competencia y composición (origen social, situación económica), y el uso que los sujetos de derecho han hecho de las instituciones. ${ }^{1}$ Es por esto que en este capítulo pasaremos a un registro particular, estudiando un caso que demuestre la complejidad de las situaciones a resolver mientras se organizaba el poder judicial. Para encarar esta tarea elegimos un expediente criminal iniciado en 1856 que permite acceder al "universo judicial" en el que magistrados, funcionarios, agentes judiciales, víctimas y victimarios se movían, en años en que los enunciados normativos de garantías estaban cambiando en conflicto con la pena de muerte.

En el proceso de abolición de una ley se pueden definir tres pasos. Primero la abolición gradual, es decir la disminución en las ejecuciones; luego la abolición general de hecho y finalmente, la abolición general de derecho. ${ }^{2}$ La pena de muerte en la provincia de Buenos Aires siguió ese camino, recorrido por sus protagonistas para quienes "en materias de derecho criminal, no son los legisladores los que van reformando las leyes penales sino la civilización las que las va derogando de hecho, subordinando la letra muerta a la conciencia humana ilustrada, y así es que sin que haya leyes derogadas expresas, una porción de penas bárbaras están abolidas...".3

En este contexto, el brutal asesinato en 1856 de un pintor de la sociedad porteña y la condena a muerte de su esposa -que lo planeó- y de sus ejecutores, instaló en la agenda política de la provincia el debate sobre el indulto de la pena capital y sobre la división de poderes del Estado que se estaba organizando. A lo largo de los doce años que se extendió la causa puede observarse en acción a todos los agentes judiciales de la justicia criminal (incluidos algunos de la justicia civil

\footnotetext{
${ }^{1}$ Eduardo Martiré, destacando textos de Alfonso García Gallo, insiste sobre la necesidad del estudio de las instituciones vinculándolas a lo social pero teniendo la precaución de no vaciarlas de lo jurídico. "La Historia del Derecho, disciplina histórica", en Revista de Instituto de Historia del Derecho Ricardo Levene, núm.20, Buenos Aires, 1969, p.93.

${ }^{2}$ Proceso abolicionista de Garruad, citado por Levagggi, 1972, op. cit., p. 43. En esta publicación, Levaggi realizó una pormenorizada investigación sobre el tema, comenzando con el marco doctrinal y el estado de la cuestión en Buenos Aires, para luego abordar casos. Se dedicó especialmente al de Clorinda Sarracán, pero sin contar con el expediente judicial. Más recientemente, Ricardo Salvatore publicó un ensayo sobre la "Pena de muerte y liberalismo", destinado a investigar el papel de la pena capital en la construcción de un orden social y político luego de Caseros. Salvatore, Ricardo, 2010, op. cit.

${ }^{3}$ Bartolomé Mitre, Diputados, 1857, 24 de julio de 1857, p.324.
} 
relacionados con los bienes y los hijos del difunto), desde el alcalde hasta los magistrados del Superior Tribunal. Pero también actuaron testigos, imputados, victimarios y distintos actores sociales, a favor o en contra de Clorinda. El expediente se convierte así en un observatorio de la organización y el funcionamiento de la justicia criminal vistos desde distintas perspectivas.

El 12 de octubre de 1856, en una chacra de Santos Lugares, Crispín y Remigio Gutiérrez asesinaron al pintor Jacobo Fiorini, instigados por su esposa Clorinda Sarracán de Fiorini. Los tres fueron condenados a la pena de muerte el 29 de noviembre del mismo año por el juez del crimen del Departamento de la Capital, Miguel Navarro Viola, iniciándose una fuerte movilización de la sociedad de Buenos Aires en contra del fusilamiento de una mujer. Pero también el asesinato inició un inesperado conflicto de poderes dentro de la construcción de la nueva legitimidad del orden político. La pena de Clorinda fue finalmente conmutada por el gobernador Emilio Castro, por los años de presidio que ya había cumplido, el 12 de abril de 1869.

Siguiendo las diversas instancias judiciales, determinaremos quienes eran los actores y las vías a través de las cuales se manifestaban, fijando el ritmo que los conflictos del Estado provincial le fueron dando a la causa, en busca de resolver una cuestión fundamental como era el derecho a la vida en el contexto de la formación del Estado de la provincia de Buenos Aires. Para esto es necesario determinar las posturas de los tres poderes del Estado provincial ante la pena de muerte y el indulto, pero también las relaciones entre ellos y el lugar que cada uno ocupaba en la construcción de la nueva legitimidad del orden político.

El capítulo se desarrolla siguiendo la evolución de la causa por dos razones; en primer lugar porque permite conocer el funcionamiento del "universo judicial" en el que magistrados, funcionarios, agentes judiciales, víctimas y victimarios se mueven. En segundo lugar por ser necesario para comprender la trayectoria de los enunciados normativos de garantías que se sancionaron en estos años. El juicio criminal se dividía en dos partes: el sumario, que tenía por principal objetivo la justificación del delito y de los autores, y el plenario, en que se discutía contradictoriamente la culpabilidad o inocencia de los procesados, dándose la sentencia condenatoria o absolutoria. ${ }^{4}$ En la evolución del proceso judicial incorporaremos los debates que éste generó y que permiten acceder al Estado que se estaba construyendo y determinar cuál de sus poderes tendría la facultad de perdonar.

\footnotetext{
${ }^{4}$ Tejedor, Carlos, Curso de derecho criminal, segunda parte: Leyes de formas, segunda edición, Buenos Aires, Librería de Cl. M. Joly, 1871 [1860], p. 130. (En adelante Curso de Tejedor) La justicia criminal investigada en base a expedientes judiciales es la que más estudios ha producido y sería aquí imposible hacer referencia a todos, mencionamos aquí algunos ejemplos: Slatta, Richard y Robinson, Karla "Continuities in crime and punishment. Buenos Aires, 1820-1850”, en Lyman L. Johnson, The problem of order in changing societies: Essays on crime and Policing in Argentina and Uruguay, 1750-1940, Albuquerque, University of Mexico Press, 1990; Barreneche, 2001, op. cit.; Salvatore, 2010, op. cit; Fradkin, 2006, op. cit; Agüero, 2010, op. cit; Salguero, Paula, "Homicidios en Buenos Aires 1830-1849. Una mirada sobre el uso de las normas y el universo de los casos", en Piazzi, , 2011, Yangilevich, , 2012, op. cit.
} 


\section{De la averiguación del delito y del delincuente (sumario)}

\section{a. La desaparición y las primeras declaraciones}

La causa fue iniciada el 27 de octubre de 1856 por Basilio Salas ${ }^{5}$, juez semanero de la Cámara de Justicia, que encargó al juez del crimen Miguel Navarro Viola ${ }^{6}$ practicar las diligencias que considerara necesarias para descubrir la causa de la desaparición de Jacobo Fiorini que había sido denunciada por la prensa ${ }^{7}$, procediendo con arreglo a derecho. ${ }^{8}$ Avanzadas las investigaciones la causa fue caratulada como asesinato, definido en el Código penal de Tejedor como "homicidio cometido con premeditación y alevosía", castigado con la pena de muerte. ${ }^{9}$ Sin embargo, en el Curso redactado por él mismo en 1860, el homicidio significaba todo ataque a la vida del hombre por accidente, premeditado o como consecuencia de una falta o un hecho intencional, sin aparecer la palabra asesinato. En la práctica pudimos observar que las palabras asesinato, homicidio o muerte eran utilizadas para caratular los expedientes ${ }^{10}$, con lo que podemos afirmar que el codificador recoge la práctica judicial.

Jacobo Fiorini, pintor italiano que llegó a Buenos Aires en 1829, se destacó como retratista y miniaturista de la sociedad porteña. Había salido de su chacra en Santos Lugares a caballo el 12 de octubre de 1856 para atender sus negocios en la capital y nunca más se supo de él. ${ }^{11}$ Su búsqueda fue iniciada el 24 de octubre por el suegro, Carlos Sarracán -a pedido de su hija- que denunció la

\footnotetext{
${ }^{5}$ Basilio Salas en 1852 -año que se matriculó- fue nombrado juez de primera instancia civil de la Capital. Tres años después pasó a formar parte de la Cámara de Justicia y en 1857 integró el Superior Tribunal en su sala civil. Fue diputado provincial entre 1854-1856; 1860-1862 y 1863-1866. No era legislador en los meses que duró este proceso penal. En 1875 no formó parte del poder judicial organizado de acuerdo a la Constitución de 1873 y reapareció como Vocal del Monte de Piedad en 1877.

${ }^{6}$ Miguel Navarro Viola nació en Buenos Aires el 6 de febrero de 1830. En 1838 falleció su padre y fue su tutor Vicente López y Planes, recibiendo una educación de fuerte influencia jesuita. En la Universidad de Buenos Aires aprendió derecho civil y de gentes con el catedrático español Rafael Casagemas y derecho canónico con José León Banegas. El 22 de noviembre de 1848, leyó su tesis sobre Familia y Propiedad, para obtener el grado de doctor en jurisprudencia, siendo su padrino Baldomero García, en cuyo estudio se formó en la profesión entre 1849 y 1851 . Partidario de la legislación española, sostenía que Adolfo el Sabio con las Partidas había enturbiado "los limpios manantiales del remoto derecho peninsular", cuya fisonomía original había desdibujado el Monarca "al echar al suelo, con una mano, lo que había edificado con la otra, y haciendo del derecho español, de suyo espontáneo y progresista en los dos Códigos anteriores a las Partidas, un esclavo del Derecho romano". Defendía la necesidad en Hispanoamérica de un derecho autóctono, de raíces vivas, para presidir la estructura legal de sus pueblos. Su biógrafo lo definió como "jurisconsulto erudito, magistrado severo, parlamentario borrascoso, historiógrafo y educador”. Rivero Astengo, Agustín, Miguel Navarro Viola. El opositor victorioso, 1830-1890, Buenos Aires, Guillermo Kraft Limitada, 1947. En 1855 fue nombrado juez del crimen del Departamento Dolores y al año siguiente ejerció el mismo cargo en la Capital, renunciando el 21 de febrero de 1857 para dedicarse a ejercer la profesión.

${ }^{7}$ El Nacional, $\mathrm{N}^{\circ} 1332 ;$ El Orden, $\mathrm{N}^{\circ} 369$, en Levagggi, 1972, op. cit.

${ }^{8}$ Archivo Histórico de la provincia de Buenos Aires. Causas criminales. Cuerpo 41, Anaquel 3, Legajo 166, exp. 2. “Crimen, Implicados Clorinda Sarracán de Fiorini, Crispín y Remigio Gutiérrez, Nicolasa Merlo y Claudia Alvarez. Asesinato perpetrado en la persona de Dn Jacobo Fiorini en Santos lugares en la noche del 12 de octubre del presenta año. 1856."

9 Art. 207, Código penal de la provincia de Buenos Aires, Buenos Aires, Imprenta y librería de Mayo, 1884, p.168. El Código penal de la Provincia de Buenos Aires, fue proyectado por Carlos Tejedor y sancionado en 1877. Luego fue adoptado con modificaciones por la ley del Congreso Nacional N¹920, dictada el 25 de noviembre de 1886 , promulgada por el presidente Juárez Celman el 7 de diciembre de 1886.

${ }^{10}$ Juzgado del crimen de Dolores, 1853-1881. Sección Histórico- Judicial de Dolores, SCBA.

${ }^{11}$ Fiorini pintó los retratos de Rosas, Mariano de Somellera, Miguel de Azcuénaga, Marcos Balcarce y Dolores Posadas de Meyer, pero hacia 1856 no estaba ya dedicado a la actividad artística y atendía su chacra en Santo Lugares, un pueblo rural a quince kilómetros de Buenos Aires.
} 
desaparición a la policía, haciéndose cargo el comisario de la Villa de Luján, Nicolás Arneaud. El juez de paz y comisario de San Isidro, Fernando Alfaro, informó al Jefe del Departamento de Policía Cayetano Cazón, que los alcaldes más inmediatos al Establecimiento habían pasado circulares para adquirir datos sobre la desaparición de Fiorini. Habían revisado varios pozos del pueblo, abandonados y cubiertos con cicuta, sin encontrar nada.

El 27 de octubre Cazón se dirigió al presidente de la Cámara de Justicia, Juan José Cernadas, comunicándole lo realizado e informándole que habiéndose presentado el juez del crimen Miguel Navarro Viola ordenó al comisario Arneaud ponerse a su disposición. ${ }^{12}$ Quedaban así establecidas las relaciones entre la administración de justicia y la policía frente a la desaparición del pintor, haciéndose cargo directamente el juez del crimen del Departamento Capital, pero con la colaboración del juez de paz de San Isidro y el comisario de Luján. Por tratarse de la investigación de un delito, el derecho de sumariar pertenecía a la justicia criminal, pero para la más rápida y eficaz resolución esta facultad era dada al jefe de policía, a los comisarios y a los jueces de paz en su condición de tal. Sin embargo en este caso que ya había alcanzado repercusión pública por la denuncia de la prensa, el Tribunal dio intervención directa al juez de primera instancia quedando los funcionarios policiales a su disposición, aunque habían iniciado las diligencias.

Mientras tanto en Santos Lugares, en otro sector de la opinión pública, ya se decía que el capataz de la chacra Crispín Gutiérrez, era quien había asesinado a su patrón, por lo que el comisario lo había mandado detener, junto con los peones, por el alcalde Manuel Pico, que se presentó en la chacra recibiendo datos de Clorinda. El 28 de octubre el comisario Arneaud los remitió al Departamento General de Policía, informando que el capataz, que se hallaba algo asustado, era el sospechoso de la muerte de Fiorini, cosa que podía serle útil al juez. Crispín realizó su primera declaración ante el juez -a continuación del peón Martín Arriola que se había ido a la casa de su madre el día del asesinato- respondiendo al interrogatorio con una minuciosa descripción de cómo el lunes 13 de octubre a la madrugada su patrón había dejado la chacra en su caballo picazo. ${ }^{13}$ No sabía la dirección que había tomado porque entró a tomar mate a la cocina, donde sólo se encontraba doña Clorinda, y desde entonces aquel no había regresado a la chacra.

\footnotetext{
${ }^{12}$ Para Carlos Tejedor el procedimiento de oficio era "una especie de ficción, por la cual una misma persona ejercita las dos facultades de acusador y juez". Entre los Romanos había nacido del descrédito de la acción popular, pero las Partidas lo limitaban a ciertos casos (L. 28, tít. 1, P. 7), haciéndolo las recopiladas general. Así los jueces del crimen tenían por ellas la misma recomendación, con más empeño todavía que el ministerio fiscal, de perseguir todo delito público que causase escándalo. El procedimiento de oficio era la base del procedimiento criminal y los autores criticaban - para Tejedor con razón- esta acumulación de funciones. Curso de Tejedor, 149-153. Expediente, f. 30v.

${ }^{13}$ La declaración indagatoria era la primera que se tomaba al reo bajo promesa de decir verdad. Si bien no estaba establecida por las leyes se la creía necesaria para la mejor instrucción del proceso. Además en las Partidas se establecía que "Preso el reo, el judgador devele fazer jurar que diga verdad de aquel fecho sobre lo que recadbaron" (L. 4, tít. 29, P. 7) Una disposición recopilada mandaba tomarla dentro de las 24 horas "por no ser justo privar a un hombre de su libertad, sin que sepa la causa porque se le quita" (Instrucción del 15 de mayo de 1778). La Constitución de 1854 prohibía el juramento en ella y en la confesión. (art. 165). Curso de Tejedor, pp. 106-110. En el expediente se utilizaba la palabra juramento con la fórmula "Su señoría le recibió juramento que le prestó en forma con arreglo a derecho (o
} 
Continuó describiendo que llevaba sombrero de pelo, una capa de paño y forro de merino, todo de color negro, como el pantalón con listas amarillas, chaleco y levita, botas de charol con zapatos de goma y un reloj de oro. Lo que había despertado sus sospechas sobre la desaparición de Fiorini, fue que el jueves o el viernes había estado en la chacra un francés que iba a instalar una casa de negocio a medias en sus terrenos, diciendo que no lo encontraba en la ciudad. Asegurándole la señora que debía estar allí, porque desde el lunes faltaba de la chacra, este hombre fue a buscarlo y nuevamente no lo halló, por lo que al día siguiente resolvió la señora que la acompañara a la ciudad. Registraron la pieza donde vivía Fiorini cuando iba a Buenos Aires, abriéndola con una llave que le dieron en la casa, pero no encontrando rastros de que su esposo hubiese estado allí retornaron a la chacra. Doña Clorinda regresó otra vez con su padre que la fue a buscar en carruaje. La declaración fue firmada por el escribano Alejandro Araujo y por el juez, dado que el declarante no sabía hacerlo.

Navarro Viola se trasladó a la casa en que se hallaba Clorinda para tomarle declaración, en la que explicó que el motivo por el que Fiorini decidió ir a la ciudad fue porque "el sábado once del corriente a la noche estuvo un individuo a hacer citación de peones, alarmando con la venida de Urquiza lo que la declarante trasmitió a su esposo, quien comenzó desde entonces a cavilar. Que el domingo doce fue la que declara a la vecindad a lo de Don Julián Paiba, a saber si era cierta la citación y que volvió a su chacra como a la una". ${ }^{14}$ Entonces la declarante explicó que Fiorini alarmado había pensado salir ese día porque se vencían unas letras, pero por el sol no lo hizo y se fue al día siguiente, y continuó describiendo el caballo y el vestuario coincidiendo con Crispín. El argumento tenía pleno sentido pues 1856 fue un año que puso a prueba a Buenos Aires ante la invasión de sus territorios por partidas federales o malones indígenas, haciéndose común el reclutamiento forzoso. ${ }^{15}$

Continuó Clorinda siendo muy cuidadosa de realizar una declaración coincidente con la rutina de su marido y mencionando posibles enemigos, pero utilizando fuentes poco precisas. El francés Resse le había dicho que, según unos amigos, hacía dos o tres días que los había convidado a almorzar y que luego había ido probablemente al encuentro de Madama Olivieri, pasando luego por

por Dios y una señal de la cruz) prometiendo a su cargo decir verdad en cuanto supiere y fuere preguntado Realizadas las preguntas generales y especiales se leía la declaración al procesado, agregando las aclaraciones que hiciese, firmando éste con el escribano y el juez. Expediente, f. 15-19.

${ }^{14}$ Las declaraciones a continuación se denominan dentro del proceso "Información de testigos". Sirven para inquirir y no para probar. Los testigos del sumario se distinguían del plenario en que se recibían sus dichos aunque fueran sospechosos o inhábiles y en que sus declaraciones se tomaban sin la citación del reo (tít. 17, P.3) Pero en el plenario y en el sumario debían estar presentes el juez y en escribano (L. 26, tít. 16, P. 3) bajo pena de multa y a la tercera vez de oficio. Si los testigos no estaban en el lugar del juicio, podía mandarse un exhorto a jueces iguales y a los subalternos un oficio de comisión. Pero si la causa era grave como muerte, perdida de miembro o destierro se mandaba a los testigos comparecer a la presencia judicial. (L. 10, tít. 8, lib. 2 Fuero Juzgo) Curso de Tejedor, pp. 93. Expediente, f. 19-19v.

${ }^{15}$ Levene, 1940, volumen I, op. cit., p. 416-417. Sobre las exigencias militares en la campaña consultar Garavaglia, Juan Carlos, "Ejército y milicia: los campesinos bonaerenses y el peso de las exigencias militares (1810-1860)"; "De Caseros a la Guerra del Paraguay: el disciplina miento de la población campesina en el Buenos Aires posrosista (18521865)", ambos en Garavaglia, 2007, op. cit. 
la casa de Carrandi en la calle del Parque, donde tenía su escritorio y que allí supo, por la hija de los dueños, que no había ido a su cuarto. Ésta le facilitó una llave del cuarto, como dijo el capataz, con la que entró sin poder decir que faltara ropa pues no sabía lo que el marido tenía allí, pues no iba al pueblo hacía quince meses. Agregó que el año anterior Fiorini había tenido una cuestión con unos italianos, Juan y José, hallándose estos en inmediaciones de la chacra. También tuvo un disgusto con Antonio Reyes que duró mucho tiempo, y que debiendo pagarle dos meses de arrendamiento por sentencia de los tribunales, había amenazado con quitarle la vida.

Pero a partir de la declaración del hermano de la víctima, Vicente Fiorini ${ }^{16}$, surgieron los graves conflictos que sufría el matrimonio, que tenía cinco hijos. Recordaba que hacía como ocho meses le había preguntado por el nombre del último de ellos, recibiendo por respuesta que se padre se lo pondría, pues era hijo de su esposa pero no suyo. Agregó que en ocasión de haber pasado dos días en la chacra, Jacobo le contó que su esposa había huido en una carreta en dirección al pueblo y que no pensaba hacer que volviese. Finalmente, si bien hacía dos meses lo había visto en la volanta en inmediaciones de la chacra y habían charlado cosas indiferentes, había oído más pormenores sobre las desavenencias entre su hermano y su esposa de Don José Ruiz. ${ }^{17}$

El 29 de octubre declaró la sirvienta Nicolasa Merlo, coincidiendo en todo con Clorinda y Crispín. El mismo día se presentó José Ruiz, mandado a citar por el juez, exponiendo que a principios del verano apareció la señora de Fiorini en su chacra pidiéndole ayuda, mas como tenía orden de no admitirla, la mandó a la casa. Dos meses más tarde se presentó en una carreta, con la cara y las manos estropeadas, diciendo "vea como me ha puesto mi esposo", pidiéndole una habitación, pero él nuevamente se negó. Puede observarse el lugar de la mujer en el matrimonio, ante la declaración de un vecino que admitía los malos tratos de Fiorini a su esposa pero que priorizaba las órdenes de su marido de no auxiliarla. ${ }^{18}$ El 30 de octubre el juez ordenó un careo entre el capataz, Martín Arriola y Nicolasa Merlo que ratificaron todas sus declaraciones. ${ }^{19}$

\section{b. La confesión de Crispín y la detención de Clorinda}

La ampliación de la declaración de Crispín Gutiérrez fue fundamental en dos aspectos, por un lado para quebrar las exposiciones coincidentes de todos los que estaban en la chacra cuando desapareció Fiorini y por otro porque generó un conflicto jurídico por la conducta del magistrado, que se mantuvo latente en toda la causa. El capataz comenzó asegurando que el patrón la maltrataba

\footnotetext{
${ }^{16}$ De cuarenta y dos años, sabía firmar.

${ }^{17}$ Expediente, f. 25 v.-27.

${ }^{18}$ Sobre la violencia conyugal y específicamente sobre la corrección de la esposa: Ghirardi, Matrimonios y familias en Córdoba 1700-1850, Córdoba, Ferreyra Editor, 2004.

${ }^{19}$ El careo es una diligencia en presencia del juez y del escribano "en que varias personas que están disconformes en sus dichos, procuran recíprocamente convencerse de las circunstancias del delito". No podía realizarse entre padre e hijo o entre marido y mujer. Los autores discrepaban sobre su utilidad, pero Tejedor, con Montesquie, consideraba que era contrario a toda defensa condenar a un hombre sin que confrontaran los testigos. Curso de Tejedor, pp. 112-114.
} 
siempre a Clorinda, hasta llegar casi a tirarla al pozo o persiguiéndola con una navaja de barba. Pero además, y esto es fundamental, el domingo víspera de la desaparición lo había tratado a él de pícaro.

Entonces, notando la visible turbación del declarante, Navarro Viola lo exhortó a que dijera la verdad, que el capataz ofreció decir a condición de que "su señoría emplease para con él toda indulgencia y le ofreciese que no se le aplicaría la pena capital". El juez le ofreció usar de "toda indulgencia que pudiese en el límite que las leyes le marcaban". ${ }^{20}$ Este diálogo es por demás descriptivo de la situación del reo que temía la pena máxima y del juez que debía atenerse a la letra de la ley. Enseguida el declarante reiteró que en efecto el domingo lo había tratado su patrón de pícaro, pero que ya muchas veces doña Clorinda le había pedido que matase a su esposo porque no podía tolerarlo. Pero no se animaba, hasta el lunes temprano cuando habiendo salido Fiorini, lo siguió y lo mató con un palo, perdiéndose su caballo.

Esta historia le resultó al magistrado inverosímil y lo exhortó nuevamente a decir toda la verdad, contando Crispín otra versión, empezando a revelar parte de lo que realmente había sucedido. El domingo a la noche tiró un pistolazo a su patrón cuando éste salió afuera a eso de las once. Sin saber dónde le pegó acabó por matarlo a palos y lo enterró detrás de la casa como a cuatro varas de la pared donde había un charco, echando encima basura Lo mismo hizo con el reloj a media cuadra de la casa, a la orilla de una zanjita donde había un cebollino. La silla de montar la quemó y la pistola quedó en el cuarto suyo y de los peones. Entonces Navarro, siendo urgente tomar las medidas del caso, suspendió la declaración. ${ }^{21}$

Mandó buscar a Clorinda Sarracán a la casa donde residía para ser llevada a la cárcel pública, debiendo quedar a disposición del juzgado. ${ }^{22}$ El mismo día el juez, el actuario Alejandro Araujo, los médicos de policía Claudio Armoedo y Manuel Blancas y el comisario Nicolás Arneaud, con una escolta de vigilantes, se trasladaron a la chacra de Jacobo Fiorini, en el partido de San Isidro, llegando a las nueve de la noche e iniciando la inspección judicial. Al día siguiente, a las cinco de la mañana, procedieron a la excavación del paraje designado por Crispín Gutiérrez. El cadáver apareció a vara y media de profundidad, poniéndolo Navarro a disposición de los facultativos, recomendando la más pronta redacción del informe médico. ${ }^{23} \mathrm{El}$ inventario de los bienes fue encomendado al alcalde Pico y su depósito a persona de conocida responsabilidad.

Esta parte del proceso permite observar el procedimiento ante el homicidio y la actuación de los agentes y funcionarios que intervenían. Se denominaba inspección judicial, en que el juez se

\footnotetext{
${ }^{20}$ Expediente, f. 43 v.

${ }^{21}$ Expediente, f. 43-45.

${ }^{22}$ Durante los años que Clorinda Sarracán estuvo presa, la cárcel pública o del Cabildo en plaza de Mayo" era, en palabras del El Nacional: "En primer lugar cárcel de criminales [encausados], segundo cárcel correccional; tercero presido dónde cumplen sus condenas muchos de los reos y cuarto cárcel de mujeres." Todo se reunía en una sola casa en cuyas habitaciones "faltaba hasta el aire para respirar". El Nacional, "La Cárcel", 5 de octubre de 1860. Citado por Levaggi, 2002, op. cit., pp. 57-59.

${ }^{23}$ Curso de Tejedor, pp. 99-100.
} 
trasladaba al paraje del delito para enterarse por inspección propia de sus circunstancias materiales, consignándolas en el expediente. ${ }^{24}$ Participaban el juez de primera instancia criminal, el secretario escribano y los médicos de policía; el primero es el que estaba a cargo, el segundo daba fe de lo actuado y los terceros son peritos que, llamados para resolver ciertas cuestiones, no son testigos ni juzgan, sino que presentan un informe por requerimiento judicial, sin resolver la cuestión de hecho ni la de derecho. ${ }^{25}$

\section{c. Las declaraciones de los acusados}

Fueron mandados a incomunicados Carlos Sarracán y Nicolasa Merlo, la que finalmente contó toda la historia. Natural del estado y soltera, ignoraba su edad (representaba 25 años), se ocupaba de sirvienta en la chacra de Fiorini y fue aprehendida en el Departamento de Policía, habiendo sido mandada de la chacra por un comisario para prestar declaración el 29 de octubre por la desaparición de su patrón. Exhibida la maza encontrada envuelta en la talma ${ }^{26}$ de Fiorini junto al cadáver, expuso que con ella lo habían matado Crispín y Remigio Gutiérrez la noche del domingo 12. Ambos se lo contaron a Clorinda, hallándose con ella y Claudia en la cocina. La patrona había dicho "gracias a Dios que ahora descansaré, que bastante me ha estropeado, y no hace más que pagar las que ha hecho conmigo". ${ }^{27}$ El patrón la celaba de Crispín y ella vivía con éste todo el tiempo que no estaba en la chacra, durmiendo juntos la misma noche del asesinato, "pues cuando la declarante le llevó mate a la cama, Crispín se estaba levantando de la misma cama desnudo". ${ }^{28}$

El domingo el patrón pasó todo el día en el altillo, teniendo puesta una silla atravesada contra la puerta para sentir si entraba alguien. Le había ordenado a la señora que pagara su conchavo a Crispín para que se fuese, pues no lo quería más en la casa, pero ella se negó, protestando que no tenía dinero para pagarle. Durante el día la patrona las había mandado con Claudia y los chicos, unas veces al cardal a comer tallos y otras al palomar a sacar pichones, echándolas cuando fueron a entrar en la sala por la tarde.

A eso de las ocho de la noche, estando ambas en la cocina oyeron un tiro y fueron a la puerta, salió la señora del palomar y fue a la cocina como asustada, diciéndoles "hijas no se lo que me pasa", entrando luego Crispín y el hermano. Cortaron un pedazo de alfombra ensangrentado y lo lavaron, lo mismo que el suelo por donde arrastraron el cadáver en un cuero hasta atrás de la casa, cavando entre los dos la sepultura mientras la patrona lavaba el forro del sofá, que creía que todavía tenía algunas manchas. Remigio al principio no se animaba a participar del asesinato, pero Crispín

\footnotetext{
${ }^{24}$ Curso de Tejedor, p. 88. Curia Philípica, P. 3, p. 10, n. 7. Posteriormente, esta diligencia judicial fue conocida como "Inspección Ocular" (etapa sumarial) o "Reconstrucción del hecho" (etapa plenaria).

${ }^{25}$ Curso de Tejedor, pp 90-92.

${ }^{26}$ Especie de esclavina usada por las señoras y caballeros para abrigo en lugar de capa.

${ }^{27}$ Expediente, f. 51 v.

${ }^{28}$ Expediente, f. 52.
} 
hizo traer un poco de ginebra y estuvieron tomando. El dinero, después que mataron al patrón, le quedó al capataz porque cuando los peones pedían dinero, era él quien se los daba.

El 1 de noviembre fue llevada a declarar la otra sirvienta, Claudia Alvarez, que agregó que el patrón tenía una bayoneta y que Clorinda se encargó de quitársela. Además de todos los detalles contó "que aunque la mayor parte del tiempo el patrón estaba en la ciudad, los días que pasaba en la chacra siempre estaba enojado con la señora, y que hace meses que habiéndole ella pegado a uno de los chicos contra el encargo del patrón de que no lo hiciese le dio un bofetón que la tiró al suelo, habiéndose venido ese día la patrona con la declarante en una carreta a lo del señor Ruiz quien le dijo que no podía quedarse allí". ${ }^{29}$

A Clorinda Sarracán le tomaron declaración indagatoria en la cárcel el 2 de noviembre, negando ella absolutamente todo. Sólo en el careo que le realizaron con Crispín, Nicolasa y Claudia, después de varias alegaciones, confesó el hecho, aceptando los cuatro ser ciertos los detalles contenidos en las declaraciones de Claudia y Nicolasa, agregando la patrona y el capataz que ellas eran sabedoras del asesinato que debía perpetrarse desde días antes, y que aún Nicolasa proponía los medios de llevarlo a cabo, aclarando ella que lo hacía en broma. También convinieron en que Carlos Sarracán no había estado en la chacra hasta nueve días después del asesinato y que Arriola no había sabido nada ni tenido la menor parte.

En la declaración de Carlos Sarracán le preguntaron qué cantidades había cobrado pertenecientes a la familia de Fiorini, respondiendo que autorizada su hija por el juez de primera instancia Benito Carrasco ${ }^{30}$ para recibir los bienes del esposo, el declarante fue comisionado por ella para cobrar algunas letras, percibiendo una de treinta y dos mil de Basarte y otra de quince mil de Pondal, colocando los cuarenta y siete mil pesos en la Casa de la Moneda, a nombre de ella por el término de un mes al interés del diez por ciento al año, recibiendo una libreta, que se encontraba en su cuarto habitación en el ropero con otros papeles. En ese acto presentaba también una letra de cincuenta onzas de oro aceptada por Simón de la Serna, vencida el catorce de octubre. Las tres letras habían sido tomadas del cuarto de Fiorini el día que fue su hija con el escribano. ${ }^{31}$

A esta altura del proceso consta el pedido de ampliación de divorcio de Clorinda, que le había sido dado con cohabitación, pero por el cruel tratamiento de su esposo requería poder vivir en casas separadas, advirtiendo a la autoridad eclesiástica que podía recurrir al juez del crimen. Sin embargo, al ser consultado el Provisor, respondió que no tenía otro antecedente sobre las desavenencias ocurridas entre los esposos, que el haberse presentado a esa Curia el año pasado por

\footnotetext{
${ }^{29}$ Expediente, f. 58 v.

${ }^{30}$ Benito Carrasco fue juez civil de la Capital entre 1855 y 1857, y era a quien se debía recurrir en cualquier cuestión relativa a la guarda de los menores y bienes de la testamentaria de Jacobo Fiorini, previa constancia en la causa criminal y avisándole al Alcalde del cuartel $6^{\circ}$, que había sido encargado del inventario.

${ }^{31}$ Expediente fs. 63 v.-64v.
} 
cortas y ligeras desavenencias, que fácilmente arreglaron sin haber quedado constancia en el libro de $^{\text {Actas. }}{ }^{32}$

\section{Del plenario o juicio propiamente dicho}

El juicio era, en palabras de Tejedor, "la discusión de la causa ante el juez”, la causa "la cosa que sufre la controversia", pleito "la misma controversia" e instancia "el ejercicio de la acción en juicio". Terminado el sumario empezaba "el juicio verdadero", caracterizado no por la publicidad, sino por ser contenciosos y contradictorio, discutiéndose la inocencia o la culpa de los acusados. ${ }^{33}$

\section{a. La acusación y la defensa}

En las confesiones Crispín había asegurado que no pudo sufrir que esa mañana lo insultase a él, con todos los hijos del país, y que había obrado en combinación con Clorinda Sarracán por ver como la maltrataba. Aceptó la infidelidad, asegurando que esa noche durmieron juntos como tenía costumbre cuando no estaba el patrón. También confesaron las sirvientas, justificándose de no haberlo hecho antes por no permitirles su patrona. En cambio Clorinda negó todo, incluido el adulterio.

El agente fiscal en lo criminal, Emilio Agrelo, encontró probado y confesado el crimen por sus autores, que habían matado "atroz y alevosamente a su patrón". 34 En cuanto a Clorinda Sarracán, si bien proyectaba el asesinato de su marido, no existía la misma comprobación plena y perfecta que la ley exigía. No negaba la culpa de la "perversa mujer", que ocultaba el hecho por mantener relaciones ilícitas con el autor, pero la pena de muerte debía ser para el hombre y no para la mujer. ${ }^{35}$ Clorinda fue parte y pedía quince años dada "la necesidad y la justicia del escarmiento para evitar la repetición de crímenes tan bárbaros como éste, lo cual no solo se consigue con la pena de muerte que por desgracia preservan nuestras leyes". Respecto a las sirvientas, no tenían otro móvil más que la orden de la patrona, por lo que pedía diez años. Para Crispín existía el móvil del insulto y se había encontrado el cadáver, plena prueba y perfecta, pidiendo por la Séptima partida y la Recopilación Castellana la pena de muerte con calidad de aleve.

\footnotetext{
${ }^{32}$ Expediente fs. 81-81 v. Sobre el divorcio y la diferencia planteada en el juicio: Ghirardi, 2004, Segunda parte, pp. 217-418.

${ }^{33}$ Curso de Tejedor pp. 119-120.

${ }^{34}$ Esta es la acusación en forma en que se reproducía la acción deducida, se fundaba con las constancias de autos y se pedía la pena. Curso de Tejedor, pp. 121-122. Expediente, f. 113. Los acusados a la vez eran testigos y cómplices, por lo que Agrelo citaba la ley 8 tít. 16 Partida $3^{\text {a }}$ de aquellos que no pueden ser testigos, señalando entre otros "aquellos contra quienes fuese probado que dijeron falso testimonio; aquellos que matasen los omes, fueras ende si lo ficiesen tornando sobre si." Según la ley 10, tampoco podían hacerlo aquellos que estuvieran presos por causa criminal, pues podrían dar falso testimonio con la promesa de ser sacados de prisión.

${ }^{35}$ Agrelo alegaba haber recorrido todas las leyes de Partidas y Recopilaciones que se ocupaban de los homicidios y en ellas sólo se ocupaban "del hombre que mata” y no de la mujer que cometía igual crimen. Expediente, f. 116.
} 
El 2 de noviembre fue notificado el defensor de pobres Simón R. Mier, del nombramiento que de oficio se le hacía para la defensa de los presos Crispín Gutiérrez, Nicolasa Merlo y Claudia Álvarez, con Joaquín Cueto como padrino. ${ }^{36}$ Clorinda nombró a Roque Pérez, pero este se excusó, quedando Carlos Tejedor a pesar de haberse negado tres veces, obligándolo Navarro Viola a aceptar poniéndole un plazo de cuarenta y ocho horas para presentar la defensa. ${ }^{37}$

El defensor de pobres, con Marcelino Aguirre como asesor, citó en su defensa a autores de la talla de Pedro Gómez de la Serna y Juan Manuel Montalbán, asegurando que era absurdo tratar de imponer pena al que confesaba ser autor de un delito, mientras no constase que este delito se había cometido y los testigos no fueran oculares. En las conferencias que había tenido con sus cuatro defendidos, pudo notar la confianza plena que Crispín había puesto en que el magistrado usaría toda la indulgencia para con él respecto a la pena de muerte. Sus declaraciones habían encaminado las investigaciones, por lo que debía cumplirse con la condición prometida, siendo legal el deseo del preso de que no aplicasen la pena máxima en él.

Si bien no era defensor de Clorinda, se explayó respecto a su situación. Consideraba que Fiorini debió dar a su ahijada, su pupila y su tierna esposa

una educación esmerada, que le imprimiese el sentimiento religioso propio de la mujer y que despertase y dirigiese los suaves instintos peculiares a ese sexo. Entonces hubiese tenido una excelente esposa y madre, y su matrimonio hubiera sido feliz. No lo hizo así, descuidó su educación, y él ha sido desgraciado, y ha contribuido con su omisión a la desgracia de su esposa. En este sentido el desgraciado Fiorini alguna parte ha tenido en la causa que ahora hace padecer a su mujer, a su capataz y peón y a sus sirvientas. ${ }^{38}$

"El joven criminalista y el nuevo magistrado" podría ostentar su talento "con una sentencia justa, dando a cada procesado su pena proporcionada al grado de su culpa, sin mancharla con sangre”. Pedía para Crispín diez años de presidio y para Remigio seis años ambos con destino a los trabajos públicos; para Nicolasa cinco años de presidio y para Claudia tres años, destinadas ambas a los trabajos a que se encontrara conveniente aplicarles. ${ }^{39}$

Para Carlos Tejedor no había confesión y no servían las declaraciones de los cómplices. ${ }^{40} \mathrm{La}$ única acusación posible era que no había dado parte de la muerte, pero lo cierto era que hubiera sido un milagro que Clorinda fuera otra cosa, después de los antecedentes de los que partía. Su marido era su padrino y había tenido antes relaciones ilícitas con la madre. Su defendida pasaba por

\footnotetext{
${ }^{36}$ Joaquín Cueto iniciaba su carrera judicial matriculándose en 1858 . Entre 1860 y 1867 fue juez del crimen del sud, pasando luego al mismo cargo en la Capital hasta 1874.

${ }^{37}$ El reo, terminado el sumario, se estaba defendiendo siempre, pero la defensa propiamente dicha era el primer escrito en que contestaba al acusador o fiscal oponiendo las excepciones que tuviera para salvarse del delito y su pena. Curso de Tejedor, p. 123. Fijando las garantías de la defensa en juicio, el Estatuto provisional para la dirección y administración del Estado del 5 de mayo de 1815 restableció el padrino en las causas criminales, que presenciaba las declaraciones y la confesión cuidando de que no fueran modificadas, sin perjuicio del abogado y procurador establecidos por ley y práctica de los tribunales.

${ }^{38}$ Expediente, f. 147.

${ }^{39}$ Expediente, f. 153.

${ }^{40}$ Expediente, fs. 166-167v.
} 
tormentos y privaciones, viviendo en miseria y soledad hacía dos años; en su desesperación recurrió al divorcio, siendo todo inútil. Cuando un marido era una carga de esta especie, no debía asombrar tanto la falta de cariño de su mujer, aunque esto no librara a Clorinda de la pena, que por fuerza debía ser moderada. El pedido de quince años de prisión del agente fiscal era un "extravío", que no se basaban en ningún principio ni ninguna ley, pudiendo ser por las condiciones atenuantes mencionadas de diez años. Ante ese tipo de dilemas la ley Recopilada ordenaba que las penas de prisión no pudieran extenderse más de 10 años. ${ }^{41}$

Terminadas las defensas, Navarro Viola mandó recibir a prueba la causa por el término de veinte horas. ${ }^{42}$ Fueron certificados por el escribano Araujo la pistola y el reloj depositados junto al cuerpo del delito:

Certifico en cuanto puedo y haga lugar por derecho que la pistola a que se refiere la anterior providencia, es fulminante de las que se cargan en la cintura, teniendo un gancho para ese objeto, es de más de cuarta de largo con la culata y caga balín: el reloj es de oro de dos tapas, de cilindro con cadena de oro de las largas y otra corta rota, se haya manchado de sangre en el exterior de ambas tapas, el vidrio rajado y la máquina está toda tomada. Y en cumplimiento de lo ordenada extiendo el presente que signo y firmo en Buenos Aires a trece de noviembre de $1856 .{ }^{43}$

Ante el planteo de la imposibilidad de ser los reos testigos, el 13 de noviembre Navarro Viola los citó como testigos necesarios para declarar pero sin hacerlo "en lo personal de cada uno."

\section{b. La sentencia}

Producido el término probatorio, el magistrado dictó sentencia el 14 de noviembre. ${ }^{44}$ En los Hechos narró la situación de los esposos, la instigación de Clorinda a Crispín para el homicidio y todas las circunstancias relativas al asesinato destacando que Clorinda preparó a sus coautores y cómplices para las declaraciones con las explicaciones que debían dar. En lo relativo a Derecho, partía de la base de que según certificado médico Fiorini había muerto por los golpes de una maza hallada junto a sus ropas. Los autores del crimen eran no sólo Crispín y Remigio Gutiérrez, ejecutores materiales del asesinato, sino Clorinda Sarracán, autora intelectual, participando de lo material al quitar "alevemente a su esposo la única arma que tenía para su defensa y entregándolo en manos de sus verdugos". Los cómplices Nicolasa Merlo y Claudia Alvarez auxiliaron a los autores principales.

Los cinco reos confesaron el delito, lo que sería suficiente fundamento para la aplicación de la respectiva pena, pero Clorinda quiso retraerse en la confesión. Sin embargo, prescindiendo de la

\footnotetext{
${ }^{41}$ Expediente, f. $162 \mathrm{v}$.

${ }^{42}$ Esta instancia se denominaba "Trámite de prueba", en que la causa se recibía a prueba por un término común. Curso de Tejedor, p. 127.

${ }^{43}$ Expediente, f. 164.

${ }^{44}$ Expediente, fs. $171 \mathrm{v}-180$.
} 
confesión la convicción era plena respecto a la esposa pues los coautores y cómplices, como testigos necesarios, bastaban por su número y la ratificación bajo juramento. El juez expuso detalladamente el fundamento de su fallo, citando autores y leyes, a lo que sumaba la obligación de dar "crudo escarmiento a la diaria multiplicación de crímenes de esta naturaleza", consideración aducida por la Ley 8, tít. 31, Part. $7 .^{45}$

En base a esto, el Fallo, condenaba a Clorinda Sarracán de Fiorini, Crispín Gutiérrez y Remigio Gutiérrez a la pena ordinaria de muerte con la calidad de alevosía y con la clasificación de parricidas. A Nicolasa Merlo la condenaba a diez años de servicio en la Convalecencia y a Claudia Almeida a cinco del mismo servicio en el Hospital de Mujeres; debiendo ambas presenciar la ejecución de Clorinda y satisfacer todos de mancomun et in solidum las costas de esta causa. ${ }^{46}$

Tal como correspondía, pasó la causa en consulta a la Excelentísima Cámara de Justicia. El Fiscal Tomás Castro justificó el maltrato por adulterio, pero aseguraba que era terrible el espectáculo sangriento de una mujer fusilada, que siguiendo sus propias inclinaciones hubiese tratado de evitarlo. Pero su deber le manda pedir la aplicación de la ley. Fue entonces aprobada la sentencia consultada, comunicándolo el 26 de noviembre de 1856 el Tribunal Superior al Ministro de Gobierno Vélez Sarsfield. El poder ejecutivo resolvió que se ejecutase en la plaza de San Isidro, el día 2 de Diciembre a las diez de la mañana, a los reos Crispín y Remigio Gutiérrez. El mismo día a las seis de la mañana en la Plaza 25 de Mayo de la ciudad, debía ser ejecutada Clorinda Sarracán.

Pero el 29 de noviembre sucedieron dos cosas que confirmaron el mundo cerrado que representaba la causa judicial y las vías paralelas de otros Poderes del Estado porque se tomaban ciertas decisiones. Por un lado Carlos Tejedor se presentó a la Cámara de Justicia asegurando el estado de embarazo de su defendida, para que tomara las medidas aconsejadas por las leyes. Se informó al poder ejecutivo y la causa pasó al juez que presentó oficio al presidente del Consejo de Higiene, para que reunido con sus médicos, se trasladaran a la cárcel pública y reconocieran a Clorinda, informando si se encontraba en estado de embarazo La Policía debía poner a su disposición dos vigilantes a caballo y el alcalde permitir a los facultativos la entrada a la pieza de la detenida. El embarazo era cierto, por lo que el mismo día el poder ejecutivo suspendió la ejecución, con aceptación de la Cámara de Justicia. ${ }^{47}$

\footnotetext{
${ }^{45}$ Expediente, f. 179.

${ }^{46}$ Expediente, fs. 171v-180. Navarro Viola se manifestó contrario a la pena de muerte en un artículo en 1854 , Una palabra contra la pena de muerte (El Plata Científico y Literario, t. III, p. 17-19) y otro el 29 de noviembre de 1856 (Súplica a favor de una madre, en El Orden, año II, №379). En éste, 15 días después de dictar la sentencia decía "nuestra tierra está harta de tanta sangre derramada. El pueblo no quiere ver más patíbulos..." Citadas por Levagggi, 1972, op. cit., p. 48.

${ }^{47}$ Los médicos afirmaban que a pesar de faltar la menstruación hacía dos meses, sólo dentro de tres meses a contar de la fecha, podrían "asegurar la existencia o ausencia de preñez, si se notaran entonces claramente los movimientos activos y pasivos del feto y los ruidos fetales, señales las más concluyentes de embarazo en el estado actual de nuestros conocimientos médicos. Pero si la que iba a ser ejecutada estaba en cinta, se suspendía su ejecución hasta el parto, pues el hijo no debía pagar por el error de su madre, ley 11, tít. 31, Part. 7. Clorinda dio a luz el 19 de julio de 1857.
} 
Por otro lado la sociedad de Buenos Aires pedía por la vida de esa mujer y en Asamblea Extraordinaria la Legislatura resolvió “en nombre del sentimiento público, se suspendan los efectos de la sentencia pronunciada contar Clorinda Sarracán como también contra Crispín y Remigio Gutiérrez, hasta la resolución que adopte sobre las peticiones que le han sido dirigidas”. El 1 de diciembre el Ministro de Gobierno se lo informó al Tribunal Superior.

\section{La sociedad movilizada y la respuesta de los Poderes}

Se había cometido un crimen extraordinario y los culpables habían sido condenados a muerte. Pero entre ellos había una mujer, cuyo fusilamiento la sociedad no estaba dispuesta a presenciar, pues estaba en abierta contradicción con los progresos de la ilustración de esos días. ${ }^{48}$ Esto se manifestó en una petición a las Cámaras con infinidad de firmas, que incluían a las señoras de la Sociedad de Beneficencia. Haciendo uso del derecho de petición, imploraban el poder moderador con que la Constitución provincial invistió al poder legislativo. Acataban la rectitud de los tribunales de justicia, que habían cumplido con el deber de aplicar el castigo al crimen con "la severidad de las leyes que no debían templar ni eludir por humanidad". Pero esa severidad se enfrentaba con los principios humanitarios de la civilización, que pedían la abolición de la pena de muerte, y entre tanto la conmutación de la pena de Clorinda. La crueldad de la ley que llevaba a su ejecución, eliminaba el efecto moral del escarmiento y “desagravio de la sociedad irritada". 49

En respuesta a este reclamo la Legislatura en Asamblea Extraordinaria en sesión de 29 de noviembre resolvió “en nombre del sentimiento público" suspender los efectos de la sentencia pronunciada contra Clorinda Sarracán como también contra Remigio y Crispín Gutiérrez, "hasta la resolución que adopte sobre las peticiones que le han sido dirigidas”. El Tribunal de Justicia, considerando "que esta suspensión menoscababa su jurisdicción” suspendió todas las causas en que hubiera de imponerse la pena de muerte." 50 No siendo posible reunir las Cámaras, el poder

\footnotetext{
${ }^{48}$ Eduardo Costa, Sesión del 24 de julio, Diputados, 1857, p. 316.

49 "Notas elevadas a la Honorable Comisión permanente impresas y firmadas." Archivo Histórico de la Provincia de Buenos Aires. Mariana Dain estudió para Córdoba en los años que estudiamos, la dimensión de las emociones que suscitaban los fenómenos de la penalidad a través de la prensa, donde circulaban los primeros rasgos de modernización punitiva que reclamaban castigos "civilizados". En un ambiente considerado inmaduro para cambios radicales, las pequeñas variaciones fueron la base de las futuras modificaciones. Dain, Mariana, "Representantes en tensión: sensibilidades y modernización punitiva en un contexto de transición. Córdoba 1855-1862" en Anuario de la Escuela de Historia Virtual, año 3, N 3, 2010, pp. 97-114.

${ }^{50}$ En Buenos Aires, a 6 de diciembre de 1856, reunidos en Acuerdo extraordinario los señores de la Excma. Cámara de Justicia Dres. D. Juan José Cernadas, D. Domingo Pica, D. Francisco de las Carreras, D. Basilio Salas, con asistencia del señor Fiscal, (Eustaquio José Torres, secretario Pedro Calleja de Prieto) dijeron: Que en nota del $1^{\circ}$ del corriente el Gobierno había comunicado al Tribunal, "que en sesión de 29 del próximo pasado la Honorable Asamblea General ha resuelto, en nombre del sentimiento público, se suspendan los efectos de la sentencia pronunciada contra Clorinda Sarracán, como también contra Remigio y Crispin Gutiérrez, hasta la resolución que adopte, sobre las peticiones que le han sido dirigidas". Que invocándose en la mencionada sanción Legislativa, para suspender la ejecución de los reos, el sentimiento público, asaltaba la duda si el mismo motivo obraría en el ánimo de los Legisladores, en otras causas en que debiese por las Leyes aplicarse la pena ordinaria, duda tanto más atendible cuanto que pudiese suceder, que el delito no viniese acompañado de las circunstancias agravantes que hay en las seguidas a aquellos procesados cuales son las de
} 
ejecutivo se dirigió al Tribunal manifestándole el inconveniente de la medida adoptada, pero este persistió, en perjuicio de la vindicta pública y los mismos procesados, al estar suspendida multitud de causas. Fue entonces que el gobernador resolvió pasar el proyecto a las Cámaras, comenzando así un largo debate que terminó el 29 de septiembre de 1857, ordenando al Tribunal Superior de Justicia que procediera inmediatamente a conocer y fallar las causas pendientes ante él con sentencia de muerte. En ningún caso podría suspender el curso ordinario de ningún género de causas, sin previo consentimiento del cuerpo legislativo. ${ }^{51}$

Comienzan así largos debates legislativos donde la discusión supera le ejecución de Clorinda para instalarse en la pena de muerte, el derecho a conmutar y el papel que jugarían los poderes del Estado en su definición. En primer lugar ¿qué función tenía la pena de muerte para estos hombres? Una respuesta la dió Ireneo Portela al asegurar que por el momento no se podía omitirla, pues no se contaba con cárceles seguras, no estaban determinadas las penas que la remplazaran y no bastarían diez años de cárcel para purgar un crimen en calidad de aleve. La pena de muerte hasta cierto punto moralizaba, sobre todo en nuestro país. Napoleón había declarado el derecho de gracia como una de las más preciosas prerrogativas de los soberanos, pero si era utilizado sobre crímenes que escandalizaban a la sociedad, no hacía más que desmoralizarla, relajando los resortes de la justicia y presentando al crimen bajo el amparo de la sociedad. Pero Vélez planteaba otra respuesta expresada “al respetable Senador que sostuvo con Filangieri que todo perdón es violación de una ley”, diciéndole con una filosofía más alta, que todos los filósofos reconocen el derecho de matar, pero nunca la obligación de matar; no hay obligación a priori. Hay derecho a matar, pero no hay obligación de matar a sus semejantes." 52

\footnotetext{
alevosía y parricidio; que actualmente el Tribunal conoce de dos causas de homicidio en las que los acusados han sido condenados a muerte en la primera instancia, y tiene noticia que se procesan otros en los diferentes Juzgados de crimen por homicidio. Que en este estado de vacilación en que se encuentra el Tribunal, ignorando la extensión y trascendencia que sobre el estado actual de nuestra Legislación penal puede tener la resolución de la Honorable Asamblea, pues no es de su competencia la interpretación de la ley, sino su aplicación a los casos ocurrentes, debía suspender la vista de las enunciadas causas, en que los reos son condenados a muerte en la primera instancia, como las que en adelante entrasen de igual género, hasta tanto resolviese la Honorable Asamblea la duda que motiva este acuerdo: que en tal virtud debían mandar como mandan, se suspenda el conocimiento de las causas indicadas comunicándose con oficio al poder ejecutivo. Con lo que se concluyó este acuerdo que firmaron los señores de la Excma. Cámara de Justicia y el señor Fiscal, por ante mí que certifico. Juan José Cernadas, Domingo Pica, Francisco de las Carreras, Basilio Salas, Eustaquio José Torres. Ante mi Pedro Calleja de Prieto. Acuerdos y sentencias, tomo I, 233-234.

${ }^{51}$ Sesión del 24 de julio, Senadores, 1857, pp. 316-329

${ }^{52}$ Diputados, 1857, pp. 228-230. Gaetano Filangieri fue uno de los más destacados juristas napolitanos de la Ilustración, con una importante difusión en el mundo hispano, que sirvió para la sustentación de reformas penales. En su obra destacó las garantías del individuo contra el soberano, sosteniendo los métodos racionales y conciencia histórica, los principios de la razón y el respeto por las costumbres de las naciones y de su propia historia. Morelli, Federica, "Filangieri y la "Otra América": historia de una recepción" en Revista Facultad de derecho y ciencias políticas, vol. 37, núm. 107, Medellín, Colombia, julio-diciembre de 2007, pp. 485-508.
} 
La cuestión de la pena capital tuvo su papel en la construcción de un orden social y político después de Caseros, tanto por la continuidad de la política penal en el castigo ejemplar, ${ }^{53}$ como por el cuestionamiento del saber tradicional que su abolición en la Constitución de 1853 marcaba como "rechazo de los políticos y juristas liberales a la pena de muerte". ${ }^{54}$ Sin embargo existe otro tema fundamental relacionado con la pervivencia de la pena de muerte, en años en que la mayoría de los liberales se declaraban en contra y explicaban las razones de la imposibilidad de su abolición. Este era la necesidad de que un poder del Estado tuviera la facultad de perdonar, sin lograr definir cuál de ellos. ${ }^{55}$ Y no era un conflicto menor, porque en definitiva establecía el poder de decisión sobre la vida que cada uno de ellos tendría en el Estado liberal en formación.

Para Francisco de Elizalde, el derecho de gracia debía existir en toda sociedad bien constituida, residiendo en alguno de los poderes públicos. En la provincia, la tradición y las leyes anteriores, que no fueron derogadas por la Constitución, concedieron al cuerpo legislativo el derecho de indultar, que había hecho uso de ese derecho en los casos exceptuados. Pero Carlos Tejedor aseguraba que no para todos los autores el derecho de gracia debía residir en alguna parte y aclaraba la diferencia entre indulto y conmutación de pena, que sólo podía aplicar el ejecutivo cuando los delitos no tuvieran calidad de aleve. Por lo tanto ni el ejecutivo ni el legislativo tenían facultad de hacer lo que hicieron, pero hasta que se sancionaran las leyes necesarias y el Código Penal, el poder ejecutivo debía tener la atribución de aminorar la monstruosidad y la barbarie de la pena de muerte, más en una mujer. ${ }^{56}$

Estaba en discusión quien tenía la facultad de perdonar, pues el indulto era perdón, como afirmó Bartolomé Mitre. ${ }^{57}$ Tanto para Antonio Cruz Obligado, Elizalde o Mitre, estaba entre las atribuciones de la Asamblea Legislativa conmutar las penas, en el caso que el ejecutivo no pudiera hacerlo. $^{58}$ Pero los senadores Domingo F. Sarmiento, Juan José Alsina y Marcelo Gamboa presentaron un proyecto de ley según el cual "la Legislatura no tiene poder para conceder indulto ni conmutación de pena en los crímenes exceptuados, ni aun mediando motivos graves y poderosos

\footnotetext{
53 "En materia penal, a pesar del auspicioso tono de algunos discursos revolucionarios, se ha señalado el carácter "estático" de la legislación y la reluctancia, de las dirigencias patrias a asumir el ideario ilustrado en el ámbito del castigo institucionalizado" Agüero, 2010, op. cit.

${ }^{54}$ Salvatore, 2010, op. cit., pp. 163-166.

${ }^{55}$ Decimos facultad de perdonar porque a lo largo de los debates suelen utilizarse como sinónimos conmutación, indulto o gracia, por esto damos las definiciones de Escriche. Conmutación de pena: El cambio de una pena incurrida por otra pena menos rigurosa, o la remisión de la pena en que ha sido condenado un delincuente, sustituyéndole otra menor. Para concederse la conmutación, es preciso que la pena se haya impuesto en sentencia de que no haya recurso alguno; pues si hubiese lugar a apelación, súplica nulidad u otro medio, se habría de echar mano primeramente de esta vía. Indulto: la condonación o remisión de la pena que un delincuente merecía por su delito. Part. 7, tít. 52, ley 1. Gracia: no es propiamente perdón, sino un don gratuito que hace el rey, pudiendo con derecho excusarse de hacerlo si quisiera. Escriche Joaquín, Diccionario razonado de legislación y jurisprudencia. Nueva edición corregida notablemente y aumentada con nuevos artículos, notas y adiciones sobre el derecho americano por Juan B. Guim, París, Librería de Rosa y Bouret.

${ }_{57}^{56}$ Diputados, 1857, p. 321.

${ }^{57}$ Diputados, 1857, p. 324.

${ }^{58}$ Diputados, 1857 , pp. 321-325.
} 
que no militan en la causa de Clorinda Sarracán y cómplices. ${ }^{, 59}$ El proyecto de ley presentado por Diputados, teniendo como causa un apremiante hecho, resolvía una cuestión gravísima de derecho que podría generar escandalosas injusticias en el futuro.

La razón primordial por la que la Legislatura no tenía el poder de conmutar penas en delitos particulares, era una razón de administración y de igualdad ante la ley, pues las Cámaras funcionaban cuatro meses y estaban ocho en receso, teniendo los reos sentenciados en los primeros meses, la esperanza de ser indultados, por eso en todo el mundo, el poder de conmutar las penas estaba en un poder permanente, que proveyera cada día según las circunstancias emergentes, porque si residiese en la Legislatura, quedarían en suspenso las sentencias "echando por tierra los efectos morales" que se buscaban al imponer las penas a los delincuentes.

Pero no todos los senadores pensaban igual, Dalmacio Vélez Sarsfield explicó que si se votaba el proyecto, las Cámaras no tendrían poder de indultar y una mujer sería ejecutada, por falta de un poder público que pudiera indultar, anomalía de la sociedad, habiéndose encerrado el senador que hizo la propuesta en un "círculo de hierro". Tratándose de una mujer desgraciada, el sacerdote José Eusebio Agüero, creía que se debía hacer todo lo posible para que el rayo que debía caer sobre la cabeza de los criminales fuera, como decía la Ley de Partidas "a virtud de una justicia y de una verdad tan clara como la luz del día”, por eso debían defenderse, debían ser oídos y brindarle todos los recursos que se les facilitaban a un criminal ordinario. Mas no era el poder legislativo el que debía ejercer el poder de gracia y perdón sino el ejecutivo “en cuya organización y contextura residen más fácilmente los medios de examen y la facilidad de suministrarse los necesarios para saber si ha llegado el caso o no de la gracia".

El problema estaba en si los delitos atroces debían o no ser considerados como privilegiados, si debían ser o no graciables como los delitos comunes. Era una cuestión grave y de mucha influencia en la moral pública, por lo que no se debía hacer gracia a los crímenes aleves, aclarando Agüero que no era un apologista de la pena de muerte. Su propuesta era una pena de muerte civil, una reclusión perpetua o una confinación hasta la muerte, pues no se podía dar el perdón en delitos atroces por su calidad, que mataban a la sociedad, aunque para otro legislador negar la facultad de perdonar era "suicidar la soberanía natural de la sociedad misma."60

Pero Alsina buscaba resolver la cuestión de derecho, más allá de la ejecución de Clorinda. Se preguntaba hasta cuando habrían de conservar las leyes debidas al absolutismo de los reyes de España, que subsistían entre ellos, en su mayor parte en materia criminal, hasta cuando mantener esas leyes que

\footnotetext{
${ }^{59}$ Sesión del 18 de agosto, Senadores, 1857, pp. 213-226.

${ }^{60}$ Senadores, 1857 , pp. 219-220.
} 
niegan al reo el recurso de apelación, la segunda instancia, que le niegan el alegar nuevos hechos en esta instancia y probarlos; derecho que prodigan esas mismas leyes aún en las causas civiles para los recursos de súplica, cuando se alegan nuevos hechos. ${ }^{61}$

Proponía abolir esas leyes que restringían derechos naturales y estaban en contradicción con la base del sistema republicano que era la igualdad en la ley. Más amplia debía ser la defensa cuanto más grave e inexorable era la pena, para que el juez pudiera apreciar con plena conciencia la importancia del delito, no siendo por falta de defensa que se hubiera dejado de indagar la verdad. Abolir los crímenes exceptuados no dañaría el orden público y no era competencia de las Cámaras conmutar o indultar, le correspondía al ejecutivo que, consecuente con el artículo de la Constitución, estudiaría la causa y procedería o no a conmutar la pena. ${ }^{62}$

Pero más allá de que se conmutara o no la pena de Clorinda, el proyecto era terminante, con un tono de orden que el poder judicial debía obedecer, lo que el diputado Félix Frías consideraba una censura y "nadie tiene la facultad de dar tal vez órdenes a un poder independiente”. Fue por eso que atacada la independencia del poder judicial, éste decidió no continuar juzgando. ${ }^{63}$ Pero para Elizalde, el Tribunal no estaba en su derecho de suspender el conocimiento de las causas, que, especialmente las criminales, debían ser resueltas pronta y decididamente, no sólo por estar comprometida la vindicta pública, sino también para no hacer sufrir al acusado. Si creía invadidas sus atribuciones, debió promover una cuestión de competencia. ${ }^{64}$ Pero Manuel García fue aún más lejos definiendo la función de cada poder,

el Poder Ejecutivo que es el que está encargado de hacer cumplir las leyes es el único poder competente para hacer que el Poder Judicial, que no es sino una ramificación del Ejecutivo cumpla esas leyes... Nada adelantaríamos y procederíamos inconstitucionalmente siempre que quitáramos al Gobierno la facultad de disponer que el Poder Judicial continúe en el conocimiento de las causas pendientes. Esto no es materia de ley ni puede pertenecer al cuerpo legislativo cuya misión es hacer la ley. Si no a cumplido la Cámara de Justicia con su deber debe el Ejecutivo hacerla cumplir bajo la responsabilidad que las Leyes reconocen en los jueces. ${ }^{65}$

Sin embargo para Mitre el Gobierno había explicado la razón de su proceder, buscando hacer cumplir con el deber, porque en la Constitución no estaban fijadas las relaciones de derecho entre la Cámara de Justicia y el Gobierno.

Desde que no están fijadas estas relaciones, desde que el Poder Judicial desconoce la autoridad del Gobierno, no hay otro poder que pueda resolver esta cuestión sino el Poder Legislativo, porque no puede decirse que no hay un poder que pueda hacer lo que quiera, sin que nadie tenga el derecho de pedirle cuenta, y aunque esto se ha dicho aquí no es esto llevar

\footnotetext{
${ }^{61}$ Senadores, 1857, p. 237.

${ }^{62}$ Senadores, 1857 , pp. 237-239.

${ }^{63}$ Diputados, 1857, p. 317.

${ }^{64}$ Diputados, 1857, p. 318.

${ }^{65}$ Diputados, 1857, p. 319.
} 
la independencia de los poderes hasta la distracción del equilibrio político, o al antagonismo, pues debe haber siempre alguien que haga cumplir la ley al que se aparte de ella. ${ }^{66}$

Es decir que ligada a las funciones estaba la independencia de los tres poderes, tema crucial al decidir qué Estado tendría la provincia de Buenos Aires. Obligado encontraba un error en el modo de entender la independencia de los poderes, pues la Constitución explicaba claramente que ésta se daba en el ejercicio de sus funciones, "es independiente la Asamblea Legislativa legislando, el Gobierno ejecutando, y los tribunales de justicia sentenciando". Pero no eran tan absolutamente independientes estos tres poderes entre sí; porque el gobierno no podía ejecutar sino las leyes que sancionaba la Legislatura y los Tribunales de Justicia no podían aplicar sino esas mismas leyes. El poder legislativo era el que tenía el derecho de interpretar la ley y señalar los errores del poder judicial al aplicarla. ${ }^{67}$

Pero lo cierto es que todos estaban de acuerdo en que la Asamblea legislativa se había equivocado y si se abría la puerta a violaciones de la Constitución, no tendrían más tarde el derecho de reconvenir a los demás por violaciones semejantes, y en el caso que los ocupaba, parte de la ley importaba una reconvención de un poder a otro, ${ }^{68}$ aunque la independencia, no tuviera la "latitud extraordinaria” que se le quería dar. El poder judicial era absolutamente independiente en el conocimiento y decisión de las causas que giraban ante él, pero no podía suspender su aplicación. ${ }^{69}$ Sin embargo, para el senador Lezica, dejar al poder ejecutivo el derecho de indultar, hacía al poder judicial dependiente. $^{70}$

En esta tormenta de ideas, Agüero buscó determinar dónde se encontraba en ese momento el derecho a la vida frente a la pena de muerte. “

Los hechos, las circunstancias llegaron a dar derechos, que antes de ellos no existían y en tal caso creo hoy a Clorinda Sarracán. Hoy ella tiene derecho a la conmiseración pública, a que se le conserve la vida y se le conmute la pena, derecho que tuvo al principio, derecho que le han dado los hechos, derecho que le ha dado la acogida que hicieron las Cámaras de su recurso, que le ha dado el tiempo que ha pasado esta infeliz devorando una muerte lenta en su calabozo, que le ha dado la tranquilidad pública y que ha abierto a los corazones a sentimientos de compasión. Todos estos hechos le dan derecho no escrito... ${ }^{71}$

\section{La liberación de Clorinda}

La causa comenzó a desacelerarse, cambiando los magistrados, ${ }^{72}$ hasta que el 8 de junio de 1866 Carlos Tejedor se presentó al juez de primera instancia, estando por cumplirse los diez años de

\footnotetext{
${ }^{66}$ Diputados, 1857, p. 326.

${ }^{67}$ Diputados, 1857, p. 328.

${ }^{68}$ Senadores, 1857, p. 214, Domingo Sarmiento.

${ }^{69}$ Diputados, 1857, p. 327, Francisco Elizalde.

${ }^{70}$ Senadores, p.250.

${ }^{71}$ Senadores, 1857, p. 255.

${ }^{72}$ Navarro Viola renunció y ante la negativa de los abogados propuestos el 21 de enero de 1857 los jueces del Tribunal reparten las causas entre los jueces civiles de acuerdo a la ley del 19 de noviembre de 1828. ROGBA, 1857, pp. 21-22.
} 
su defendida en presidio, tiempo que era el máximum que por las leyes vigentes podía durar esa pena. ${ }^{73}$ Por tanto, solicitaba el proceso correspondiente por escribanía, a lo que el juez Manuel $\mathrm{H}$. Langenheim -a cargo de la causa- respondió que continuaba vigente la suspensión de la Asamblea Legislativa.

Es necesario hacer aquí una breve referencia a la ley que derogó los delitos exceptuados, a los efectos de la facultad acordada al ejecutivo por art. 108 de la Constitución, que permitió la libertad de Clorinda, ya que los Gutiérrez habían escapado de la cárcel. La eliminación de los delitos exceptuados ya había sido reclamada, pero el proyecto original fue presentado en la sala de sesiones de Senadores el 20 de septiembre de $1866 .{ }^{74}$ La Comisión de Negocios Constitucionales - Carlos Tejedor, J.J. Montes de Oca, Antonio C. Obligado - había tomado en consideración las diferentes solicitudes pendientes sobre conmutación de la pena de muerte y las notas del poder ejecutivo sobre el tema y aconsejaba la adopción del proyecto según el cual se declaraba que después de la ley de 29 de septiembre de 1857, habían cesado los casos de aleve a que se refería el artículo 108 de la Constitución de la provincia y se devolvía al poder ejecutivo las solicitudes pendientes para que resolviera. $^{75}$

El 20 de agosto de 1866 el gobernador Adolfo Alsina con sus ministros Nicolás Avellaneda y Mariano Varela, presentaron una nota que explicaba las causas que dieron origen a la ley, y contrariamente a lo que se puede suponer, no fue Clorinda. En febrero de 1865 había sido condenado a muerte Pastor Duré con calidad de aleve. ${ }^{76}$ El auto llegó a manos del gobernador para la ejecución de la sentencia y este pidió informe al Tribunal Superior, considerando que después de la ley de 29 de septiembre de 1857, que había hecho apelables todas las sentencias en materia criminal, desaparecía la excepción que limitaba la prerrogativa de conmutar la pena capital, por el art. 108 de la Constitución.

En su informe el Tribunal le dio otro sentido al artículo constitucional, sosteniendo que antes y después de la ley de 1857, quedaban excluida la conmutación de la pena capital de los delitos

\footnotetext{
${ }^{73}$ Ley 13, tít. 24, lib. VIII Recopilación Castellana.

${ }^{74}$ Senadores, 1866, pp. 43-45.

${ }^{75}$ Se refería a la ley que organizó el Superior Tribunal de Justicia, específicamente a su artículo $7^{\circ}$, según el cual "En las sentencias que hubiese condenación de muerte, se otorgará el recurso a la otra Sala, cualquiera que sea la naturaleza del delito." ROGBA, 1857. p. 115.

${ }^{76}$ El día 26 de agosto de 1861, saliendo Lorenzo Armentúa de una estancia se encontró con Pastor Duré, y le preguntó si venía a matarlo. Ofendido Duré por esa injuria le dio muerte, robándole unos botones del tirador y ochenta pesos papel. Preso desde el 19 de septiembre de 1861, fue dictada la sentencia de última instancia el 16 de febrero de 1865 y recibiendo el Gobierno el 17 el proceso para su cumplimiento. Pero el Gobierno recordaba que tenía una facultad humanitaria acordada por la Constitución, con delitos exceptuados desaparecidos por la ley de 1857, cuya interpretación del artículo $8^{\circ}$ estaba en el Curso de derecho criminal de Tejedor, que como redactor de la Constitución conocía su espíritu. Además se trataba de casi un niño que cumplía 18 años el 9 de agosto de 1861, que había pasado cuatro años en la incertidumbre de su suerte, por motivos ajenos a la justicia. Pronto una penitenciaría iba a funcionar haciendo verdad la pena del presidio, y un Código criminal ya se redactaba, que sino prescribía la pena de muerte la aplicaría sólo a crímenes horrendos. Entonces el Gobierno debía dar un paso en una nueva vía, como medio único de salvar la vida de un hombre.
} 
exceptuados por las leyes. El ejecutivo creyó "que debía buscar en la verdad de la interpretación auténtica la solución competente”. Para eso en el mensaje de ese año presentó el problema con las notas intercambiadas con el Tribunal de Justicia, pidiendo al poder legislativo una decisión que dejara una regla establecida segura para delante. Ahora, reclamaba nuevamente esa decisión porque necesitaba tener un punto de partida para proceder en el caso Duré y otro análogo.

Obligado presentó el proyecto que tenía por objeto resolver la verdadera inteligencia del art. 108 en presencia de la ley del 29 de septiembre de 1857. El art. 108 decía que el poder ejecutivo podía conmutar la pena de muerte, previo informe del Superior Tribunal, salvo los casos exceptuados. La ley suprimía esos casos concediendo apelación a todos los casos con pena de muerte. Desde la filosofía nadie podía responder por la infalibilidad de los jueces, además de una legislación imperfecta, sin contar con un código criminal. Por ello se debía admitir el proyecto, que fue aprobado en general y en particular por unanimidad.

Pasó más de un año, para que en la sesión del 25 de septiembre de 1867, entrara a discusión el despacho de la Comisión de Legislación de Diputados - Alejo B. González, José A. Ocantos, Amancio Alcorta, Anselmo Loyola - del 16 de septiembre. La Comisión había estudiado proyecto enviado por Senadores según el cual por el artículo $7^{\circ}$ de la ley del 29 de septiembre de 1857 , habían cesado los casos de aleve a que se refería el artículo 108 y aconsejaba el rechazo proponiendo otro proyecto que era el que finalmente fue sancionado como ley. ${ }^{77}$

Para el Gobierno, la distinción entre exceptuados y no exceptuados, para los efectos de la facultad de conmutar, había desaparecido desde que la ley de 29 de septiembre de 1857 que declaró apelable toda sentencia con causa de muerte. Pero el Tribunal, oyendo a su fiscal Torres el 30 de marzo de 1865, respondió que ese artículo sólo importaba una reforma favorable al procesado en cuanto a la tramitación de la causa, dándole el recurso de apelación, denegado por la antigua legislación a los reos de determinados delitos, pero que no se extendía a los delitos exceptuados por leyes expresas, de perdón o de conmutación.

El Gobierno no conmutó la pena de Duré pero le contestó al Superior Tribunal que recurriría a la Legislatura y en el mensaje de 1865 dio cuenta del incidente. ${ }^{78}$ Los reos estaban en una posición indefinible sin saber cuál sería su destino y Clorinda Sarracán, cuya ejecución había suspendido la Asamblea en 1856, había pasado ya diez años en la cárcel y recurría a la Legislatura para resolver

\footnotetext{
${ }_{77}^{77}$ Diputados, 1867, pp.347-354.

${ }^{78}$ Mensaje del Gobierno de la provincia de Buenos Aires. Buenos Aires, Mayo $1^{\circ}$ de 1865. ROPBA, 1865, p. $108-109$. Explicaba que la finalización de la construcción de la Penitenciaría buscaba fines benéficos y saludables, entre ellos la minoración de la pena de muerte, que tanto pugnaba con el espíritu del siglo. Daba cuenta del caso de un joven de 18 años, que cometió una muerte cuya alevosía surgió de su propia declaración. El Gobierno entendía que habiendo leyes que declaraban apelables toda sentencia había desaparecido la distinción de delitos exceptuados. El Superior Tribunal rechazó esta interpretación y por esto recurría a la Legislatura.
} 
su situación, pues nada podían hacer el poder judicial (la sentencia estaba suspendida) ni el poder ejecutivo (no podía conmutar).

En estas circunstancias el Senado mandó el proyecto y la Comisión de Legislación se dedicó a su estudio, reuniéndose con los profesores de la Cámara. Su opinión fue que el artículo $7^{\circ}$ de la ley del 29 de septiembre de 1857 únicamente hizo apelable toda sentencia de muerte, cualquiera fuese la naturaleza del delito, aplicando el derecho sagrado de la defensa. Pero para dejar de existir las leyes que establecían delitos que escapaban al perdón del soberano era necesaria una derogación que hasta entonces no había existido. Por esto el proyecto del Senado era errado.

Proponían entonces otro proyecto, porque había que resolver las dificultades existentes. En toda sociedad debía existir un poder encargado de mitigar las penas impuestas por la inflexibilidad de la Justicia. Una ley podía modificarlo, pues no era la Constitución la que establecía los casos exceptuados sino las leyes que ya existían. De toda institución podía abusarse, pero que siendo realmente útil no se podía suprimir o condenar por eso, pero no se debía temer su realización al lado de las garantías que acompañaban ese derecho, apoyadas en la publicidad y la responsabilidad de los gobiernos representativos, garantías universales y absolutas. Para mayor seguridad se agregaba que debía aumentarse el tiempo de presidio para que en los casos de conmutación el ejecutivo pudiera imponerlo hasta ese tiempo cuando los considerase conveniente.

Seguía presente la idea de que la pena de muerte no era oportuno abolirla todavía, menos sin disponer de un sistema penitenciario, pero podía ampliarse la facultad de los tribunales en la graduación de las penas y sobre todo facilitar al poder ejecutivo el ejercicio de conmutar y abrir las puertas al arrepentimiento y a la reparación de los crímenes, para que la justicia y la vindicta pública quedaran satisfechas. Esto acercaría a la abolición de la pena de muerte y a un castigo digno de los delitos, "dejando en manos de jueces y gobiernos el poder de administrar la verdadera justicia y la verdadera gracia".

Había diputados en contra como Montes de Oca, para quien "el derecho público es el que trata de los diversos poderes en que el pueblo ha derogado su soberanía y el que define sus respectivas atribuciones; mientras que el derecho común se ocupa de las cosas ordinarias de la vida cotidiana”. El artículo primero al ampliar la facultad concedida a uno de los poderes era cosa del derecho público y el $2^{\circ}$ era parte del derecho común, la Constitución Provincial mantuvo la calidad de aleve de los delitos y su excepción. El proyecto era inaceptable. ${ }^{79}$ Sin embargo se votó y aprobó 25 contra 3.

En la sesión de Senadores del 1 de agosto de 1868, la Comisión de Negocios Constitucionales -Marcelino Ugarte, Guillermo Zapiola, Ambrosio P. Lezica- aconsejaba en nota del 20 de julio de

\footnotetext{
${ }^{79}$ Sesión del 30 de septiembre, Diputados, 1867, pp. 358-359.
} 
1868 la adopción de las modificaciones propuestas por Diputados. ${ }^{80}$ Ugarte la presentó sosteniendo que ambas Cámaras habían estado de acuerdo en el pensamiento fundamental de que la facultad de indultar en los casos de pena capital no debía tener restricciones. La discordia nacía en la forma de expresar ese pensamiento común. La ley fue aprobada, pero no podemos dejar de destacar la intervención de Esteves Saguí:

No hay más que echar la vista a nuestros Tribunales. Hoy están bien compuestos, pero mañana quien sabe. El Poder Ejecutivo tiene en el Poder Legislativo su contrapeso. Pero el Poder Judicial, por una monstruosidad de aquellas que no se comprenden, es un Poder tan absoluto, aún más que la audiencia. Entonces digo: ¿Por qué no hemos de dejar una facultad, a uno de los poderes que independiente, ajeno a todas las pasiones, sea un contrapeso para el extremado poder del otro? ${ }^{81}$

El problema no tuvo solución hasta que el 25 de agosto de 1868 Clorinda le escribió al gobernador Adolfo Alsina, explicando que

los años transcurridos desde el terrible suceso que dio origen a esta causa, la huida de los principales ejecutores del sangriento drama, la justa creencia de que su detención no pasaría de diez años según la ley Recopilada y hasta el mismo interés que la opinión pública ha desplegado en mi obsequio todo conspira para que VE no abandone la silla del Gobierno de la provincia que tan dignamente ha ocupado sin ejercer uno de esos actos magnánimos que acabarán de revelar al pueblo la justicia con que acaba de elevarlo a la Vicepresidencia de la República". Le suplicaba que "dando por compurgada la participación que yo hubiera podido tener en la prematura muerte de mi esposo, se sirva ordenar mi inmediata libertad. ${ }^{82}$

Las respuestas del asesor de gobierno y del asesor especial, nombrado ad hoc, ofrecen una síntesis de lo que implicaba la conmutación de pena por parte del gobernador. El 28 de agosto el asesor de gobierno, José María Moreno afirmaba que las Cámaras Legislativas de la provincia proporcionaron al gobernador la gran prerrogativa de poder evitar el triste espectáculo del patíbulo, "en todos los casos que se juzgaban exceptuados de la facultad conferida al poder ejecutivo por el art. $108^{83}$ de la Constitución y creo que usted no trepidará en ejercitarlo, disminuyendo en lo posible la aplicación de una pena tan combatida, tan justamente reprochable como necesaria y como justa, y que subsiste aun en el sistema penal, en nombre de una dura necesidad". ${ }^{84}$

\footnotetext{
${ }^{80}$ Senadores, 1868 , pp. 45-54.

${ }^{81}$ DSS, 1868 , pp. 54.

${ }^{82}$ Expediente, pp. 284-287.

${ }^{83}$ El poder ejecutivo podrá conmutar la pena capital, previo informe del Tribunal, mediando graves y poderosos motivos, salvo los delitos exceptuados por las leyes.

${ }^{84}$ Moreno hace referencia a la "Ley derogando los delitos exceptuados por el artículo 108 de la Constitución provincial"

Art. $1^{\circ}$ Quedan derogadas las leyes sobre delitos exceptuados, a los efectos de la facultad acordada al Poder Ejecutivo por el artículo 108 de la Constitución.

Art. $2^{\circ}$ Extiéndase a veinte años el máximun de la pena de presidio a que se refiere la ley 13 , tít. 24 , libro $8^{\circ}$ de la Recopilación Castellana. ROGBA, 1868, p. 225. La conmutación fue aplicada en un caso de Azul en 1872. Heridas y muerte a Heraclio Romero de J. Burgos y D. Ponce Miñana. Juez Manuel Irigoyen, Azul, 1872. Pena de muerte conmutada por veinte años, SCBA, Sección Histórica Judicial de Dolores, Juzgado del crimen de Dolores, 1853-1881, $15 / 4$.
} 
Pero su aplicación no representaba para el poder ejecutivo la excarcelación sino que sus facultades se limitaban a evitar la muerte por la aplicación de la pena inmediata, librando al condenado del patíbulo, pero haciéndole sufrir el castigo que la justicia social había creído deber imponerle, castigo que, en los casos de conmutación, se cumplía con la aplicación de la pena que seguía inmediatamente a la última en graduación. El poder ejecutivo no tenía facultades judiciales, y por consiguiente no podía examinar la mayor o menor culpabilidad del agente del delito, ni el mérito de las pruebas en las causas criminales; no era tribunal donde el interés social turbado o herido por un delito pudiera reclamar la debida reparación, el acusado defenderse y la justicia exigir una exacta aplicación de la ley, debía pues limitarse a la conmutación de la pena capital. Por esto a Clorinda se le debía asignar el máximo de pena de 20 años, contándole el tiempo de prisión sufrida. $^{85}$

Pero la causa pasó a Marcelino Ugarte, a quien se nombró Asesor especial y que no pensaba como Moreno, pues en la ley del 4 de agosto se habían ofrecido todos los medios de establecer la proporcionalidad con el delito, según la "mayor o menor intensidad de las circunstancias agravantes". Al apreciar la intensidad de las circunstancias para graduar la pena el poder ejecutivo no ejercía facultades judiciales, usaba de su criterio para poner en ejercicio su atribución constitucional, con un informe del Tribunal Superior. Por eso creía que estaba autorizado para conceder lo solicitado por Clorinda Sarracán, conmutando la pena de muerte por el tiempo de presidio que, dentro del máximum señalado por la ley, creyera justo en base al informe del Tribunal, el carácter del delito, el grado de arrepentimiento que hubiera mostrado en prisión y demás circunstancias que la hicieran más o menos digna de ser tratada con piedad, "por el que tiene la preciosa facultad constitucional de perdonar en nombre de la sociedad". ${ }^{86}$

El ministerio de gobierno pidió, como correspondía, informe al Tribunal. El fiscal Torres creía que "por el Proceso se ve que los Tribunales cumplieron con su deber y que hoy nada pueden agregar a la cosa juzgada". Sin embargo se permitía decir que después de doce años de prisión con la pena de muerte sobre la cabeza, era pertinente que la última pena se conmutase, pues sino excitaría el sentimiento público. Si el ejecutivo resolvía hacer uso de la facultad que le confería la ley podía imponer la pena que considerase justa pues a él competía fijar el número de años de presidio. $^{87}$

El Tribunal consideraba que este informe tenía que abarcar todos los aspectos sobre los que debía resolver el poder ejecutivo, "así corresponde también por ser favorable al completo acierto y a prevenir las colisiones de ambos Poderes", por desempeñar atribuciones que se rozaban con el poder judicial. Esto se hacía más necesario por el conflicto de opiniones entre el fiscal y el asesor,

\footnotetext{
${ }^{85}$ Expediente, fs.. 288-288v.

${ }^{86}$ Expediente, pp. 289-291v.

${ }^{87}$ Expediente, pp. 293v- 294.
} 
que generaban una cuestión gravísima, en la que estaba en discusión la posible usurpación de la competencia exclusiva de los jueces, para quienes debía reconocerse al poder ejecutivo la facultad de conmutar la pena capital, sólo por la inmediata. ${ }^{88}$

Pero el Presidente del Tribunal, Andrés Somellera elevó el informe diciendo que después de sancionada la ley del 4 de agosto de 1868 no veía inconveniente para que el poder ejecutivo usara la facultad que le confería el art. 108 de la Constitución provincial, "sacando así esta causa tan expectable de la situación anormal en que se halla colocada por circunstancias excepcionales.” En cuanto al modo y los límites en que debía ejercer la facultad, “es cuestión en que el Tribunal juzga no poder entrar sin exceder sus atribuciones", pues era atribución del ejecutivo, y no podía determinar la manera en que debía usar de ella. En caso de dudar sobre el verdadero alcance del artículo constitucional, era el poder ejecutivo quien debía interpretarla. Al Tribunal sólo correspondía expresar en cada caso, si había o no inconveniente que obstara al ejercicio de la facultad de hacer gracia. ${ }^{89}$

Finalmente el 12 de abril de 1869 el gobernador conmutó la pena de Clorinda por el presidio sufrido en la cárcel pública por más de doce años. Consideraba que la facultad acordada no limitaba la pena y de haberse hecho en la época de la condena la conmutación, la condena no hubiera podido alcanzar más de diez años de presidio que como máximum fijaba la ley de Recopilación vigente entonces, siendo principio de derecho penal reconocido que en el cambio de penalidad debía siempre aplicarse al reo la pena menor siendo esta anterior o posterior al hecho que produjo la condenación. ${ }^{90}$

\section{Conclusión}

El caso de Clorinda Sarracán es paradigmático de la situación entre los tres poderes públicos del Estado provincial y de lo que sucedía dentro del poder judicial, sus movimientos internos y su relación con la ley. El seguimiento del expediente confirma la distancia entre el mundo judicial y la sociedad, en la suspensión de la sentencia determinada por el magistrado ante la confirmación del embarazo y en su prohibición reiterada de publicar la sentencia. Los doce años de debates terminaron por otorgar el perdón de la pena de muerte, que había sido pedido por una parte sociedad que no terminaba de rechazarla, pero que definitivamente no la quería para una mujer.

En años en que las ideas cambiaban, la discusión llevó a una encrucijada legislativa que generaba posibles soluciones, pero que también paralizaba las decisiones. El derecho a la vida quedó finalmente en manos del gobernador, y no en la sentencia de un juez ni tampoco en la asamblea de los legisladores. Se definía así a qué poder se subordinaban los otros dos.

\footnotetext{
${ }^{88}$ Expediente, pp. 294-295.

${ }^{89}$ Expediente, pp. 296-296v.

${ }^{90}$ Expediente, pp. 297-297v.
} 
Pero esto no responde a una pregunta crucial en relación al valor de la vida ¿Por qué Navarro Viola sentenció a muerte a una mujer, cuando se manifestaba en contra de esta pena? A lo largo de la causa y de los debates, incluso en los reclamos presentados por los vecinos de Buenos Aires, surge que el concepto de hacer justicia era cumplir con la ley, aunque el magistrado estuviera en contra de la pena de muerte. Pero esto no es suficiente.

Quizá contribuiría a develar la incógnita, determinar a quién respondía el joven abogado a cargo del juzgado del crimen de la Capital. Ciertamente no respondía ni a los otros poderes, ni a la sociedad, respondía por sus acciones a la Cámara de Justicia. Concretamente por la consulta que estaba obligado a realizar de su sentencia, pero fundamentalmente, hasta que se organizara el jury en 1878, por el ejercicio de la superintendencia del Tribunal Supremo que incluía el enjuiciamiento a un magistrado.

En la segunda mitad del XIX la aceptación de la división de poderes, la separación de la moral y de la religión del derecho y el absolutismo de la ley, respondían a un proyecto donde lo justo estaba siendo definido por la legislación y la administración de justicia buscaba concebirse como poder independiente. Sin embargo la acción de Navarro todavía podría estar sujeta a una lectura objetiva de las normas que el derecho liberal comenzaba a sancionar para proteger los derechos subjetivos. Este juez que se confesaba católico y había sido alumno de Rafael Casagemas podía estar sujeto a un esquema de garantía de inspiración religiosa que buscaba más a salvaguardar la conciencia del juez que proteger unos inimaginables derechos individuales del reo. ${ }^{91}$

Pero la conciencia de Navarro estaba más torturada por la vida de Clorinda que por condenar a la pecadora. El mismo día que dictó la sentencia fue publicado en el diario El Orden un breve editorial titulado "Súplica a favor de una madre", en defensa de la vida de la condenada. Si bien es cierto que el editor era Luis L. Domínguez, éste había explicado en el mismo número, que era el redactor con ayuda de sus compañeros, entre los que se contaba Navarra Viola. Entonces éste podría haber sido quien redactara este pedido de perdón, y quien brindara la información necesaria referente al embarazo. El mismo diario afirmaba que "persona de respeto le informa que Clorinda tiene sus primeros síntomas de embarazo, aunque son dudosos." Como sea, el texto reflejaba el pensamiento de estos católicos liberales, que reconociendo a Clorinda como asesina aceptaban la función de la justicia, y como pecadora, recurrían a una actitud evangélica de la sociedad para que perdonara su vida.

La justicia cumple su deber, y Clorinda es condenada con sus cómplices al suplicio de los parricidas. Pero entonces se levantan también los sentimientos generosos de esta parte de la sociedad a quien el crimen de Clorinda ha ofendido de un modo más directo, e imitando la mansedumbre del que dio su sangre por la redención del mundo pronuncia la palabra perdón a

\footnotetext{
${ }^{91}$ Agüero, 2010, op. cit.
} 
favor de la fragilidad de una miserable mujer que quizá no ha comprendido todo ni la magnitud de su culpa. Dios no quiere que el pecador muera, sino que se convierta y viva. ${ }^{92}$

La sensibilidad y modernización punitiva se había manifestado cuando al implorar por Clorinda Sarracán lo hacían "en nombre de la justicia contrariada por la rigidez de la ley, en nombre de la sensibilidad pública." Pasarían muchos años antes de que la pena de muerte fuera abolida, pero en la construcción del poder provincial era decisivo definir quién decidiría sobre la vida. No sólo quedaba libre Clorinda, también quedaba claro el poder que los poderes tendrían en el Estado provincial.

\footnotetext{
${ }^{92}$ Diario EL Orden, año II, N ${ }^{\circ} 397,29$ de octubre de 1856.
} 


\section{Capítulo XI}

\section{La propiedad: vías administrativas y judiciales para la resolución de conflictos de tierras en la provincia de Buenos Aires, 1860-1880. Luis Goya contra los chacareros}

\section{Introducción}

La expansión de la frontera bonaerense tuvo su apoyo en la fundación de fortines y centros poblados con el uso extensivo de la tierra que poco a poco se incorporaba. A partir de 1820 la política de reparto de tierras del Gobierno provincial combinó dos sistemas, la donación condicionada (con requisitos de ocupación y población) e incondicionada (premios por combate o fidelidad) y la enfiteusis. ${ }^{1}$ En la década siguiente continuó el contrato enfitéutico pero se acentuó la apropiación plena mediante la donación. Para 1840 no se registraron transferencias a manos privadas y la enfiteusis cesó al no renovarse más los contratos y quedar sin resolución los derechos de los enemigos políticos de Rosas, muchos de ellos exiliados.

La etapa siguiente, entre 1852 y 1880, años de organización institucional y de profundos cambios en la vida económica y social de la provincia, se inició con un resurgimiento de la inseguridad en la frontera, situación que debió ser afrontada por el Estado. La expansión del ovino, relacionada con el mercado internacional, requería de seguridad y condiciones de crecimiento como el ferrocarril, la creación de nuevos pueblos y fortines, política crediticia y de tierras que alentara la población en las zonas aptas para la producción pero que todavía resultaban poco atractivas para la instalación. $^{2}$

Las políticas de tierras revisaron lo actuado por Rosas ${ }^{3}$ y mezclaron los sistemas anteriores, reiterando las donaciones para estimular la población de los distritos fronterizos, adoptando el sistema de arriendo y la propiedad plena. En 1860 comenzó un proceso de transferencia a manos privadas guiada por las normas legales de 1864, 1867, 1871, 1876, y 1878 que decidieron las ventas de tierras arrendadas. El sistema de arriendo regularizó la situación de tenedores precarios de tierras públicas y la transferencia a manos privadas terminó con ocupantes de derechos dudosos que llevaban años de litigio por la lenta tramitación o que estaban amparados por la falta de control en la

\footnotetext{
${ }^{1}$ Infesta, , 2003, op. cit..

${ }^{2}$ Valencia, Marta, Tierras públicas, tierras privadas, Buenos Aires, 1852-1876, La Plata, Universidad Nacional de La Plata/ Archivo Histórico de la Provincia de Buenos Aires, 2005.

${ }^{3}$ Infesta, María Elena y Valencia, Marta, “Tierras, premios y donaciones, 1830-1860”, en Anuario IEHS, Instituto de Estudios Histórico-Sociales, Tandil, Universidad Nacional del Centro de la Provincia de Buenos Aires, núm. 2, 1987, pp.177-213.
} 
campaña, fruto de la deficiencia institucional, la falta de municipalidades y jueces de paz representantes del poder central. ${ }^{4}$

Junto con la preocupación de regularizar la propiedad de la tierra, el Estado debía afrontar en esta nueva etapa el desafío de extender la frontera y dar seguridad a los pobladores para que se asentaran y creciera el desarrollo de la agricultura. ${ }^{5}$ Este era el rol que jugaban los ejidos, proveedores del mercado interno de los pueblos, en los que el acceso a la propiedad de las chacras iba de la mano del desarrollo agrícola-ganadero y la vida del centro de población. ${ }^{6}$

El proceso de formación de los pueblos y sus ejidos fue largo y complejo e iba de la mano de conflictos entre particulares y el Estado por la posesión de la tierra, pero ¿qué sucedía cuando las tierras habían sido dadas en donación condicionada, el ocupante había cumplido con las condiciones y aspiraba a la propiedad, pero eran en tierras privadas? ${ }^{7}$

Este fue el caso de un grupo de vecinos que se movilizó para dar origen a un pueblo, el fortín Esperanza, y luego para retener tierras del ejido que el Estado le prometió en propiedad sin considerar que tenían un dueño, el estanciero Luis Goya. El conflicto, que pasó por distintas instancias administrativas y judiciales a lo largo de veinte años (1860-1880), permite establecer las

${ }^{4}$ Valencia, 2005, op. cit., pp. 19- 26.
${ }^{5}$ Banzato Guillermo y Valencia, Marta, "Los jueces de paz y la tierra en la frontera bonaerense, 1820-1885", en
Anuario IEHS, Instituto de Estudios Histórico-Sociales, Tandil, Universidad Nacional del Centro de la Provincia de
Buenos Aires, núm. 20, 2005, pp. 211-237.
${ }^{6}$ Barcos, María Fernanda ha realizado un estudio sobre el proceso de ocupación y acceso a la propiedad legal de los
ejidos, analizando la legislación al respecto y tomando el caso del ejido de Monte como modelo, "Los ejidos de los
pueblos de campaña: ocupación y acceso a la propiedad legal en Monte, 1829-1865", en Mundo Agrario, Revista de
estudios rurales, núm. 14, $1^{\circ}$ sem., 2007. En su tesis doctoral, "De cada labrador un soldado y de cada agricultor un
propietario: Economía, sociedad y política en el ejido de la Guardia de Luján (Mercedes), 1810-1870", demostró la
necesidad de incluir los ejidos en el estudio de la estructura productiva de un partido (UNLP, 2010, inédita). Sobre la
evolución de los ejidos ver Infesta y Valencia, 1987, op. cit.; Garavaglia, 1993, op. cit., pp. 121-146; Fradkin, 1999, op. cit..

${ }^{7}$ Muchos son los estudios sobre los conflictos en la sociedad rural rioplatense, por ejemplo González Bernaldo, Pilar, "El levantamiento de 1829: el imaginario social y sus implicaciones políticas en un conflicto rural", en Anuario IEHS, Instituto de Estudios Histórico-Sociales, Tandil, Universidad Nacional del Centro de la Provincia de Buenos Aires, núm. 2, 1987, pp. 137-176, sobre el conflicto político en la época de Rosas; Salvatore, Ricardo, "Reclutamiento militar, disciplinamiento y proletarización en la era de Rosas", en Boletín del Instituto de Historia Argentina y Americana "Dr. Emilio Ravignani", 3ra serie, núm. 5, 1992 y "El mercado de trabajo en la campaña bonaerense (1820-1860). Ocho inferencias a partir de narrativas militares", en Bonaudo, Marta y Pucciarelli, Alfredo, La problemática agraria. Nuevas aproximaciones, Buenos Aires, CEAL, 1993, t. 1, pp. 59-92, en relación a las presiones del mercado de trabajo y la coerción estatal; Garavaglia, 1999, op. cit. que estudió el conflicto desde las representaciones y disputas políticas a nivel social; Banzato, Guillermo, "De ocupantes a propietarios, los conflictos entre vecinos de la frontera bonaerense. Chascomús y Ranchos, 1800-1840", en Quinto Sol, Santa Rosa, Facultad de Ciencias Humanas, año 4, núm. 4, 2000 , pp. 11-38, analizó los litigios entre vecinos cuando la posesión de hecho sobre un terreno estaba en vías de convertirse en propiedad plena, cada vez que se accedía a los títulos mediante los distintos sistemas de otorgamiento de tierras públicas. Este estudio le permitió apreciar el juego de intereses de los hacendados y sus conexiones con el poder civil en la frontera, el rol de las autoridades y los fundamentos que se daban en los dictámenes. A esto debemos agregar los trabajos de Blanca Zeberio, "El liberalismo y los derechos de propiedad en Argentina. Controversias jurídicas y proyectos políticos en la etapa codificadora"; María Fernanda Barcos, "Los intersticios de la ley. De la sanción a la implementación de la legitimación ejidal en Mercedes (Buenos Aires), 1810-1870" y Marta Valencia, "La última frontera de la provincia de Buenos Aires antes de la campaña de Roca”, en Blanco, Graciela y Banzato, Guillermo (comps.), La cuestión de la tierra pública en Argentina. A 90 años de la obra de Miguel Ángel Cárcano, Rosario, Prohistoria Ediciones, 2009; Banzato, Guillermo, La expansión de la frontera bonaerense. Posesión y propiedad de la tierra en Chascomús, Ranchos y Monte, 1780-1888, Bernal, Universidad Nacional de Quilmes, 2005. 
vías a través de las cuales los actores de la sociedad civil buscaban resolver los conflictos generados por la posesión de la tierra. Los chacareros recurrieron al poder ejecutivo, apoyados por el juez de paz en su carácter de presidente de la Municipalidad de su partido. De este modo, inicialmente, la instancia judicial no fue la vía elegida por las partes antagónicas. Sin embargo, a partir de la sanción de la Constitución Provincial de 1873, la Suprema Corte bonaerense tomó intervención en el asunto, pues la nueva Carta Magna indicaba claramente que los conflictos entre particulares y el Estado eran de su competencia. Ante la negativa del Gobierno de realizar una permuta, Luis Goya presentó su reclamo ante la justicia y, aunque la criticaba duramente, creía que era el poder del Estado encargado de defender su propiedad. Esta diferencia puso de manifiesto que, después de más de medio siglo de iniciada la etapa independiente republicana en tierras bonaerenses, persistía la falta de definición en la división de poderes, resultando aún incierto cuál de ellos debía ser el "guardián de las leyes".

Este capítulo se propone conocer la relación entre administración de justicia y propiedad. Siguiendo el litigio entre Luis Goya, dueño de tierras del Fortín Esperanza, y los chacareros, a quienes fueron prometidas, seguiremos el proceso legal para la resolución de los conflictos que hemos planteado. Analizamos de este modo la actitud del Gobierno, que debía dar respuesta a la gestión de administraciones anteriores, como así también las relaciones entre el poder ejecutivo y el poder judicial, que a nivel local estaban representadas en la figura del juez de paz. Damos cuenta, entonces, de las modificaciones que se fueron operando durante este período en el que se fue definiendo la división de poderes y se organizó la administración de justicia bonaerense.

La pesquisa no se limitó a un solo expediente, sino a los cinco que tuvieron relación con el proceso: el pedido de permuta del propietario; el cobro de arrendamientos y desalojo ante la negativa del poder ejecutivo; el pedido de escrituración de uno de los chacareros; la solicitud de los vecinos de General Alvear y, finalmente, la presentación ante la Suprema Corte de los chacareros desalojados. Dada la complejidad y riqueza del proceso, optamos por seguirlo en base a los recursos legales presentados y/o utilizados por el estanciero y los chacareros, a pesar que en algunos casos los expedientes se superpongan o, como en el caso del reclamo de los vecinos, forme parte de la evolución del cobro de arrendamientos.

\section{Del fortín Esperanza al partido de General Alvear}

El 29 de diciembre de 1853 el gobernador Pastor Obligado firmó el decreto que admitía "la patriótica propuesta de los vecinos del Saladillo y Las Flores para construir un Fortín entre ambos Partidos, quedando autorizados para proceder a sus trabajos de conformidad a las bases que han 
presentado". ${ }^{8}$ El objetivo era construir el fortín a sus propias expensas para protegerse de las depredaciones de los “indios”. Tanto el General Manuel Hornos, comisionado por el Gobierno nacional para recorrer las zonas central y sud de la provincia de Buenos Aires, con el objetivo de dar solución a los problemas de frontera, como el Departamento Topográfico, apoyaron la propuesta del "Fortín Esperanza". 9

Los encargados de las obras fueron el juez de paz de Saladillo José Atucha y el vecino José Portugues, que dirigió la construcción con forma de estrella de cuatro puntas, midiendo cada uno de los lados casi 200 metros, con un baluarte y un cañón. La fortificación estaba rodeada por un foso de cinco varas de ancho, una pieza para la comandancia, cocina, otra cuadra menor para el cuerpo de guardia y cuarto de bandera, todos construidos de barro y paja; el potrero fue edificado dentro de la defensa rodeado de un foso y parapeto. El fortín quedó bajo la jurisdicción del partido de Las Flores, según el decreto de creación de este distrito firmado por Rosas el 25 de diciembre de 1839, según el cual le pertenecían las tierras que arrancaban de la margen derecha del arroyo del mismo nombre sobre la que se ubicaba la nueva defensa.

Dos años más tarde, los vecinos de Saladillo y Las Flores solicitaron el establecimiento de un pueblo junto al fuerte, apoyados por el Departamento Topográfico, el fiscal y el asesor de gobierno, ${ }^{10}$ "siendo un deber de la autoridad el propender, por razones tan obvias como poderosas, a que en la campaña se críe el mayor número posible de nuevos centros de población, concurriendo además en este caso la especialidad de que siendo fronterizo aquel punto, el establecer en él un pueblo contribuirá más eficazmente a contener las incursiones de los salvajes" se establecería un punto de apoyo, que más adelante serviría para poder extender la línea de frontera.

Un ingeniero debía levantar la traza del pueblo y su ejido, siguiendo las instrucciones del Departamento Topográfico. Las tierras de propiedad particular dentro de las cuatro leguas cuadradas del ejido no obstaban a su traza y "quedaban siempre en propiedad de sus dueños". El reparto y adjudicación de solares, quintas y chacras se realizaba una vez aprobadas las trazas, entre

\footnotetext{
${ }^{8}$ ROGBA, 1853, p.176.

${ }^{9}$ Capdevila, Darío, El Fortín Esperanza y el Pueblo y Partido de General Alvear. Estudio complementario: Noticias biográficas del Tte. Cnel. Juan Agustín Noguera, Tapalqué, Ediciones Patria, 1969.

${ }^{10}$ Cuando se organizó la provincia de Buenos Aires fue asesor de gobierno y auditor de guerra Pedro José Agrelo, nombrado el 13 de mayo de 1820. Durante la gestión de Manuel Pinto como gobernador, por decreto del 14 de octubre de 1852, se suprimió la Asesoría, diciendo que no era mayormente necesaria. Por decreto del 28 de diciembre de 1854 fue creada la Asesoría General de Gobierno, para asesorar sobre la validez y justicia de las funciones específicas de Gobierno, ocupándola en esa ocasión Dalmacio Vélez Sarsfield. La Fiscalía General de Gobierno comenzó a funcionar el 8 de agosto de 1821 y apareció el cargo en la ley de presupuesto de 1855, como defensor de los derechos patrimoniales del Estado, parte legítima en los juicios contencioso administrativos. Por la ley del 11 de enero de 1867 , de ventas de tierras públicas dentro de la línea de frontera, las cuestiones entre arrendatarios y sub-arrendatarios serían tramitadas en audiencia verbal ante uno de los ministros, el fiscal y el asesor de gobierno (art. $5^{\circ}$ ) y el fallo del Gobierno debía ser fundado precedido por el dictamen escrito del fiscal y asesor (art. $6^{\circ}$ ) ROPBA, 1867, p.48; reiterado esto en la ley del 15 de agosto de 1871 (art. $6^{\circ}$ y $7^{\circ}$ ) ROPBA, 1871, p.499. El fiscal fue suprimido en la ley de presupuesto de 1879, reapareciendo como fiscal de estado con la Constitución de 1889.
} 
tanto el comandante del fuerte, asociado a dos vecinos de probidad, inscribía las peticiones en un libro. $^{11}$

Esta resolución de Obligado respondía a un plan político y un modo de operar en el territorio que tenía una larga tradición en la administración española: la fijación de una frontera mediante la formación de pueblos con instalaciones militares y agricultores domiciliados con el otorgamiento de tierras baldías. Esta estrategia se tornó más compleja con la acción borbónica, unida al desarrollo de las ideas ilustradas que en su implementación intentó usar recursos demográficos y políticas migratorias a partir de una visión nueva del espacio territorial del imperio. Luego, la política enfitéutica de Martín Rodríguez buscó desde el principio preservar el desarrollo de los pueblos y sus ejidos de la ocupación de las tierras rurales aledañas que promovía el sistema.

En 1825 se intentó descentralizar en parte las decisiones de la administración creando las Comisiones de Solares, organizadas como cuerpos ejecutivos con los sectores más influyentes de cada partido (juez de paz, comandante militar, hacendados). De este modo, dichas Comisiones funcionaban en relación directa con el poder político, pero involucraban a las redes de poder local en la toma de decisiones y la administración de un extenso terreno con poca población. Su función era ordenar y adjudicar los solares, observando los títulos de propiedad existentes para otorgar la posesión definitiva de las tierras y sus ejidos. Debían señalar también los baldíos para darlos a quienes quisieran poblarlos, para lo cual los obligaba a edificar casa y cercar el solar en un año, reservándose dos solares en la plaza principal para la construcción de escuelas, casa de justicia y templo.

En 1827 las Comisiones quedaron facultadas para repartir en enfiteusis y bajo tasación las suertes de quintas y chacras que se hallaban comprendidas en las partes baldías de los ejidos. ${ }^{12}$ Las Comisiones tenían la facultad de otorgar permisos de edificación en los pueblos y en 1828 se eximió a los jueces de paz de conformarlas, haciéndolo tres vecinos propuestos por el Departamento y aprobados por el Gobierno. Pero el juez de paz seguía siendo, por sus amplias atribuciones, el nexo entre las autoridades locales y el poder provincial, vinculándose al mismo tiempo con los pares del partido, reservándole la normativa sobre la tierra pública un papel importante, como garante del cumplimiento de las condiciones establecidas. ${ }^{13}$

\footnotetext{
${ }^{11}$ Decreto del 28 de agosto de 1855 creando el pueblo de Esperanza. ROGBA, 1855, pp.102-103.

${ }^{12}$ El ejido según la legislación indiana era el campo o conjunto de terrenos que circundaban una ciudad o poblado, en los que no se labraba ni se plantaba y eran comunes a todos los vecinos. Su rol principal en América era ser espacio de reserva para el crecimiento de la ciudad, mientras que el lugar de uso común para que el ganado pastase y crecieran motes silvestres de árboles frutales pasó a denominarse dehesa. La idea de ejido se fue distorsionando y se transformó en "un campo conteniendo en su centro una población, y alrededor de esta casas de recreo, jardines y chacras". Aliata, Fernando, "La acción del Departamento Topográfico y las Comisiones de Solares en la consolidación de los poblados bonaerenses. Dolores entre 1831 y 1838 ", ponencia presentada en las jornadas de discusión interdisciplinaria: espacios urbanos-espacios rurales, CEHR, FHCE; IDEHAB, FAU, 2005, cita 15, p.7.

${ }^{13}$ Banzato y Valencia, 2005, op. cit., p.232.
} 
Volviendo al pueblo de Esperanza, en marzo de 1856 el comandante participaba que el sargento mayor de ingenieros Ludovico D’Horbourg, había terminado los trabajos de delineación y en 1868 el Departamento Topográfico informaba que la población era de alguna importancia y que se había señalado "un ejido de poco más de una legua cuadrada, que ha servido para la distribución de solares, quintas y chacras" y que "la figura bajo la cual fue trazado fue arbitraria e irregular, y así ha permanecido". En el mismo año los vecinos del pueblo pidieron la creación de un nuevo partido con tierras de Saladillo y Tapalqué, a lo que accedió el gobernador Adolfo Alsina y el 22 de julio de 1869 Emilio Castro promulgó la ley de creación del partido de General Alvear, sobre la base del fortín Esperanza.

La primera autoridad provista fue el juez de paz Melitón Ruiz, el 26 de agosto de 1869 con una partida de policía de sargento y siete soldados. ${ }^{14}$ El 25 de septiembre fue nombrada la primera Comisión municipal de los partidos de Campaña que aún no tenían formados sus centros de población. La misma estaba compuesta de cuatro vecinos designados por el Gobierno a propuesta del juez y presidida por el juez de paz, ${ }^{15}$ Quien a fines de 1870 solicitó la mensura del ejido. El 23 de marzo de 1872 se aceptó la propuesta del agrimensor Jorge Meincke para realizar la mensura y el 3 de agosto la del Departamento Topográfico de dar al ejido siete leguas y media. La mensura fue aprobada por el Gobierno el 19 de junio de $1874 .^{16}$

En la conformación del pueblo de General Alvear el poder ejecutivo, por medio de delegados especiales, otorgó a los pobladores que ya se habían agrupado alrededor del nuevo centro de seguridad, la propiedad de algunos lotes de chacras bajo la condición de poblarlos y cultivarlos. Dos eran los objetos primordiales: la recompensa al esfuerzo y al sacrificio, y la necesidad de dar impulso a la nueva población por medio de la subdivisión de la propiedad en lotes pequeños, susceptibles de un fácil cultivo, trazando el pueblo y el ejido, poniendo en posesión de los lotes correspondientes a los donatarios. Entre los favorecidos por esas concesiones se encontraban Luciano Agüero, Carmen Burgos, Pablo Roldán, Francisco Tarija, Valerio Miranda, Benjamín Soza, Julián Garnica, Cánsio Zapata, Juan Garnica, Cipriano Leiva de Torres, ${ }^{17}$ "quienes bajo la fe de la palabra empeñada por un gobierno ilustrado, consagraron todos sus esfuerzos al mejoramiento de ese pequeño pedazo de tierra que constituía toda su riqueza y todo su porvenir" ${ }^{\prime 18}$.

\footnotetext{
${ }^{14}$ Ruiz permaneció durante todo el proceso que estudiamos.

15 Decreto sobre el nombramiento de una Comisión para los partidos que no tienen Municipalidad, 19 de febrero de 1867. ROPBA,1867, pp.89-90

${ }^{16}$ Levene, Ricardo, Historia de la provincia de Buenos Aires y formación de sus pueblos, La Plata, Taller de Impresiones Oficiales, 1941, pp.227-229. Según el Censo de 1881 la población del partido era de 4696 habitantes, 574 del centro urbano y el resto de la campaña.

17 Archivo Histórico de la provincia de Buenos Aires (en adelante AHPBA), Escribanía Mayor de Gobierno (en adelante EMG), legajo 234, expediente 16359, año 1869. "Luis Goya contra Luciano Agüero y otros sobres cobro de arrendamientos" (en adelante "Goya c/Agüero")

${ }^{18}$ Archivo de Demandas Originarias de la Suprema Corte de Justicia de la provincia de Buenos Aires, legajo 6 expediente B 705, año 1876. “Agüero D. Luciano representado por D. Cipriano de Elía con el Poder Ejecutivo de la
} 


\section{$\underline{\text { II. Los recursos de Luis Goya para recuperar sus tierras }}$}

\section{a. La propuesta al Gobierno}

Luis Goya nació en 1820 y fue un estanciero emprendedor que colaboró activamente con la fundación de la Sociedad Rural Argentina en 1866. El testamento redactado en 1869 permite observar que por su patrimonio habían pasado transacciones de tierras con el Estado, arrendamientos, compras y transferencias de derechos, de las que conservaba 64.776 hectáreas en distintas parcelas de Saladillo y Tapalqué. Estas estancias estaban organizadas y en producción, con encargados a los que participaba con un tercio de las utilidades y a los que reconocía en su legado la mitad de las haciendas por sus buenos servicios. ${ }^{19}$

Al establecerse el Fortín Esperanza, el campo de Goya estaba bajo mojones borrados pero cuya ubicación era bien conocida, a pesar de lo cual mandó al agrimensor Luis Huergo a fijar los límites de sus tierras, quien demostró que al trazarse el ejido había quedado comprendida una parte de su terreno. Como, según sus dichos, no estaba en su ánimo estorbar el desarrollo de la población, solicitaba que, previo informe del comandante del fortín y del agrimensor, se le compensara por las tierras incluidas en el nuevo emprendimiento con otras que fueran de propiedad pública. Ante el pedido, el ministro de gobierno Pablo Cárdenas requirió informe al Departamento Topográfico, elevado por el escribano mayor de gobierno Alejandro Araujo, quien informó a Goya. ${ }^{20}$

El Departamento Topográfico iniciaba su informe destacando que el reclamo de Luis Goya, de habérsele tomado parte de sus terrenos en los límites de un ejido, había sucedido ya en muchos pueblos de campaña y sin embargo el Gobierno no había indemnizado a sus dueños. Que una parte de sus tierras estuvieran dentro del ejido no significaba que fuera a ser privado de su propiedad. La única limitación a la que quedaba afectado era la de no poder utilizarla para pastoreo, y además si los chacareros que se habían instalado no le pagaban los arrendamientos, él podría realizar los reclamos a quien correspondiera. ${ }^{21}$

Hasta aquí se presentaba muy clara la postura del Departamento Topográfico, basada en el respeto a la propiedad particular de las tierras que quedaban dentro del trazado del ejido. Sin

provincia sobre propiedad de unos terrenos situados en el ejido del pueblo General Alvear" (en adelante "Agüero c/ el Poder Ejecutivo").

19 Poco antes de morir vendió las haciendas de mejor calidad de la Estancia "La Pacífica", arrendando el casco al comprador y conservando majadas de poco valor en sus campos de General Alvear. A su muerte dejó deudas de entre 5 y 7 millones de pesos en los bancos Hipotecario, Provincia, Argentino y con un particular. Para cubrir estas deudas la testamentaria se desprendió de propiedades rurales entre 1876 y 1879, dado que la crisis financiera de 1873 había depreciado su valor menos que sus propiedades urbanas y una quinta junto al arroyo Maldonado con jardines y sembrados. A la muerte de Goya, el 73,5\% de su fortuna estaba invertida en propiedades urbanas, 5,3\% en chacras y terrenos y $21 \%$ en estancias, y seguían en litigio las tierras reclamadas. Valencia, 2005, op. cit., pp. 198-199; 203.

${ }^{20}$ AHPBA-EMG, legajo 234, expediente 16358, año 1864 (en adelante "Propuesta de Goya"). Este expediente tiene la carátula y la primera foja deteriorada, por lo que hemos reconstruido parte del texto.

${ }^{21}$ ROGBA, 1855, pp.102-103. Así lo establecía el decreto de creación del pueblo en su artículo $3^{\circ}$ "La existencia de tierras de propiedad particular, que pueda haber dentro de las cuatro leguas cuadradas que debe comprender el ejido, no obstará en modo alguno a la traza de éste; quedando siempre dichas tierras en propiedad de sus dueños". 
embargo, el informe continuaba haciendo referencia a la posibilidad de indemnización o permuta de las tierras privadas que tomaba un ejido, por lo que el Gobierno podía aceptar la propuesta del suplicante, para lo que correspondía realizar una mensura y establecer la parte que debía ser compensada, cuya resolución quedaba a su agrado. ${ }^{22}$

El expediente pasó luego al fiscal general de gobierno, Cosme Becar, para quien el Estado provincial no debía aceptar la proposición pues estaba en todo su derecho de fijar un nuevo pueblo. Pero finalmente, otra vez daba lugar y recomendaba aceptar lo propuesto por Goya, pues eran respetables sus derechos de propiedad que lo autorizaban a exigir el precio del terreno que se le expropiara, "todo en la forma y término indicados por el Departamento Topográfico". ${ }^{23}$ En cambio para el asesor general de gobierno, Carlos Tejedor, el pedido de Goya era inadmisible, pues para atraer la población alrededor del Fortín Esperanza el Gobierno podía utilizar esas tierras. En esos casos se recurría antiguamente a la permuta porque el ejido tenía que ser forzosamente público, pero ya no era así y se respetaba la propiedad de la tierra que quedaba dentro del trazado. ${ }^{24}$

El 28 de enero de 1865 el gobernador Mariano Saavedra resolvió en tres líneas que según lo expuesto por el Departamento Topográfico, dictaminado por el fiscal y aconsejado por el asesor, no se hacía lugar a la solicitud, y esto dio paso a la profundización del litigio. Los dos primeros informes dejaban de manifiesto las ideas dominantes del momento. Por un lado, un poder ejecutivo que resolvía según su criterio, y por otro, la cuestión del fortalecimiento de la propiedad privada de la tierra. ${ }^{25}$ La firmeza de Tejedor le dio argumento al poder ejecutivo para no hacer lugar al pedido de Goya, quien solicitó el expediente para reclamar por sus derechos ante el juez de primera instancia. Rechazada la permuta propuesta al Gobierno, quedaba a salvo su derecho de cobrar arrendamientos a los diversos ocupantes de sus terrenos que habían formaron chacras, dando por sentado que el Gobierno no tenía ninguna responsabilidad en este asunto.

El damnificado, acompañado por su abogado, Alfredo Lahitte, solicitó al magistrado que librara oficio al juez de paz del partido de Tapalqué (recordemos que General Alvear todavía no tenía juez de paz) para que intimara a los ocupantes de su campo a abonar el arrendamiento. El juez civil de primera instancia de la Capital, Emilio Agrelo, libró el oficio el 28 de julio de 1868, comenzando así un largo litigio que terminaría en 1880 ante la Suprema Corte, ya muerto Goya. ${ }^{26}$

\footnotetext{
${ }^{22}$ Informe firmado por Saturnino Salas, Mariano Moreno, Germán Kuhn, Ignacio Casagemas, Born Benvil, presentado el 25 de octubre de 1864, "Propuesta de Goya", f.2 vuelta.

23 "Propuesta de Goya", f. 6, 4 de enero de 1865.

24 "Propuesta de Goya", f. 7, 18 de enero de 1865.

${ }^{25}$ Valencia, 2005, op. cit., pp.153-155.

${ }^{26}$ En el año 1853 se habían instalado jueces de primera instancia en la campaña y las tierras que Goya reclamaba pertenecían al Departamento del Centro (con cabecera en Mercedes), sin embargo la competencia de estos magistrados era criminal, autorizados para atender y resolver causas civiles, que eran generalmente litigadas en Buenos Aires. Habían pasado más de tres años de la resolución y en el proceso estas demoras fueron normales.
} 


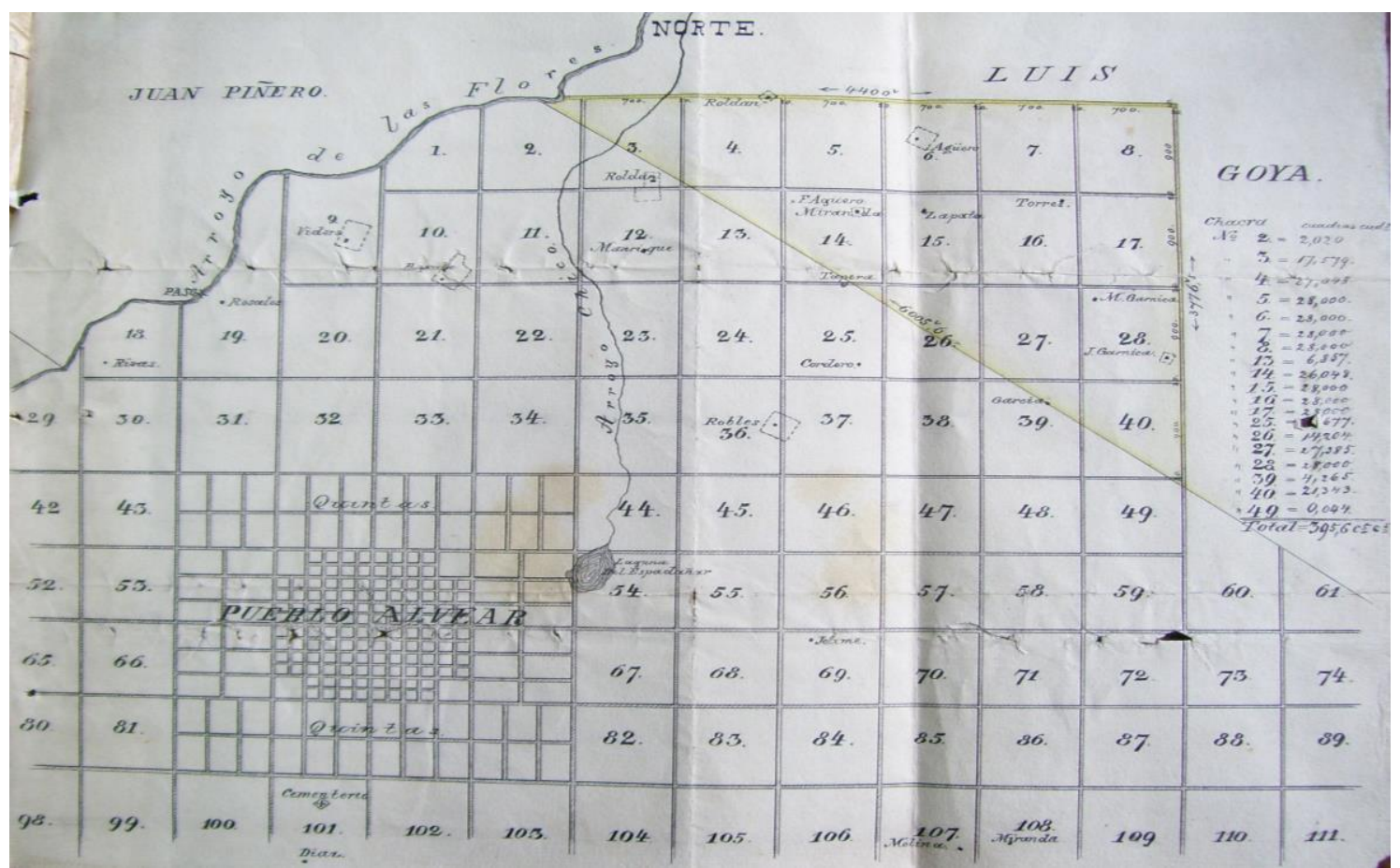

Croquis elevado el 15 de octubre de 1875 al Ministro de Hacienda Rufino Varela con el informe solicitado al Departamento de Ingenieros representando el terreno de Luis Goya (I, H, G) tomado del ejido. La línea carmín IG es el límite del terreno, AHPBA-EMG, leg.234, expte.16359, año 1869. "Luis Goya contra Luciano Agüero y otros sobres cobro de arrendamientos", f. 387.

\section{b. Cobro de arrendamientos y desalojo: el juicio en primera instancia}

Iniciada la causa con el oficio que el juez Agrelo envió al juez de paz de Tapalqué, quedaban reclamados los arrendamientos de los campos de Luis Goya por ser de su "legítima propiedad". El 1 de junio de 1869 el juez de paz Estanislao Colman mandó a notificar a los ocupantes y dos días después estos respondieron que no se creían obligados a pagar el arrendamiento a Goya por no ocupar su campo. Dos de ellos explicaron que no tenían ni habían tenido hacienda de su propiedad en el campo de Goya, que lo único que tenían era una suerte de chacra que les había sido concedida por la Comisión nombrada por el Superior Gobierno para el reparto de terrenos pertenecientes al ejido del pueblo trazado para poblar. ${ }^{27}$

Para los chacareros, la tierra que ocupaban de ninguna manera podía pertenecer a Goya porque el Gobierno se las había dado para iniciar el poblamiento del Fortín Esperanza. No cabía la posibilidad de que los terrenos sobre los que se encontraban fueran de propiedad privada. Goya, por su parte, respondía que no había duda alguna de que estaban en el deber de reconocerlo como propietario y de abonarle los arrendamientos que le adeudaban según el plano de mensura y los títulos de su campo. Estas posturas se mantuvieron a lo largo de todo el litigio y fue desde ellas que cada parte intentó resolver la cuestión. Por esto es importante ver, en adelante, el papel que jugaron las autoridades a las que les tocó participar en el proceso y en calidad de qué lo hicieron.

27 “Goya c/Agüero", fs. 26-27. 
En el conflicto pasó a tener intervención el juez de paz, pero ahora se trataba de Melitón Ruiz, juez del nuevo partido de General Alvear, presente en toda la causa a pesar de renovarse anualmente su cargo. Ruiz solicitó que, como "según la mensura del año 56 cuando este punto se decretó pueblo, se donaron las chacras a los ocupantes", se suspendiera todo juicio hasta tanto se dictaminara sobre la consulta realizada por la Comisión municipal al Gobierno. ${ }^{28}$ Es decir que Ruiz se dirigía al juez de primera instancia como juez de paz pero notificándolo de una acción de la corporación municipal de la cual era presidente, según el decreto sobre funcionamiento de Comisiones de partido. ${ }^{29}$

A Goya no le extrañaba la actitud de los demandados de no pagar, pero sí le resultaba "bien extraño, por cierto, la oficiosidad con que el juez de paz ha asumido la personería de aquellos, haciendo presente a VS. el motivo que le detiene en cumplir lo que se le ha ordenado". Continuaba recordando sus intentos por dejar las tierras a los chacareros y finalizaba comentando "la flojedad de los resortes legales para hacer respetar uno de los derechos fundamentales como el derecho a la propiedad. ${ }^{, 30}$ Asimismo, afirmaba que el Superior Gobierno ya había decidido sobre el asunto, por lo que se debía intimar para que los arrendamientos vencidos fueran pagados dentro de los ocho días, conforme a la planilla que presentaba en el expediente. ${ }^{31}$

Listado de chacareros intimados por arrendamientos adeudados a Luis Goya

\begin{tabular}{|l|l|l|l|l|}
\hline \multicolumn{1}{|c|}{ Chacarero } & \multicolumn{1}{|c|}{ explotación } & años & \multicolumn{1}{c|}{ c/ año } & total \\
\hline Luciano Agüero & 300 cabezas vacunas-1500 ovejas & 4 & 5000 & 20000 \\
\hline Carmen Burgos & 550 cabezas vacunas & 4 & 5000 & 20000 \\
\hline Pablo Roldán & 1000 ovejas & 4 & 3000 & 12000 \\
\hline Francisco Tarija & chacra de siembra & 4 & 2000 & 8000 \\
\hline Valerio Miranda & 200 ovejas y chacra de siembra & 2 & 2000 & 4000 \\
\hline Benjamín Sosa & chacra de siembra & 4 & 2000 & 8000 \\
\hline Julián Garnica & 300 cabezas vacunas-700 ovejas & 4 & 4000 & 16000 \\
\hline Cánsio Zapata & 100 cabezas vacunas-chacra de siembra & 4 & 2000 & 8000 \\
\hline Juan Garnica & 200 yeguas-700 ovejas & 4 & 4000 & 16000 \\
\hline Cipriano Leiva de Torres & 350 cabezas vacunas-2000 ovejas & $21 / 2$ & 6000 & 15000 \\
\hline
\end{tabular}

Fuente: Archivo Histórico de la provincia de Buenos Aires, Escribanía Mayor de Gobierno, legajo 234, expediente 16359, año 1869. "Luis Goya contra Luciano Agüero y otros sobres cobro de arrendamientos"

\footnotetext{
28،Goya c/Agüero", f.38, 27 de mayo de 1870.

${ }^{29}$ En todo este caso será difícil determinar cuándo el juez de paz actúa como presidente de la municipalidad y cuándo como juez delegado, cumpliendo las funciones encargadas por el juez de primera instancia.

${ }^{30}$ Goya hará permanente alusión al derecho de propiedad en un período en que el debate sobre los límites de éste y del derecho de uso de bienes comunes preocupó a hacendados y labradores. "Podemos afirmar que el proceso de delimitación de los derechos de propiedad fue sin duda exitoso y se impuso por sobre una diversidad de formas sociales de propiedad. Este nuevo orden legal fue una dimensión consustancial a los cambios estructurantes que se produjeron en el Plata. Los derechos de propiedad sentaron nuevas reglas de juego, proceso que, como se ha visto a través del pensamiento de los juristas, no fue ni lineal, ni unívoco.” Zeberio, 2009, op. cit., p. 52.

31 "Goya c/Agüero", f. 39. Garavaglia, en el estudio de inventarios de chacras de campaña entre 1770 y 1815 pudo observar una mayor participación del rubro animales en el total. Garavaglia, 1993, op. cit., p.135.
} 
Según el juez de paz, la municipalidad que presidía no podía permitirle a Goya posesionarse de las chacras que correspondían al ejido del pueblo, ni menos aún percibir arriendos anuales o mensuales, exclusivos del municipio. Si alguien debía cobrar algún arrendamiento, esta era la Comisión municipal de General Alvear. ${ }^{32}$ Para Goya, esto confirmaba "toda la ignorancia y altanería de que podía hacer gala un funcionario subalterno" y era una de las tantas consecuencias "de poner al frente de los juzgados de paz de campaña a hombres incompetentes sin las instrucciones necesarias para ejercer cumplidamente las funciones que les encarga la ley. Con cortas excepciones, porque seguramente las hay como en todo orden de cosas, los juzgados de paz de campaña se hallan desempeñados por individuos que carecen absolutamente de las cualidades necesarias".

Quedaba así de manifiesto el contenido del enfrentamiento del municipio con Goya, quien optó por movilizar su causa asegurando que Ruiz sostenía su desobediencia con parcialidad y arrogancia, desconociendo que el Gobierno había reconocido ya sus derechos de propiedad, por lo que consideraba que ya era hora de que el juez de primera instancia le hiciera sentir "de una vez por todas a dicho Juez de Paz que ni las Leyes ni los respetos debidos al Juzgado de VS. se burlan impunemente.",33

El damnificado intentaba manifestarle al juez que su poder estaba siendo cuestionado y que debía imponerse al funcionario subalterno, llegando a decirle que la declaración sobre el cobro de los arrendamientos por parte de la municipalidad se trataba de "un reto de potencia a potencia". Decir que "por el mero hecho de alcanzar la demarcación del ejido a terrenos de mi propiedad estos dejan de pertenecerme pasando a ser patrimonio de la municipalidad" demostraba que era un funcionario que "no tiene idea ni de los respetos que se debe a los Superiores".

Goya explicaba que el objetivo de los ejidos era fijar un espacio para la agricultura, sujeto a leyes y reglamentos muy distintos de los terrenos de pastoreo, alterando en cierto modo el uso de la propiedad, pero no desvirtuaba en lo más mínimo el dominio particular que se tuviera de ella, la traza de los ejidos no despojaba a nadie de lo que legítimamente le pertenecía. ${ }^{34}$ Y para terminar dando fuerza a su reclamo se preguntaba: “ ¿el Gobierno y las municipalidades pueden donar lo que no les pertenece?, ¿llegará a tanto la ignorancia de un funcionario?”, insistiendo en advertir sobre los nuevos desacatos que venían a "ultrajar el Magisterio".

\footnotetext{
${ }^{32}$ La ley de Municipalidades, sancionada el 16 de octubre de 1854, en su artículo 68 daba a uno de los miembros la función de recaudar las rentas municipales, aclarando en el artículo 71 que se consideraba como tal el canon enfitéutico que pagaran con arreglo a la ley los terrenos públicos destinados para ejido en cada pueblo de campaña. ROGBA, 1854, pp. 107-117. La ley de ejidos del 3 de noviembre de 1870 establecía en el artículo $7^{\circ}$ que "el producto que se obtenga por la enajenación de los solares, y por arrendamientos de quintas y chacras, se declara renta municipal". ROPBA, 1870 , pp. 738-750.

33 "Goya c/Agüero", f.53, 18 de octubre de 1870.

34 “Goya c/Agüero", f.56.
} 
El juez de primera instancia dio intervención al Superior Tribunal de Justicia y éste dio vista al fiscal del tribunal, Sixto Villegas, quien explicaba que a pesar de creerse la municipalidad con derechos, el juez de paz no estaba autorizado a eludir los mandatos superiores y tenía la obligación de cumplir sin perjuicio de que hiciere valer sus derechos en la forma legal. No era representante de cada vecino para salir a juicio y debía darles la oportunidad de presentar sus excepciones, pues de lo contrario se convertía en resistente a la autoridad impidiendo la marcha legal de la justicia. ${ }^{35}$

Ruiz contestó al Superior Tribunal, en febrero de 1871, que su juzgado no había tenido “animo ni idea de desobedecer sus mandatos", a su entender la cuestión tocaba los intereses del municipio y él como representante o delegado del Superior Gobierno, “en la jurisdicción que le está demarcada", creyó conveniente elevarlo a consulta del Ministerio respectivo. ${ }^{36} \mathrm{Si}$ bien era cierto que también debía ser ejecutor de los mandatos del juzgado civil ${ }^{37}$, llevaba todo al conocimiento del Superior Gobierno, con quien había tenido una conferencia, aprobando su conducta. A pesar de esto, dio cumplimiento a las órdenes de citación, pero los demandados respondieron que nada debían a Goya por ocupar chacras del ejido del pueblo, como lo expresaban los boletos que el jefe del partido les había dado.

Entre tanto Leyva de Torres, Francisco Tarica y Benjamín Sosa dejaron de ser vecinos y falleció Cánsio Zapata. El resto de los demandados quedó representado por José Portugues, quien el 25 de octubre de 1872 se presentó retomando los antecedentes de la causa para fundamentar el pedido a realizar. ${ }^{38}$ Afirmaba que se debía saber si los terrenos le pertenecían a Goya, cosa en la que la justicia no podía intervenir, "pues lo que se relaciona con las concesiones de tierras públicas es contencioso administrativo y sólo al poder ejecutivo compete su conocimiento",39 por lo que debía suspenderse todo procedimiento hasta tanto terminara el expediente ante el Gobierno. Firmó el escrito junto con el abogado Delfín Gallo y Agrelo pidió al procurador municipal, Roque Robles de General Alvear que intimara a los vecinos a comparecer ante el juzgado. ${ }^{40}$

\footnotetext{
35 "Goya c/Agüero", f.66, 11 de enero de 1871.

${ }^{36}$ Por la ley de 1854 "el juez de paz es el único conducto para comunicarse la Municipalidad con las autoridades", ROGBA, 1854, p.115.

${ }^{37}$ Según el Manual de los jueces de paz en las demandas civiles y asuntos administrativos, redactado por Carlos Tejedor en 1861 a pedido del Gobierno para repartir en los juzgados el juez de paz, este era juez en comisión cuando recibía algún despacho del Tribunal de Justicia, Consulado o jueces de $1^{\circ}$ instancia, capítulo $3^{\circ}$, p.18.

${ }^{38}$ Melitón Ruiz pidió que se lo excusara para desempeñar asuntos pertenecientes a Luis Goya y en adelante siguió el procurador municipal. Por la ley de Municipalidades art. 65, el procurador municipal debía suplir al juez de paz en ausencia o enfermedad. ROGBA, 1854, p.115.

${ }^{39}$ La jurisdicción contencioso administrativa atiende la "protección de los derechos de los administrados frente a los actos del Estado provincial, mediante el control de la legalidad de su actividad, a través de acciones -muchas veces denominadas recursos- de plena jurisdicción y anulación”. Díaz Couselo, José María, “Origen y consolidación del contencioso administrativo en la provincia de Buenos Aires (1854-1906) y su influencia en el derecho público de las demás provincias, en Revista de Historia del Derecho, Buenos Aires, Instituto de Historia del Derecho, n 22, 1994, p.52.

40 “Goya c/Agüero”, f.159.
} 
A lo expuesto por Portugues, Goya respondió con los títulos de propiedad y las escrituras que explicaban como había accedido a las tierras que reclamaba. ${ }^{41}$ El 5 de noviembre de 1872 , Goya se presentó al juez de primera instancia y retomó, en un contexto político que lo acompañaba, ${ }^{42}$ su crítica a la justicia, pues llevaba ya cuatro años en "un sencillo asunto en el cual la chicana y mala fe han campeado libremente, probando así cuan inútiles son las leyes cuando no se cumplen y cuan justo es el clamor público, respecto a la ineficacia de los procedimientos judiciales para hacer efectivos los derechos agredidos". ${ }^{43}$ Reconociendo que a los chacareros se les había permitido poblar en creencia de que era terreno público, había propuesto la permuta del campo equivocadamente ocupado por chacras, pero rechazada ésta y en defensa de sus derechos, solicitaba al juez que expidiera el decreto de solvendo (obligarlos a pagar) con los pobladores con arreglo al artículo 86, tit. $6^{\circ}$, sección $3^{\circ}$ libro $2^{\circ}$ del Código Civil recientemente sancionado. ${ }^{44}$

El 29 de enero de 1873 Goya reclamó que el expediente se encontraba paralizado en poder de Agrelo, suspendido -acusado de sustracciones indebidas de depósitos en el Banco Provincia de la sucesión de Santiago Donohag- y remplazado por Aurelio Prado. Éste resolvió el 27 de junio de 1873 sobre lo pedido por los demandados de suspender el proceso hasta que respondiera el Gobierno y el pedido de solvendo de Goya. En el primer caso, sostenía que no se trataba de mejor derecho a tierra pública, sino de tierra de propiedad particular ocupada por terceros como si fuera pública. Habiendo salido el terreno de Goya de la propiedad del Estado por venta realizada hacía más de 30 años, la cuestión entre él y los ocupantes no era contencioso administrativa y fuera cual fuera la resolución del poder ejecutivo no podía privar a Luis Goya de su propiedad ni quitarle el derecho a los arrendamientos.

\footnotetext{
${ }^{41}$ El 28 de abril de 1851 José Portugués y Francisco Laurel firmaron una escritura por la cual terminaron con la sociedad que los hacía dueños de un establecimiento de estancia denominado 9 de julio en el partido de Las Flores, de 14 y 3/4 leguas compradas al concurso de José Ortiz Basualdo el 20 de febrero de 1846. La mitad del terreno limpio quedó para Francisco Laurel que lo vendió el 7 de mayo de 1851 "para en todo tiempo y para siempre jamás” a Don Luis Goya. Sobre estas tierras Goya tuvo conflicto con Ortiz Basualdo que terminaron resolviendo ante el Superior Tribunal en 1863 por lo que "las cuatro leguas de Goya se ubicaran en el costado que mira al Sud Oeste o sea a la Pampa tomando de frente los necesario para formar 4 leguas cuadradas" siendo el frente el Arroyo Las Flores. Texto de la escritura, "Goya c/Agüero", f. 171. Sobre el movimiento de las tierras de Luis Goya ver Valencia, 2005, op. cit., p.199.

${ }^{42}$ El año 1872 fue de gran desasosiego en una provincia que no podía terminar con su texto constitucional, y así comenzar a reorganizar su estructura institucional. En la administración de justicia, especialmente, las quejas y reclamos se multiplicaban, haciendo hincapié en el retardo en los juicios y en un sistema procesal que requería cambios urgentes. A esto se sumaba que volvió a tornarse dificultoso ocupar los cargos de magistrados vacantes, ya sea por los bajos salarios, la inestabilidad económica y política y los cambios que se avecinaban con motivo de la sanción de la nueva Constitución.

${ }^{43}$ Después de 1872 volvió a tornarse dificultoso lograr que los abogados aceptaran los cargos de juez, esto podía ser por los bajos salarios, la inestabilidad económica y política y los cambios que se avecinaban con motivo de la sanción de la nueva Constitución, a lo que se sumaba el aumento del número de juzgados de cinco en 1854 a once para la Capital y tres para la Campaña, en 1873.

44 “Goya c/Agüero", fs.183-188. El Código Civil fue redactado por el Dr. Dalmacio Vélez Sárfield, y convertido en ley No340 el 25 de setiembre de 1869, aclarando en esta ley que comenzaría a regir el $1^{\circ}$ de enero de 1871.
} 
En la segunda cuestión -el reclamo del estanciero- la acción ejecutiva sólo procedía si existía contrato, y que en esa situación se le estaba dando el nombre de arrendamiento a la indemnización por la ocupación del terreno sin que hubiera mediado convención alguna entre propietario y ocupante. Por todo esto no hizo lugar al pedido de ambas partes, siendo la primera vez en todo el proceso que podemos asistir a una sentencia de la justicia, fundada y que determinaba cual era la jurisdicción del conflicto, la relación entre Goya y los chacareros y su derecho de indemnización. Pero nada decía sobre la responsabilidad del Gobierno de haber prometido la propiedad de tierras que ya tenían propietario. ${ }^{45}$

El procurador ${ }^{46}$ Domingo D. Ghiraldo, se presentó el 1 de julio representando a Luciano Agüero para entablar recurso de apelación. Prado lo tuvo por parte y se lo concedió ante la Sala $2^{\circ}$ de lo Civil del Superior Tribunal. Explicó que los terrenos estaban en posesión de su representado a consecuencia de concesiones legales hechas por el poder ejecutivo de la provincia y que entró en "perfecta buena fe en virtud de un título legal y persuadido de que nadie sino él tenía derecho a la propiedad que se le concedía". Planteaba dos cuestiones claves que generaban el conflicto en todo el proceso: quién tiene derecho a esos terrenos y quién debía ser la autoridad competente para resolver las dificultades que sobre su propiedad se suscitaban.

Él interpretaba que las tierras en cuestión habían sido dadas por el poder ejecutivo a dos personas distintas y que debía resolver la cuestión como un caso contencioso administrativo. Eran contencioso administrativas "todas aquellas cuestiones que teniendo origen en actos del poder ejecutivo o sus delegados, pueden en su consecuencia afectar a los intereses públicos, ya sea porque pueden comprometer el orden o la ley, ya sea porque pueden dar margen a perjuicios o indemnizaciones en contra del Estado". Para atender al conflicto debía el poder ejecutivo resolver la cuestión de propiedad, que no podía ser entendida por los tribunales ordinarios por tratarse de un asunto de propiedad pública de tipo puramente administrativo, por esto insistía en suspender el proceso. $^{47}$

Goya creía cuestionado su derecho de propiedad, y reiteraba el intento de permutar las tierras, pues si todos los que poseían chacras en los ejidos de los pueblos, debían pagar el correspondiente arrendamiento a la municipalidad mientras no compraran la propiedad, el Gobierno no los podía

\footnotetext{
45 “Goya c/Agüero", f.191 vuelta.

46 "Procurador o personero, es el que trata, y gestiona los pleitos, o negocios de otro, representando su persona en virtud de su mandato y poder" (lib.1, tít.5, Part.3) "El procurador para parecer en juicio debe presentar el poder bastante, firmado por abogado, quien responde del interés y daños causados, si resultase no serlo. Si el colitigante contradijere la suficiencia del poder, el Juez debe resolver, substanciando el artículo, para evitar la nulidad" Curia Filípica, part.1, juicio civil 10, núm.20. El poder debía otorgarse ante escribano público y el procurador tener más de 25 años. Manuel Antonio de Castro, Prontuario de práctica forense, segunda edición aumentada con notas en que se exponen las variaciones introducidas por las leyes o la jurisprudencia, desde la época en que escribió el autor, Buenos Aires, Imprenta de la Nación Argentina, 1865.

47 “Goya c/Agüero", f.213.
} 
haber agraciado con la posesión. ${ }^{48}$ De todas formas no le incumbía ni le importaba saber de quién recibieron esa posesión ni en qué forma se la dieron, pues habían ejercido una acción de dominio sobre su propiedad que se hallaba ocupada por un extraño, lo que bastaba para exigir el desalojo y el pago de arrendamientos o indemnización por el tiempo que fue usufructuado lo que era de él; si los demandados se sentían perjudicados debían reclamar a quien correspondiera, pues despojarlo sería ilegal y absurdo. ${ }^{49}$

La Sala del Superior Tribunal, compuesta por Manuel H. Langenheim, Carlos Eguía y Manuel M. Escalada, confirmó la sentencia de primera instancia el 12 de enero de $1874 .{ }^{50}$ Ante esta situación Goya solicitó al juez de primera instancia que no permitiera que los ocupantes alteraran cosa alguna, pues sólo contaban con su hacienda para responder a la deuda que él reclamaba. El juez Prado no hizo lugar al pedido, fundándose en la ley 76 de Toro, por no haber sido contestada la demanda ni la acción deducida. ${ }^{51}$

La sentencia fue notificada por el procurador municipal a los chacareros, recibiendo diversas respuestas. Juan Garnica contestó que se encontraba ocupando el terreno como chacra por la concesión hecha por el comisionado para la distribución de tierras en el ejido y que si resultaba propiedad de Goya él estaba dispuesto a desocuparlo, pero que sus circunstancias no le permitían adquirir compromisos ni de arrendamiento ni de indemnización por lo que no se presentaba en la ciudad. Martina García se presentó porque ocupaba la chacra de Cansio Zapata y explicó que, según la nueva mensura, solamente quedaba en las tierras de Goya la mitad de su rancho y que poseía muy poca hacienda como en el resto del ejido. Mamerto Garnica expuso que la chacra la ocupaba su hermano Julián fallecido. Valerio Miranda pobló la tierra por ser campo de chacra y no podía ir a Buenos Aires por no contar con recursos. Para Pablo Roldán, él ocupaba tierras del ejido que no le constaba que pertenecieran a Goya, pero que hacía tres años las había abandonado. ${ }^{52}$

Uno de los chacareros, Carmen Burgos, llegó a un acuerdo con el demandante en abril de 1874 , por el que reconocía la propiedad de sus tierras y pagaba $\$ 30000 \mathrm{~m} / \mathrm{c}$ por el tiempo transcurrido. Pero a pesar de acordar Burgos, aseguró que él y los demás pobladores contaban con las seguridades que les había dado el Gobierno de comprar ese campo y adjudicarlo a los poseedores. En el arreglo se contemplaba la posibilidad de pactar un arrendamiento, de no hacerlo se debería concretar el desalojo en 60 días. La transacción fue aprobada por el juez Prado que simultáneamente recibió de Melitón Ruiz la notificación de que en acuerdo de la municipalidad se

\footnotetext{
${ }^{48}$ Sobre el arrendamiento de las tierras públicas desde 1857, ver Valencia, 2005, op. cit., capítulo 2.

49 "Goya c/Agüero", f.217, 18 de noviembre de 1873.

50 “Goya c/Agüero", f. 221.

${ }^{51}$ La ley 76 de Toro mandaba que la justicia a ninguno diera por enemigo en rebeldía sin legítima probanza, y esto después de tres meses de hecha la condenación, con tal que lo hubiera pedido así el acusador y si de otra suerte lo hiciere que no valiera. Sancho de Llamas y Molina, Comentario crítico-jurídico-literal de las 83 Leyes de Toro, Madrid, Imprenta de Repullés, 1827, t. I, p.10.

${ }^{52}$ De estos chacareros sólo Mamerto Garnica sabía firmar. "Goya c/Agüero”, f.254, 10 de febrero de 1874.
} 
había concedido permiso para que se practicaran las demarcaciones de terrenos en el partido según los artículos 48 y 50 del Código Rural, para lo que habían puesto en conocimiento a los vecinos por intermedio del Alcalde del Cuartel $2^{\circ}$ y a los tenientes alcaldes. ${ }^{53}$

Mientras tanto, Ghiraldo se mantenía en la postura de hacer participar al Gobierno del litigio por lo cual recurrió a una nueva figura jurídica: la concesión había sido hecha por la Administración de la provincia, con cargas que habían sido cumplidas. Según los documentos, las antiguas leyes y el nuevo Código Civil, "los concesionarios o donatarios tenían derecho de reclamar de evicción a los cedentes o donatarios cuando la cesión o donación fuese con cargos”, por esto el poder ejecutivo debía ser citado de evicción a fin de que asumiera la personería que le correspondía en el asunto. ${ }^{54}$ Desde ya que Goya se manifestó contrario, pues las tierras no eran públicas hacía muchos años y si Agüero se consideraba perjudicado "en buena hora," debía reclamar ante quien correspondiera, pero antes tenía que desalojar sus terrenos y abonara la indemnización, pues no podía permitir que se le siguiera negando el goce de su propiedad.

Y aquí se complican más las cosas. El juez Prado no consideraba perjudicial para Goya la citación de evicción, por lo que dio intervención al agente fiscal de lo civil. Pero para Ghiraldo, esto no era correcto pues la citación correspondía al fiscal de gobierno, defensor de los derechos y el ejercicio de las acciones del poder ejecutivo en uso de sus facultades administrativas, que pasaba a ser parte en este asunto. Prado realizó entonces la citación al ministro de gobierno, Amancio Alcorta, quien solicitó los autos que le fueron enviados pidiendo pronta devolución el 12 de agosto de 1874. El pedido del ministro tenía su origen en un expediente iniciado por los vecinos de General Alvear (que veremos en detalle más adelante) y que finalizó con un arreglo entre Goya y el Gobierno, por el que le entregaría a cambio de sus tierras un sobrante de tierra pública. De los arrendamientos adeudados el propietario reclamaba $\$ 250000$, perdonando $\$ 50000$.

Pero en el expediente por cobro de arrendamientos resurgieron los conflictos entre el estanciero y el juez de paz. El primero reclamaba las garantías acordadas por la Constitución a la propiedad y se quejaba de la conducta del juez de paz “inaudita y escandalosa”. Melitón Ruiz contestaba que "en la pequeña área de campo que pretende y reclama el Señor Goya como de su propiedad" sólo quedaba un vecino, Luciano Agüero, quien ocupaba un área de terreno de 16 leguas cuadradas, igual extensión a la que tenían las chacras antes de realizarse la mensura del año

\footnotetext{
53 “Goya c/Agüero", f.247, 13 de abril de 1874.

54 "Evicción: la recuperación que uno hace judicialmente de una cosa propia que otro poseía con el justo título; o bien el despojo jurídico que uno sufre de una cosa que justamente había adquirido; o sea el abandono forzoso que el poseedor de una cosa tiene que hacer de ella en todo o en parte por virtud de una sentencia que a ello lo condena...Llámese también evicción la sentencia que ordena el abandono, y aún la demanda que se pone para obtenerlo." Escriche, Joaquín, Diccionario razonado de Legislación y Jurisprudencia. Nueva edición con suplemento, París, Garnier hermanos, libreros-editores, 1869, p. 665. "El poseedor ha sido evincido cuando por una sentencia ha sido excluido de la posesión que tenía sobre una cosa sometida a su poder". Garrone, José Alberto, Diccionario Manual Jurídico, Buenos Aires, Buenos Aires, Abeledo-Perrot, 2000. "Goya c/Agüero”, f.251.
} 
anterior. Esto generó nuevamente la intervención del fiscal y el Departamento de Ingenieros ${ }^{55}$ que envió los croquis que demostraban que los terrenos en permuta eran municipales. Por lo tanto, el ministro de hacienda mandó oficio a la municipalidad para que manifestara si aceptaba la permuta. De ser así, se concretaría y Goya recibiría $\$ 300000$ por los arrendamientos vencidos. Pero el presidente de la municipalidad (Melitón Ruiz) informó que en sesión del 18 de diciembre de 1875 se había dispuesto que de ninguna manera se estuviera conforme con la permuta. ${ }^{56}$

El 22 de febrero de 1876 se presentó Candelaria F. de Goya, viuda de Luis Goya, reclamando el desalojo y los arrendamientos. El fiscal general de gobierno, Juan S. Fernández, contestó que el mal ya estaba hecho, que la tierra había sido despoblada y con tanto terreno municipal baldío podrían acomodarse; sugería que se ordenara al juez de paz activar el desalojo del poblador que quedaba pudiendo la testamentaria tomar posesión del terreno. El 7 de julio de 1876 el gobernador Carlos Casares y el ministro de Hacienda Rufino Varela firmaron la resolución mandando a realizar lo indicado por el fiscal ${ }^{57}$ y el procurador Cipriano Elía se presentó por Luciano Agüero ante la Suprema Corte.

\section{Los recursos de los chacareros para recuperar sus tierras}

\section{a. Luciano Agüero intenta escriturar}

El chacarero que peleó hasta el final e intentó escriturar su chacra fue Luciano Agüero, corriendo el expediente paralelo al proceso que hemos seguido. ${ }^{58} \mathrm{El}$ expediente comienza con el boleto de concesión firmado en el Fortín Esperanza el 3 de julio de 1863, que entregaba tierra por el comisionado del reparto de terrenos. Agüero había solicitado verbalmente y obtenido la chacra $\mathrm{N}^{\circ}$ 10, compuesta de 800 varas de costado de la plaza del pueblo al norte y se comprometía en el término de un año a hacer en la referida chacra una población, del mejor modo posible, de no cumplir perdía el derecho a ella, entre tanto no podían vender ni traspasar bajo pena de nulidad.

Cumplido el año, debía concurrir con esa boleta al Comandante que se hallase, para obtener la escritura que el Superior Gobierno le entregaría por conducto del Departamento Topográfico y a cuyo efecto quedaba anotado en el registro de foja $\mathrm{n}^{\circ}$ 9. Es de destacar que en el reverso del boleto dice "Cumplió con la obligación que reza en boleta presentándose al Superior Gobierno que se le otorgue su escritura por conducto Departamento Topográfico", firmando Guillermo Leyter,

\footnotetext{
55 El Departamento de Ingenieros surgió de la reforma constitucional de 1873, reemplazando al Departamento de Topografía y Estadística el 19 de abril de 1875, presidido por Francisco Lavalle. Saturnino Salas que lo presidía desde 1857 recibió la jubilación.

56 "Goya c/ Agüero", fs. 292 y 292 vuelta.

57 "Goya c/ Agüero", fs. 294 a 297.

${ }^{58}$ AHPBA-EMG, leg.234, expte.16360, año 1869, “Agüero Luciano sobre escrituración de un terreno de chacra en el ejido del Pueblo Esperanza" (en adelante "Escrituración”)
} 
encargado de reparto de terrenos de Fuerte Esperanza y el juez de paz de Tapalqué Facundo Ricabarra, sin fecha. ${ }^{59}$

El 18 de febrero de 1869 se presentó Agüero pidiendo la escrituración de la chacra, justificando el cumplimiento de las obligaciones impuestas sobre población y cultivo. Juan S. Fernández, que en ese momento era Ministro de Gobierno, le pidió informe al Departamento Topográfico, que respondió no tener conocimiento de haber autorizado al juez de paz de Tapalqué para distribuir los terrenos del pueblo Esperanza, ni sabía a qué plano o proyecto se sujetó dicho funcionario para las concesiones. Tenía conocimiento del plano levantado por D’Horbourg y elevado al Gobierno, sin haber duplicado en su Archivo. La sugerencia era que se pidiera al juez de paz explicara cómo había practicado la distribución de los terrenos.

El juez de paz contestó que cuando el pueblo de Esperanza dejó de ser un fuerte militar y se agregó su ejido al partido, quien estuvo a cargo del reparto de tierras fue el alcalde, desconociendo la autorización que su antecesor hubiera tenido para conceder los terrenos, que según él, se habían realizado por la autorización otorgada el 7 de marzo de 1856. El plano al que se sujetó se encontraba en la Alcaldía y era copia fiel del levantado por el mayor de ingenieros Ludovico D’Horbourg, aprobado por el Superior Gobierno. El informe fue recibido y pasó al Departamento Topográfico que puso una nueva objeción, observando que el área de terreno solicitada por Agüero superaba el máximun fijado por el decreto del 18 de marzo de $1869 .{ }^{60}$ El fiscal general de Gobierno José María Moreno determinó finalmente que el alcalde no tenía autorización para repartir tierras del ejido del pueblo por lo que declaraba "nula y de ningún valor" la concesión y rechazaba el pedido de escrituración. ${ }^{61}$

Pero el asesor de gobierno, Cosme Becar, hizo notar que el boleto no estaba firmado por el alcalde, sino por el jefe militar de la localidad, Francisco Elía, "comisionado sin duda para ese reparto" de terrenos comprendidos en la legislación vigente. La Comisión municipal de Esperanza afirmó que las donaciones fueron hechas en virtud de las instrucciones del Departamento Topográfico del 24 de marzo de 1856, dirigidas al jefe militar del pueblo y aprobadas por el Superior Gobierno el 29 de marzo de 1856, autorizando al jefe para la distribución de los solares, quintas y chacras por resolución del 7 de marzo de 1856. El comandante militar le escribió al presidente del Departamento Topográfico, el 22 de mayo de 1856, acusando recibo de instrucciones y plano del 7 de abril para desempeñar la comisión que el Superior Gobierno le confió de repartir los terrenos del pueblo, agotando los esfuerzos para seguir las instrucciones ordenadas, e iniciando el reparto observando el artículo $4^{\circ}$ de las indicaciones y el superior decreto del 7 de julio de 1856.

\footnotetext{
59 "Escrituración”, fs. 1 y 1 vuelta.

${ }^{60}$ ROPBA, 1869, pp.108-110.

61 “Escrituración", f. 6 vuelta, 14 de octubre de 1869.
} 
El 15 de febrero de 1872 se presentó Agüero afirmando que la concesión no la había hecho el alcalde sino el jefe militar autorizado, quien cumplió con todas las condiciones de población exigidas y que la concesión se hizo según el plano e instrucciones dadas por el Gobierno y el Departamento Topográfico. Pedía que se ordenara la escrituración inmediata del terreno concedido, firmando Portugues a ruego por no saber hacerlo. La Comisión municipal de Esperanza informó, firmando Melitón Ruiz como presidente, que la chacra constaba de cinco piezas de barro revocadas con techo de paja, inclusive la cocina, todas en perfecto estado, en cultivo, "en abundante escala y más de cuatro mil plantas de distintas clases, tanto en frutales como maderos, cuidadas con todo esmero". 62

El expediente en manos del jefe de la Oficina de Tierra fue mandado al asesor de gobierno, que dictaminó, con arreglo a la ley de ejidos del 3 de noviembre de $1870^{63}$, que debía ordenarse la escrituración solicitada previa determinación del área. Pasó al Departamento Topográfico, según el cual el 12 de marzo de 1856 el comandante fue autorizado a repartir los solares, quintas y chacras pero que en el archivo no se encontraban las instrucciones, sí el plano, y debía oírse al asesor y al fiscal. Aquí ingresó Goya en este expediente, calificando de inadmisible la solicitud de Agüero, lo cual había complicado la tramitación, tal como se explicó.

Recordemos la resistencia de Ruíz en el expediente por cobro de arrendamientos de citar a los chacareros. Pues bien, nos encontramos aquí con su nota al ministro de gobierno, Antonio Malaver, informándole que su juzgado había recibido un oficio del juez de $1^{\circ}$ instancia, Emilio Agrelo, notificando a los demandados, que ocupaban tierras donadas por el Superior Gobierno, por lo que él había pedido se suspendiera el procedimiento hasta que este dictaminara al respecto. Por ello, empeñado en el cumplimiento de sus deberes y en la duda de qué debía hacer, consultaba al Gobierno para que "con mayor ilustración a la verdad posible" se lo indicara.

Malaver lo derivó al fiscal con recomendación de pronto despacho y éste al Departamento Topográfico, comenzando una especie de círculo vicioso que hizo que el expediente continuara de oficina en oficina hasta que el 8 de noviembre de 1880. Entonces, Sixto Villegas por la Suprema Corte, informó al comisionado nacional que Agüero había desistido de la demanda entablada contra el poder ejecutivo de la provincia sobre propiedad de unos terrenos en el ejido del pueblo de General Alvear. ${ }^{64}$

\footnotetext{
62 “Escrituración”, fs. 8 y 8 vuelta, informe trascripto del original el 11 de diciembre de 1872 .

${ }^{63}$ ROPBA, 1870, Buenos Aires, pp.739-750.

64 “Escrituración”, f. 37.
} 


\section{b. La presentación de los vecinos}

Mientras el proceso avanzaba, a fines de 1873, un grupo de 112 vecinos, entre ellos Mamerto Garnica y Luciano Agüero, presentaron una nota al gobernador Mariano Acosta relatando el origen de su partido y diciéndole que Goya debía discutir con él y no con "pobrecitos paisanos que nada conocen y que tanto han sufrido", que poblaron esas tierras porque la autoridad allí reconocida los había autorizado dentro del ejido. Darle a Goya lo que pedía era darle parte de lo único mejor que ese pueblo tan combatido tenía. Concretamente pedían que se fijara el valor de las tierras que la comunidad estaba pronta a pagar, tratando al gobernador como "padre" en cuya rectitud confiaban. $^{65}$

La nota pasó al jefe de la Oficina de Tierras Públicas ${ }^{66}$ y de éste al Departamento Topográfico que explicaba cómo, sobre la última mensura, surgía que los lotes habían quedado dentro del terreno de Goya y que el Superior Gobierno resolvería como creyera justicia. Esta introducción de chacras al terreno de Goya provenía del trazado que hizo en 1856 el ingeniero militar D’Horbourg, aprobado por el Gobierno, sobre el que se fueron realizando las concesiones. ${ }^{67}$

Para el fiscal de gobierno, Juan S. Fernández, el Fortín Esperanza era conocido y en su momento había podido apreciar la importancia del servicio prestado por los chacareros cuando poblaban ese desierto que era frontera. Declaraba su simpatía por ellos y decía al gobernador que podía evitar el enorme perjuicio que se les causaría, "lanzándolos de un terreno que han cultivado y adelantado con su capital y riesgo de sus vidas y que han entrado a poseer de buena fe, descansando en la confianza que naturalmente debía inspirarles la autoridad, de que les concedía lo que tenía derecho a concederles". Ofrecía cuatro soluciones posibles: compensarlo a Goya con el sobrante de las chacras; darle otras chacras dentro del ejido; comprarle tierras y para el pago vender una extensión del ejido; o en caso de no aceptar la venta voluntaria, expropiarle, previa autorización de la Legislatura, formando fondos con la venta de una parte del ejido. ${ }^{68}$ Para esto debía citar a Goya a un comparendo verbal al que asistiera el presidente del Departamento Topográfico. ${ }^{69}$

El ministro de gobierno puso fecha el 26 de agosto de 1874 para concretar el juicio ordenado (este es el arreglo que aparece en el expediente de Goya contra los chacareros, al que hacemos

\footnotetext{
${ }^{65}$ AHPBA-EMG, leg.280, expediente 19008, año 1872, "Vecinos del partido de General Alvear sobre el ejido de dicho pueblo", fs. 1-3 (en adelante "Vecinos")

${ }^{66}$ La Oficina de Tierras Públicas fue creada por ley el 3 de septiembre de 1859. La nota pasó al Jefe de la Oficina pues él debía indagar los bienes y tierras que pertenecían al Estado, teniendo atribuciones para solicitar los títulos particulares. ROGBA, 1859, Buenos Aires, Imprenta de Mayo, 1859, pp.86-87.

67 "Vecinos", f.7.

${ }^{68}$ Según el artículo 17 de la Constitución Nacional uno de los fundamentos de la propiedad era el principio de inviolabilidad, por lo que ningún habitante podía ser privado de ella, sino por sentencia fundada en ley. La expropiación por utilidad pública debía ser establecida por ley e indemnizada. Blanca Zeberio, "Un mundo rural en cambio", en Bonaudo, Marta, (directora) Nueva Historia Argentina, Liberalismo, Estado y orden burgués, tomo IV, Buenos Aires, Sudamericana, 1999, p. 304.

69 "Vecinos", fs. 8-9.
} 
referencia previamente). Al mismo comparecieron, ante el ministro Alcorta, el presidente del Departamento Topográfico, el fiscal general de gobierno y Luis Goya con su abogado Lahitte. Allí se dieron algunas explicaciones sobre el objeto del juicio y el interesado dijo que estaba dispuesto a vender el terreno al Gobierno, por el precio de tasación que fijaran los peritos. Goya debía determinar el monto de los arrendamientos adeudados por el tiempo que los actuales poseedores habían usufructuado el terreno. ${ }^{70}$ Esto significaba que los vecinos habían logrado la intervención del Gobierno para resolver el asunto.

El expediente terminó con el arreglo y siguió la causa iniciada por Luis Goya, donde el 24 de noviembre de 1874 manifestaba estar dispuesto a aceptar a cambio del área de su propiedad ocupada por chacras, el sobrante de propiedad pública que por su mala calidad, por ser bañados, ofrecían la única ventaja de terminar con ese conflicto. Los vecinos solicitantes reconocían a su entender el valor de las tierras de su propiedad, demostrando aún los contrarios la perfecta justicia que lo asistía. En cuanto a los arrendamientos reclamaba $\$ 250000$, perdonando $\$ 50000$ de la suma adeudada, apoyándose en las declaraciones de Carmen Burgos cuando hicieron el arreglo. Pero como ya hemos podido ver, a este convenio le faltaba un convidado, el municipio, que obstaculizó la concreción del acuerdo y llevó al fracaso el recurso utilizado por los vecinos para no perder las tierras que habían trabajado y sobre las que había nacido y crecido el pueblo de Esperanza.

\section{c. El reclamo ante la Suprema Corte}

La prolongación del conflicto atravesó la transformación del poder judicial por la Constitución de 1873 y la organización de la Suprema Corte que comenzó a funcionar el 23 de enero de 1875. Lo que aquí nos interesa es la competencia contencioso administrativa que se le atribuye, hecho que impactó fuertemente en el desarrollo del Derecho Público de Buenos Aires y otras provincias. ${ }^{71}$

\footnotetext{
70 "Vecinos", f. 12 v.

${ }^{71}$ La justicia administrativa después de 1810 no encontró un sistema que amparara a las personas frente a los actos del Gobierno, relacionado esto con la falta de realización de la división de poderes, necesaria para concretar el sistema contencioso administrativo. Se enfrentaban dos posiciones basadas en diferentes interpretaciones de la doctrina de la división de poderes; una defendía la revisión judicial, pues la separación de poderes no implicaba independencia absoluta sino especialización de funciones, la otra no aceptaba la revisión judicial en los actos administrativos, salvo sometimiento voluntario, pues la independencia de los órganos era absoluta y cada uno cumplía sus funciones sin control del otro. La Constitución de 1854 intentó modificar la estructura vigente con un nuevo sistema político, jurídico y administrativo, rigiéndose hasta la sanción del Código de Procedimiento contencioso administrativo en 1906, por el procedimiento civil y la jurisprudencia. Determinó que "las causas contenciosas de hacienda y las que nacen de los contratos entre los particulares y el gobierno, serán juzgadas por un tribunal especial, cuyas formas y atribuciones las determinará la ley de la materia." La ley que organizaba el Superior Tribunal en 1857 le otorgaba conocer en pleno "de todo recurso de apelación que se interpusiese de resoluciones de gobierno en asuntos con particulares" mientras no se estableciera el tribunal especial, que no se estableció. La Constitución de 1873 fue la primera en Argentina que quitó al poder administrador la jurisdicción administrativa, influyendo en constituciones provinciales posteriores, dejando definitivamente determinado que no correspondía al poder ejecutivo la facultad jurisdiccional en materia administrativa. La Suprema Corte tenía entre sus atribuciones decidir las causas contencioso administrativas, en única instancia, y en juicio pleno, previa denegación de la autoridad administrativa competente de reconocer los derechos reclamados por la
} 
Ante esta nueva perspectiva, en septiembre de 1876, el procurador Cipriano de Elía (firmando con el abogado Delfín Gallo), se presentó ante la Suprema Corte, reclamando por los legítimos derechos de los chacareros, amparándolos contra la resolución del poder ejecutivo, contraria según su opinión, "a la ley, a la justicia y a la equidad”. Repasó todas las cuestiones que ya hemos visto, por lo que recuperaremos las ideas que enriquezcan el análisis; en primer lugar destacaba que Goya conocía las concesiones realizadas y que no había pretendido derecho a los terrenos mientras era necesario el esfuerzo para llevar adelante la nueva población, pero sí cuando ya no existía peligro y había aumentado el valor de las tierras. Logró el desalojo de los campos y quienes no podían pagar los arrendamientos abandonaron todo; los que continuaron citaron de evicción al poder ejecutivo para que los defendiera, convirtiendo la causa en contencioso administrativa y creyéndose los demandados a salvo. Pero esto no fue así y el Gobierno olvidó compromisos adquiridos por administraciones anteriores. ${ }^{72}$

A esto se sumó la representación municipal indebida del juez de paz, rechazando la propuesta de Goya de permuta, en nombre de los municipales y vecinos de Alvear. Esta manifestación hizo cambiar la postura del fiscal, fundado en el abandono de los terrenos, resolución tomada por el poder ejecutivo como dictamen, sin referirse a los derechos de los pobres chacareros. Esto tenía a su entender vicios de forma y de fondo; en cuanto a lo primero, nunca pudo acceder al expediente porque estaba en el Departamento Topográfico, en el despacho del Gobernador, del Ministro o en casa del Fiscal, dificultad que no había encontrado Goya. Aunque el procedimiento contencioso administrativo no se hallara legislado aún, debía atenderse el principio constitucional por el cual ninguna persona podía ser condenada en juicio civil o criminal sin ser oídas las razones en que se fundaban sus derechos, peor aún si la otra parte había sido oída.

Sobre las cuestiones de fondo, explicaba que los chacareros de Alvear no habían abandonado las concesiones que les fueron hechas, ante el desalojo debieron dejar sus poblaciones por no contar con medios para seguir el juicio, pero otros siguieron, como Luciano Agüero que conservaba sus terrenos con "población, arboleda de importancia y un número de animales relativamente considerable". Los donatarios abandonaron por fuerza mayor, habiendo cumplido con las obligaciones de la donación, por ello el poder ejecutivo como donante debía responder a la citación de evicción, defendiendo sus actos.

Las relaciones entre el Gobierno y los chacareros importaban un contrato con obligaciones recíprocas, el primero concedía la propiedad de las tierras con compromiso de escriturarlas,

parte interesada. Díaz Couselo, 1994, op. cit.; Díaz Couselo, José María, "La revisión de los actos administrativos en la Argentina (1853-1900), en Revista Chilena de Historia del Derecho, Facultad de Derecho, Universidad de Chile, núm.16 (1990-1991), pp. 413-444.

72 “Agüero c/ el Poder Ejecutivo". 
cumplidas las condiciones de población y cultivo, debiendo decretar la indemnización o expropiar de no poder dar la escritura. Pero el ejecutivo había dejado a gran número de familias sin hogar, confiadas en su protección, que además habían prestado grandes servicios al desenvolvimiento de la campaña. Los terrenos no pertenecían a Goya, las tierras le fueron compradas por Portugues y la primera mensura de 1862 partió de un punto equivocado y sin protestos a la hora de entregar los terrenos a los chacareros. La fuerza de la defensa de los chacareros se encontraba en que las tierras tenían origen fiscal y la cuestión debió subordinarse a las necesidades públicas, indemnizando a los particulares. $^{73}$

Ante este planteo, importante fue lo expuesto por el fiscal Fernández respecto al papel del Gobierno en este conflicto. Citado de evicción, intervino en el asunto por cuestionarse la propiedad pública de un terreno, pasando a ser parte del juicio el que reclamaba las tierras. Reconocida por la justicia la propiedad de Goya, no le quedó más que hacer lo mismo, pero interesado en los chacareros, por oficiosidad tramitó la permuta que quedó sin sentido al verse las tierras abandonadas de casi todos los concesionarios y poseedores. Agüero no tenía derecho de quejarse porque él no era parte en la cuestión de propiedad entre el Estado y Goya, menos aún en los arreglos discrecionales del poder ejecutivo, por lo que la demanda debía ser desestimada por infundada e improcedente. $^{74}$

Pero para Elía los chacareros damnificados por la resolución y por el desalojo tenían derecho a apelar de una sentencia que los afectara directa o indirectamente, según las leyes de Indias 2 y 4 tit.23 Part. $3^{\circ}$. Además el poder ejecutivo no había actuado como tribunal de apelación, sino como tribunal de primera y única instancia, al ser una causa contencioso administrativa, según la Constitución atendiendo los reclamos de los particulares que sintiesen sus derechos afectados por resoluciones gubernativas. Todos los chacareros tenían derechos, adquiridos por concesiones de donaciones formales, atacados por Goya. Según el Gobierno los títulos no existían y quienes tanto habían luchado y fueron arrancados de sus hogares no podían reclamar ante el supremo guardián de las leyes tutelares del ciudadano ante la injusticia y el abuso. ${ }^{75}$

Según el fiscal se reclamaba el derecho de propiedad, pero según el procurador no era así, pues con arreglo al Código Civil no existía derecho de propiedad sino una vez extendida la correspondiente escritura pública. Se estaba solicitando el respeto al contrato con obligaciones recíprocas establecido entre los chacareros y el poder ejecutivo; invocar despoblación, era decir

\footnotetext{
73 “Agüero c/ el Poder Ejecutivo”. Presentación de Elía, fs. 1-10.

74 "Agüero c/ el Poder Ejecutivo", fs. 22-23 vuelta.

75 “Agüero c/ el Poder Ejecutivo", fs. 26-28.
} 
abandono de derechos, era reconocer que esos derechos existieron. Finalmente Agüero fue reconocido como parte, pero no los otros chacareros. ${ }^{76}$

Fallecido Goya, se presentaron pidiendo el expediente José Portugues y los herederos para llegar a un arreglo que pusiera fin a la cuestión. Sabiniano Kier, presidente de la Suprema Corte, solicitó la causa al fiscal y en septiembre presentaron las partes la propuesta, Portugues en representación de los chacareros y los abogados Martel y Castro por los herederos. El primero adquiría los terrenos en litis a $\$ 150.000 \mathrm{~m} / \mathrm{c}$ la legua, quedando a salvo los derechos para proseguir el cobro de los arrendamientos hasta la fecha; la testamentaria se comprometía a entregar mensurada la fracción y deslindadas las chacras, concluida la cual se realizaría el pago y la escrituración.

Notificaron al asesor general de gobierno, Fernández ${ }^{77}$, quien declaró no tener personería. El demandante debía desistir en su demanda para concretar el acuerdo, realizado lo cual no tenía por qué figurar aquel en el expediente. Desistió entonces D’Elía, por instrucciones de sus poderdantes, el 5 de abril de 1880. Se lo hicieron saber al asesor y la Suprema Corte dio por desistida la causa, sin tener que tomar parte, mandando a archivarla y comunicar al poder ejecutivo, cosa que sucedió el 9 de octubre estando representado por el comisionado nacional.

\section{Conclusión}

Este estudio de caso partió de la inquietud de conocer la conducta de la Suprema Corte de Justicia provincial ante un conflicto relacionado con la propiedad, particularmente de tierras y específicamente suscitado por la política ejidal, orientada hacia el crecimiento de la población y la frontera. A pesar de habernos encontrado con varios casos, uno llamó particularmente nuestra atención y a medida que nos introducíamos en él, era como seguir un camino que nos llevó hasta la creación del primer fortín después de la caída de Rosas, la formación del pueblo y su correspondiente ejido. En este conflicto el Gobierno había entregado en concesión a los chacareros tierras que no le pertenecían y de allí en más aparecieron personajes y conflictos relacionados con la administración de justicia.

Este caso nos ha ofrecido el relato, desde diferentes puntos de vista, del modo en que se gestó un pueblo a partir de la movilización de los vecinos de partidos asolados por la inseguridad y que se arriesgaron a formar el nuevo poblado, a lo que se sumó luego el Gobierno accediendo a legalizar la

\footnotetext{
${ }^{76}$ Firman Sabiniano Kier, Manuel María Escalada, Araujo y Alejo B. González Garaño. “Agüero c/ el Poder Ejecutivo", fs. 35 vuelta y 36 .

${ }^{77}$ El 4 de marzo de 1879, la Suprema Corte en Acuerdo Extraordinario resolvió que el asesor general de gobierno ejercitara en las demandas contencioso administrativas la defensa de los actos del poder ejecutivo que estaban antes a cargo del extinguido fiscal de gobierno, Acuerdos y Sentencias, tomo II, pp.423-423. Juan S. Fernández fue fiscal de gobierno del 14 de mayo de 1873 al 17 de abril de 1878 y el 2 de mayo fue nombrado asesor general de gobierno al 31 de diciembre de 1878 y del 29 de enero de 1879 al 17 de octubre de 1880, por ello interviene como fiscal y asesor en el juicio.
} 
situación, dejando en claro que las tierras de propiedad privada que quedaran dentro del ejido, seguirían siéndolo, con la única salvedad de no dedicarlas al pastoreo.

Pero las cosas no resultaron tan sencillas ni lineales, pues las demarcaciones eran difusas y el archivo de los planos inseguro. Las primeras autoridades fueron militares y cambiantes, colaborando al clima generado por un Estado embrionario y de instituciones débiles, que mantenía la centralización administrativa en instituciones municipales encabezadas por el juez de paz, gobierno y justicia de su partido, y que buscaba ser fiel al Gobierno central sin perder los beneficios del partido. ${ }^{78}$

El conflicto en sus diversos niveles giraba entre las oficinas del Departamento Topográfico, el fiscal y el asesor de gobierno, en las que se pueden ir siguiendo los cambios políticos coyunturales, las relaciones con el Gobernador y el desarrollo del concepto de la propiedad privada. En algunos casos, como la escrituración solicitada por Agüero, puede vislumbrarse un entorpecimiento del trámite, con una clara intención de no otorgar la escritura, como cuando determinaron que la donación había sido realizada por el alcalde. Sin embargo la actitud de Juan S. Fernández, agrimensor y abogado, fue más compleja, con un claro cambio de posición apoyado en el abandono de las tierras por los chacareros, que requeriría de un seguimiento más minucioso de su carrera política y de los bienes de que disponía.

La justicia fue duramente criticada por Goya, a la que de todas formas le confió sus intereses, y los chacareros no consideraban que fuera el poder del Estado encargado de resolver el conflicto hasta que tuvo plenamente la competencia en los asuntos en que los particulares eran perjudicados por el Gobierno. Esta diferencia está mostrando la falta de definición de la división de poderes y de cuál de ellos debía ser el "guardián de las leyes". Hasta la creación de la Suprema Corte, el Gobierno podía ser parte del conflicto -representado en su fiscal- y juez -a través de sus ministros.

El juez Prado, que luego sería el primer secretario de la Corte, dictó una sentencia que respondía a las demandas de Goya y de los chacareros en un juicio que daba por sentada la propiedad del demandante, especificando una cuestión de términos, importante para esos años de cambios en la concepción del derecho.

¿Por qué el Gobierno no aceptó la primera propuesta de permuta de Goya? Posiblemente por estar atravesando años de dura crisis económica y no querer hacerse cargo de errores de administraciones pasadas; tal vez por el conflicto que le suscitaría con la Comisión municipal, beneficiada por el arrendamiento de las chacras; quizá por la ineficiencia administrativa del sistema o por las tres cosas juntas. Lo cierto fue que uno de los más importantes fundadores del pueblo salió a comprar las tierras para los chacareros, pues la propiedad privada estaba consagrada y la de Goya

\footnotetext{
${ }^{78}$ Valencia, 2005, op. cit., p.217; Zeberio, 2009, op. cit.
} 
incuestionada, los arrendamientos debían ser pagados y la Suprema Corte, con pocos años de funcionamiento, no debió dar su fallo ante la resignada renuncia del procurador de Agüero, que reclamaba al Gobierno cumpliera con lo prometido. 


\section{Conclusión}

La organización de los poderes del Estado, implicó romper en parte los moldes de la estructura colonial, y en parte admitir su supervivencia mediante innovaciones que se adaptasen a las nuevas formas políticas que se estaban gestando.

Emilio Ravignani , 1939

"Toda justicia se hace en nombre del soberano; este soberano es el pueblo, cuya autoridad está dividida en tres ramos; el poder legislativo, el ejecutivo y el judicial. Esta autoridad se encuentra entera en los tres poderes constituyentes, que son correlativos sin poder confundirse. La ley sólo es su antorcha y su guía: el uno la hace; el otro la aplica; y el tercero la hace ejecutar, y por eso a este se le llama ejecutivo. “1 Esta definición la escribió Bellemare en su Plan para organizar la justicia de Buenos Aires en 1828 y un poder judicial independiente era indispensable para poder concretarlo. A lo largo de esta investigación comprobamos que el sistema judicial de la provincia de Buenos Aires comenzó su formación como poder del Estado a partir de la reforma rivadaviana, en base a un proyecto de influencias foráneas pero adaptado a las características locales y con la mirada puesta en lograr la división de poderes. El problema residía en que la independencia del poder judiciario, declarada desde el 25 de mayo de 1810, estuvo permanentemente subordinada a las potestades judiciales del poder ejecutivo y fue muy difícil llevarlo a la práctica.

Desde 1821, la independencia del poder judicial generó una relación conflictiva con los otros dos poderes fundamentalmente por no estar determinadas las funciones y competencias de cada uno y las pautas de relación entre ellos. Pero también los conflictos se producían por la falta de definición en la estructura y el funcionamiento interno de cada uno de los poderes, cuestión difícil de resolver y que se mantuvo presente aún después de sancionada la Constitución provincial de 1873. Antonio Malaver, en 1875 expresaba su preocupación por los riesgos que conllevaba no dejar especificadas correctamente las atribuciones de la Suprema Corte, en especial la interpretación de la ley, que definía como límite con los otros dos poderes, y la aplicabilidad de la ley que garantizaba la igualdad y la aplicación de la jurisprudencia.

La interpretación de la ley fue fundamental para la delimitación de la administración de justicia a través de la sentencia. Era una atribución exclusiva del poder legislativo, no de los jueces, y la seguridad individual implicaba dar seguridad frente al fallo judicial, desterrando la arbitrariedad del magistrado, de allí la estricta aplicación del texto de la ley, la fundamentación obligatoria de las

\footnotetext{
${ }^{1}$ Plan Bellemare, pp. 1-2.
} 
sentencias y la formación de la jurisprudencia. Por esto, la competencia de la Suprema Corte de interpretar la ley no era una atribución judicial, sino política necesaria en la relación entre los tres poderes en un modelo "de frenos y contrapesos", por el que se optó. El proceso alcanzó su madurez entre 1853 y 1881, como parte fundamental del proyecto liberal, asentado sobre la autoridad de la ley. El poder judicial garantizaba la legitimidad del sistema político republicano de matriz liberal, pero dentro de los límites posibles que el máximo tribunal podía manejar, quedaron fuera de su alcance los nombramientos, los jury y el presupuesto.

A la dificultad de establecer los límites entre poderes se sumó lo conflictivo de la relación urbano-rural, y lo que es más interesante para esta provincia, que no estuvo fijado por un límite imaginario, sino por un curso de agua, el río Salado. Una de las luchas en la organización judicial en formación fue incluir al ámbito rural con una fisonomía institucional que tendía a consolidar la relación entre Estado y sociedad civil. Este movimiento no se generó solamente en un sentido ciudad-campaña, sino que también fue motivado por los reclamos de quienes desde el "desierto" exigían seguridad para sus haciendas y sus vidas. De hecho, el primer intento de extender el sistema judicial a la campaña fracasó. Fue en 1853 en que se pudo comenzar ese proceso y la Constitución de 1873, a pesar de ser ideal en algunas de sus propuestas, dio protagonismo y efectividad a las instituciones judiciales que se formaron y pusieron en funcionamiento con una nueva concepción de justicia, que sin dejar de lado el derecho natural, se consolidó en una función más positiva, atenta a los derechos individuales y de propiedad.

Los límites internos se manifestaban en la superintendencia ejercida por más alto tribunal, que determinaba también su independencia. Si bien ésta era ejercida por la Real Audiencia y la Cámara de Justicia, la diferencia al instalarse el Superior Tribunal fue su configuración constitucional como gobierno judicial de un poder del Estado. La superintendencia de la Suprema Corte habilitaba y obligaba a sus magistrados a enfrentar los conflictos internos, debiendo ejercer control y poder disciplinario, haciéndolo también responsable de formular proyectos que lo pusieran en funcionamiento y manejar las cuestiones edilicias, aunque sin disposición plena de su presupuesto.

Los protagonistas en la toma de decisiones a la hora de definir una determinada organización judicial compartían una cultura jurídica, un universo ligado a la producción de derecho que vinculaba a las élites dirigentes y a los profesionales de la ley. Pero esta cultura jurídica se adaptaba a un nuevo orden en búsqueda de su legitimidad, con un concepto de justicia en transformación que ubicaba a la ley accesible y aplicable por encima de todo. Llegado el momento de tomar decisiones y sobre todo de discutirlas, el camino a seguir no era uno, en muchos casos se bifurcaba e incluso terminaba en una calle sin salida, donde los enfrentamientos terminaban por resolverse en función del poder. La formación común en la universidad de Buenos Aires y lecturas de autores norteamericanos, ingleses y franceses, a las que accedían en muchos casos por el manejo de la 
lengua original, era la base de esa cultura común, que mostraba sus diferencias al manifestar las preferencias por los modelos de un determinado país, que no seguían ciegamente sino adaptando a las circunstancias locales.

Estaban de acuerdo en la necesidad de establecer una justicia rápida y económica, administrada por magistrados que no constituyeran una clase distinta, pero sí una reserva moral letrada, sin dejar de ser parte del pueblo, al que le garantizaran sus derechos individuales y del que estuvieran garantidos por el texto constitucional. Pero para alcanzar este objetivo, algunos consideraban necesarios cambios estructurales y otros como Vélez, que tenían como obsesión codificar, estaban en contra de todo cambio porque ya estaban las leyes patrias. Respecto a los magistrados, compartían el concepto de "desdoblamiento funcional”, según el cual un mismo hombre desempeñaba dos funciones diversas dentro de distintos poderes o dentro del mismo poder judicial, fruto de estar cerrados a que ciudadanos ajenos a la elite cultural administraran justicia.

Los magistrados debían ser letrados, rentados e inamovibles desde 1821, pero llegado el momento de definir estas características, garantías de independencia del poder judicial, los debates fueron extensos y demostraron, que junto con la elección, importaban lo conflictivo de adaptar las instituciones instaladas a las nuevas necesidades y al absolutismo de la ley. La primera disyuntiva era si debían los magistrados ser legos o letrados, relacionada en un principio con la falta de profesionales, pero fundamentalmente con la opción entre el juicio por jurado y la participación del pueblo en la administración de justicia o del juez formado en derecho. En la provincia, esta última ya estaba definida, y los intentos por instaurar la primera fueron sólo formales y no pasaron de la letra del texto constitucional. Castro lo había impuesto en 1821 y los largos debates cincuenta años después no cambiaron la idea de una justicia administrada por abogados.

Si eran letrados, no cabía duda que serían rentados, pero había un punto de discusión en torno a fijar o no una diferencia entre los magistrados de la ciudad y los de la campaña, que no se aceptó, a igual función igual sueldo. La otra cuestión relacionada con los sueldos fue su intangibilidad, que si bien estaba establecida para el poder judicial nacional, no logró imponerse para la provincia. El ingreso de los jueces quedaba en la misma condición de vulnerabilidad del resto de los funcionarios provinciales, a lo que se sumaba que tanto sus jubilaciones como las pensiones de sus viudas e hijos quedaban subordinadas en cada caso particular a la decisión de los legisladores.

La inamovilidad estuvo siempre ligada a la permanencia y a la independencia, pero Rivadavia en pro de evitar la anarquía, quería declarar en comisión a los jueces para dar libertad al ejecutivo, objetivo no logrado en la ley pero si alcanzado en la práctica, muy avanzado el siglo XIX. Establecida la inamovilidad, su límite era la buena conducta, garantizada por el juicio del magistrado y la relación con los otros poderes. Si el juez permanecía en el cargo mientras durase su buena conducta -e incluso los funcionarios que integraban el juzgado, según la superintendencia de 
la Corte- debía dedicarse exclusivamente a su función, lo que fue dando el perfil del profesional que se dedicaría a administrar justicia y las pautas de la carrera judicial. Pero a su vez requería de un jurado específico para juzgarlo, en función de su responsabilidad y garantía para el desempeño en sus funciones. El conflicto se planteó en torno a quién debía juzgarlo: miembros del mismo poder o de los otros poderes; finalmente el Jury se compuso de siete diputados y cinco senadores profesores de Derecho.

No todos los intentos de cambios y reformas llegaron a concretarse, pero aprendimos a poco de iniciar esta investigación que los fracasos son tan valioso como los logros. De allí el valor que ha tenido "barrer" los registros oficiales y los debates parlamentarios en busca de discusiones no concluidas, rechazadas por una de las Cámaras legislativas o vetadas por el poder ejecutivo. Lo cierto es que en 1881 la estructura del poder judicial estaba conformada, en jurisdicciones y en competencias y las modificaciones que se fueron generando han sido sobre ella. De los cuatro departamentos judiciales que lo formaban en un principio, con una cabecera departamental y el nombre determinado por su orientación cardinal (Norte, Centro, Sud y Capital), hoy funcionan diecinueve, denominados por su ciudad cabecera. Incluso, las competencias se fueron ampliando (por ejemplo tribunales de menores, tribunales laborales, tribunales de familia, tribunales de casación, juzgados en lo contencioso-administrativo, etc.), separándose recientemente el Ministerio Público, pero sin modificar la estructura determinada por la ley de 1881 en juzgados de paz (que desde 1978 son letrados), juzgados de primera instancia, Cámaras de Apelación, Suprema Corte y el Ministerio Público con defensores, fiscales y procurador. La codificación estaba en marcha y la cita de las Partidas u otra legislación hispana después de la sanción de los códigos estaba en función de la fundamentación de las sentencias.

Entonces, ¿qué impedía que la administración de justicia de la provincia de Buenos Aires planeada y legislada fuera aplicada? Uno de los problemas era el enfrentamiento entre ciudad y campaña, que José Manuel Estrada daba por resuelto en 1873 y que Eduardo Gutiérrez ponía en labios de Hormiga Negra, protagonista de su novela gauchesca publicada en 1881. Este gaucho reclamaba, a través de sus desventuras, sobre dos diferencias fundamentales entre el hombre de la ciudad y el de la campaña. ${ }^{2}$ La primera se refería al homicidio cometido en función del honor. Según la experiencia de Hormiga Negra, para la justicia de campaña una muerte era siempre un asesinato, ya fuera cometida de un modo alevoso, ya fuera la consecuencia de un duelo en el que se hubieran cubierto todas las formalidades. El hombre de campaña entendía que había sido un duelo, cuando ante la ofensa de su honor la muerte sucedía "en buena ley", de frente y sin puñaladas

\footnotetext{
${ }^{2}$ Eduardo Gutiérrez inició la publicación del folletín biográfico de Hormiga Negra, en el diario La Patria Argentina, que se terminó convirtiendo en una de las mayores obras que escribió. El personaje en quien se inspiró fue Guillermo Hoyos, gaucho con frondoso prontuario judicial. Sin copiarlo totalmente, lo construyó a partir de las fuentes judiciales. Eduardo Gutiérrez, Hormiga negra, Buenos Aires, Editorial Tor S.R.L., 1950.
} 
alevosas. Para el aparato judicial era un homicidio, mientras que el duelo en los bosques de Palermo, con sable o pistola, no se juzgaba de la misma forma. ${ }^{3}$

La otra diferencia entre el hombre urbano y el hombre rural se generaba en relación a la falta de trabajo, como lo exponía el protagonista de Gutiérrez. El primero era un desafortunado, el segundo era un vago.

Así se ve que nuestro paisano al que por desgracia falta momentáneamente el trabajo, es aprehendido, juzgado y condenado por vago, a los horrores de un cuerpo de línea. Mientras que en la ciudad, al joven que por desgracia se halla en tal situación sólo provoca el sentimiento más generoso entre sus relaciones, sin que la justicia tenga que hacer con él. Porque el habitante de nuestra campaña no tiene libertad, ni derechos, ni opinión, ni siquiera mujer e hijos, cuando estas han tenido la desgracia de agradar al Juez de Paz o al Comandante.

Hormiga Negra tenía la esperanza de que su causa llegara a Buenos Aires, allí la justicia no era tan brutal como en la campaña, y sobre todo allí no se había ganado enemigos. La sentencia fue de seis años, con costas, en el presidio de Buenos Aires. El mismo condenado expresó lo que significaba eso, "ya no estoy entre "justicias" [jueces de paz o alcaldes] salvajes y malditos y puedo hablar sin sentir crujir mis huesos por el sable".

El otro problema se generaba en relación con los derechos individuales y su defensa. En 1815 los derechos de los habitantes del Estado fueron definidos como la vida, la honra, la libertad, la igualdad, la propiedad y la seguridad. El artículo $8^{\circ}$ de la Constitución provincial de 1873 declaraba que todos los habitantes de la provincia eran por su naturaleza libres e independientes, y tenían derecho de defender y de ser protegidos en su vida, libertad, reputación, seguridad y propiedad. Pero a medida que avanzaban los años del período que hemos estudiado, se generalizaron en el discurso como "derechos civiles", junto con el ejercicio de una justicia cuya finalidad dejaba de lado la defensa del bien común para asegurar la seguridad individual. En relación con la administración de justicia se fue generando una tensión entre vida y propiedad a la hora de tomar decisiones. Es por esto que para observar al poder judicial en funcionamiento elegimos una causa relacionada con la propiedad de la tierra y otro con la vida de un hombre y la defensa de la vida de la mujer que planeó su muerte.

Clorinda Sarracán y sus cómplices mataron cruelmente a Fiorini y el juez no tuvo dudas en que les correspondía la pena de muerte. Pero los vecinos de Buenos Aires, aceptando que la justicia cumplía con su deber, condenando a los parricidas que habían ofendido a la sociedad, reclamaban el perdón a favor de una miserable mujer embarazada que no dimensionaba la magnitud de su culpa.

\footnotetext{
${ }^{3}$ Respecto al honor en la ciudad Sandra Gayol afirma: "En el Buenos Aires decimonónico el honor ya no dependía del estatus heredado sino de la percepción subjetiva y objetiva de la propia honorabilidad. Era un honor republicano, es decir, un derecho que a priori tenían todos los ciudadanos y que, al mismo tiempo, oficiaba como garante de las instituciones y los valores republicanos. Todos, al menos en principio, pueden sentir, reclamar y esperar honor."Gayol, Sandra, Honor y duelo en la Argentina moderno, Buenos Aires, Siglo XXI Editores Argentina, 2008, p. 18.
} 
Este conflicto generó el enfrentamiento entre los tres poderes que, desplazando el derecho a la vida como centro de la discusión, estuvo durante doce años sin resolver la sentencia de Clorinda. Todo el tema se centró en cuál de ellos tenía el derecho de conmutar la pena. La pena de muerte se conservaba como el máximo castigo y el derecho del Estado a disponer sobre la vida.

Si bien es cierto que la propiedad como principio absoluto, fue imponiéndose desde la práctica, el concepto de propiedad privada existía, como lo demuestra la escritura de las tierras de Luis Goya, firmada en 1851, al asegurar que Francisco Laurel se las vendía “para en todo tiempo y para siempre jamás". ${ }^{4}$ Agüero sabía que debía al año de ocupar las tierras y cumpliendo con todas las condiciones, escriturar las tierras que el Estado le había otorgado, pero no lo hizo. ¿Por qué? ¿Por desconocimiento, por falta de dinero para hacerlo? ¿Su cultura judicial lega no tenía presente la relación entre propiedad y escritura? No lo sabemos, pero lo que si pudimos observar a lo largo de todo este conflicto es que el poder judicial, como parte del Estado, no tenía todavía claro su papel en la defensa de propiedad. Hasta que los derechos de los ciudadanos no tuvieran el mismo valor para todo el territorio provincial y el poder judicial fuera totalmente independiente para juzgar su violación, la modernización de su estructura no lograría por sí, brindar una justicia accesible y rápida.

Al terminar esta tesis doctoral doy por cumplidos los dos grandes objetivos que me movieron a embarcarme en este proyecto. En primer lugar, la necesidad de crear una especie de "guía" para la selección y catalogación de documentos judiciales, y para el acceso de los investigadores de las ciencias sociales a la fuente judicial, ya sea para su estudio en sí o en búsqueda de información. En segundo lugar, la formulación de una propuesta de abordaje de la historia del poder judicial como un todo, posible de seguir desarrollando en el tiempo y para otras provincias, pero sobre todo que sirva a aquellos que hoy tienen la responsabilidad de preservar un poder judicial independiente que administre una justicia al alcance de todos la que la necesitan.

\footnotetext{
${ }^{4}$ Texto de la escritura, Goya c/Agüero, 171.
} 


\section{BIBLIOGRAFÍA}

ACADEMIA NACIONAL DE LA HISTORIA, Nueva Historia de la Nación Argentina, La configuración de la República independiente, 1810-1914, tomos IV al VI, Buenos Aires, Planeta, 2000-2001.

ACEVEDO, Edberto Oscar, "La primera organización judicial en las provincias de San Juan y San Luis", en Revista de Historia del Derecho, núm. 9, Instituto de Investigaciones de Historia del Derecho, Buenos Aires, 1981.

ABÁSOLO, Ezequiel, "Elementos toquevilleanos en la formulación de proyectos políticos concretos: la génesis del municipalismo en la Argentina decimonónica" en Investigaciones y Ensayos, núm. 53, Academia Nacional de la Historia, Buenos Aires, 2003, pp. 91-113.

ABÁSOLO, Ezequiel, "La cultura jurídica indiana en el Estado de Buenos Aires. Un examen de la cuestión a partir de los diarios de sesiones de la legislatura porteña (1852-1861)", en Revista de Historia del Derecho, núm. 34, Instituto de Investigaciones de Historia del Derecho, Buenos Aires, 2004.

ADELMAN, Jeremy, Republic of Capital, Buenos Aires and Legal Transformation of the Atlantic World, Stanford University Press, Stanford, California, 1999.

AGÜERO, Alejandro, "Formas de continuidad del orden jurídico. Algunas reflexiones a partir de la justicia criminal de Córdoba (Argentina), primera mitad del siglo XIX", en Nuevo Mundo Mundos Nuevo [En línea], Debates, 2010. Puesto en línea el 23 de marzo de 2010, URL: http://nuevomundo.revues.org/59352. Consultado el 25 de marzo de 2010.

AGÜERO, Alejandro, "Tradición jurídica y derecho local en época constitucional. El "Reglamento para la administración de justicia y policía en la campaña" de Córdoba", 1856, Revista de Historia del Derecho Sección Investigaciones núm 41, Instituto de Investigaciones de Historia del Derecho, Buenos Aires, enero-junio 2011, pp. 1-43.

ALIATA, Fernando, "La acción del Departamento Topográfico y las Comisiones de Solares en la consolidación de los poblados bonaerenses. Dolores entre 1831 y 1838 ", ponencia presentada en las jornadas de discusión interdisciplinaria: espacios urbanos-espacios rurales, CEHR, FHCE; IDEHAB, FAU, 2005.

ALONSO, Fabián, BARRAL, María E., FRADKIN, Raúl y PERRI, Gladis, "Los vagos de la campaña bonaerense: la construcción histórica de una figura delictiva (1730-1830)", en Prohistoria, N5, Rosario, 2001, pp. 171-202.

ALONSO, Paula, (compiladora) Construcciones impresas. Panfletos, diarios y revistas en la formación de los Estados Nacionales en América Latina, 1820-1920, Buenos Aires, Fondo de Cultura Económica, 2004.

ALTAMIRANO, Carlos, "Ideas para un programa de Historia Intelectual", Prismas, Revista de historia intelectual, núm.3, Universidad Nacional de Quilmes, 1999, pp. 203-208.

ALTAMIRANO, Carlos, Historia de los intelectuales en América Latina I, Buenos Aires, Katz Editores, 2008. 
ANNINO, Antonio, (compilador) Historia de las elecciones en Iberoamérica en el siglo XIX, Buenos Aires, FCE, 1995.

ARNOLD, Linda, "The Suprema Corte de Justicia in México: its First Step, 1825-1826), en Anuario Mexicano de Historia del Derecho, N¹, 1989, pp. 3-14.

ARNOLD, Linda, "Buscando a México: conflictos, jurisprudencia y la Suprema Corte mexicana (1825-1853), en Anuario Mexicano de Historia del Derecho, N4, 1992, pp. 252-268.

ARNOLD, Linda, "Política y justicia. La Suprema Corte de Justicia mexicana (1824-1855), en Estudios históricos, Instituto de investigaciones jurídicas, serie C, núm.62, UNAM, 1996.

BANZATO, Guillermo y VALENCIA, Marta, "Los jueces de paz y la tierra en la frontera bonaerense, 1820-1885", en Anuario IEHS, Instituto de Estudios Histórico-Sociales, Tandil, Universidad Nacional del Centro de la Provincia de Buenos Aires, núm. 20, 2005, pp. 211-237.

BANZATO, Guillermo, "De ocupantes a propietarios, los conflictos entre vecinos de la frontera bonaerense. Chascomús y Ranchos, 1800-1840", en Quinto Sol, Santa Rosa, Facultad de Ciencias Humanas, año 4, núm. 4, 2000, pp. 11-38.

BANZATO, Guillermo, La expansión de la frontera bonaerense. Posesión y propiedad de la tierra en Chascomús, Ranchos y Montes, Bernal, Universidad de Quilmes, 2005.

BARBA, Enrique M., "Rivadavia y su tiempo", en Rivadavia, homenaje de la Facultad de Humanidades y Ciencias de la Educación, La Plata, UNLP, 1945.

BARBA, Fernando E., [1967] Los autonomistas del 70. Auge y frustración de un movimiento provinciano con vocación nacional, Buenos Aires, Capítulo, CEAL, 1982.

BARCOS, María Fernanda, "Los ejidos de los pueblos de campaña: ocupación y acceso a la propiedad legal en Monte, 1829-1865”, en Mundo Agrario, Revista de estudios rurales, núm. 14, $1^{\circ}$ sem., 2007.

BARCOS, María Fernanda, "Los intersticios de la ley. De la sanción a la implementación de la legitimación ejidal en Mercedes (Buenos Aires), 1810-1870”, en Blanco, Graciela y Banzato, Guillermo, (compiladores) La cuestión de la tierra pública en Argentina. A 90 años de la obra de Miguel Ángel Cárcano, Rosario, Prohistoria Ediciones, 2009.

BARRAL, María E. y FRADKIN, Raúl O., "Los pueblos y la construcción de las estructuras de poder institucional en la campaña bonaerense (1785-1836)", en Boletín del Instituto de Historia Argentina y Americana "Dr. Emilio Ravignani”, Tercera serie, núm.27, $1^{\text {o }}$ semestre 2005, pp.7-48.

BARREIRO, José Carlos, "A rua e a taberna. Algunas consideraçoes teóricas sobre la cultura popular e cultura polític. Brasil, 1820-1880. I Congreso de Latinoamericanistas, Salamanca, 1996. História, Sao Pablo, 16:173-184, 1997.

BARRENECHE, Osvaldo, "Criminal Justice and State Formation in Early Nine teenth. Century Buenos Aires", en Eduardo Zimmermann (ed.), Judicial Institutions in Nineteenth-Century Latin America, Institute of Latin American Studies, University of London, 1999, pp.86-103.

BARRENECHE, Osvaldo, Dentro de la ley, TODO. La justicia criminal de Buenos Aires en la etapa formativa del sistema penal moderno de la Argentina, La Plata, Ediciones Al Margen, 2001. 
BARRENECHE, Osvaldo, “¿Lega o letrada? Discusiones sobre la participación ciudadana en la justicia de la ciudad de Buenos Aires durante las primeras décadas de la independencia y la experiencia republicana", en Palacio, Juan Manuel y Candioti, Magdalena, (compiladores) Justicia, política y derechos en América Latina, Buenos Aires, Prometeo Libros, 2007, pp. 181-202.

BARRIERA, Darío G., "Voces legas, letras de justicia. Culturas jurídicas de los legos en los lenguajes judiciales (Río de la Plata, siglos XVIII-XIX) en Montecón Movellán, Tomás, (editor) Bejtin y la historia de la cultura popular: cuarenta años de debate, PubliCan, Universidad de Cantabria, Santander, 2008, pp 347-368.

BARRIERA, Darío G., (compilador), Justicias y fronteras. Estudios sobre historia de la justicia en el Río de la Plata. Siglos XVI-XIX, Ed. Universidad de Murcia, 2009.

BARRIERA, Darío G., "Saberes jurídicos, quehaceres judiciales y representaciones mentales: puntos de referencia para interpretar sus relaciones", en Avances del CESOR, VI, Rosario, pp. 103107.

BARRIERA, Darío G., (coordinador), La justicia y las formas de autoridad. Organización política y justicias locales en territorios de frontera. El Río de la Plata, Córdoba, Cuyo y Tucumán, siglos XVIII y XIX, ISHIR CONICET-Red Columnaria, Rosario, 2010.

BARRIERA, Darío G., "El execrable libro de sus hechos: Cultura jurídica, retórica y deslegitimación de la autoridad en un proceso contra el alcalde del Rosario (1810-1811)", en Anuario del Instituto de Historia Argentina, núm. 10, 2010, pp. 57-84. [en línea] http://www.memoria.fahce.unlp.edu.ar/art_revistas/pr.4699/pr.4699.pdf. Consultado el 3 de noviembre de 2012.

BARRIERA, Darío G., “Justicias, jueces y culturas jurídicas en el siglo XIX rioplatense”, en Nuevo Mundo Mundos Nuevo [En línea], Debates, 2010. Puesto en línea el 23 de marzo de 2010, URL: http://nuevomundo.revues.org/59352. Consultado el 25 de marzo de 2010.

BARRIERA, Darío G., “Rediseñando lo judicial, reinventando lo jurídico: el 'Reglamento' de 1833 y los orígenes de la Justicia de Paz en la Provincia de Santa Fe", en Ayrolo, Valentina (coord.) Actas de las IV Jornadas de Trabajo y Discusión sobre el siglo XIX: Las Provincias en la Nación, Mar del Plata, 2011.

BARRIERA, Darío G. y TÍO VALLEJO, Gabriela, "Historia política e Historia del Derecho: confluencias, divergencias y resistencias", en Dossier: Historia política e Historia del Derecho, PolHis, año 5, núm. 10, segundo semestre, 2012, pp.23-25.

BARRIERA, Darío G., "Justicia de proximidad: pasado y presente, entre la historia y el derecho", en Dossier: Historia política e Historia del Derecho, PolHis, año 5, núm. 10, segundo semestre, 2012, pp. 50-57.

BECCARIA, Cesare, [1764] De los delitos y de las penas, edición crítica bilingüe y estudio preliminar por Francisco P. Laplaza, Ediciones Arayú, Buenos Aires, 1955.

BONAUDO, Marta, (directora) Nueva Historia Argentina. Liberalismo, estado y orden Burgués (1852-1880), Tomo IV, Buenos Aires, Editorial Sudamericana, 1999.

BONAUDO, Marta y Sonzogni, Élida, "Los grupos dominantes entre la legitimidad y el control”, en Bonaudo, 1999, op. cit. 
BONAUDO, Marta, "Hecho jurídico...hecho político. La conflictiva relación entre poder y justicia en la construcción de la República Posible. Santa Fe 1856-1890", en Carzolio, María Inés y Barriera, Darío G., (compiladores) Política, cultura, religión. Del Antiguo Régimen a la formación de los Estados nacionales, Rosario, Prohistoria, 2005, pp. 215-240.

BONAUDO, Marta, REGUERA, Andrea y ZEBERIO, Blanca, (coordinadoras) Las escalas de la historia comparada, tomo I: "Dinámicas sociales, poderes políticos y sistemas jurídicos", Buenos Aires, Miño y Dávila, 2008.

BOTANA, Natalio, La tradición republicana: Alberdi, Sarmiento y las ideas políticas de su tiempo, Buenos Aires, Sudamericana, 1997.

BOTANA, Natalio, "Las ideas políticas de la generación de 1837”, en Palabra y persona, Buenos Aires, Año 1, núm.2, oct., 1997.

BRAGONI, Beatriz, MÍGUEZ, Eduardo, Un nuevo orden político. Provincias y Estado Nacional 1852-1880, Buenos Aires, Biblos, 2010.

BRETAS, Marcos Luiz, A guerra das ruas: povo e policía na ciudade do Río de Janeiro, Arquivo Nacional, Río de Janeiro, 1997.

BURKHOLDER, Mark y CHANDLER, D. S., De la impotencia a la autoridad. La Corona española y las audiencias en América 1687-1808, México, Fondo de Cultura Económica, 1984.

CABRERA ACEVEDO, Lucio Cabrera La Suprema Corte durante el fortalecimiento del porfirismo, 1882-1888, México, Suprema Corte de Justicia de la Nación, 1991.

CACOPARDO, Fernando y DA ORDEN, María Liliana, "Territorio, sociedad y Estado en la provincia de Buenos Aires: una aproximación a partir de los Registros Gráficos, 1830-1890" en Registros, revista anual de Investigación del Centro de Estudios Históricos Arquitectónico-Urbanos, "La transformación física del territorio en la constitución de la Argentina moderna", Facultad de Arquitectura, Urbanismo y Diseño, Universidad Nacional de La Plata, Año5, Núm. 5, Abril de 2008.

CACOPARDO, Fernando, "El estado en la definición territorial de la Argentina del siglo XIX: construcciones legales, cuadrícula territorial y urbanística en la frontera de la provincia de Buenos Aires al sur del río Salado". En: Revista Perspectivas Urbanas, nº 8, año 2007. En

línea: http://hdl.handle.net/2099/2763>. Consultado el 31 de octubre de 2012.

CAIMARI, Lila, "Castigar civilizadamente. Rasgos de la modernización punitiva en la Argentina (1827-1930)", en Gayol, Sandra y Kessler, Gabriel (comp.), Violencias, delitos y justicias en la Argentina, Buenos Aires, Manantial, 2002.

CAIMARI, Lila, "Whose Criminals are These? Church, State Patronatos and the Rehabilitation of Female Convicts (Buenos Aires, 1890-1940)”, The Americas, vol.54, №2, 1997.

CAIMARI, Lila, Apenas un delincuente, crimen, cultura y castigo en la Argentina, 1880-1955, Colección Historia y Cultura, Buenos Aires, Siglo XXI, 2004.

CAIMARI, Lila, (compiladora) La ley de los profanos. Delito, justicia y cultura en Buenos Aires (1870-1940), Buenos Aires, FCE, 2007. 
CANDIOTI, Magdalena, "Revolución y derecho. La formación jurisprudencial en los primeros años de la Universidad de Buenos Aires (1821-1829), en Barriera, Darío G. (compilador),, "Justicias y Fronteras. Estudios sobre Historia de la Justicia en el Río de la Plata, Siglos XVI-XIX", Murcia, Editum, 2009, pp.119-142.

CANSANELLO, Oreste Carlos, "Concentración de poderes y garantías individuales en Buenos Aires", en Revista de Historia del Derecho, núm. 29, Buenos Aires, Instituto de Investigaciones de Historia del Derecho, 2001.

CANSANELlO, Oreste Carlos, De súbditos a ciudadanos, ensayo sobre las libertades en los orígenes republicanos 1810-1852, Buenos Aires, Imago mundi, 2003.

CAPDEVILA, Darío, El Fortín Esperanza y el Pueblo y Partido de General Alvear. Estudio complementario: Noticias biográficas del Tte. Cnel. Juan Agustín Noguera, Tapalqué, Ediciones Patria, 1969.

CASAGRANDE, Agustín, Los vagabundos y la justicia de Buenos Aires durante el periodo tardo colonial (1875-1810). Construcciones jurídicas y criminalidad, Buenos Aires, Instituto de Investigaciones de Historia del Derecho, 2012.

CASTÁN VÁZQUEZ, José María, La influencia de la literatura jurídica española en las codificaciones americanas, Discurso leído en su recepción pública a la Real Academia de Jurisprudencia y Legislación, Madrid, 1984.

CERCÓS, Sergio, "La práctica jurídica en la campaña bonaerense en el período federal", en $L a$ fuente judicial en la construcción de la memoria", Suprema Corte de Justicia de la provincia de Buenos Aires, La Plata, 1999.

CERNADAS DE BULNES, Mabel, Valentín Alsina, Periodista, jurista y hombre de gobierno., Bahía Blanca, Utopía ediciones, 1996.

COING, Helmut, Las tareas del Historiador del derecho (reflexiones metodológicas), Publicaciones de la Universidad de Sevilla, Sevilla, 1977.

CORBETTA, Juan Carlos, Textos constitucionales de Buenos Aires, Buenos Aires, Suprema Corte de Justicia, 1984.

CORBETTA, Juan Carlos, (coordinador) Suprema Corte de Justicia de la provincia de Buenos Aires. Historia. Organización. Competencia, Buenos Aires, Función Pública, 1997.

CORVA, María Angélica, "La Justicia letrada en la campaña bonaerense", en revista Temas de historia argentina y americana $\mathrm{N}^{\mathrm{o}}$ 7, Julio-Diciembre, 2005, UCA, Facultad de Filosofía y Letras, Instituto de Historia Argentina y Americana.

CORVA, María Angélica, "La Justicia de Paz en la Constitución de la Provincia de Buenos Aires de 1873", en Revista de Historia del Derecho del Instituto de Investigaciones de Historia del Derecho, No 33, 2005, Buenos Aires, pp. 69-129.

CORVA, María Angélica, "Los magistrados de la provincia de Buenos Aires: sueldos, jubilaciones y pensiones (1854-1881), en Revista de Historia del Derecho $\mathrm{N}^{\mathrm{o}} 36$, Buenos Aires, Instituto de Historia del Derecho, 2008. 
CORVA, María Angélica, "Íntegros y competentes: los magistrados de la provincia de Buenos Aires en la segunda mitad del siglo XIX”, en: Barriera, 2009, op. cit. pp. 179- 204.

CLAVERO, Bartolomé, Institución histórica del derecho, Madrid, Marcial Pons, 1992.

CUTOLO, Vicente Osvaldo, Nuevo diccionario biográfico argentino (1750-1930), Buenos Aires, Elche, 1985.

CHIARAMONTE, Juan Carlos y BUCHBINDER, Pablo, "Provincias, caudillos, nación y la historiografía constitucionalista argentina (1853-1930)", en Anuario IEHS, núm. 7, 1992.

CHIARAMONTE, Juan Carlos y TERNAVASIO, Marcela, "Procesos electorales y cultura política: Buenos Aires 1810-1850”, en Ciencia Hoy, volumen 5, núm. 30, 1995.

CHIARAMONTE, Juan Carlos, Ciudades, provincias y estados. Orígenes de la nación argentina, Buenos Aires, Biblioteca del Pensamiento Argentino I, Ariel Historia, 1997.

CHIARAMONTE, Juan Carlos, "La cuestión de la soberanía en la génesis y constitución del Estado argentino", ponencia presentada en el Simposio "Argentina-Brasil, La Visión del Otro, Una aproximación interdisciplinaria a la cuestión de la soberanía", organizado por la Fundaçao Centro de Estudios Brasileiros, la Fundaçao Alexandre Gusmão, y la Biblioteca Nacional argentina; Buenos Aires, 5 y 6 de diciembre de 2000.

CHIARAMONTE, Juan Carlos, Nación y Estado en Iberoamérica. El lenguaje político en tiempos de las independencias, Buenos Aires, Editorial Sudamericana, 2004.

DAIN, Mariana, "Representantes en tensión: sensibilidades y modernización punitiva en un contexto de transición. Córdoba 1855-1862" en Anuario de la Escuela de Historia Virtual, año 3, $\mathrm{N}^{\circ}$ 3, 2010, pp. 97-114.

DÁVILO, Beatriz, "De los derechos a la utilidad: el discurso político en el Río de la Plata durante la década revolucionaria", en Prismas, $N^{\circ}$, Universidad Nacional de Qulmes, 2003, p. 74-75.

DE LA FUENTE, Ariel, Children of Facundo, caudillo and gaucho insurgency during the argentine state-formation process (La Rioja, 1853-1870), Duke University Press, Durham and London, 2000.

DE MANDEVILLE, Bernard, La fábula de las abejas, o cómo los vicios privados hacen la prosperidad pública. Madrid, Fondo de Cultura Económica, 1982.

DE PAZ TRUEBA, Yolanda, Mujeres y esfera pública entre 1880 y 1910, Rosario, Prehistoria Ediciones, 2010.

DEVOTO, Fernando, "Acerca de la construcción de la identidad nacional en un país de inmigrantes. El caso argentino (1852-1930)", en VV.AA., Historia y presente en América Latina, Valencia, Fundaciò bancaixa, 1996.

DÍAZ, Benito "La organización de prefecturas de campaña de Buenos Aires durante el gobierno de Valentín Alsina”, en Trabajos y comunicaciones, núm. 8, UNLP, 1959, pp. 37-68.

DÍAZ, Benito, Juzgados de Paz de Campaña de la provincia de Buenos Aires (1821-1854), La Plata, Universidad Nacional de La Plata, Facultad de Humanidades, 1959. 
DÍAZ COUSELO, José María, "El desempeño de la función pública y la adquisición de la ciudadanía (1853-1912)", en Revista de Historia del Derecho, núm. 3, Instituto de Investigaciones de Historia del Derecho, Buenos Aires, 1975.

DÍAZ COUSELO, José María., "La historia jurídica y el problema de las fuentes del derecho", en Revista de Historia del Derecho, núm. 14, Instituto de Investigaciones de Historia del Derecho, Buenos Aires, 1986.

DÍAZ COUSELO, José María, Código de Comercio Argentino. Estructura. Relaciones con el Código Civil. Unificación, Buenos Aires, 1988

DÍAZ COUSELO, José María, "La revisión de los actos administrativos en la Argentina (18531900), en Revista Chilena de Historia del Derecho, Facultad de Derecho, Universidad de Chile, núm.16 (1990-1991), pp. 413-444.

DÍAZ COUSELO, José María, “Origen y consolidación del contencioso-administrativo de la provincia de Buenos Aires (1854-1906) y su influencia en el derecho público de las demás provincias", en Revista de Historia del Derecho, núm. 22, Instituto de Investigaciones de Historia del Derecho, Buenos Aires, 1994.

DÍAZ COUSELO, José María, "La Real Ordenanza de Intendentes y la revolución”, en Mariluz Urquijo, José María, (director) Estudios sobre la Real Ordenanza de Intendentes del Río de la Plata, Buenos Aires, Instituto de Investigaciones de Historia del derecho, 1995.

DÍAZ COUSELO, José María, "Pensamiento jurídico y renovación legislativa", en Nueva Historia de la Nación Argentina, tomo 5, Academia Nacional de la Historia, Buenos Aires, Planeta, 2000, pp.363-403.

DÍAZ COUSELO, José María, "Las Ideas de Ricardo Zorraquín Becú sobre la Historia del Derecho", Revista de Historia del Derecho, núm. 28, Homenaje a Ricardo Zorraquín Becú, Buenos Aires, Instituto de Investigaciones de Historia del Derecho, 2000, pp. 39-75.

DÍAZ COUSELO, José María, "La tradición indiana y la formación del derecho argentino", en Temas de historia argentina y americana, Buenos Aires, Pontificia Universidad Católica Argentina, Facultad de Filosofía y Letras, Centro de Historia Argentina y Americana, julio-diciembre de 2005a.

DÍAZ COUSELO, José María, "Pervivencia indiana y cambio en la organización de la justicia ordinaria en Buenos Aires (1810-1854)", en Actas del XV Congreso del Instituto internacional de Historia del Derecho indiano, Diputación de Córdoba, Universidad de Córdoba, 2005b.

DIAZ COUSELO, José María, "La jurisdicción arbitral indiana. La continuidad después de la revolución en Buenos Aires (1810-1880)", en Biblioteca Jurídica del Instituto de Investigaciones Jurídicas, Universidad Nacional de México, 2007.

DI GRESIA, Leandro, “Jueces rústicos: saberes legos. Esbozo para un estudio de la formación judicial de los Jueces de Paz en el sudbonaerense (segunda mitad del siglo XIX), en XI Jornadas Interescuelas/ Departamentos de Historia, Tucumán, 19 a 22 de septiembre de 2007.

DI GRESIA, Leandro, "Una aproximación al estudio de la cultura judicial de la población rural bonaerense. Tres Arroyos, segunda mitad del siglo XIX”, en Barriera, Darío, (coordinador), La 
justicia y las formas de autoridad. Organización política y justicias locales en territorios de frontera. El Río de la Plata, Córdoba, Cuyo y Tucumán, siglos XVIII y XIX, ISHIR CONICET-Red Columnaria, Rosario, 2010, pp. 155-191.

DI GRESIA, Leandro, "Jueces de paz, masones y conservadores en la campaña bonaerense. Una aproximación a las redes vinculares en el sur de la provincia de Buenos Aires (Tres Arroyos, 18651910)", en Mundo Agrario, vol. 11, núm. 21, segundo semestre de 2010, UNLP.

DOMINGO, Pilar, "Judicial Independence: The Politics of the Supreme Court in Mexico", en Journal of Latin American Studie, Vol. 32, Parte 3, Cambridge University Press, Cambridge, 2000, pp. 705-735.

EGÜES, Carlos A., "Las ideas políticas en el constitucionalismo argentino del siglo XIX. Un aporte metodológico", en Revista de Historia del Derecho, núm. 24, Instituto de Investigaciones de Historia del Derecho, Buenos Aires, 1996, pp. 425-62.

EGÜES, Carlos A., "Objeto y método en la historia de las ideas políticas", en Investigaciones y Ensayos, Academia Nacional de la Historia, núm.49, Buenos Aires, 1999.

ESCRICHE, Joaquín, Diccionario razonado de legislación y jurisprudencia, Madrid, Biec y Droma Edición, 1874-1876.

FARGE, Arlette, La atracción del archivo, Valencia, Edicions Alfons el Magnànim-IVEI, 1991.

FASANO, Juan Pablo, "Jueces, fiscales y escribanos: trayectorias profesionales dentro y fuera de la justicia penal (Buenos Aires 1840-1880)", Congreso 2009 de la Asociación de Estudios Latinoamericanos, Río de Janeiro, Brasil, del 11 al 14 de junio de 2009.

FERNÁNDEZ, Sandra, PONS, Adriana, VIDELA, Oscar, "Las burguesías regionales", en Bonaudo, Marta (directora), Nueva Historia Argentina. Liberalismo, estado y orden Burgués (18521880), Tomo IV, Buenos Aires, Editorial Sudamericana, 1999, pp. 423-481.

FLORIA, Carlos y GARCÍA BELSUNCE, César, Historia de la argentinos, Buenos Aires, El Ateneo, 2009.

FLORY, Thomas, El juez de paz y el jurado en el Brasil imperial, 1808-1871. Control social y estabilidad política en el nuevo Estado, Buenos Aires, Fondo de Cultura Económica, México, 1986.

FOUCAULT, Michel, Seguridad, territorio, población. Curso en el Collège de France (19771978), Buenos Aires, Fondo de Cultura Económica, 2006.

FRADKIN, Raúl O., "Entre la ley y la práctica: la costumbre en la campaña bonaerense de la primera mitad del siglo XIX”, en Anuario IEHS, n.12, 1990.

FRADKIN, Raúl O., "Las quintas y el arrendamiento en Buenos Aires (siglos XVIII y XIX)", en CANEDO, Mariana y MATEO, José -compiladores- Tierra, población y elaciones sociales en la campaña bonaerense (siglo XVIII y XIX), Grupo de Investigación en Historia Rural Rioplatense, Universidad Nacional de Mar del Plata, 1999, pp. 7-39.

FRADKIN, Raúl O., La historia de una montonera: bandolerismo y caudillismo en Buenos Aires, 1826, Buenos Aires, Siglo XXI Ediciones Argentina, 2006. 
FRADKIN, Raúl Osvaldo (compilador), El poder y la vara. Estudios sobre la justicia y la construcción del Estado en el Buenos Aires rural (1780-1830), Buenos Aires, Prometeo Libros, 2007.

FRADKIN, Raúl Osvaldo, “Misión imposible? La fugaz experiencia de los jueces letrados de Primera Instancia en la campaña de Buenos Aires (1822-1824)", en Barriera, Darío G., (compilador) Justicias y Fronteras. Estudios sobre historia de la Justicia en el Río de la Plata, Murcia, Editum, 2009, pp. 143-164.

FRADKIN, Raúl Osvaldo, "Justicia, policía y sociedad rural en Buenos Aires, 1780-1830", en Bonaudo, Marta, Reguera Andrea y Zeberio, Blanca, (coordinadoras) Las escalas de la historia comparada, tomo I: "Dinámicas sociales, poderes políticos y sistemas jurídicos", Buenos Aires, Miño y Dávila, 2008.

FRADKIN, Raúl Osvaldo, "Bandolerismo y politización de la población rural de Buenos Aires tras la crisis de la independencia (1815-1830)", en Nuevo mundo. Mundos nuevos, 2005. [En línea], Debates, 2005. Puesto en línea el 22 de febrero de 2005, URL: http://nuevomundo.revues.org/59352. Consultado el 16 de mayo de 2010.

FURLONG, G., Cartografía Histórica Argentina. Mapas, planos y diseños que se conservan en el Archivo General de la Nación, Buenos Aires, 1964.

GALLO, Ezequiel y CORTÉS CONDE, Roberto, Historia Argentina. La República conservadora, Buenos Aires, Paidós, 1972.

GALLO, Ezequiel, "Liberalismo, centralismo y federalismo. Alberdi y Alem en el 80", en Investigaciones y Ensayos, 45, enero-diciembre de 1995.

GALLO, Klaus "A la altura de las luces del siglo: el surgimiento de un clima intelectual en la Buenos Aires posrevolucinaria", en Altamirano, Carlos, Historia de los intelectuales en América Latina I, Buenos Aires, Katz Editores, 2008.

GALLO, Klaus, Bernardino Rivadavia. El primer presidente argentino, Buenos Aires, Edhesa, 2012.

GARAVAGLIA, Juan Carlos y MORENO, José Luis, (compilador) Población, sociedad, familia y migraciones en el espacio rioplatense. Siglos XVIII y XIX, Buenos Aires, Cántaro, 1993.

GARAVAGLIA, Juan Carlos, "Las chacras y quintas de Buenos Aires, ejido y campaña, 17501815”, en MANDRINI, Raúl y REGUERA, Andrea, Huellas en la tierra, Tandil, IEHS, 1993, pp. 121-146.

GARAVAGLIA, Juan Carlos, "Paz, orden y trabajo en la campaña: la Justicia rural y los Juzgados de Paz en Buenos Aires, 1830-1852, en Desarrollo Económico, vol.37, núm.146, Buenos Aires, julio-setiembre 1997.

GARAVAGLIA, Juan Carlos, Poder, conflicto y relaciones sociales, HomoSapiens, Rosario, 1999.

GARAVAGLIA, Juan Carlos, "La apoteosis del Leviathán: El estado en Buenos Aires durante la primera mitad del siglo XIX”, en Latin American Research Review, volume 38, number 1, 2003, pp.135-168. 
GARAVAGLIA, Juan Carlos "El despliegue del Estado en Buenos Aires: de Rosas a Mitre", en Desarrollo Económica, vol.44, № 175 (octubre-diciembre 2004), pp.415-445.

GARAVAGLIA, Juan Carlos, y Schaub, Jean-Frédéric, Lois, justice, coutume. Amérique et Europe latines (16è-19è siècle), Editions de IEHESS, Collection Recherches d’histoire et de sciences sociales, 99, París, 2005.

GARAVAGLIA, Juan Carlos, Construir el estado, inventar la nación. El Río de la Plata, siglos XVIII-XIX, Buenos Aires, Prometeo Libros, 2007.

GARAVAGLiA, Juan Carlos, San Antonio de Areco, 1680-1880. Un pueblo en la campaña, del Antiguo Régimen a la modernidad argentina, Rosario, Prohistoria ediciones, 2009.

GARCÍA BASALO, J. Carlos, Historia de la penitenciaría de Buenos Aires (1869-1880), Buenos Aires, Editorial Penitenciaria Argentina, 1979.

GARGARELLA, Roberto, "El período fundacional del constitucionalismo sudamericano (18101860)", en Desarrollo Económico, vol.43, № 170, julio-setiembre 2004, pp.305-328.

GARRIGA, Carlos, "Historia y derecho, historia del derecho", en Istor, Revista de Historia Internacional, año IV, núm.16, México, primavera del 2004, pp.3-8.

GARRIGA, Carlos, “Orden jurídico y poder en el Antiguo Régimen” en Istor, Revista de Historia Internacional, año IV, núm.16, México, primavera del 2004, pp. 13-44.

GARRIGA, Carlos, "Gobierno y Justicia: el Gobierno de la Justicia", en Lorente Sariñena (directora), La jurisdicción contenciosa-administrativa en España. Una Historia de los orígenes, Cuadernos de Derecho Judicial VII, Madrid, Consejo del Poder Judicial, Centro de Documentación Judicial, 2009.

GARRONE, José Alberto, Diccionario Manual Jurídico, Buenos Aires, Buenos Aires, AbeledoPerrot, 2000.

GAYOL, Sandra, "Entre lo deseable y lo posible. Perfil de la Policía de Buenos Aires en la segunda mitad del siglo XIX”, en Estudios Sociales, Revista Universitaria Semestral, Año VI, N¹0, Santa Fe, $1^{\circ}$ semestre de 1996, pp.123-138.

GAYOL, Sandra, "Sargentos, cabos y vigilantes: perfil de un plantel inestable en ele Buenos Aires de la segunda mitad del siglo XIX”, en Boletín Americanista, V. 36, N 46, Barcelona, 1996.

GAYOL, Sandra y KESSLER, Gabriel, (compiladores) Violencias, delitos y justicias en la Argentina, Buenos Aires, Manantial, 2002.

GAYOL, Sandra, Honor y duelo en la Argentina moderna, Buenos Aires, Siglo XXI, 2008.

GELMAN, Jorge, "Crisis y reconstrucción del orden en la campaña de buenos Aires. Estado y sociedad en la primera mitad del siglo XIX" en Boletín del Instituto de Historia Argentina y Americana "Dr. Emilio Ravignani”, tercera serie, núm. 21, 1er Semestre de 2000, pp. 7-32.

GHIRARDI, Matrimonios y familias en Córdoba 1700-1850, Córdoba, Ferreyra Editor, 2004.

GHIRARDI OLSEN A., El primer Alberdi, Buenos Aires, Editorial Astrea, 1989. 
GHIRARDI OLSEN, A., Introducción al razonamiento forense, Universidad Nacional de Córdoba, 2002.

GOLDMAN, Noemí, "Crisis imperial, Revolución y guerra (1806-1820)", en Noemí Goldman, Nueva Historia Argentina, Revolución, República, Confederación (1806-1852), Buenos Aires, Editorial Sudamericana, 2005.

GOLDMAN, Noemí, "Los orígenes del federalismo rioplatense”, en Goldman, 2005, op. cit., pp. 103-124.

GONZÁLEZ BERNALDO DE QUIRÓS, Pilar, Civilidad y política en los orígenes de la Nación Argentina. Las sociabilidades en Buenos Aires, 1829-1862, Buenos Aires, FCE, 2000.

GONZÁLEZ BERNALDO DE QUIRÓS, Pilar, "Las pulperías de Buenos Aires: historia de una expresión de sociabilidad popular", Siglo XIX, nueva época, núm. 13, enero-junio.

GONZÁLEZ BERNALDO, Pilar, "El levantamiento de 1829: el imaginario social y sus implicaciones políticas en un conflicto rural", en Anuario IEHS, Instituto de Estudios HistóricoSociales, Tandil, Universidad Nacional del Centro de la Provincia de Buenos Aires, núm. 2, 1987, pp. 137-176.

GORELIK, Adrián, "Historia de la ciudad e historia intelectual", en Prismas, Revista de Historia intelectual, núm. 3, Buenos Aires, Universidad Nacional de Quilmes, 1999.

GUERRA, François-Xavier, Modernidad e independencia, Madrid, MAPFRE, 1992.

GUILLAMONDEGUI, Julio César, "La justicia consular en Buenos Aires (1794-1810)", en Boletín de la Academia Nacional de la Historia, volumen XXXIII (1962) 2 edición, Buenos Aires, 1963, pp.795-838.

GUILLAMONDEGUI, Julio César "Primer proyecto de Código de Comercio rioplatense (1824)", en Revista del Instituto de Historia del Derecho Ricardo Levene, Núm. 16, Buenos Aires, Imprenta de la Universidad, 1965.

GUILLAMONDEGUI, Julio César, "Notas para el estudio de la justicia mercantil patria de las provincias argentinas" en Revista del Instituto de Historia del Derecho, núm.20, 1992.

HABERMAS, Jüger, Historia y crítica de la opinión pública, México, Ed.Gili, 1981.

HALPERÍN DONGHI, Tulio, Revolución y Guerra. Formación de una élite dirigente en la Argentina criolla, México, Siglo XXI, 1979.

HALPERÍN DONGHI, Tulio, Proyecto y construcción de una nación (1846-1880), Buenos Aires, Biblioteca del Pensamiento Argentino II, Ariel Historia, 1995.

HALPERIN DONGHI, Tulio, Historia de la Universidad de Buenos Aires, EUdeBA, Buenos Aires, 2002.

HARDOY, Jorge, Las ciudades en América Latina, Buenos Aires, Paidós, 1972.

HESPANHA, António Manuel, "A historiografia jurídico institucional e a morte do estado", en Anuario de Filosofía del derecho, III, 1986. 
HESPANHA, António Manuel, “Sabios y Rústicos. La dulce violencia de la razón jurídica”, en $L a$ Gracia del Derecho, CEC, Madrid, 1993, pp. 17-60.

HESPANHA António Manuel, Cultura jurídica europea. Síntesis de un milenio, Tecnos, Madrid, 2002.

HERAS, Carlos, "La supresión del Cabildo de Buenos Aires", en Humanidades, núm.20, Universidad de La Plata, 1925, pp. 445-485.

HOBBES, Thomas, [1651] Leviatan. O la materia, forma y poder de una república eclesiástica y civil, Buenos Aires, Fondo de Cultura Económica, 2009.

IBAÑEZ FROCHAM, Manuel, La organización judicial argentina, Buenos Aires, La Facultad, Bernabé y cía., 1938.

INFESTA, María Elena, La Pampa criolla. Usufructo y apropiación privada de tierras públicas en Buenos Aires, 1820-1850, La Plata, Archivo Histórico de la Provincia de Buenos Aires, 2003.

INFESTA, María Elena y VALENCIA, Marta, “Tierras, premios y donaciones, 1830-1860”, en Anuario IEHS, Instituto de Estudios Histórico-Sociales, Tandil, Universidad Nacional del Centro de la Provincia de Buenos Aires, núm. 2, 1987, pp.177-213.

La Fuente Judicial en la construcción de la memoria, jornadas organizadas por la Suprema Corte de la Provincia de Buenos Aires y la Universidad Nacional de Mar del Plata, Mar del Plata, 1999.

LAPLAZA, Francisco P., "El proceso histórico de la codificación penal argentina (I)", en Revista del Instituto de Historia del Derecho Ricardo Levene, núm.24, Facultad de Derecho y Ciencias Sociales de la Universidad de Buenos Aires, Buenos Aires, 1978.

LEIVA, Alberto David, "La colegiación de abogados en el foro de Buenos Aires", en Revista de Historia del Derecho, núm. 12, Instituto de Investigaciones de Historia del Derecho, Buenos Aires, 1984.

LEIVA, Alberto David, Aprendizaje jurídico y entrenamiento profesional (siglos XVIII al XX), Buenos Aires, Ediciones Dunken, 1996.

LEIVA, Alberto David, "Del periodismo forense a las revistas jurídicas". Un aspecto en la evolución de la literatura jurídica argentina (1850-1950)", en La revista jurídica en la cultura contemporánea, edición al cuidado de Víctor Tau Anzoátegui, Buenos Aires, Ediciones Ciudad Argentina, 1997.

LEIVA, Alberto David, "La enseñanza penal de Carlos Tejedor", en Revista de Historia del Derecho, núm. 26, Instituto de Investigaciones de Historia del Derecho, Buenos Aires, 1998.

LEIVA, Alberto David, Historia del foro de Buenos Aires. La tarea de pedir justicia durante los siglos XVIII a XX, Buenos Aires, Editorial Ad-Hoc, 2005.

LETTIERI, Alberto R., Vicente Fidel López: la construcción histórico-política de un liberalismo conservador, Buenos Aires, Editorial Biblos, Fundación Simón Rodríguez, 1995.

LETTIERI, Alberto R., "De la "República de la Opinión" a la "República de las instituciones", Bonaudo, 1999, op. cit. 
LETTIERI, Alberto R., “Opinión pública y régimen político en Buenos Aires después de Caseros”, en Investigaciones y Ensayos, Academia Nacional de la Historia, núm. 49, Buenos Aires, 1999.

LETTIERI, Alberto R., La construcción de la República de la opinión, Buenos Aires frente al interior en la década de 1850, Buenos Aires, Prometeo Libros, 2006.

LEVAGGI, Abelardo, "La pena de muerte en el derecho argentino precodificado. Un capítulo de la historia de las ideas penales", en: Revista del Instituto de Historia del Derecho Ricardo Levene Número 23, Buenos Aires, Imprenta de la Universidad, 1972, pp. 17-91.

LEVAGGI, Abelardo, El cultivo de la Historia Jurídica en la Universidad de Buenos Aires (18761919), Buenos Aires, Editorial Perrot, 1977.

LEVAGGI, Abelardo, Historia del derecho penal argentino, Buenos Aires, Editorial Perrot, 1977.

LEVAGGI, Abelardo, "La interpretación del derecho en la Argentina en el siglo XIX", en Revista de Historia del Derecho, núm. 7, Buenos Aires, Instituto de Investigaciones de Historia del Derecho, 1978.

LEVAGGI, Abelardo, "El Supremo decreto de Rosas sobre quitas y esperas" en Revista del Instituto de Historia del Derecho Ricardo Levene, núm. 26, Buenos Aires, Imprenta de la Universidad, 1980-1981.

LEVAGGI, Abelardo, "Espíritu del constitucionalismo argentino de la primera mitad del siglo XIX", en Revista de Historia del derecho, núm.9, Buenos Aires, Instituto de Investigaciones de Historia del Derecho, 1981.

LEVAGGI, Abelardo, "La codificación del procedimiento criminal en la Argentina en la segunda mitad del siglo XIX”, en Revista de Historia del Derecho, núm.11, Buenos Aires, Instituto de Investigaciones de Historia del Derecho, 1983.

LEVAGGI, Abelardo, coordinador, Fuentes ideológicas y normativas de la codificación latinoamericana, serie V Centenario del Descubrimiento de América, Instituto de Ciencias Políticas, Universidad del Museo Social Argentino, Buenos Aires, 1992.

LEVAGGI, Abelardo, Orígenes de la codificación argentina: los reglamentos de administración de justicia, Buenos Aires, Universidad del Museo Social Argentino, 1995.

LEVAGGI, Abelardo, Las cárceles argentinas de antaño, Buenos Aires, Editorial Ad-Hoc, 2002.

LEVAGGI, Abelardo, "Constitucionalismo argentino 1810-1850", en IUSHISTORIA, Revista electrónica, $\mathrm{N}^{\circ} 2$, octubre de 2005, Buenos Aires, Universidad del Salvador, www.salvador.edu.ar/juri/reih/index.htm. Consultado el 6 de octubre de 2009.

LEVENE, Ricardo, Historia de la provincia de Buenos Aires y formación de sus pueblos, vol. I, La Plata, Talleres de impresiones oficiales, 1940.

LEVENE, Ricardo Historia del derecho argentino, Editorial Guillermo Kraft Lda., Buenos Aires, 1958. 
LEVENE, Ricardo, La Academia de Jurisprudencia y la vida de su fundador Manuel Antonio de Castro, Buenos Aires, Facultad de Derecho y Ciencias Sociales, Instituto de Historia del derecho, Colección de Estudios para la Historia del derecho Argentino, 1941.

LÓPEZ ALVES, Fernando, State formation in Latin America, 1810-1900, Duke University Press, Durham \& London, 2000.

LYNCH, John, Las revoluciones hispanoamericanas 1808-1826, Barcelona, Editorial Ariel, 1998.

MAGID, Henry M., “John Stuart Mill”, en Strauss, Leo y Cropsey, Joseph, Historia de la filosofía política, México, FCE, 1993.

MALAGARRIGA, Carlos, Reseña de la legislación comercial argentina (1810-1960), Buenos Aires, Depalma, 1961.

MÉNDEZ CALZADA, L., La función judicial en las primeras épocas de la independencia, Losada, Buenos Aires, 1944.

MARILUZ URQUIJO, José M., "Las sociedades anónimas en Buenos Aires antes del Código de Comercio", en Revista del Instituto de Historia del Derecho Ricardo Levene, Núm.16, Buenos Aires, Imprenta de la Universidad, 1965 , pp.31-65.

MARILUZ URQUIJO, José M., Estado e Industria 1810-1862, Buenos Aires, Macchi, 1969.

MARILUZ URQUIJO, José M., "La Real Audiencia de Buenos Aires y el Juzgado de Provincia", Academia Nacional de la Historia, (tirada aparte de la Memoria del II Congreso Venezolano de Historia), Caracas, 1975.

MARILUZ URQUIJO, José M., (director) Estudios sobre la Real Ordenanza de Intendentes del Río de la Plata, Buenos Aires, Instituto de Investigaciones de Historia del derecho, 1995

MARILUZ URQUIJO, José M, “Dalmacio Vélez Sarsfield: tradición y modernidad”, en Revista de Historia del Derecho, núm. 29, Instituto de Investigaciones de Historia del Derecho, Buenos Aires, 2001.

MARTINEZ SIERRA, Ramiro, El mapa de las pampas. Tomo II, Archivo General de la Nación, Buenos Aires, 1975.

MARTIRÉ, Eduardo, "La Historia del Derecho, disciplina histórica", en Revista de Instituto de Historia del Derecho Ricardo Levene, núm.20, Buenos Aires, 1969.

MARTIRÉ, Eduardo, "Las historias especiales y la Historia del Derecho", en Trabajos y comunicaciones, núm. 21, La Plata, Facultad de Humanidades y Ciencias de la Educación, 1972.

MARTIRÉ, Eduardo, "Consideraciones metodológicas sobre la Historia del Derecho", Lecciones de Historia Jurídica, IV, Buenos Aires, Editorial Perrot, 1977.

MARTIRÉ, Eduardo, “La Constitución reformada de 1860", en Revista de Historia del Derecho, núm. 12, Instituto de Investigaciones de Historia del Derecho, Buenos Aires, 1984.

MARTIRÉ, Eduardo, Las Audiencias y la Administración de Justicia en las Indias, Buenos Aires, Librería Histórica Perrot, 2009. 
MAYO, Carlos, MALLO, Silvia y BARRENECHE, Osvaldo, "Plebe urbana y justicia colonial. Las fuentes judiciales. Notas para su manejo metodológico", en Estudios-Investigaciones, núm.1, Facultad de Humanidades y Ciencias de la Educación, UNLP, 1989.

MAYO, Carlos A. (editor), Vivir la frontera. Población, parentesco. La casa, la pulpería, la escuela (1770-1880), Buenos Aires, Biblos, 2000.

MELO, Carlos, "Historia de los partidos políticos argentinos entre 1862-1930”, en Historia Argentina Contemporánea 1862-1930, Vol. II., Buenos Aires, Edición de la Academia Nacional de la Historia, El Ateneo, 1964.

MOLINA, Eugenia, El poder de la opinión pública. Trayectos y avatares de una nueva cultura política en el Río de la Plata, 1800-1852, Santa Fe, Universidad Nacional del Litoral, 2009.

MOLLE, Alejandro, El Departamento Judicial Mercedes, Mercedes, 1997.

MORELLI, Federica, "Orígenes y valores del municipalismo iberoamericano", Arucaria, Universidad de Sevilla, Sevilla, España, 2007, pp. 116-129.

MORELLI, Federica, "Entre el antiguo y el nuevo régimen. La historia política hispanoamericana del siglo XIX”, en Historia Crítica, núm. 33, Bogotóa, enero-julio 2007, pp. 122-155.

Morelli, Federica, "Filangieri y la "Otra América": historia de una recepción" en Revista Facultad de derecho y ciencias políticas, vol. 37, núm. 107, Medellín, Colombia, julio-diciembre de 2007, pp. 485-508.

MORESO, José Juan, La teoría del derecho de Bentham, Barcelona, PPU Promociones y Publicaciones Universitarias, 1992 (Manuales, 7)

MOSSE, Valeria, "La construcción estatal en la frontera sur. Un análisis a partir de los derechos de propiedad", Jornada de Debate Estado, justicia y conflictividad en la campaña rioplatense, siglos XVIII-XIX, Red de Estudios Rurales, Instituto de Historia Argentina y Americana "Dr. Emilio Ravignani", Universidad de Buenos Aires, 2006.

MYERS, Jorge, Orden y virtud. El discurso republicano en el régimen rosista, Universidad Nacional de Quilmes, 1995.

MYERS, Jorge, "La revolución de las ideas: la generación romántica de 1837 en la cultura y en la política argentinas", en Goldman, 2005, op. cit.

NINO, Carlos Santiago, “Justicia”, en Doxa, Cuadernos de Filosofía del Derecho, 14, 1993, pp. 6174.

NINO, Carlos Santiago, “Justicia”, en Doxa, Cuadernos de Filosofía del Derecho, 14, 1993, pp. $61-74$

OSSORIO, Manuel, Diccionario de Ciencias Jurídicas, Políticas y Sociales, 24 ${ }^{\mathrm{a}}$ edición actualizada, corregida y aumentada por Guillermo Cabanellas de las Cuevas, Buenos Aires, Editorial Heliasta, 1997.

ORTIZ, Tulio, Historia de la Facultad de Derecho, Buenos Aires, Facultad de Derecho, UBA, 2004. 
OSLAK, Oscar, La formación del Estado argentino. Buenos Aires, Ed. de Belgrano, 1990.

OTAEGUI, Julio C., "La codificación comercial en América Latina”, en La codificación: raíces y perspectivas I. El Código Napoleón, Buenos Aires, Educa, Colección Prudentia Iuris, 2003.

PAGANINI Rosana, SOUTO Nora, WASSERMAN Fabio "El ascenso de Rosas al poder y el surgimiento de la Confederación (1827-1835), en Goldman, 2005, op. cit.

PALACIO, Juan Manuel, La paz del trigo. Cultura legal y sociedad local en el desarrollo agropecuario pampeano, 1890-1945, Buenos Aires, Edhasa, 2004.

PALACIO, Juan Manuel y CANDIOTI, Magdalena, (compiladores) Justicia, política y derechos en América Latina, Buenos Aires, Prometeo Libros, 2007.

PARRY, Adolfo E. Responsabilidad de los Magistrados de la provincia de Buenos Aires, Taller de Impresiones Oficiales, La Plata, 1923.

PÉREZ GUILHOU, Dardo, "Ideas políticas de Vicente Fidel López en la Convención Constituyente Provincial de 1870-1873”, en Enrique M. Barba, In memoriam, Estudios de Historia, Buenos Aires, 1994

PÉREZ GUILHOU, Dardo, Liberales, radicales y conservadores. Convención constituyente de Buenos Aires 1870-1873, Buenos Aires, Instituto Argentino de Estudios Constitucionales y Políticos, Editorial Plus Ultra, 1997.

PÉREZ GUILHOU, Dardo, Las provincias y la organización nacional 1852-1853, Instituto Argentino de Estudios Constitucionales y Políticos, Mendoza, Editorial de la Facultad de Filosofía y Letras de la Universidad Nacional de Cuyo, 2003.

PÉREZ GHILHOU, Dardo, 1854 Dos proyectos políticos constitucionales, Buenos Aires y Mendoza, Instituto Argentino de Estudios Constitucionales y Políticos, Mendoza, 2005.

PIAZZI, Carolina, A., "Notas sobre la instalación del Juzgado de Alzadas en la provincia de Santa Fe (1855-1863)" en: Barriera, Darío, (coord). La justicia y las formas de autoridad. Organización política y justicias locales en territorios de frontera. El Río de la Plata, Córdoba, Cuyo y Tucumán, siglos XVIII y XIX, ISHIR CONICET-Red Columnaria, Rosario, 2010, pp.233-261.

PIAZZI, Carolina, A., Justicia criminal y cárceles en Rosario (segunda mitad del siglo XIX), Rosario, Prohistoria, 2011.

PIAZZI, Carolina, (coordinadora) Modos de hacer justicia. Agentes, normas y prácticas (Buenos Aires, Tucumán y Santa Fe en el siglo XIX), Rosario, Prohistoria Ediciones, 2011.

PICCIRILLI, Ricardo "Guret Bellemare, los trabajos de un jurisconsulto francés en Buenos Aires, Contribución a la Historia del derecho Argentino", Instituto de Historia del Derecho, Buenos Aires, 1942 .

PICCIRILLI, Ricardo, Rivadavia y su tiempo, tomo I y II, Buenos Aires, Peuser, 1943.

PIHLAJAMÄKI, Heikki, "Democracia, derecho y ciudadanía. El debate sobre el jurado y sobre el derecho de prueba en la Argentina a fines del siglo XIX", en: Revista de Historia del Derecho Ricardo Levene, núm. 30, Buenos Aires, 1995. 
PIOMBO, Oscar Horacio, La opción al título de escribano público en la provincia de Buenos Aires, Ediciones Universidad Notarial Argentina, La Plata, 1971.

PLOTKIN, Mariano Ben y ZIMMERMANN, Eduardo, (compiladores) Los saberes del Estado, Buenos Aires, Edhasa, 2012.

PLOTKIN, Mariano Ben y ZIMMERMANN, Eduardo, (compiladores) Las prácticas del Estado. Política, sociedad y elites estatales en la Argentina del siglo XX, Buenos Aires, Edhasa, 2012.

PRESSEL, Griselda, "Hacia un sistema republicano. La justicia en el paso del Antiguo Régimen a la Modernidad. Entre Ríos a mediados del siglo XIX”, en 2010, op. cit., pp. 193-207.

PUGLIESE, María Rosa, "La administración de justicia", en Nueva Historia de la Nación Argentina, tomo 5, Academia Nacional de la Historia, Buenos Aires, Planeta, 2000, pp.405-438.

RAFART, Carlos Gabriel y BOHOSLANSKY, Ernesto, "La frontera y la historia social del delito. Un primer balance", en Historia y cultura, 27, julio, 2001. Sociedad Boliviana de Historia, La Paz, Bolivia, pp.127-147.

RAMÍREZ BRASCHI, Dardo, Judicatura, poder y política. La Justicia en la provincia de Corrientes durante el siglo XIX, Corrientes, Moglia Ediciones, 2008.

RAVIGNANI, Emilio, Asambleas constituyentes argentinas seguidas en los textos constitucionales, legislativos y pactos interprovinciales que organizaron políticamente la Nación, tomo VI, segunda parte, 1810-1898, Buenos Aires, Talleres S.A: Jacobo Peuser, Ltda., 1939.

RAWLS, John, Teoría de la justicia, México, Fondo de Cultura Económica, 1995.

RICO, Alejandra, "Policía, soldados y vecinos. Las funciones policiales entre las reformas rivadavianas y la caída del régimen rosista”. Tesis de maestría. Universidad Nacional de Luján.

RIVERO ASTENGO, Agustín, Miguel Navarro Viola. El opositor victorioso, 1830-1890, Buenos Aires, Guillermo Kraft Limitada, 1947.

ROBLES, Nélida N., "La justicia civil en la campaña bonaerense: una aproximación cuantitativa (1825-1834)", en Prohistoria, año V, número 5, Rosario, primavera del 2001.

ROJAS GÓMEZ, Mauricio F., "Estrategias y legitimidad en las rupturas matrimoniales y bigamia de la provincia de Concepción, 1820-1875", en Revista de Historia del Derecho, Nº19, 2003-2004, Centro de Investigaciones de Historia del Derecho del Departamento de Ciencia del derecho, Facultad de Derecho de la Universidad de Chile

ROMAY, Francisco L., "Reseña histórica de la policía rural bonaerense", en Primer Congreso de Historia de los pueblos, Archivo Histórico de la provincia de Buenos Aires, 1950, pp. 108-138.

ROMAY, Francisco L., "Historia de la Policía Federal Argentina”, Biblioteca Policial, Buenos Aires, 1966; "Reseña histórica de la policía bonaerense", Primer Congreso de Historia de los Pueblos.

ROMERO, José Luis, "La ciudad latinoamericana y los movimientos políticos”, en Hardoy, Jorge y Tobar, Carlos (editores), La urbanización en América Latina, Buenos Aires, Editorial del Instituto Torcuato Di Tella, 1969, pp. 297-310. 
ROMERO, José Luis, Latinoamérica, las ciudades y las ideas, Buenos Aires, Siglo XXI, 2001.

RUIBAL, Beatriz, Ideología y control social: Buenos Aires, 1880-1920, Buenos Aires, Centro Editor de América Latina, 1993.

RUIZ Moreno, Isidoro J. La federalización de Buenos Aires. Los debates y las leyes. Edición del Instituto Histórico de la Organización Nacional, Buenos Aires, Editorial Emecé, 1980.

SÁBATO, Hilda, Capitalismo y ganadería en Buenos Aires: la fiebre del lanar, 1850-1890, Buenos Aires, Sudamericana, 1989.

SÁBATO, Hilda, "Ciudadanía, participación política y la formación de una esfera pública en Buenos Aires, 1850-1880”, Entrepasados, núm. 6, Buenos Aires, 1994.

SÁBATO, Hilda, La política en las calles. Entre el voto y la movilización. Buenos Aires, $1862-$ 1880, Buenos Aires, Editorial Sudamericana, 1998.

SÁBATO, Hilda, (coordinadora) Ciudadanía política y formación de las naciones. Perspectivas histórica de América Latina, México, Fondo de Cultura Económica, 1999.

SÁBATO, Hilda y LETTIERI, Alberto, La vida política en Argentina del siglo XIX. Armas, votos y voces, Buenos Aires, Fondo de Cultura Económica, 2003.

SÁBATO, Hilda, "La política Argentina en el siglo XIX: notas sobre una historia renovada"; en Ensayos sobre la Nueva Historia Política en América Latina, siglo XIX, México, El Colegio de México y Comité Internacional de Ciencias históricas, 2007.

SÁBATO, Hilda Buenos Aires en armas. La revolución de 1880, Siglo XXI, Buenos Aires, 2008.

SÁBATO, Hilda, Historia de la Argentina, 1852-1890, Buenos Aires, Siglo XIX Editores, 2012.

SALAS, Rubén Darío, El discurso histórico-jurídico y político-institucional en clave retóricohermenéutica. Del Clasicismo ilustrado a la Post-Modernidad, Instituto de Investigaciones de Historia del Derecho, Buenos Aires, 2004.

SALDÍAS, Adolfo, Un siglo de instituciones, tomo II, La Plata, Impresiones Oficiales, 1910.

SALGUERO, Paula, "Homicidios en Buenos Aires 1830-1849. Una mirada sobre el uso de las normas y el universo de los casos", en Piazzi, Carolina, (coordinadora) Modos de hacer justicia. Agentes, normas y prácticas (Buenos Aires, Tucumán y Santa Fe en el siglo XIX), Rosario, Prohistoria Ediciones, 2011.

SALVATORE, Ricardo, "Reclutamiento militar, disciplinamiento y proletarización en la era de Rosas", en Boletín del Instituto de Historia Argentina y Americana "Dr. Emilio Ravignani", 3ra serie, núm. 5, 1992.

SALVATORE, Ricardo, "El mercado de trabajo en la campaña bonaerense (1820-1860). Ocho inferencias a partir de narrativas militares", en Bonaudo, Marta y Pucciarelli, Alfredo, La problemática agraria. Nuevas aproximaciones, Buenos Aires, CEAL, 1993, t. 1, pp. 59-92.

SALVATORE, Ricardo, AGUIRRE, Carlos, JOSEPH, Gilbert M., (editors) Crime and Punishment in Latin America. Law and society Since Colonial Times, Duke University Press, Durham, 2001. 
SALVATORE, Ricardo, Wandering Paysanos, Statae order and subaltern experience in Buenos Aires during Rosas era, Duke University Press, Durham and London, 2003.

SALVATORE, Ricardo, Subalternos, derechos y justicia penal. Ensayos de historia social y cultural argentina, 1829-1940, Barcelona, Gedisa, 2010.

SALVATORE, Ricardo y Barreneche, Osvaldo, El delito y el orden en perspectiva histórica, Rosario, Prohistoria Ediciones, 2013.

SANUCCI, Lía E.M, "Crónica de la primera Convención Constituyente Bonaerense, 1870-1873”, en Trabajos y Comunicaciones, núm.12, Facultad de Humanidades y Ciencias de la Educación de la Universidad Nacional de la Plata, 1964.

SANJURJO DE DRIOLLET, Inés, La organización político-administrativa de la campaña mendocina en el tránsito del Antiguo Régimen al orden liberal, Buenos Aires, Instituto de Investigaciones de Historia del Derecho, 2004.

SANTOS, Juan José, "El Monitor de la Campaña de Exaltación de la Cruz y las reformas político administrativas de la campaña bonaerense (1870-1873)", Buenos Aires, 2002.

SANUCCI, Lía E.M, "Crónica de la primera Convención Constituyente Bonaerense, 1870-1873”, en Trabajos y Comunicaciones, núm.12, Facultad de Humanidades y Ciencias de la Educación de la Universidad Nacional de la Plata, 1964.

SEGHESSO DE LÓPEZ ARAGÓN, María Cristina, "Génesis histórica del Poder Judicial Argentino" (1810-1853), en El Poder Judicial, Instituto argentino de estudios constitucionales y políticos, Buenos Aires, Ediciones Depalma, 1989.

SEDEILLAN, Gisela, "La conformación y consolidación de la institución judicial en Tandil, 18721901”, Tesina de licenciatura, inédita, 2001.

SEDEILLAN, Gisela, "La pérdida gradual de las funciones policiales del juzgado de paz: la creación de la institución policial en Tandil 1872-1900, en Anuario Sgretti, Córdoba, 2005.

SEDEILLAN, Gisela, "El papel de la policía de la provincia de Buenos Aires en la instrucción sumarial en el período de codificación del derecho", en Bohoslavsky, Ernesto, Caimari, Lila y Schettini, Cristiana, (organizadores) La policía en perspectiva histórica. Argentina y Brasil (del siglo XIX a la actualidad), 2009.

SEDEILLAN, Gisela, La justicia penal en la provincia de Buenos Aires. Instituciones, prácticas y codificación del derecho (1877-1906), Buenos Aires, Biblos, 2012.

SEOANE, María Isabel, "La guarda de huérfanos en el siglo XVIII" (Aspectos de un estudio general de la institución en el actual territorio argentino), en Revista de Historia del Derecho, núm. 6, Instituto de Investigaciones de Historia del Derecho, Buenos Aires, 1978.

SEOANE, María Isabel, "Instituciones protectoras del menor en el siglo XVIII" (Notas para su estudio en el actual territorio argentino), en Revista de Historia del Derecho, núm. 5, Instituto de Investigaciones de Historia del Derecho, Buenos Aires, 1977. 
SEOANE, María Isabel, "Instituciones tutelares del menor en el derecho argentino precodificado (1800-1870)", en Revista de Historia del Derecho, núm. 7, Instituto de Investigaciones de Historia del Derecho, Buenos Aires, 1980, pp. 199-203.

SEOANE, María Isabel, La enseñanza del derecho en la Argentina. Desde sus orígenes hasta la primera década del siglo XX, Buenos Aires, Perrot, 1981.

SEOANE, María Isabel, "El procurador general de la ciudad. Consideraciones acerca del ejercicio del oficio en el Cabildo de Buenos Aires", en Revista de Historia del Derecho, núm. 12, Instituto de Investigaciones de Historia del Derecho, Buenos Aires, 1984.

SERRANO RODONNET, Antonio E., Fábulas forenses de Miguel Esteves Saguí, Colección del IV Centenario de Buenos Aires, Universidad de Buenos Aires, 1981.

SLATTA, Richard y ROBINSON, Karla "Continuities in crime and punishment. Buenos Aires, 1820-1850", en Lyman L. Johnson, The problem of order in changing societies: Essays on crime and Policing in Argentina and Uruguay, 1750-1940, Albuquerque, University of Mexico Press, 1990.

SOLARES ROBLES, Laura, Bandidos somos y en el camino andamos, Bandidaje, caminos y administración de justicia en el siglo XII. El caso de Michoacán, Morelia Michoacán, Instituto Michoacano de Cultura, Instituto de Investigación Dr. José María Luis Mora, dic.,1999.

SOSA, Gualberto Lucas, Instituciones de la moderna justicia de paz letrada, La Plata, Librería Editora Platense, 1993.

SOZZO, Máximo, "Usos de la violencia y construcción de la actividad policial en la Argentina" en Gayol, Sandra y Kessler Gabriel (editores) Violencia, delitos y justicia en la Argentina, Buenos Aires, Manantial, 2002.

SPECKMAN GUERRA, Elisa, Crimen y castigo: legislación penal, interpretaciones de la criminalidad y administración de justicia (ciudad de México, 1872-1910), México, UNAM, Instituto de Investigaciones Históricas. 2002.

STORNI, Carlos Mario, "Las disposiciones de los códigos rurales en materia laboral y sus raíces históricas", en Revista de Historia del Derecho, núm. 1, Instituto de Investigaciones de Historia del Derecho, Buenos Aires, 1973.

STORNI, Carlos M., "Notas sobre el Código Rural de la provincia de Buenos Aires de 1865", en Revista de Historia del Derecho, núm. 7, Instituto de Investigaciones de Historia del Derecho, Buenos Aires, 1980.

STRAUSS Leo y CROPSEY, Joseph, Historia de la filosofía política, México, FCE, 1993

SZUCHMAN, Mark, "Construyendo la ciudad, construyendo el Estado: transición política y arquitectónica en la Argentina urbana, 1810-1860", en Naciones, gentes y territorios: ensayos de historia e historiografía comparada de América Latina y el Caribe, Medellín, Universidad de Antioquia, 2000.

TANZI, Héctor José, Constituciones de la provincia de Buenos Aires, Cuadernos de San Isidro, 1, San Isidro, Colegio de Abogados, 1974. 
TAU ANZOÁTEGUI, Víctor, "La administración de justicia en las provincias argentinas (18201853)", en Revista de Historia del Derecho, núm. 1, Instituto de Investigaciones de Historia del Derecho, Buenos Aires, 1973.

TAU ANZOÁTEGUI, Víctor, "La costumbre en el Derecho Argentino del siglo XIX. De la revolución al Código Civil", en Revista de Historia del Derecho, núm. 4, Instituto de Investigaciones de Historia del Derecho, Buenos Aires, 1976.

TAU ANZOÁTEGUI, Víctor, Tau Anzoátegui, Víctor, "En torno a la mentalidad de nuestros juristas del ochocientos", en Revista de Historia del Derecho, núm. 5, Buenos Aires, Instituto de Investigaciones de Historia del Derecho, 1977.

TAU ANZOÁTEGUI, Víctor, Las ideas jurídicas en la Argentina (siglos XIX y XX), Buenos Aires, Editorial Perrot, 1977.

TAU ANZOÁTEGUI, Víctor, "Los orígenes de la jurisprudencia de los tribunales en la Argentina", en Revista de Historia del Derecho" núm. 6, Instituto de Investigaciones de Historia del Derecho, Buenos Aires, 1978.

TAU ANZOÁTEGUI, Víctor, "Los comienzos de la fundamentación de las sentencias en la Argentina", en Revista de Historia del Derecho, núm. 10, Buenos Aires, Instituto de Investigaciones de Historia del Derecho, 1982.

TAU ANZOÁTEGUI, Víctor, [1977] La codificación en la Argentina (1810-1870) Mentalidad social e ideas jurídicas, 2da. Edición, Buenos Aires, Librería Histórica Emilio J. Perrot, 2008.

TERNAVASIO, Marcela, Municipio y política, un vínculo histórico conflictivo. La cuestión municipal en Argentina entre 1850 y 1920, Tesis de maestría en Ciencias Sociales, Rosario, FLACSO, 1991.

TERNAVASIO, Marcela, "De la ciudad colonial al municipio moderno: la supresión de los Cabildos en el Estado de Buenos Aires", Jornadas Inter. Escuelas- Departamentos de Historia, Neuquén, 1999.

TERNAVASIO, Marcela, "La supresión del Cabildo de Buenos Aires: ¿crónica de una muerte anunciada?, en Boletín del Instituto de Historia Argentina "Dr. Emilio Ravignani" Tercera serie, núm. $21,1^{\circ}$ semestre de 2000 .

TERNAVASIO, Marcela, "La división de poderes en los orígenes de la política argentina", en Ciencia Hoy, Buenos Aires, volumen 14, núm.80, abril-mayo, 2004.

TERNAVASIO, Marcela, Gobernar la Revolución. Poderes en disputa en el Río de La Plata, 18101816, Buenos Aires, Siglo XXI, 2007.

TERNAVASIO, Marcela, Historia de la Argentina, 1806-1852, Buenos Aires, Siglo XXI, 2009.

THOMPSON, E. P., Tradición, revuelta y conciencia de clase. Estudios sobre la crisis de la sociedad preindustrial, Barcelona, Editorial Crítica, 1989.

TÍO VALLEJO, Gabriela, "De bosques perennes y jardines tardíos. El encuentro entre historia política e historia del derecho en las lecturas de una larga transición”, en Dossier: Historia política e Historia del Derecho, PolHis, año 5, núm. 10, segundo semestre, 2012, pp. 58-66. 
TJARKS, Germán O., El Consulado de Buenos Aires y sus proyecciones en la Historia del Río de la Plata, Buenos Aires, Facultad de Filosofía y Letras, Instituto de Historia Argentina Dr. Emilio Ravignani, 1962.

TORRES, Germán, "Dimensiones en el proceso de transformación del espacio pampeano" (18501890), monografías.com, el 14 de junio de 2006.

TRIBIÑO, Carlos R., "El Fiscal de Estado (Antecedentes de la institución y su régimen jurídico en la provincia de Buenos Aires), El Derecho, tomo 110, Buenos Aires, 1985.

TRUYOL Y SERRA, Antonio, Historia de la Filosofía del Derecho y del Estado, Madrid, Biblioteca de la Revista de Occidente, 1976.

URIBE-URAN, Víctor Manuel, "La América Latina colonial y postcolonial: ¿tierra de abogados y leguleyos?", en Naciones, gentes y territorio. Ensayos de historia e historiografía comparada de América Latina y el Caribe, Medellín, en Uribe-Uran, Víctor y Ortiz Mesa, Luis Javier (editores) Naciones, gentes y territorio. Ensayos de historia e historiografía comparada de América Latina y el Caribe, Medellín, Editorial Universidad de Antioquía, 2000, pp. 141-174.

URIBE-URAN, Victor Manuel, "Colonial Lawyers, Republican Layers and the Administration of Justice in Spanish America", en Zimmerman, Eduardo, (editor) Judicial Institutions in NineteenthCentury Latin America, Institute of Latin American Studies, University of London, 1999, pp. 25-48.

URIBE-URAN, Victor Manuel, (editor) State and Society in Spanish America during the Age of Revolucion, Scholarly Resources Inc., Wilmington, 2001.

URIBE-URAN, Víctor M. "Elites, construcción del Estado y negocios. El cambio de significado del Honor, Status y Clase: los letrados y burócratas de Nueva Granada en el período tardo colonial y temprano post-colonial", en Uribe-Uran, op. cit, 2001, pp.59-88.

VALENCIA, Marta, Tierras públicas, tierras privadas, Buenos Aires, 1852-1876, La Plata, Universidad Nacional de La Plata/ Archivo Histórico de la Provincia de Buenos Aires, 2005.

VALENCIA, Marta, "La última frontera de la provincia de Buenos Aires antes de la campaña de Roca”, en Blanco y Banzato, 2009, op. cit.

VILE, M.J.C., [1967] Constitucionalismo y separación de poderes, Madrid, Centro de Estudios políticos y constitucionales, 2007.

VIVAS, Mario Carlos, "El Código de comercio español de 1829 y su vigencia en Córdoba." en Revista de Historia del Derecho, Núm. 8, 1980.

WEBER, Max, Economía y sociedad, México, Fondo de Cultura Económica, 1983.

YANGILEVICH, Melina y MÍGUEZ, Eduardo, "Justicia criminal y Estado en la frontera de Buenos Aires, 1852-1880", en: Boletín del Instituto de Historia Argentina y Americana Dr. Emilio Ravignani, número 32, Buenos Aires, ene. /jun. 2010.

YANGILEVICH, Melina "Crónicas de conflicto y desilusión. Prefecturas de campaña, juzgados de paz y comisarías (1857-1859)" en Barriera, Darío (coordinador) La justicia y las formas de autoridad. Organización política y justicias locales en territorios de frontera. El Río de la Plata, 
Córdoba, Cuyo y Tucumán, siglos XVIII y XIX, ISHIR CONICET-Red Columnaria, Rosario, 2010, pp. 129-154.

YANGILEVICH, Melina, Estado y criminalidad en la frontera sur de Buenos Aires (1850-1880), Rosario, Prohistoria, 2012.

ZAFFARONI, Eugenio Raúl, "Reconstrucción institucional de la justicia", estudio preliminar de Guarnieri, Carlo, Judicialismo, Buenos Aires, Hammurabi, Serie Negra, 2003.

ZEBERIO, Blanca, “Un mundo rural en cambio”, en Bonaudo, en Bonaudo, 1999, op. cit.

ZEBERIO, Blanca, "Los derechos civiles en transición. Controversias jurídicas y proyectos políticos”, en Bonaudo, Marta; Reguera, Andrea y Zeberio, Blanca (coordinadoras) Las escalas de la historia comparada, tomo I: "Dinámicas sociales, poderes políticos y sistemas jurídicos", Buenos Aires, Miño y Dávila, 2008, pp. 285-307.

ZEBERIO, Blanca, "El liberalismo y los derechos de propiedad en Argentina. Controversias jurídicas y proyectos políticos en la etapa codificadora”, en Blanco y Banzato, 2009, op. cit.

ZETTERBAUM, Marvin, “Alexis de Tocqueville", en Strauss, Leo y Cropsey, Joseph, Historia de la filosofía política, México, FCE, 1993.

ZIMMERMANN, Eduardo, "El Poder Judicial, la construcción del estado y el federalismo: Argentina, 1860-1880", en Posada-Carbó, Eduardo, (editor) In Search of a New Order: Essays on the Politics of Nineteenth-Century Latin America. Londres: ILAS, 1998, pp. 131-152.

ZIMMERMANN, Eduardo, (editor) Judicial Institutions in Nineteenth-Century Latin America, Institute of Latin American Studies, University of London, 1999.

ZIMMERMANN, Eduardo, (editor) "The Education of Lawyers and Judges in Argentina's Organización Nacional (1860-1880), en, Zimmermann, 1999, op. cit., pp. 104-123.

ZIMMERMANN, Eduardo, "Centralización, justicia federal y construcción del Estado en la organización nacional”, en Revista de Instituciones, Ideas y Mercados Número 46, mayo 2007, pp. 265-292.

ZORRAQUÍN BECÚ, Ricardo, La organización judicial argentina en el período hispánico, Buenos Aires, Librería del Plata, 1952.

ZORRAQUÍN BECÚ, Ricardo, “Apuntes para una teoría Apuntes para una teoría de la Historia del Derecho”, en Revista de Instituto de Historia del Derecho Ricardo Levene, núm.24, Buenos Aires, 1968, p. 323-342.

ZORRAQUÍN BECÚ, Ricardo, "Las fuentes del derecho argentino (Siglos XVI a XX)”, en Revista de Historia del Derecho, núm. 1, Instituto de Investigaciones de Historia del Derecho, Buenos Aires, 1973.

ZORRAQUÍN BECÚ, Ricardo, "Las fuentes de la Constitución de 1853", en Revista de Historia del Derecho, núm. 16, Instituto de Investigaciones de Historia del Derecho, Buenos Aires, 1988.

ZORRAQUÍN BECÚ, Ricardo, Historia del derecho argentino, Editorial Perrot, Buenos Aires, 1996. 
ZUSMAN, Perla y MINVIELLE, Sandra, "Sociedades Geográficas y delimitación del territorio en la construcción del Estado-Nación argentino", Instituto de Geografía, Universidad de Buenos Aires. Documento descargado de http: //www. educ.ar.

\section{FUENTES ÉDITAS}

\section{Documentos oficiales}

Acuerdos y sentencias dictadas por la Suprema Corte de Justicia de la Provincia de Buenos Aires, Autos acordados desde 1810, acuerdos extraordinarios, resoluciones y noticias referentes a la administración de justicia. Segunda edición autorizada, realizada por el secretario de la Suprema Corte, Dr. Aurelio Prado y Rojas, tomos I y II, Buenos Aires, Jacobo Peuser, 1892.

Acuerdos de la Honorable Junta de Representantes de 1821.

Censo General de la provincia de Buenos Aires. Demográfico, agrícola, industrial, comercial. Verificado el 9 de octubre de 1881, bajo la administración del doctor don Dardo Rocha, Buenos aires, Imprenta de El Diario, 1883.

Código rural de la provincia de Buenos Aires, edición oficial, Buenos Aires, Imprenta de Buenos Aires, 1865.

Colección completa de leyes del estado y Provincia de Buenos Aires desde 1854 a 1881, recopiladas, concordadas y anotadas por Federico Ketzelman y Rodolfo F. De Souza, tomos I al VI, Buenos Aires, Editorial Lex, 1930.

Constitución del Estado de Buenos Aires de 1854, Sección VI Del Poder Judicial, en Corbetta, Juan Carlos Textos constitucionales de Buenos Aires, SCBA, La Plata, 1984, pp. 73-80.

Constitución de la provincia de Buenos Aires de 1873, Sección V Del Poder Judicial, en Corbetta, Juan Carlos Textos constitucionales de Buenos Aires, SCBA, La Plata, 1984, pp. 111-118.

Debates de la Convención Constituyente de Buenos Aires, 1870-1873, publicación realizada bajo la dirección de Luis V. Varela, tomos I y II, Buenos Aires, Imprenta La Tribuna, 1877.

Diario de sesiones de la Sala de Representantes de la Provincia de Buenos Aires de 1854, Imprenta de la Sociedad Tipográfica Bonaerense, Buenos Aires, 1863.

GARCÍA, Manuel, Manual para los jueces de paz de campaña, Buenos Aires, Imprenta de la Independencia, 1825.

Memoria del Ministerio de Gobierno de la Provincia de Buenos Aires, 1866-1867, Buenos Aires, Imprenta del Siglo, 1867.

Memoria de los diversos Departamentos de la Administración de la Provincia de Buenos Aires. Departamento de Gobierno 1871, Buenos Aires, Imprenta del Siglo, 1872.

Memoria de las diversas reparticiones dependientes del Ministerio de Gobierno de la Provincia de Buenos Aires, Buenos Aires, Imprenta del Mercurio, 1873. 
Memoria de las diferentes reparticiones del Ministerio de Gobierno de la Provincia de Buenos Aires correspondiente al año 1873, Buenos Aires, Imprenta de la Prensa, 1874.

Proyecto de ley sobre la organización de los tribunales y su jurisdicción, Buenos Aires, Imprenta del Siglo, 1870.

Recopilación de leyes, decretos y resoluciones sobre organización y procedimientos administrativos vigentes en la provincia de Buenos Aires, con anotaciones, publicación oficial, tomos I al IV, La Plata, Imprenta Buenos Aires, 1888-1890.

Registro estadístico de la provincia de Buenos Aires, año 1874, publicado bajo la dirección del Doctor Faustino Jorge, Jefe de la Oficina de estadística, segunda época, año vigésimo primero, Buenos Aires, Imprenta de Pablo Emilio Coni, 1876.

Registro Nacional, 1810

TEJEDOR, Carlos, Manual de Jueces de Paz en los procesos criminales, Buenos Aires, Imprenta Argentina "El Nacional", 1861.

TEJEDOR, Carlos, Manual de Jueces de Paz en los procesos civiles y administrativos, Buenos Aires, Imprenta Argentina "El Nacional”, 1861.

TEJEDOR, Carlos, Curso de derecho criminal. Primera parte: leyes de fondo. Segunda parte: leyes de forma, Buenos Aires, Librería de Cl. M. Joly, 1871.

VÉLEZ SARSFIELD, Dalmacio, Dictámenes en la Asesoría de Gobierno del estado de Buenos Aires, Edición de José M. Mariluz Urquijo y Eduardo Martiré (con la colaboración de Alberto David Leiva). Facultad de Derecho y Ciencias Sociales, Instituto de Historia del Derecho Ricardo Levene, Colección de textos y documentos para la Historia del Derecho Argentino, XII, Buenos Aires, 1982.

\section{Diarios de sesiones de la Cámara de Diputados (Diputados) y de Senadores (Senadores)}

Biblioteca de la Legislatura de la provincia de Buenos Aires

\section{Registro Oficial}

Los Registros Oficiales consultados entre 1821 y 1850 fueron impresos en la Imprenta del Mercurio en 1874, hasta 1845 y desde 1846 en 1875.

Registro Oficial de del Gobierno de Buenos Aires de 1853, Buenos Aires, Imprenta de "El Orden", 1856.

Registro Oficial del Gobierno de Buenos Aires de 1854, Buenos Aires, Imprenta de "El Orden", 1856.

Registro Oficial del Gobierno de Buenos Aires de 1855, Buenos Aires, Imprenta de "El Orden", 1856.

Registro Oficial del Gobierno de Buenos Aires de 1856, Buenos Aires, Imprenta de "El Orden", 1856.

Registro Oficial del Estado de Buenos Aires de 1857, Imprenta de "El Orden", Buenos Aires, 1857. Registro Oficial del Gobierno de Buenos Aires de 1858, Buenos Aires, Imprenta de "La Tribuna", 1858.

Registro Oficial del Gobierno de Buenos Aires de 1859, Buenos Aires, Imprenta de Mayo, 1859. Registro Oficial del Gobierno de Buenos Aires de 1860, Imprenta del Comercio del Plata, 1860. Registro Oficial del Gobierno de Buenos Aires de 1861, Imprenta del Comercio del Plata, 1861. Registro Oficial del Gobierno de Buenos Aires de 1862, Imprenta del Comercio del Plata, 1862. 
Registro Oficial de la provincia de Buenos Aires de 1863, Imprenta del Comercio del Plata, 1863. Registro Oficial de la provincia de Buenos Aires de 1864, Imprenta del Comercio del Plata, 1864.

Registro Oficial de la provincia de Buenos Aires de 1865, Buenos Aires, Imprenta de "El Nacional", 1865.

Registro Oficial de la provincia de Buenos Aires de 1866, Buenos Aires, Imprenta de "La Tribuna", 1866.

Registro Oficial de la provincia de Buenos Aires de 1867, Buenos Aires, Imprenta de "El Nacional", 1868.

Registro Oficial de la provincia de Buenos Aires de 1868, Buenos Aires, Imprenta del Mercurio, 1869

Registro Oficial de la provincia de Buenos Aires de 1869, Buenos Aires, Imprenta del Mercurio, 1869

Registro Oficial de la provincia de Buenos Aires de 1870, Buenos Aires, Imprenta El Mercurio, 1870.

Registro Oficial de la provincia de Buenos Aires de 1871, publicación oficial, Imprenta del Mercurio, 1871.

Registro Oficial de la provincia de Buenos Aires de 1872, publicación oficial, Buenos Aires, Imprenta del Mercurio, 1872.

Registro Oficial de la provincia de Buenos Aires de 1873, publicación oficial, Buenos Aires, Imprenta del Mercurio, 1873.

Registro Oficial de la provincia de Buenos Aires de 1874, Buenos Aires, Imprenta del Mercurio, 1874.

Registro Oficial de la provincia de Buenos Aires de 1875, Buenos Aires, Imprenta del Mercurio, 1875.

Registro Oficial de la provincia de Buenos Aires de 1876, Buenos Aires, Imprenta de José y Luis Rossi, 1876.

Registro Oficial de la provincia de Buenos Aires de 1877, Buenos Aires, Imprenta del Mercurio, 1877.

Registro Oficial de la provincia de Buenos Aires de 1878, Buenos Aires, Imprenta del Mercurio, 1878.

1879 sin portada

Registro Oficial de la provincia de Buenos Aires de 1880, Buenos Aires, Imprenta de la Penitenciaría, 1880.

Registro Oficial de la provincia de Buenos Aires de 1881, Buenos Aires, Tip de la Esuela de Artes y Oficios, 1881.

En el texto se hace utilizan las siguientes siglas:

ROPBA: Registro Oficial de la provincia de Buenos Aires

ROEBA: Registro Oficial del Estado de Buenos Aires de 1857

ROGBA: Registro Oficial del Gobierno de Buenos Aires

\section{Publicaciones periódicas}

Diarios La Tribuna y El Nacional.

La Revista de Buenos Aires, bajo la dirección de Miguel Navarro Viola y Vicente G. Quesada, tomos I al XXIV, 1863-1871, Buenos Aires, Imprenta de Mayo.

Revista de Legislación y Jurisprudencia, a cargo de J.M. Moreno, C. Araujo, A. E. Malaver, J.J. Montes de Oca, tomos I al IX, 1869-1873, Buenos Aires, t. I-IV, Imprenta Buenos Aires, t. V-VII, Imprenta La Prensa, t. VIII-IX, Imprenta de Pablo E. Coni. 


\section{$\underline{\text { Fuentes bibliográficas }}$}

ALBERDI, Juan Bautista, Obras completas, tomos I al VIII, Buenos Aires, La Tribuna Nacional, $1886-1887$

BECCARIA, Cesare, De los delitos y las pena, edición crítica bilingüe y estudio preliminar, Buenos Aires, Ediciones Arayú, 1955.

BELLEMARE, Guret, [1839] Plan general de organización judicial para Buenos Aires, "Noticia preliminar de Ricardo Levene", Facultad de derecho y ciencias sociales, Instituto de Historia del derecho, Colección de textos y documentos para la Historia del derecho Argentino VIII, Buenos Aires, Facultad de Derecho, UBA, 1949.

CASTRO, Manuel Antonio de, [1834] Prontuario de práctica forense, Buenos Aires, Facultad de Derecho y Ciencias Sociales, Instituto de Historia del Derecho Argentino, 1945. Reedición facsimilar con apéndice documental.

ESEN, Dereq, Manual de práctica criminal, título único. De las atribuciones a los tenientes alcaldes, jueces de paz y alcaldes ordinarios, en materia criminal, 1872.

ESTEVES SAGUÍ, Miguel, Tratado elemental de los procedimientos civiles en el foro de Buenos Aires, Buenos Aires, Imprenta Americana, 1850.

ESTRADA, José Manuel, Reformas judiciales, Buenos Aires, 1874.

GONZÁLEZ, Florentino, Lecciones de derecho constitucional, Buenos Aires, J.A. Bernheim, 1869.

GONZÁLEZ BERNALDO DE QUIRÓS, Pilar, Civilidad y política en los orígenes de la Nación Argentina. Las sociabilidades en Buenos Aires, 1829-1862, Buenos Aires, FCE, 2000.

HAMILTON, Alexander; MADISON, Santiago y JAY, John, El Federalista, artículos sobre la constitución de los Estados Unidos escritos en 1788 y corregidos por los mismos autores con un apéndice que contiene los artículos de Confederación y la Constitución de los Estados Unidos, Buenos Aires, Imprenta del Siglo Traducción de José María Cantilo, 1868.

MALAVER, Antonio E., Curso de procedimientos judiciales en materia civil y mercantil, Buenos Aires, Imprenta de Pablo E. Coni, 1875.

MUNILLA, Eduardo, Manual de escribanos teórico-práctico, tomo I, Buenos Aires, Imprenta del Porvenir, 1867.

SÁENZ, Antonio, "Instituciones elementales sobre el Derecho Natural y de Gentes. (Curso dictado en la Universidad de Buenos Aires en los años 1822-1823)", Buenos Aires, Instituto del Historia del Derecho, Facultad de Derecho y Ciencias Sociales, 1939. Introducción de Ricardo Levene

SOMELLERA, Pedro, Principios de derecho civil (curso dictado en la Universidad de Buenos Aires en el año 1824), Buenos Aires, Imprenta de los Expósitos, 1824. Reedición facsimilar. Noticia preliminar de Jesús H. Paz, Buenos Aires, Facultad de Derecho y Ciencias Sociales, Instituto de Historia del derecho argentino, 1939.

VARELA, Florencio, "Disertación sobre los delitos y las penas", 1827. Tesisi doctoral publicada en la Revista de Legislación y Jurisprudencia, tomo V, Buenos Aires, 1870, p.43. 


\section{FUENTES INÉDITAS}

Informe de la Comisión nombrada para censurar el curso de Derecho natural dictado por Doctor Antonio Sáenz y acuerdo de la muy Ilustre Sala de doctores de esta Universidad, Buenos Aires, Imprenta de la Independencia, 1823.

Archivo Histórico de la provincia de Buenos Aires "Dr. Ricardo Levene"

- Cámara de Senadores de la Provincia de Buenos Aires, 1854-1882

- Cámara de Diputados de la Provincia de Buenos Aires, 1853-1882

- Cámara de Apelaciones, Sala 9. Contiene documentos de la Cámara de Apelaciones, del Superior Tribunal y de la Suprema Corte de la provincia de Buenos Aires.

- Juzgado del Crimen, 1853-1881

- Juzgados de paz, sala 39

- Ministerio de Gobierno de la provincia de Buenos Aires, 1864-1881

\section{Archivo General de la Nación}

- Archivo de Tribunales y protocolos

- Estado de Buenos Aires, 1852-1864

- Archivo "Los López”, legajo 2368, carta n 4270. Carta de Vicente Fidel López a Félix Frías, Montevideo, 23-X-(sin año).

- Ministerio de Gobierno de la provincia de Buenos Aires, 1853-1863

Suprema Corte de Justicia de la provincia de Buenos Aires

- Acuerdos y sentencias de la Suprema Corte de la provincia de Buenos Aires, 1875-1896, 21 libros manuscritos. Sala Histórica, S.C. B.A.

- Expedientes de la Suprema Corte de la provincia de Buenos Aires.

- Expedientes del Departamento Judicial del Sud.

- Expedientes del Departamento Judicial del Centro.

- Fondos documentales de los juzgados de paz de los partidos de la provincia de Buenos Aires (expedientes, notas, libros).

\section{Biblioteca Nacional, Ciudad de Buenos Aires}

- Tesis doctorales de abogados en la Colección Candiotti

Acevedo, Carlos Alberto, Ensayo histórico sobre la legislación comercial argentina. Tesis para optar al grado de doctor en Jurisprudencia a la Facultad de Derecho, Imp. Alsina, Buenos Aires, 1914 